\title{
A GENERALIZED INVESTIGATION OF SELECTED HIGHWAY DESIGN AND CONSTRUCTION FACTORS BY REGIONAL GEOMORPHIC UNITS WITHIN THE CONTINENTAL UNITED STATES
}

MARCH 1970 -NUMBER 8

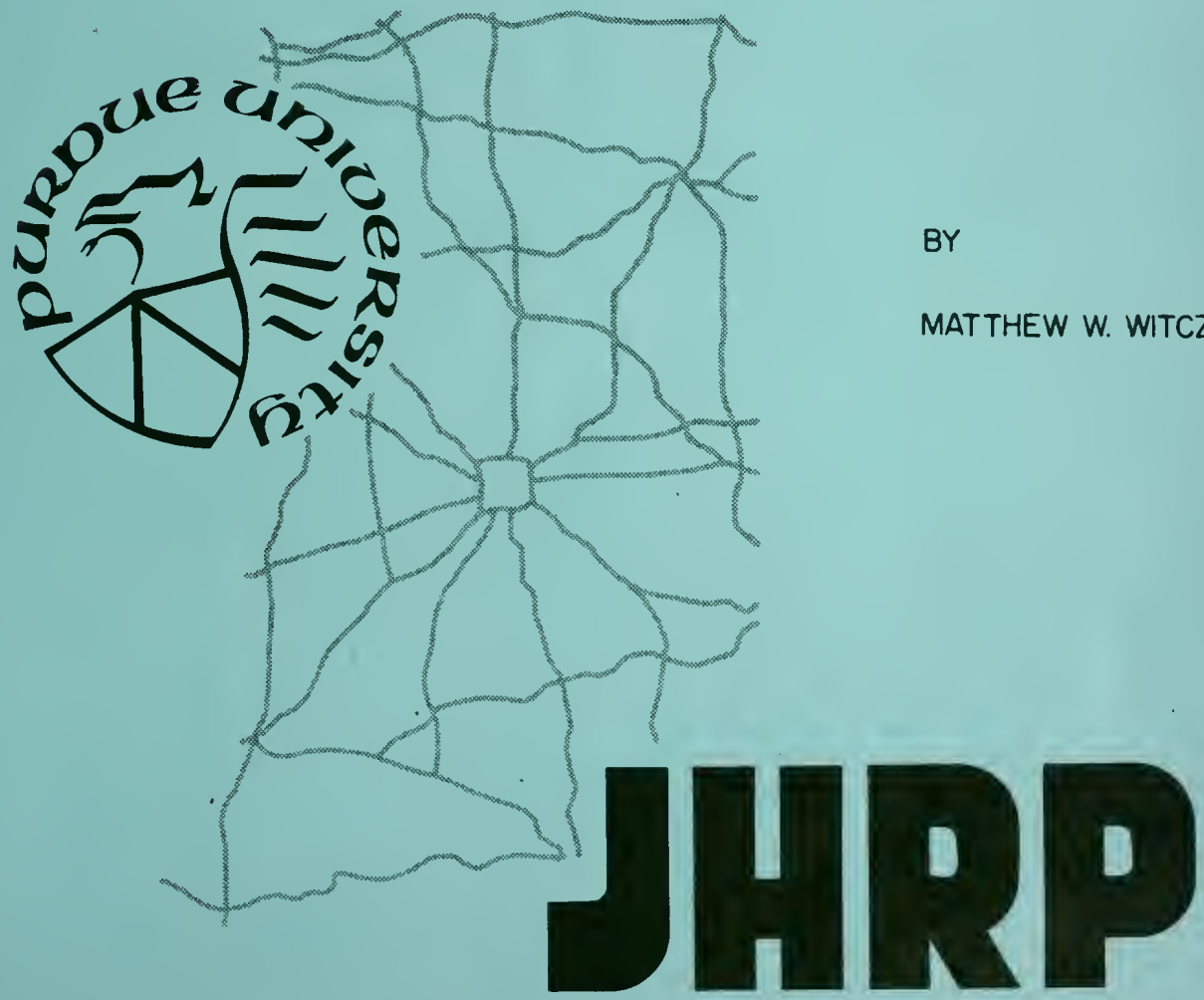

JOINT HIGHWAY RESEARCH PROJECT PURDUE UNIVERSITY AND INDIANA STATE HIGHWAY COMMISSION 

Final Report

A GENERALIZED INVESTIGATION OF SELECTED IIGGNAY DESIGN AND CONSTFICTION FACTORS EY FEGIU:AL GEOIORHHIC UNITS WITHIN THE CONTINENTAL UNITED JTATES

\author{
$(N \cdot C \cdot H \cdot R \cdot P \cdot I-3(I))$ \\ by \\ Matthew W. Witczak
}

Purdue University Lafayette, Indiana

March, 1970 
Digitized by the Internet Archive in 2011 with funding from

LYRASIS members and Sloan Foundation; Indiana Department of Transportation 
ACKNONLEDGEMENTS

This study was conducted by use of funds provided by the National Cooperative Hichway Research Procram. The work was carried out in the School of Civil Engineerin." at Furdue University, Lafayette, Indiana and is an extension of the research summarized in the Interim Report on this same subject which was submitted to the National Cooptrative Highway Research Frogram under date of September, 1965.

This research was conducted under the guidance of Frofessors C. W. Lovell, Jr., and E. J. Yoder. AcknowIGdiement is also made to Professors M. W. Melhorn, C. F. Scholer and K. E. Woods, for their instructive sugeestions.

A portion of the analysis concerning hich volume chance soils and frost problems is based upon the work conducted by Mr. H. P. Jensen and Mr. A. M. Oshornc, formerly Graduate Assistants in Research at Furdue University.

Liberal use has been made of data appearing in published literature dealing with eology, eomorkolory and physiographic mapping. These sources are referenced in the report. Some of the information dealine with aecregate sources and problems was obtained by means of a questionnaire sent to each state highway agency of the adjacent 48 states. 
Special acknowledgement is made to the works of

Fenneman, Lobeck, Noods and Lovell. The basic physiographic units studied are those proposed by Woods and Lovell (Reference 390). 
TABLE CF CONTENTS

IIST $\mathrm{CF}$ TABLES $\ldots \ldots \ldots \ldots \ldots \ldots \ldots \ldots \ldots \ldots \ldots \ldots \ldots \ldots \ldots \ldots \ldots$

IIST CF FIGURES $\ldots \ldots \ldots \ldots \ldots \ldots \ldots \ldots \ldots \ldots \ldots \ldots \ldots \ldots \ldots \ldots \ldots$

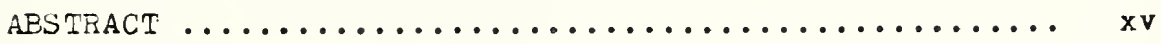

INTECDUCTICN $\ldots \ldots \ldots \ldots \ldots \ldots \ldots \ldots \ldots \ldots \ldots \ldots \ldots \ldots \ldots \ldots \ldots \ldots$

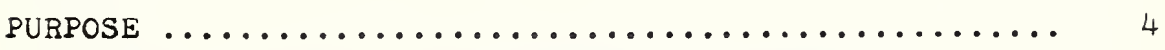

SEIECTED SCIENTIFIC AND ENGINEERING BACKGRCUND

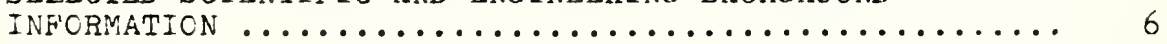

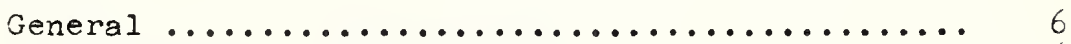

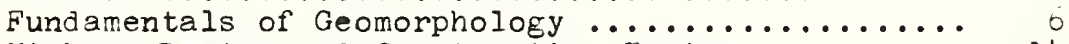

Highway Design and Construction Factors .......... 14

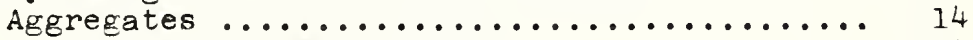

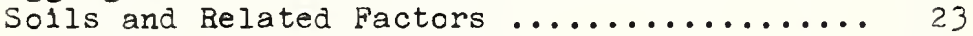

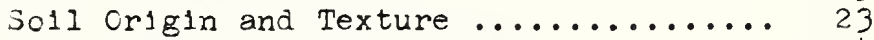

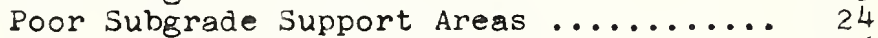

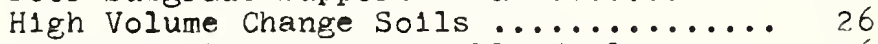

Frost and Frost Susceptible So1ls ..... 26

INVESTIGATION PBOCEDURES $\ldots \ldots \ldots \ldots \ldots \ldots \ldots \ldots \ldots \ldots . \ldots \ldots$

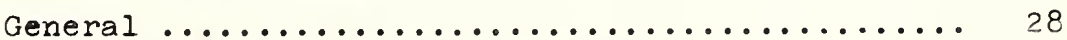

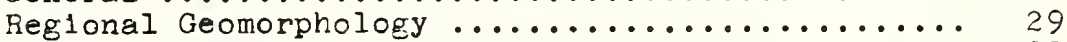

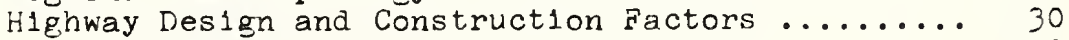

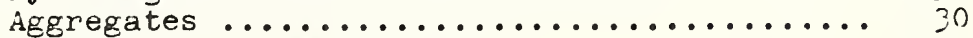

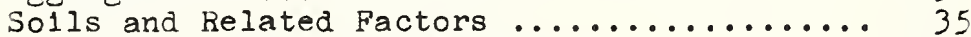

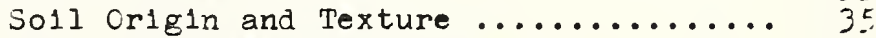

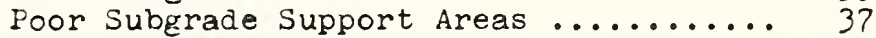

High Volume Change Solls ............. 37

Frost Action and Frost Susceptible

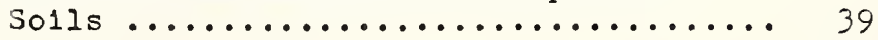

RESULTS ...................................... 4

Physlography (Geomorphology) ............... 41

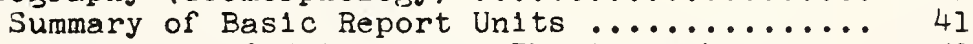

Comparison of Un1ts Among Physlographers .... 53

Physlographic Boundaries ...................... 57

H1ghway Design and Construction Factors ......... 62 
TAPLE CF CONTENTS (cont1 nued)

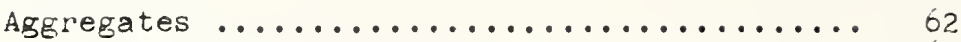

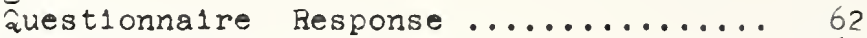

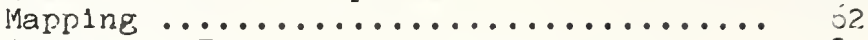

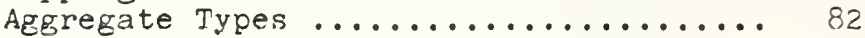

Avallabll1ty of quality Aggregates

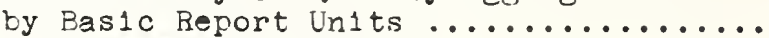

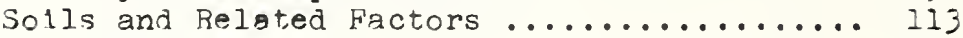

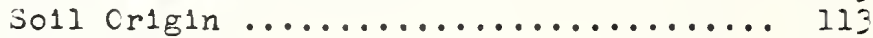

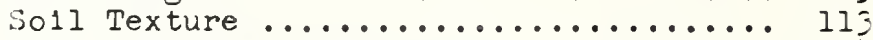

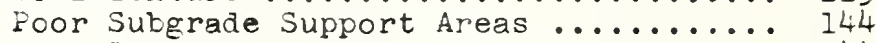

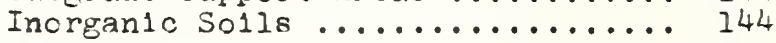

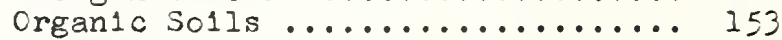

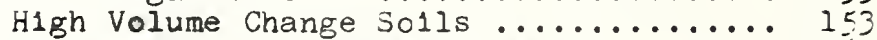

Frost and Frost Susceptible Solis ..... 165

SUMMARY AND CONCIUSIONS .................... 174

Generalized Summary Comparison Between Eastern

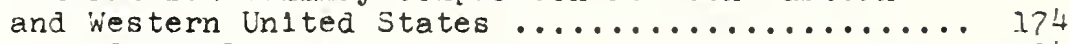

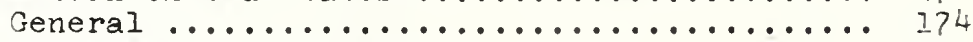

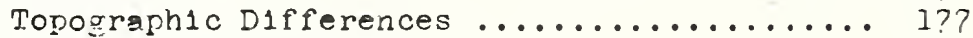

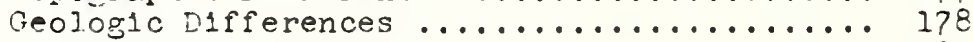

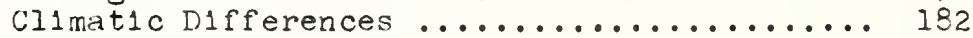

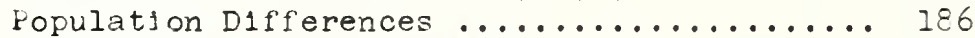

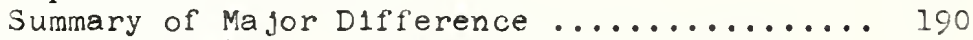

Summary of Individual Subject Areas Considered ... 100

Physlography and Reglonal Physlographic

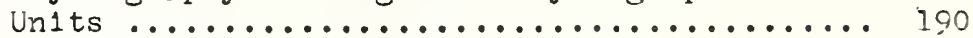

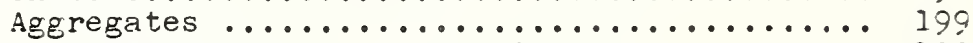

Design Factor Rating Summary ........... 199

General1zed Distribution of Aggregates.. 202

Fotent1al Aggregate Avallability

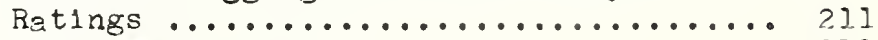

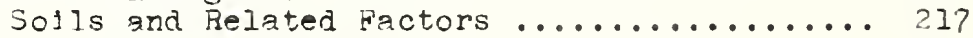

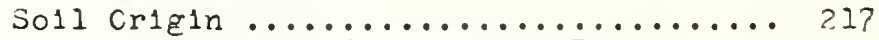

Uniqueness of Crigin to Basic

Report Provinces/Sect1ons ....... 217

Relation of Transported Surficial

Crigin Areas to Regional Physio-

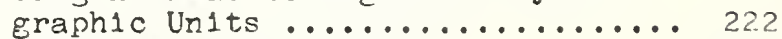

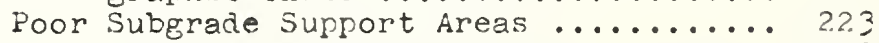

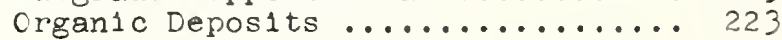

Design Factor Rating Summary.. 223

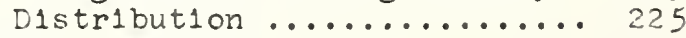

Inorgan1c Deposits ...............23J

Design Factor Rat1ng Summary.. 231

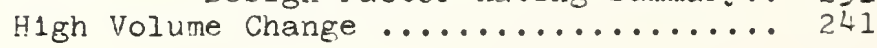


TABLE OF CONTENTS (continued)

Design Factor Rating Summary ..... 241 Distribution .......................... 44

General Geologic-Origin Farent Material Inferences ............ 248 Importance of Climate Upon the Reglonal Distribution of High Volume Change ............... ? 49 Frost and Frost Susceptible solis ..... 252

Distribution ................ 252 Composite Factor of Design Summary Rating by

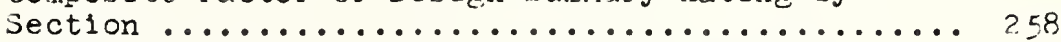
I Imitations Associated with Using Fhyslographic Units as Unique Highway Engineering Factor of Design Units

General

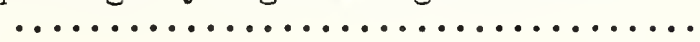

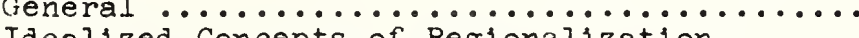

Idealized Concepts of Regionalization .......

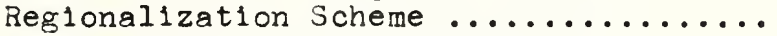

Basic Concepts of Regionalization

Within Physiographic Units ......... 263

Utility of Physlographic Units to Factors

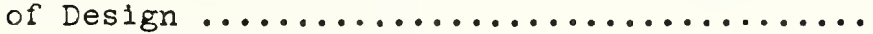

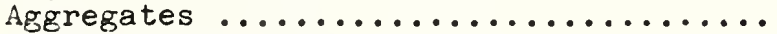

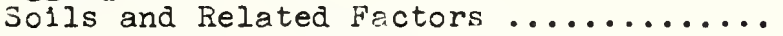

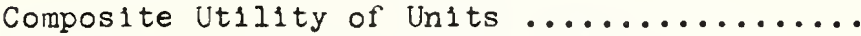

Concept of a Unique Highway Engineering-

Physlographic Category .............. 278

Recommended Physlographic-Highway Englneering

Units of the Continental United States ......... 273

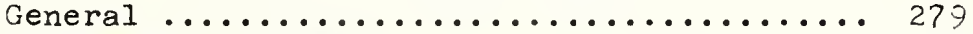

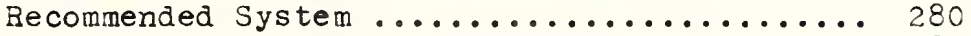

General Description of Recommended Units .... 287

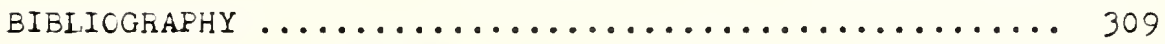

APPENDIX A - Sample NCHRP Materials questionnalre.... 339

APFENDIX B - Description of Bas1c Unit Boundaries..... 345

APFENDIX C - State Aggregate Production Data ........ 393

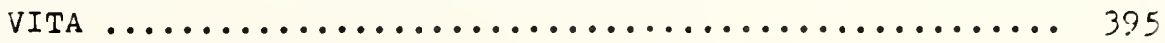




\section{IIST CF TABIES}

Table

1. Differences Eetween Physiographers in Fhysiographic Divisions

2. Summary of Feglonal Fhysiographic Unit Categorles

3. Crushed and Broken Stone Sold or lised by Froducers in the United States in 1958

by Kinds and Princlpal Uses (in Thousands

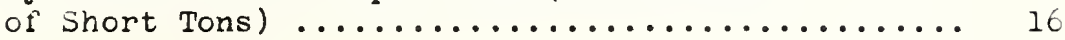

4. Physicgraphic Unit Code ................. 42

5. Occurrence of Fhysiographic Sections

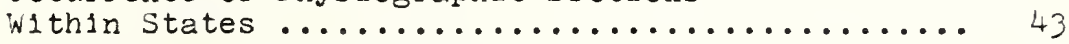

o. Area Summary of Basic Report Units ........... 45

7. Geomorphic Summary of Physiographic Sections .... 49

¿. Differences in Physiographic Categorizations

Between Physiographers and Bas1c Report Units.... 54

9. Response to Materlals auestionnalre by State.... 63

10. Reference Summary of State Fit/quarry-Aggregate Areas

11. Aggregate Type Code ..................... 83

12. Summary of General Aggregate Types Used

by State

13. Summary of General Aggregate Types Used

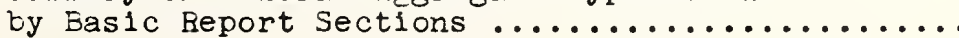

14. Summary of Surficial Soll Origin by Sections .... 114

15. General Soll Classification Correlation ........ Ilt 


\section{JIST OF TABLES (continued)}

Tatle

Page

16. General1zed Severity Category of Poor Subgrade support Fotential by Textural Classification ..... 146

17. Reference Summary of High Volume Change So1 I Iocations obtalned From Englneering I1terature ... 155

18. Geolog1c Age Summary of High Volume Change

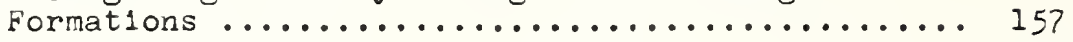

19. Surmary of Geolog1c Formations Showing H1gh Volume Change by Frequency of Occurrence

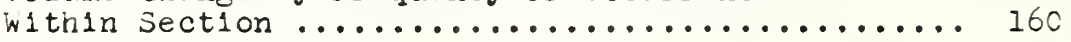

20. Crigin-Parent Material Summary of High Volume Change Pedologic Soll Series ................ 152

21. Jummary of Fedologic Soll Series Showing High Volume Change by Frequency of cccurrence within

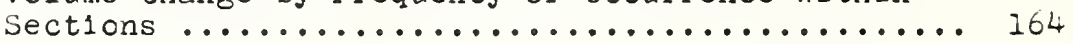

22. Final Adjusted High Volume Change Frequency of Cccurrence Ratings by Basic Report Section ....... 166

23. Status of Physiographic Sections and their General Relationship to Ground Freezing ........ 168

24. Frequency of Cccurrence Ratings of Frost Susceptible Solls Within Physiographic Sections considered in the Freezing Zone ........ 173

25. Classification of Major Fhysiographic Unit Categories 'ilthin the United States ........... 176

20. Summary of Estimated Potential Avallability Ratings of quality Aggregates within Sections .... 200

27. Summary of Major Crushed Stone Types Ut111zed as Highway Aggregate Within Sections .......... 204

28. Summary of Najor Highway Functional Uses of Crushed Sandstone Aggregate Within Sections ..... 208

29. Summary Compar1son Between Cccurrence of Areas Iacking Aggregate From Materials Questionnaire and jections Having an Aggregate Avallab1l1ty Rating More Severe Than Adequate to Lim1ted ..... 213 


\section{LIST CF TABLES (continued)}

Table

Page

30. Summary Comparison Between Sections Possessing Areas Lacking Aggregate From Materials questionraire and Sections Having an Aggregate Ava11ability Rating Less Severe Than I1mited to Froblem

31. Generalized Summary of the Predominant Geologic Conditions Existent Within Sections Possessing an Aggregate Avallability Rating More Severe

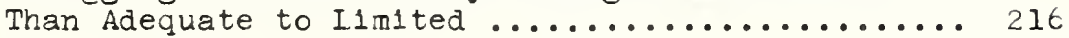

32. Summary of Generalized Degree of Homogene1ty of Najor Soll Origins Found in Sections by Province

33. Summary of Est1mated Frequency of Cccurrence Bating of Creanic Poor Subgrade Support Areas Within Sections

34. Summary of Sections Possessing Crganic Type Deposits Grouped by Major Geomorphic Modes

35. Summary of Estimated Frequency of CccurrenceSever1ty Rat1ng of Inorganic (clayey) Poor

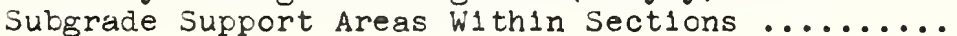

36. Summary of Estimated Frequency of Cccurrence Rating of High Volume Change Solls (Final Adjusted Rating) within Sections .............. 242

37. Summary of Section Frequency of Cccurrence Rat1ng by Frost Susceptible Soll Type .......... 253

38. Summary of Highest Frequency of Cccurrence Rating of Frost Susceptible Soll Category by

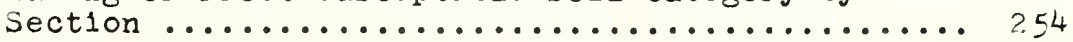

39. Composite Factor of Design Summary Rating by Physlographic Section

40. Summary of Sections Where Uniqueness of Regional Sand Gravel Distribution and Occurrence is Generally Good.

41. Summary of Aggregate Production Rankings by State

42. Summary of State Aggregate Production Factors by Increasing Magnitude 


\section{LIST CF FIGURES}

F1gure

Page

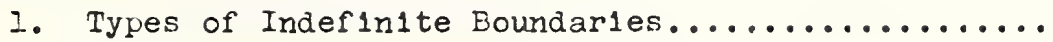

2. D1stribution of General1zed Potent1al

Crushed Carbonate Stone Areas................. 64

3. Distribution of Generalized Potent1al

Crushed Granit1c/Metamorph1c Complex Stone Areas.. 65

4. D1stribution of Generalized Potent1al

Crushed Igneous (Exclusive of Gran1te) Stone

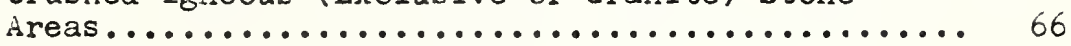

5. Distribution of Generalized Potent1al Sand

Grave Areas............................... 67

6. Distribution of Sand and Sand Gravel F1ts

in the U.S.............................. 70

7. Distribution of Crushed Stone Quarries in the

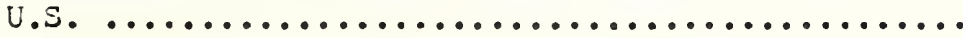

8. Distribution of Miscellaneous Aggregate Type Locations in the U.S.

9. Distribution of Counties Not Producing Sand-Gravel in $1964 \ldots \ldots \ldots \ldots \ldots \ldots \ldots \ldots \ldots \ldots . . \ldots \ldots$

10. Distribution of Counties Not Producing Crushed Stone in 1964.

11. D1stribution of Counties Not Producing SandGravel Nor Crushed Stone in 1964.............. 76

12. Questionnalre Summary of Areas Lacking

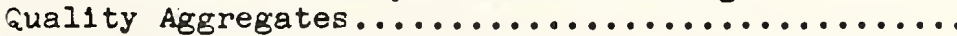

13. Summary of State Crushed Stone Production Groupings

14. Summary of State Sand Gravel Production Groupings 
LIST OF FIGURES ( continued)

F1gure

Page

15. State Sand Gravel/Crushed Stone Froduction

Ratio Groupings..........................

16. Ceneralized Soli Texture Map of the Continental

United States (Map Sheet I: Southwest U.S.)..... 117

17. Generalized Soll Texture Map of the Continental

United States (Map Sheet II: Northwest U.S.).... 118

18. Generalized Soll Texture Map of the Continental

United States ( Map Sheet III: South Central

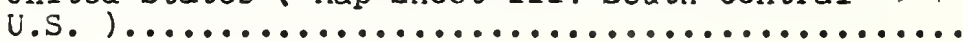

19. Generalized Soll Texture Map of the Continental United States ( Map Sheet IV : North Central U.S.)

20. Generalized Soll Texture Map of the Continental

United States ( Map Sheet V: Southeast U.S. )..... 121

21. Generalized SolI Texture Map of the Continental

Un1ted States ( Map Sheet VI: Northeast U.S.).... 122

22. Location of High Volume Change Solls Problems

as Encountered in Englneering I1 terature

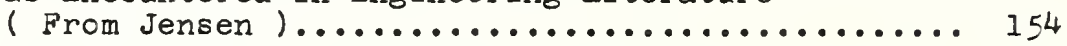

23. Distribution of Generalized High Volume Change

So11 Areas Within the U.S. (Geologic Analysis).. 158

24. Distribution of Generalized High Volure Change Soll Areas Within the U.S. (Pedolog1c Analys1s). 163

25. Physlographic Sections Considered W1thin the

Freezing Zone and Their Relationship to

Sourwine's Freezing Border..................... 167

26. Generalized Frost Susceptible Solls Map of the Northern States ( Map Sheet I: Northwest U.S.)... I69

27. Generalized Frost Susceptible Solls Map of the Northern States ( Map Sheet II: North Central

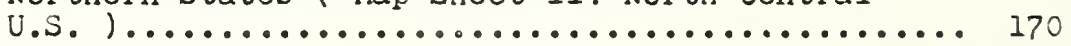

28. Generalized Frost Susceptible Solls Map of the Northerm States ( Map Sheet III: Northeast U.S. ). 


\section{IIST OF FIGURES ( continued)}

F1gure

Page

29. Iocation of Major Phys1ograph1c Un1t Categorles Within the U.S.

30. D1stribution of Paleozolc Formations Occuring at or Near the Surface within the U.S. ..........

31. Distribution of Ple1stocene Ice Sheet in the U.S..

32. Annual Precip1tation Map of the U.S. .......... 183

33. Annual Temperature $\operatorname{Map}$ of the U.S. ............ 185

34. Freezing Index Map of the U.S. .............. 187

35. Annual Potent1al Evapotranspiration Map

of the U.S.

36. Population Map of the UnIted States............ 189

37. Comparison of Eastem Lowland and Valley

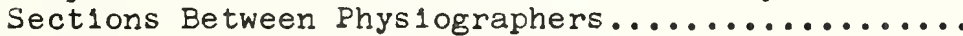

38. Difference in Reglonal Physlographic Unit

Delineation at Two Different Levels of

Examinations.

39. Est1mated Potential Ava1lab1l1ty Rat1ng of

Quality Aggregate Resources by Physlographic

init.

201

40. D1stribution of Twenty Leading Carbonate

Producing States During the 1956-1958 Per1od..... 206

41. Est1mated Frequency of Cccurrence Rating of

Potential Poor Subgrade Support Areas ( Crganic

Depos1ts ) by Phys1ograph1c Un1t...............

42. D1stribution of Major Ice Sheets in the Central Portion of the Central and Eastern Lowland

Province 000000000000000000000000000

43. Est1mated Frequency-Sever1ty Occurrence Rat1ng of Potential Poor Subgrade Support Areas

(Inorgan1c/Clayey Depos1ts) by Phys1ograph1c

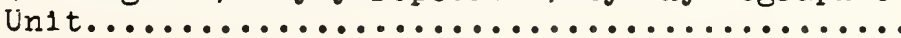

44. Estimated Final Ad justed Frequency of Cccurrence Rating of High Volume Change Solls by Phys 1ograph1c Un1t. 
Figure

Fage

45. Areas Where Average Annual Precipitation is

Less Than Average Annual Evapotranspiration...... 251

46. Recommended Phys1ograph1c-Highway Engineering Units of the Continental United States

( Map Sheet I: Northwest U.S.)................ 281

47. Recommended Physiographic-Highway Englneering

Units of the Continental United States

( Map Sheet II: Southwest U.S.).............. 282

48. Recommended Physiograph1c-Highway Englneering

Units of the Continental United States

( Map Sheet III: North Central U.S.).......... 283

49. Recommended Phys1ograph1c-Highway Eng1neering

Units of the Continental United States

( Map Sheet IV: South Central U.S.)............. 284

50. Recommended Phys1ographic-Highway Engineering

Units of the Continental United States

( Map Sheet V: Northeast U.S.)............... 285

51. Recommended Physiographic-highway Engineering

Units of the Continental United States

( Map Sheet VI: Southeast U.S.)............... 286

52. Completed Sample NCHRF Materials Questionna1re

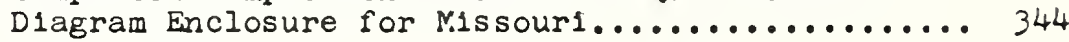

53. Western Mountains of the Pacific Coast Range

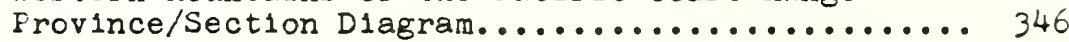

54. Sierra Cascade Province/Section D1agram......... 349

55. Pacific Trough Province/Section Diagram......... 351

56. Columbia Plateau Province/Section Dlagram....... 353

57. Basin and Range Frovince/Section Dlagram........ 355

58. Colorado Plateau Province/Section Diagram....... 356

59. Rocky Mountaín System Diagram................ 359

60. Great Plains Frovince/Section Diagram........... 361

61. Central Lowland Province/Section Diagram........ 366 
IIST OF FIGURES ( cont1nued)

Figure

Page

62. Iaurentian Upland Province/Section Diagram....... 370

63. Ozark and Ouachita Province/Section Dlagram...... 372

64. Interior Low Plateaus Province/Section Diagram.... 375

65. Appalachian Plateau Province/Section Diagram..... 37?

66. Rldge and Valley Province/Section Diagram........ 381

67. Old Appalachian Province/Section Diagram........ 383

68. Triass1c Lowland Province Diagram............. 385

69. New England Mar1t1me Frovince/Section Diagram..... 38 ?

70. Atlantic and Gulf Coastal Plaln Province/

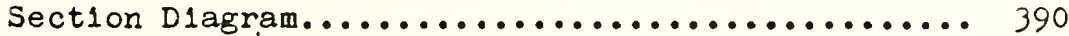




\section{ABSTRACT}

This report concerns an investigation of the occurrence and distribution of selected highway factors within regional geomorphic units comprising the adjacent 48 states. The regional classification system used as a basis of examination was that proposed by Woods-Lovell. This system was slightly modified to produce 97 sections for investigation. The highway factors analyzed by section were: avallability of quality aggregate resources, soil origin and texture, high volume change solls, potentially poor subgrade support conditions (clayey and organic type) and frost susceptible soils. A generalized evaluation of the utility of using Physiographic Sections as information filing units for the highway factors was also conducted.

Several generalized national maps were developed to aid in the analysis of the factors considered. Potential aggregate maps of the United States were compiled and used along with various other sources of information, including a state highway aggregate questionnaire, to obtain a qualitative estimate of the potential aggregate availability 
rating for each section. For factors of design relative to so11 texture, a generalized so11s map of the United States was developed. Estimates of the frequency of occurrence for soll texture units were made for each Section. Based upon the latter results, frequency of occurrence of organic deposits and the combined severity-frequency rating of plast1c (clayey) solls was assessed for each Section. Th1s served as a measure of the poor subgrade support potential. The frequency of occurrence of high volume change soils, within Sections showing a general climatic environment conduclve to volume change, was developed via potential high volume change maps. These were obtained by a combined eng1neering case study, as well as maps of potentlal high volume change areas derived from a pedologic and geologic analysis. A generalized frost susceptibility map for the northern United states was complied. Sections generally within the Ireezing zone were defined and the frequency of occurrence by frost susceptible soll type was qualitatively determined for each Section. A summary table of the salient composite highway factors investigated was complied for each section, and represents a brief and concise summary of the major findings.

In order to ottain a generalized evaluation of the utility of physiographic units for uniquely cataloging highway factors, the science of regional geomorphology was examined to ascertain the points of uniqueness used to delineate and separate sections from their surrounding units. An 
investigation of the presence of smaller units variant to the modal characteristics of the secticns was also conducted.

It was found that because of the multjplicity of factors used to define and bound Fhyslographic Sections, it is not possible to make a blanket conclusion regarding the validity of utilizing these sections as "filing systems" for highway factors. Although generalizations regarding the design factors can and have been made within the physiographic units, the uniqueness of the units appears to be dependent upon the factor in question, the degree to which variant units are present within the section, and the modal characteristics which define the section.

The majority of Sections examined showed a significant presence of smaller, varlant unlts within them. Based upon this consideration, plus the overall 1mportance of the parent material - origin characteristics to the highway engineer, a suggested highway engineering - physiographic unit map of the Continental United States is presented. This system is comprised of 242 tentative units. 


\section{INTRCDUCTICN}

While englneering design and construction decisions are unique solutions to particular protlems, the efficacy of such solutions depends strongly upon the store of highly relevant experiences which can be utlilied as background or perspective input. Generalized solutions do exist and are as helpful in art-orlented declsions as are general solutions in rigorous scientific analysis. It is important to recognize that valid and instructive definitions of site and route conditions, and the englneering problems inherent to such conditions, can be deduced from descriptions generalized for areas which are orders of magnltude larger than the job area. Detalled investigations of the job area subsequently validate the predictions, quantify the characterization, and reveal the anomalies where and if present.

The requisite input for highway design and constructtion decisions is deduced through a process of convergence, for example, moving from a general understanding of a large plece of geography to the specifics of a site or route which is no more than a point or a thin line on any but a very large scale map. Where one starts in the defining process is somewhat dependent upon the geographical scope of his operation ... federal, regional, state, county, municipal. 
Just as one night loglcally study an object first by unmagn1fled visual inspection and then by successively greater lmage magnification, the highway englneer might examine bedrock geology on first a national level, followed by successively larger scale maps of region, state, county, topographic quadrangle, and flnally, speclal coverage of the site or route of speciflc and lmmediate practical concern. Descriptors attached to each level of the examination would differ in degree of specification but would not contradict (anomalies excepted).

In the search for geographic units within which ground conditions, environment, engineering problems, and presumediy, design and construction practice, demonstrate significant homogene1ty, one might first try the jurlsalctional or political units (groupings of states, individual states, highway a1stricts, Individual counties, and the l1ke). However, since such units bear only colncidental relationship to the factors which produce the surface materials (origin, parent material and environment), they are largely unsultable. The experienced highway engineer recognizes this to be the case and, for example, does not apply the same technology in areas of resiaual clay and clayey glaclal till even though these lie within the same highway district. Indeed, pernaps the most effective argument for formally developing the concept of generally unlque reglons lies in the strong framework which it provides for organizing and relating experiences. cne of the most versatile and effective types of 
areal unlt currently known for purposes of examining the concept of reglons possessing common highway engineering factors of design, if not for 1mplementing it in optimal form, 1s that developed by the reglonal physlographer. Subdivision of geography in this geological - geographlcal sclence is accomplished by reference to a number of major descriptive features of the surface and subsurface.

In summary this thesis is bullt upon the premise that physlographic (geomorphic) units can form an orderly fling system for the many engineering experiences that, when synthesized, constitute engineering judgement. This fling system can be particularly valuable for organizations with large geographlcal jurlsdiction (reglonal, national) and for engineers youthful in the process of collecting and organizing experiences, 1.e., in the process of acquiring engineering judgement. 


\section{PURPOSE}

The major purpose of this research was to investigate the distribution and occurrence of several salient factors of highway location, design and construction within a selected, pre-existant regional physiographic classiflcation system for the Continental United States. The classification selected was a slightly modified version of the Woods - Iovell Engineering - Physiographic system, presented in 1960 ( $122^{1}$. This version resulted in the establishment of 97 "unique" areas" to be investigated within the United States.

The highway factors considered within this report are: the avallability of aggregates, soll origin and textural considerations, high volume change solls, potentially poor subgrade support solis (clayey and organic types) and frost susceptible so1ls.

An allied purpose of comparatle 1mportance was an evaluation of the ut1lity of physiographic units for organizIng and correlating data and experiences. In so doing, the geologlc sclence of regional geomorphology (physlography) was examined to determine the criteria used to define the uniqueness

1. Underlined numbers in parenthesis refer to entries in the B1bl1ography.

2. Termed Physiographic Sections. 
of a physlographic unit, and to bound or separate it from other units. As a result of such examination, pertinent inclusions could be reached as to the suitability of generalizing any highway factor within any defined physiographic unit. 
SEIECTED SCIENTIFIC AND ENGINEERING

BACKGROUND INFORN.ATION

\section{General}

In order to provide a common base of understanding of frequently used geologic and engineering terminology, certain fundamental information about geomorphology, phys10graphy, aggregates and soll problem follows.

\section{Fundamentals of Geomorphology}

Physlography or Geomorphology

Throughout the report the reader w1ll be confronted w1 th the terms "physlograph1c" or "physlography" and "geomorphic" or "geomorphology". Physlography is defined as (ㄹ): "...synonymous with physical geography; a description of ex1sting nature as displayed in the surface arrangement of the globe, 1ts features, atmospheric and oceanic currents, climates, magnet1sm, I1fe, as well as the changes or varlations to which these are subjected". Geomorphology, on the other hand, is defined as: "...the systematic examination of landforms and their interpretation as recoros of geologic history". The major dissimilarities between the two are: (1) Physlography consists primarliy of describing the topographic expression and Its geographic extent, whlle Geomorphology emphasizes 
interpretation of the origin and development of landforms; and (2) Physlography appears to be more inclusive, since it includes the "environment" of the topography (atmosphere, ocean, climate, etc). Fenneman (18) states: "Geomorphology is definitely ilmited to the genetic (pertalning to the relationships of a common orlgin) study of landforms". Iobeck (38) points out that Physlography includes Climatology, Geomorphology and Oceanography.

However, the examination and description of landforms or topographic expressions are basic to both sclences. Fenneman states: "The term Physlography as used in the United States is the approximate equivalent of Geomorphology". Further, if a Geomorphologist studies the areal extent of landforms, he would be acting as a reglonal Geomorphologist, and his activity would very closely resemble that of the Physiographer.

In the words of another author1ty: "For many years, In the United States, the study of the orlgin of landforms has been called Geomorphology, whereas the discussion of the regional distribution and the geomorphlc historles of landscapes has been termed Physlography. It seems to me that this inconsistency should be eliminated..." (Thornbury (65)). Accordingly, the author has taken the position that "geomorphic unit" is synonymous with "physlographic unit".

The Physlograph1c (Geomorph1c) Un1t Varlous physlographers have set forth definltions 
of a physiographic un1t. Bowman (65) suggests 1t is "... a tract in which the topographic expression is in the main uniforn". Hinds (65) states $1 t$ 1s, "... characterized by a distingulshing geological record, particularly in the later part of earth history, and by more or less uniform relief features or combinations of features throughout 1 ts area". Malott ( $\underline{6}$ ) somewhat more comprehensively explains: "A phys1ographic unit is an area or division of the land in which topographic elements of altitude, relief and type of landforms are characteristic throughout, and, as such, is set apart or contrasted with other areas or units with different sets of character1st1c topograph1c elements".

In most simple terms, physiography is topographic expression; while the Implication of a physiographic unit is that 1 t contains a unlque set of landforms, 1.e., different from 1 ts physlographic ne1ghbors. Iandforms, or topographic expression, are not readily adapted to exact quantitative evaluation and are generally qualitatively categorized in terms of altitude, relief, form, and interrelationships of the landscape features (65).

Geomorphic Control Factors

A fundamental concept of geomorphic thought, advanced by Davis ( $\underline{64})$, is that topographic expression of any area depends upon the three control factors of structure, process, and stage.

Structure has a slightly different context than the 
normal geologic usage. Thornbury (녀) defines it (structure) as "... all those ways in which the earth materials out of which landforms are carved differ from one another in their physical and chemical attributes. It includes such phenomena as rcck attitudes, the presence or absence of joints, beding planes, faults and folds, rock massiveness, physical hardness of the minerals, susceptibility of mineral constituents to chemical alternation, permeability (1mpermeability) of rocks, and various other ways in which rccks of the earth's crust differ from one another. The term structure also has strat1graphic implications... Is the region one of essent1ally horizontal sedimentary rocks or is it one in which the rocks are steeply dipplng or folded or faulted?"

Process describes ways in which the land surface has been modified. Geomorphically, these processes may be thought of as those orlginating from agencies outsice the earth's crust (degradational: tending to level down; or aggradational: tending to level upl; or those that originate within the earth's crust (diastrophism: forces that cause the deformation of the earth's crist; or vulcanism: the movement of molten rock or magma onto or toward the earth's surface).

An exact and universally accepted definition of stage has not been formulated, however, in a very broad sense it involves a change with time. Sparks (28) refers to this as the evolutionary phase of landform development.

Eased upon the foregoing, Thornbury (65) summarizes the Importance of the geomorphic control factors by stating: 
"This is equivalent to saying that a certain region possessed an inltial geologic framework, as determined by the kind and arrangement of 1 ts rocks; this geologic structure has been subjected to gradational processes which have produced a certain assemblage of landforms; and the characteristics of these landforms are to a certain degree related to the length of t1me that the geomorphic process have been at work".

Categories of Feglonal Physlographic (Geomorphic) Units

It has been previously stated that a physiographic unlt is one of repetitive and/or unique landforms. Obviously, as the size of an area under consideration increases, detall gives way to generality. As a consequence, one should intuitively expect a greater diversity of landforms or topography in the larger major units than in the smaller minor ones. Furthermore, as the definition of areal physiographic units is quite subjective, it is highly probable that, as Fenneman (18) has stated, "...even in the single science of physlography, two men, or the same man at different times may wish to emphasize different elements of the plcture, and accordingly, to divide the total area in a different manner". Since land features may be examined at a variety of scales (different degrees of generalization), several levels or categorles of physlographic units are needed. Fenneman 
$(\underline{18}, 19)$ used three categories ${ }^{2}$, in order of major to minor:

(1) Division, (2) Province and (3) Section.

Table 1 compares the Physlographic Divisions of

Fenneman with those of lobeck(28). The latter authorlty d1vides North Amerlca into six Divisions; while Fenneman uses eight Divisions in the U.S. alone. The major difference is in the North American Cordillera Division of Lobeck. However, this discrepancy appears to be minor, since lobeck subdivides this Division into three parts which match the fenneman Divisions (Table 1).

Differences are compounded at the Province and SectIon scale; these are discussed later. In addition, others (Freeman et al, as c1ted by Thombury (65) ) have inserted the intermedlate grade of "Subprovince".

A slightly different classification has evolved frcm the excellent work conducted in England by the Military Engineering Experimental Establishment (MEEE) (43, 44). The descriptors used (in order of major to minor extent) are the:
(I) Iand Zone,
(2) I and Division,
(3) Iand Province, and (4)

Iand Region.

Table 2 summarlzes the varlous categorical terminologles. For this study the terminology adopted is the system of: (1) Division, (2) Province, (3) Section, and (4)

1. Fenneman (19) states on page 55, with respect to the central Texas Section of the Great Plains Province, "...the Section...embraces a number of clearly distinguished subdivisions which for lack of a technical term may here be called districts". The term has not however gained any consis tent usage. 


\section{Table 1}

Differences Between Physiographers in Physiographic Divisions

\section{$\underline{\text { Lobeck }}^{1}$}

A. Appalachian Highlands

B. Atlantic Plain

C. Canadian Shield

D. North American Cordillera ${ }^{4}$
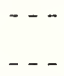

E. Interior Plains 5

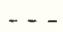

F. Antillean Mountain System ${ }^{6}$

\section{Fenneman $^{2}$}

Appalachian Highlands

Atlantic Plain

Laurentian Upland ${ }^{3}$

Pacific Mountain System

Intermontaine P1ateau System

Rocky Mountain System

Interior Plains

Interior Highlands

Mapping of North America.

2 Mapping of the United States only.

3 One of three provinces in Lobeck's Canadian Shield Division.

4 Lobeck recognizes three subdivisions within the North American Cordillera, which are the same as the Fenneman Divisions.

5 Lobeck's Interior Plains include Fenneman's Interior Highlands. Fenneman's Interior Highland Division contains the Ozark Plateau and Ouachita Provinces.

6 Not in the U. S. 


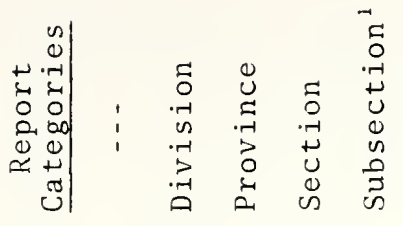

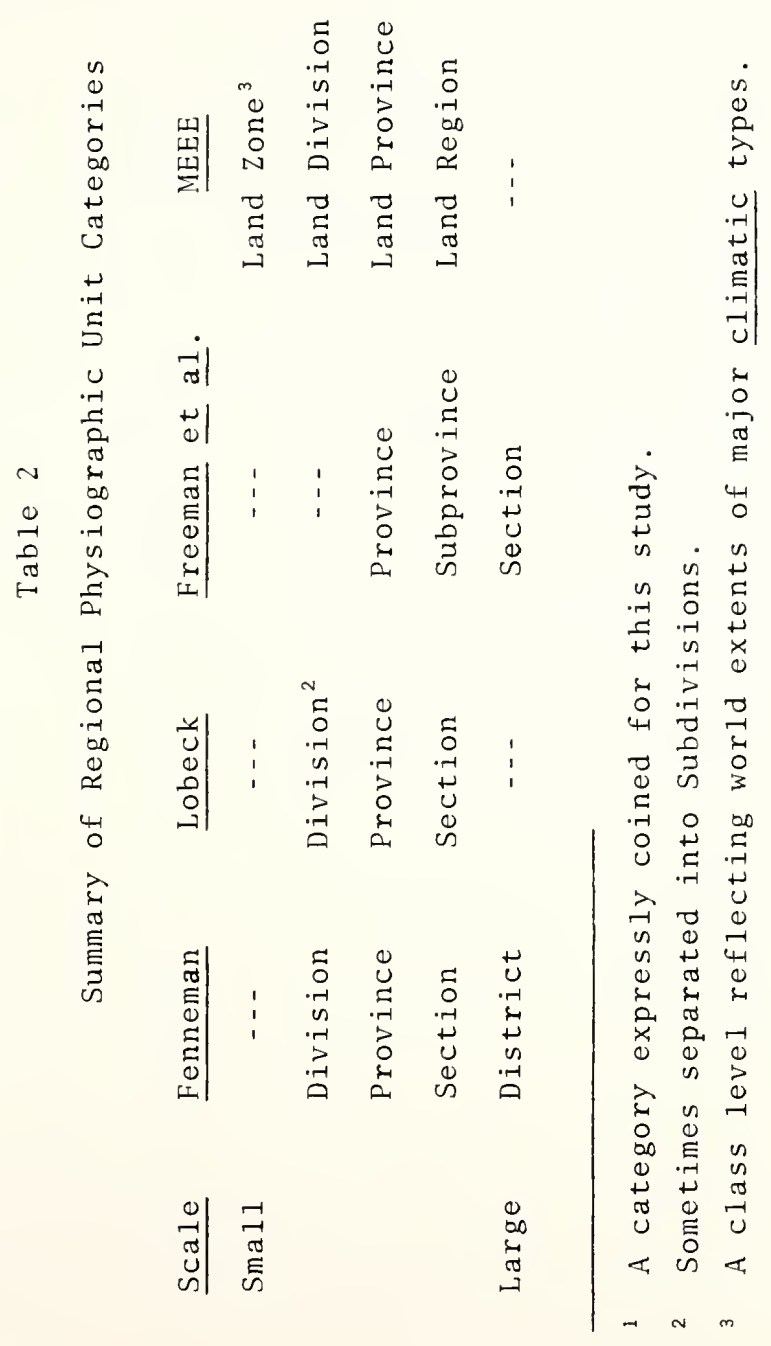


Subsection. 1

\section{H1ghway Des 1 gn and Construction Factors}

Aggregates

\section{General}

One of the more 1mportant facets of highway design and construction lies in the avallablilty and selection of good quality mineral aggregates. Wlthin the United States, a wlde varlety of natural granular deposits, crushed stone and artiflclal aggregates are presently used for base/subbase, concrete and bltuminous pavement mixes. In some areas, however, good quallty aggregate sources may be in short supply. The following discussion provides a basic background on the major sources and types of aggregates used in the highway industry, as well the potentlal problems assoclated with aggregate uses in different parts of the pavement structure. Aggregate Types

Aggregate types can be generally grouped by source into three categorles, $(\underline{142})$. These are: (a) natural sand and gravel, (b) crushed stone and (c) artiflclal aggregates. Sand and gravel deposits occur primarlly through deposition by water. Hence, orlgins may be of glacial (glacio - fluvial), alluvial, lacustrine or marine. In 1958, approximately 680,080 short tons of sand and gravel were sold within the United States. Of this total, 407,734 tons, or

1. Category description adapted especially for this project. 
nearly 60\% was utilized by the paving industry (13I).

A wide variety of rock is avallable for use as crushed stone, viz., sedimentaries, 1gneous and wetamorphics. Severinghaus (125) states: "Sat1sfactory physical and chem1cal properties can be found in each type so that economic avallability becomes the prime determinant for development". The most widely used crushed stones are those of the cartonate group (11mestones and dolomite). G1IJson et al, (107) states that, "...no other solid rocks are as 1mportant as these in the Industrial life of the world, nor are any so widely known". Th1s statement is vertifled by Table 3 which shows the quantity by type and principal use for crushed stone in 1958 for the United States. Although the data (in terms of quantity) are over 10 years old, they provide a valuable guide in noting the relative quantities of each type used as well as the principal types of crushed rock used for aggregates. Artificlal aggregates as defined by woods (142) consist or: (a) blast furnace slag, (b) cinders and (c) other lightwelght aggregates. Woods' definition of the latter is confined primarily to "a manufactured ageregate" ; while KIInefelter (128) states: "Ilghtwelght aggregates may be natural or manufactured materlals or by-products from other commercial operations. Natural materials include pumlce and pumiclte, tuffs, breccla, scorla, jiatomite... Manufactured naterials include expanded perlite, vermiculite, slag, clay, shale and slate. By-products include cinders, air cooled slags and coke breezen" 
in

का

范

$\rightarrow \stackrel{0}{0}$

0

$+4$

5 동

咅㟧

E

(n)

in is

บ 3

도

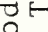

\&

‥

in $>$

(1) 0 in

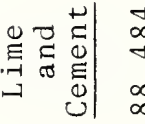

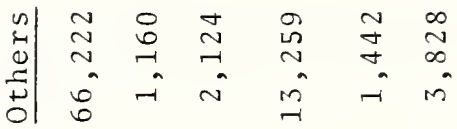

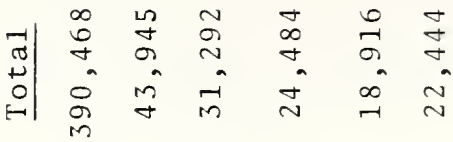

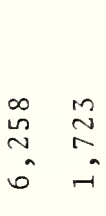

0
0
01
01
0
0
0
0

궁

岂

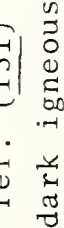

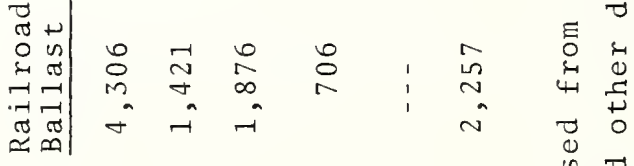

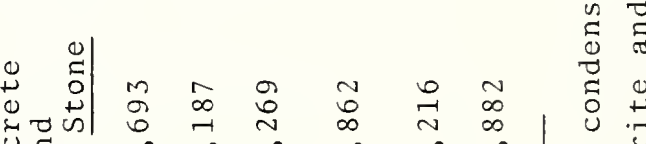
Uु

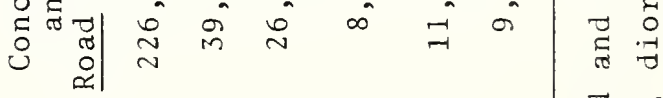

0.7

壮

ᄂ

$\succ \infty$

苂

$\nabla-$

(1).

in

药

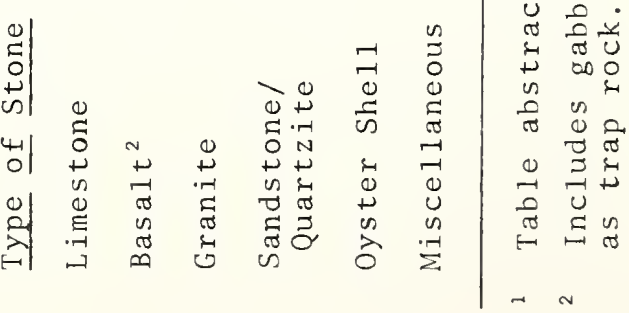




\section{Highway Aggregate Problems}

General

Although it is not the intent of this report to present a detalled treatise on the historical backgrounds, pertinent variables, and general test procedures used to ascertain quality requirements for highway aggregates; a brief overview of general aggregate problems is presented. It should be apparent to the reader versed in aggregates and their subsequent protlems, that many factors other than those associated with a particular material type are intrinsic to the designation of an aggregate as belng suitable or unsultable for use in highway construction.

Ilke the highway design engineer, who must base the structural pavement design upon the factors of traffic and environment, and their interrelationship with the foundation so1l, for a particular type (rigld or flexible) pavement; the materials engineer must likewise examine the interrelated effects of traffic, environment and pavement type on the materials (aggregate) used.

In bituminous pavement construction, there are a large number of combinations of aggregate - bituminous materials that may comprise any one of several bituminous layers. Rigid pavements generally are "simpler" as only one fundamental mix combination is utilized. Because of the fundamental differences in design concepts between a rigld and flexible pavement, the importance and role of aggregate and aggregatebinder layers within each type differs. A rigid pavement 
derives its strength primarily through the binding medium in the form of slab action. Ideally, the role of the aggregates within a concrete pavement is to serve as an inert filler. Eltuminous pavements are designed to distribute the load to the subgrade solls, and as a result, the aggregate fraction plays an increasingly important role in strength considerations.

Traffic considerations become very important in several aggregate problems, while in others, their effect is small. Such problems as abrasion and skid resistance must be evaluated in light of anticlpated traffic conditions. However, this factor is not directly related to the expansion of concrete pavements caused by several cement - aggregate chemical reactions. The role of environment upon aggregate performance is quite complex and is varlable in its effect upon aggregate evaluation. It 1s, however, generally an active consideration in most problems. Aggregate Problems

It should be realized that it is not generally possible to state that an aggregate is elther "good" or "bad" per se. However, for a given use (function) and environment (location), an overall evaluation of the aggregate quallty requirements can be accomplished.

The most general descriptor of aggregate quality is durability. Several definltions of this general problem appear in the 11 terature. Lew1s (132) states that durab111ty "... refers to the ablilty of the concrete to withstand the attack 
of natural agents of weathering and deterloration, without consideration of the structural adequancy of the materials to carry the loads to which 1 t $1 \mathrm{~s}$ subjected". Woods (142) notes that this term "...refers to the resistance of a paving mixture to disintegration by weathering or the abrasive forces of traff $1 c^{n}$. Hveem (116) in a general statement declares: "Durability means, in a broad sense, the ability of the aggregate to remain unchanged over a fairly long period of time in spite of adverse natural processes or forces to which it is subjected".

To insure aggregate durability, particularly in concrete pavement, aggregates must possess the characteristic of soundness. Soundness 1 mplies a direct resistance to the forces of weathering (142). Neville (152) states that soundness is the "...name given to the ability of an aggregate to resist excessive changes in volume as a result in changes in physical conditions. Lack of soundness is thus distinct from expansion caused by chemlcal reactions between the aggregate and the alkali in cement". These physical changes are assoc1ated with freezing - thawing, heating and cooling, and wetting and drying (152, 164).

Another desirable durability characteristic, relevant only for aggregates utllized in portland cement concrete pavements, is the absence of certain chemical reactions with the cement matrix. In general, each type of harmful chemical reaction manifests 1 tself by destructive expansion of the reactive products, eventually causing loss of pavement 
serviceability.

The most common type of reaction is the alkal1 aggregate or alkal1 - silica reaction. In essence, the alkalies in cement attack the sillceous minerals of the aggregate, forming an alkal1 - silica gel around the aggregate which has a tendency to increase in volume. This gel "... Is confined, and internal pressures result leading to expansion, cracking and disruption of the cement paste" (152). The reactive forms of silica frequently occur in opaline or chalcedonic cherts, siliceous limestones, rhyolites and rhyolitic tuffs, dacites and dacite tuffs, andesites and andesitic tuffs and phyllites ( 152 ).

A more recently discovered and less frequently occurring chemical reaction is the carbonate reaction (alkal1carbonate or dedolomitization reaction). In this case alkalles of the cement and a particular type of argillaceous, dolomitic IImestone w1Il react to form an expansive product which may lead to pavement destruction (112, 158). This reaction differs from the well known alkal1-silica type in that no visible gel or reaction products are formed (158). The characteristics of potentially reactive carbonate rocks, as postulated by Hadley, are dolomitic limestones in which: the dolomite comprises 40-60\% of the total carbonate fractIon, there is an approximate 10-20\% clay fraction, and a texture of small dolomite crystals is scattered through a matrix of extremely fine-grained calcite and clay (112). Another cement-aggregate problem, occurring only in 
the central Great Plains area of the United States, is the "sand-gravel reaction". It is quite similar to the alkal1silica reaction, except that limiting the alkal1 content of the cement within ordinary limits will not prevent excessive cracking, expansion and general deterioration. Tests and field experience have demonstrated that the deterloration can be controlled if the sand and gravel aggregates are supplemented by 25 to $40 \%$, by weight, of satisfactory coarse aggregates (171).

The final type of chemical problem is the sulphate reaction, which occurs by the formation of gypsum and calclum sulphoaluminate from a reaction of soluble sulphates with the cement pastes. The soluble sulphates may be present In the mineral aggregates (oxidation products of iron sulfides, gypsum, or aluminate-jaros1te (142)), or may occur where certain aclalc mine waters or solls containing alkal1, magnesium or calclum sulphates form an effective groundwater sulphate solution ( 152 ).

Aggregate degradation refers to the production of finer aggregates by weathering (both physical and chemical) and/or mechanlcal breakdown due to the action of mixers, mechanical equipment and/or traffic $(24,27)$. This mechanical breakdown can occur by compressive fallure from concentrated loads at points of contact between aggregates, as well as by the abrasive action of individual aggregates moving with respect to each other $(\underline{108})$. Because of the intrirsic differences in rigid and flexible pavements, this factor is of 
greater relative importance in bituminous layers (142). The resistance to degradation is commonly measured by the Ios Angeles Abrasion test. Moavenzadeh (147) found, however, that the aggregate of a bituminous mixture is more important in defining overall degradation properties than the abrasion resistance of the aggregates themselves.

Goetz (108) noted that "...stripping, or the separation of the bituminous flim from the aggregate, through the action of water, is probably the greatest single problem in durability of bituminous mixes". This problem occurs primarily with aggregate high in sillca (hydrophill1c). Rock types wh1ch are basic (rather than ac101c) generally have a great affinity for bitumen and tend to hold the coating in the presence of water (hydrophophobic).

Aggregates used in surface courses should possess a high skid or polishing resistance. Many factors affect the antiskid properties of any given surface; however, one of the more important factors is the polishing characteristics of the mineral aggregate used. Goodwin (109) has summarized the general features of aggregates that affect skid resistance. Although skidding is a problem on both portland cement and bituminous pavements, it is generaliy more magnifled in the latter because "...1t usually requires less traff1c to define the polishing characteristics of aggregates in bituminous mixtures since the degree of exposure is greater for the individual pleces of aggregate than with portland cement slirfaces" (176). In add1t1on, the sk1d resistance of 
portland cement surfaces depends primarily "... on the fine aggregate portion of the mix... a coarse aggregate with high polishing characteristics can be permitted in a mix if the mortar surface has adequate skid resistance" (89).

In general, the polishing resistance of an aggregate is directly related to the hardness of the minerals comprisIng the aggregate. Pure limestones, 1.e., pure calcium carbonate, characteristically exhibit the poorest skid resistance amone the major aggregate sources. Iimestones contain a wide variety of mineralogic compositions. Gray ( 110$)$ observes that "...blanket rejections of 11 mestone for skid resistance purposes solely because they belong to this heterogeneous trade name group may result, in many cases, in the refusal to consider perfectly adequate materials."

Solis and Related Factors

\section{So11 Origin and Texture}

Many definitions of the term soll exist within the sciences of geology and pedology as well as within Civil Engineering. Each definition intrinsically fits the particular area of interest. An engineer, moy define so11 as "... everything from rubbish to sand, gravel, silt, clay, shale, partly cemented sandstone, soft or badly shattered rock; everything except solid rock" (211). The slaking test is ordinarily applied to distinguish solid rock, but there will obviously be a number of borderline cases.

An 1mportant aspect of solis is their mode of origin, 
1.e., transported or non-transported. Transporting agencies are 1ce, water, wind and combinations. Non-transported so1is have been residually develcped by the combination of their physical and chemical environments. Detalled explanations of each mode of origin can be found in many readily avaliable reports (214, 236, 237, 248, 222, 225).

Solis may be divided into slze fractions, and the relative amount of these fractions determines the overall descriptor of texture. Particle size distribution or texture is the basis of certain classification schemes viz., the U. S. Department of Agriculture, and forms a basic portIon of the Pedologic Soll Classiflcation system. In general, the major limitations of such systems for engineering purposes lies in their fallure to ldentify or measure the relative plasticity characteristics imparted by the clay size fraction. Stating this in another way, two samples of clay possessing an equivalent distribution of clay sizes may vary considerably in their engineering performance due to differences in the type of clay minerals present.

As a consequence, common engineering soll classiflcations ccmbine textural and plasticity evaluations, e.g., Unifled, AASHO and FAA SO1I Classification systems. Excellent reviews on the merits of the various classification systems have been presented by IIu (244) and Wahls and Futrell (293). Poor Subgrade Support Areas

In general, the finer the soll texture and/or the greater the plasticity characteristics of the soll, the 
poorer the anticipated performance of this material as a subgrade for a highway or alrfield pavement. The effect of so11 type upon structural pavement analysis must be evaluated in detall against such design factors as type of pavement, traffic considerations and environmental factors. However, it can be stated that due to the relative differences in stress distributing characteristics between a rigid and flexible pavement system, the effect of subgrade support is more important in a layered flexible pavement than a rigid pavement (213).

As defined in this report, the term organic deposit refers to peat bogs, muck lands, and assoclated swamps and tidal marshes. Areas of organic terrain called muskeg may also be included although this term is usually reserved for the widespread but relatively thin accumulations common north of the U.S.. Various definitions for each of these categories of organic terrain have been stated in the I1terature (296). In essence, they are orlmarily connected w1th various stages of vegetative decomposition and/or high water levels which elther saturate most of the ground or completely cover the area in question.

Organic materials are not used in embankments. Cther Froblem materials are avolded for subgrade use as well. Because of their low topographic position, organic foundations for embankments are potentlally numerous. A comprehensive technology exists for the handling of such so-called "soft ground" problems. These range from relocation to avold them, 
through compressing them in place, to excavation and displacement, and, in rare instances, bridging with a "peat trestle".

\section{High Volume Change So11s}

Throughout many areas of the Unlted States, a very important highway design consideration is the swelling and shrinking of subgrades and foundation solls. The two most important prerequisites for potentially high volume changes are the presence of a relatively active clay structure and a combination of climatic conditions which allow altemate drying and saturation of the soll to occur to appreciable depths.

Swelling pressures vary greatly, but, in general, the relatively light "surcharge" of a highway pavement does not afford enough of a counter pressure to prevent volume change. As a result, highway pavements are subject to severe damage through cyclic heaving (swell) and loss of support (shrinkage).

Frost Action and Frost Susceptible Solis

Another 1mportant facet of highway design deals with the problems assoclated with frost action. This problem generally manifests 1 tself in two effects: those induced during the cold or freezing period (heave), and those assoclated with the warmer melting perlod (reduced strength).

Detrimental frost action requires three conditions:

(a) freezing temperatures, (b) frost susceptible so1ls, and (c) a source of water (298). Major heaving due to 1 ce lense 
formation may be expected if a highly susceptible soll is frozen slowly, with water readily avallable.

In general design analysis, the air freezing index (FI) is of ten used to quantify the magnitude and duration of cold effects at the site. Frost susceptible solls are generally defined as those solls having greater than 3 to 10 by welght, finer in size than $0.02 \mathrm{~mm}(243)$. For purposes of appraising the relative frost susceptibli1ty among solis, the Corps of Engineers has adopted the Frost Rating Class1flcation system. Ratings range from an F-1, Indicative of the least frost susceptible solls (gravelly solls with between 3 to $20 \%$ finer than $0.02 \mathrm{~mm}$ in size), to an F-4, indicative of the most susceptible solls (s1lts, lean clays, varved clays, etc.).

The problem of reduced strength is accentuated by deep freezing penetration. As thawing proceeds at shallow depths, dralnage may be effectively prevented by the underlying still-frozen zone. Since the water present in this zone may be of greater volume than before freezing, due to lce lense growth, the supporting capacity of the subgrade may be dramatically lowered. 


\section{INVESTIGATION PROCEDURES}

\section{General}

The basic approach to achleve the previously defined objectives was to map either materials or the incidence of a potential highway engineering factor or problem for the U.S. or some part thereof. Whenever feasible, the severity of a problem was also rated. Significant input was derived from the sciences of physlography (geomorphology), geology, pedology and climatology, as well as engineering experience. This input was interpreted, summarized and represented in a form deemed most sultable for the unique needs of the highway engineer.

However, while the concept of generalization is simple, its practical implementation in anything approaching optimal form is a most difficult matter. Of foremost concern is the cholce of an approprlate level for the generalization. Broad generalizations have limited predictive capabilities; Ilmited or local geographic generalizations require almost as much efiort as speciflc job-location descriptions, and, are difficult to justify economically as a separate step. The course of action adopted in this study was to accept the reglonal physlographic Section as the base unit for generalization. 
The source information varied widely in quantity (and probably in quality as well) from section to section. Since the author was almost wholly dependent upon the expressed opinions of others, as extracted from maps, reports, and questionnalres, the validity of his inferences is variable. Another factor which worked to reduce the overall reliability of the conclusions is the scope of the study. In dealing with over three million square miles of geography, and with a multitude of highway factors, no one area or factor recelved the attention that a researcher would intrinsically desire. It remains for further studies to reexamine the conclusions with a concentration on certain areas and/or ractors.

\section{Reglonal Geomorphology}

Information concerning the physlographic and geologic characteristics of the reglonal unlts was based heavily, though not ent1rely, upon the writings of Fenneman (18, 19), Lobeck ( 38$)$, Thornbury ( $\underline{65})$, and Woods-Lovell (2). Much valuable information concerning the particular characteristics of many Sections were obtained from many other individual references such as (21) and (84).

The quantity of physlographic mapping avallable at a continental or national scale was known to the author, but an uncertainty existed as to the avallablilty of larger scale work. Accordingly, a reasonably comprehensive mapping search was conducted. As a result of this effort the following 
Information was located: 40 state physlographlc dlagrams for 30 states; one new Province dlagram; and 6 Subsection diagrams. 1 In several instances, two or three different physiographic interpretations of a glven state were located.

The detalled mapping can be placed in one of two broad grouplngs, directly physlographlc, and indirectly physlograph1c. In the second category are the Agricultural Iand Resource maps, which are dellneated utllizing not only phys10graph1c concepts but also the relation of land use and management to the factors of soll, cllmate and topography. In numerous instances, the "physlograph1c" boundarles were those shown on a land resource or pedolog1c map.

In addition to the mappling search, a falriy detalled examination of the physlographic boundarles of the basic report units was undertaken.

\section{Highway Design and Construction Factors}

\section{Aggregates}

\section{Major objectives}

The overall objectives of this phase of the project were to investigate the type and distribution of aggregates used in the United States, and to obtain information concernIng any quality problems or $11 \mathrm{mltat}$ tons inherent to these aggregates. From this, a qualitative estimate was formed of

1. For purposes of brevity, these diagrams are not included, although many have been used for the Recommended H1ghway Engineering-Physiographic Unit System proposed in the Summary and Conclusions. 
the potentlal avallability of quality aggregate resources within each of the report sections.

Methods of Analysis

General

The analysis was comprised of three phases: 1dent1flcation and mapping of potential aggregate sources; 1dent1flcation and correlation of quality problems with the sources, based upon the 11terature; and collection of current englneerIng experlence through questionnalres directed to each state highway agency.

Mapping

The major types of aggregates mapped were sand-gravel sources and crushed-stone sources. The latter were subdivided into carbonate rocks, granitic/metamorphic complexes, and other igneous (primarlly basaltic type) rocks. Several extant state or reglonal maps of real or potential sources were located in the i1terature. References (20, 102, 166, 169, 172) were particularly valuable. Where such information was not located, the author attempted to derive 1t from sources such as generalized state or regional geologic maps, originparent materlal diagrams, and aggregate production data.

The total output of individual counties ${ }^{1}$ producing sand-gravel and/or crushed stone (1rrespectlve of type) was obtained and plotted for 1964 from reference (182). In addition, state productions of sand-gravel and crushed stone were obtained and mapped on the basis of output ratio of sand-gravel 1. Or parishes in Lou1s lana 
to crushed stone. This information was obtained from references (125, 189). The factors of population and market demand obviously influence such data, but they did supply perspective and guldance in certain areas where such was otherwise lacking.

\section{Aggregate Problems}

Many aggregate problems are ldent1fled and described in the 11terature, particularly reference (144). This information was supplemented by that obtained through the materials questionna1re.

Materials questionnaire

The questionnalre responses provided a current resume relative to aggregate types, uses, qual1ty and ava11ab111ty. A sample response (from the state of M1ssour1) is shown in Append1x A.

The questionnalre was written for coded answers that could be applied to the basic Sections with a minimum of effort. It was composed of seven basic questions and three enclosures. The questionnalre was malled to each state with Column 1 (materlal type) of Enclosure 1 completed. This In1t1al listing of probable aggregate type was based primar$11 y$ on an examination of the non-matal11c"mineral industry summary for each state in reference (188). Beferences (169) and (I72) provided supplementary information.

Several general problems common to the physlcal and chemical properties of aggregates used in both concrete and bituminous pavements are Iisted in Question III. This 
problem listing is not all inclusive in nature, nor is each problem unique in itself. For example, the chemical reactions for concrete aggregates would also be considered a durability problem. Another code permitted the respondent to rate the relative severtty of any reported problem. Question IV dealt with the general functional uses of each aggregate type.

Answers to Questions I thru IV were recorded in specifled forms on Enclosure I. Therefore this enclosure provides a summation, with respect to basic report units, of aggregate uses, problems, and problem severitles.

Question $V$ asked the respondent to indicate on Enclosure 3 the approximate boundaries of areas lacking in sultable aggregates. Questions VI and VII attempted to identify areas where the avallabll1ty of aggregates and/or cementing medium played a major role in the selection of pavement type (portland cement or bituminous).

General I1mitations of Analysis

Practical IIm1 tations

Input information on aggregates was interpreted for mapping, according to physiographic units. There are several difficulties inherent to such an interpretation.

For example, aggregates can be quarried in one physlograph1c un1t and transported for use (and subsequent performance) in another unit. Although the author attempted to remove this factor from his interpretations, it was not always possible to do so with confidence. Population densities, and 
the consequent relative demand for aggregates, introduces an additional problem. The natural tendancy is to overestimate the aggregate avallability in high density areas and to underest1mate the potential where the density is low. St1ll another factor is the relative size and shape of the physlographic units. A small unit may be inherently impoverished in aggregate sources due to 1 ts geology, but the existance of quallty sources in an adjacent unit effectively negates the potential. shortage. The large unit, on the other hand, may contain enough geologic varlability to admlt both potential abundance and scarcity, depending on the local area. Mapping IImitations

The several different methods of mapping aggregate factors have been previously noted. As pointed out, there were several broad geographic areas where the author's def1nition of potentlal aggregate areas was very qualltative.

In addition, because of the extreme varlability in characteristics and performance of crushed sandstone, combined with the limited information concerming actual production of crushed sandstone, the mapping of sandstone redrock areas as potential sources was not undertaken on a national scale.

Another very 1mportant and limiting factor concerns the distribution of sand-gravel sources. An attempt was made to map major potential river and stream deposits in adition to areas assoclated with other modes of origin. However, since stream deposits can be quite localized, they will not 
show on any but a very large scale map. (Since tnis difflclilty is encountered to some degree with all aggregate types, the Eeneralized source mapping must be supplemented with at least as much information as is contalned in the unit descriptions of this text.)

Quality I1mitations

The criterla of aggregate acceptance or rejection is dependent not only upon the particular specifications of a given jurisdictional unit, e.g., state, but also upon the particular use of the aggregate. As a consequence, a part1cular aggregate source may be acceptable for a given use in one portion of the country while in another location it cculd be rejected. Differences in service environments account for a part of the discrepancy whlle relative scarcity of aggregates, and simple differences in opinion also contribute. As a great deal of information concerning aggregate problems was obtained from state units and then transformed for the basic report units, the factor of differing criteria between jurisdictional units should be kept in mind.

\section{Solls and Related Factors}

\section{So11 Origin and Texture}

Yajor Object1ve

The major objective of this phase of the study was to map a generalized distribution of soll orlgin and texture for the U.S., and accordingly, to define (to a rather small scale) the distributions within each report unit. 
Method of Analysis

For the examination of the factor of soll origin, primary emphasis was placed on the work conducted by Jenkins et. al. (234). Numerous other ind1v1dual state references, maps, and regional geomorphic descriptions provided supplemental information.

The generalized so1l textural map of the United States was developed to a scale of $1: 2,500,00$ which corresponded to the scale of the national geologic map (269) as weII as the pedologic map of the U.S. by the U.S.D.A. (23I). Many references were consulted in the preparation of the map. Principal among these were distribution reports and maps developed for national, reglonal, or state coverage. Within the national group were references $(\underline{232}, \underline{236}$, 250, 279, 295, 296). Reglonal soll references were avallable for the western Un1ted States (294), north central region (227), southeast region (287) and the northeastern United States (263). Many individual state so11 maps were also heav1Iy used for soll data. The references varled widely in content and in data of preparation, e.g., only old coverage was ava1lable for some geographic areas (246, 247), while very mojern information was located for others (22?, 289).

The mapplng technique was to retain as much detalied soll information as practicable. This, in part, is the reason for the wide variety of legended soll units contained in the map. In many areas, only a very qualitative assessment of the soll conditions could be made due to the I1mited information 
ava1lable.

Every attempt was made to distinguish and map the general texture of the parent material. Within residual so1l areas, this information was not always possible to ottain, and major emphasis was placed on the general texture in the subsoll ( $B$ horizon) as well as the weathered parent. materials. Perhaps the most obvious limitation of this mapping technique is the possible obscuring of a highly clayey type of $B$ horlzon which may produce special highway problems. Within each basic report unit, a qualitative assessment was made of the frequency of occurrence of each major soll type. This analysis was based primarily upon the results of the generalized mapping.

Poor Subgrade Support Areas

Major Cbjective

The major purpose of this phase of the project was to rate for each section the combined severity-frequency of occurrence of highly clayey solls, and the frequency of occurrence of organic deposits. Method of Analysis

The qualitative assessment of poor subgrade areas within each unit was based primarily upon an examination of the national textural map and supplementary soll descriptions. High Volume Change So11s

Major orjective

In this phase of the project, the major purpose was to assess qualitatively the relative frequency of occurrence 
of high volume change solls within the Sections. vethods of Analysis ${ }^{1}$

Three sources of input were avallable: (1) reports in the literature of occurrences of high volume change protlens within the Continental United States; (2) predictions of swelling solis in pedologlc mapping and (3) predictions from geol.cg10 mapping. Two a1stritution maps were drawn; one based upon the pedolog1c input, and one for the geologic inf'crmation.

Frequency of occurrence was qualitatively assessed for each method of analysis (pedologlc and geologic), within each section. A final rating of high volume change frequency within each unit was taken as the higher rating given by the two methods of analysis. 2

Characteristics of the Analysis

The geolog1c and the pedolog1c-based mapplngs reflect the potential of the mapped unit to produce sweling problems, but do not attempt to rate the degree of the potential. The generalized prediction is also significantly influenced by the scale of the mapping. Reported problems of swelling difficulties with engineering structures confirm that the potential has been realized by interaction with the cilmatic and loading environment.

1. The description provided is a combination of the author's effort with that of H. P. Jensen (333).

2. Several exceptions occurred in areas of surficlal transported materials underlain by potential high volume change geologlc formations. A detalled discussion of these areas is presented under Results. 
Erest Action and Erost Susceptible So11s

Major Cbjective

The frequency of occurence was determined for frost susceptible so1I groupings within the Sections generally lying within the freezing zone. No rating was attached to the severity of subsequent frost problems. Nethods of Analysis

The definition of that portion of the Continental U.S. In which freezing is potentlally a significant problem was based upon the work of Sourwine (20). The boundaries suggested by Sourwine were compared with the Section borders, and the Sections were placed wholly, (a) within the frost zone, or (b) outside the frost zone.

In order to ascertain the distribution of frost susceptible soils within the previously defined freezing zone, a composite map was developed, based upon the work of Bloom (20) and csborne (166). The resultant mapolng covered twentynine northern states and a portion of Maryland. This map covered most but not all of the area within Sections previously defined as lying within the frost zone. The author rated the frequency of occurrence of frost susceptible so1 is in each Section by combining the methods of Bloom $(20)^{2}$, with an examination of the generalized soll textural map of the United

1. Bloom (90), after work by Haas, and using the Corps of Englnee $\overline{r s}$ system, considered sands and loamy sands as F-2; silty clay loam, clay loam, silty clay and clay as F-3 and sandy loam, loam, silt loam and silt as F-4. 
States.

Characteristics of the Analysis

Several minor difficulties were introduced by the differing generalizations effected by Bloom, Csborne and the author. In many cases, continuity of frost susceptible sol I type was not maintained through political borders and the author subsequently modified many of these areas to achieve 1t. Numerous other small difflculties had to be resolved, e. g., differences in base maps, boundarles, so11 units generalized and the $11 \mathrm{ke}$. 
RESUITS

\section{Ihys 1cgraphy (Geomorpholcgy)}

Summary of Easic Report Units

Description and Location

Tre basic physlographic units were bounded and named in essentlally the form suggested by Woods and Iovell (82). Table 4 lists each basic report Province and section, and provides an alpha-numeric code for identification.' Table 5 keys the sections to the states of the U.S. Indiv1dual Frovince and Section diagrams are contained within Appendix D.

Areas

Approximate areas of each Section and Province were determined by planimetering a national map with a scale of 1:5,000,000. The area of the U.S. (exclusive of Hawa11 and Alaska) was taken as $3,022,396$ square miles (26). Table 6 summarlzes area data keyed to the unit code of Table 4. Geomorphic Characteristics

Table 7 summarlzes the general geomorphic characteristics of each report section. This table is not meant to

1. This alpha-numerlc code is frequently used throughout the text. It differs from the references by lacking the underI1ne. For example (18) is a reference, while (18) is a unit identification code. 
Table 4

Physiographic Unit Code

1. Western Mountains of the Pacific Coast Range Province

a. Olympic Mountain Section

b. Oregon Coast Range Section

c. Klamath Mountain Section

d. California Coast Range Section

e. Los Angeles Range Section

2. Sierra - Cascade Province

a. Northern Cascade Mountain Section

b. Southern Cascade Mountain Section

c. Sierra Nevada Section

d. Lower California Section

3. Pacific Troughs Province

a. Puget Sound Section

b. Willamette Valley Section

c. California Valley Section

4. Columbia Plateau Province

a. Walla-Walla Section

b. Blue Mountain Section

c. Snake Rivet Plains Section

d. Payette Section

e. Harney Section

5. Basin and Range Province

a. Great (Closed) Basin Section

b. Sonoran Desert Section

c. Salton Trough Section

d. Open Basin (Mexican Highland) Section

e. Sacramento Highland Section

f. Great Bend Highland Section

6. Colorado Plateau Province

a. High Plateaus of Utah Section

b. Uinta Basin Section

c. Canyon Lands Section

d. Navajo Section

e. Grand Canyon Section

f. Datil Section

7. Northern Rocky Mountain Province

a. Montana Section

b. Bitteroot Section

c. Salmon Rivet Section

8. Middle Rocky Mountain Province

a. Yellowstone Section

b. Bighorn Mountain Section

c. Wind Rivet Mountain Section

d. Wasatch Section

e. Uinta Mountain Section

9. Southern Rocky Mountain Province

a. Front Range

b. Western Section

c. San Juan Mountain Section

10. Great Plains Province

a. Glaciated Missouri Plateau Section

b. Unglaciated Missouri PIateau Section

c. Bighorn Basin Section

d. Wyoming Basin Section

e. Black Hills Section

f. High Plains Section

g. Colorado Piedmont Section

h. Raton Upland Section

i. Pecos Valley Section

j. Plains Border Section

k. Central Texas Mineral Section

1. Edwards Plateau Section

m. Osage Plains Section

Note: Numbers Represent Physiographic Provinces Letters Represent Physiographic Sections
11. Central and Eastern Lowlands Province

a. St. Lawrence Lowland Section

b. Champlain Lowland Section

c. Hudson River Valley Section

d. Mohawk River Valley Section

e. Eastern Lakes and Lacustrine Section

f. Central Till plain Section

g. Driftless Section

h. Western Lakes and Lacustrine Section

i. Dissected Loessial and Till Plain Section

12. Laurentian Upland Province

a. Superior Upland Section

b. Adirondack Section

13. Ozark and Ouachita Province

a. St. Francois Mountain Section

b. Springfield-Salem Plateau Section

c. 1. Boston Mountain Section

2. Arkansas Valley Section

3. Ouachita Mountain Section

14. Interior Low Plateaus Province

a. Blue Grass Section

b. Nashville Basin Section

c. Shawnee Hills Section

d. Highland Rim Section

15. Appalachian Plateau Province

a. Catskill Mountain Section

b. New York Glaciated Section

c. Allegheny Mountain Section

d. Kanahwa Section

e. Cumberland Section

16. Newer Appalachian (Ridge and Valley) Province a. Pennsylvania-Maryland-Virginia Section

b. Tennessee Section

17. 01der Appalachian Province

a. Blue Ridge Section

b. Piedmont Section

18. Triassic Lowland Province

19. New England Maritime Province

a. Seaboard Lowland Section

b. New England Upland Section

c. Connecticut Lowland Section

d. White Mountain Section

e. Green Mountain Section

f. Taconic Section

g. Reading Prong Section

20. Atlantic and Gulf Coastal Plain Province

a. Embayed Section

b. Sea lsiand Section

c. Florida Section

d. East Gulf Section

e. Mississippi Loessial Upland Section

f. Mississippi Alluvial Plain Section

g. West Gulf Section 
Table 5

Occurrence of Physiographic Sections

Within States

State

Al abama

Arizona

Arkansas

California

Colorado

Connecticut

Delaware

Florida

Georgia

Id aho

Illinois

Indiana

lowa

Kansas

Kentucky

Louisiana

Maine

Maryland

Massachusetts

Michigan

Minnesota

Mississippi

Missouri

Montana

\section{Physiographic Unit Code ${ }^{1}$}

$14 \mathrm{~d} ; 15 \mathrm{e} ; 16 \mathrm{~b} ; 17 \mathrm{~b} ; 20 \mathrm{~d}$.

$$
5 a, b, c, d ; 6 d, e, f \text {. }
$$$$
13 b, c 1, c 2, c 3 ; 20 f, g \text {. }
$$

$1 c, d, e ; 2 b, c, d ; 3 c ; 5 a, b, c$.

$6 b, c, d ; 8 e ; 9 a, b, c ; 10 d, g, h, f$.

$$
19 b, c, f \text {. }
$$

$17 b ; 20 a$.

$$
20 \mathrm{~b}, \mathrm{c}, \mathrm{d} \text {. }
$$

$15 \mathrm{e} ; 16 \mathrm{~b} ; 17 \mathrm{a}, \mathrm{b} ; 20 \mathrm{~b}, \mathrm{~d}$.

$$
4 a, b, c, d ; 5 a ; 7 a, b, c ; 8 a, d \text {. }
$$

$11 \mathrm{e}, \mathrm{f}, \mathrm{g}, \mathrm{i} ; 14 \mathrm{c} ; 20 \mathrm{~d}$.

$11 \mathrm{e}, \mathrm{f} ; 14 \mathrm{a}, \mathrm{c}, \mathrm{d}$.

$11 \mathrm{~g}, \mathrm{~h}, \mathrm{i}$.

$10 f, j, m ; 11 i$.

$14 \mathrm{a}, \mathrm{b}, \mathrm{c}, \mathrm{d} ; 15 \mathrm{~d}, \mathrm{e} ; 20 \mathrm{~d}, \mathrm{e}, \mathrm{f}$.

$20 d, e, f, g$.

$19 a, b, d$.

$15 \mathrm{c} ; 16 \mathrm{a} ; 17 \mathrm{a}, \mathrm{b}, ; 18 ; 20 \mathrm{a}$.

$19 a, b, c, e, f ; 20 a$.

$11 \mathrm{e} ; 12 \mathrm{a}$.

$11 \mathrm{~g}, \mathrm{~h}, \mathrm{i} ; 12 \mathrm{a}$.

20d,e,f.

$10 \mathrm{~m} ; 11 \mathrm{i} ; 13 \mathrm{a}, \mathrm{b} ; 20 \mathrm{f}$.

$7 a, b ; 8 a, b ; 10 a, b, c$. 
Table 5 (cont'd.)

State

Nebraska

Nevada

New Hampshire

New Jersey

New Mexico

New York

North Carolina

North Dakota

Ohio

Oklahoma

oregon

Pennsylvania

Rhode Is 1 and

South Carolina

South Dakota

Tennessee

Texas

Utah

Vermont

Virginia

Washington

West Virginia

Wis cons in

Wyoming

Physiographic Unit Code

$$
\begin{aligned}
& 10 \mathrm{~b}, \mathrm{f}, \mathrm{j} ; 11 \mathrm{i} \text {. } \\
& 2 c ; 4 c, d ; 5 a, b \text {. } \\
& 19 \mathrm{a}, \mathrm{b}, \mathrm{d} \text {. } \\
& 11 \mathrm{c} ; 18 ; 19 \mathrm{~g} ; 20 \mathrm{a} . \\
& 5 \mathrm{~d}, \mathrm{e} ; 6 \mathrm{~d}, \mathrm{f} ; 9 \mathrm{a}, \mathrm{b}, \mathrm{c} ; 10 \mathrm{f}, \mathrm{h}, \mathrm{i} \text {. } \\
& 11 \mathrm{a}, \mathrm{b}, \mathrm{c}, \mathrm{d}, \mathrm{e} ; 12 \mathrm{~b} ; 15 \mathrm{a}, \mathrm{b}, \mathrm{d} ; 18 ; 19 \mathrm{~b}, \mathrm{f}, \mathrm{g} \text {. } \\
& 17 \mathrm{a}, \mathrm{b} ; 20 \mathrm{a}, \mathrm{b} \text {. } \\
& 10 \mathrm{a}, \mathrm{b} ; 11 \mathrm{~h} \text {. } \\
& 11 \mathrm{e}, \mathrm{f} ; 14 \mathrm{a} ; 15 \mathrm{~b}, \mathrm{~d} \text {. } \\
& 10 f, j, m ; 13 b, c 1, c 2, c 3 ; 20 \mathrm{~g} \text {. } \\
& 1 b, c ; 2 b ; 3 b ; 4 a, b, d, e ; 5 a \text {. } \\
& 11 \mathrm{c}, \mathrm{e} ; 15 \mathrm{~b}, \mathrm{c}, \mathrm{d} ; 16 \mathrm{a} ; 17 \mathrm{a}, \mathrm{b} ; 18 ; 19 \mathrm{~g} ; 20 \mathrm{a} \text {. } \\
& 19 a, b \text {. } \\
& 17 \mathrm{a}, \mathrm{b} ; 20 \mathrm{~b} \text {. } \\
& 10 \mathrm{a}, \mathrm{b}, \mathrm{e}, \mathrm{f} ; 11 \mathrm{~h}, \mathrm{i} \text {. } \\
& 14 \mathrm{~b}, \mathrm{~d} ; 15 \mathrm{e} ; 16 \mathrm{~b} ; 17 \mathrm{a} ; 20 \mathrm{~d}, \mathrm{e}, \mathrm{f} \text {. } \\
& 5 \mathrm{~d}, \mathrm{e}, \mathrm{f} ; 10 \mathrm{f}, \mathrm{i}, \mathrm{j}, \mathrm{k}, \mathrm{l}, \mathrm{m} ; 20 \mathrm{~g} \text {. } \\
& 5 \mathrm{a} ; 6 \mathrm{a}, \mathrm{b}, \mathrm{c}, \mathrm{d}, \mathrm{e} ; 8 \mathrm{~d}, \mathrm{e} \text {. } \\
& 11 b ; 19 b, d, e, f \text {. } \\
& 15 \mathrm{~d}, \mathrm{e} ; 16 \mathrm{a}, \mathrm{b} ; 17 \mathrm{a}, \mathrm{b} ; 18 ; 20 \mathrm{a} \text {. } \\
& 1 \mathrm{a}, \mathrm{b} ; 2 \mathrm{a}, \mathrm{b} ; 3 \mathrm{a} ; 4 \mathrm{a}, \mathrm{b} ; 7 \mathrm{~b} \text {. } \\
& 15 \mathrm{c}, \mathrm{d} ; 16 \mathrm{a} ; 17 \mathrm{a} \text {. } \\
& 11 \mathrm{e}, \mathrm{f}, \mathrm{g} ; 12 \mathrm{a} \text {. } \\
& 7 \mathrm{a} ; 8 \mathrm{a}, \mathrm{b}, \mathrm{c}, \mathrm{d} ; 9 \mathrm{a}, \mathrm{b} ; 10 \mathrm{~b}, \mathrm{c}, \mathrm{d}, \mathrm{e}, \mathrm{f} \text {. }
\end{aligned}
$$

Note: 1. See Table 4 for description of Physiographic Unit Code 
Table 6

Area Summary of Basic Report Units

\% U.S.

$\frac{\text { Province }}{1} \frac{\text { Land }}{3.4}$

Section Province Sq. Miles 102,760

a

6.9

14.9

$\begin{array}{ll}\text { c } & 19.5 \\ \text { d } & 37.5\end{array}$

$\begin{array}{ll}\text { c } & 19.5 \\ \text { d } & 37.5\end{array}$

e 21.2

7,090

b

15,300

20,040

38,540

$\frac{21,790}{102,760}$

2

3.0

90,670

\begin{tabular}{rrr} 
a & 17.8 & 16,140 \\
b & 39.4 & 35,720 \\
c & 35.3 & 32,010 \\
d & 7.5 & 6,800 \\
\hline & & 90,670
\end{tabular}

3

1. 4

42,310

$\begin{array}{ll}\mathrm{a} & 34.3 \\ \mathrm{~b} & 11.1 \\ \mathrm{c} & 54.6\end{array}$

14,510

4,700

$\frac{23,100}{42,310}$

4

3.8

114,850

$\begin{array}{ll}\mathrm{a} & 36.6 \\ \mathrm{~b} & 16.6 \\ \mathrm{c} & 15.1 \\ \mathrm{~d} & 17.9 \\ \mathrm{e} & 13.8\end{array}$

42,040

19,060

17,340

20,560

$\frac{15,850}{114,850}$

5

$12.0 \quad 362,690$

$\mathrm{a}$
$\mathrm{b}$
$\mathrm{c}$
$\mathrm{d}$
$\mathrm{e}$
$\mathrm{f}$

48.4

15.1

2.9

22.6

6.4

4.6

$$
\begin{array}{r}
175,540 \\
54,770 \\
10,520 \\
81,970 \\
23,210 \\
16,680 \\
\hline 362,690
\end{array}
$$


Table 6 (cont'd.)

\% U.S. $\quad \%$ of $\frac{\text { Province }}{6} \frac{\text { Land }}{4.1} \quad \frac{\text { Sq. Miles }}{123,920} \quad$ Section Province Sq. Miles

\begin{tabular}{rrr}
$\mathrm{a}$ & 13.2 & 16,360 \\
$\mathrm{~b}$ & 10.2 & 12,640 \\
$\mathrm{c}$ & 21.8 & 27,010 \\
$\mathrm{~d}$ & 27.0 & 33,460 \\
$\mathrm{e}$ & 20.3 & 25,160 \\
$\mathrm{f}$ & 7.5 & 9,290 \\
\hline & & 123,920
\end{tabular}

$\begin{array}{lll}7 & 3.5 & 105,780\end{array}$

\begin{tabular}{llr} 
a & 41.4 & 43,800 \\
$\mathrm{~b}$ & 32.6 & 34,480 \\
$\mathrm{c}$ & 26.0 & 27,500 \\
\hline & & 105,780
\end{tabular}

$8 \quad 1.5 \quad 45,340$

\begin{tabular}{rrr}
$\mathrm{a}$ & 24.8 & 11,250 \\
$\mathrm{~b}$ & 20.7 & 9,380 \\
$\mathrm{c}$ & 7.9 & 3,580 \\
$\mathrm{~d}$ & 37.8 & 17,140 \\
$\mathrm{e}$ & 8.8 & 3,990 \\
\hline & & 45,340
\end{tabular}

$9 \quad 2.0 \quad 60,450$

\begin{tabular}{lll}
$\mathrm{a}$ & 41.7 & 25,210 \\
$\mathrm{~b}$ & 37.2 & 22,490 \\
$\mathrm{c}$ & 21.1 & 12,750 \\
\hline & & 60,450
\end{tabular}

$10 \quad 21.6 \quad 652,840$

$\begin{array}{rrr}\text { a } & 11.2 & 73,120 \\ \mathrm{~b} & 18.9 & 123,390 \\ \mathrm{c} & 0.6 & 3,920 \\ \mathrm{~d} & 5.4 & 35,250 \\ \mathrm{e} & 1.0 & 6,530 \\ \mathrm{f} & 20.4 & 133,180 \\ \mathrm{~g} & 4.0 & 26,110 \\ \mathrm{~h} & 2.1 & 13,710 \\ \mathrm{i} & 4.4 & 28,720 \\ \mathrm{j} & 6.1 & 39,820 \\ \mathrm{k} & 3.2 & 20,890 \\ \mathrm{l} & 5.7 & 37,220 \\ \mathrm{~m} & 17.0 & 110,980 \\ & & 652,840\end{array}$


Table 6 (cont'd.)

\begin{tabular}{|c|c|c|c|c|c|}
\hline Province & $\begin{array}{l}\% \text { U.S. } \\
\text { Land } \\
\end{array}$ & Sq. Miles & Section & $\begin{array}{c}\quad \% \text { of } \\
\text { Province } \\
\end{array}$ & Sq. Miles \\
\hline 11 & 13.0 & 392,910 & $\begin{array}{l}a \\
b \\
c \\
d \\
e \\
f \\
g \\
h \\
i\end{array}$ & $\begin{array}{r}0.5 \\
0.7 \\
1.0 \\
0.6 \\
22.4 \\
21.7 \\
5.2 \\
25.1 \\
22.8\end{array}$ & $\begin{array}{r}1,960 \\
2,750 \\
3,930 \\
2,360 \\
88,010 \\
85,260 \\
20,430 \\
98,630 \\
89,580 \\
\end{array}$ \\
\hline & & & & & 392,910 \\
\hline 12 & 2.4 & 72,540 & $\begin{array}{l}\mathrm{a} \\
\mathrm{b}\end{array}$ & $\begin{array}{l}87.6 \\
12.4\end{array}$ & $\begin{array}{r}63,550 \\
8,990\end{array}$ \\
\hline 13 & 2.2 & 66,490 & $\begin{array}{l}\mathrm{a} \\
\mathrm{b} \\
\mathrm{c} 1 \\
\mathrm{c} 2 \\
\mathrm{c} 3\end{array}$ & $\begin{array}{r}5.7 \\
55.4 \\
8.4 \\
12.8 \\
17.7\end{array}$ & $\begin{array}{r}3,790 \\
36,840 \\
5,580 \\
8,510 \\
11,770 \\
66,490\end{array}$ \\
\hline 14 & 1.7 & 51,380 & $\begin{array}{l}\mathrm{a} \\
\mathrm{b} \\
\mathrm{c} \\
\mathrm{d}\end{array}$ & $\begin{array}{r}16.3 \\
5.6 \\
32.2 \\
45.9\end{array}$ & $\begin{array}{r}8,380 \\
2,880 \\
16,540 \\
23,580 \\
51,380\end{array}$ \\
\hline 15 & 3.4 & 102,760 & $\begin{array}{l}a \\
b \\
c \\
d \\
e\end{array}$ & $\begin{array}{r}3.2 \\
21.9 \\
10.4 \\
44.7 \\
19.8\end{array}$ & $\begin{array}{r}3,290 \\
22,500 \\
10,690 \\
45,930 \\
20,350 \\
102,760\end{array}$ \\
\hline
\end{tabular}

16

1.5

45,340

\begin{tabular}{lll}
$\mathrm{a}$ & 57.4 & 26,020 \\
$\mathrm{~b}$ & 42.6 & 19,320 \\
\hline & & 45,340
\end{tabular}


Table 6 (cont'd.)

Province $\stackrel{\circ \text { U.S. }}{ }$ Land $\quad$ Sq. Miles Section Province

17

3.0

90,670

$\begin{array}{ll}\text { a } & 21.8 \\ \text { b } & 78.2\end{array}$

Sq. Miles

0.2

6,040

None

$$
6,040
$$

19

2.3

69,520

a

17.0

51.5

11,820

b

2.7

35,800

c

16.2

1,880

7.6

11,260

e

2.5

5,280

1,740

g

2.5

$\frac{1,740}{69,520}$

20

14.0

423,140

Grand

Totals

$100.0 \quad 3,022,400$

8.0

12.6

8.2

21.8

5.4

10.8

33.2

33,850

53,330

34,680

92,240

22,860

f

45,700

g

$\frac{140,480}{423,140}$

$3,022,400$ 
Table?

Geomorph1c Sumary of Physlographlc Sectiona

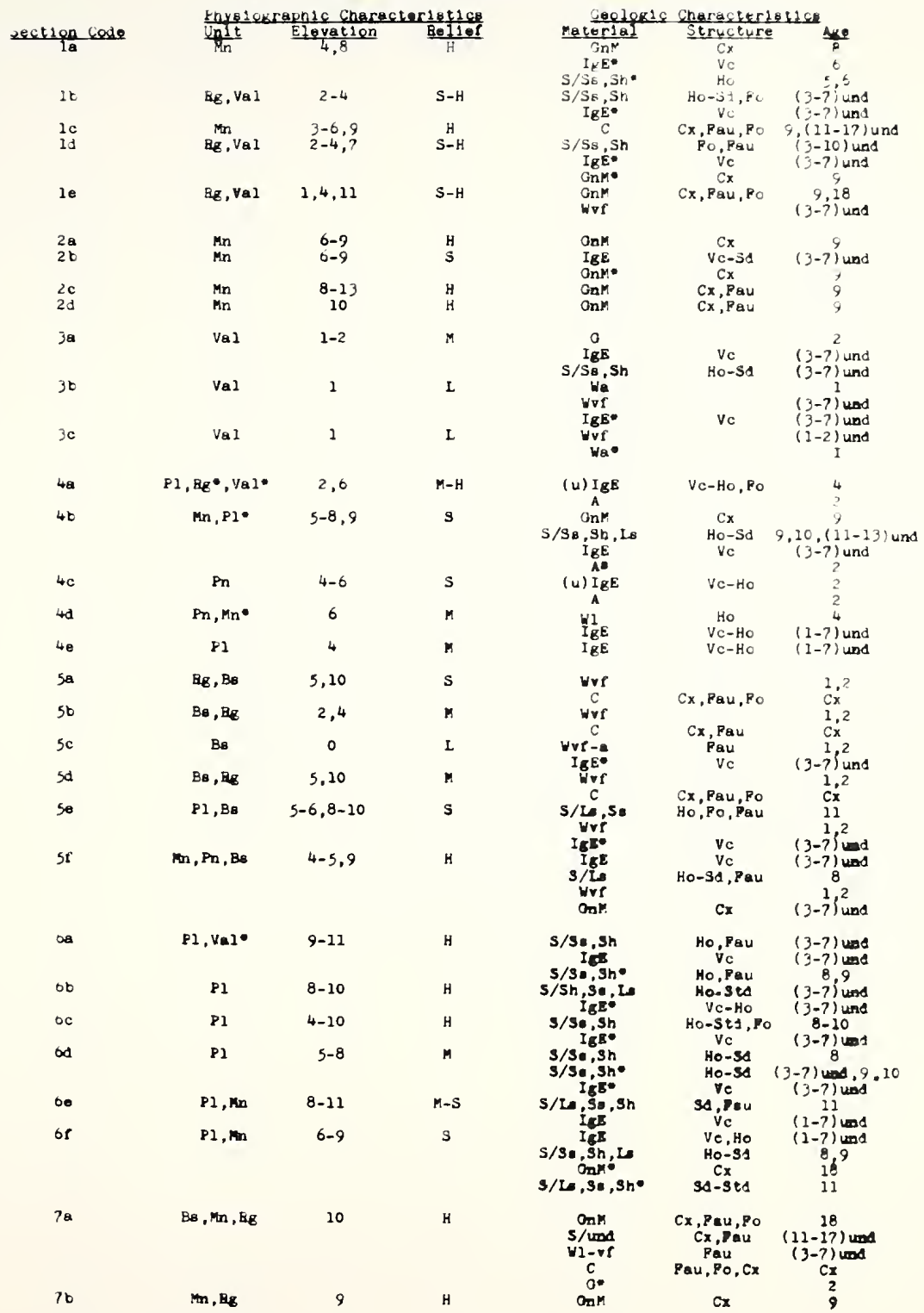

son Trble legend and cotes on lest pege of mble. 
Table? (Cont'd)

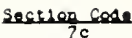

$7 \mathrm{c}$

8

$8 \mathrm{~b}$

$8 c$

86

$9 \mathbf{a}$

gr

$9 c$

$10 a$

$10 \mathrm{~b}$

$10 \mathrm{c}$

10 e

$10 \mathrm{f}$

$\log$

$10 \mathrm{~h}$

101

101

$10 \mathrm{k}$

101

$10 \mathrm{~m}$

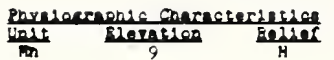

in

Mn, PI

m, B

in, ing

man, $\mathrm{Be}$

Fn

12

in

Be, $\mathrm{Val}$,

Mn, PI 12

P1

PI, Mn*, Val $\quad 2-4$

8 e

$\mathrm{B}, \mathrm{me}$

$5-6$
$7-3$

Non, P1

Pn

F1

$3-4$

P1, Pn

4-7

vo

$\mathrm{Val}$

$0-9,13$

$2-5$

$\mathrm{PI}, \mathrm{Mn}$

2

$\stackrel{P I}{P n, M n}$

H

H

H

I
$11 \mathrm{a}$

$11 \mathrm{~b}$

$11 \mathrm{c}$

$11 d$

$11 e$

$11 \mathrm{f}$

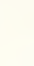
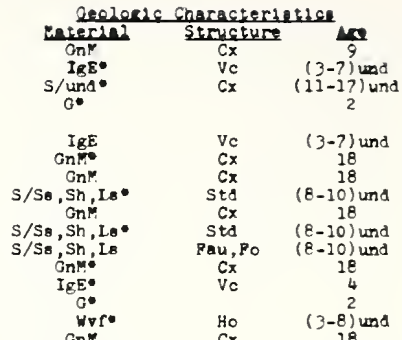

$\mathrm{S} / \mathrm{SB}, \mathrm{Sh}, \mathrm{Ls} *$

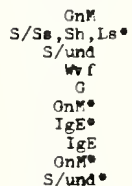

Ve
$C x$
$C x$
Std
$C x$
Std
Pau, Po
Cx
Vc
Ho
Cx

$(3-7)$ und

18
18

$(8-10)$ und

$(8-10)$ und
$(8-10)$ und

$(8-10)$
18

$(3-8)$ und

$(8-10)$ und

G
(u) $S / S h, S e$
S/Sh, Se, Io
GnMe

IgE

S/Se, Sh

$\mathrm{S} / \mathrm{Se}$, Sh

IgE.

onf

$\mathrm{S} / \mathrm{I}_{\mathrm{B}}$

S/Sh

$\mathrm{S} / \mathrm{Ss}^{\circ}$

$\mathrm{IgE}$

Wvf

S/SE, Sh, Is

$\mathrm{S} / \mathrm{Ss}, \mathrm{Sh}$. Is IgE:

$\mathrm{S} / \mathrm{Sh}, \mathrm{Ss}, \mathrm{Ls}$

$S / S s, S h$

S/Ss, Ls, Sh

Wvf

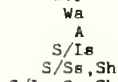

S/ $58, \mathrm{Sh}$

18 , Se, Sh

S/LE

S/Is, Sh, Ss
S/Is, Ss, Sh

Gnive

$S / I=, S 8, S h$

Std

st

18
$(8-10)$
un

$(3-7)$ und

$(3-7)$ und

2
18

(3-7) und

$(3-7)$ und

$(8-10)$ und

std

(e

$\begin{array}{cc}\text { Ho } & (3-7) \text { und }, 8 \\ \text { Ho } & (3-7) \text { und }, 8 \\ \text { Cx } & 18 \\ \text { Ve } & (3-7) \text { und } \\ \text { Ho-Std } & (3-7) \text { und }\end{array}$

$\begin{array}{ll}\text { Ho-std } & (3-7) \text { und } \\ 0-5 t d, 80 & (3-7) \text { und }\end{array}$

Ho-std 8

Ve $(3-7)$ und

$C x$

Sa - Std

Sd-Std

Ho-std

Vc

Ho-Sd

Ho-std

Vc

$\mathrm{Ho}$ Std
$\mathrm{Vc}=\mathrm{Ho}$

$\mathrm{Cx}$

Ho-Sd
Ho-Sd

Ho-Sa

18

18

11

$(3-7)$ un

$(3-7)$ und

$(3-7)$ und , 8

$(3-7)$ und

$(3-7)$ und 8
$(3-7)$ und

10-1

$10-11$
11
8

(3-7) und

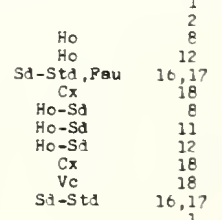

(u) $\mathrm{S} / \mathrm{Is}, \mathrm{G} s ; \mathrm{Sh}$

(u) $\mathrm{S} / \mathrm{Is}_{\mathrm{g}}$, Ss, Sh

(u) $s /$ Is , Sh

(u) $S / 38$

(u) $\mathrm{GnN}$

(u) $\mathrm{S} / \mathrm{Sh}$, Is , Ss

(u) $/ \mathrm{Ss}$ :

(u)

(u) $s /$ und
(u) Gnve.

(u) Gn:

(a) $s /$ und

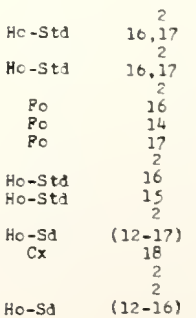


Table? (Con'd)

\begin{tabular}{|c|c|c|c|c|c|c|}
\hline \multirow{3}{*}{$\frac{\text { Dection Code }}{11 z}$} & \multicolumn{3}{|c|}{ Physlopraphie Chargeter 1 st 1 cs } & \multicolumn{3}{|c|}{ Stolup1c Charat te 10 1CS } \\
\hline & Un1t & Elevation & Rel $\overline{\text { ef }}$ & Mater1al & Structure & Ant \\
\hline & Fn & & & $3 / 3 s, 3 h$ & Ho- 31 & 37 \\
\hline & & & & (u) $s / u_{n} d^{*}$ & $\mathrm{HC}-\mathrm{ji}$ & $1:, 1 t, 1 t$ \\
\hline $12 n$ & En & 2 & I & $\mathrm{G}$ & & 2 \\
\hline & & & & (u) S/Ss, sin & $\begin{array}{ll}40-24 \\
H o-i g\end{array}$ & 8 \\
\hline 111 & $\bar{r}: \hat{1}$ & 1 & s. & G & Ho-s4 & $a^{-1<1}$ \\
\hline & & & & A & & 2 \\
\hline & & & & $\begin{array}{l}\text { (u)s/und } \\
\text { (u)s/und }\end{array}$ & $\begin{array}{l}\mathrm{Ho}=3 \mathrm{~d} \\
\mathrm{Ho}=\mathrm{Sd}\end{array}$ & $\begin{array}{l}\{8,1<-14\} \\
(11,1 \leq-18)\end{array}$ \\
\hline $12 a$ & Pn & 2 & $r_{i}$ & G & & 2 \\
\hline & & & & (u) GnM & Cx & 18 \\
\hline & & & & (u) $\mathrm{S} / \mathrm{Ss}, \mathrm{Sh} *$ & Ho-Sd & $1 ?$ \\
\hline $12 \mathrm{~b}$ & P1,Mn & $1-4$ & H & G & & 2 \\
\hline & & & & (u) GnM & $\mathrm{Cx}, \mathrm{Fau}$ & 18 \\
\hline $13 a$ & $N n, V a 1 *$ & 2 & S & 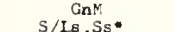 & $\mathrm{Cx}$ & 18 \\
\hline $13 b$ & Pl & 2 & I & $\begin{array}{c}\text { S/Is,Ss" } \\
\text { S/Is }\end{array}$ & $\begin{array}{l}\text { Ho-Sd } \\
\text { Ho-Sd }\end{array}$ & $\begin{array}{l}17 \\
1 t\end{array}$ \\
\hline & & & & $\mathrm{S} / \mathrm{L} 6$ & $\mathrm{Ho}-\mathrm{Sd}$ & 13 \\
\hline $13 \mathrm{el}$ & P1 & $2-3$ & S & $\mathrm{S} / \mathrm{Sg}, \mathrm{Sh}, \mathrm{L}_{6}$ & Ho-sd & 12 \\
\hline $13 \mathrm{c} 2$ & Val & 1 & $r$ & $\begin{array}{l}\text { S/Sh } \\
\text { S/Ss, Sn }\end{array}$ & $\begin{array}{l}\text { Ho-Sd } \\
\text { Fo, Fau }\end{array}$ & $\begin{array}{l}14 \\
12\end{array}$ \\
\hline & & & & Wg* & & 1 \\
\hline $13 c 3$ & $\mathrm{mn}, \mathrm{Rg}$ & $2-3$ & $S-H$ & $\mathrm{~S} / \mathrm{S} 8, \mathrm{~S} n$ & Fo, Fou & 12 \\
\hline $14 a$ & $\mathrm{~F} 1$ & $1-2$ & r. & S/Is, Sh & Sd & 10 \\
\hline $14 b$ & PI & $1-2$ & $r$ & $\begin{array}{c}\text { S/Is } \\
\text { S/In }\end{array}$ & $\begin{array}{l}\text { Sd } \\
\text { Sd }\end{array}$ & $\begin{array}{l}15 \\
16\end{array}$ \\
\hline $14 \mathrm{c}$ & PI & 1 & N. & $\mathrm{S} / \mathrm{Ss}, \mathrm{Sn}$ & Sd & 12 \\
\hline & & & & $\mathrm{S} / \mathrm{Ss}, \mathrm{Sn}, \mathrm{Is}$ & Sd & 13 \\
\hline & & & & Wa* & & 1 \\
\hline 140 & PI & $1-2$ & r. & $\mathrm{S} / \mathrm{LB}, \mathrm{Sn}$ & Sd & $1 ;$ \\
\hline & & & & $\mathrm{S} / \mathrm{Sh}, \mathrm{S} 8,16$ & Sd & 14 \\
\hline 150 & PI & 4 & $\mathrm{H}$ & (u) S/SB, Sh & Ho & 14 \\
\hline & & & & G & & 2 \\
\hline $15 b$ & Pl & 2 & $M-S$ & $\mathrm{G}$ & & 2 \\
\hline & & & & (u)S/Sh, Ss, Is & Ho-Sd & 14 \\
\hline & & & & $\begin{array}{l}\text { (u)S/SB } \\
\text { (u) } S / S s \text { Sh }\end{array}$ & Ho-Sd & 13 \\
\hline 150 & $\mathrm{Pl}, \mathrm{Rg} *$ & $2-4$ & $\mathrm{~s}$ & $\begin{array}{l}\text { (u) } \mathrm{S} / \mathrm{Ss}, \mathrm{Sh}, \mathrm{Is} * \\
\mathrm{~S} / \mathrm{S} \mathrm{s}, \mathrm{Sh}\end{array}$ & $\mathrm{Ho}-\mathrm{Sd}$ & 12 \\
\hline & & & 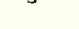 & $\begin{array}{l}\text { S/Sg, Sh } \\
\text { S/SE }\end{array}$ & $\begin{array}{l}\text { Ho-Sta, } F_{0} \\
\text { Ho-Std, } F_{C}\end{array}$ & 12,13 \\
\hline & & & & $\mathrm{S} / \mathrm{Sh}, \mathrm{I}_{\mathrm{B}}$ & Ho-Std, Fc & 13 \\
\hline 150 & PI & & & $\mathrm{S} / \mathrm{Sn}, \mathrm{SB}_{\mathrm{B}}$ & Ho-Std,Fo & 14 \\
\hline 150 & 81 & $3-4$ & $M-S$ & $\mathrm{~S} / \mathrm{Sh}, \mathrm{Sg}$. Is & Ho & 12 \\
\hline & & & & S/Sn, Le & Ho & 11 \\
\hline 150 & $P 1, \mathrm{Mn}, \mathrm{Val}$ & 3 & $M-S$ & $\mathrm{~S} / \mathrm{S}_{\mathrm{S}}, \mathrm{Sh}$, Is & Ho & 13 \\
\hline & & 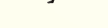 & & $\begin{array}{l}\text { S/SB, Sh } \\
\text { S/SB, She }\end{array}$ & $\begin{array}{l}\text { Ho } \\
\text { Paus }\end{array}$ & $\begin{array}{l}12 \\
12\end{array}$ \\
\hline & & & & S/L & Fo & 16 \\
\hline & & & & S/10,Se, Sh & Ho-Sd & 13 \\
\hline $16 a$ & $R g, V a l$ & $1-3$ & $\mathrm{~s}$ & S/I , Sh, Se & Po, Fau & $12-17$ \\
\hline $10 \mathrm{~b}$ & $\mathrm{Val}, \mathrm{Bg}$ & $1-3$ & s & $\mathrm{S} / \mathrm{L} \mathrm{g}, \mathrm{Sn}, \mathrm{Se}$ & Fau, Fo & $12-17$ \\
\hline $17 \mathrm{a}$ & $M n, R g$ & $2-6$ & $\mathrm{~N}-\mathrm{S}$ & Gnk & Cx, Pau & 17,18 \\
\hline & & & & S/LB: & Ho & 16 \\
\hline $17 \mathrm{~b}$ & $P_{n}, V_{a}{ }^{\circ}$ & $1-2$ & L & $\begin{array}{l}\text { GnM } \\
\text { s/st }, \text { sh* }\end{array}$ & $\begin{array}{l}\text { Cx } \\
\text { Ho }\end{array}$ & 16. $\underset{10}{(11-17) \text { und }}$ \\
\hline 18 & Val & 1 & J & $\mathrm{S} / \mathrm{S} \cdot \mathrm{Sh}$ & Ho, Pau & 10 \\
\hline & & & & $I e^{\mathrm{E}}$ & Ve & 10 \\
\hline & & & & $S / L^{*}$ & Po & $1 t$ \\
\hline & & & & Gnk: & $C x$ & 18 \\
\hline & & & & $\mathrm{G} \bullet$ & & 2 \\
\hline $19 a$ & Pn & 1 & L & G & & 2 \\
\hline & & & & Wos & & 2 \\
\hline & & & & $\begin{array}{l}\text { (u) GnK } \\
\text { (u) } S \text { /und }\end{array}$ & $\begin{array}{c}C x \\
C x, H O-S d\end{array}$ & $\begin{array}{c}18 \\
(12-1 ?) \text { wnd }\end{array}$ \\
\hline $19 \mathrm{~b}$ & P1 & $1-2,4$ & M & $0^{2}$ & & 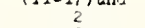 \\
\hline & & & & $\begin{array}{l}\text { (u) GnM } \\
\text { (u)s und }\end{array}$ & $\mathrm{Cx}_{\mathrm{Cx}}^{\mathrm{Cx}}$ & 18 \\
\hline $19 c$ & Val & 1 & M & G & $\mathrm{Cx}, \mathrm{HO}-\mathrm{Sd}$ & $\begin{array}{c}(1 \lambda-17\rangle) \text { und } \\
2\end{array}$ \\
\hline & & & & (u)s/Se, Sh & Ho, Pau & 10 \\
\hline $19 \mathrm{~d}$ & $M n$ & & & (u) IgE & $\dot{v}_{c}$ & 10 \\
\hline & $m a$ & 4,6 & $\mathrm{H}$ & $\mathrm{On}_{\mathrm{n}}$ & $C x$ & $\begin{array}{r}18 \\
2\end{array}$ \\
\hline 190 & $\min$ & $2-3,5$ & $\mathrm{H}$ & GnM & $\mathrm{Cx}, \mathrm{Fo}$ & 18 \\
\hline $19 f$ & & & & G* & & 2 \\
\hline $19 t$ & $\mathrm{Kg}, \mathrm{Pl}, \mathrm{V}$ & 2,4 & $\mathbf{S}$ & $\operatorname{Cn} M$ & $C x$ & 18 \\
\hline & & & & $\begin{array}{l}\text { OnM* } \\
\text { S/Is* }\end{array}$ & $\mathrm{Cx}-\mathrm{HO}$ & 17 \\
\hline & & & & $0 *$ & Ho-Sd & $\begin{array}{r}17 \\
2\end{array}$ \\
\hline
\end{tabular}


Table $?$ (Cont'd)

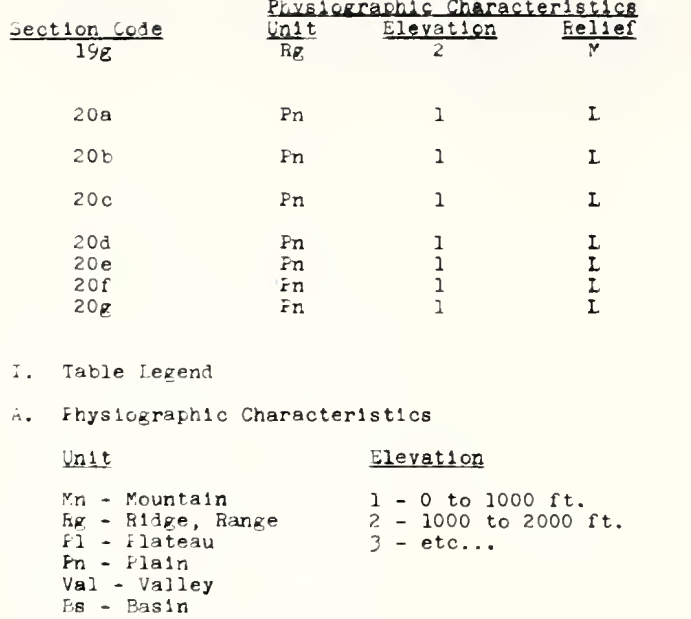

\begin{tabular}{|c|c|c|}
\hline \multicolumn{3}{|c|}{ Character1st1cs } \\
\hline Gn $x$ & $C x$ & $\frac{18}{18}$ \\
\hline G* & & 2 \\
\hline Wes & Ho-Sd & $2,(3-7)$ und \\
\hline Wes & Ho-Sd & 8 \\
\hline Wes & Ho-Sd & $(3-7)$ und, 8 \\
\hline Wes* & $\mathrm{Ho}-\mathrm{S} \alpha$ & 2 \\
\hline wes & Ho & 2 \\
\hline Wes/La & Ho-Sd & 6 \\
\hline Wca & Ho-Sd & $1-8$ \\
\hline A & & $?$ \\
\hline Wa & & 1 \\
\hline Wes & Ho-Sd, Fau & $1-8$ \\
\hline
\end{tabular}

E. Geolcgic Characteristics

\section{Materga]}

\section{Bellef}
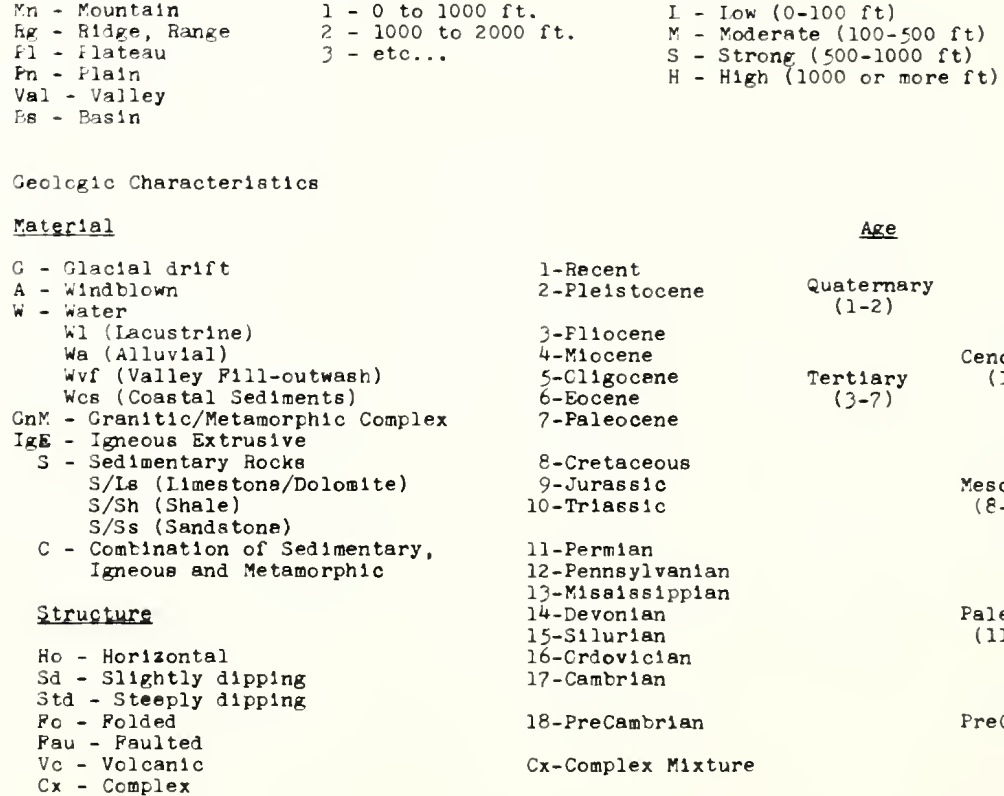

\begin{tabular}{|c|c|}
\hline $\begin{array}{l}1 \text {-Racent } \\
2 \text {-Plels tocene }\end{array}$ & $\begin{array}{l}\text { Quaternary } \\
(1-2)\end{array}$ \\
\hline $\begin{array}{l}\text { 3-Fllocene } \\
\text { 4-M1ocene } \\
\text { 5-Cl1gocene } \\
\text { 6-Eocene } \\
\text { 7-Paleocene }\end{array}$ & $\begin{array}{c}\text { Tert1ary } \\
(3-7)\end{array}$ \\
\hline $\begin{array}{l}\text { 8-Cretaceous } \\
\text { 9-Jurass1c } \\
10-\operatorname{Tr} 1 \mathrm{ass} 1 \mathrm{c}\end{array}$ & \\
\hline 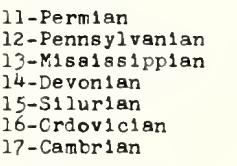 & \\
\hline 18-PreCambrian & \\
\hline Cx-Complex Mixture & \\
\hline
\end{tabular}

Age

II. Explanatory Notes

1. (*) Indicatea a minor or variant characterist1c compared to the major or modal characterlstics of the Section.

2. (und) Indicates undifferentlated. Th1s may be applied to materlal or age (ag...(11-17) und 1 mplies age is und 1 fferentlated Faleozolc ...(11-17) 1mplles ali syatems of Paleozolc Era are present in Section).

3. (u) Indicates matarlal (genaraliy consolldated) that underlies a transported matarial. 
replace or substitute for the monumental writings of Fenneman and others. Ilberal use has been made of information found in these writings. However, the primary exphasis has been accorded to certain physlograph1c factors deemed most relevant to highway englneers. These factors are : orlgins of surficial materials, topography, parent material type and geologic age.

Comparison of Units Among Physlographers

while this report basically follows the physiographic subdivision system of woods-Iovell (2), several minor differences occur. These changes are primarily within: the Basin and Range Province ( 5$)$, the Sierra-Cascade Province (2), the Northern Rocky Mountain Frcvince (?), and the Older Appalachian Frovince (17). They are generally in accord with two distinguished physlographers, viz., Fenneman or Iobeck. Tatle 8 is a summary of differences between the basic report units and the various "standard" Physlographic categorizations.

The most probable reason for the variations is the qualitative and subjective nature of the classification criteria. Thus, it is not surprising, for example, that Ioteck and Fenneman place the csage Plains Section in the Central Lowlands Province, while Woods-Iovell consider that the nonglaciated plains do not belong in a predominately glaciated province.

Cther differences may stem from chronology or from varlations in speclal knowledge of particular areas. The 
Table 8

Differences in Physiographic Categorizations Between Physiographers and Basic Report Units

Basic Report Units

1. Western Ytns., Pacific Coast Range Prov.

a. Olympic Mtn. Sect.

b. Oregon Coast Rge. Sect.

c. Klamath Mtn. Sect.

d. Calif. Coast Rge Sect.

e. Los Angeles Rge. Sect.

2. Sierra-Cascade Prov.

a. Nor. Cascade Mtn.

Sect.

b. Sou. Cascade Mtn. Sect.

c. Sierra Nevada Sect.

d. Lower Calif. Sect.

3. Pacific Troughs Prov.

a. Puget Sound Sect.

h. Williamette Valley

Sect.

c. Calif. Valley Sect.

4. Columhia Plateau Prov.

a. Walla-Walla Sect.

b. Blue vtn. Sect.

c. Snake R. Plain Sect.

d. Payctie Sect.

e. Harney Sect.

5. Basin and Range Prov.

a. Great (lilosed) Basin Sect.

b. Sonoran llesert Sect.

c. Salton Trough Sect.

d. Ppen Basin (Mex.

e. Sacramento High Sect.

f. Great Rend High. Sect.

6. Colorado Plateau Prov.

a. High Plats. of Utah Sect.

b. Uinta Basin Sect.

c. Caryon Lands Sect.

d. Navajo Sect.

e. Grand Canyon Sect.

f. Datil Sect.

7. North. Rocky Mtn. Prov.

a. Montana Sect.

b. Bitterroot Sect.

c. Salmon River Sect.

\section{Woods - Love 11}

Western Mtns. or Pacific Coast Ranges
nd $^{1}$
nd
nd
nd
nd

Eastern Mtns. or Sierra-Cascade-Coast Mtns.

Cascade and Sierra

Nevada Mtns.

\section{nd}

nd

nd

nd

nd

nd

nd

nd

nd

nd

Basin and Range and Mex. Highlands Provinces

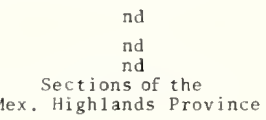

.

nd
nd
nd
nd
nd
nd
nd
nd
nd


Table 8 (cont'd.)

\section{Basic Report Units}

8. Middle Rocky Mtn. Prov.

a. Yellowstone Sect.

b. Bighorn Mtn. Sect.

c. Wind River Mtn. Sect.

d. Wasateh Sect.

e. Uinta Mtn. Sect.

9. South. Rocky Mtn. Prov.

a. Front Range

b. Western Section

c. San Juan Mtn. Sect.

10. Great Plains Prov.

a. Gilac. Missouri Plat. Sect.

b. Ungl. Missouri Plat. Sect.

c. Bighorn Basin Sect.

d. Wyoming Basin Sect.

e. Black Hills Sect.

f. High Plains Sect.

g. Colorado Piedmont Sect.

h. Raton Upland Sect.

i. Pecos valley Sect.

j. Plains Border Sect.

k. Cent. Texas Mineral Sect.

1. Edwards Plateau Sect.

m. Osage Plains Sect.

Woods-Lovel 1

nd

nd

nd

nd

nd

nd

nd

nd

nd

nd

nd

nd

nd

nd

nd

nd

nd

nd

nd

nd

nd

nd

nd

11. Central and Eastern

Lowland Province

a. St. Lawrence Low. Sect.

b. Champlain Low. Sect.

Central and Eastern Lowlands and Plains

c. Hudson R. Valley Sect.

nd

nd

d. Mohawk R. Valley Sect.

nd

e. E. Lakes and

Lacustrine Sect

f. Cent. Till Plain Sect.

g. Driftless Sect.

h. W. Lakes and

Lacustrine Sect

i. Dissect. Loess and

Till PI. Sect.

12. Laurentian Upland Prov.

a. Superior Upland Sect.

b. Adirondack Sect.

13. Ozark and Ouachita Prov.

a. St. Francis Mtn. Sect.

b. Springfield-Salem Plat

cl. Boston Mtn. Sect.

c2. Arkansas Valley Sect.

c3. Ouachita Mtn. Sect.

ove 1

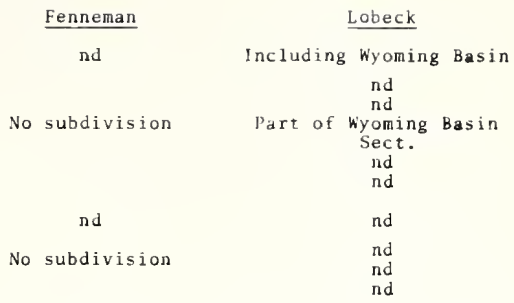

Parts of 3 provinces

nd

nd

Part of Middle Rocky Mtns.

Wyoming Basin Prov.

nd
nd
nd
nd
nd
nd
nd
nd
Sect. of cent.

Low. Prov.

Parts of 4 Provinces

Nor, Sect.

St. Lawrencé $V$.

Champlain Sect.

St. Lawrence $V$

Sect. of Valley

and Ridge Prov.

Sect. of Appalach.

plat. Prov.

Eastern Lake Sect.

$$
\text { nd }
$$

Western Lake Sect.

Dissect. Till

plains Sect.

Parts of 2 Provinces

nd

Adirondack Province

Ozark Plateaus and

Ouachita Provs.

Part of SpringSalem plat.

Includes St. Francis Mtns.

$$
\begin{aligned}
& \text { nd } \\
& \text { nd } \\
& \text { nd }
\end{aligned}
$$

Parts of 2 Provinces

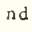

nd

Sect. of Middle

Rocky Mtns.

Sect. of Middle Rocky Mtns.

nd

nd

nd

n

nd

nd

ad

Sect. of Cent.

Low. Prov.

parts of 2 provinces

Sect of Newer

Appalachian Province

Sect. of Newer

Appalachian Province

Sect. of Newer

Appalachian province

part of tast.

Lake Sect.

Includes Mohark R. Valley

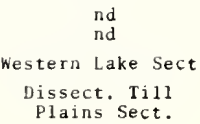

nd

nd

nd

Ozark and Ouachita Provs.

nd

nd

nd

nd 
Table 8 (cont'd.)

\section{Basic Report Units}

14. Interior Low Plateaus Province

a. Blue Grass Sect

b. Nashville Basin Sect.

c. Shawnee Hills Sect.

d. Highland Rim Sect.

15. Appalachian Plateau Province

a. Catskill Mtn. Sect.

b. N. Y. Glaciated Sect.

c. AlIegheny Mtn. Sect.

d. Kanahwa Sect.

e. Cumberland Sect.

16. Newer Appalachian (Ridge and Valley) Province

a. Penna.-Md.-Va. Sect.

b. Tennessee Sect.

17. Older Appalachian Prov.

a. Blue Ridge Section

b. Piedmont Section

18. Triassic Low Iand Prov.

19. New England Maritime Province

a. Seaboard Low. Sect.

b. N. Eng. Upland Sect.

c. Connecticut Low. Sect.

d. White Mtn. Sect.

e. Green Mtn. Sect.

f. Taconic Sect.

g. Reading Prong Sect.

20. Atlantic and Gulf

Coastal plain Prov.

a. Embayed Sect

b. Sea Island Sect.

c. Florida Sect.

d. East Guif Sect.

e. Miss. Loess, Upld, Sect.

f. Miss, Alluv. Pln. Sect.

8. West Gulf Sect.

\section{Woods-Love 11}

nd

nd

nd

nd

nd

nd

nd

nd

nd

nd

Ridge and VaIley

Prov.

nd

No Counterpart

Blue Ridge Prov. Piedmont Prov.

nd

nd

nd

nd

Grouped

nd

nd

nd

nd

nd

nd

nd
Fenneman

nd

Lexington Plain nd

Suggested not De-1imited

nd

nd

Sou. New York Sect. nd

Subdivided into Mtn. and Plateau Sects.

Jalley and Ridge Prov.

Middle Section

No Counterpart

Blue Ridge Prov.

piedmont Upland of

the Piedmont Prov.

Piedmont Lowlands of

the Piedmont Prov.

New England Prov.

nd

Part of N.E. Upland Sect. nd

nd

Part of N.E. Upland Sect, Part of N.E. Upland

Coastal Plain Prov.

nd

nd

Includes Miss.

Loess. Upl and

Part of East Gulf

Coast plain

nd

Lobeck

nd

nd
nd
Part of Highl and

Includes Shawnee Hills

nd

New York State Sect. nd

nd

nd

Newer or Folded

Appalachian Prov.

$$
\text { nd }
$$

nd

nd

nd

nd

nd

nd

nd

nd

Sect.

nd nd

nd

nd

Includes Miss.

Loess. Upiand

Part of East Gulf Sect.

nd 
physlographic subdividing of Fenneman was completed with the publication of his two companion volumes covering the U.S. (19, 18) in 1931 and 1938, respectively. Lobeck's divisioning was putlished in 1948; while the work of woodsIovell, accomplished in 1958, had a definite engineering perspective. Difference in detall of subdividing is prcnounced in the Rocky Mountains, where Fenneman stops at the Province level and lobeck formally divides into Sections.

\section{Physlographic Boundaries}

\section{Definition}

Fenneman (18) has stated that each defined physiographic unit"...should be as homogeneous as possible; that is, 1t should admit of the largest number of general statements befcre detalls and exceptions become necessary." In fact, any physiographic unit, except the ultimate landform, consists of two parts: (1) a modal topographic expression developed from a unique set (or sets) of geomorphic control factors, and (2) inherent variations from this modal expression. As a consequence, a physlographic boundary ideally delimits different modal topographic expressions, but of practical necessity admits certain variants within any bounded unit.

Description of Basic Unit Boundaries

A great deal of information was obtalned concerning the description of the boundaries of the basic units. This information has been summarized and coded to the physiographic 
dlagrams and is contalned within Appendix B. Not all of the borders are described in this Appendix. In particular, most of the Rocky Mountain areas, portions of the Easin and Range Province as well as Columbla Plateau Frovince have not been summarlzed.

\section{Types}

Physlographic boundarles are elther relatively definite or indefinite, depending upon the contrast of adjacent topographic expressions. As Thornbury (65) points out: "An escarpment comes as near as any topographic feature to representing a sharp change from one topographic area to ancther." He emphasizes the 1ndefinlte nature of most boundarles with the following statement. "Classiflcations of any sort are to a considerable degree artificlal. They represent man's attempt to plgeonhole natural phenomena into distinct compartments with sharply drawn boundaries between them. In nature, clear-cut (geomorphic) boundarles are the exception rather than the rule."

The difficulties of defining a boundary between two modal expressions are categorized in Figure 1 as: (1) Interfingering, (2) Gradational (Transistional), (3) CverlappIng (Inclusive), and (4) Exclusive.

When vlewed at a large scale, Type (1) shows an 1rregliar boundary, elther definlte or indefinlte, between the modal areas. However when reduced to a smaller mapping scale, the detall w1ll be lost and the mapped boundary must te classed as indefinlte. An example has been noted by 
TYPE I INTERFINGERING

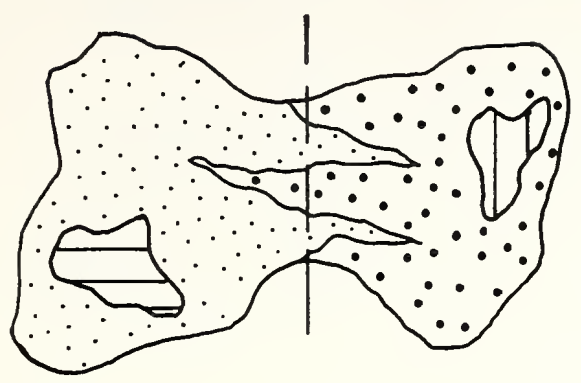

TYPE 2 GRADATIONAL

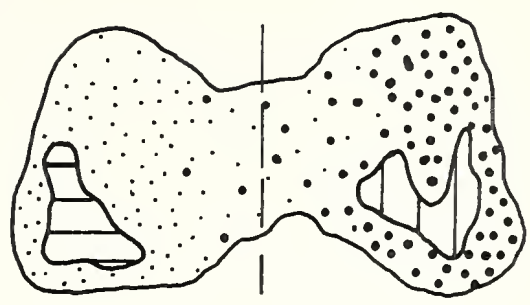

TYPE 3 OVERLAPPING

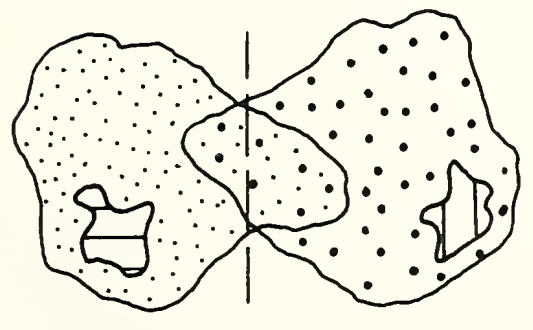

LEGEND:

TOPOGRAPHIC AREAS

MODAL
$\because \mathrm{M} 1$
$\because \mathrm{M} 2$
$\mathrm{M} / 2$

TYPE 4 EXCLUSIVE

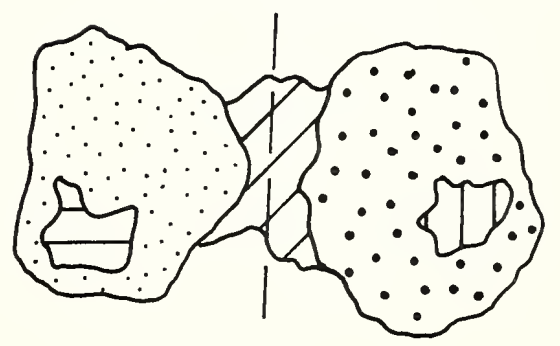

FIG. I TYPES OF INDEFINITE BOUNDARIES 
Fenneman (18) to exist between the westem Iakes and Iacustrine and the Superior Upland Section. Thornbury (65) states: "The arbitrary straight-Iine boundary at the west (of the Superior Upland) reflects the difficulty of determining where it should be drawn here."

Type (2) borders are characterized by a gradual merging of modal expressions. An example is the boundary between the Loessial Upland Section and the East Gulf Section. The distinguishing characteristic of the former section is the surficlal cover of the aeolian materials. However, since the thickness of loess gradually decreases from west to east within the Section, the location of the eastern boundary is arbitrary. The Type (2) indefinite boundary can be anticlpated where soll origin is used as a discriminating factor, e.g., glacial origin areas bordering residual origin areas.

Type (3) borders occur when a major descriptive characteristic of one modal area extends into an adjacent molal area. An excellent example is the Driftless Section - Superior Upland Section contact. The Driftless Section is character1zed by Cambrian sedimentaries and the absence of glacial t1ll. The Superior upland Section was covered by the 1 ce sneets an: is underlain principally by FreCambrian crystaline rocks. However, in the area between the sections, glacial till overlies Cambrian rocks. Fence, within a modal area designated as $M_{12}$ on Figure 1 , the glacial origin is common to the Superlor Upland Section while the bedrock is that of the Driftless 
section. Another example occurs at the Columtla PlateauBasin and Range Province border, where the blocky topograph1c expression of the Basin and Range coexists with the geologlc parent materlal of the Columbia Plateau.

A Iype (4) boundary is effected when two modal expressions are separated by a small area of variant expression, 1.e., one that is not clearly identified with either modal area. Prime examples occur extensively in the Atlantic and Gulf Coastal Plain Province. In particular, the Embayed Section - Sea Island Section and the fiorida Section Sea Island Section - East Gulf Section torders are of this type.

\section{Cther Considerations}

From the preceding discussion it is apparent that the guidelines for classifying and bounding physiographic units are qualitative and thus subject to a great deal of individualistic interpretation. Where the topographic expressions lack contrast, recourse to such factors as rock type and age, or even soll type or color, may be required to establish the boundary. Cne such example occurs where the Triassic Iowland Frovince adjoins the Atlantic Coastal Flain. Thornbury (65) states, "...there is no marked topographic break; the Fall Ine is missing here. However, the two areas are readily recognizable because of the contrast that the red solis of the Triassic Iowland make with the solls of the Coastal Plain".

It is well to focus on the control factors trat 
characterize the modal topographic expressions, rather than on the arbitrary line enclosing them. Or as Fenneman (18) states 1t: "Some of the boundary Iines are almost as sharp in nature as on the map. Some of them represent broad generalizations which are highly important in a rational discussion, even though the Ines themselves are hard to locate in the field... No one can be so conscious of the limitations of such a map as the men who labor to produce it. No geological reader will be misled by 1 ts seemingly definite committments".

\section{Highway Design and Construction Factors}

\section{Aggregates}

\section{Questionnaire Response}

The overall response to the materials questionnalre was considered good. Thirty-nine of the 48 states answered the entire questionnaire, while four states partially completed 1t, and five states did not answer any of the questions. As an ald to the development and presentation of the results, the response to the questionnalre is summarized by state in Table 9.

\section{Mapping}

Fotential Aggregate Areas and PIt and quarry Iocations Figures 2 to 5 summarize the attempt to delineate reglons in the United States where potential reglonal crushed stone and sand gravel deposits occur. The crushed stone sources are further subdivided into carbonate rocks, 


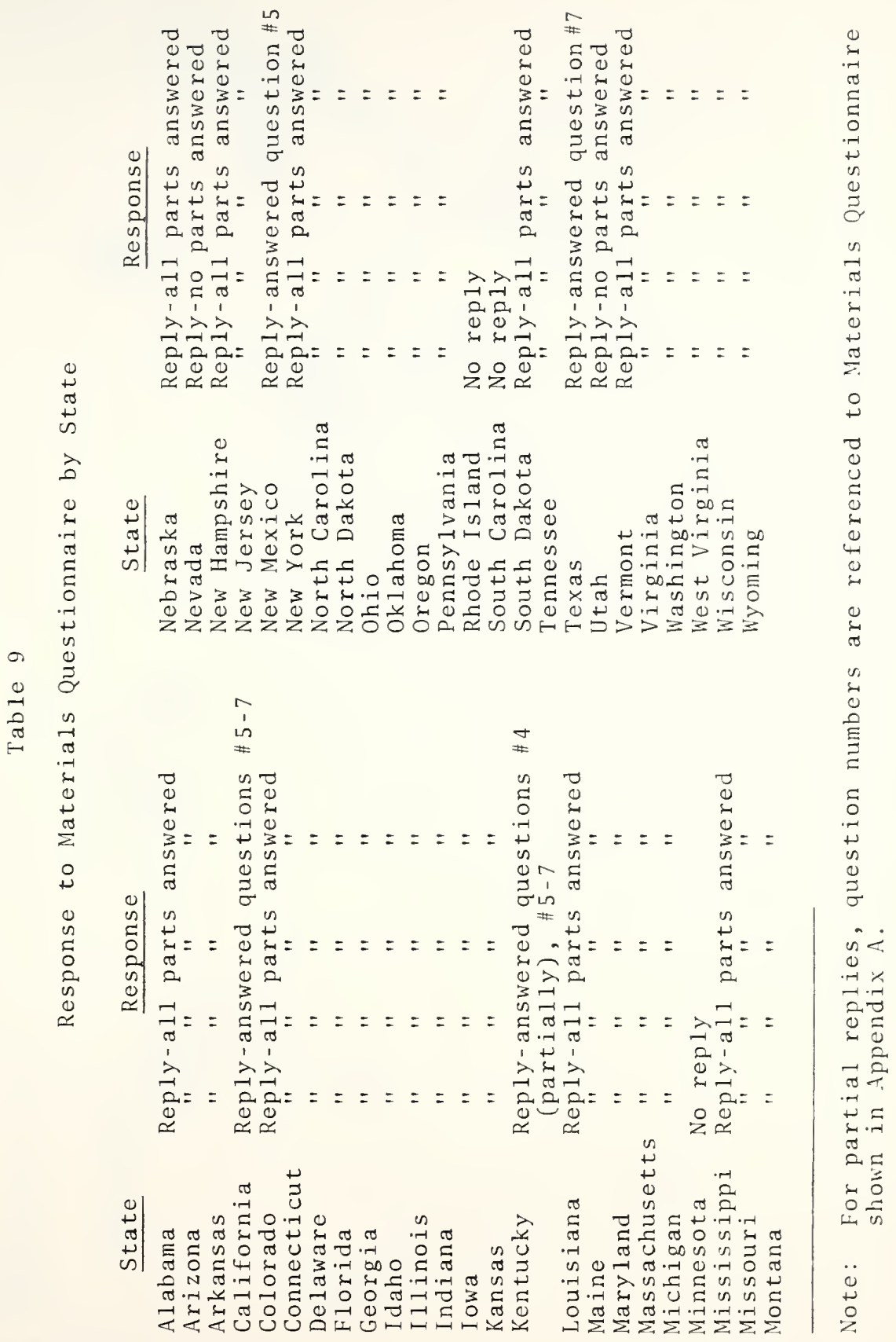




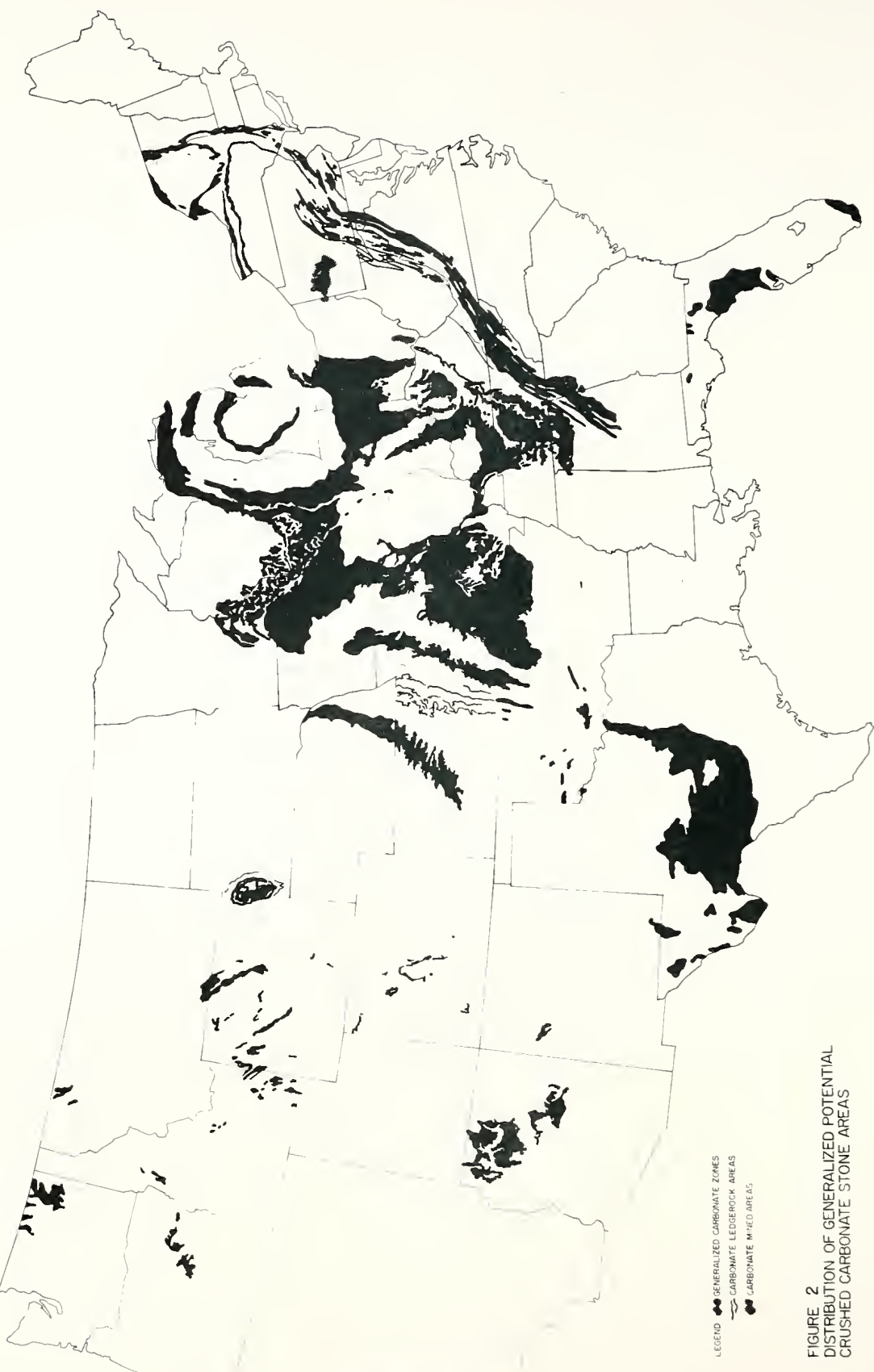




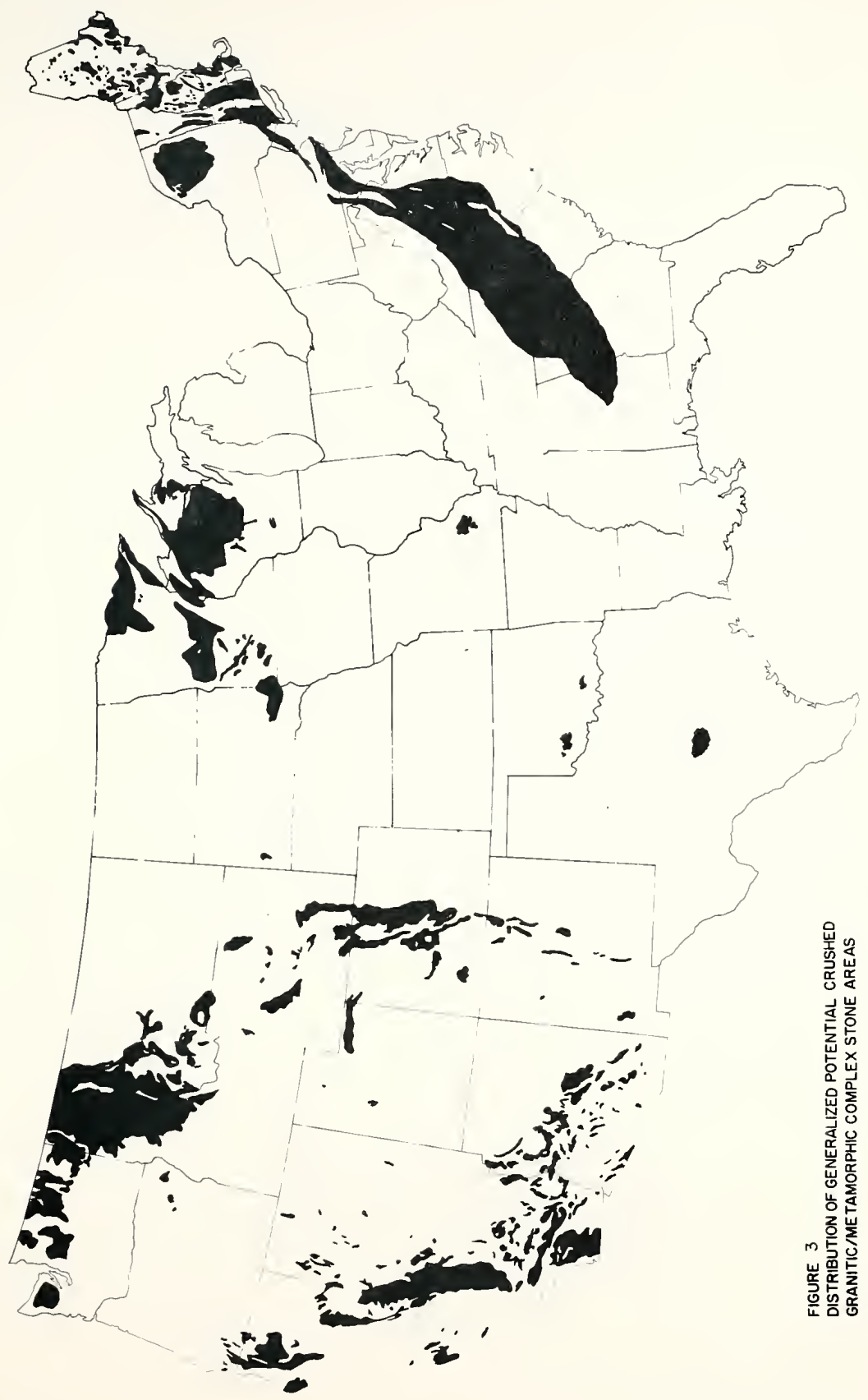




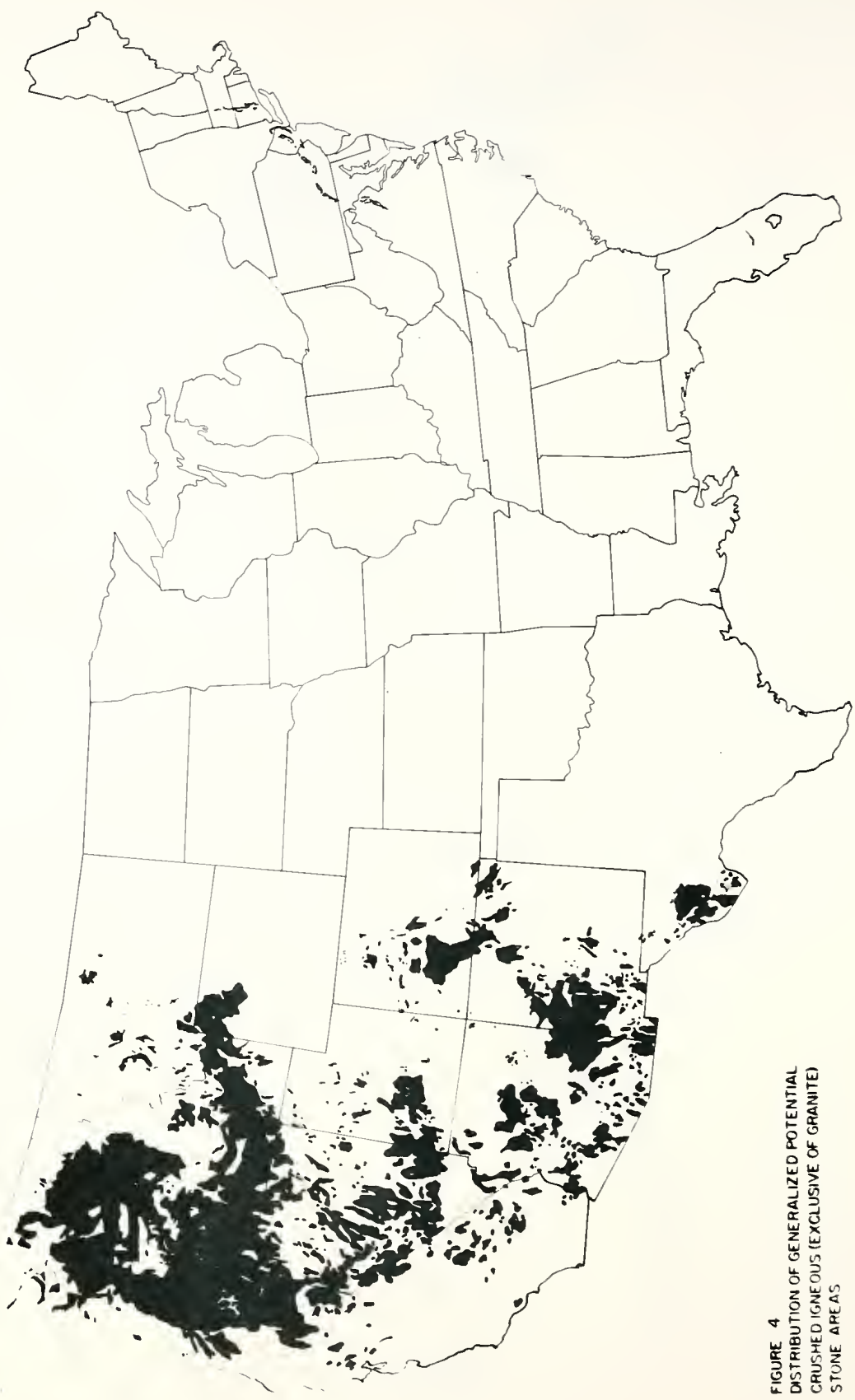




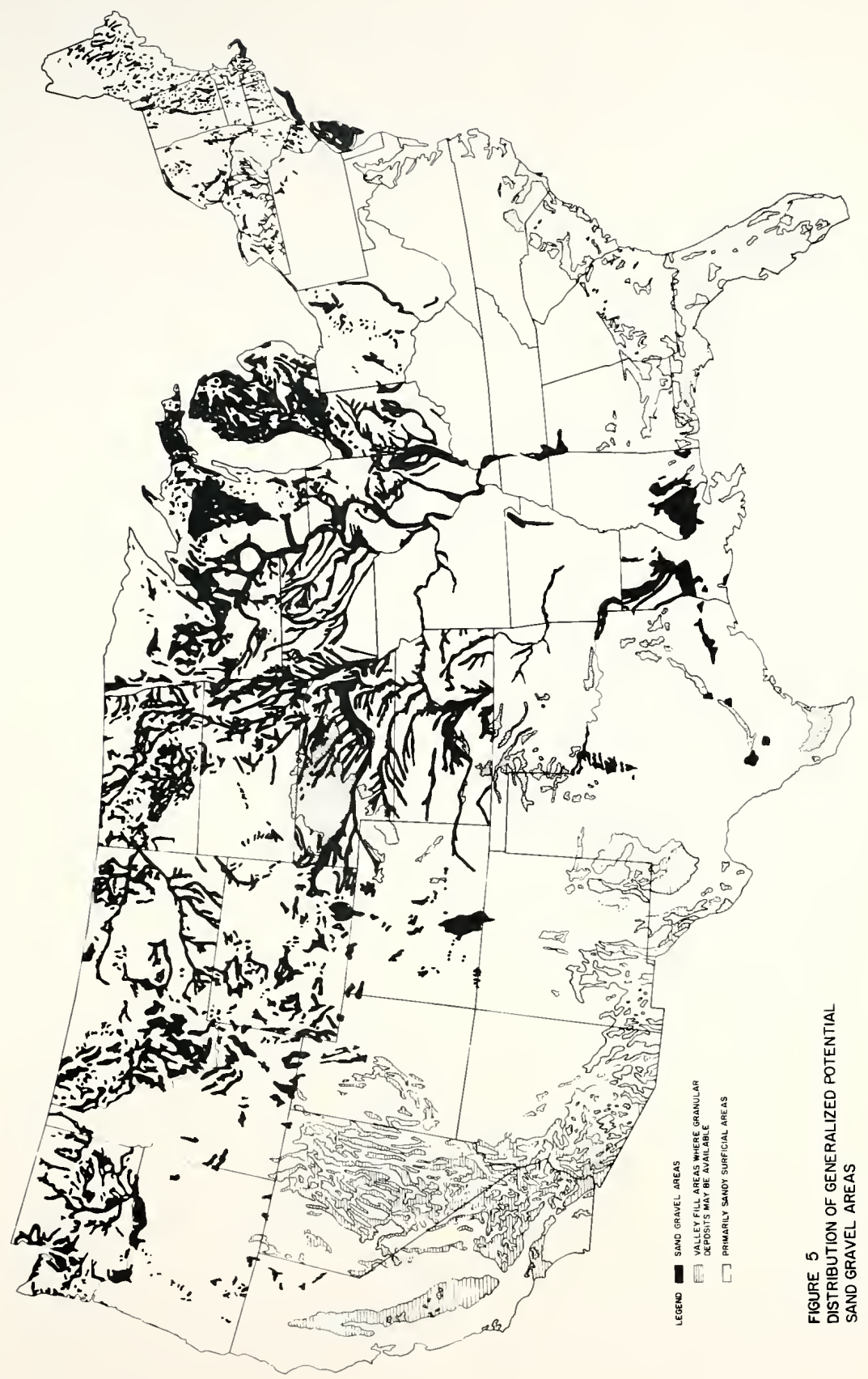


granitic/metamorphic complex type rocks, and other igneous rocks. It $1 \mathrm{~s}$ the general opinion of the author that the mapping of the carbonate zones east of the Rocky Mountain Great Plalns border afforis a relatively accurate pattern of the distribution of these sources. Not all of the carronate rock sources have been mapped due to the great diff1culty in determining their distribution. Areas where regional carbonate sources may occur but are not mapped are: (a) the northern portion of the New England Upland Section (19b), e.g., In Valne; (b) the Pecos Valley Section (101); (c) Ranges of the Easin and Range Province (5), composed of carbonate rocks (in part or total); and (d) along the western flank of the Slerra Nevada Section (2c) and other minor areas in California.

The relative accuracy of the granitic/metamorphic complex areas is slightly less than that of the carbonate rocks. For the most part, the Cormer areas were distingulshed on the basis of geologic distribution rather than any qualitative estimate of the problems associated with their use as ageregates.

The relative accuracy of definition of the other lgneous rock areas is the poorest of the three crushed stone areas. Distribution of these rocks was obtained by a method sinilar to that for the granitic/metamorphic map.

The relative accuracy of the sand-gravel map is quite variatle due to the wide range of references interpreted for assembly of the zones. Further subdivision of types of 
granular deposits has been made on this map.

Figures 6 to 8 1Ilustrates the distribution of pits and quarries within the United States. Flgure 6 shows the avallable data concerning the distribution of sand and sandgravel pits.

Flgure? shows crushed stone quarries irrespective of the major geologic rock type, 1. e., metamorphic, 1 gneous, and carbonates. Figure 8 represents the alstribution of iniscellaneous type sources. Included within this group, but not separately 1dentifled, are slag, lightwe1ght aggregate, caliche, clam/oyster shells and coquina.

Table 10 summarizes by state the references from which information concerning potential aggregate areas as well as the pit and quarry distribution was obtained. Distribution of Counties Not Froducing Aggregate Sources Individual counties within the united jtates not producing sand-gravel, and crushed stone during 1964 were located from reference (189). Flgure 9 and 10 show the distribution of those units not producing sand-gravel or crushed stone, respectively. Figure 11 maps counties not producing elther, 1.e., non-aggregate producing counties. The large size of western ccunties $11 \mathrm{~m} 1 \mathrm{ted}$ the usefulness of this mapping in generalizing as to potentlal aggregate areas. Consequently, use of these maps was $11 \mathrm{~m} 1$ ted to the eastern part of the United States.

Areas Iacking qual1ty Aggregates (Materlals Questionnalre) Additional guidance in ldentifying areas lacking 


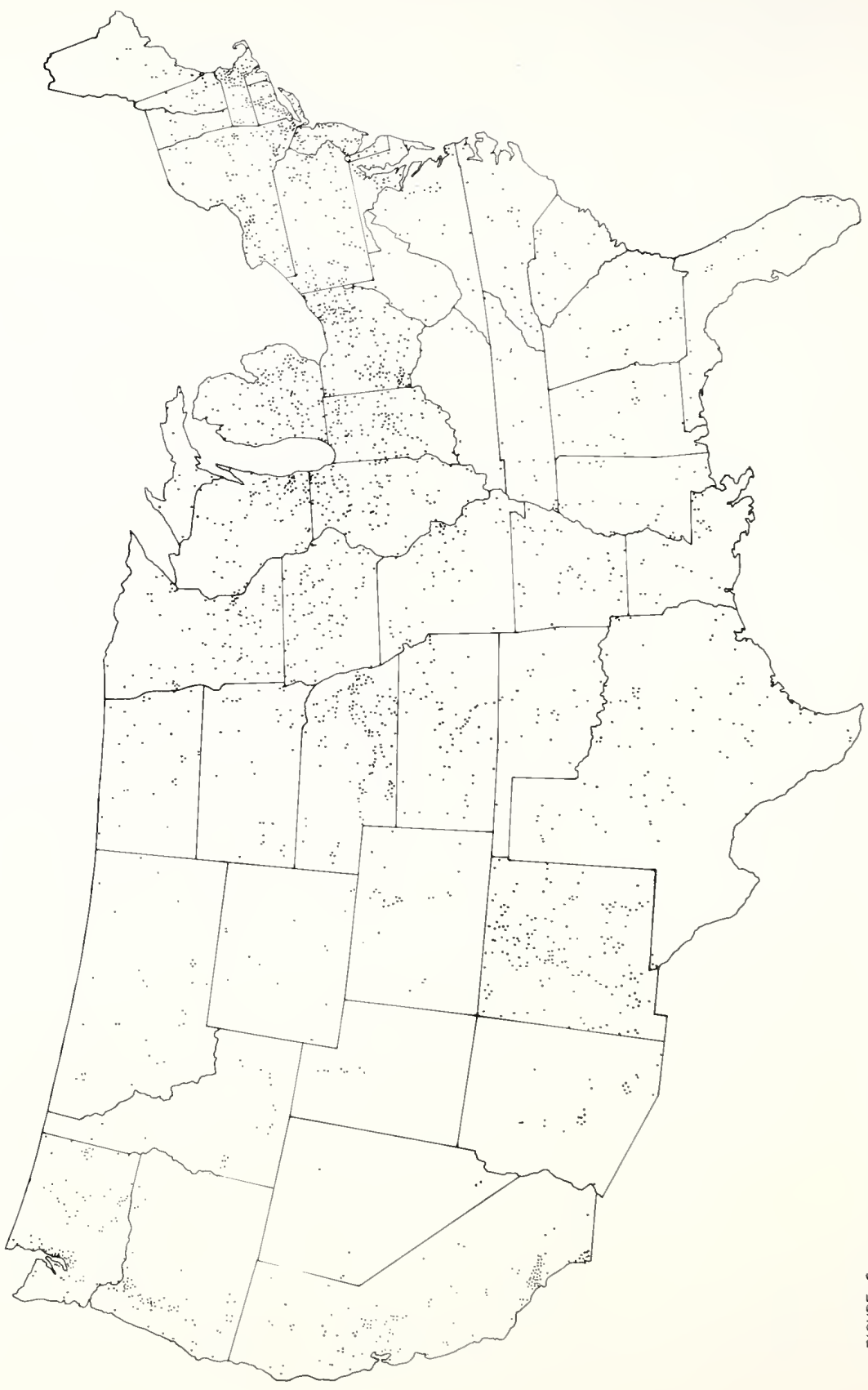

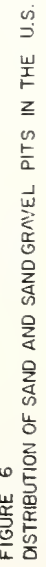




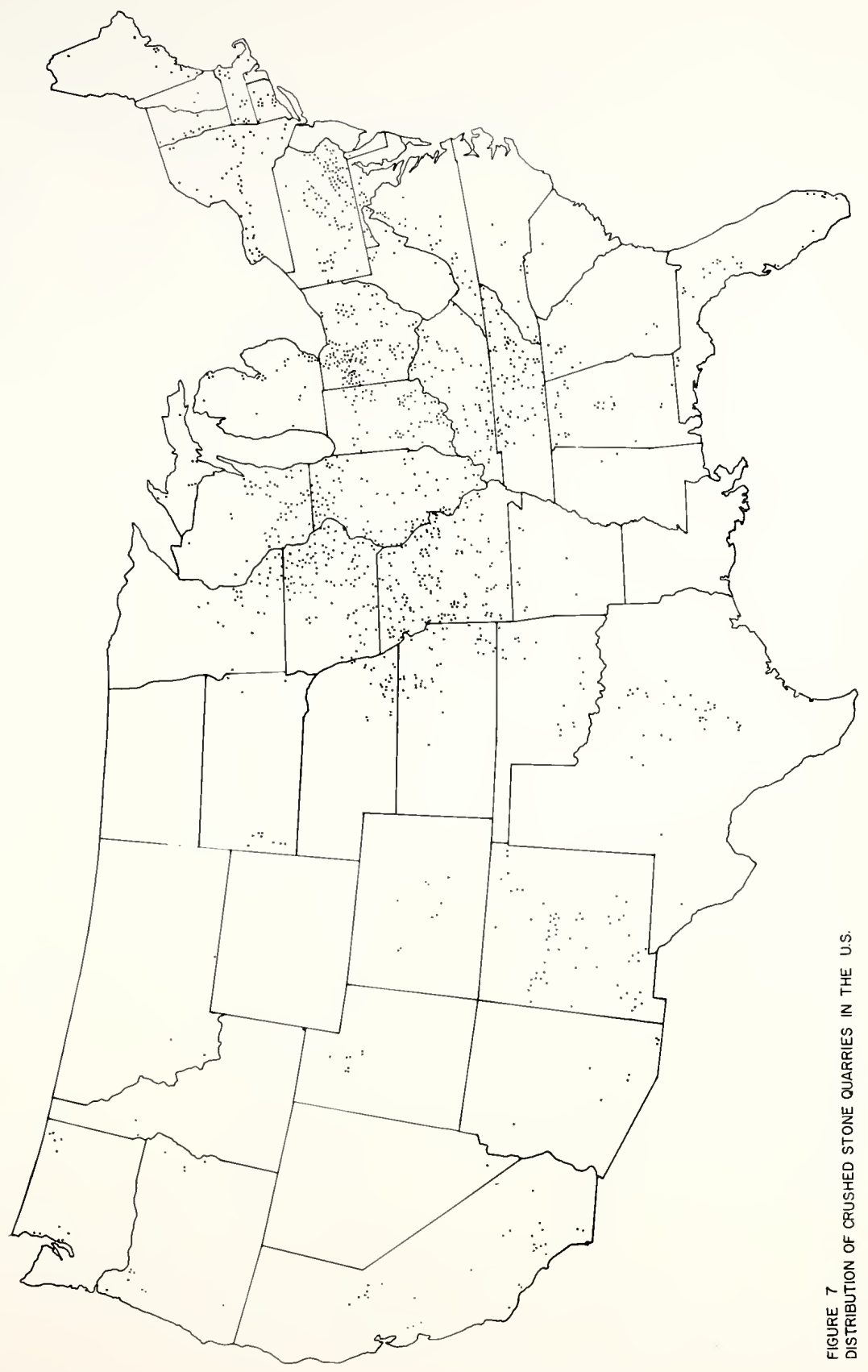




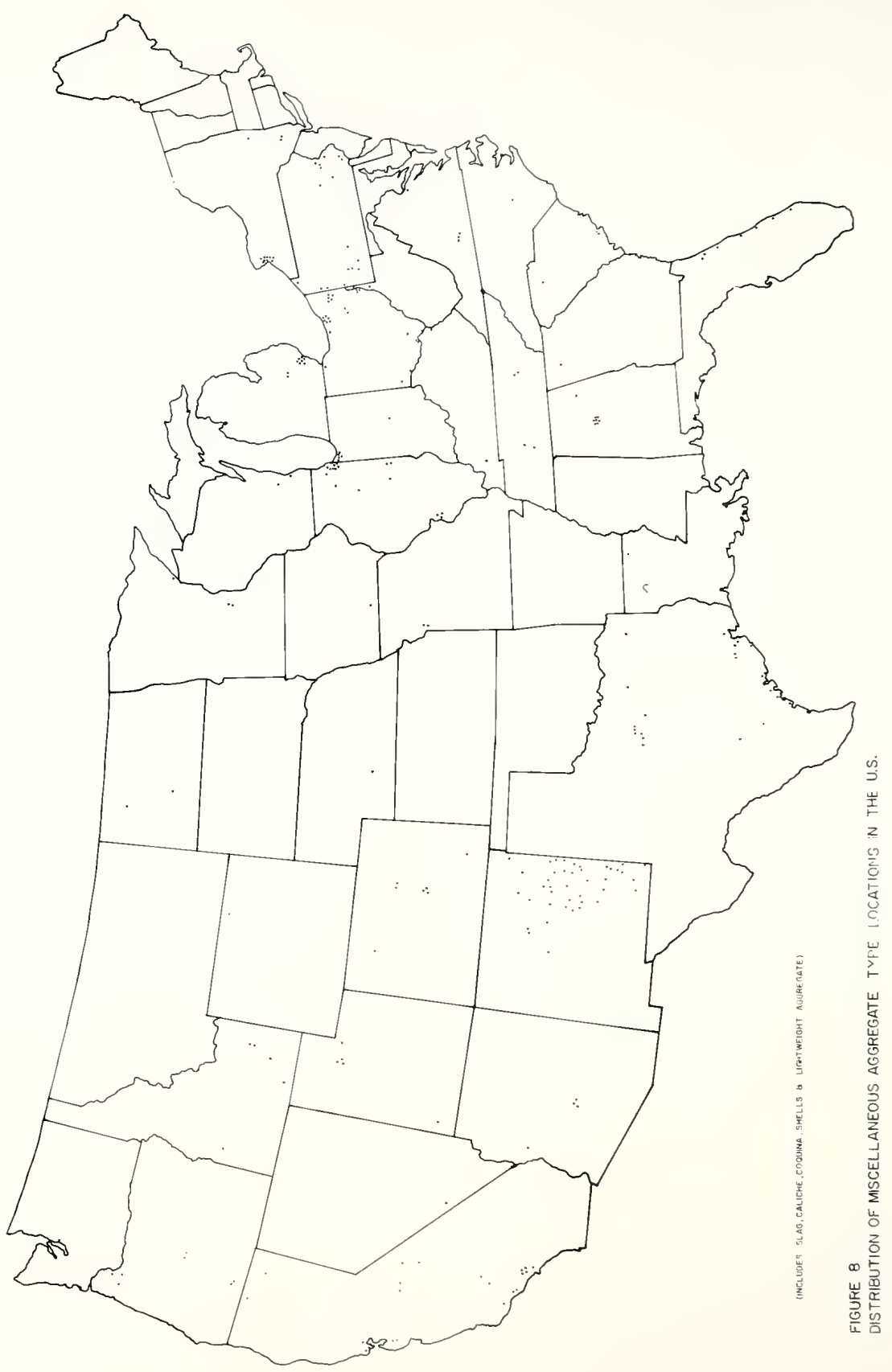


Table 10

Reference Summary of State Pit/Quarry-Aggregate Areas

$\quad$ States
Alabama
Arizona
Arkansas
California
Colorado
Connecticut
Delaware
Florida
Georgia
Idaho
Illinois
Indiana
Iowa
Kansas
Kentucky
Louisiana
Maine
Maryland
Massachusetts
Michigan
Minnesota
Mississippi
Missouri
Montana
Nebraska
Nevada
New Hamphire
New Jersey
New Mexico
New York
North Carolina
North Dakota
Ohio
Oklahoma
Oregon
Pennsylvania
Rhode Is1and
South Carolina
South Dakota
Tennessee
Texas
Utah
Vermont
Virginia
Washington
West Virginia
Wisconsin
Wyoming

Pits/Quarries

$$
\left(\frac{169}{169}, \frac{172}{172}\right)
$$

$(107,169,172)$

$(166,169,172)$

$(\underline{166}, \underline{169}, 1172)$

$(169,172)$

(169, 172)

$(169,172)$

$(166,169,172)$

$(\underline{107}, 169,172)$

$(90,104,169,172)$

$\left(\frac{90}{122}, \frac{169}{172}\right)$

$(107,169,172$

$(16 \overline{9}, 172$

$(169,172)$

$(166,169,172)$ $(169,172)$

$(166,169,172)$ (169,172)

$(169,172,174)$

$(169,172)$

$(169,172)$

$(166,169,172)$

(169,172)

$(\overline{169}, \overline{172})$

$(166,169,172)$

$\left(166,169, \frac{172}{172}\right)$

$(155,169,172)$

$(107,157,166,169,172)$

(169.172

$(90,169,172)$

$(107,169,172)$

$(107,169,172)$

$(166,169,172)$

$(166,169,172)$

$(166,169,172)$ $(166,169)$

$(90,166,169)$

$(107,166,169)$

(107, 166, 169)

$(166,169,172)$

$(166,169,172)$

$(107,169,172)$

$(95,166,169,172)$

$(107,166,169)$

$(90,169,172)$

$(166,169,172)$
Crushed Stone

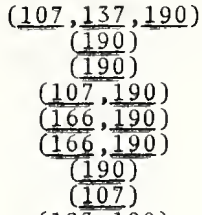

$\left(12 \frac{1}{3}, 190\right)$

(166, 190)

$(90,107,190)$

$\left(\overline{90}, \overline{104}, \frac{190}{190}\right)$

$\left(90, \frac{107}{190}\right)$

$(90,190)$

$(107,190)$

$166,190)$

(190)

$(166,190)$

$(107,190)$

$(90,174,190)$

$(90,107,190)$

(166, 190)

$(90,190)$

(190)

$(166,190)$

$(166,190)$

(190)

$(107,166)$

(190)

$\left(90, \frac{107}{107}, \frac{190)}{90)}\right.$

$(166,190)$

$(107,166,190)$

(190)

(190)

$(90,190)$

$(107,190)$

$(107,123,190)$

(190)

$(166,190)$

$(107,137,190)$

(190)

$(107,190)$

(90,190)

$(166,190)$
Sand Grave 1

$(123)$

(123)

$(123,190)$

$(123,204)$

$(123,166)$

(184)

(123)

(123)

$(166,204)$

(90)

(90)

$(90,122)$

$(90,123)$

(123)

$(123,133)$

(184)

(184)

(90)

$(90,174)$

$(123,204)$

(190)

(166)

$(90,123)$

(123)

$(166,184)$

(166)

(123)

(137)

(123)

(90)

(90)

$(123,190)$

(166)

(166)

(149,184)

(123)

(90)

(123)

(123)

$(123,166)$

(184)

(190)

$(95,166)$

(166)

(90)

(166)

Note: Numbers in parenthesis pefer to bibliography number 


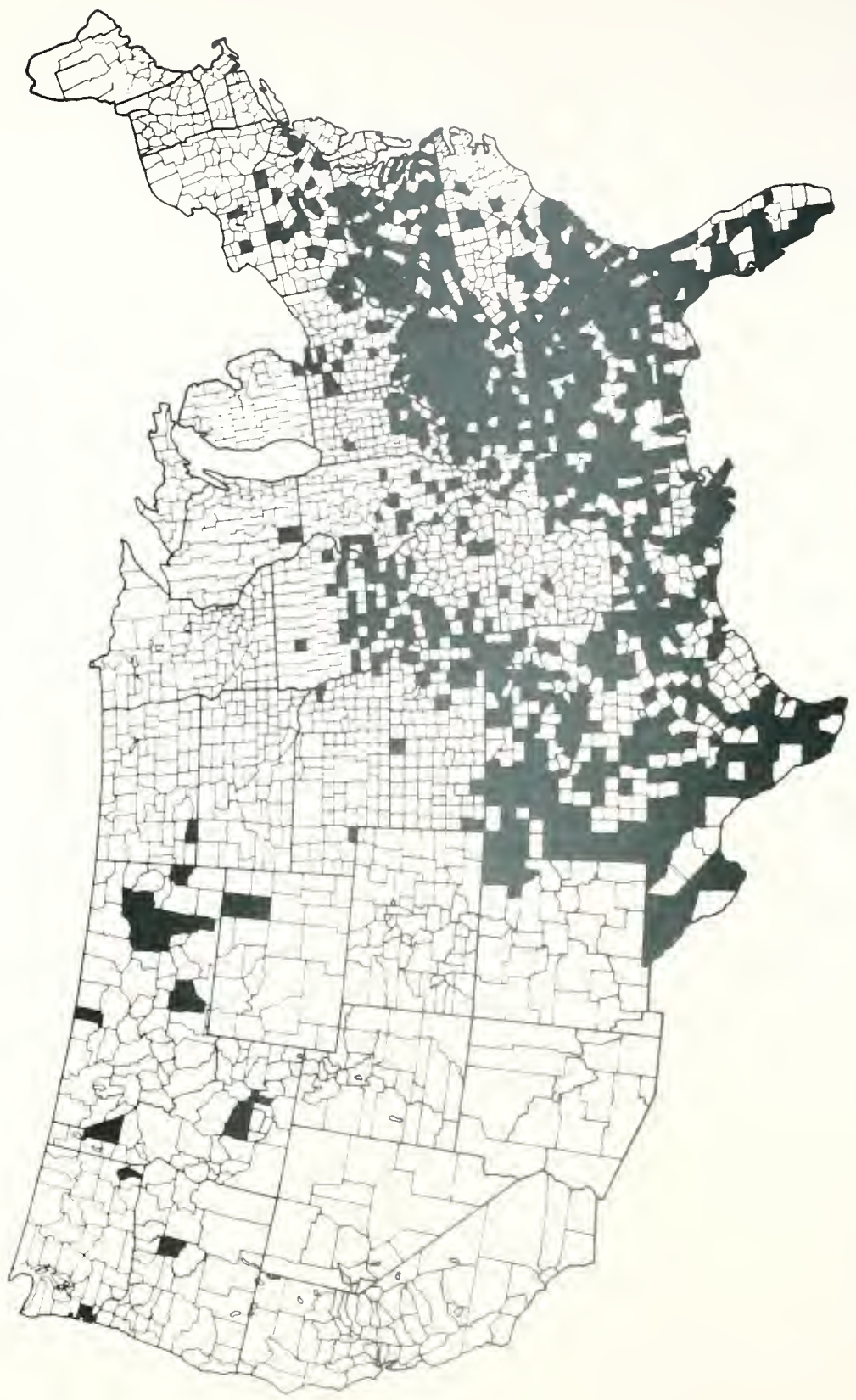




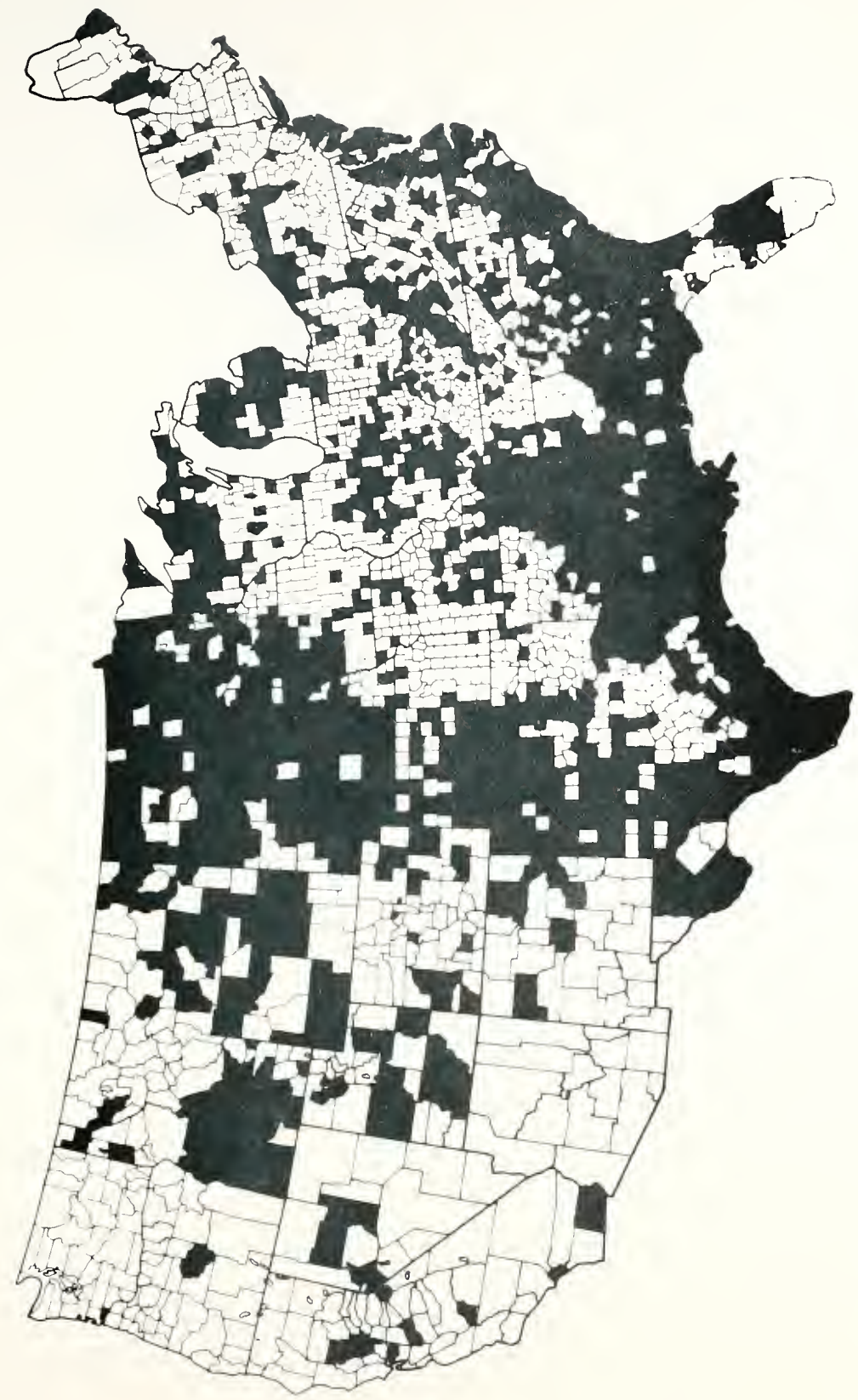




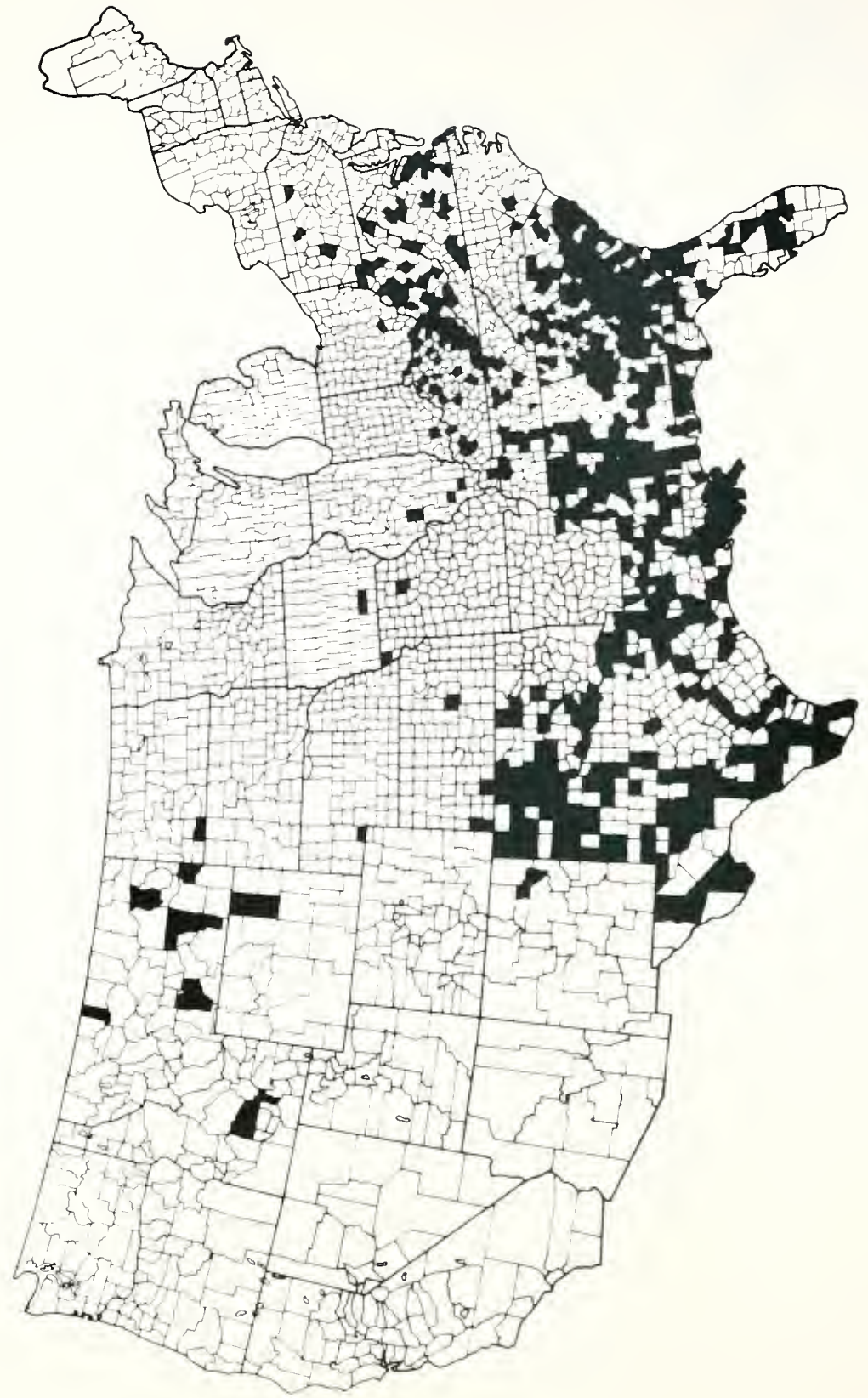

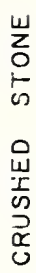

$\stackrel{\pi}{\circ}$

1
w
$\frac{1}{2}$
0
1
0
2
0

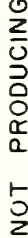

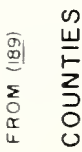

$\stackrel{1}{\circ}$

$z$
0
0

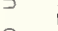

w

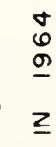

$\frac{1}{4}$ 
qual1ty aggregate resources was obtalned from the Materlals Questionnalre. Figure 12 shows the aggregate - poor areas reported by the representative state highway officials who completed this portion of the questionnalre. This map was relled upon heavily to provide the est1mated potentlal ava1lab1l1ty ratings of each basic report unit. State Aggregate Froduction Data Quantitative state production data for sand-gravel and crushed stone sources were obtalned from references (125, 189). The sand-gravel data were for 1964, while those for the crushed stone were the reported output for 1958 . Differences between states were determined in part by variations in demand caused by size of population and area. In an attempt to "normalize" these production outputs, they were divided by the product of area times population, yieldIng a "production density". ${ }^{1}$ These were arranged in numerical order and divided into three groups or zones.

In addition, a production output ratio of sandgravel to crushed stone was determined for each state. This ratio was grouped in five zones based upon a visual examination of the numerical ranking. The pertinent data for production tonnage, population and area for each state is presented in the Tables within Appendix C. Figures 13 to 15 portray the zones previously described.

1. The production density is tons/sq. mi./cap1ta. 


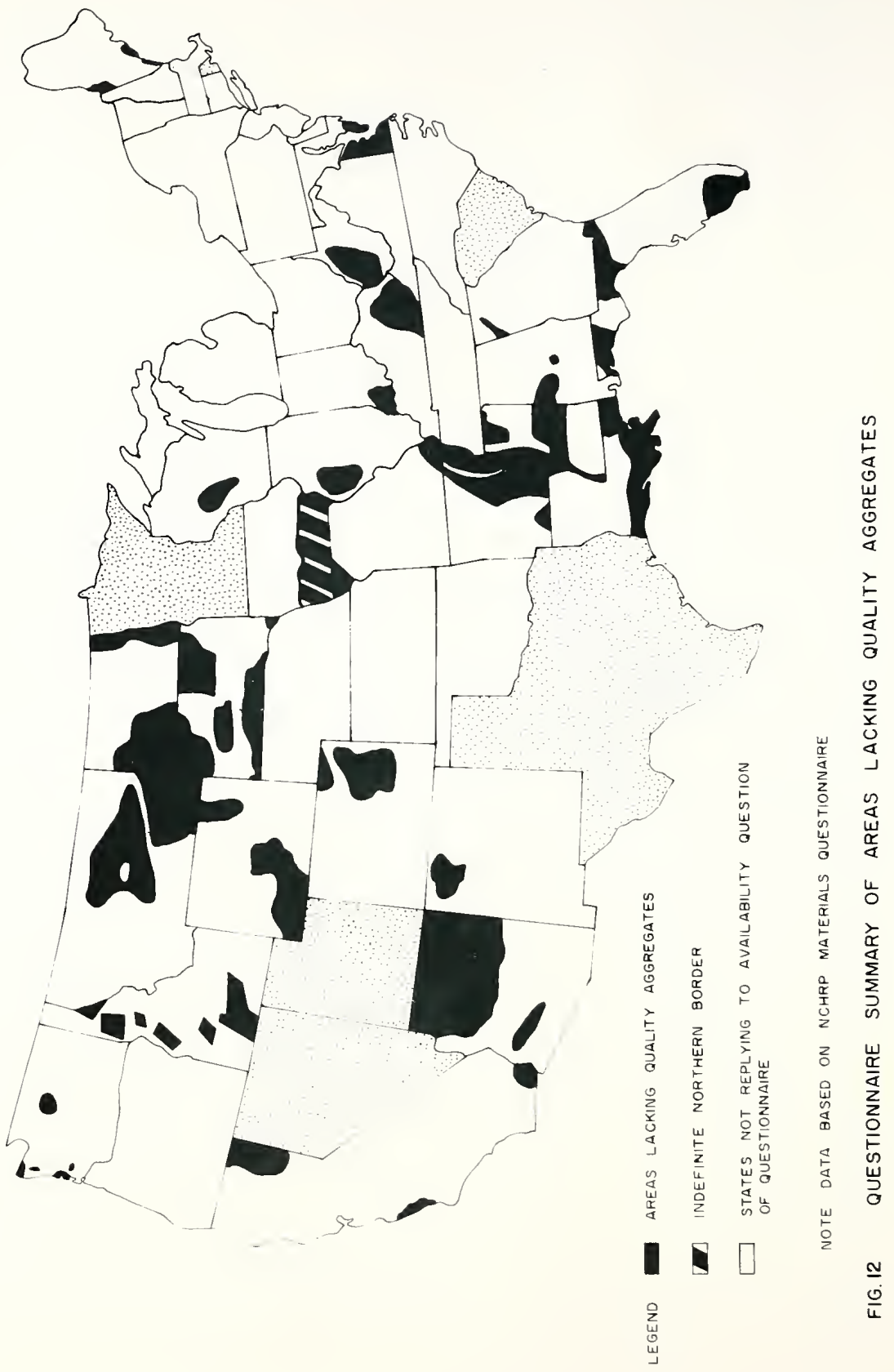




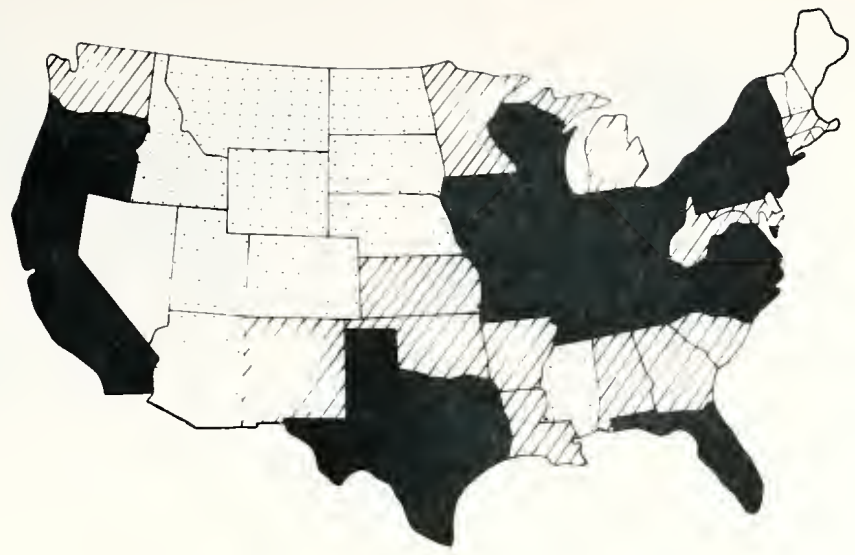

GROUPINGS BASED UPON TOTAL PRODUCTION (TONS)

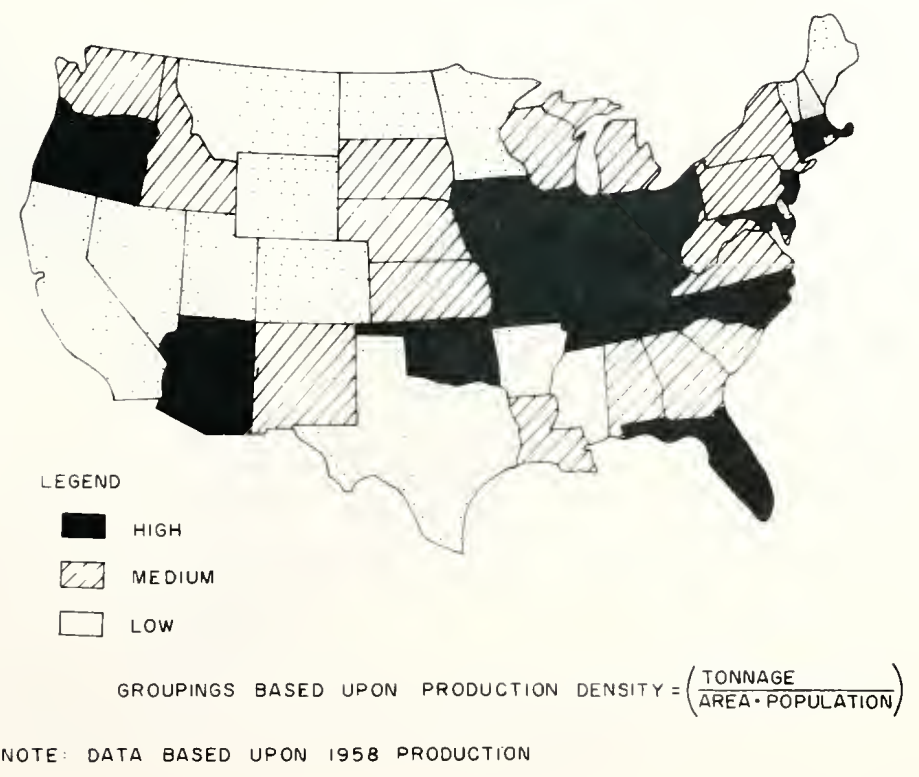

FIG. 13 SUMMARY OF STATE CRUSHED STONE PRODUCTION GROUPINGS 


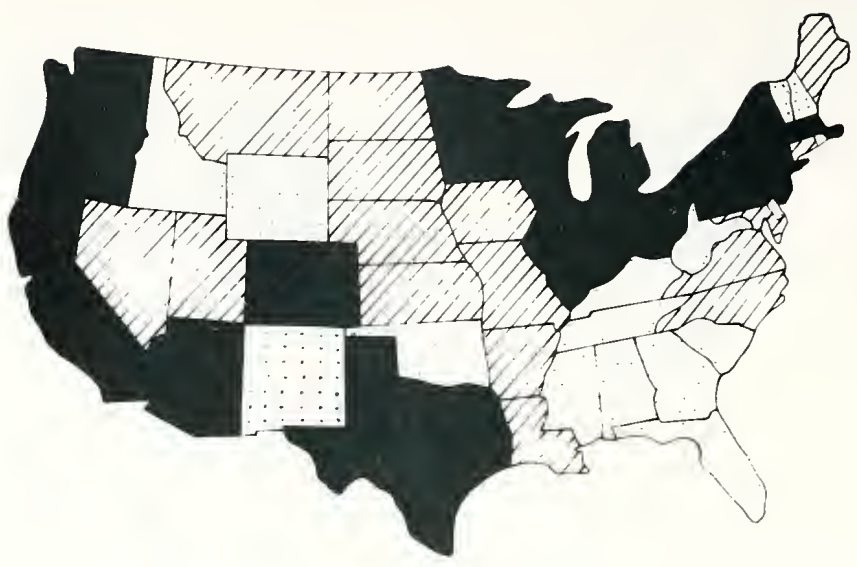

GROUPINGS BASED UPON TOTAL PRODUCTION (TONS)

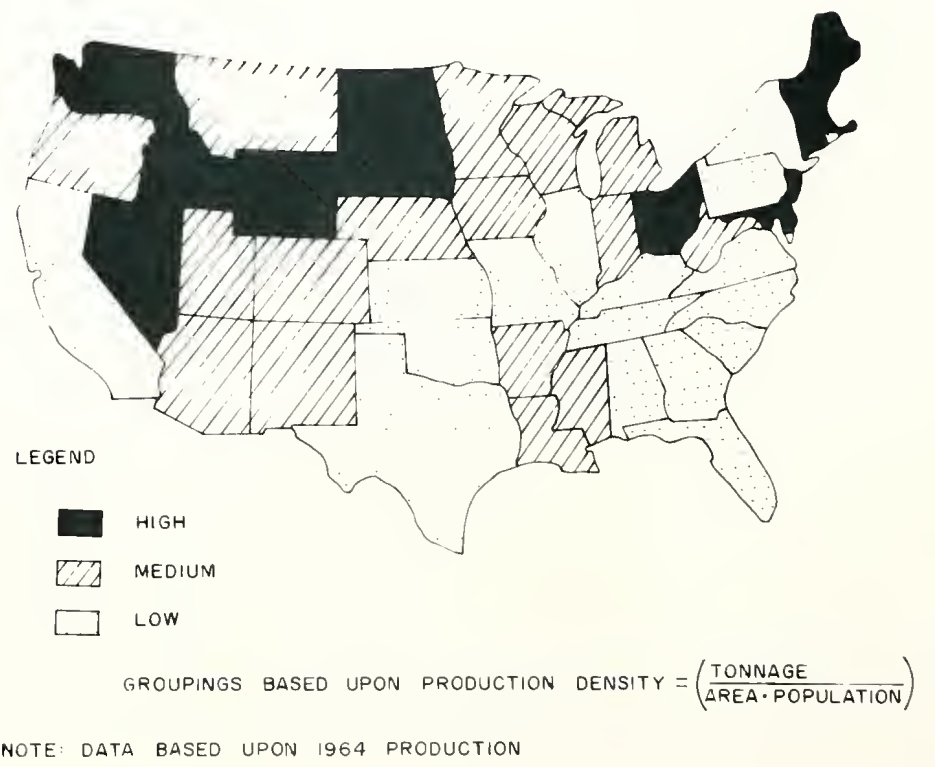

FIG. 14 SUMMARY OF STATE SAND GRAVEL PRODUCTION GROUPINGS 


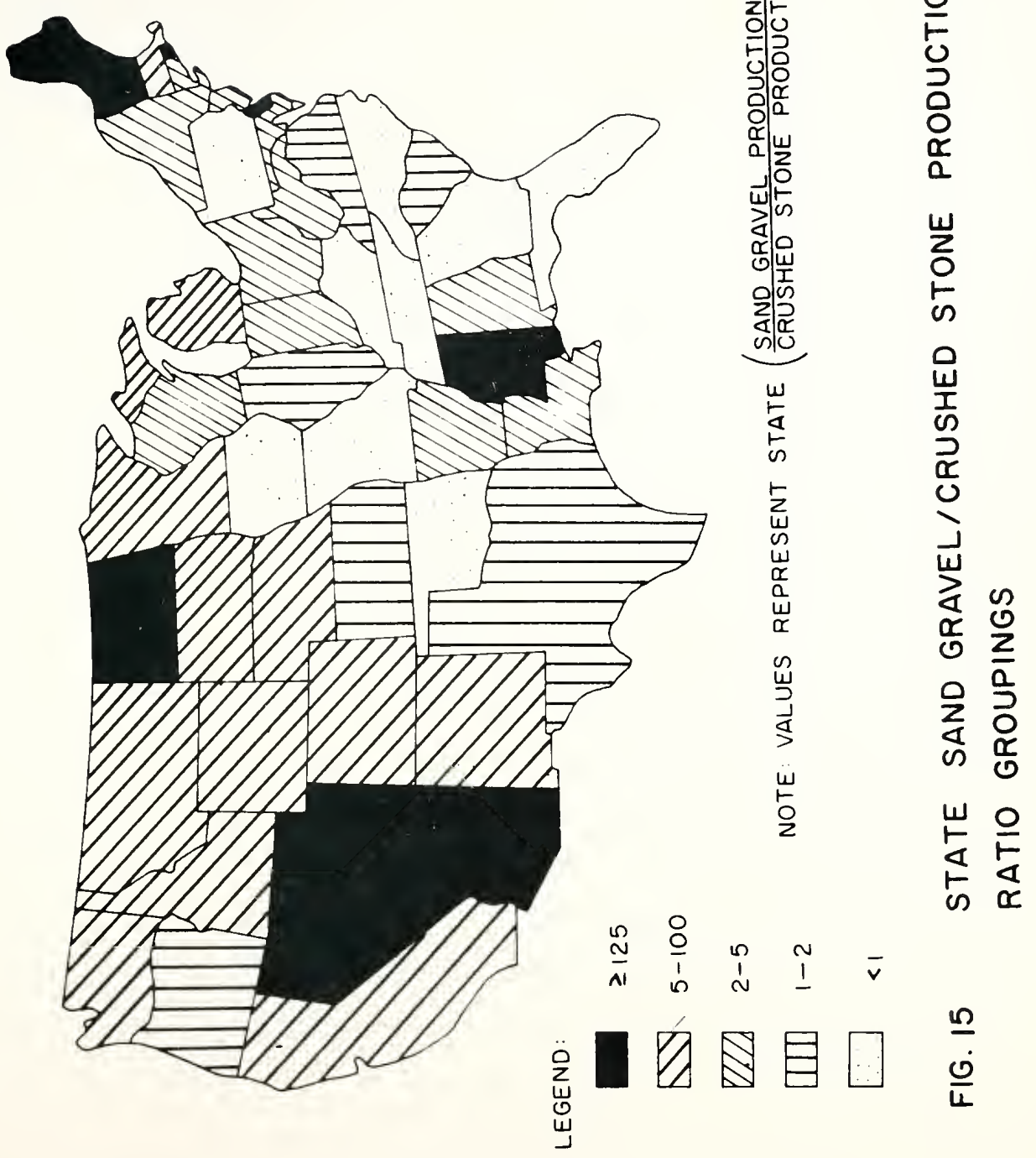




\section{Aggregate Types}

Aggregate Type Code

A wide variety of aggregate sources is used in the highway industry, and a total of thirty-four (34) types are recognized within this report. Table 11 lists these aggregates, keyed to a numerical code. In the table, the aggregates have been grouped as sands and gravels, crushed stone and miscellaneous. The last group consists primarily of artiflcial aggregates as well as the author's interpretation of several "localized" aggregate sources, e.g., coquina, clam/ cyster shell, etc. The crushed stone group has been further subdivided by type of rock. The relation between the coded aggregate number and the general category of aggregate shoula te apparent (sedimentary crushed stone types have the 10 series, 1gneous crushed stones are denoted by the 20 series, etc.).

state usaze

A resume of the major aggregate type sources used by each state is given in Table 12. This summary is based primarily upon the responses to the Materlals Questionna1re. Where states did not provide such information, input was obtained from references (144, 169, 172, 188), and is accordingly more tentative. Pertinent remarks extracted from the questionnalre responses as well as several by the author, are also shown in the table. Section Lisage

Table 13 is a summary of the aggregate types used 


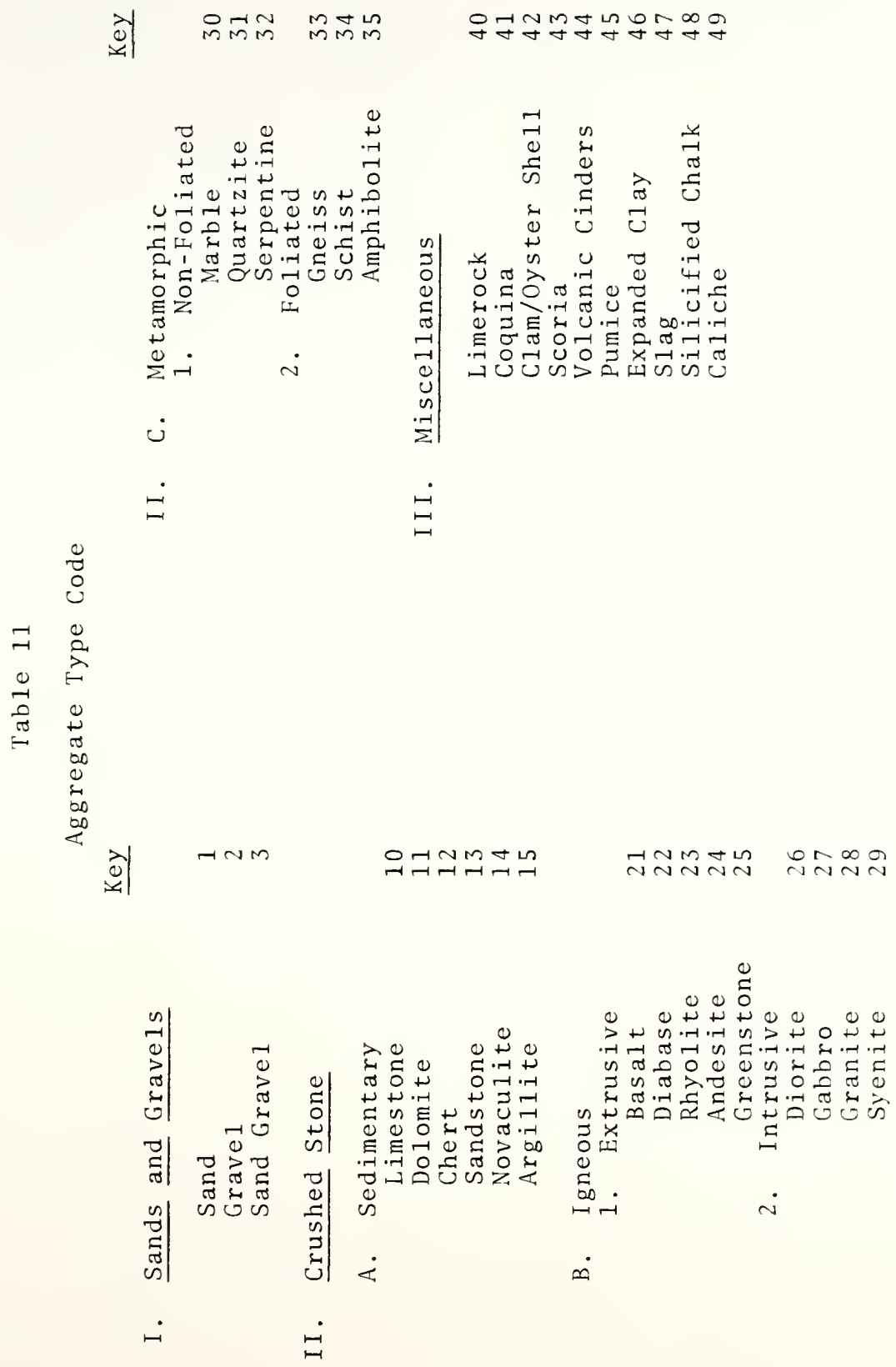



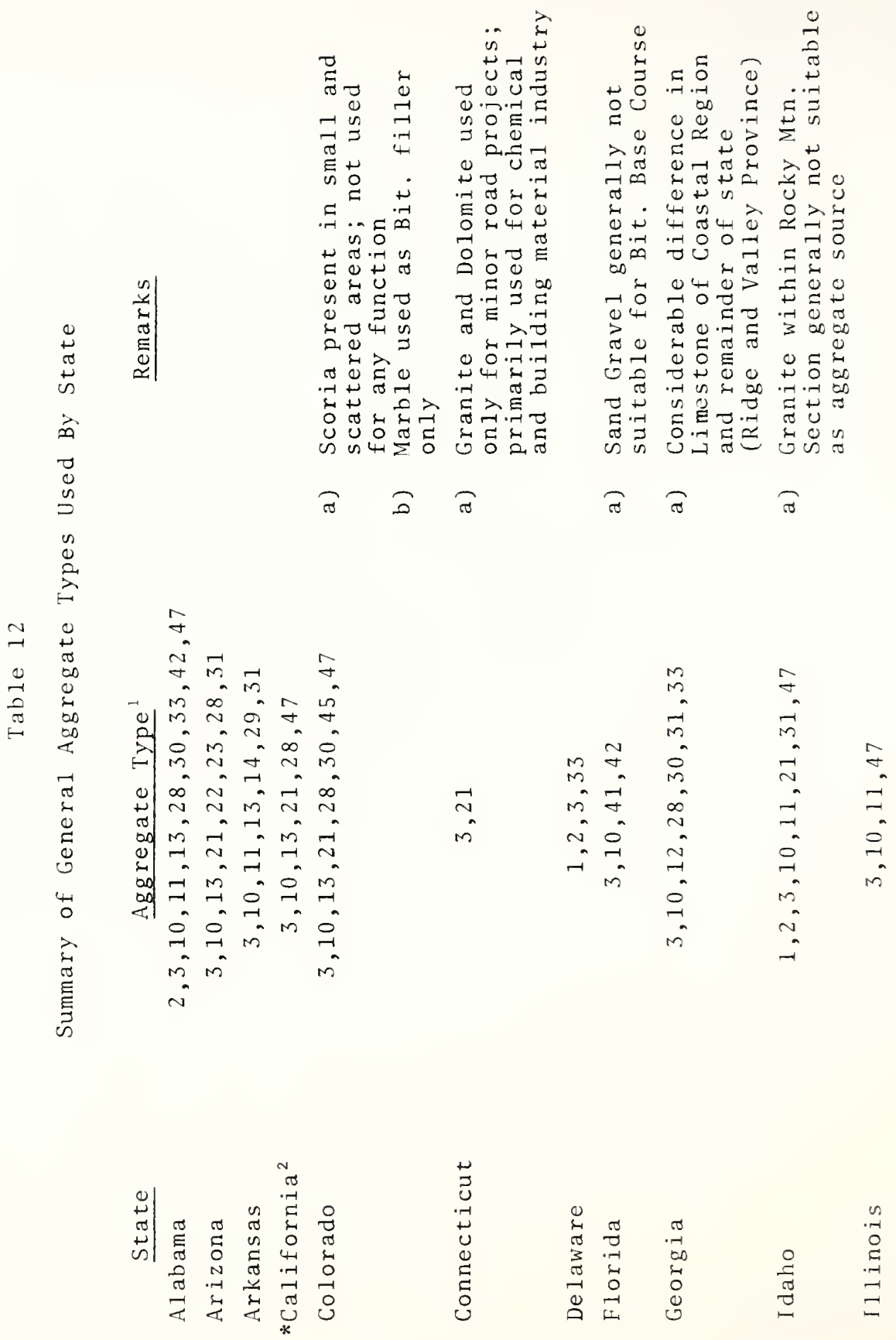


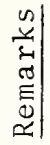

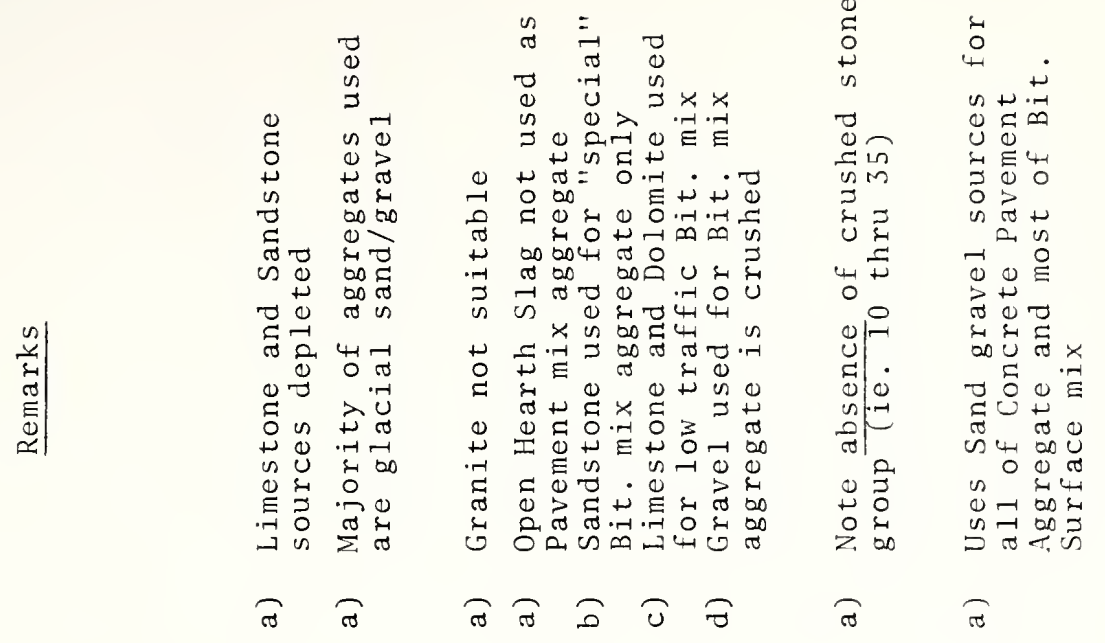

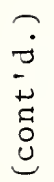
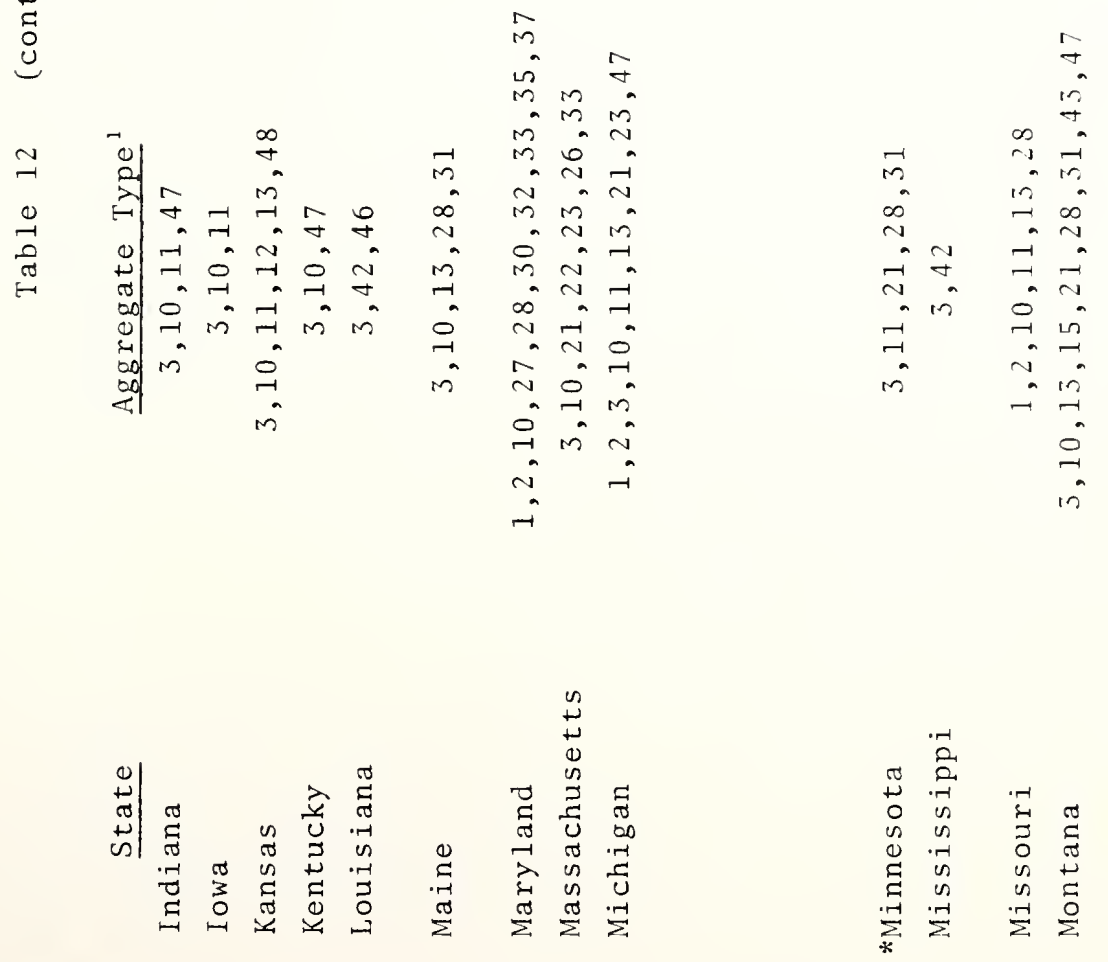


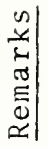

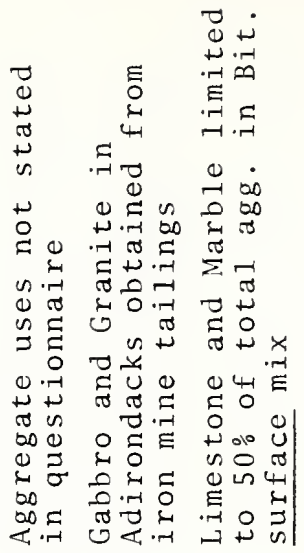

का

$\square$
\pm
\pm
0
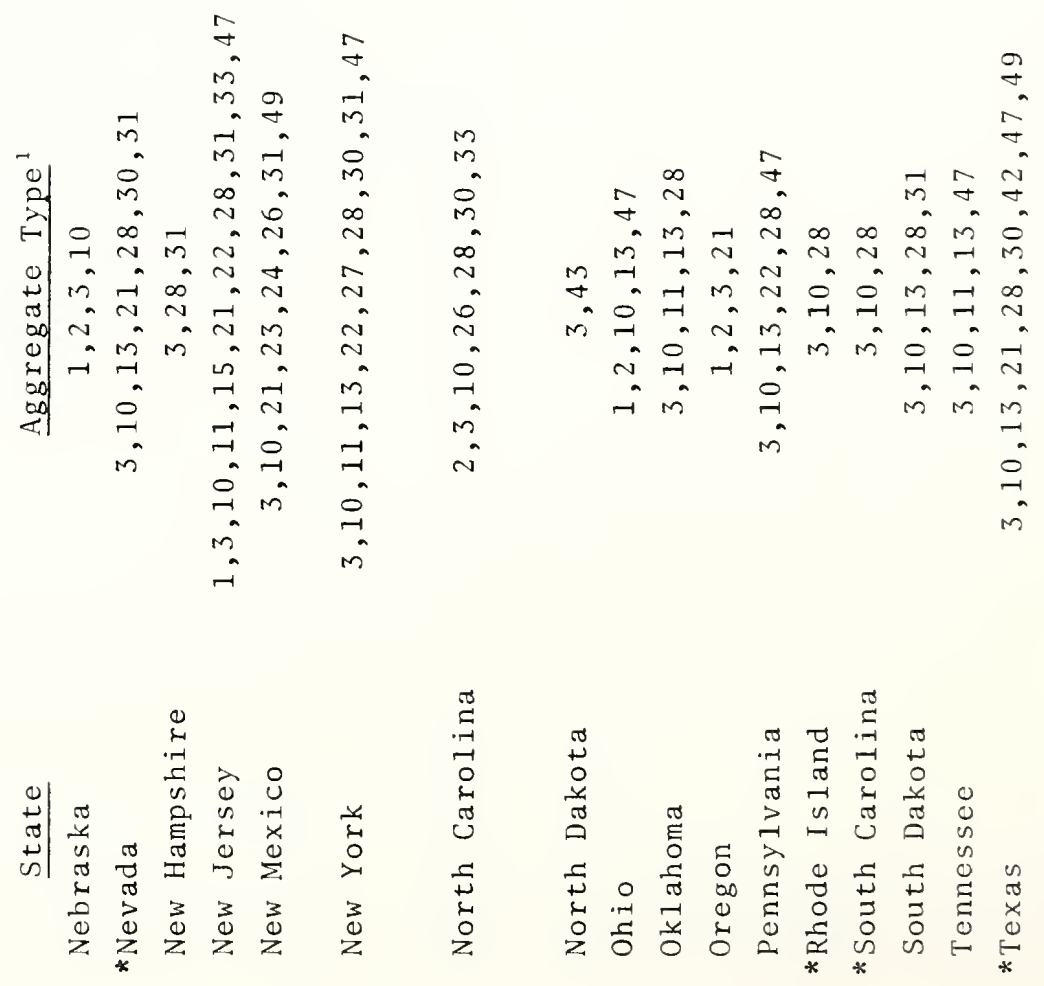


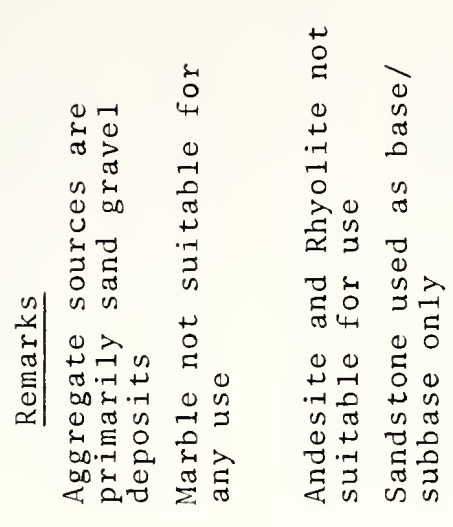

ชิ

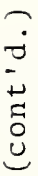

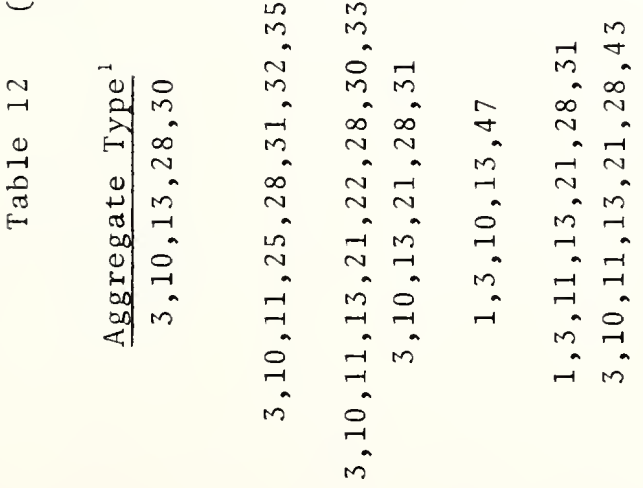

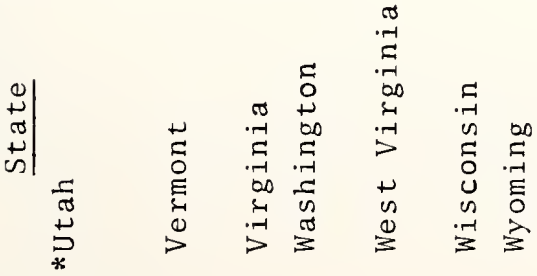

* $\underbrace{\infty} \stackrel{0}{0}$

o

a

(1) 0 (1)

2 in 0

ก.

ฮี

द्ञ०त

강

Ex क

至 0

$4 \equiv$

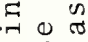

in

*웧

in 00

-

- क्ष.त

$\stackrel{0}{\circ}$

तो

.

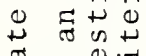

$\pi \quad 0 .-1$

我元

$\overbrace{-1.4}^{0}+\pi$

bo 3 n

क $\nabla$ का

(क) 0.01

원

के

ते 5 마

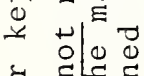

क ELE.

4 क ह 한

$\Rightarrow+\underset{0}{\pi}$

$+40$

$\rightarrow$ ⿰冫

ส 000

- 10.70

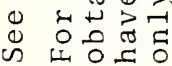

$\rightarrow N$

in
$\stackrel{+}{+}$
0
$z$ 


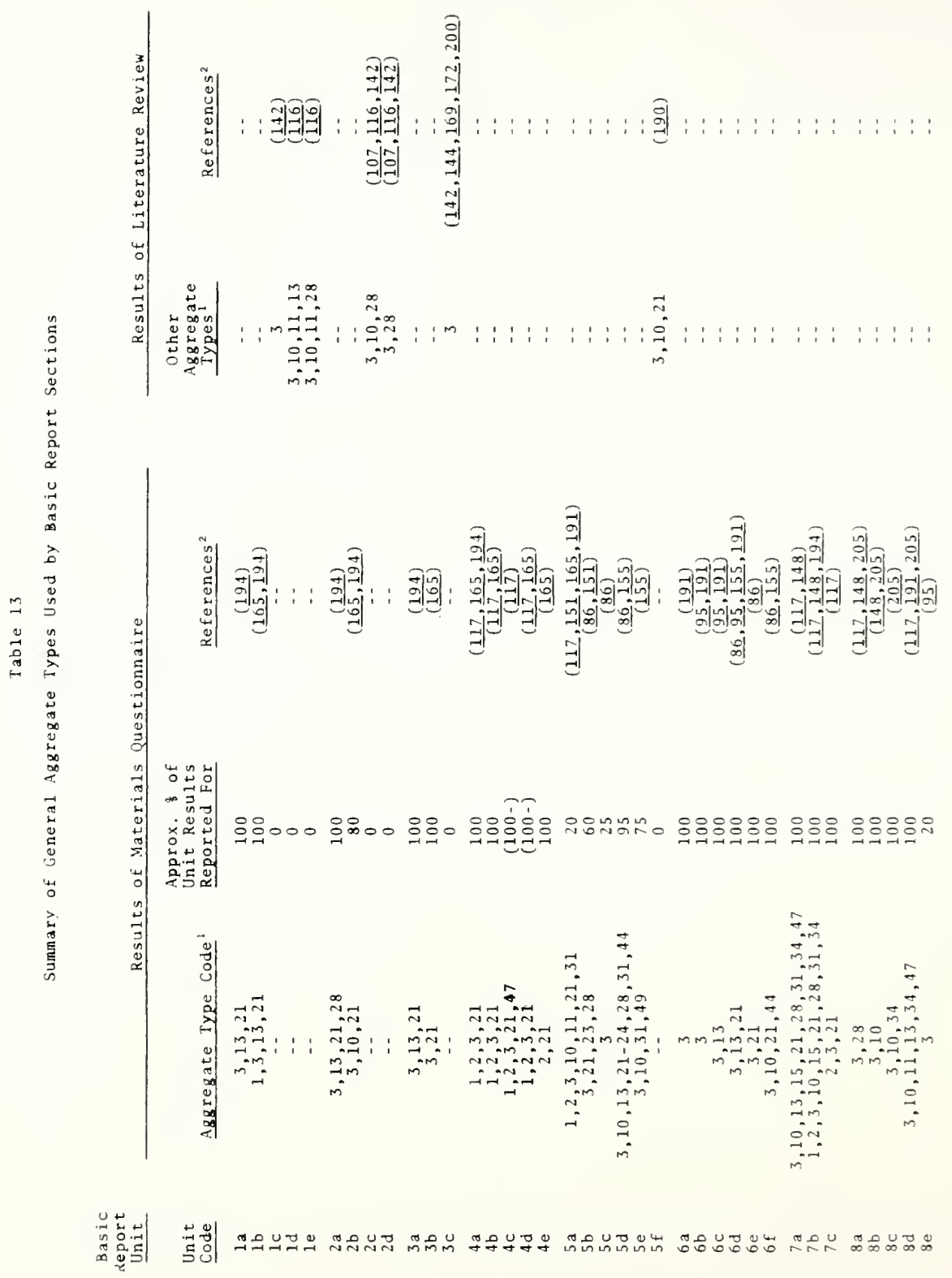



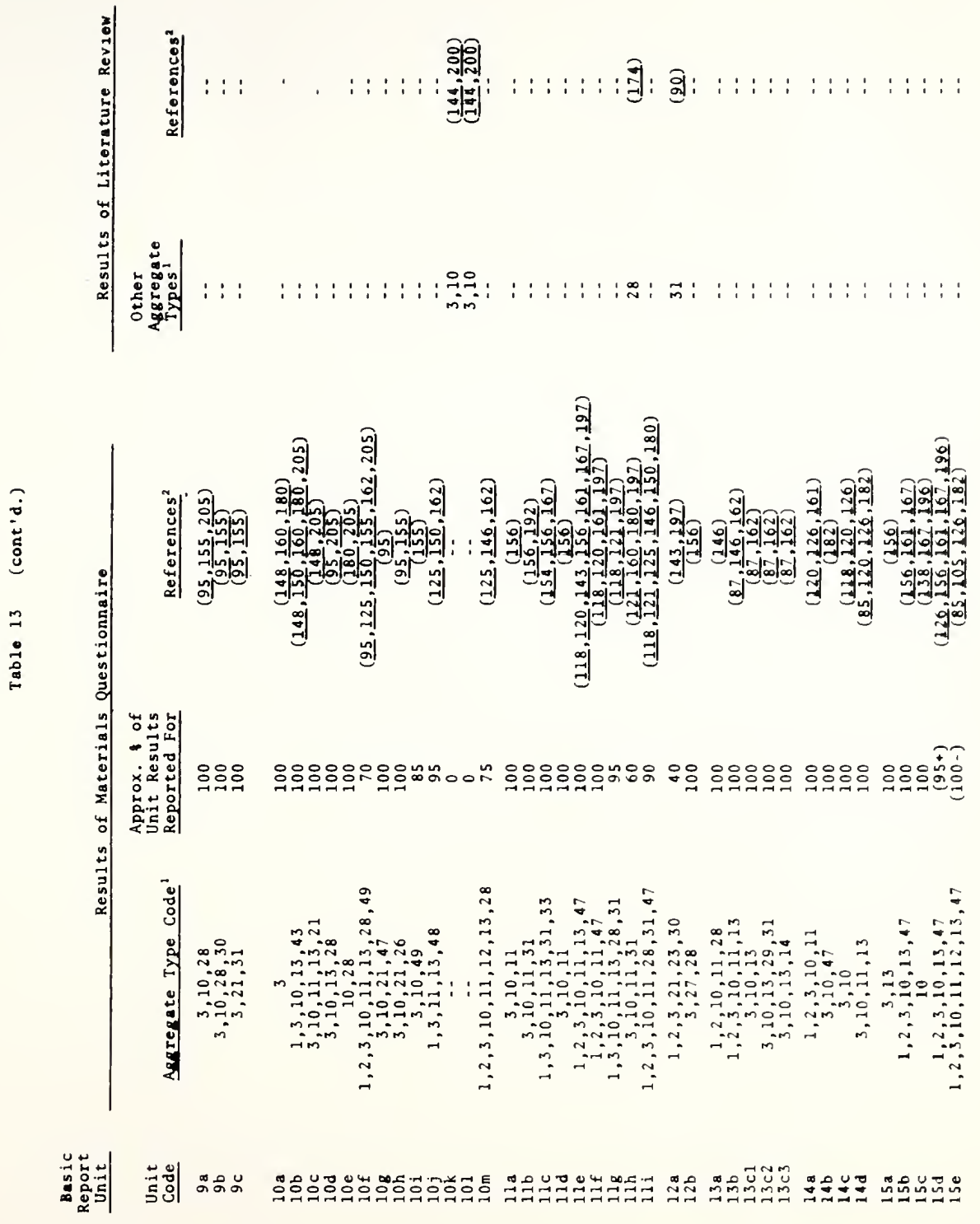

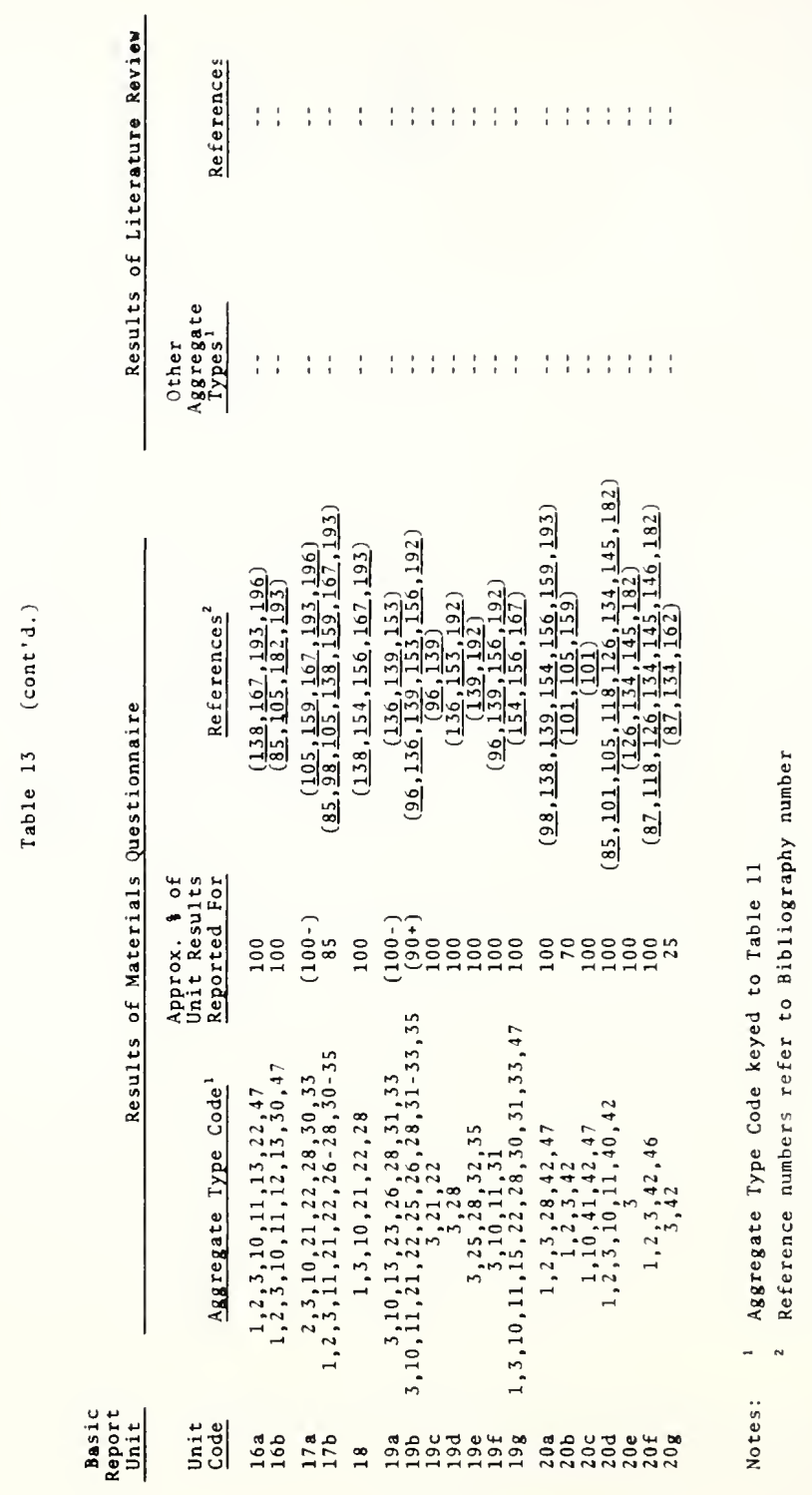
within the basic report Sections. Results have been complied primarily from the Materials Questionnaire. In addition, where a review of the I1terature has indicated an aggregate scurce not appearing in the questionnalre response, the reference is cited.

Avallability of Qual1ty Aggregates by Easic Report Un1ts General

The primary objective of this phase of the project was to determine a potential avaliabilty rating of quality aggregate resources for each basic report unit. This rating was based upon an analysis of the various inputs of data previously described. An arbitrary rating scale was devised, consisting of the following: (a) abundant to adequate, (b) adequate to $11 \mathrm{mited}$, (c) limited to problem and (d) severe problem.

Ratings were assigned to the basic report units $\mathrm{ky}$ : (a) determining the major type or types of aggregates used; (b) examining their relative distribution within the unit; and (c) assessing the major quality problems of the aggregate sources. Thus it was possible for an area possessing an abundant distribution of a potential aggregate type to recelve a "compromised" rating of (adequate to $11 \mathrm{mited}$ ) due to the presence of a major (widespread) problem w1th that particular aggregate type. An example is afforded by the Springfield-Salem Plateau where an abundance of cherty carbonate rocks yields widespread durability problems when used as concrete pavement aggregate. on the other hand, a 
more limited supply of a good quality aggregate type, which was well distributed within the basic unit, cculd produce an sbundant to adequate rating. The Trlassic Iowland unit, with 1 ts areally limited but well distributed good quality trap ridges, is an excelient example.

Estimated Fotential Ava1lability Rating of Basic Report Lnits The following paragraphs give the avallatlity ratings for the aggregate resources within the 97 sections, and triefly describe the aggregate types, uses and protlems. The discussions are arranged in order of numerical code identification.

Section: la Olympic Mountains Avallatility Rating: Adequate to I1mited

Remarks: Crushed stcne sources are 11 mited. The major pcrttion of the bedrock comprising the area is slates, phylittes and argillites; none of which are currently used as aggregate sources within washington. Crushed sandstone is used as subbase/base aggregate. Basalt is used as both bltuminous and concrete aggregate, however, widespread abrasion and durablilty problems are frequently encountered. Sand-gravel sources are generally located along the perlphery of the section. Several scattered but regionally defined areas lacking quality aggregates occur.

Section: lb cregon Coast Range Avallability Fating: Ilmited to Problem Femarks: The wldespread soft sandstones and shales afford little, if any, sultable aggregate. Crushed sandstones of suitable quality for base/subbase aggregate may be locally obtalned. Crushed basalts, of quality similar to those of the Olympic Mountain section, are used for all aggregate functions. Sand-gravel sources do not appear to be widely distributed, and frequently give abrasion and durability problems when used locally as concrete pavement aggregate.

Section: Ic Klamath Mountains Avallability Rating: Adequate to I1mited Remarks: This rating is based solely upon an examination of 
existant geologic conditions, and should consequently be considered as highly speculative. In this rugged mountalnous area, adequate crushed stcne sources appear to be avallable. Sand-gravels may be obtained from rivers, such as the Klamath (200).

Section: Id California Coast Range

Avallability Rating: Ilmited to Protlem

Remarks: Th1s Section is quite similar to the cregon coast Ranges. Sandstones are prominent in the area; however, they generally are of low abrasion resistance (116). Crushed 11 mestone sources are found south of the San Franclsco area in the Southern Callfornia Coast Range (107). Sand-gravel sources from the Salinas $\mathrm{R} 1 \mathrm{ver}$ have been noted to be reactive with cement (171).

Section: le Ios Angeles Ranges

Avallability Fating: I Im1 ted to Problem

Femarks: Within this section the avallability and general quality of crushed granitic and carbonate sources appears to be good $(107,116)$. The crushed stone sources are primarliy developed in the Traverse Ranges, wh1le sand-gravel deposits appear to be abundantly avallable within the Frovince of Southern Californla Subsection. Alkal1-aggreete reactions have occurred w1th sand-gravel sources from the Santa Clara River (121).

Section: 2a Northern Cascade Avaliablilty Rating: Adequate to Ilmited

Remarks: The potentlal for crushed stone sources appears to be quite good within the Section. Crushed granites of good quality, basalts exhibiting localized abrasion and durability problems, and sandstones of quality sultable for base/subbase aggregate are avallable. Sand-gravels of good quality are generally located along the borders of the section. A region near the Glacler Peak lacks quality aggregate sources.

Section: $2 \mathrm{~b}$ Southern Cascade Avallability Rating: Abundant to Adequate

Remarks: Crushed basalt of falrly good quality and sand-gravel are the major sources of aggregate for all functions. Crushed limestone sultable for base/ subbase aggregate may be locally avallable. In general the potentlal supply of aggregates appears to be quite adequate. 
Section: 2c Sierra Nevaja

Avallakility Rat1ng: Abundant to Adequate

Femarks: Crushed gran1te and natural granular deposits are

abundantly avallable. Iocalized carbonate areas

are present on the western side of the section. Cement-aggregate reactions may occur with sandgravel sources.

Section: 2d Lower California

Avallability Rating: Abundant to Adequate

Remarks: This Section is similar to the Sierra-Nevada in major types of potentlal aggregates. Crushed gran1 tes of good quality are adequately avallable.

Section: $3 a$ Puget Sound

Avallability Rating: Abundant to Adequate

Remarks: Th1s Section possesses a rather abunaant distribution of glacial granular deposits in the form of terraces and outwash plains. Iocalized deposits of sand-gravel may cause alkal1-aggregate reaction. quality crushed stone sources (primarily basalt) are avallable. Iocalized problems of stripping, abrasion and durability occur with this aggregate. Andesite and rhyolite are generally not sultable for use.

Section: 3t W1llamette Valley

Ava1lability Rat1ng: Abundant to Adequate

Remarks: Th1s Section 1s quite similar to the Puget Sound Section in that the major aggregate sources are sand-gravel and crushed basalt. However, the granular material is obtained primarily from either alluvial fans adjacent to the mountalnous areas and/or the river and stream system within the Sectlon. Quality aggregates are generally avallable, however problems with volcanlc rock may be somewhat similar to the Puget Sound Section.

Section: 3c Great Valley

Availability Rating: Abundant to Adequate

Remarks: Sand-gravel may be obtained from fans and aprons near mountain ranges surrounding the section and from alluvial deposits assoclated with 1 ts rivers and streams. Bedrock sources are little exploited due to the relatively deep alluvial cover in the Valley. Quality crushed stone sources must be obtained from nearby mountainous area.

Section: $4 a$ Walla-Walla

Avallability Rating: Abundant to Adequate

Remarks: Sand-gravel sources are generally well alstributed within the Washington portion of the section both from glaclal outwash and along major rivers 
such as the Snake and Columbia. Ioess and callche may be present in the outwash deposits. Oual1ty crushed basalts are generally avallable.

Section: $4 \mathrm{t}$ Blue Mountains

Avallability Rating: Abundant to Adequate

Remarks: The major sources of aggregate are sand-gravels and crushed basalt; the general quallty of both scurces appears to be good. Sedimentary rocks and granite are avallable, although, at present, they are not used as aggregate sources by cregon.

Section: 4c Snake River Plain

Avallabli1ty Rating: Ilmited to Problem

Remarks: A large fortion of the area 1 s veneered by loessial deposits that overlie young basaltic and ac1dic flows. In general, the crushed basalts of the area, where available, appear to possess poor abrasion, durability, and adhesion characteristics (117). Sand-gravel sources are generally lacking except near the mountalnous borders and along some terrace portions of the Snake $\mathrm{R} i v e r$. Idaho indicates that suitable concrete gravels are generally lacking. Ilmited sand-gravels frequently possess a wide spectrum of aggregate problems including the alkal1-aggregate reaction.

Section: 4d Payette

Ava1lability Rating: Adequate to I1mited

femarks: The sources of granular deposits are primarily located along the major river terraces. The quality of these sources appears to be highly varlable. Widespread abrasion, durability, alkali-aggregate reaction and adhesion problems are noted within the Idaho portion. Crushed basalt sources, where avallable, appear to te of varlable quality. Easalts may frequently be interbedded with fluvial sediments.

Section: 4 e Harney

Availability Rating: I1mited to Problem

Remarks: The Section does not possess an overall abundance of elther natural granular deposits or suitatle crushed stone sources. Rivers and streams are scarce in the section, and a vast portion of the area is surfaced by the disintegrated pumice deposits of the Great Sandy Desert. Iimited problems with alkali-aggregate reaction are encountered with gravels of the area, while crushed basalt, where avallable, produced widespread adhesion problems. 
Section: 5a Great Basin

Avallability Rat1ng: Abundant to Aiequate

Remarks: Natural sand-gravel sources from alluvial fans and aprons near the mountain ranges are rather abundant. Granular lacustrine deposits are ut111zed as aggregates within old Lakes Iahontan and Bonnev1lle. Many mountain ranges may afford sultable crushed stone resources. Cccurrence of alkal1-aggregate reactions have been noted within some portions of the Section.

Section: 5b Sonoran Desert

Avallability Rating: Abundant to Adequate

Kemarks: Natural sand-gravel deposits are found near the mountain ranges (similar to section 5a). Quality crushed stones (primarliy lgneous) are located in and developed from ranges in the Section. Alkal1aggregate reactions are assoclated with the widespread 1 gneous activity. Iocalized areas lacking qual1ty aggregates occur.

Section: 5c Salton Trough

Avallability Rating: Ilmited to problem

Remarks: Although sand and fine gravel are locally avallable, aggregate sources are generally lacking in the southern California portion (Imperial Valley). Alkal1-aggregate reactions may be a problem with sources within and east of the Section.

Section: 5d Open Basin

Avallablilty Rating: Abundant to Adequate

Remarks: Natural sand-gravel sources are generally avallable from the nearby mountain ranges (similar to sections $5 \mathrm{a}$ and 5b). Many different types of quality crushed stone sources can be developed from the mountain ranges.

Section: 5e Sacramento Highlands

Avallability Rating: Abundant to Adequate

Remarks: Sand-gravel and crushed 11 mestone sources appear to be well distributed and extensively used. (From the general pit and quarry locations provided by New Mexico (155)). Information concerning the aggregate quality was lacking.

Section: $5 f$ Great Bend Highlands Avallablilty Rating: Abundant to Adequate llemarks: Sand-gravel, crushed lgneous and I1mestone sources appear, from geologic maps, to be well distributed. Definite information on aggregate type and quality was lacking.

Notes: In general, the ratings given to the individual 
Sections of the Easin and Range Province are based upon potential avallability of aggregate rescurces and are not greatly modifled by quality $11 \mathrm{~m} 1 \mathrm{tat} i \mathrm{~ns}$ due to insufficient data.

Section: 6a HIgh Plateaus

Avallabli1ty Rat1ng: Adequate to I1m1ted

Remarks: The quality of sand-gravel sources is quite variable. Alluvial gravels derived from Mesozolc sandstone and shales are of poor quality.

Section: $6 \mathrm{~b}$ Uinta Basin Avallablilty Rat1ng: Ilmited to Problem

Remarks: Generally, the best quality is usually found in the northern portion near the Uinta Mountains. Tertlary sandstones and shales, which comprise the major portion of the Section, are of very poor quality for road aggregates.

Section: $6 \mathrm{c}$ Canyon Iands

Avallability Rating: Ilmited to Problem

Remarks: The area is primarliy soft sandstone deposits from the Mesozo1c and the late Paleozolc, that afford very poor quality (abrasion) aggregates. Riverbed gravels are avaliable in I1mited quantity and qual1ty.

Section: 6d Navajo Avallability Rating: Inited to Problem Remarks: A major portion of the Section is underlain by soft sandstones and shales, whlch are poor aggregate sources. Localized lgneous areas exist, and crushed basalt of good quality may be obtalned.

Section: 6e Grand Canyon

Ava1lablilty Rat1ng: Adequate to I1mited

Remarks: The rating given to this section is based on the geologlc potentlal and may be too high because of practical problems of accessibility. Fotential crushed limestone sources may be developed in the Kaibab and other I1mestone formations. Igneous activity is widespread in the central portion of the Section and good quality crushed basalt may be obtained.

Section: óf Datil

Avallability Rating: Abundant to Adequate

Remarks: This rating, like that of the Grand Canyon Section, is questionable, as information concerning quality of aggregate sources is not complete. This Section appears to have a good potential in crushed Ilmestone and basalt. The use of volcanic cinders generally results in durablilty problems. 
Section: ?a Montana

Avallatility Rat1ng: Abundant to Adequate

Remarks: The Section possesses a wlde varlety of sultable crushed stone sources as well as reglonal sandgravel deposits. The Belt Mountains located in the eastem portion have potential materials of construction that are similar in type and quality to the anticlinal ranges found throughout the Rocky Mountain System. The Tertlary Basins af ford varlable qual1ty glacial sand-gravel deposits which generally veneer the basin flil. Sedimentary, metamorphic and 1 gneous rocks are crushed as aggregates w1thin Montana; however, sand-gravels are the primary aggregate source within the Section (148). The prominant problem, associated with several aggregate types, is poor adhesion.

Section: 7t Bitterroot

Ava1lability Rat1ng: Adequate to I1mited

Remarks: In general, the Washington portion of the Section contains good quality glacial valley gravels, as well as suitable granites, quartz1tes and 11 mestones (124). The remainder of the section possesses a wide array of crushed stone sources that may be of rather poor quality. The major problems are adhesion and abrasion.

Section: 7c Salmon River Mountains Avallability Rat1ng: Imited to Problem

Remarks: The major rock of this Section is the massive Idaho bathol1th (Jurassic age). Idaho (1I7) notes that this prevalent rock is generally unsultable for use as a highway aggregate. Crushed basalt is used, but 1 t frequently possesses poor abrasion and adhesion properties. Sand-gravel sources, where avallable, frequentiy contain substances deleterlous to concrete. Idaho (III) notes that quality concrete aggregates are generally not avaliable.

Section: 8a Yellowstone

Avallability Rating: Adequate to I Imited

Bemarks: The use and quality of volcanic areas as crushed stone sources was not noted in the Questionnalre responses. However, quality sand-gravels as well as crushed I1mestone (steeply dipping flanking strata around the Pre-Cambrian core) are major sources of aggregates.

Section: $8 \mathrm{c}$ Wind River Mountains Ava1labil1ty Rating: Abundant to Adequate Remarks: (Remarks 1dentical to Section 8b) 
Section: 8d Wasatch

Avallability Rating: Adequate to Ilmited

Remarks: The rating is based primarliy upon the quality information concerning aggregate problems within the Idaho portion of the Section. The potential sources of crushed stone are extremely variable by type and geologic age. Idaho indicates that the sand-gravels and crushed carbonate (IImestone and dolomite) sources may have extremely poor abrasion and durability characteristics. Alkal1-aggregate reactions may occur with sand-gravels and 11 mestones as well. The Jackson Hole area of Wyoming has adequate glacial outwash sands and gravels.

Section: 9a Front Range Avallatility Rating: Abundant to Adequate

Remarks: In general, the potential avallability of good quality crushed stone obtained from the Fre-Cambrian crystalline ranges is undoubtedly quite high. The primary sources of crushed aggregates are gran1 tes and flanking 11 mestones.

Section: $9 b$ Western

Avallability Rating: Abundant to Adequate

Remarks: Due to the presence of numerous ranges 1 dent1cal to those of the Front Range Section, the Western Section has a similar crushed stone potential. Fiegional sand-gravel sources derived predominantly from glaclal outwash are found within the North and Midale Farks, as well as the San Luis Valley portlons of the Section.

Section: 9c San Juan

Availability Rating: Abundant to Adequate

Remarks: Sand-gravels and crushed basalts of good quality are avallable.

Section: 10a Missouri Plateau (Glaciated) Ava1lability Rating: I1mited to Froblem

Remarks: Sultable crushed stone scurces are non-existent. within a large majority of the section and, as a result, sand-gravel sources are exclusively used as highway aggregate $(148,160,180)$. These aggregates are located primarily along portions of the Missouri Biver, from limited stratified glaclal deposits, and from isolated gravel-capped benches in Montana, viz., Flaxvilie gravels (142). In general, the overall quality of the sand-gravel sources is rather poor. The widespread presence of deleterious material in the gravels, due to the underlying soft sanastone and shale bedrock, renders them unsultable for use in concrete, particularly in North and South Dakota. 
Section: 10b rissour1 Plateau (Unglaclated)

Availability Rating: Severe Problem

Remarks: Within this unit, sand-gravels, crushed I1mestones, some sandstones and scorla are used as highway aggregates. The major source of sand-gravels are the terraces assoclated with the Yellowstone River in Montana (142, 148), and the Cheyenne and white Rivers in South Dakota (180). A potential source of sand-gravel also appears along the eastern portIon of the Black Hills - Unglaclated Plateau border in South Dakota. Avallability of crushed stone sources is extremely I1mited in the Section due to the widespread presence of soft sandstones and shales. The quality of sand-gravel sources in the Section appears to be poor, with the most noted problems belng abrasion and deleterious constitlients. Almost the entire section has been categorlzed by the respective state highway departments as lacking quality aggregate supplies.

Section: $10 \mathrm{c}$ Bighorm Basin Avallability Rating: Abundant to Adequate

Remarks: Sand-gravels, crushed carbonates, sandstones, and basalts are used. Of these, the sand-gravels are the most important source, and appear to be widely distributed throughout the undt. The qual1ty of these aggregates appears to be good, as no problems were reported. Crushed stone sources are avallable only near the surrounding mountain ranges. The regional bedrock of the unit (Tertiary sediments) is generally unsultable for crushing.

Section: lod wyoming Basin

Avallability Rating: I.1mited to Problem

Remarks: A large area within the central portion of the unlt has been reported to lack quality aggregate (205). The major source of aggregate is sandgravel, but limited supplies of crushed limestones, sandstones and granites are avallable. For the most part, these aggregates are primarliy avallable. between the mountain extensions of the bordering Midde Rocky Mountain Province. In particular, basin areas such as the Wind River, northern part of the Green River Basin, and the Waskakie Basin appear to possess a good regional supply of aggregates $(166, \underline{200})$. Problems within the unit are assoclated with aurablitty (205), alkall-aggregate reaction (144) and adhesion (25). These problems are generally of a locallzed nature, and are predomlnantly assoclated with the sand-gravels. 
Section: $10 \mathrm{e}$ Black Hills

Availability Rating: Abundant to Adequate

kemarks: In general, good qual1ty crushed limestones, gran1 tes, felsites and felsite porphyries are abundantly available within the unit (20, 180, 205).

Section: lof High Plains

Avallability Rating: Ilmited to Problem

Remarks: The unit possesses an almost complete absence of bedrock sultable for crushing aue to the modal parent material of Tertlary outwash. The major aggregates are sand-gravels from major rivers (and thelr tributaries) originating in the Rockies and flowing directly east to the Missouri and Mississipp1 R1vers. These occur in the northern porticn of the Section and include the Niobrar, Platte, RepubIlcan, Arkansas, and Canadian Rivers. In general, these sand-gravels are deflclent in the coarse sizes and frequently cause the unique "sand-gravel" reaction in concrete. Localized, but noteworthy, adhesion problems are also associated with the sand-gravels in the north $(\underline{200})$. In the southern portion, sand-gravels are not abundant and caliche is frequently used as aggregate.

Section: log Colorado Fiedmont

Avallability Rating: Ilmited to Problem

Remarks: This unit bears many marked similarities in general

aggregate characteristics to the Unglaciated M1ssour1 Plateau ( $10 \mathrm{~b})$. Aggregate types are sandgravels, restricted to areas ad facent to the Rocky Mountains and along the South Platte and Arkansas Rivers $(25,144)$, and $11 \mathrm{mited}$ sources of $11 \mathrm{mes}$ tones, basalts and slag. A large area has been clted by Colorado (25) as lacking quality aggregates. This area is underlain primarily by relatively soft sandstone, shale and clay shales. Problems of adhesion are the most common problem associated with the sand-gravels.

Section: 10h Raton Upland Avallability Rating: Adequate to Iimlted

Remarks: Sand-gravels, crushed limestone, basalts and diorites are commonly used as highway aggregate within the unit with the 1 gneous rocks appearing to be the most abundant source. Localized adhesion problems, identical to those of the Colorado fledmont, are encountered w1th sand-gravels. No areas were 1dent1fled by Colorado and New Nexico as lacking in aggregate sources. 
Section: 101 Pecos Valley

Avallability Rating: Ilmited to Problem

Remarks: The major sources of aggregates utilized within the unit are sand-gravel, callche and very $11 \mathrm{~m}-$ 1 ted crushed 11 mestone. An examination of the pit and quarry locations shows that caliche plts are widely distributed. Ilmestone quarries are not extensive within the Permian and early Mesozolc deposits which are characteristically gypsum, sandstone and shale bedrock.

Section: $10 \mathrm{~g}$ Plalns Eorder

Avallatility Rating: Ilmited to Problem

Remarks: Sand-gravels, crushed dolomltes, sandstones and siliclfied chalk are used as highway aggregates (125, 150). The sources of sand-gravel are primarily I1mited to the major rivers and tributar1es. The Republican and Arkansas Rivers provide aggregates similar in quality to the High Plains Section to the west. Potentlal crushed stone areas are generally confined to the Blue HIIIs Subsection of Kansas. Wldespread carbonate reactions have been noted by Kansas (125). The quality of crushed sandstone appears reasonably good, although widespread adhesion and $11 \mathrm{~m} 1 \mathrm{ted}$ durablilty problems are assoclated with 1 ts use. The unit rating tends toward the "limited" than the "problem" category.

Section: 10k Central Texas Mineral Avallability Rating: Abundant to Adequate

Remarks: This rating is based on falrly limited information. The major sources of potential aggregates are sand-gravels, I1mestones and granites. Crushed I1mestones of Upper Cretaceous (Edwards and Commanche) are similar to those of the Edwards Plateau. Carbonates of Cambrian to Ordovician age are located around the flanks of the Ilano uplift granitic core. The quality of aggregates is unknown to the author, and the rating is based priarily upon the abundant distribution of potential sources.

Section: 101 Edwards Plateau Ava1lability Rating: Abundant to Adequate Femarks: Cretaceous 11 mestone of qual1ty acceptable for most engineering purposes is very widespread throughout the area and forms an 1 mportant part of the crushed stone industry of Texas (107, 200). In addition, numerous river valleys provide gravels of both carbonaceous and sil1ceous character (144). 
Section: 10m Osage Plains

Ava1labil1ty Bat1ng: Adequate to I1mited

Remarks: The major types of aggregates ut1lized for highway construction are sand-gravels and crushed carbonate rocks. In addition, minor uses of sandstones, granites, and chat occur (107, 125, 144, 146, 162). There 1 s an extremely w1de range of aggregate avallability. Gravels occur in sutstantial quantities in Texas and Cklahoma (142, 144). Four major carbonate zones of variable quality are present. The cherty IImestones of the FIInt H1IIs offer little sultable aggregate for concrete, but can be used as base/subbase aggregates (144). The Pennsylvanian 11 mestones found in the Scarped Plalns (northeast portion of Section) also possess undesirable durability characteristics for concrete aggregate (125, 146). L1mestones of Crdoviclan age, found adjacent to the Wichlta and Artuckle uplifts, have provided one third to one half of Oklahoma's annual Iimestone production (107). The cartonates found in the southwestern portion are very similar in characteristics to carbonates found in the Central Texas Mineral and Edwards Plateau Sections of Texas (10?).

Crushed granites of good quality are located in the uplift cores of the Wichlta and Arbuckle areas of cklahoma. Locally, sandstones of qual1ty sultable for base/subbase use can be obtilined.

The remalning bedrock of the area is composed of sandstone and shale, and generally affords ilttle if any sultable aggregate.

Section: Ila St. Lawrence Lowlands

Avallab1l1ty Rating: Abundant to Adequate

Remarks: Major aggregate sources are gooj quality glaclal sand-gravels and crushed carbonates (Ordovician). The carbonates are adequately distributed throughout the entire section.

Section: Ilb Champlain Lowland

Avallability Rating: Abundant to Adequate

Bemarks: The major sources of aggregates used are glaclal sand-gravels and crushed carbonates (Cambrianordoviclan). Crushed quartzite is used within the section but the source is outside its boundarles. Crushed marble is not sultable as normal highway aggregate due to 1 ts poor abrasion characteristics. The quality of the remaining aggregates appears to be quite good.

Section: Ilc Hudson Rlver Valley Avallability Rating: Abundant to Adequate Remarks: Major sources of aggregate are glacial sand-gravels 
and crushed carbonates. The Ordoviclan limestones are located primarily near the contacts with the ad gacent uplands. New Jersey reports that the sand-gravel sources contain much deleterlous natter. The crushed carbonates may exhibit poor skid resistance. Crushed sandstone is used for all aggregate functions. Crushed quartzites and gnelsses are used in the Section, but their orlgin is from the older crystalline areas to the east (New England Maritime Province).

Section: Ild Mohawk Valley

Avallabli1ty Rating: Abundant to Adequate

Remarks: Good quality sand-gravels and crushed carbonates are located within the Section. The carbonates are found primarlily near the border contacts with the Adirondacks to the north and the Appalachian Plateau to the south. Iow skid resistance is locally a problem with these carbonates.

Section: Ile Eastern Iakes and Lacustrine Plains Avallability Rat1ng: Adequate to Ilmited

Remarks: The avallability as well as type and distribution of aggregates used in the Section is highly variable. Much stratified granular material is present within the Cary and younger Wisconsin drift in M1chigan. The quality of these deposits, however, is generally compromised by the presence of chert partlcles, as well as high abrasion loss. Crushed carbonate sources are generally found along the outer periphery of the Michigan Basin in eastern Wisconsin, in the upper peninsula of Michigan, and in southeastern Michigan. A major problem with many of these carbonate rocks is their poor skid resistance. Slag is also used extensively.

Section: IIf Central T1ll Plalns Avallabli1ty Rating: Adequate to I1mited

Remarks: This Section appears to possess the most variable aggregate avaliability rating in the Province. Major aggregate sources are crushed carbonates (predominantly dolomites) and glacial sand-gravel. The major sand-gravel deposits occur in the numerous glaclal sluiceways. Stratifled glacial landforms are not present in any great quantity. The avallability of crushed carbonates in the Section ranges from abundant in the Indlana - Ohio area due to the Cincinnati Arch (predominantiy Silurlan dolomites) to almost a complete absence in the IIIInolan Coal Basin (western portion of the Section). Reglonal areas lacking aggregate within the Section are located within this Structural Basin area. 
Section: Ilg Driftless Section

Avallability Rating: Iimited to Problem

Remarks: The major sources are $11 \mathrm{~m} 1$ ted sand-gravels, crushed carbonates (predominantly dolomites), sandstones, granites and quartzites. The supply is variable, with a large area in the central portion of Wisconsin (Central Sand Plain) generally lacking in coarse aggregates. The avallability of aggregates generally increases to the southwest. crdovician dolomites afford crushed stone of variable quality. They generally possess poor abrasion resistance and durability. The crushed sandstone (Cambrian) is 11 kewise rather weak and is used primarily for subbases. Good qual1ty crushed quartzites are located in the Baraboo area. Sand-gravel sources are confined to Iimited glacial outwash in and along the Mississippi River and its tributaries in Minnesota.

Section: Ilh western Lakes and lacustrine Plains Ava1lability Rating: Iimited to Problem

Remarks: The major type of aggregate is sand-gravel of glaclal origin. Crushed stone sources are IImited to: the good quality, but rather small, Sioux Uplift area in South Dakota; scattered granitic areas in Minnesota; and localized Devonian and Mississipplan Iimestones in Iowa. There are large areas completeIy vold of aggregates, viz., large old glacial lakebeds (Dakota and Agassiz). Sand-gravels, where available, are frequently contaminated by sandstone and shale particles from the dominant regional bedrock.

Section: 111 Dissected Loessial and Till Plains Avallability Rating: Adequate to Iimited

Remarks: As with the Central Till Plain Section, the availability of aggregates is quite variable within the Section. Alluvial, glacial and interglacial gravels are used as aggregates. Crushed stone sources are primarily Iimestones, with the Sioux Uplift area providing good quality crushed quartzites and granites in South Dakota and Minnesota. wuality aggregates are also found in the northeast, where S1lurian and Devonian carbonates are extensively quarrled for road aggregate. Crushed stone sources are limited to non-existent in the western portion, while quality natural granular deposits are limited in the south. This subsequently leaves large reglonal areas in southwest Iowa and northwest Missouri vold of quality aggregate supplies. Localized alkali-carbonate reactions have occurred in the Iowa portion of the Section. Alkali-silica reactions of a more frequent nature are found with the sand-gravels found in Nebraska and Kansas. 
Section: 12a Superior Upland Avallability Rating: Abundant to Adequate

Remarks: In general, the avallability of good quality, crushed stone sources and glacial sand jeposits is quite adequate within the Section. Major crushed stone sources are primarily PreCambrian 1gneousmetamorph1c complexes. Reglonal sand-gravel sources may be lacking within the northeast portion of Minnesota where bedrock is generally near the surface.

Section: 12b Adirondack Mountains Avallability Rating: Abundant to Adequate Remarks: This Section is quite simllar in aggregate characteristics to the Superior Upland. Quality potential crushed stone sources (PreCambrian 1gneous-metamorphic complex) are presently utilized as a source of aggregate. Sand-gravel deposits of glacial origin are present and utilized as aggregates within the Section.

Section: $13 a$ St. Francis

Avallability Rating: Abundant to Adequate

Remarks: Ilmestone and granlte generally are the best sources of crushed stone. The Cambrian 11 mestone generally lacks chert 1 mpurities and contrasts strongly with the carbonates in the surrounding SpringfieldSalem Plateau. Dolomite is generally of poor quality, frequently cherty and similar in performance characteristics to Section 13b. Gravel deposits produce wldespread durablilty problems when used in concrete. Sandstone is generally unsultable for use.

Section: 13b Springfield-Salem Plateau Avallability Rating: Adequate to Ilmited

Remarks: Although carbonate rocks predominate in the entlre Section, their use in concrete mixes is limited by chert 1 mpur1ties. Carbonate rocks produce poor skid resistance when used in bltuminous pavements. S1milar to Section 13a, river gravels are suspect for concrete pavement. Sandstone is generally low in abrasion resistance and consequently cannot be consldered as a major source. Aggregate avallabll1 ty nay act as a major factor in the selection of pavement type.

Section: 13cl Boston Mountalns

Avallablity Rat1ng: I1mited to Problem

Remarks: Potential sources may be extremely limited due to the widespread distribution of sandstone and shale. I1mestone, where avallable, is frequently cherty and performs similarly to Section 13b. Sandstone 
generally has poor abrasion resistance. Avallability of aggregate sources may act as a significant factor in determining pavement type.

\section{Section: 13c2 Arkansas Valley}

Avallability Rating: Ilmited to Problem

Remarks: The type and quallty aspects of aggregate resources are quite similar to section 13cl. Sandstone is generally of low abrasion resistance, but may be of slightly better quality than that of the Boston Mountain Section. Alluvial sand-gravel deposits, where avallable, are generally good scurces. Avallability of aggregates is less of a problem than in the Boston Mountain Section.

Section: 1303 Quachita Mountains

Avallability Rating: Adequate to L1mited

Remarks: As a large portion of this Section is underlain by sandstone and shales, simliar to Sections $13 \mathrm{cl}$ and $13 \mathrm{c} 2$, it does not possess an abundance of quality scurces. However, the Novaculite Uplift Subsection generally provides a good potential crushed stone source. Sandstone may be of questlonable quality. Alluvial sand-gravel sources are generally of good quality.

Section: 14a Blue Grass

Avallability Rating: Abundant to Adequate

Remarks: Good quality crushed carbonate sources (lower crdovician) are available in the Inner Blue Grass Sutsection and in scattered inliers of the Cuter Elue Grass Subsection. The majorlty of the upper ordoviclan Ilmestone in the Outer Blue Grass Subsection 1.s arglliaceous and unsultable for use in construct1on. Skld resistance may be protlem with the carbonates. Sand-gravels (Ch10 River) generally are of good quality.

Section: 14b Nashville Basin Avallablilty Rating: Abundant to Adequate

Remarks: Good quality crushed limestone (lower Crdovician)

is avallable throughout the entire section. Iow skid resistance may be a protlem with the carbonate sources. The gravels may be cherty and generally of poor durablilty in concrete. Poor adhesion with bltuminous materials may be a problem with the gravels of the Section.

Section: $14 \mathrm{c}$ Shawnee

Avallability Rating: Ilmlted to Problem

Remarks: A major source of qual1ty crushed carbonates is the Mississipplan age rocks. The remaining rocks are 
of Pennsylvanian age and generally are of little value for highway aggregates. Sand-gravels deposits are badly contaminated with chert and shale of low specific gravity and demonstrate poor durablitty in concrete.

Section: 14d Highland Bim

Avallablilty Rating: Abundant to Adequate

Remarks: The avallabllity of good quality scurces is commonly adequate but highly variable. Quality crushed carbonate sources are generally wldespread in the Western Pennyroyal Ilmestone Plain Subsection. Chert particles may be abundant in the sandgravels.

Section: $15 a$ Catskill Mountains

Avallability Rating: Adequate to Iimlted

Remarks: The major sources are sand-gravels and crushed sandstones. Overall, good quality aggregates can be obtained; however, there is much relatively soft sandstone and assoclated glacial sand-gravels.

Section: 15b New York Glaclated

Avallabilty Rating: Adequate to I1mited

Remarks: Sultable crushed carbonate aggregate 1s located adgacent to the outfacing escarpment in New York. Some hard, quality sandstones are crushed in southeast New York and northern Pennsylvania. Slag is avallable near the Youngstown, Chio area and near other steel centers outside the Section in the Central Lowlands Province. Glaclal outwash sanas and gravels are quite well distributed along the river valleys. Sandstone, of varlatle hardness, may form the largest percentage of gravel part1 cles.

Section: 15c Allegheny Yountains Avallability Rating: Adequate to Iimited

Remarks: Th1s Section is quite difficult to categorize for potential aggregate avallablilty. The only highway aggregate type used is crushed limestone. The occurrence of this rock type is quite restricted. Hard I1mestones, conglometerates and local quartzites do exist and may provide quality supplies. The same may be sald of river sands and gravels(144).

Section: 15a Kanawha Avallability Rat1ng: IIm1ted to Problem Remarks: In general, there is a shortage of quality aggregate resources within the entire section. IImited crushed stone sources are primarliy limestones and sandstones. The overall quality of these sources is considered poor due to durablity 
problems, although localized sources of sultable qual1ty may exist. Major streams provide an 1mportant source of sand-gravel aggregates in much of the section. The coarseness and amount of gravel decrease to the south and west.

Section: $15 \mathrm{e}$ Cumberland Plateau

Avallability Rating: Adequate to Iimited

Remarks: The avaliablilty of aggregates is highly varlable. Crushed aggregate sources (primarily limestones) are generally abundant to adequately avallable in the southerm portions of the section due to the presence of varlant Ordoviclan Ilmestone valleys and I1mestone found along the outfacing escarpments. In and around the Kentucky and northern Tennessee portions, the avallabllity of quality aggregate supplies is consldered to be of a "Iimited to problem" nature.

Section: 16a Pennsylvania-Maryland-Virginia

Avallablilty Rating: Abundant to Adequate

Remarks: Valleys in Cambrian and Crdoviclan carbonate rocks generally provide a good source of crushed stone; however, widespread skid problems may occur. Cherty layers or pockets may be present in the carbonate formations, but their presence is less widespread than in the Tennessee Section (16b).

Section: 16b Tennessee Avallability Rating: Abundant to Adequate Remarks: Aggregate sources and skld problems are similar to Section 16a. The regional distribution of chert may be more widespread in this section due to the M1ss1ss1ppian Fort Payne formation (22, 137, 184).

Section: $17 a$ Blue Ridge Avallablilty Rating: Abundant to Adequate Remarks: Construction materlals have characterlstics similar to the Pledmont Section (17b).

Section: 17b Pledmont Avallab1l1ty Rating: Abundant to Adequate

Remarks: The section possesses complex and numerous types of potential crushed stone sources. Granitic and gnelssic sources are generally of good qual1ty. Trlass1c basins w1thin the Section possess traprock (basalts, dlabase, etc.) of good to excellent qual1ty. Sand-gravels are primarliy river deposits and may yleld several localized problems.

Section: 18 Triassic Lowland (no sections)

Avallability Rating: Abundant to Adequate Remarks: Crushed stone of good quallty is generally obtalned 
frow traprock sources within the Trlassic Sediments. Crushed 11 mestone is avaliable from the crdovician Ilmestone valleys whlch are varlant to the Prcvince. Crushed granlte can be obtained from local piedmont areas within and surrounding the Province. Glacial sand-gravel deposits are avallable in the northem portion. These deposits may contain deleterlous materials for concrete. Triassic sandstone $1 \mathrm{~s}$ generally soft, and 1 ts use as an aggregate scurce is not cited.

Section: 19a Seaboard Lowland

Avallabli1ty Rating: Adequate to I.1mited

Remarks: The distribution of the Precumscot Fm (fine grained marine deposits) overlying much of the area may possibly increase localized areas where aggregate sources are lacklng. Crushed stone sources are generally similar in characteristics (types and problems) to Section $19 b$.

Section: 19b New England Upland

Avallab111ty Fiat1ng: Abundant to Adequate

Remarks: Good quality glacial fluvial sand-gravels are generally abundantly distributed. Crushed stone sources of granite and 11 mestone may be of poor quality due to abrasion resistance and durab111ty.

Section: $19 \mathrm{c}$ Connecticut Lowland Avallabil1ty Bat1ng: Abundant to Adequate

Remarks: Glaclal and terrace sand-gravels are generally abundant and of good quality. cccaslonally, soft sandstone particles may be encountered in the gravels. The traprock found in the Triassic sediments is generally an excellent crushed stone source.

Section: 19d White Mountains Avallability Bating: Adequate to Ilmited Remarks: The region 18 sparsely inhablted, and no known or existent pits or quarries were cited for the sect1on. Granite, may have poor abrasive characteristics. A region within Malne was stated to lack quality aggregate resources from the questionnalre.

Section: 19e Green Mountains Avallability Rating: Abundant to Adequate

Femarks: This rating is based upon rather $11 \mathrm{mited}$ information. The crushed stone potential in the old FreCambrian crystalline rocks of the Section is consldered good. Questionnalre results indicated no w1despread problems with aggregates in the area. 
Section: 19f Taconic Mountains

Ava1lability Rating: Abundant to Adequate

Remarks: The major bedrock type of the Taconic Ranges is schist. However, 1 ts use was not reported in the Materials questionnaire. Sand-gravels, crushed carbonates, and quartzite sources occur and are of good quality. Vermont marble is not a suitable highway aggregate.

Section: $19 \mathrm{~g}$ Reading Prong

Ava1labli1ty Rating: Abundant to Adequate

Bemarks: New Jersey reports that marble found in the Section is unsultable. A wide variety of good quality crushed stone types are avallable within and surrounding the section.

Section: $20 a$ Northern Embayed

Avallability Rating: Adequate to Iimited

Eemarks: The avallability of aggregate sources is quite varlable. Iong Island and Cape Cod generally have abundant quantities of glaclal sand-gravel. Within the remainder of the Section, sand-gravels are generally found in the higher terraces. The coastal portion of Virginia possesses very restricted supplies of aggregates. The major aggregate source is sand-gravel, with minor utilization of slag and clam/oyster shells for highway aggregate.

Section: 20b Sea Island

Avallabli1ty Rating: Adoquate to I1mited

Remarks: Sand-gravel from river and stream terraces, as well as along the Fall-Iine Hills, generally afford the major aggregate supply in the entire section.

Section: $20 \mathrm{c}$ Florida

Avallabli1ty Rating: Iimited to Problem

Remarks: Crushed Ilmestone sources are avallable in the Ilme-Sink Area (northwest portion of the peninsula) and in the extreme southem tip. Coquina is used, particularly along the east coast of Florida. The remainder of the area is veneered with sand, resulting in large areas in the southern and central portion being vold of coarse aggregate. Florida (101) states that concrete aggregate is lacking everywhere except along the southern t1p. The avallability of aggregates is considered by Florida as a major factor in the selection of a pavement type.

Section: 20d East Gulf Coast Availability Rating: Adequate to I1nited

Remarks: The avaliabll1ty of aggregates appears to be quite varlable. The occurrence of quality aggregates 
decreases as one proceeds toward the coast except in the Southern P1ne HIIIs of M1ss18sippi. Local 11 mestones, 11 merock and clam/oyster shells are used, but sand-gravel sources are the most 1mportant. These deposits are nowhere widespread except in the southem portions of Missis81ppl and Loulsiana. Skid resistance, adhesion and the presence of deleterious materials in the sand-gravels are the most salient problems. The limestones of the Coastal Plain appear to be signiflcantly different in quality from 11 mestones found in the adjacent Provinces.

Section: 20e Mississippl Loessial Upland Avallability Rating: Ilmited to Problem

Remarks: In general, aggregate supplies are lacking. The only source of aggregates are sand-gravel deposits from terraces along some major rivers and from the "Lafayette gravels" in the southern portion of the section. Skidding problems, assoclated with sandgravel sources may be a major problem. Mississippi reports that aggregate avallability is a major factor in determining pavement type (145).

Section: $20 f$ Mississippl Alluvial Plain

Ava1labil1ty Rating: Severe Problem

Remarks: The only sources of aggregates are local terrace and point bar sand-gravels. An exception to the areal deflciency are the good quality sand-gravel deposits of Crowley's R1dge in Arkansas. Aggregates play an important role in determining pavement type in Mississ1pp1 and Missour1 (145, 146). Much of the needed aggregate must be 1 mported from bedrock reglons in Arkansas, Missourl and Tennessee, or from coastal plain sediments in these states (144).

Section: $20 \mathrm{~g}$ West Gulf Coast Avallability Rating: Adequate to Ilmited

Remarks: The characteristics of aggregates in this section are quite similar to those of the East Gulf Coast. No information concerning aggregate problems was avaliable. 
Solls and Related Factors

So11 Origin

The basic Provinces have been divided into three major categories and $s 1 x$ minor or subcategorles of soll origin. The major categories are: (a) non-transported, (b) transported, and (c) mixtures.

The non-transported class has been further subdivided into areas: in which bedrock predominates (non-s011), thin residual solls predominate, and significant residual solls are developed. Transported soll Provinces have been divided into those in which water is the dominant mode of transport, and areas characterized by glacial surficial deposits. Wind deposited solls do not form the predominating soil origin of any Province, although they do characterlze several Sections. Table 14 groups the sections according to their origin classes. So11 Texture

General

A wide varlety of information was utilized to map the general distribution of solls within the United States. By far the greatest amount of detalled information was in terms of soll texture. However, the data varled from classiflcation by engineering systems to such generalities as "flne textured" or "moderately coarse". Table 15, developed from references $(\underline{216})$ and $(\underline{219})$, was helpful in the requislte correlations and interpretations of descriptions.

The soll texture map of the Unlted states is shown in s1x map sheets (Figures 16 to 21). Every effort has been 
Table 14

Summary of Surficial Soil Origin by Sections

1. Provinces Characterized by Non Transported Soils

A. Bedrock Predominating

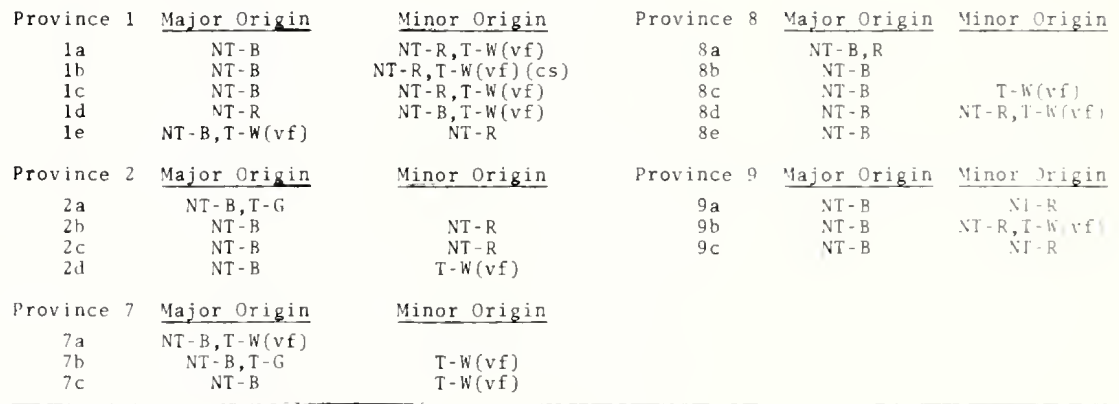

B. Thin Residual Soil Development

\begin{tabular}{|c|c|c|c|c|c|}
\hline Province 4 & Major Origin & Minor Origin & Province 6 & Major Origin & Minor Origin \\
\hline $\begin{array}{l}4 a \\
4 b \\
4 c \\
4 d \\
4 e\end{array}$ & $\begin{array}{c}T-L \\
N T-B, R \\
T-L \\
T-W(1), N T-R \\
N T-R\end{array}$ & $\begin{array}{l}N T-B \\
N T-B\end{array}$ & $\begin{array}{l}6 a \\
6 b \\
6 c \\
6 d \\
6 e \\
6 f\end{array}$ & $\begin{array}{l}N T-B \\
N T-R, B \\
N T-R, B \\
N T-R \\
N T-R \\
N T-R\end{array}$ & $T-W(v f)$ \\
\hline
\end{tabular}

C. Significant Soil Development

\begin{tabular}{|c|c|c|}
\hline Province 13 & Major Origin & Minor origin \\
\hline $\begin{array}{l}13 \mathrm{a} \\
1.3 \mathrm{~h} \\
1.3 \mathrm{cl} \\
13 \mathrm{c} 2 \\
13 \mathrm{~cm}\end{array}$ & $\begin{array}{l}\text { NT }-R \\
\text { NT - R } \\
\text { NT - R } \\
\text { NT - R } \\
\text { NT - R }\end{array}$ & $\begin{array}{c}T-W(A 1) \\
N T-B\end{array}$ \\
\hline Province 14 & Major Origin & Minor origin \\
\hline $\begin{array}{l}14 \mathrm{a} \\
14 \mathrm{~b} \\
14 \mathrm{c} \\
14 \mathrm{~d}\end{array}$ & $\begin{array}{l}N T-R \\
N T-R \\
N T-R \\
N T-R\end{array}$ & $\begin{array}{c}N T-B \\
T-W(A 1)\end{array}$ \\
\hline
\end{tabular}

\begin{tabular}{|c|c|c|}
\hline Province 15 & Major Origin & Yinor Origin \\
\hline $\begin{array}{l}15 a \\
15 b \\
15 c \\
15 d \\
15 e\end{array}$ & $\begin{array}{r}T-G \\
T-G \\
N T-R \\
N T-R \\
N T-R\end{array}$ & $\begin{array}{l}N T-B \\
N T-B\end{array}$ \\
\hline Province 16 & Major Origin & Minor origin \\
\hline $\begin{array}{l}16 a \\
16 b\end{array}$ & $\begin{array}{c}N T-R, B \\
N T-R\end{array}$ & $\mathrm{NT}-\mathrm{B}$ \\
\hline Province 17 & Major Origin & Minor Origin \\
\hline $17 \mathrm{a}$ & $\begin{array}{l}\text { NT - B } \\
\text { NT - R }\end{array}$ & \\
\hline Province 18 & $\frac{\text { Yajor Origin }}{\text { NT-R }}$ & $\frac{\text { Minor Origin }}{T-G}$ \\
\hline
\end{tabular}

Note: See second page of Table for legend 
Table 14 (cont'd.)

II. Provinces Characterized by Transported Soils

A. Water Deposited Soils

\begin{tabular}{|c|c|c|c|c|c|}
\hline Province & Major Origin & Minor Origin & Province 20 & Major Origin & Minor Origin \\
\hline $\begin{array}{c}3 a \\
3 b \\
3 c \\
\text { Province } 5 \\
5 a \\
5 b \\
5 c \\
5 d \\
5 e \\
5 f\end{array}$ & $\begin{array}{c}T-G, N T-R \\
T-W(A I), N T-R \\
T-W(v f) \\
5 \quad \text { Major Origin } \\
T-W(v f), N T-B \\
T-W(v f), N T-B \\
T-W(1)(v f) \\
T-W(v f), N T-B \\
T-W(v f), N T-B, R \\
T-W(y f) \text {. }\end{array}$ & $\begin{array}{c}\text { NT - R } \\
\frac{\text { Minor Origin }}{\mathrm{T}-\mathrm{L}} \\
\text { NT - B }\end{array}$ & $\begin{array}{l}20 \mathrm{a} \\
20 \mathrm{~b} \\
20 \mathrm{c} \\
20 \mathrm{~d} \\
20 \mathrm{e} \\
20 \mathrm{f} \\
20 \mathrm{~g}\end{array}$ & $\begin{array}{c}T-W(c s) \\
T-W(c S) \\
T-W(c S) \\
T-W(c S) \\
T-L \\
T-W(A 1) \\
T-W(C S)\end{array}$ & $\begin{array}{l}\mathrm{T}-\mathrm{G} \\
\mathrm{NT}-\mathrm{K}\end{array}$ \\
\hline
\end{tabular}

B. Glacial Deposited Soils

\begin{tabular}{|c|c|c|c|c|c|}
\hline Province 11 & Major Origin & Minor Origin & Province 12 & Major Origin & Minor Origin \\
\hline $\begin{array}{l}11 a \\
11 b \\
11 c \\
11 d\end{array}$ & $\begin{array}{c}T-W(m), G \\
T-W(m), G \\
T-G, W(m) \\
T-G\end{array}$ & NT - B & $\begin{array}{c}12 \mathrm{a} \\
12 \mathrm{~b} \\
\text { Province } 19\end{array}$ & $\begin{array}{c}T-G \\
I-G \\
\text { Major Origin }\end{array}$ & Minor Origin \\
\hline $\begin{array}{l}11 \mathrm{e} \\
11 \mathrm{f} \\
11 \mathrm{~g} \\
11 \mathrm{~h} \\
11 \mathrm{i}\end{array}$ & $\begin{array}{c}T-G, W(1) \\
T-G \\
N T-R, T-L \\
T-G, W(1) \\
T-G, L\end{array}$ & $T-L$ & $\begin{array}{l}19 \mathrm{a} \\
19 \mathrm{~b} \\
19 \mathrm{c} \\
19 \mathrm{~d} \\
19 \mathrm{e} \\
19 \mathrm{f} \\
19 \mathrm{~g}\end{array}$ & $\begin{array}{c}T-G, W(m) \\
T-G \\
T-C \\
T-G, N I-B \\
T-G, N I-B \\
T-G \\
T-G, N I-B\end{array}$ & $\mathrm{VI}-\mathrm{B}$ \\
\hline
\end{tabular}

111. Provinces Characterized by Mixed Origin

\begin{tabular}{|c|c|}
\hline Province 10 & Major Origin \\
\hline $\begin{array}{l}10 \mathrm{a} \\
10 \mathrm{~b} \\
10 \mathrm{c} \\
10 \mathrm{~d} \\
10 \mathrm{e} \\
10 \mathrm{f}\end{array}$ & $\begin{array}{c}T-G \\
N T-R \\
N T-R \\
N T-R \\
N T-R, B \\
T-W(\text { ow })\end{array}$ \\
\hline
\end{tabular}

Legend: NT - Non-Transported Soils B - Bedrock

R - Residual Soil

\section{Minor Origin}

$\mathrm{T}-\mathrm{W}(\mathrm{OW})$

T - L , NT - R
Major Mrigin Minor origin

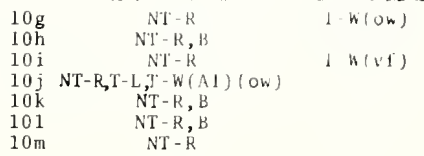

T Transported Soils

G - Glacial

$L$ - Wind

W - Water

(ow) - outwash

(vf) - valley fill

(1) - lacustrine

(A1) - Alluvium

(m) - marine

(cs) - coastal sediments 


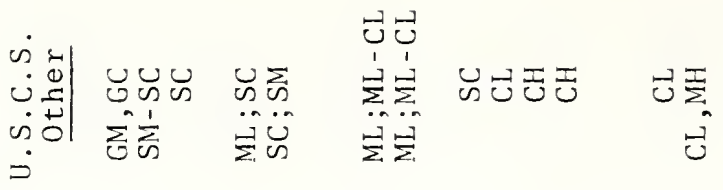

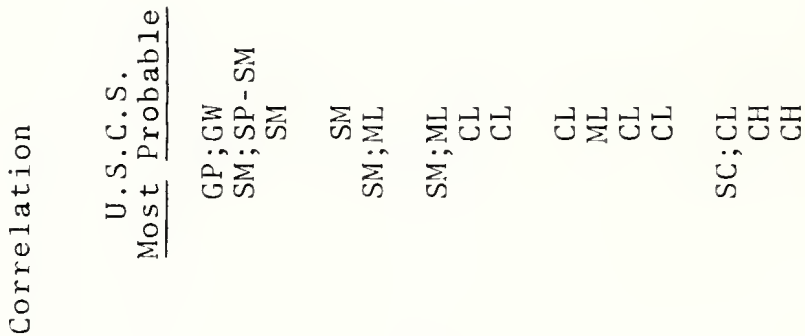

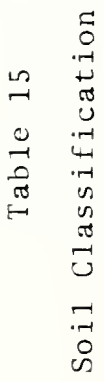

ฐ్

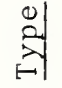

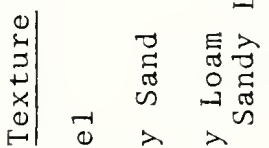

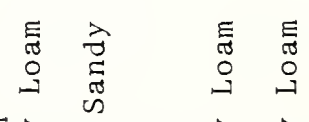

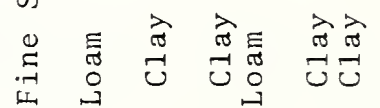

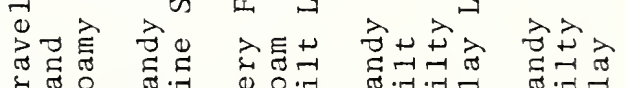

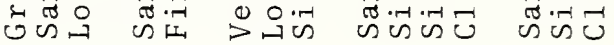

范

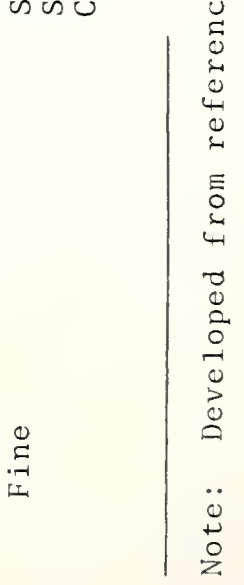




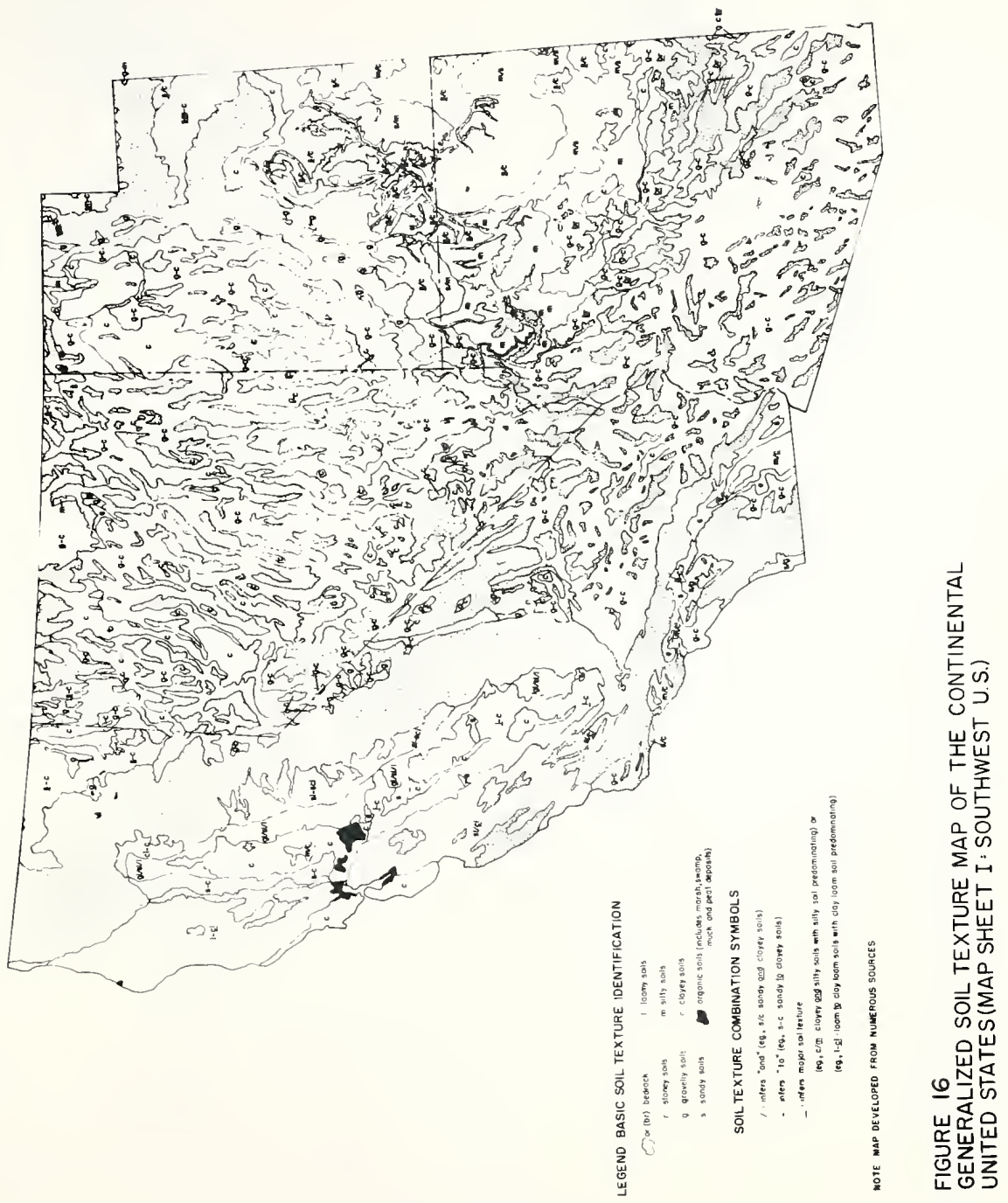




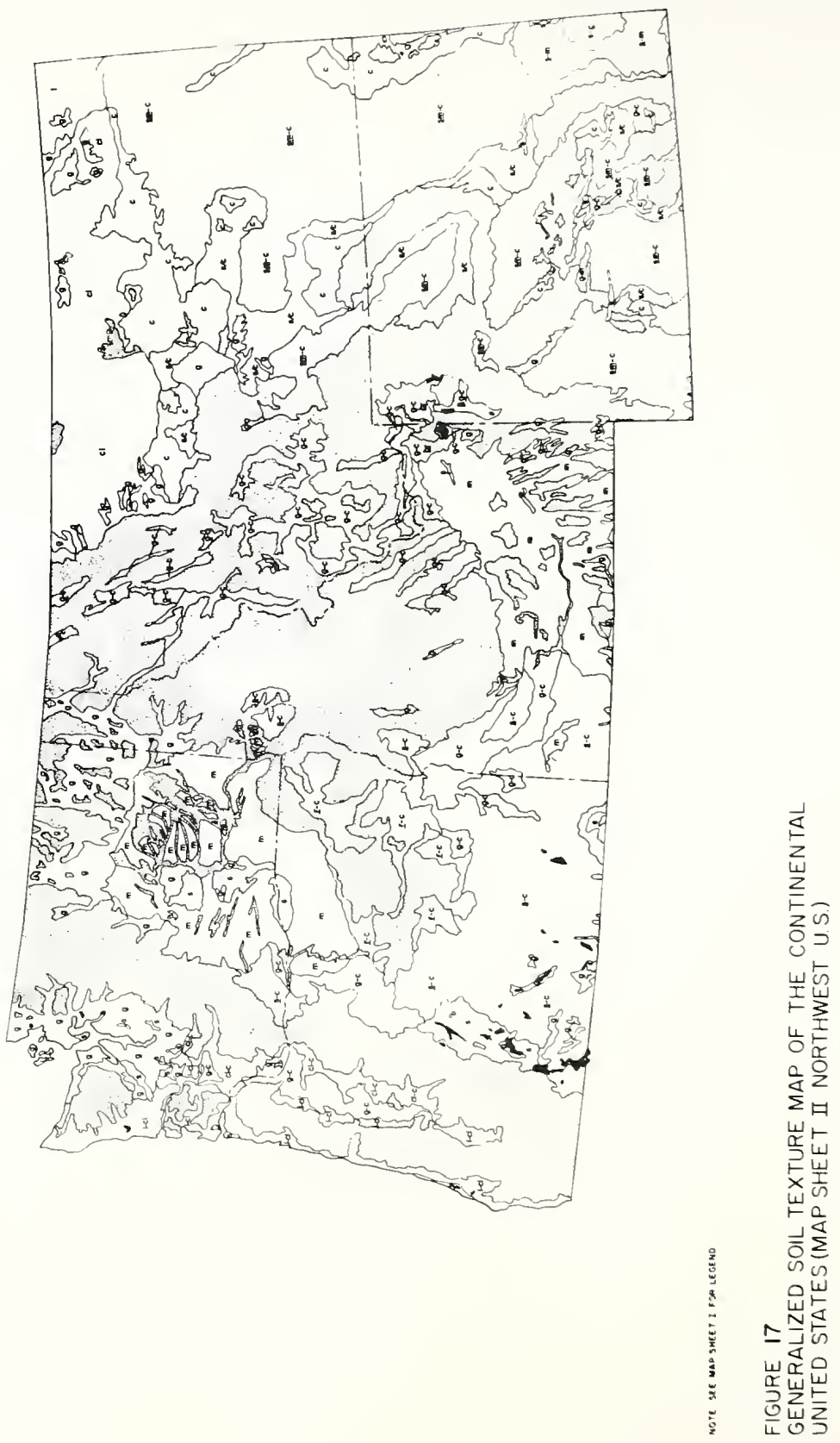




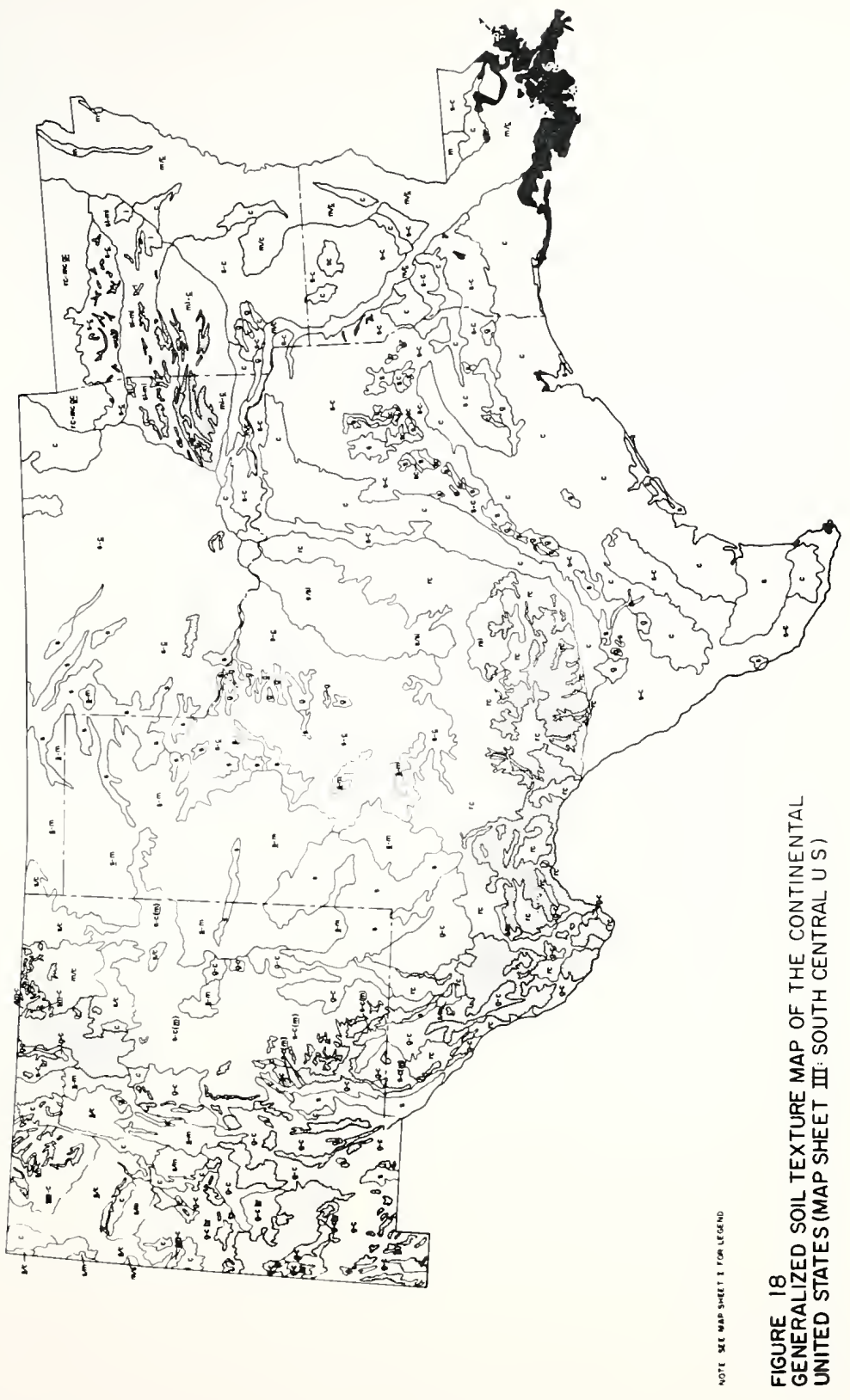




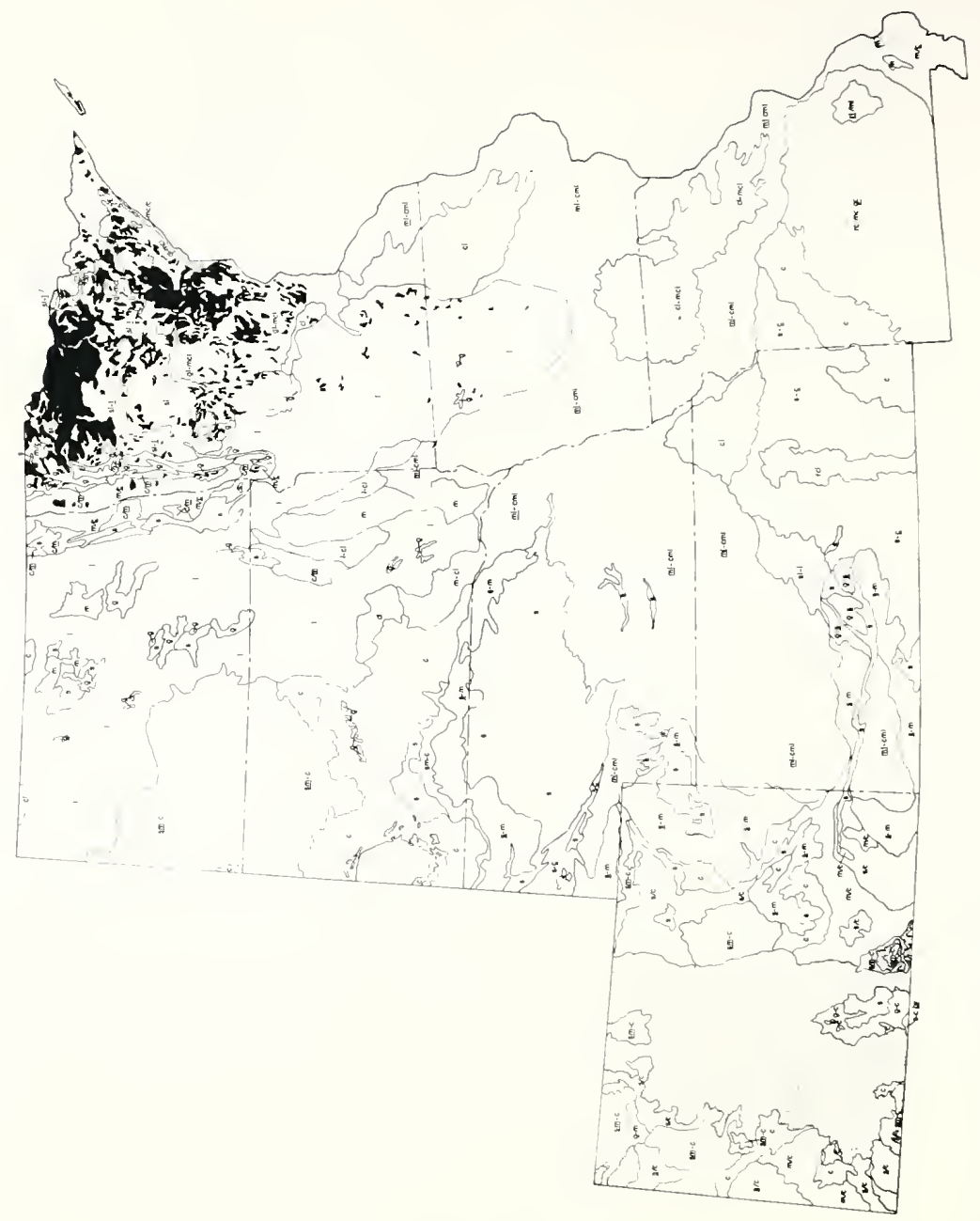

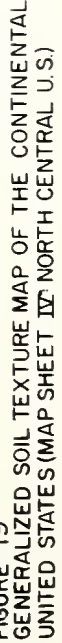




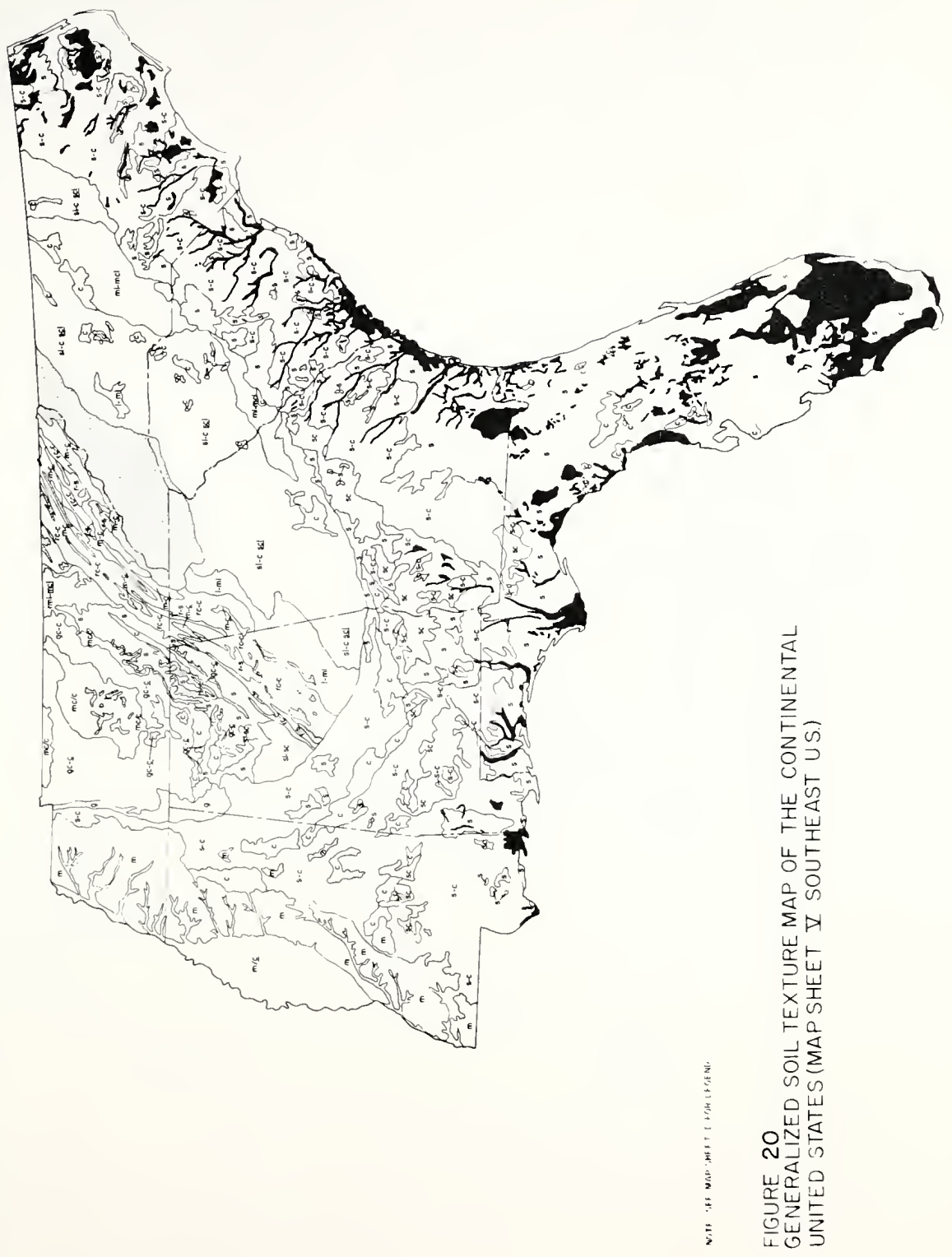




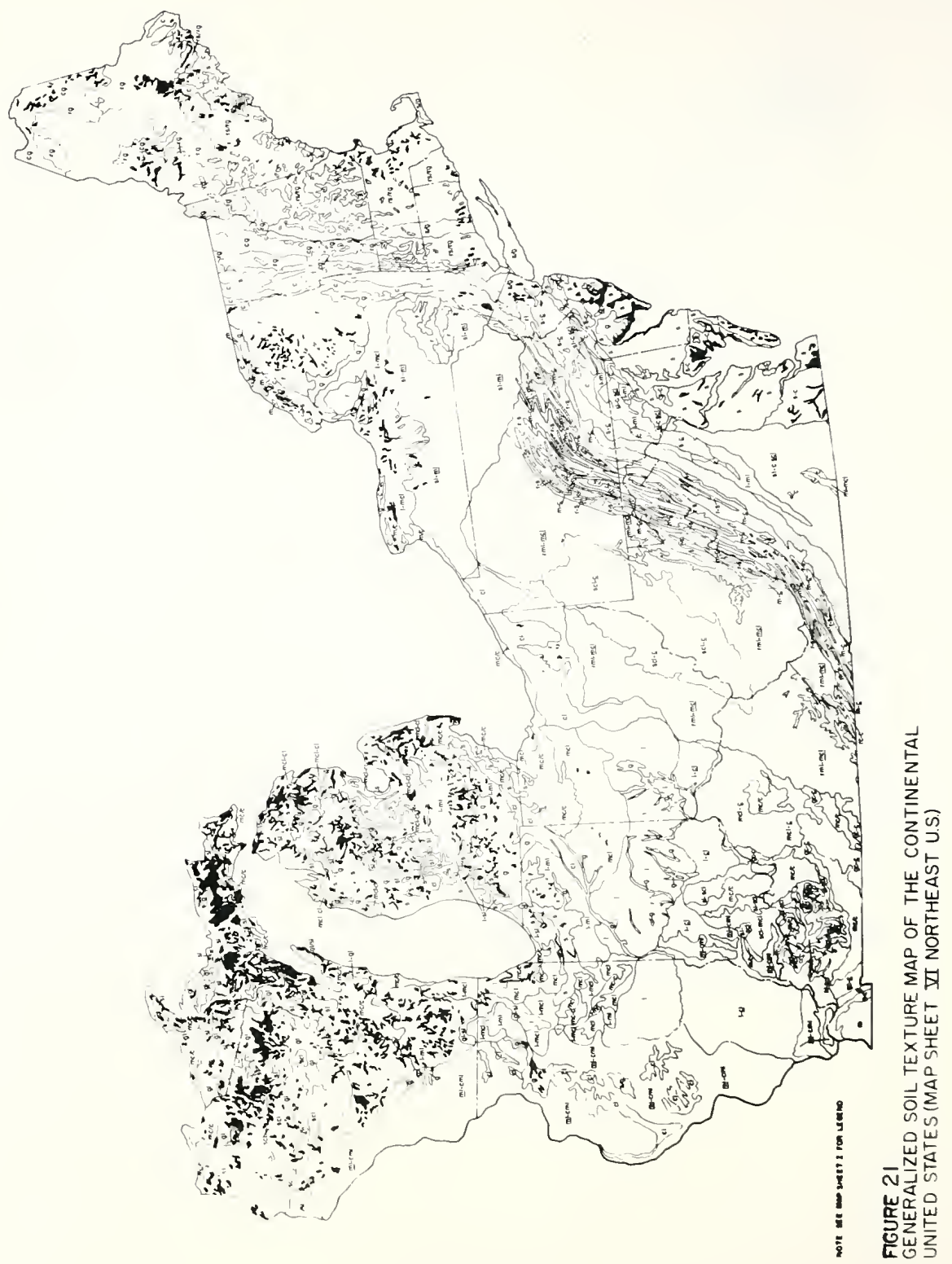


made to keep the level of map unit descriptions as detalled as the information from which it was obtained. This factor resulted in a rather wide range of map unit comblnations. In general, three broad categories of unlts are mapped. They are (a) single textured units, (b) multiple textured units and (c) gradationally textured units. When soll types occur in combination, and one is known to dominate, it is underlined in the designation. The legend for the so1l types is shown on F1gure 16 and is considered to be selfexplanatory.

Section Distribution

General. The major soll types within each Section are discribed in the following paragraphs. In some cases, several map units have been combined for brevity. The descriptions are presented in the Province sequence of Table 14. The codes used to describe the frequency of occurrence of solls within the sections are as follows: (VW) very widespread, $\left(N_{i}-W\right)$ medium to widespread, ( $\left.I-M_{1}\right)$ limited to medium, (N-I) non-existent, to 11 mited. Distribution of Solis by Basic Report Units

\section{Province 1}

\section{Section 1a}

1. Non so11 area (VW).

2. Loamy to clay loam solis (L-M) : thin residual solls developed from sandstones and shales.

3. Gravelly solls (N-I): surround the north and

east flanks of the mountanious portion.

4. Crganic solls $(\mathrm{N}-\mathrm{I})$. 
Section 1b

1. Non soll area (VW): sandstone and shale bedrock.

2. Ioamy to clay loam solls $(N-I)$ : residually developed from sandstones and shales.

3. Sandy solis (N-I): appears in small coastal plain areas.

4. Organic solls $(N-I)$ : associated with coastal plain portion.

Section Ic

1. Non soll area (VW).

2. Loamy to clay loam $(N-I)$ : residual sandstones and shales within small areas near coast.

Sect1on 10

1. Non soll area (I-M).

2. Loamy to clay loam (clay loam predominating) $(I-M)$ : residual sandstones and shales found primarily in the northern coastal range area.

3. Sandy loam to clay loam (clay loam predominating) (I, M): residual sandstones and shales found primarily in the southern coastal range area.

4. Clayey solis (N-I): generally associated with shale hills near San Franclsco.

5. Crganic solis (N-I): muck deposits near San Francisco Bay.

Section le

1. Non soll area $(M-W)$ : generally associated with Transverse Ranges.

2. Gravelly to clayey solls (I-M): primarily found in Ios Angeles Basin; appears that coarse textured solls predominate.

Province 2

jection 2a

1. Non soll area (VW): generally granitic type mountains.

2. Graveliy solls (N-I) : associated with valley outwash and glacial drift.

Section $2 b$

1. Non soll area (VW): generally igneous rocks. 
2. Clay loam to clay $(I-M)$ : resldual solls on western flank developed from basic lgnecus rocks. In many cases, this unit gradually merges into the troughs as foothills.

3. Sandy to clayey solis (sandy predominating) $(I-M)$ : residual solls developed primarliy from basic and actalc igneous rocks on the eastern flanks of the mountain range.

\section{Section 2c}

1. Non soll area (VW): generally granlt1c rocks.

2. Sandy loam to sandy clay loam (I-M): residual solls from granitic rocks occurring along the western portion of the unit.

\section{Section 2.d}

1. Non soll area (VW): generally granltic rocks.

2. Gravelly to clayey solls (gravelly solls predominating) (N-L): assoclated with valley fill material.

\section{Province?}

\section{Section ?a}

1. Non soll area (M-W): rugged mountalnous areas.

2. Gravelly to clayey solls (I-M) : these solls are assoclated with the basin areas characterist1c to the unit; texture is frequently coarse but clayey so11s are within many basins.

\section{Section 2b}

1. Non soll area $(M-W)$.

2. Gravelly solls (I-M): this unit occurs as coarse textured glaclal arift in the Washington portion and valley fill in the remalning areas.

\section{Section ?c}

1. Non soll area (VW): primarily assoclated with granitic batholith.

\section{Province 8}

Section 8 a

1. Non soll area (VW): rugged Igneous/metamorphic rocks. 
2. Gravelly to clayey solls (bedrock predcminating) (I-M) : generally assoclated with thin residual solis from volcanic rocks.

Section $8 \mathrm{~b}$

1. Non soll area (VW).

Section $8 c$

1. Non soll area (VW).

Section 8d

1. Non soll area $(\mathrm{M}-\mathrm{W})$.

2. Gravelly to clayey solls (gravelly predominating) ( $\mathrm{N}-\mathrm{I})$ : assoclated with coarse textured glaclal outwash in Jackson Hole.

3. Sandy silt to clay (sandy silts predominating) $(\mathrm{N}-\mathrm{I})$ : thin residual solis developed from sandstones and shales.

4. Crganic (N-I): assoclated with glaclal outwash in Jacks on Hole.

Section $8 \mathrm{e}$

1. Non soll area (VW).

Frovirce 2

Section 9a

1. Non soli area (VW).

Section $9 b$

1. Non soll area (VW).

2. Gravelly and sandy solis $(N-I)$ : this unit is generally assoclated with the glaclal and

alluvial outwash found in the San Iuls Valley.

Section 9c

1. Non soll area (VW).

2. Sandy to clayey (bedrock predominating) (N-I): this unit is assoclated with thin (generally) residual solls developed from basalts within the San Iuls H1Ils portion. 
Province 4

Section $4 a$

1. S1Ity solls (VW) : aeolian (Loessial deposits).

2. Sandy and gravelly solls (I-M): generally coarse textured deposits from alluvial deposition.

3. Non so1l areas $(I-M)$ : generally basaltic rock.

\section{Section $4 \mathrm{~b}$}

1. Non so1l area ( $\mathrm{VW}$ ).

2. Stoney to clayey (stoney predominating) ( $L-M)$ : generally residual solls developed from basic igneous rocks.

Section $4 \mathrm{c}$

1. Silty solis (VW): aeolian deposits cverlying acidic flows.

2. Non soll area $(\mathrm{N}-\mathrm{L})$ : bare acidic lava areas.

Section $4 d$

1. Sandy to clayey solls (sandy predominating) (I-M) : generally thin residual solls from extrusive flows.

2. Gravelly to clayey (I-M): assoclated w1th Jacustrine areas which characterize the lin1t: textures vary considerably.

3. Silty (N-I) : small aeolian area which is variant to the unit.

Section $4 \mathrm{e}$

1. Sandy to clayey solls (sandy predominating) $(M-W)$ : thin residual solis developed from flows present in the unit.

2. Sandy $(L-M)$ : assoclated with pumice deposits in Great Sandy Desert area.

3. Organic $(\mathrm{N}-\mathrm{I})$ : appear in isolated areas within the western portion of the unit.

\section{Province 6}

Section 6a

I. Non soll areas (VW).

2. Sandy and clayey solis (sandy predominating)

$(\mathrm{N}-\mathrm{I})$ : thin residual solls developed from sandstone and shale.

3. Gravelly solls $(\mathrm{N}-\mathrm{L})$ :associated with valley deposits. 
Section 6b

1. Sandy silt to clay (sandy silt predominating) $(M-W)$ : thin residual solis developed primarliy from Tertiary sandstones and shales.

2. Non soll area $(L-M)$ : sandstones and shales.

3. Gravelly solis (N-I) : associated with outuash from Uinta Mountains: occur within northernmost portion of unit.

Section 6c

1. Sandy, silty and clayey solis (sandy predominating) ( $M-W)$ : generally thin residual soils from sandstones and shales.

2. Clayey so1ls (N-I): assoclated w1th clay shales.

3. Non soll area $(\mathrm{N}-\mathrm{I})$ : associated with canyon lands.

\section{Section 6a}

1. Sands, silts and clays (sandy predominating) $(M-W)$ : associated with residual development from sandstones and shales.

2. Non soil area $(\mathrm{N}-\mathrm{I})$.

3. Clayey so11s $(\mathrm{N}-\mathrm{L})$ : assoclated with clay shales.

\section{Section $6 e$}

1. Silty soils $(M-W)$ : thin residual soils from I1mes tone.

2. Silty and sandy solis $(I-M)$ : thin residual so1ls from sandstones and shales.

3. Graveliy to clayey solls (bedrock predominating) (I-M): thin residual solis from flows.

4. Non so11 area $(\mathrm{N}-\mathrm{I})$.

Section $6 f$

1. Clayey solls $\left(L-M_{i}\right)$ : associated w1th clay shales.

2. Sands, silts and clays (sandy predominating)

$(I-Y)$ : thin residual solis associated with sandstones and shales.

3. Gravelly to clayey (bedrock predominating) (I-M): thin residual solis from flows.

4. Non soil areas $(N-I)$.

Province 13

Sect1on 13a

1. Stoney loams (VW) : residual solls developed 
from granitic type rocks.

2. Silty loams $(I-M)$ : residual solls developed

from sedimentary rocks within isolated valiey areas.

Section $13 \mathrm{~b}$

1. Stoney clays to silty clays (eravelly clay predominating) (VW): soll unit is assoclated with residual development from cherty I1mestones (primarily).

Section 13c1

1. Sandy to clayey solls (clayey predominating) $\left(M-W^{\prime}\right)$ : residual solls developed primarliy from sandstones and shales: stoney solls may locally occur.

2. Non soll areas $(N-I)$ : associated with rugged sandstone outcrops.

Section $13 c 2$

1. Sandy loam to silty loam $(M-W)$ : residual so1 is developed from folded sandstones and shales.

2. Loamy solis $(\mathrm{N}-\mathrm{I})$ : associated primarliy with alluvial deposits from Arkansas River.

3. Non so1l areas: rugged sandstone (primarily).

\section{Section 1303}

1. Silty loam to clayey solis (clayey predominating) $(M-W)$ : residual solis developed from sandstones, shales and minor areas of slates and quartzites.

2. Non soll area $(I-N)$ : associated with rugged sandstones, and novaculite of unit: appears to be more widespread in northern and eastern (Cklahoma) portion.

Province 14

Section $14 a$

1. Silty clay loam to clayey solls (clayey predominating) ( $M-W)$ : residual solls developed within the cuter Blue Grass and Eden Shale Belt units: parent materials are arg1liaceous 11 mestones (Outer Blue Grass) and shale with minor siltstone (Eden Shale Belt).

2. Silty clays and clays $(I-M)$ : residual so1 is developed within Inner Blue Grass from pure 11 mestones. 
Sect1on 14b

1. Silty clays and clays (VW): residual solls from 11 mestones.

2. Non soll area $(N-I)$ : associated with bare I1mestones outcrops known as "glades".

Section $14 c$

1. Sandy loams to sandy clay loams (I- $\left.Y_{1}\right)$ : residual solls developed from sandstones, shales and minor amounts of 11 mestone.

2. Sandy clay loam to silty clay loam (I-M): residual solis similar to \#I.

3. Silts and clays $(N-I)$ : associated with alluvial areas within unit.

4. Silty loam to clayey silt loam (silty loam predominating) ( $N-I)$ : aeolian deposits generally found in the western portion of the unit and irregularly along portions of the chio.

Section 142

I. Gravelly clay to clayey (clayey predominating) $(M-W)$ : residual solls generally associated with cherty limestones.

2. Silty clay and clayey solis (I-ri): residual solis from relatively pure 11 mestones.

\section{Province 15}

\section{Section $15 a$}

1. Non soll area $(M-W)$ : bare, hard sandstone to higher area.

2. Stoney solis $(M-W)$ : associated with sandstonederived drift.

3. Sandy loams to silty loams (silty loams predominating) (I-M): glacial drift generaliy in valley portions.

Section $15 b$

1. Sandy loam to silt loam (silt loam predominating) (M-W): glacial drift found primarily in New York and Pennsylvania generally derived from hard sandstones with some shale.

2. Clay loam and loamy solis (I-M): glacial drift found primarily in the western portion (Ohio and northwest Pennsylvania): arift is generally more plastic (1.e., less silty) than drift noted in \#l. 
3. Gravelly and sandy solls $(N-L)$ : generally assoclated with valley (glaclal) outwash; found primarlly in New York State.

4. Organlc solls (N-I): small scattered areas.

Section 150

1. Stoney silt loam to slity clay loam (s1lty clay loam predominating) (M-W): assoclated with residual soll developed primarily from sandstones and shales; appears similar to soll found in ad jacent Kanawha unit.

2. Non soll areas (I-M): associated with rugged sandstone areas in the southern portion.

\section{Section 15 a}

1. Stoney silt loam to silty clay loam (silty clay loam predominating) $(M-W)$ : residual solis developed primarliy from Mississippian rocks and the Pottsville and Allegheny formations of Pennsylvanian age.

2. Sandy clay loam to clayey (clayey predominatlng) (M-W): residual solis developed from parent material higher in soft shale and limestone outcrops than \#I; geologlcally, this unit conforms to the Conemaugh and Monongahela formations of Pennsylvanlan age and the Dunkard formation of Permian age. Residulim developed from these rocks is generally more plastic than the other soll unit of the section.

3. Non soll area $(N-I)$ : isolated areas in southern portion of unit.

Section $15 e$

1. Sandy solls $(M-W)$ : generally assoclated w1th resldual solls from sandstone.

2. Sandy loam to sandy clay $(N-L)$ : residual solis similar to soll unit \#1.

3. Non soll areas $(N-L)$ : rugged sandstone areas.

4. Gravelly clay to clay (clay predominating) $(\mathrm{N}-\mathrm{L})$ : residual soll developed from cherty I mestones in the Sequatchie and Wills Creek Valleys.

5. Clayey $(\mathrm{N}-\mathrm{I})$ : residual solis developed from pure IImestone and found in assoclation with the variant 11 mestone valleys noted in sol1 und $\# 4$. 
Province 16

Section 16a

1. Stoney to sandy solls $(M-W)$ : generally assoc1ated with thin residual cover from sandstones occupying ridges of the unit.

2. Non so11 areas ( $L-M)$ : sandstone ridges.

3. Silty to clayey (clayey predominating) (I-M): residuals solls developed from 11 mestones and shales within the valley portion; texture of these solls varles greatly but fine textured sol1 resiojum is generally common in many portlons of the valley areas.

Sect1on $16 \mathrm{~b}$

I. Stoney clays to clays $(M-W)$ : residual solls from carbonate rocks that are frequently cherty in nature; chert residue may yleld a stoney or gravelly to clayey matrix.

2. Silty to clayey (clayey predominating) (I-M): residual solis from chert free carbonates.

3. Non so11 area $(\mathrm{N}-\mathrm{I})$ : sandstone ridges.

4. Stoney to sandy solis $(N-I)$ : thin residual development from sandstone ridges.

Province 17

Section 12a

1. Non soll area $(V-W)$ : although the entire SectIon has been noted to be of a non soll area type, thin to moderately thick residual solis are present. Generally, the type of soll depends upon the parent rock and possesses a counterpart so11 within the Pledmont Plateau Section to the southeast.

Section $12 \mathrm{~b}$

1. Sandy loam to clay (sandy clay loam predominating) (VW) : residual solis developed primarily from granitic and gne1ssic rocks.

2. Silty loam to silty clay loam (I-M): assoc1ated with residual solls of the slate Belt areas of the Carolinas.

3. Loamy to silty loam $(I-M)$ : residual so1ls generally developed from schists.

4. Clayey solis $(N-L)$ : residual solis primarily assoclated with basic 1 gneous rocks. 
Special remarks: This unit is characterized by a relatively deep development of residual so11. Generally, almost all solls possess very heavy (clayey) $\mathrm{E}$ horlzons. In addition, much mica is present in the soll and frequently ylelds A-?-5 or $\mathrm{MH}$ Englneering soll class $1-$ flcation.

\section{Province 18}

1. Sandy to clayey (clayey predominating) (VW): residual solis from Triassic sandstones and shales.

2. Clayey (N-L): residual so1 is from I1mestones in valieys.

3. Stoney to clayey $(\mathrm{N}-\mathrm{I})$ : residual solls associated with trap rlages; portions may be non soll area.

4. Sandy loam to clay (sandy clay loam predominating) (N-I): residual solis from granitic and gneissic rocks.

5. Sandy and gravelly $(\mathrm{N}-\mathrm{I})$ : glaclal drlft in northern portion of the unit.

6. Organlc solis $(\mathrm{N}-\mathrm{I})$ : associated with glaciated portion.

\section{Province 3}

Section $3 a$

1. Graveliy and sandy solis $\left(N_{-}-W\right)$ : assoclated with glacial deposits.

2. Clay loam to clay $(L-M)$ : residual solls developed from basalts found within the Trough.

3. Crganic (N-I): found in glaclated portion.

Section 3b

1. Gravelly to clayey (VW): this unit is assoc1ated with the alluvium of the flood plains or non-marine terraces occupying much of the unit; soll texture is extremely variable.

2. Loamy to clayey loam (N-I): residual so1ls from sandstones and shales along the west flank of the valley.

3. Clayey loam to clay (N-I): resiaual solis from basic igneous rocks on the eastern side of the valley.

Section 3c

1. Ioamy to clayey (loam predominating) (I-M): assoclated with flatter trough areas. 
2. Clayey (I-M): generally associated with mixed alluvium and valley terraces within the Trough.

3. Graveliy loams, sandy loams and loams ( $L-M$ ): generally assoclated with alluvial fans along Sierra Nevada.

4. Sandy $(N-I)$ : wind modified areas found predominating in the southern portion of the Valley.

5. Crganic (N-I): occurs in Sacramento - San Joaquín delta.

\section{Province 5}

Section 5 a

1. Gravelly to clayey $(M-W)$ : valley $f 1 l l$ areas that characterize the basin portion; soll texture is generally highly variable but varles gradationally in size as one proceeds towards the central portion of the basins.

2. Non soll area $(M-W)$ : mountain ranges of the un1t.

3. Clayey (I-M): assoclated with old lacustrine beds (playas) common to the central basin area.

4. Silty solis $(N-I)$ : aeolian deposits occurring in the northeast portion.

5. Sandy to clayey (sandy predominating) (N-I): residual solis, generaliy thin, develcped from extrusive rocks in the northwest portion.

Section 5b

1. Gravelly to clayey $(M-W)$ : assoclated with valley fill; general characteristics similar to those found in the Section 5 a.

2. Non so1l area ( $L-M$ ): ranges.

3. Clayey (N-I): assoclated with playas similar to Section 5a; frequency of occurrence is not as great as Section 5 a.

jection $5 c$

1. Silts and clays (clayey predominating) (M-W): associated with fine textured lacustrine and alluvlal solls of the unit.

2. Sandy solls $(N-I)$ : wind modifled dune areas.

3. Gravelly to clayey $(\mathrm{N}-\mathrm{I})$ : valley f111.

4. Non soll area (N-I) : mountain range to the east. 
Sect1on 5 d

1. Gravelly to clayey $(M-W)$ : valley $f 111$.

2. Non soil area $(I-M)$ : ranges and mountalns.

3. Gravelly to clayey (bedrock predominating)

$(\mathrm{N}-\mathrm{I})$ : thin residual solis from extrusive rocks; found in the northern portion.

4. Clayey $(\mathrm{N}-\mathrm{I})$ : found in central basin areas.

Section 5e

1. Non so11 areas $(I-M)$.

2. Sandy to clayey (silty predominating) (I-M): residual solis derived primarily from sandstones and shales.

3. Gravelly to clayey $\left(I-M_{i}\right)$ : assoclated with water deposited solis (predominatly valjey fili).

4. Stoney clays $(N-I)$ : residual soll from limestone.

\section{Section $5 f$}

1. Non soll area $(M-H)$.

2. Stoney clays $(I-M)$ : residual soils from limestones comparable to those found in the Edwards Flateau.

3. Gravelly to clayey $(I-M)$ : valley flII.

\section{Province 20}

\section{Section 20a}

1. Sandy $(M-W)$ : associated with coastal terraces.

2. Mixed sands and clays $(M-W)$ : coastal deposits.

3. Crganic $\left(I-M_{1}\right)$ : associated with $t j d a l$ marshes which occupy areas of the outer coastal plain but which may follow estuaries up to the inner zone.

4. Clayey (N-I): assoclated with Cretaceous deposits in Rar1tan Iowland; of ten assoclated with greensand belt.

5. Sandy and gravelly solis $(\mathrm{N}-\mathrm{L})$ : glacial deposits on Cape Cod and Iong Island.

\section{Section 20 b}

1. Mixed sandy and clayey $(M-W)$ : coastal deposits.

2. Sandy $(I-M)$ : coastal deposits.

3. Organic (I-M): similar to Section 20 .

4. Sand clay $(N-I)$ : coastal, deposits.

Section 20c

1. Sandy (VW) : coastal deposits. 
2. Organic $(M-W)$ : area contains many large swamps.

3. Clayey (L-M) : generally assoclated with resldual solls from water deposited marls and chalky limestones; major concentration occurs around the Ccalla uplift and in scuthern Florida.

4. Non soll area (N-I): minor area of limerock south of Everglades.

Section $20 d$

1. Mixed sands and clays (M-W): coastal deposits.

2. Sandy clay $(I-M)$ : coastal deposits.

3. Sands (I-M) : coastal deposits.

4. Clayey so1ls (I-M): primarliy associated with residual development upon Cretaceous and younger limestones and chalks in the Belted Coastal Plain area.

5. Crganic (N-I): small outer coastal areas possess isolated deposits.

Section $20 \mathrm{e}$

1. Silty (VW): loessial deposits.

2. Silts and clays (clays predominating) (N-I): assoclated with floodplains of rivers dissecting the area.

Section 20 r

1. Silts and clays (clays predominating) ( $W$ i : : alluvium from Mississippl and Red Rivers.

2. Silty $(\mathrm{N}-\mathrm{I})$ : loessial area varlant to alluvial plain called Crowley's Ridge.

3. Crganic (N-I): assoclated with deltaic deposits of the Mississippi River.

\section{Sect1on $20 \mathrm{~g}$}

1. Clayey $(M-W)$ : generally assoclated w1th three distinct areas and types; residually developed from limestones and chalks (cretaceous); marine clays found along the coast; and 1solated aliuvial clays similar to those which characterize the Mississippi Alluvial Plain Section.

2. Mixed sands and clays (I-M): coastal deposits.

3. Sands and gravels (N-I): coastal deposits.

4. Crganic $(\mathrm{N}-\mathrm{I})$ : minor areas along coast. 
Province 11

Section 11a

1. Clays and silts (clays predominating) $(M-W)$ : assoclated with marine deposits; frequently interspersed with silty type t111.

2. Crganic deposits $(I-M)$.

3. Non so11 areas $(\mathrm{N}-\mathrm{I})$.

4. Sandy so11s $(N-I)$.

Sect1on 11b

1. Clayey solis (VW): assoclated with marlne deposits.

2. $\operatorname{Crgan} 1 \mathrm{c}(\mathrm{N}-\mathrm{I})$.

Section 11c

1. Clayey solis $(M-W)$ : marine clays restricted to northern portion.

2. Loamy $(M-W)$ : glaclal drift derived from slates, Iimestones and sandstones in southern portions.

3. Organic (N-I): occurs in southern portion.

Section 11d

1. Loamy to silty clay loams $\left(M_{-}-W\right)$ : glaclal t111 predominatly from dark shale; low in lime.

2. Stcney so1ls (L-H): occurs in Tug H111 Cuesta.

3. Gravelly solls $(N-I)$ : occurs near Tug H1ll Cuesta.

4. Crganic (N-I).

Section 11e

1. $\operatorname{Crganic}(M-W)$.

2. Solis associated with glacial lacustrine areas (reworked till in part) (I-N):

a. Silty clays, clays, silty clay lcam, clay loam.

3. So1ls associated with glac1al drift (primar1ly late $W$ iscons in age) $(Y-W)$ :

a. Gravelly loam, sandy loams and loams $\left({ }_{1}-W\right)$ : occur extensively in Michigan and Wisconsin.

b. Ioam to silty clay loam (I-M) : occurs in New York and portions of Illinols and Wisconsin.

c. Sandy loam to loam (N-I): occurs in Ind 1 ana. 


\section{d. Loam to silty loam $(N-I)$ : occurs in parts of Wisconsin, Michigan and Ind1- ana. \\ e. Clay loam (N-I): occurs primar1ly in tri-state area of Michigan, Chio and Indiana.}

Section 11 f

1. Organic $(\mathrm{N}-\mathrm{I})$.

2. Silty loam to clayey silt loam (I-M) : loessial deposits in western Illinols and solithwestern Indiana.

3. Gravelly solls ( $N-I)$ : alluvial (slulceway) terraces.

4. Solls associated with glacial drift $(M-W)$. a. Illinolan till (I-M):

1. Ioam to clay (clay loam predominating).

11. Clay loam: occurs primarily in Illinols.

b. 'isconsin (early) t1ll (I-M):

1. Silty clay loam $\left(I-V_{i}\right)$ : occurs in Illinols, Ind lana and Oh1o.

11. Loam $\left(I-V_{1}\right)$ : generally occurs in a belt south of soll unit (b1).

111. Ioam to silty clay loam $(I-M)$ : Illinols.

1v. Loam to silty loam $(N-I)$ : IIIInc1s.

\section{Section IIg}

1. Sandy solls $(M-W)$ : assoclated with old glaclal lacustrine area and residual solls from Cambrian sandstones and shales; forms the greatest portion of the Central Sand Plain of Wisconsin.

2. Silty loam to clayey silt loam (silty loam predominating) ( $N-W)$ : aeolian deposits that mantle Cambrlan sandstones and shales and younger $\mathrm{Pa}-$ leozolc carbonates.

3. Creanic (N-I): occur principally within northeast portion.

Section 1 hh

1. Solis associated with glaclal t1ll (V'i).

a. Ioamy $(M-W)$ : occurs in all states within section.

b. Gravelly lcam, sandy loam and sandy clay loam ( $I-M)$ : occurs primarily in northern Minnesota. 
2. Solls associated with glacial lacustrine areas (I-M):

a. Clays and s11ts: fine texture lacustrine deposits.

b. Sandy and gravelly solls: water-sorted (beach) deposits.

3. Organic ( $I-M)$ : occur primarily in northeast.

Special Remarks: The clayey textured solls appear to be more prominant in the Iake Agassiz. area with silty solls flanking the finer clays on all sides. Sandy beach deposits predominate on the western side (North Dakota) whlle gravelly material is found in Minnesota. Lake Souris appears to have an equitable distribution of both silt and clay size deposits, while lake Dakota appears more silty in texture. Both of the latter lacustrine areas have assoclated granular beach deposits.

Section 111

1. Silty loam to clayey silt loam (silty loam predominating) (M-W): aeollan deposits overlying glacial drift.

2. Clay loam to silty clay loam (clay loam predominating) (M-W): glacial drift; primarily Kansan, in part, Iowan.

Province 12

Section 12 a

1. Solls associated with glacial drift (M-W): mainly gravelly loams, sandy loams, sandy clayey loams, and silty clay loams.

2. Non soll areas (I-M).

3. $\operatorname{Crgan1C}(I-M)$.

4. Silty clays and clays $(N-I)$ : lacustrine deposits.

Province 19

Section 19a

1. Clayey solls (M-W): marine clays generally present in northern portion.

2. Stoney sandy and gravelly solls $(M-W)$ : glacial arift, generaliy thin and similar to that found in the adjacent upland und to the north.

3. Organic (I-M): includes muck and peat bogs assoclated with glaclation as well as marshy deposits in estuarine deltas near mouths of 
rivers and streams.

4. Non soll area $(\mathrm{N}-\mathrm{I})$.

Section $19 \mathrm{~b}$

1. Stoney sandy and gravelly solls $(M-W)$ : generally thin glacial drift of Wisconsin age derlved from two major rock groups: (a) granites, gneisses and schists and $(t)$ shales and I1mestones; sedimentary rock derived till found primarily in the northern portion.

2. Non soll areas $(I-M)$.

3. Clayey gravelly solls $(\mathrm{N}-\mathrm{I})$ : glacial t1ll generally derlved from limestones and shales in northeast Malne.

4. Crganic $(N-I)$.

5. Clayey solls $(\mathrm{N}-I)$ : small scattered areas of marine clays which are modal to the adjacent Seaboard Lowland un1t; existence of this soll unit may be due to the relatively indefinite border which separates the New England Upland from the Seaboard Iowland.

Section 190

1. Sandy and gravelly solls (VW): coarse glaclal drift occurring within till, outwash plains and terraces.

2. Organ1c $(N-I)$ : small area noted in southern portion.

3. Non so1l area $(\mathrm{N}-\mathrm{I})$ : assoclated with trap ridges.

Section 19d

1. Non soll area (VW).

2. Stoney gravelly and clayey gravelly solls

$(\mathrm{N}-\mathrm{I})$ : 1solated patches of glacial drift similar to that found in New England Upland Section.

3. Organ1c $(\mathrm{N}-\mathrm{I})$.

Section $19 \mathrm{e}$

1. Non so11 area $(M-W)$.

2. Stoney gravelly solis $(M-W)$ : generally thin cover of coarse glacial arift.

Section $12 \mathrm{f}$

1. Loamy (VW) : glaclal till derived from schists, slates, shales and limestones; minor areas 


\author{
may be stoney. \\ 2. Non soll areas $(\mathrm{N}-\mathrm{I})$.
}

Section $12 \mathrm{~g}$

1. Non so11 area $(M-W)$ : occurs with glaclated portion.

2. Stoney loam $(M-W)$ : thin residual solis developed from primarily gnelssic rocks; occurs in nonglaclated portion.

\title{
Province 10
}

Section 20a

1. Loamy solis ( $M-W)$ : forms bulk of glaclal t1ll of North Dakota and South Dakota portions of Section.

2. Clay loam ( $\mathrm{N}-\mathrm{W})$ : glaclal till found primarily in Montana and smaller 1 solated areas of the Dakotas.

3. Non soli areas $(\mathrm{N}-\mathrm{L})$ : several hocky Mountain outliers.

4. Gravelly solls (N-I) : found near Montana border with Rocky Mountalns and in the north central portion of Montana.

Section 10b

1. Sandy silt to clayey (sandy silt predominating) $(M-W)$ : residual solls derlved from sandstones and shales.

2. Clayey $(M-W)$ : assoclated with clay shales of the unit; Plerre Hilis area is a primary example.

3. Gravelly solls $(\mathrm{N}-\mathrm{I})$ : small 1solated areas assoclated w1 th outwash.

4. Non soll areas $(N-I)$.

\section{Section $10 \mathrm{C}$}

1. Sandy silts to clayey (sandy silt predominating) $(M-W)$.

2. Clayey $(N-I)$ : assoclated $w 1$ th scattered areas of clay shales.

3. Gravelly to clayey $(\mathrm{N}-\mathrm{I})$ : coarse textures generally predominate; assoclated with outwash from surrounding mountain areas; occur in areas whlch 11 e between Rocky Mountain appendages which protrude into the section.

4. Non soll area $(\mathrm{N}-\mathrm{I})$ : scattered exhumed gran1t1c areas protruding through Tertiary sed1ments. 
Section $10 \mathrm{e}$

1. Non soll area ( $I-M)$ : associated with granitic core and volcanlc rock areas.

2. Clayey solls $(I-M)$ : residual solis developed from Triassic shales and Permian limestones.

3. Sandy and silty solis $(\mathrm{N}-\mathrm{L})$ : associated with residual solis developed from the Cretaceous Dakota Sandstone; this unit encircles the area and gradualiy merges (topographically) into the surrounding Missourl Plateaus.

Section $10 f$

1. Sandy to silty (sandy predominating) (M-W): original plains outwash mantle; gravelly textures and clays are occaslonally found.

2. Sandy (I-M) : corresponds to Nebraska Sand Hills plus several other scattered areas; in part wind reworked.

3. Silty loam to clayey silt loam (silt loam predominating) (I-M): aeolian deposits occur in the northeast portion and extend into the Central Lowland Province.

4. Sandy to clayey (clayey predominating) (N-I): residual solls developed primarily from Brule clay within Goshen Hole Lowland area of Nebraska and wyoming.

Section $10 \mathrm{~g}$

1. Sandy to clayey (M-W) : residual solls from Tertlary and Cretaceous sandstones and shales.

2. Clayey (I-M) : assoclated w1th clay shales.

3. Sandy to silty (sandy predominating) ( $\left.L-i_{i}\right)$ : varlant Great Plains outwash mantle.

Section $10 \mathrm{~h}$

1. Sandy to clayey (VW): see comments of Section log.

2. Non soll areas $(\mathrm{N}-\mathrm{I})$.

Section 101

1. Sandy to clayey (silt predominating) (VW): residual solis developed from sandstones and shales (minor limestones) of Triassic, Jurassic and Permian age; may be thinly developed and lack any widespread clayey residue.

2. Gravelly to clayey (L-M): valley fill in southem portion. 
3. Sandy to silty (sandy predominant) (N-I):

isolated areas of Great Plains outwash units.

Section 101

1. Silty loam to clay silt loam (s1lty loam predomlnating) ( $I-M)$ : aeollan areas overlylng bedrock and Plalns outwash.

2. Sandy to clayey (clayey predominating) (I-M): residual solis from sandstones, shales and l1mestones of Cretaceous and Permian age.

3. Sandy loam to loam $(\mathrm{N}-\mathrm{I})$ : residual soll in Smokey Hills area.

4. Sandy to silty (sandy predominating) (N-I): Tertlary Plains outwash variant to undt.

5. Sandy and gravelly solls (N-I): generally assoclated with alluvial solis within Arkansas Iowland; portion may be wind reworked.

Sect1on 10k

1. Sandy to clayey (clayey predominating) (I-M): residual solis from Permian sandstones and shales.

2. Stoney sandy loams (L-M) : residual so1ls from granitic type rocks of Ilano Uplift.

3. Stoney clays (I-M) : residual from Cretaceous limestones.

4. Sands and sandy loams $(N-I)$ : residual solis from Pennsylvanian sandstones and shales.

5. Non so11 areas $(\mathrm{N}-\mathrm{I})$.

Section 101

1. Stoney clays $(M-W)$ : residual solls from Cretaceous 11 mestones.

2. Non soll area $\left(\mathbb{M}_{-}-\mathbf{N}\right)$ : bare IImestone outcrops.

Section $10 \mathrm{~m}$

1. Sandy to clayey (clayey predominating) (VW): residual solis from Permian sandstones and shales and Pennsylvanian l1mestones, sandstones and shales.

2. Stoney clay loams $(N-I)$ : residual from cherty IImestones in Flint Hilis.

3. Clayey $(\mathrm{N}-\mathrm{L})$ : assoclated with Pennsylvanian shales in Cherokee Lowland.

4. Non soll area $(\mathrm{N}-\mathrm{I})$ : Wichita and Arbuckle Nountains.

5. Sands and gravels $(N-I)$ : scattered solis of water transported origin. 


\section{Foor Subgrade Support Areas}

Inorgan1c Solls

General. Solls are used in two general ways along a highway route. They are elther: (a) stressed in place as foundations for structures (including embankments) and in cut slopes or (b) they are excavated and compacted to form embankments, backilils for structures, and subgrades. The poorer solls are wasted, e.g., organics are not used as constructional materials and are often excavated and/or displaced in embankment foundation situations. Iocal "problem" soils are avolied in subgrade locations, of ten for the reason that they are difficult to hande and/or compact. A number of soll textures can be troublesome in subgrades, 1.e., non plast1c silts, micaceous silts, poorly graded sands, but problems of subgrade support are most common with clays. For this reason, the rating of sections with respect to protlems of subgrade support was accomplished by a combined consideration of the clayeyness of surficlal solis and the frequency of occurrence of such solls.

The rating is compromised as topography becomes rough and more subgrade solls originate from deposits not mapped in the surficlal coverage (F1gures 16 to 21). All textural types coarser than (and including) the very fine sandy loam in Table 15 were consldered to afford satisfactory subgrade support. Finer textures were grouped into four severity categories based upon the most probable Unifled Soll Classification, also given in Table 15. The resulting 
severity groups are shown in Table 16.

Severity ratings of each Section were then qualitatively formilated by combining textural type and distribution information with the general severity rating of Table 16. The severity ratings and descriptive remarks follcw in a sequence identical to that utilized in the discussion of soll origin and texture. Severlty rating codes are ldentical to those used within the soll texture descript1on.

Severity Rating by Bas1c Report Un1t

Province I

Section la $(N-I)$ : lean clays developed from residual sandstones and shales may be present in minor portions of the area.

Section It $(N-I)$ : comments similar to section la. Section IC $(N E)$

Section Id (I-M): lean clays may be found over a great portion of the area from residual sandstones and shales.

Section le $(\mathrm{N}-\mathrm{I})$ : minor areas of lean to highly plastic clays may be found withir. the Los Angeles Easin.

Province 2

Section 2a (NE)

Section 2b $(N-I)$ : lean and plastic clays may be assoclated with resicual solis from basic 1 gneous rocks on the

Section 2 c $(N-I):$ western rlank of the Range. minor area of residual solis from granitic rocks may afford lean

Section 2d (NE) clay development.

Province? Section 7a $(N-I)$ : clay solis generally confined to Section 7b (NE) basin areas.

Section $7 c$ (NE) 


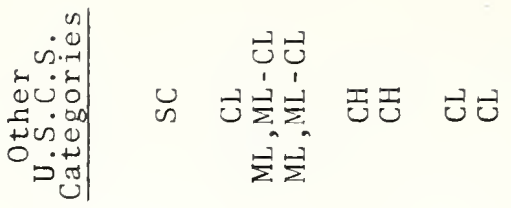

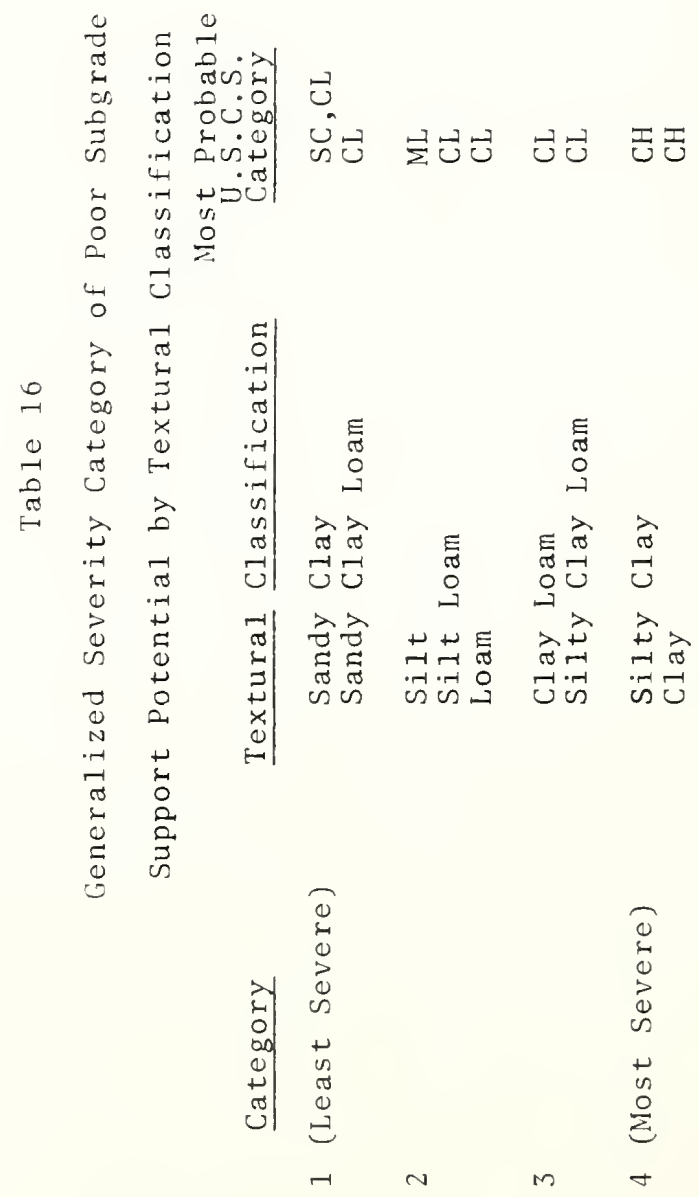


Province 8

Sect1on 8a (NE)

Sect1on $8 b$

Sect1on 8c

Section $8 \mathrm{~d}(\mathrm{~N}-\mathrm{I})$

lean to plastic clays may be found in minor areas from resid-

Section 8e (NE) ual sandstones and shales.

Province 9

Section $9 a(N E)$

Section $9 b$ (NE)

Section 9c (NE)

Province 4

Section $4 a(N E)$

Section $4 b$ (NE)

Section $4 c$ (NE)

Section 4d $(N-I)$ : highly plastic clays may be asso-

Section $4 e$ (NE)

clated with lacustrine areas.

Province 6

Section 6a (N-I): clays may be assoclated with shales in southern portion of unit; remalnder of solls may be thin and coarse textured.

Section 6b $(N-I)$ : highly plastic clays may be assoclated with shales within the urit.

Section 6c (N-I): clays may be associated with clay shales; sandy texture predominates.

Section 6d (N-L): similar to Section 6c.

Section $6 e(N-I)$ : plastic clays may locally be assoclated with residual solis from volcanic material.

Section 6f (I-M): highly plast1c clays are assoclated with shales and clay shales.

Province 13

Section 13a (N-I): silt loam developed from sed1mentary rocks may be of a lean clay varlety.

Section 13b (I-M): highly plastic solls may be found throughout the area; however, chert residue in stoney or Eravelly form, may increase the subgrade support.

Section $13 \mathrm{cl}$ (I-M): highly plastic resiaual solls may be assoclated with the sandstones and shales of the unit.

Section $13 \mathrm{c} 2(\mathrm{~N}-\mathrm{I})$ : lean clays are assoclated with the residual solls and alluvial 


deposits of the area; clay
shales are also found in the
area.
Section I3C3 (L-M) :hlghiy plastic solls may develop
from resldual solls.

Province 14

Section 14a (VW): development of highly plastic

residual solis is very widespread

in the unit.

Section 14b (VW): same as Section $14 a$.

Section 14c (L-M): residual solls appear to be less plastic (1.e., more silty and sandy) than in other sections of Frovince; lean clays may be assoclated with residual solis while the more plastic solls are assoclated with the limited alluvial deposits in the area.

Section $14 d(M-W)$ : highly plastic solls may be frequently encountered with residual solls of the unit.

Province 15

Section 15a (N-I): silty loam glacial drift in the valleys may frequently be of a lean clay varlety.

Section 15b (I-M): lean clays from glaclal arlft are present throughout most of the Section; plasticity of the drift may be greater within the western portion of the unit; highly plast1c solls are generally not existent within the unit.

Section $15 \mathrm{C}$ (I-M) : silty clay loam residual solls may generally be a lean to heavy clay material.

Section 15d $(M-W)$ : comments similar to Section 150; in addition, residual solls developed frcm Conemaugh, l'onongahela and Dunkard formations may be highly plastic.

section $15 e(N-I)$ : only clayey type solls within the unit are assoclated with the variant 11 mestone valleys in the section; residual solls developed in these 11 mestones may be highly plastic.

Province 16

Section $16 a$ (I-M): lean to heavy plastic clays are generally assoclated with the limestcne and shale residual 
Section 16b (I-M): $\begin{aligned} & \text { solls of the valley. } \\ & \text { clayey solis are associated with }\end{aligned}$ residual solls of the area; quantity of cherty residue in clay matrix may increase potential subgrade support.

Province 12 Section 17a (NE) Section $I ? b(M-W)$ : lean clays are present throughout entire Section; highly plastic solis are associated with residual solis developed from basic igneous rocks.

Province $18\left(M-W_{i}\right)$ : lean to highly plastic clay solls are associated with each residual soil type within the unit.

Province 3

Section 3a $(\mathrm{N}-\mathrm{I})$ : lean to highly plastic clays may be associated with residual basalts.

Section 3b (L-M): highly plastic clays may frequently underlie portions of the flood plains within the unit; similar type clays may be assoclated with residual solis found in the adjacent border uplands. Section $3 c(M-W)$ : clays of variable plasticity characteristics are quite frequently associated with both alluvium and valley trough solls within the central portion of the valley.

\section{$\frac{\text { Province } 5}{\text { Section } 5 a}(I-M):$}

Section $5 b(N-I):$

Section $5 c(M-W)$ :

$\frac{\text { Section } 5 a}{\text { Section } 5 e}(N-I):$ plastic clay solis are generally associated with lacustrine areas occliping the central portlons of the basins.

comments similar to section $5 a$ except frequency of occurrence is less in this section. highly plastic solis are widely distributed in association with lacustrine and alluvial deposits. comments similar to section 5b. clayey solls of unknown plastic1ty characteristics may be assoclated with valley fill and 
Section residual solls from limestones. comments similar to section $5 e$.

Province 20

Section 20a $(N-I)$ : highly plastic clays are primarily associated with Cretaceous rocks in the Raritan Lowland.

Section 20b ( $N-I)$ : clays may be associated with mixed coastal sediments; sand clay of unit not considered as a poor subgrade material in this unit.

section 20c (I-M): highly plast1c clay solls may be residually developed from carbonate rocks in the unit.

Section 20d ( $I-M$ ): clays developed from limestones and chalks are frequently highly plastic in nature.

Section 20e (N-I): highly plastic clays are generaliy assoclated with minor alluvial areas.

Section 20f (VW): highly plastic solls are widespread in the unit from alluvial origin.

Section 20g $(M-W)$ : highly plast1c clays are widespread from a varlety of orlgins in the unit.

rrovince 11 Section 11a $(M-w)$ :

highly plastic clays are widely distributed throughcut the area from marine deposits.

jection 11b $(r-w)$ : comments similar to Section $11 a$. jection IIC $(M-W)$ : lean and plast1c clays from marine and glacial deposits may be distributed throughout the area; marine clays may be highly plast1c.

Section Ild $(L-M)$ : major portion of drift may be of a lean clay varlety.

Section lle (I-M): most highly plast1c clays are those associated with the lacustrine areas; clayey till appears to be Iimlted to the cuter (southern and western) limits of drift; this t1ll is generally of the lean clay varlety and not widely distributed; predominating till textures in the unit are coarse textured. Section If $(M-W)$ : unit has a more extensive areal distribution of clayey type 
Section 12g $(N-I)$ :

Section IIn $(N-I):$

Section $111(N-W)$ : solls than the Eastern Iakes and Lacustrine Sections; generally the most plastic solls are associated with the oldest drift (Illinolan); these solls, however, are not as plastic as those associated with glacial lacustrine origin; overall a lean clay type of soll may be prevelant throughout most of the entire section.

lean clays may occasionally be assoclated with aeclian deposits; major texture of unit is primarily sandy to silty.

most plastic solls appear in Elacial lacustrine deposits (rrimarlly Lake Aggassiz); na jor t1ll texture of unit is graveliy loam to loam, with loamy till predominatine, somewhat similar in coarseness to that of the Eastern Lakes and Lacustrine Section; lean clays may be assoclated with the loamy arift. lean clay soll is distributed throughout the greatest portion of the unit; less plastic (silty) solls are associated with the loess deposits while highly plastic solls are those associated with the Kansan arift.

Province 12

Section 12a $(N-I)$ : highly plastic clays are only associated with minor areas of lake deposits; arift texture is granular in nature.

Section 12b (NE)

$\frac{\text { Province } 19}{\text { Section } 19 a}(N-W):$

highly plastic clays are assoclated with narine clays widely distributed in area. Section 12b (N-I): minor areas of marlne clays similar to that found in section $19 a$ may protrude into unit.
( NE)

$(\mathrm{NE})$

$(N E)$

$(N-I)$ : although loam texture predominating in unit has a potential for a lean clay classification, 
Section 19g (NE)

Province 10

Section 10a (L-M):

jection $10 \mathrm{~b}(M-W)$ :

Section $10 \mathrm{C}(\mathrm{N}-\mathrm{I})$ :

Section $10 d(N-I)$ :

Section 10e $(N-I)$ :

Section $10 f(N-I)$ :

jection $10 \mathrm{~g}(I-M)$ :

Section $10 \mathrm{~h}$ ( $\left(\mathrm{L}-\mathrm{M}_{1}\right)$ : Sect1on $101(N-I)$ :

Section 10 s $(N-I):$

Section $10 \mathrm{k}(\mathrm{N}-\mathrm{I})$ : it is generally the finest texture present in the unit; much of the area has a stoney fraction and subgrade support should not be a problem.

entire till portion may be consldered as clayey type; lean clays will be more prominant in the Dakotas while plasticity of the t1ll increases in the Montana portion; most probable clay throughout unit is a lean clay type.

wliely distributed and highly plastic clays are of ten assoclated with the clay shales and shales of the area. highly plastic clays may frequently be assoclated with shales of the unit; however, predominant texture is semigranular.

comments similar to section $10 \mathrm{c}$. highly plastlc clays are assoclated with shales of the area; clays from resiaual limestones are frequently less plastic. only potential clayey area is that found in Goshen Hole Iowland from shaley bedrock; predominating texture of unit is sandy to silty. highly plastic solis are assoclated with clay shales and shales of the unit. comments simliar to section 10g. unit generally lacks any regional clay type solls; occasionally, hidhly plastic solis may be asscclated with shales. most plastic solls associated with resldual sandstones and shales in southeast and eastern portions of the unit. highly plastic solls are generally confined to the residual solls developed from Permian rocks in the western portion of the unit. 
Section 101 (I-M): plast1c clays may be associated with residual 11 mestones found throughout the unit.

Section $10 m(M-N)$ : highly plastic solls may be quite frequently associated with the residual solis throughout much of the area.

Crgantc jolls

No attempt was made to rate the severity of support problems associated with organic deposits within the Sect1ons. Qualitatively assessed frequency of occurrence ratIngs have been previously presented under the description of soll textures. The reader is referred to this discussion. High Volume Change Solls

Engineering Iiterature

As previously noted, a literature search of high volume change occurrences was undertaken. The fruition of this effort is shown in Figure 22. In these locations the swelling potential was realized. The numbers contained withIn this diagram are legended to Table 17 , which is a summary of the individual references containing the information. Geologic Investigation

The association of high volume change solis with particular geologic formations was obtained from literature searches. Table 18 summarizes the results by geologlc age and formations, as reported and mapped by Jensen (233). Flgure 23 illustrates the distritution of these formations within the United States. The base map used by Jensen was reference $(384)$. These are areas of swelling potential. 


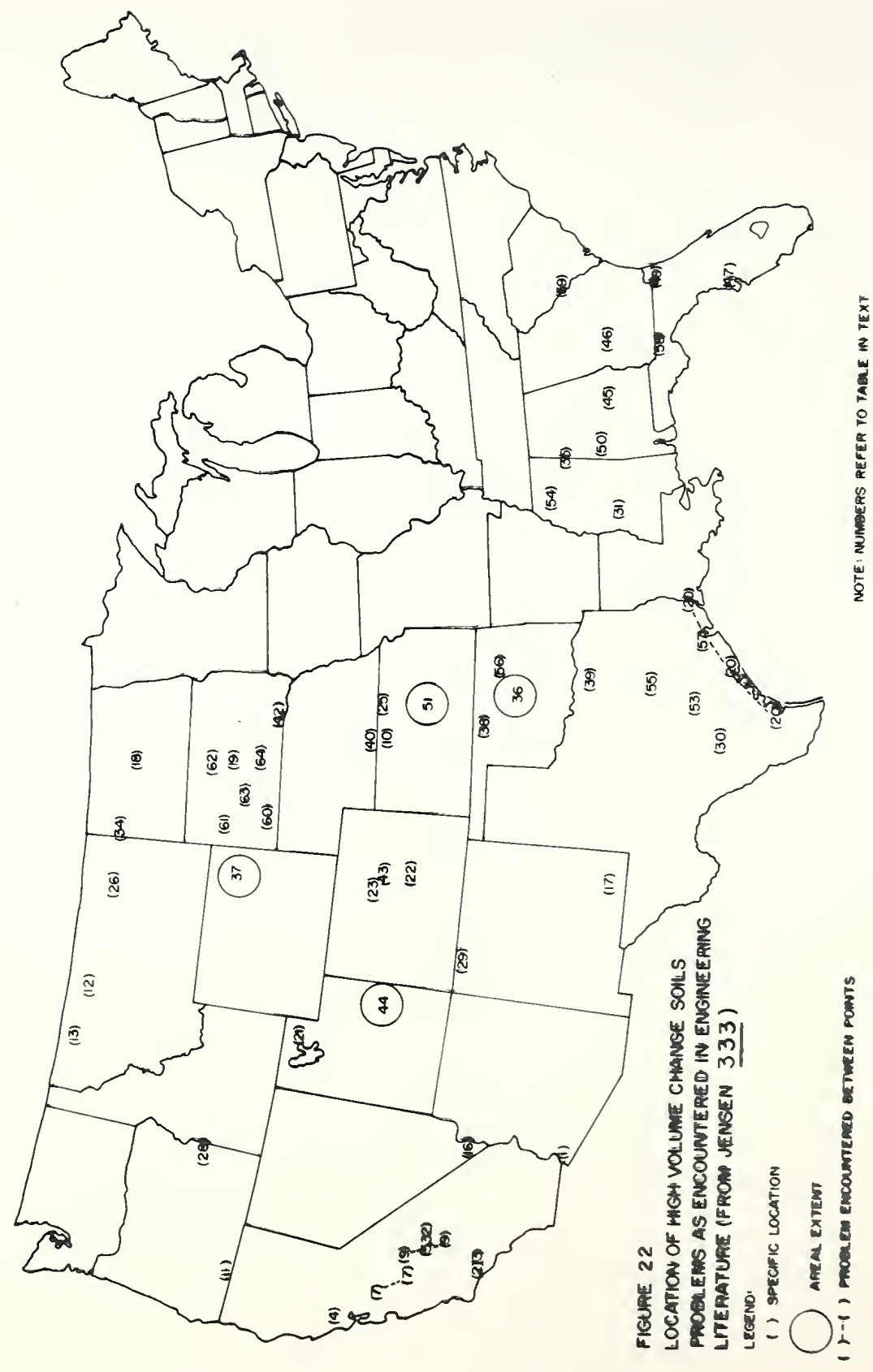


Table 17

Reference Summary of High Volume Change

Soil Locations Obtained from Engineering Literature

Map

Number ${ }^{1}$
Project-Location

Gila - Canals; Arizona

Casitas Canal; California

Ojai Valley Pump; California

Putah Canal; California

Lind-Strath Reservoir; California

Lindmore Reservoir; California

Delta-Mendota Canal; California

Contra Costa Cana1; California

Friant Kern Canal; California

Kirwin Dam; Kansas

Emigrant Dam; Oregon

Tiber Dam Spillway; Montana

Shelburne Dam; Montana

BLM-Collins Dam; Montana

Little Porcupine Plant; Montana

Boulder City; Nevada

McMillan Reservoir; New Mexico

McClusky Canal; North Dakota

Oahe Pump; South Dakota

Gulf Coast Canal; Texas

Gateway Canal; Utah

Colorado Springs; Colorado

Denver-Boulder Turnpike; Colorado

Fire Mountain Canal; Colorado

Courtland Canal; Nebraska

Fort Peck Dam; Montana

Ortega Reservoir; California

Malheur River Siphon; Oregon

Navajo Dam; New Mexico

29

30

31

32

33

34

35

36

37

38

39

40

San Antonio; Texas

Jackson; Mississippi

Porterville; California

Bexar County; Texas

Fort Union Dam; North Dakota

West Point; Mississippi

Permian Red Beds; Oklahoma

Heavy Bentonite Areas; Wyoming

Great Salt Plains Dam; Oklahoma

Sherman; Texas

Harlan County Dam; Nebraska

$\underline{\text { Reference }}^{2}$

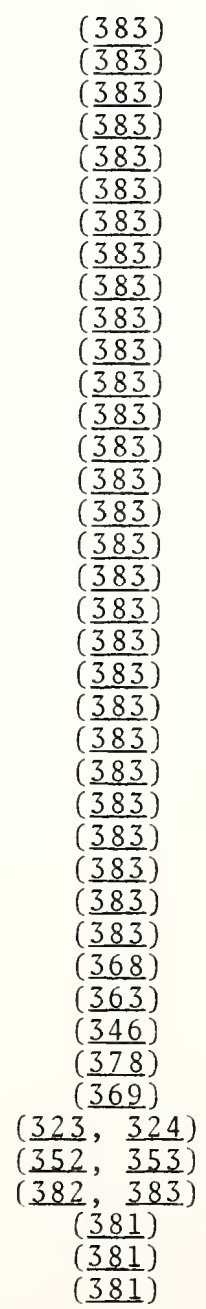


Table 17 (cont'd.)

\begin{tabular}{|c|c|c|}
\hline $\begin{array}{c}\text { Map } \\
\text { Number }\end{array}$ & Project-Location & Reference $^{2}$ \\
\hline 41 & Kanopolis Dam; Kansas & $(\underline{381})$ \\
\hline 42 & Fort Randall Dam; South Dakota & $(\underline{381})$ \\
\hline 43 & Denver; Colorado & 10) \\
\hline 44 & East Central Utah & $(\underline{328})$ \\
\hline 45 & Montgomery; Alabama & (72) \\
\hline 46 & Central Georgia & $(\underline{372})$ \\
\hline 47 & Central Florida & $(\underline{372})$ \\
\hline 48 & North East Mississippi & $(372)$ \\
\hline 49 & North Central Florida & $(372)$ \\
\hline 50 & Tombigbee River; Alabama & 372) \\
\hline 51 & Kansas & $(300)$ \\
\hline 52 & Texas & $(\underline{322})$ \\
\hline 53 & Austin; Texas & 316 \\
\hline 54 & Panola County; Mississippi & $(378)$ \\
\hline 55 & Waco, Interstate 35 ; Texas & $(\underline{350})$ \\
\hline 56 & Tulsa; Oklahoma & $(\underline{352}$ \\
\hline 57 & Houston-Urban Freeway; Texas & $(32 \overline{9})$ \\
\hline 58 & NW-Limon, Interstate 10 ; Colorado & $(307)$ \\
\hline 59 & Tallahassee; Florida & $(\overline{372})$ \\
\hline $60-64$ & Western South Dakota & $(\underline{370})$ \\
\hline
\end{tabular}

1 Map number keyed to Figure 22.

2 Reference number refers to bibliography number. 


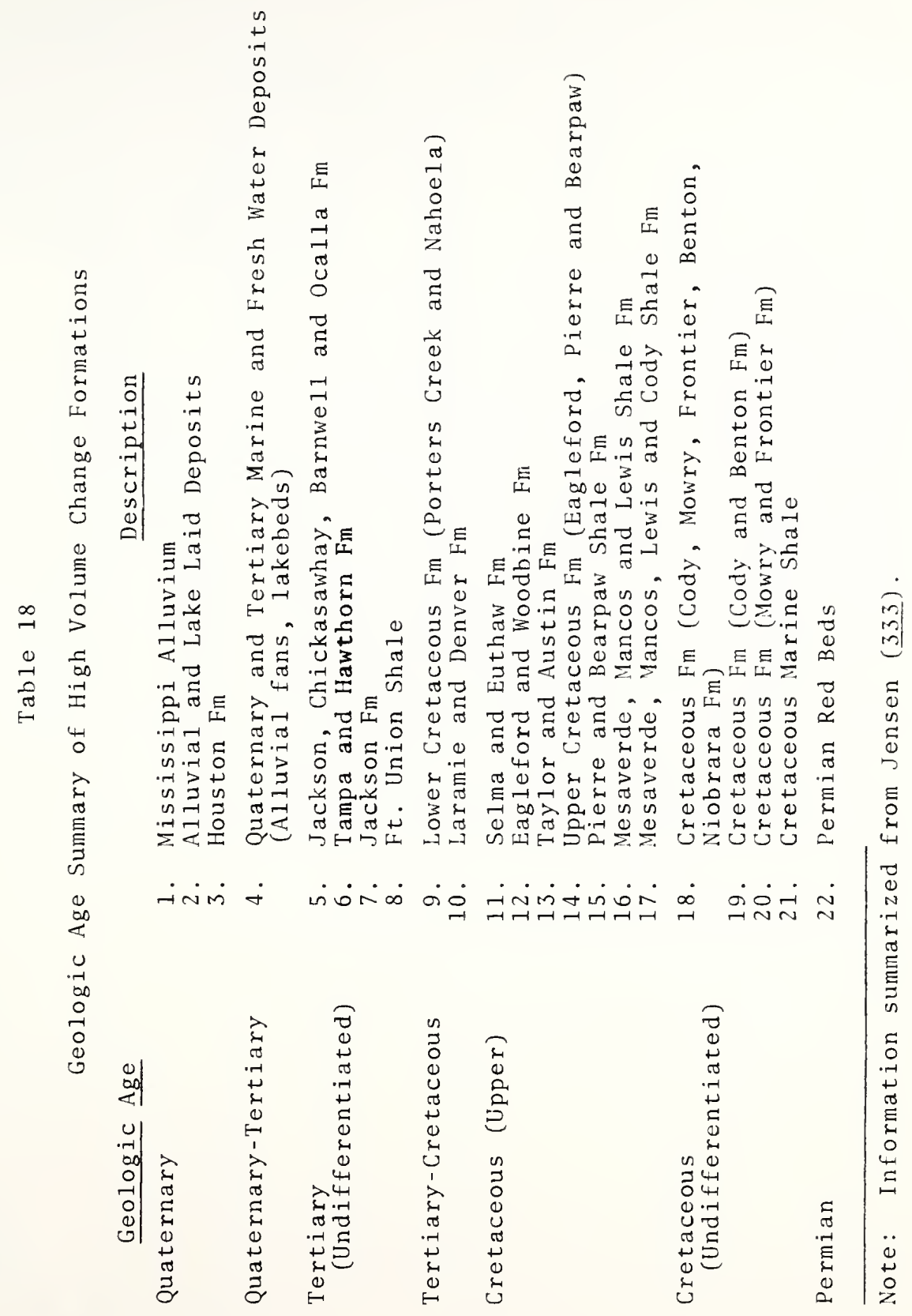




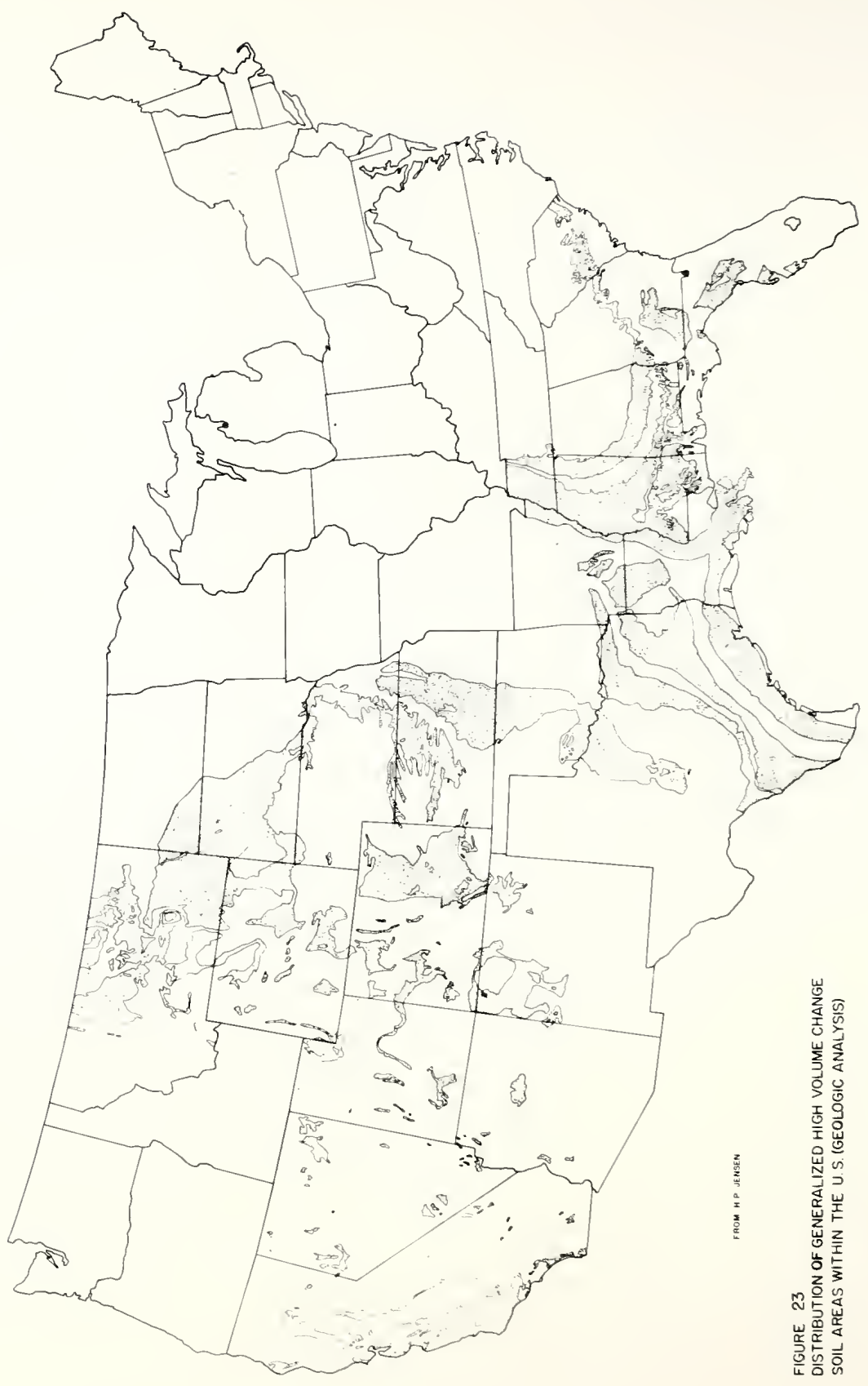


Based upon information obtalned from this phase of the project an examination of the occurrence and frequency of high volume change formations within the basic report sectlons was undertaken. Table 19 is the result of this effort, and largely rates the potentlal for volume change protlems. Fedologic Investigation

A comparable study was undertaken with pejologic information. Table 20 sumnarizes the data based upon parent material-origin considerations. Figure 24 shown the distribution of these areas within the United States. The base map used by Jensen was reference (322).

A frequency of occurrence rating was also estatilished for each section possessing high volume change soli serles, which is given in Table 21. Again the rating is largely one of potential volume change problems. Adjusted Frequency of Occurrence Rating by Section

The final frequency of occurrence rating for each Section possessing high volume change potential is generally based upon the higher geologic or pedologic rating. Several exceptions occur, however, where transported surficlal deposits mantle high volume change geologic formations. An example occurs in the Mississippl Loessial Upland Section. Based upon the pedolog1c mapping, a Non Existent to I1mited ratine was ottained.

A frequency rating of Very widespread was, however, obtalned from the geologic phase due to the existence of high volume change formations underlylng the loessial 


Physiographic Unit
1d California Coast Range
1e Los Angeles Range
2d Lower California
3c California Valley
5a Great Basin
5h Sonoran Desert
10d Hyoming Basin
10c Bighorn Basin Plateaus of Utah
10b Missouri Plat (Glac.)
6h Uinta Basin
6c Canyon Lands
6d Navajo

\section{High Volume Change Formations}

1. Quaternary and Tertiary Marine and Fresh Water Deposits (Alluvial fans, lakebeds)

2. Cretaceous Marine Shales

1. Quaternary and Tertiary Marine and Fresh Water Deposits (Alluvial fans, lakebeds)

1. Quaternary and Tertiary Marine and Fresh Water Deposits (Alluvial fans, lakebeds)

1. Quaternary and Tertiary Marine and Fresh Water Deposits (Alluvial fans, lakebeds)

1. Quaternary and Tertiary Marine and Fresh Water Deposits (Alluvial fans, lakebeds)

1. Quaternary and Tertiary Marine and Fresh Water Deposits (Alluvial fans, lakebeds)

1. Mesaverde, Mancos and Lewis Shale Fm

2. Quaternary and Tertiary Marine and Fresh water Deposits (Alluvial fans, lakebeds)

1. Mesaverde, Mancos and Lewis Shale Fm

1. Cretaceous Fm (Cody, Mowry, Frontier, Benton and Niobrara)

1. Mesaverde, Mancos and Lewis Shale Fn

2. Cretaceous Fm (Cody, Mowry, Frontier, Benton and Niobrara)

1. Quaternary and Tertiary Marine and Fresh water Deposits (Alluvial fans, lakebeds)

1. Mesaverde, Mancos and Lewis Shale Fm

2. Cretaceous Fm (Cody, Mowry, Frontier, Benton and Niobrara)

1. Pierre and Bearpaw Shale Fm

2. Cretaceous Fm (Cody and Benton)

1. Pierre and Bearpaw Shale Fm

2. Cretaceous Fm (Cody and Benton)

3. Ft. Union Shale

4. Mesaverde, Mancos, Lewis and Cody Shale $\mathrm{Fm}$

1. Cretaceous Fm (Cody and Benton)

2. Mesaverde, Mancos, Lewis and Cody Shale Fm

1. Ft. Union Shale

2. Mesaverde, Mancos, Lew is and Cody Shale Fm

3. Cretaceous Fm (Cody and Benton)
Estimated Occurrence within Section (AIl Formations Considered) Medium to Widespread

Limited to Medium

Non Existent to Limited

Limited to Medium

Limited to Medium

Non Existent to Limited

Limited to Medium

Limited to Medium

Limited to Medium

Medium to Widespread

Limited to Medium

Limited to Medium

Limited to Medium

Very Widespread

Limited to Medium

Limited to Medium 
Table 19 (cont'd.)
Physiographic Unit Description

Colorado Piedmont

10h Raton Upland
$10 \mathrm{j}$ Plains Border
lok Central Texas Mineral
$10 \mathrm{~m}$ Osage Plains
$11 \mathrm{i}$ Dissected Loessial and
Till Plains
$20 \mathrm{~b}$ Sea Island
$20 \mathrm{C}$ Florida
$20 \mathrm{~d}$ East Gulf Coast
$20 \mathrm{f}$ Mississippi Alluvial Plain
$20 \mathrm{~g}$ Mississippi Loessial
Upland

\section{High Volume Change Formations}

1. Mesaverde, Mancos and Lewis Shale Fm

2. Upper Cretaceous Fin (Eagleford, Pierre, Bearpaw)

3. Laramie and Denver $\mathrm{Fm}$

4. Cretaceous Fin (Cody, Mowry, Frontier, Benton, and Niobrara)

1. Cretaceous Fm (Cody, Mowry, Frontier, Benton, and Niobrara)

1. Cretaceous Fm (Cody, Mowry, Frontier, Benton, and Niobrara)

1. Permian Red Beds

1. Permian Red Beds

1. Permian Red Beds

2. Cretaceous Fm (Cody, Mowry, Frontier, Benton and Niobrara)

1. Lower Cretaceous fm (Yorters Creek and Nahoela)

2. Jackson, Chickasawhay, Barnwe 11 and Ocalla Fm

1. Tampa and Hawthorn Fm

2. Jackson, Chickasawhay, Barnwell and Ocalla Fm

1. Tampa and Hawthorn Fm

2. Jackson, Chickasawhay, Barnwell and ocalla Fm

. Selma and Euthaw Fm

4. Lower Cretaceous Fm (Porters Creek and Nahoela)

1. Tampa and Hawthorn Fm

2. Jackson, Chickasawhay, Barnwell and Ocalla $\mathrm{Fm}$ )

1. Mississippi Alluvium

1. Taylor and Aust in Fm

2. Eagleford and Woodbine Fm

4. Houst on Fm
3. Jackson $\mathrm{Fm}$

1 Information summarized from Jensen (333)

2 Formations overlain by glacial drift within Section

3 Formations overlain by glacial drift and loessial deposits within Section

* Formations overlain by loessial deposits within Section
Estimated Occurrence Within Section (Al] Formations Considered)

Very widespread

Medium to Widespread

Limited to Medium

Limited to Medium

Mediuin to Widespread

Non Lxistent to Limsted

Limited to Medrum

Limited to Medium

Very widespread

Very Widespread

Very Widespread

Very Widespread 

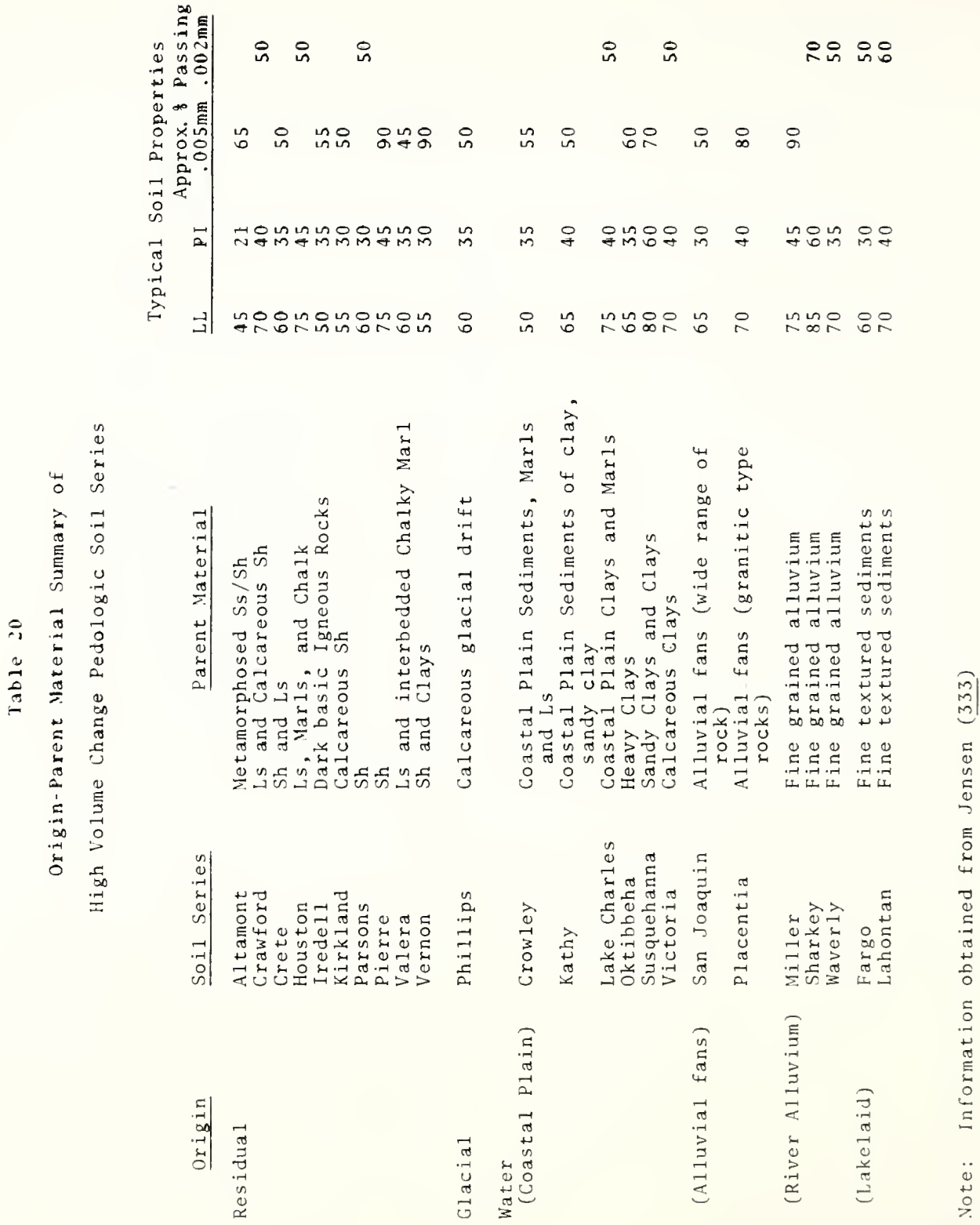


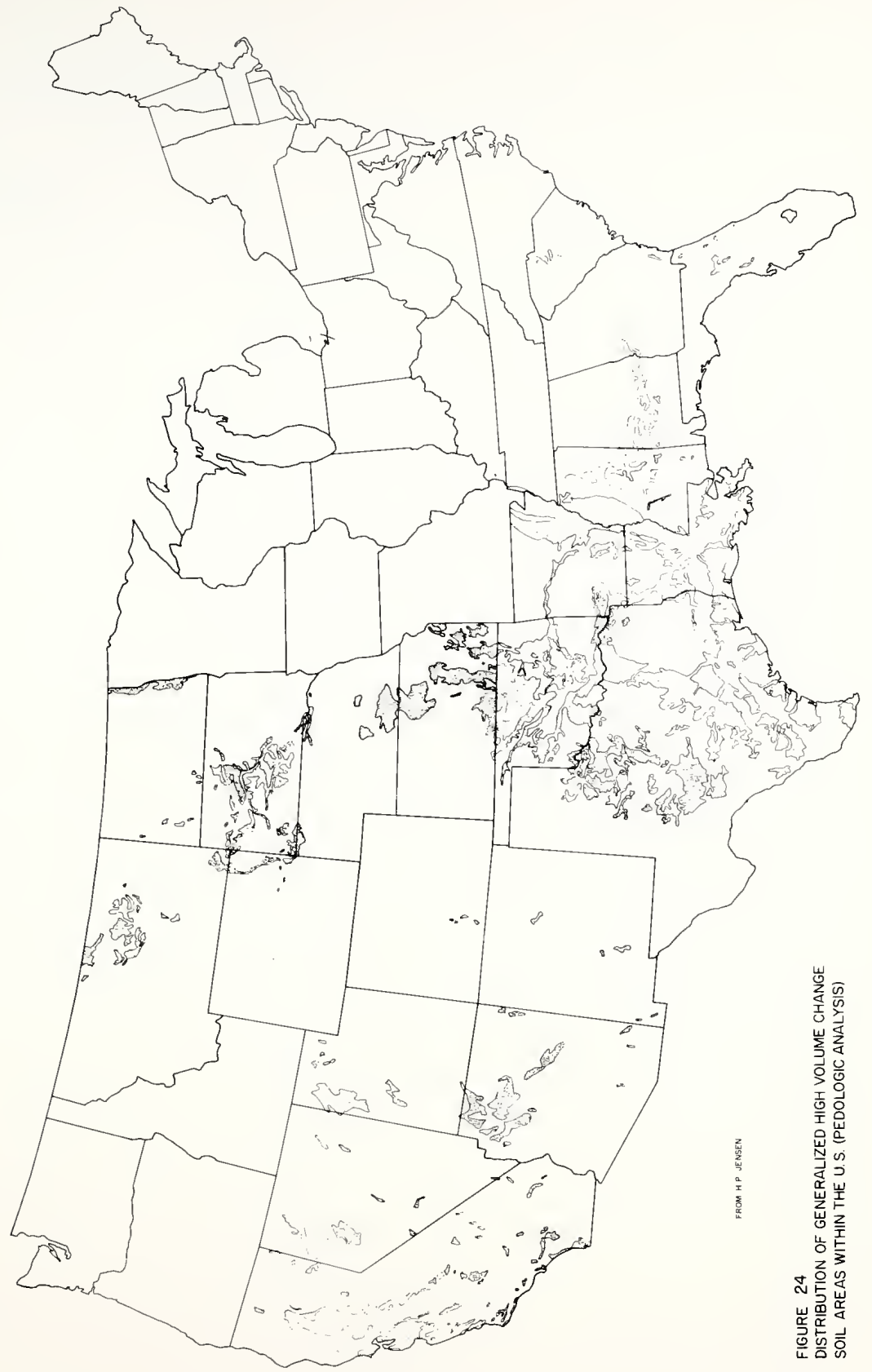


Table 21

Summary of Pedologic Soil Series Showing High Volume Change

by firequency of Occurrence Within Sections

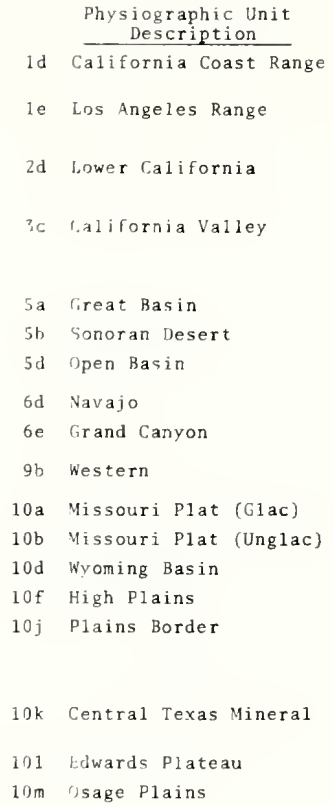

\begin{tabular}{|c|c|}
\hline \multicolumn{2}{|c|}{$\begin{array}{l}\text { High Volume } \\
\text { Change Soil Series }\end{array}$} \\
\hline \multicolumn{2}{|c|}{$\begin{array}{l}\text { 1. P1acentia } \\
\text { 2. A1tamont }\end{array}$} \\
\hline \\
\hline $\begin{array}{l}1 \\
2\end{array}$ & $\begin{array}{l}\text { Placentia } \\
\text { San Joaquin }\end{array}$ \\
\hline $\begin{array}{l}1 . \\
2 . \\
3 .\end{array}$ & $\begin{array}{l}\text { Placentia } \\
\text { San Joaquin } \\
\text { Altamont }\end{array}$ \\
\hline 1 . & Lahontan \\
\hline 1. & Lahontan \\
\hline 1 . & Lahontan \\
\hline 1 . & AItamont \\
\hline 1 . & Valera \\
\hline 1 . & Lahontan \\
\hline 1 . & Phi11ips \\
\hline 1 . & Pierre \\
\hline 1 . & Phillips \\
\hline 1 . & Crete \\
\hline $\begin{array}{l}1 \\
2 \\
3 \\
4\end{array}$ & $\begin{array}{l}\text { Crete } \\
\text { Miller } \\
\text { Vernon } \\
\text { Kirkland }\end{array}$ \\
\hline $\begin{array}{l}1 \\
2\end{array}$ & $\begin{array}{l}\text { Valera } \\
\text { Crawford }\end{array}$ \\
\hline 1 & Valera \\
\hline $\begin{array}{l}1 . \\
2 . \\
3 . \\
4 \\
5\end{array}$ & $\begin{array}{l}\text { Vernon } \\
\text { Miller } \\
\text { Kirk1 and } \\
\text { Crawford } \\
\text { Parsons }\end{array}$ \\
\hline 1. & Fargo \\
\hline 1. & Miller \\
\hline 1. & 1 rede 11 \\
\hline $\begin{array}{l}1 . \\
2 . \\
3 .\end{array}$ & $\begin{array}{l}\text { Susquehanna } \\
\text { Houston } \\
\text { Oktibbeha } \\
\text { Crowley }\end{array}$ \\
\hline 1 . & Waver 1 y \\
\hline $\begin{array}{l}1 . \\
2 . \\
3 . \\
4 .\end{array}$ & $\begin{array}{l}\text { Sharkey } \\
\text { Waverly } \\
\text { Crowley } \\
\text { Miller }\end{array}$ \\
\hline & $\begin{array}{l}\text { Susquehanna } \\
\text { Waverly } \\
\text { Miller } \\
\text { Houston } \\
\text { Crowley } \\
\text { Lake Charles } \\
\text { Kathy } \\
\text { Victoria } \\
\text { Valera }\end{array}$ \\
\hline
\end{tabular}

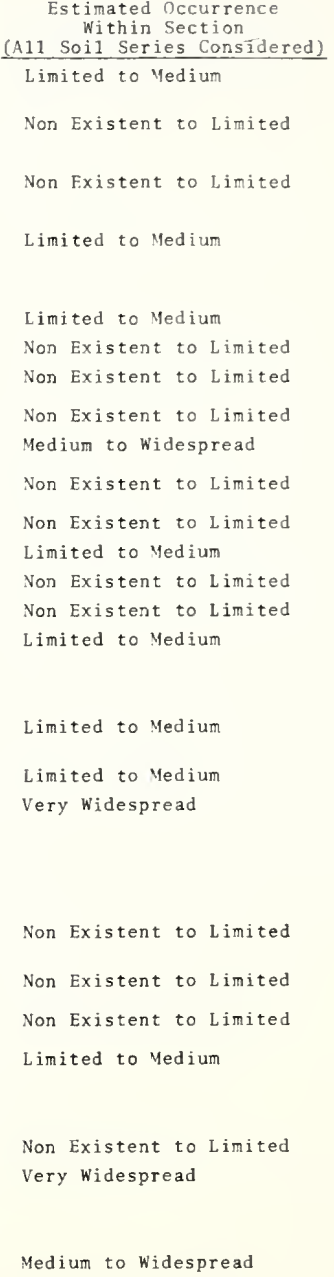

Note: Information summarized from Jensen (333) 
mantle. As the basic characteristics of the section are based upon loessial parent naterial, and these are not conductive to high volume change, a final rating of Non-Existent to Ilmited was selected.

Table 22 represents the adjusted frequency of occurrence rating for each section contalning potential high volume change areas. Frost Action and Frost Suscept1ble So1ls Fhysiographic Sections Within the Freezing Zone The selection of Sections experiencing significant Irost was based upon an analysis by Sourwine (20). Figure 25 shows the relationship between sections considered to be within the freezing zone and the limit proposed by Sourwine. Table 23 summarizes the separation of Sections into groupings where, I. ground freezing is assumed to be a potential hazard, and II. the factor of ground freezing is probably insignificant.

Composite Frost Susceptible Solls Map of the Northern States Figures 26 through 28 1llustrate the composite frost susceptible solls map for the northern United States, using the Corps of Engineer's susceptibility classification. As previously noted, this map is slightly modifled from the work of Bloom (20) and Cstorne (166). Distribution of Frost Susceptible Solls by Section General. For each section considered to be within the freezing zone, a qualitative assessment of the frequency was made of the frost susceptible solls. The ratings are based 
Table 22

Final Adjusted High Volume Change Frequency of Occurrence Ratings by Basic Report Section

\begin{tabular}{|c|c|c|c|}
\hline $\begin{array}{c}\text { Unit } \\
\text { (Section) } \\
\text { Code } \\
\end{array}$ & $\begin{array}{l}\text { Pedologic } \\
\text { Rating } \\
\end{array}$ & $\begin{array}{c}\text { Geologic } \\
\text { Rating } \\
\end{array}$ & $\begin{array}{r}\text { Final } \\
\text { Rating }\end{array}$ \\
\hline $\begin{array}{l}1 \mathrm{~d} \\
1 \mathrm{e}\end{array}$ & $\begin{array}{l}L-M \\
N-L\end{array}$ & $\begin{array}{l}M-W \\
L-M\end{array}$ & $\begin{array}{l}M-W \\
L-M\end{array}$ \\
\hline $2 \mathrm{~d}$ & $N-L$ & $N-L$ & $N-L$ \\
\hline $3 c$ & $L-M$ & $\mathrm{~L}-\mathrm{M}$ & $L-M$ \\
\hline $\begin{array}{l}5 \mathrm{a} \\
5 \mathrm{~b} \\
5 \mathrm{~d}\end{array}$ & $\begin{array}{l}L-M \\
N-L \\
N-L\end{array}$ & $\begin{array}{l}L-M \\
N-L \\
N E\end{array}$ & $\begin{array}{l}L-M \\
N-L \\
N-L\end{array}$ \\
\hline $\begin{array}{l}6 \mathrm{a} \\
6 \mathrm{~b} \\
6 \mathrm{c} \\
6 \mathrm{~d} \\
6 \mathrm{e} \\
6 \mathrm{f}\end{array}$ & $\begin{array}{l}N E \\
N E \\
N E \\
N-L \\
M-W \\
N E\end{array}$ & $\begin{array}{l}L-M \\
L-M \\
L-M \\
M-W \\
L-M \\
L-M\end{array}$ & $\begin{array}{l}L-M \\
L-M \\
L-M \\
M-W \\
M-W \\
L-M\end{array}$ \\
\hline $9 b$ & $N-L$ & $\mathrm{NE}$ & $N-L$ \\
\hline $\begin{array}{l}10 \mathrm{a} * \\
10 \mathrm{~b} \\
10 \mathrm{c} \\
10 \mathrm{~d} \\
10 \mathrm{f} \\
10 \mathrm{~g} \\
10 \mathrm{~h} \\
10 \mathrm{j} \\
10 \mathrm{k} \\
10 \mathrm{l} \\
10 \mathrm{~m}\end{array}$ & $\begin{array}{l}N-L \\
L-M \\
N E \\
N-L \\
N-L \\
N E \\
N E \\
L-M \\
L-M \\
L-M \\
V W\end{array}$ & $\begin{array}{l}L-M \\
V W \\
L-M \\
L-M \\
N E \\
V W \\
M-W \\
L-M \\
L-M \\
N E \\
M-W\end{array}$ & $\begin{array}{l}N-L \\
V W \\
L-M \\
L-M \\
N-L \\
V W \\
M-W \\
L-M \\
L-M \\
L-M \\
V W\end{array}$ \\
\hline $\begin{array}{l}11 \mathrm{~h} \\
11 \mathrm{i} *\end{array}$ & $\begin{array}{l}N-L \\
N E\end{array}$ & $\begin{array}{l}N E \\
N-L\end{array}$ & $\begin{array}{l}N-L \\
N E\end{array}$ \\
\hline $13 c 2$ & $N-L$ & $\mathrm{NE}$ & $N-L$ \\
\hline $17 \mathrm{~b}$ & $N-L$ & $\mathrm{NE}$ & $N-L$ \\
\hline $\begin{array}{l}20 \mathrm{~b} \\
20 \mathrm{c} \\
20 \mathrm{~d} \\
20 \mathrm{e}^{*} \\
20 \mathrm{f} \\
20 \mathrm{~g}\end{array}$ & $\begin{array}{l}N E \\
N E \\
L-M \\
N-L \\
V W \\
M-W\end{array}$ & $\begin{array}{l}L-M \\
L-M \\
V W \\
V W \\
V W \\
V W\end{array}$ & $\begin{array}{l}\mathrm{L}-\mathrm{M} \\
\mathrm{L}-\mathrm{M} \\
\mathrm{VW} \\
\mathrm{N}-\mathrm{L} \\
\mathrm{VW} \\
\mathrm{VW}\end{array}$ \\
\hline \multicolumn{4}{|c|}{$\frac{20 \mathrm{~g}}{(*) \text { indicates }} \stackrel{M-W}{\text { adjusted rating }}$} \\
\hline 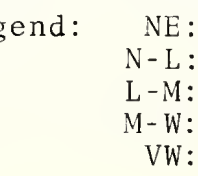 & \multicolumn{3}{|c|}{$\begin{array}{l}\text { Non Existent to Limited } \\
\text { Limited to Medium } \\
\text { Medium to Widespread } \\
\text { Very Widespread }\end{array}$} \\
\hline
\end{tabular}




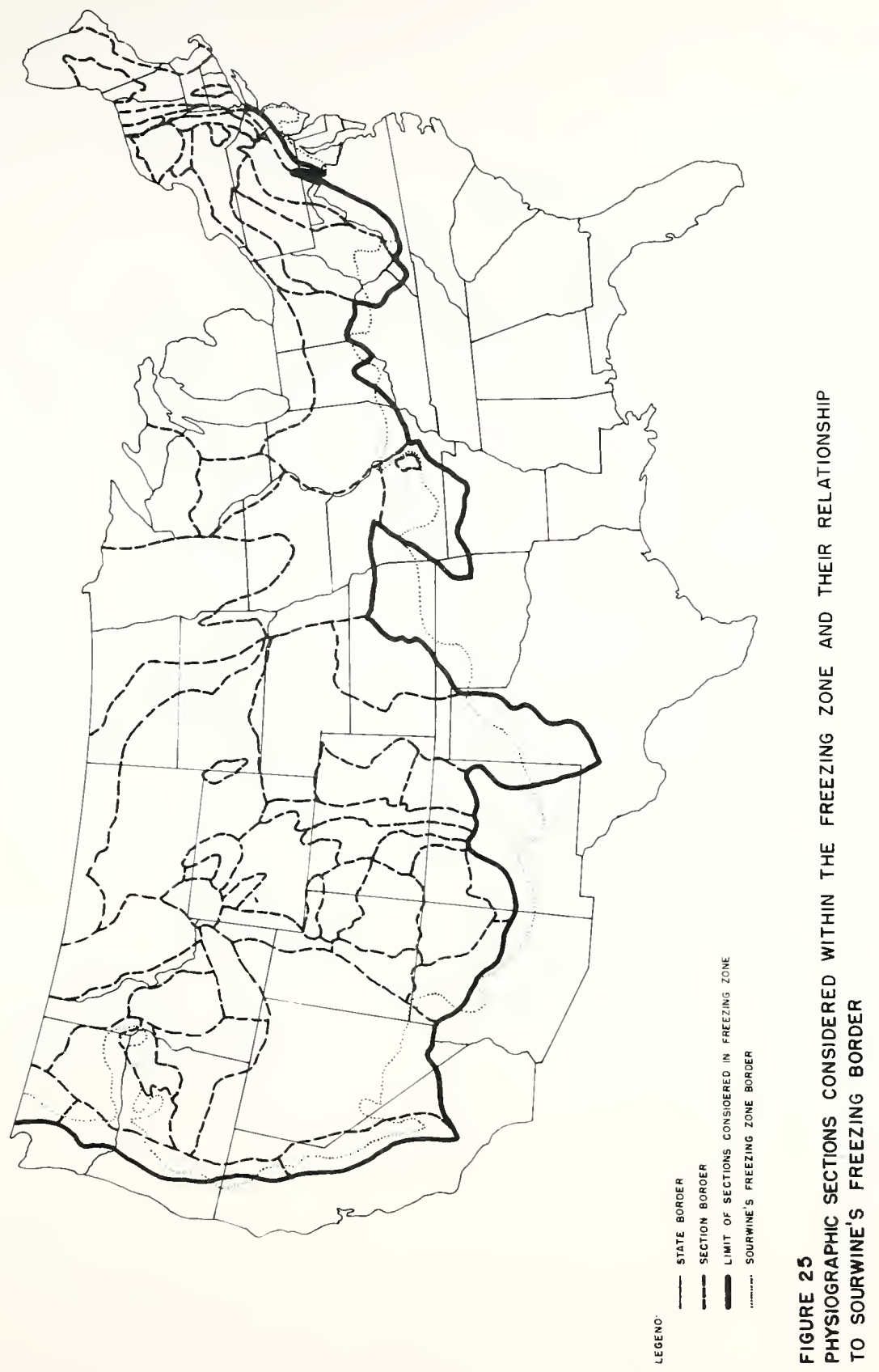


Table 23

Status of Physiographic Sections and

Their General Relationship to Ground Freezing

I. Physiographic Sections Analyzed for Distribution and Occurrence of Frost Susceptible Soil Type (Considered, in the main, to be within zone of ground freeze danger).

a. Section Codes Having Entire Area Within Dangerous Freezing Zone

$\begin{array}{lllllllllll}4 \mathrm{c} & 6 \mathrm{a} & 7 \mathrm{a} & 8 \mathrm{a} & 9 \mathrm{a} & 10 \mathrm{a} & 11 \mathrm{a} & 12 \mathrm{a} & 13 \mathrm{a} & 15 \mathrm{a} & 19 \mathrm{a} \\ 4 \mathrm{~d} & 6 \mathrm{~b} & 7 \mathrm{~b} & 8 \mathrm{~b} & 9 \mathrm{~b} & 10 \mathrm{~b} & 11 \mathrm{~b} & 12 \mathrm{~b} & & 15 \mathrm{~b} & 19 \mathrm{~b} \\ 4 \mathrm{e} & 6 \mathrm{c} & 7 \mathrm{c} & 8 \mathrm{c} & 9 \mathrm{c} & 10 \mathrm{c} & 11 \mathrm{c} & & & 15 \mathrm{c} & 19 \mathrm{c} \\ & 6 \mathrm{~d} & & 8 \mathrm{~d} & & 10 \mathrm{~d} & 11 \mathrm{~d} & & & & 19 \mathrm{~d} \\ & 6 \mathrm{f} & & 8 \mathrm{e} & & 10 \mathrm{e} & 11 \mathrm{e} & & & & 19 \mathrm{e} \\ & & & & & 10 \mathrm{~g} & 11 \mathrm{f} & & & & 19 \mathrm{f} \\ & & & & & 10 \mathrm{~h} & 11 \mathrm{~g} & & & & 19 \mathrm{~g} \\ & & & & & 10 \mathrm{j} & 11 \mathrm{~h} & & & & \end{array}$

b. Section Codes Having Portion of Area Outside Dangerous Freezing Zone

2 a $\quad 4 a \quad 5 a \quad 6 e \quad 10 f \quad 13 b \quad 15 d \quad 16 a \quad 18$

$2 b \quad 4 b$

$2 \mathrm{c}$

II. Physiographic Sections Not Analyzed for Distribution and Occurrence of Frost Susceptible Soil Type

(Considered, in the main, to be outside zone of ground freeze danger).

a. Section Codes Having Entire Area Outside Dangerous Freezing Zone

$\begin{array}{llllllllll}1 \mathrm{a} & 2 \mathrm{~d} & 3 \mathrm{a} & 5 \mathrm{~b} & 10 \mathrm{k} & 13 \mathrm{cl} & 14 \mathrm{~b} & 15 \mathrm{e} & 16 \mathrm{~b} & 20 \mathrm{~b} \\ 1 \mathrm{~b} & & 3 \mathrm{~b} & 5 \mathrm{c} & 101 & 13 \mathrm{c} 2 & & & & 20 \mathrm{c} \\ 1 \mathrm{~d} & & 3 \mathrm{c} & 5 \mathrm{f} & & 13 \mathrm{c} 3 & & & & 20 \mathrm{~d} \\ 1 \mathrm{e} & & & & & & & & & 20 \mathrm{e} \\ & & & & & & & & & 20 \mathrm{f} \\ & & & & & & & & & \end{array}$

b. Section Codes Having Portion of Area Within

Dangerous Freezing Zone

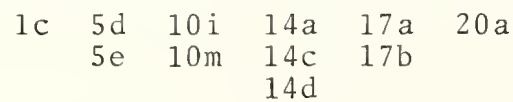




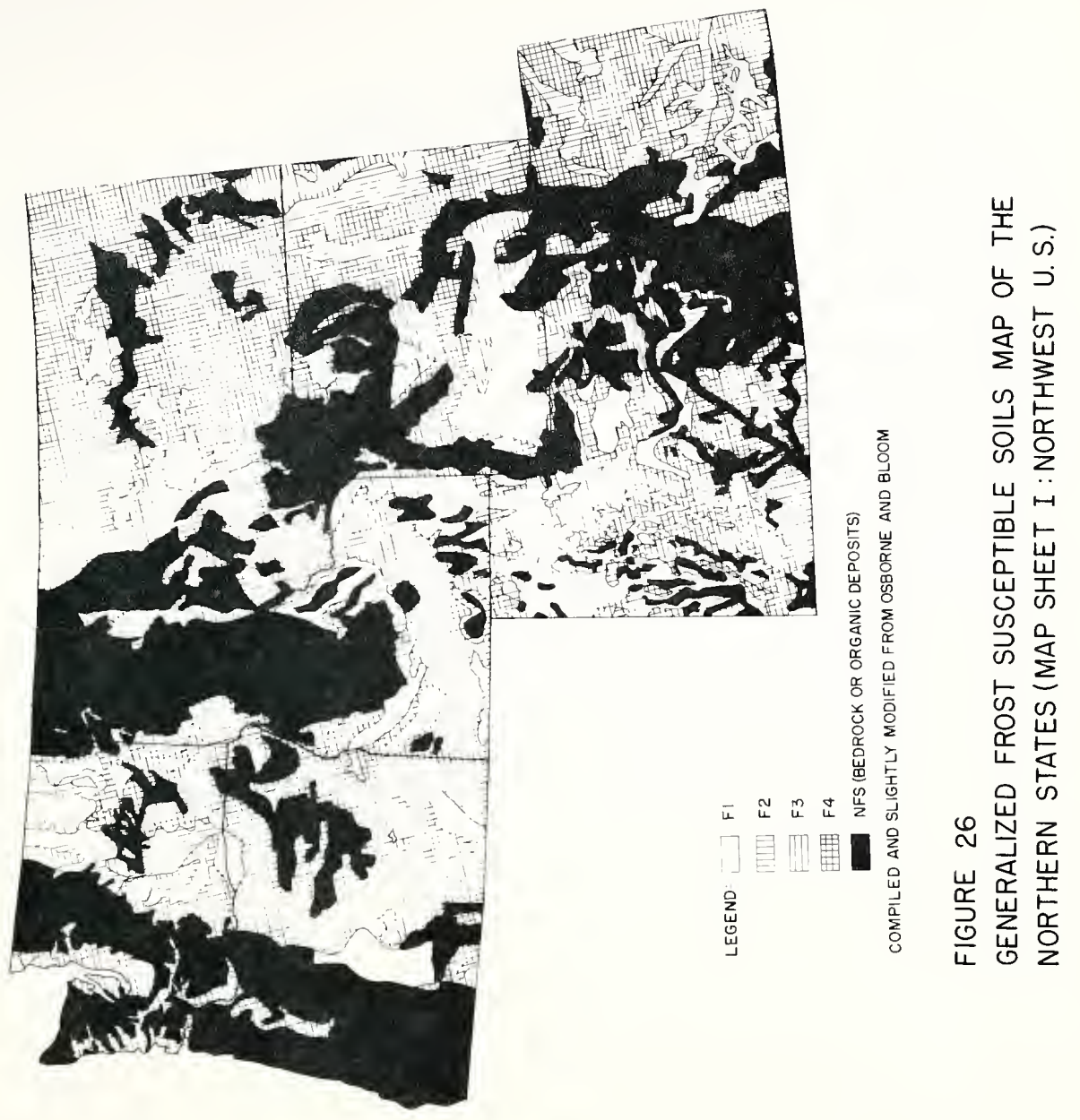




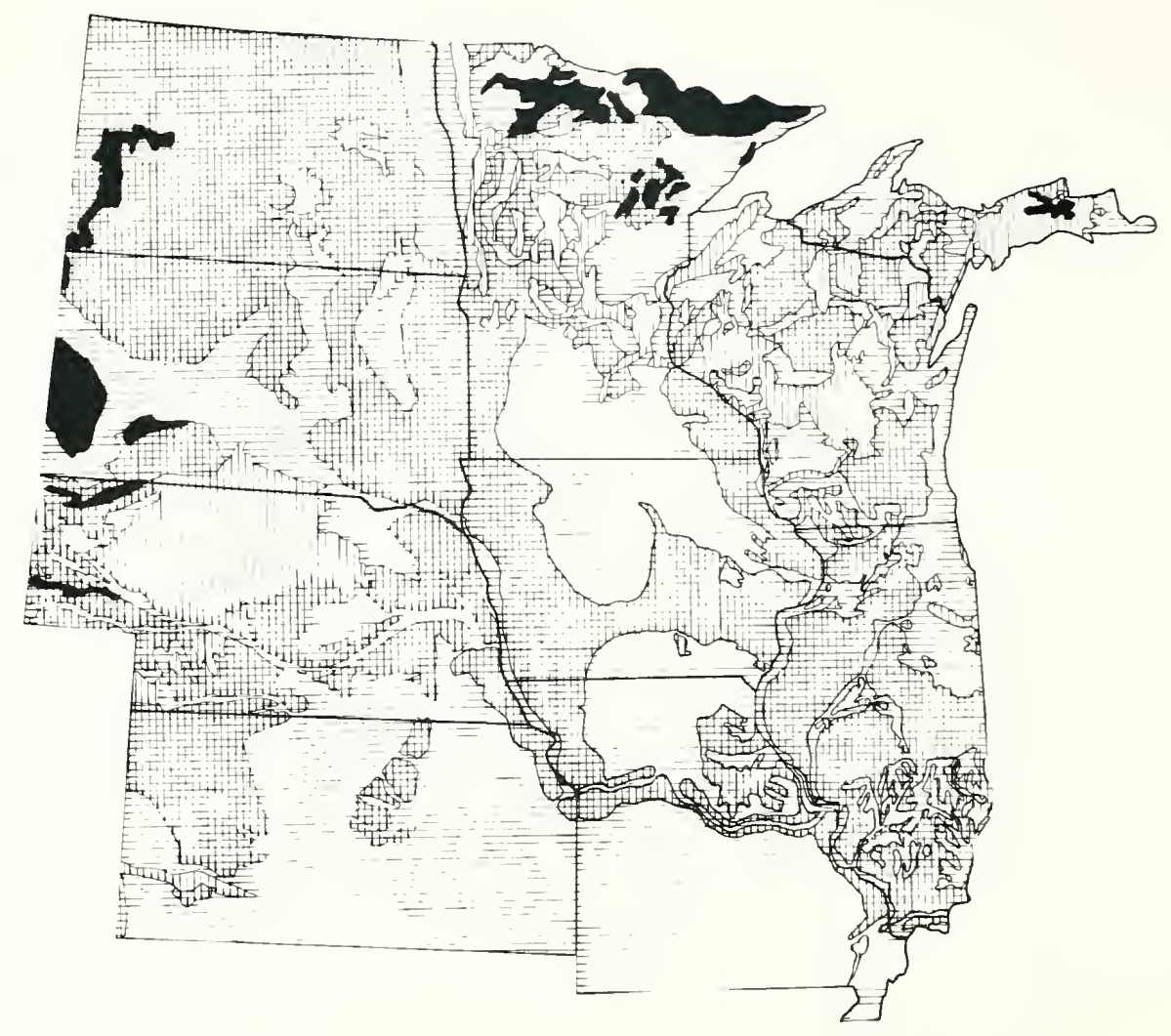

NOTE: SEE MAP SHEET I FOR LEGEND

FIGURE 27

GENERALIZED FROST SUSCEPTIBLE SOILS MAP OF THE NORTHERN STATES (MAP SHEET II:NORTH CENTRAL U.S.) 


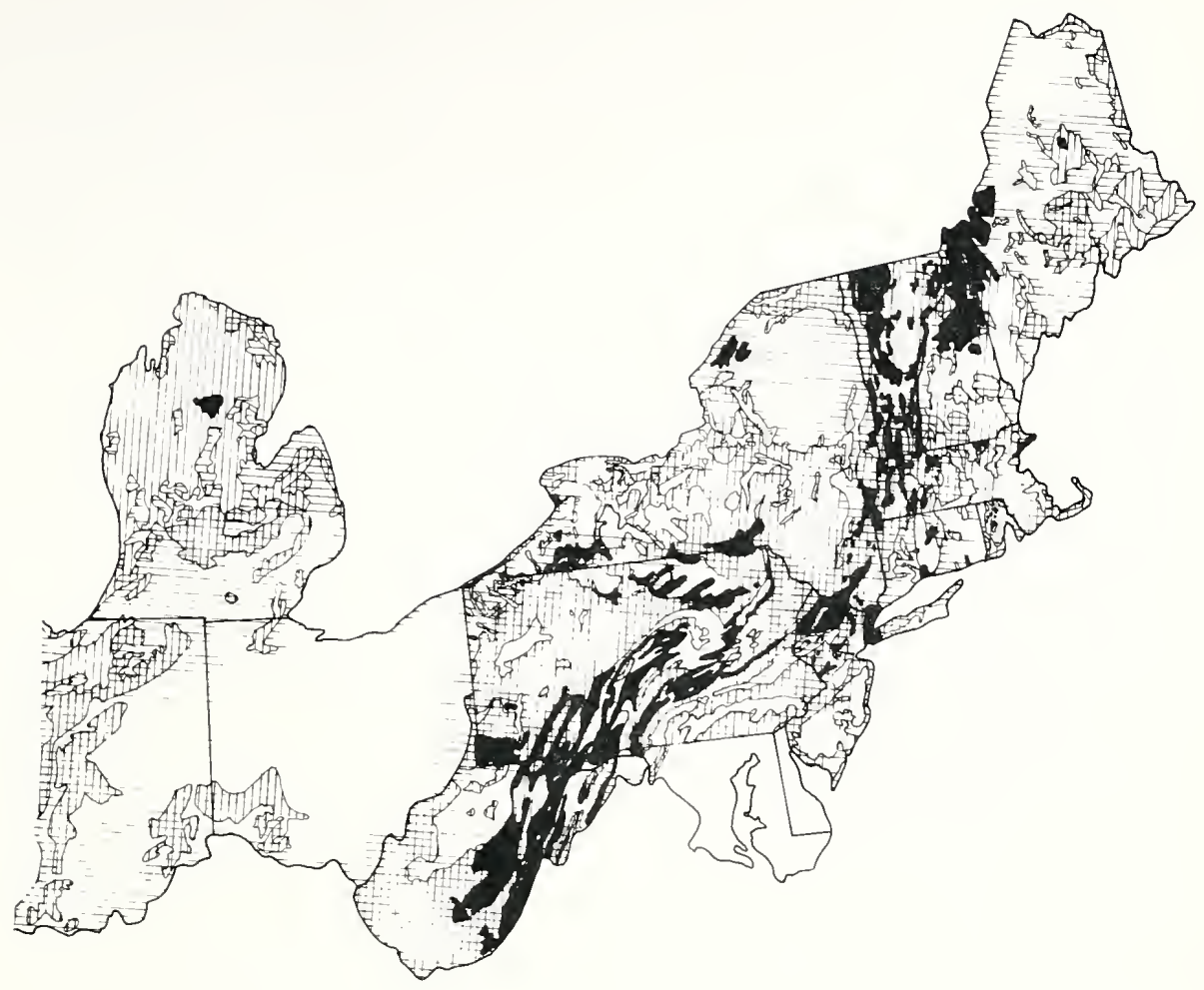

NOTE: SEE MAP SHEET I FOR LEGEND

FIGURE 28

GENERALIZED FROST SUSCEPTIBLE SOILS MAP OF THE NORTHERN STATES (MAP SHEET III: NORTHEAST U.S.) 
upon an examination of the frost maps (Figures 26 through 28). For portions of Sections not mapped in (20) or (166), but occurring within the freezing zone, an evaluation of the generalized frost susceptible soll conditions was conducted by the author with the procedure previously described. 1 jection D1stribution. The frequency of occurrence rating of frost susceptible solis within each section considered to be in the frost zone is shown in Table 24.

I. See "Investigation Procedures - Frost Action and Frost Susceptible So11s; Method of Analys1s". (pg. 39) 
Table 24

Frequency of Occurrence Ratings of Frost Susceptible Soils

Within Physiographic Sections Considered in the Freezing Zone

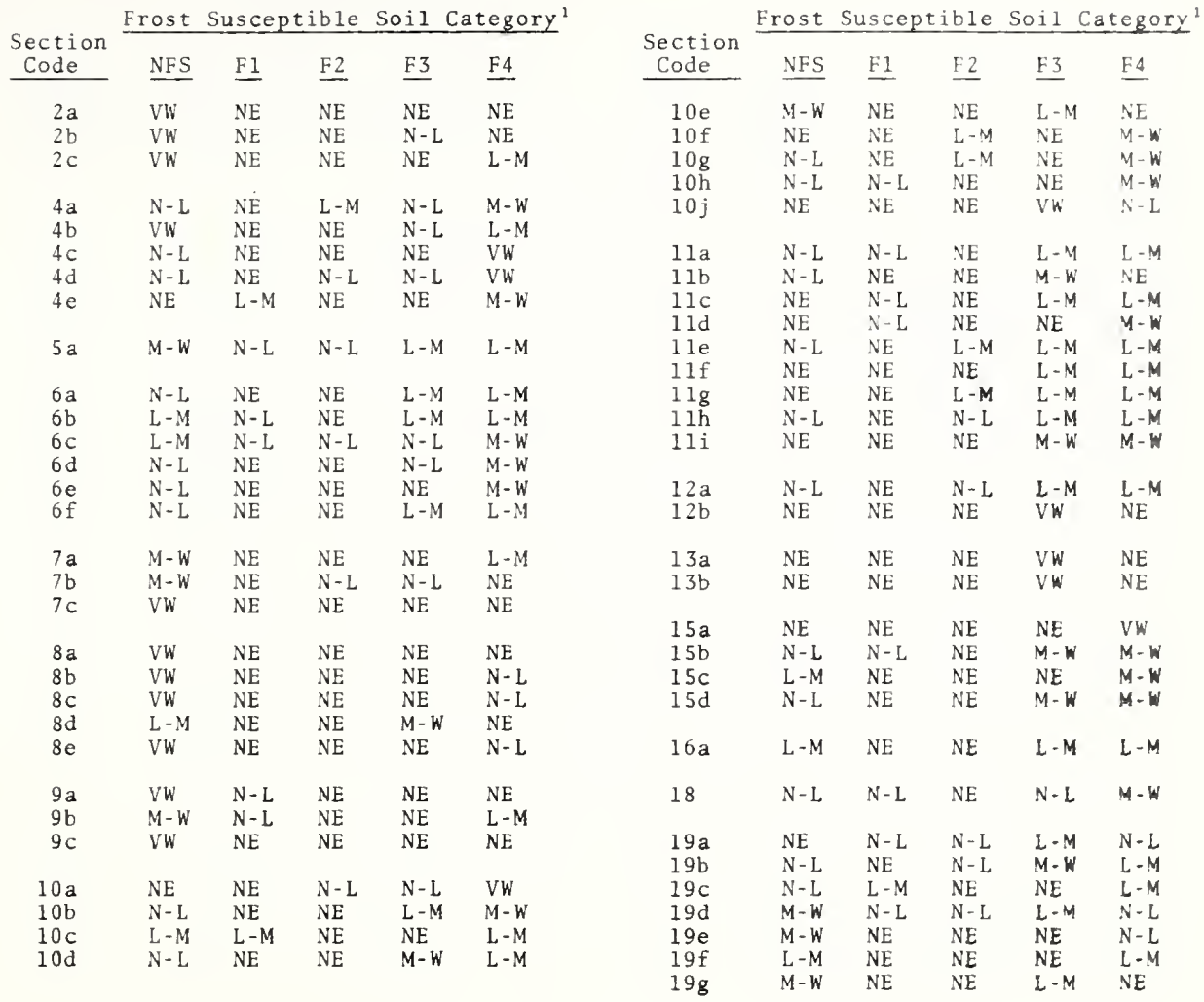

Legend: $\quad$ Frequency of Occurrence

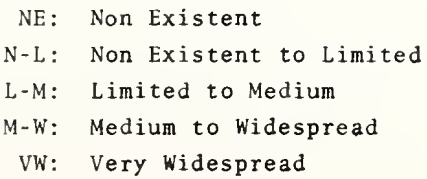

Note: ${ }^{1}$ U. S. Corps of Engineers Frost Classification 


\section{SURMARY AND CCNCIUSICNS}

\section{Generalized Jumgiary Comparison Eetween Eastern and Western}

\section{United States}

General

Vany difficulties are encountered in any attempt to summarize in brief and adequate form the physiographic, geologic and pertirent highway englneerirg factors peculiar to regional geomorphic units within the continental United states. However, in the autror's opinion, ease of discussion occurs if the United States is alvided into two major geographic groupings: an eastern and western portion.

The western portion essentially corresponds to the L. 3. portion of the North American Corliluera Division suggested ty Iobeck. This urit is comprised of physiographic provinces, identified in Table 4, with unit codes 1 through 9. The provinces of the eastern group (unit Provinces codes 10 trru 20) lie east of and including the Great Plains Frovince. Figure 29 shows this basic grouplng as well as generalized locations of the various divisions and provinces of each major group. The identification legend shown on this diagram is keyed to Table 25 which describes the physiographic units in question. Within these two groups, major differences can be characterized in terms of topography, 


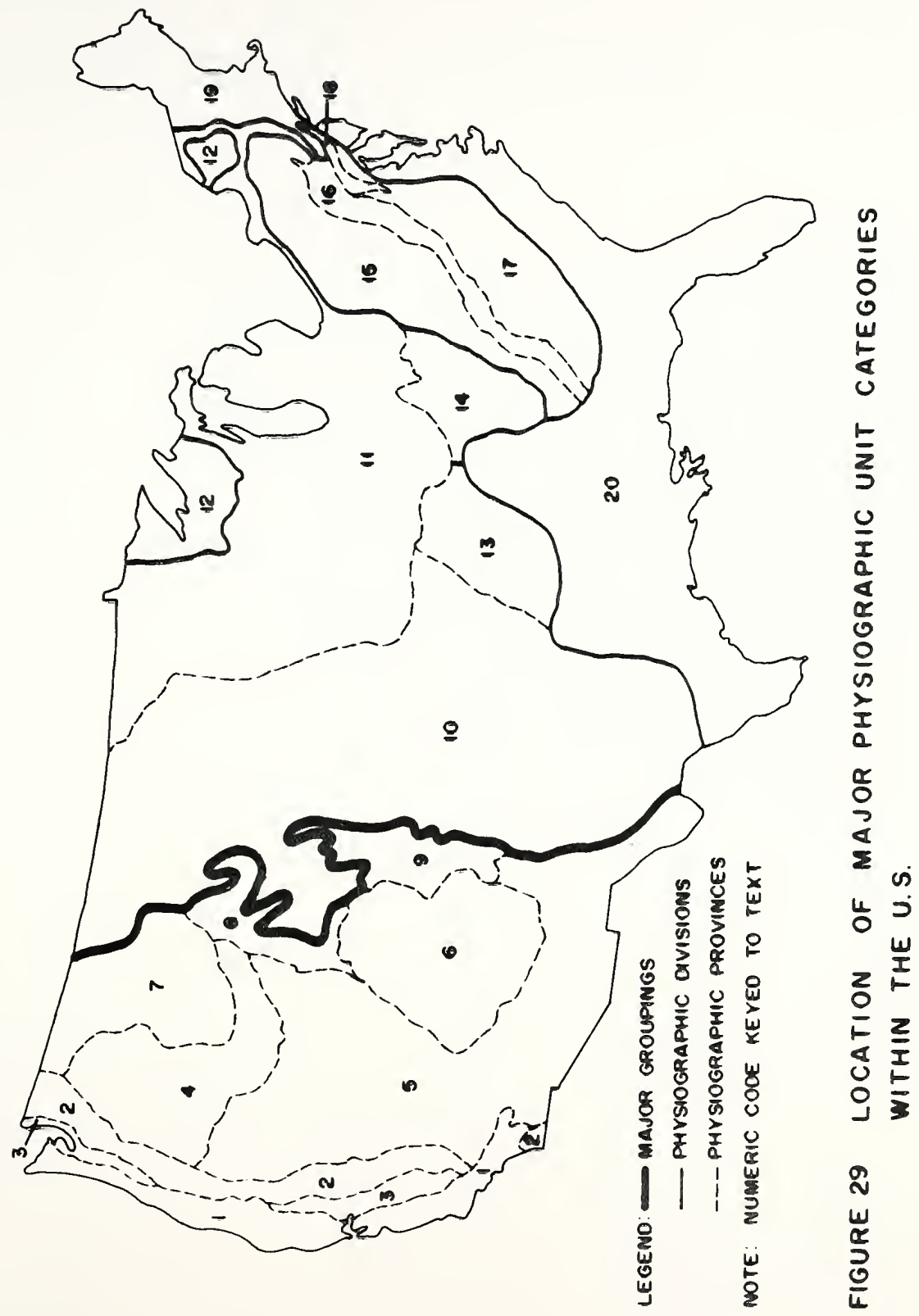




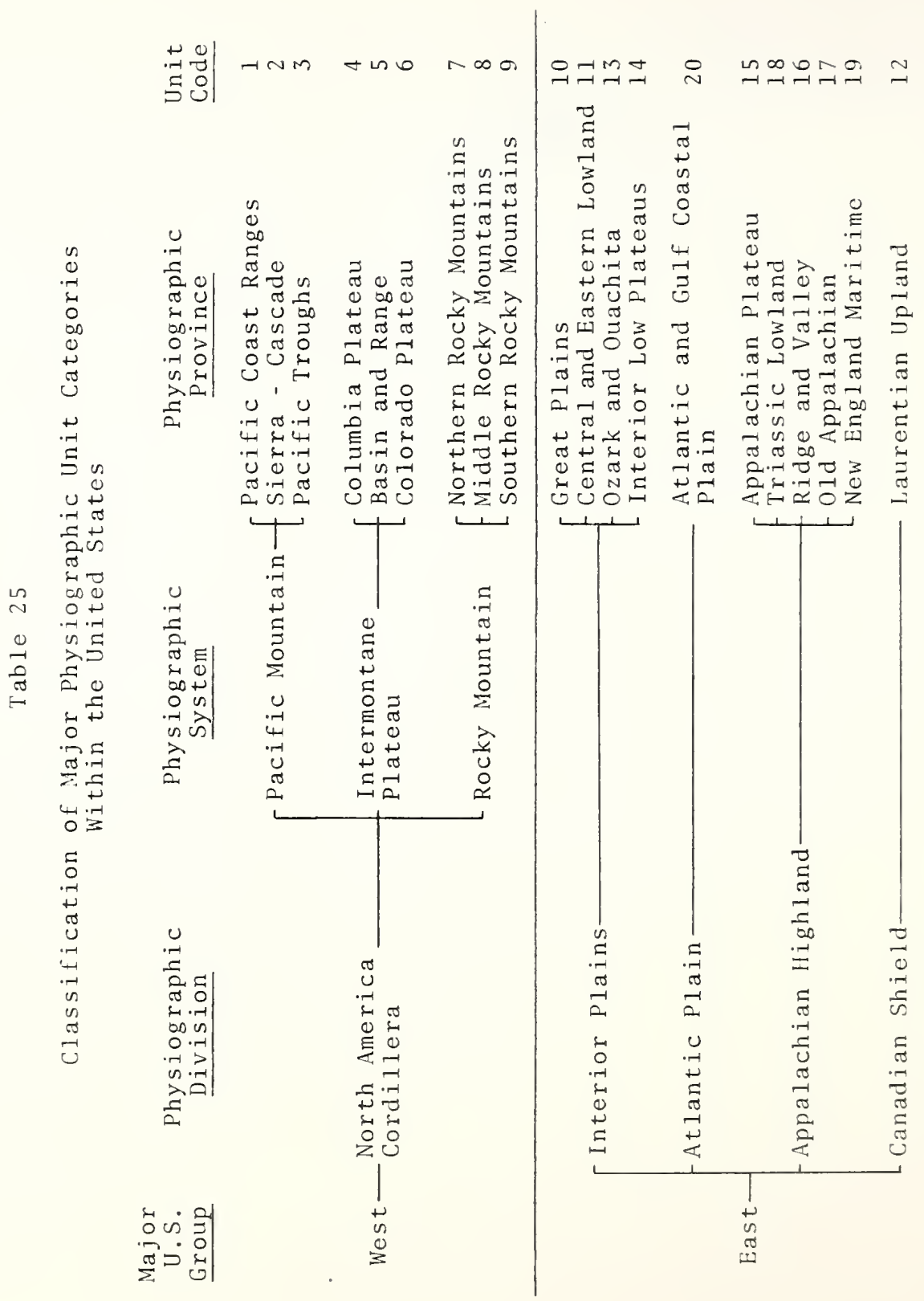


population, climate and historical geclcgy.

Topographic Differences

The entire western unit may generally be considered as a highland unit. Elevations in this area are the highest within the continental United States, directly attributable to the two parallel trending mountainous systems found in the area. The orogenies which have occurred have naturally formed areas of high rellef. Iarge changes of elevition are not only comron within the mountainous areas but also occur within much of the Intermontane Plateau system. Large changes occur between the basins and ranges proper, characteristic of tre Basin and Range Province. Within the Flateau Frovinces relief is due primarily to destructional processes leaving some of the most majestic canyon areas found in the world. In direct contrast to high relief and elevations found in the west, most of the east is of low elevation and relief. The topographic differences are directly related to the presence of the Interior and Atlantic Plains Divisions which are characterized primarily by relatively mild dipping sedimentary strata. In addition, many of the once "mountaincus portions" of the area have been leveled by widespread erosion to form plateaus and uplands of mild relief. Some areas of high relief are found in the east, particularly in the Appalachian Highlands Division. However, much of the "mountainous terraln" has been formed by erosion of flat lying sedimentary strata (Appalachian Plateau Frovince) or folded sedimentary strata (Ridge and 
Valley). The "true" mountainous areas in the east are confined to the Elue Rldge (Old Appalachlan Frovince), portlons of the Adrondacks (Iaurentian Upland Province) and along the westem and northem portions of the New England varitime Frovince.

\section{Geologic Differences}

Cne of the more signiflcant geological differences between the eastem and western areas is the rather literal presence of vulcanisim present in the west. ${ }^{1}$ Extrusive rocks of Tertiary and Quatemary age are widespread in the west wille practically non existent from a reglonal viewpolnt in the east. Granitic type rccks, of ten associated with the mountain bullding common to the west, are widely present. Geologlcally, these rocks are generally confined to Jurassic and/or PreCambrian Perlods of time. Within the east, these rocks are generally found in larger areas and occur within the "Crystalline Appalachians" (Cld Appalachian and New England Maritime Provinces) as well as the Iaurentlan Lifland Province.

In general, sedimentary strata are more predominant in the eastern U.S. than in the west. Figure 30 11lustrates the distribution of Paleozolc strata within the U. S. As can be seen from the diagram, Paleozolc strata form a large portion of the eastem phys1ography. This broad expanse of

I. This fact may be noted by looking at Flgures 3 anc 4 which show potential crushed stone areas within the united states. 

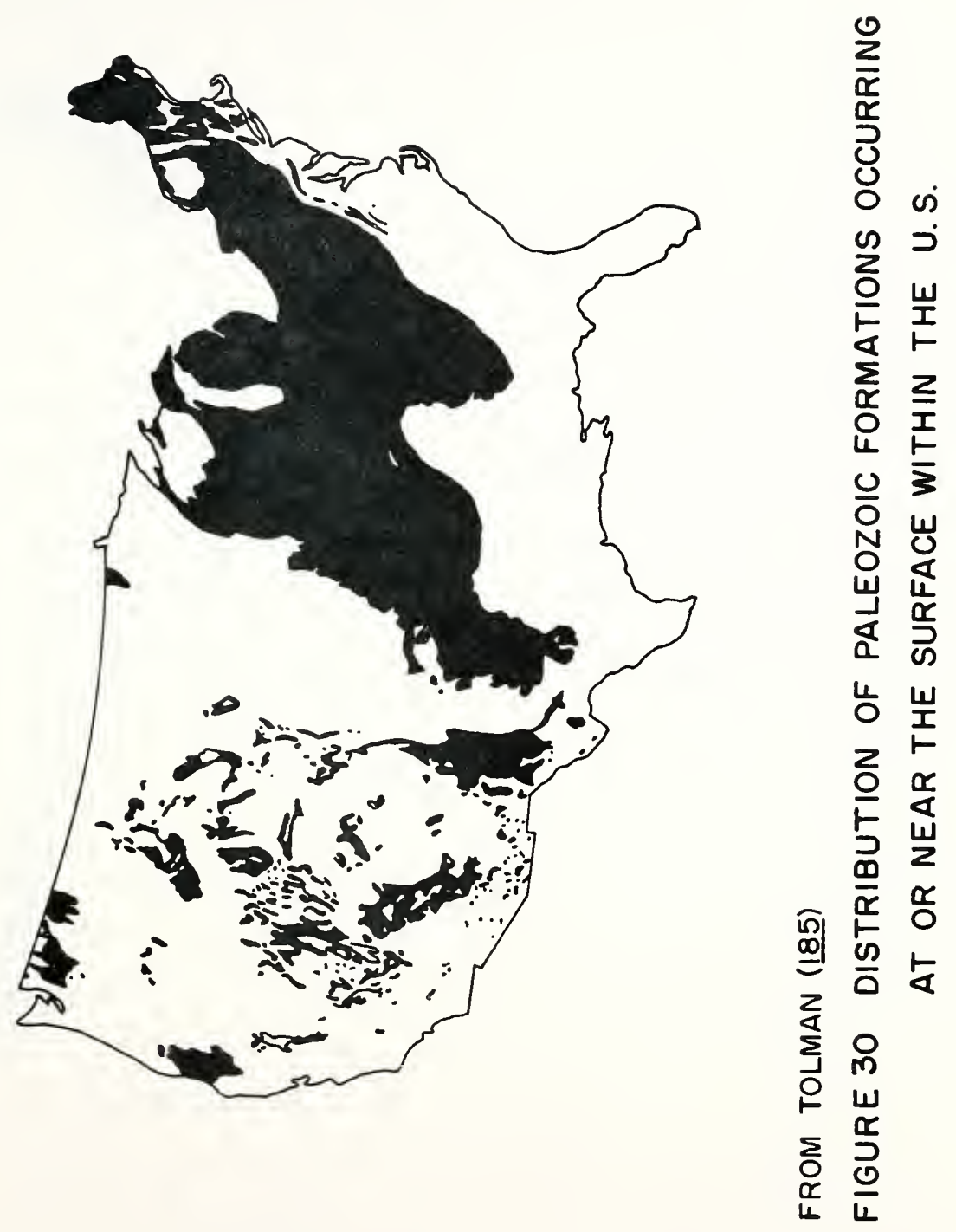
strata in the east is directly due to the flat lying to relatively mild dipping strata found in the region. In contrast, Paleozolc strata of the west are scattered in distribution and of ten occur in highly tilted structure around massive uplifts which are characterized by narrow bands. Tertiary and Mesozolc sedimentary strata are found distributed throughout both areas. Within the western portIon, major areas of occurrence are the California and Oregon Coast Ranges of the Pacific Coast Ranges and much of the flat lying sediments of the Colorado Plateau Frovince. Within the eastern portion, the greatest concentrations are found in much of the Great Flains Province, the western portion of the Central Iowland Frovince, Atlantic and Gulf Coastal Flains Province and the Triassic Lowland Province. With tr.e exception of the folded and faulted areas within the Pacific Coast Ranges and scattered areas surrcunding the uplifts in the west, most of these strata are relatively undisturbed and horizontal to mildy dipping.

Altrough continental glaciation has occurred contincusly across the northern tier of the United States, the western portion has relatively little area affected by glaclation in contrast to the east. Figure 31 illustrates the general distribution of continental glaciation in the U.S.. In the westem portion, much of the glaclal arift veneers rugged mountainous terrain and as a result affords only slight modification to the regional topography. In the eastern U.S., the effect and distribution of glaciation is 

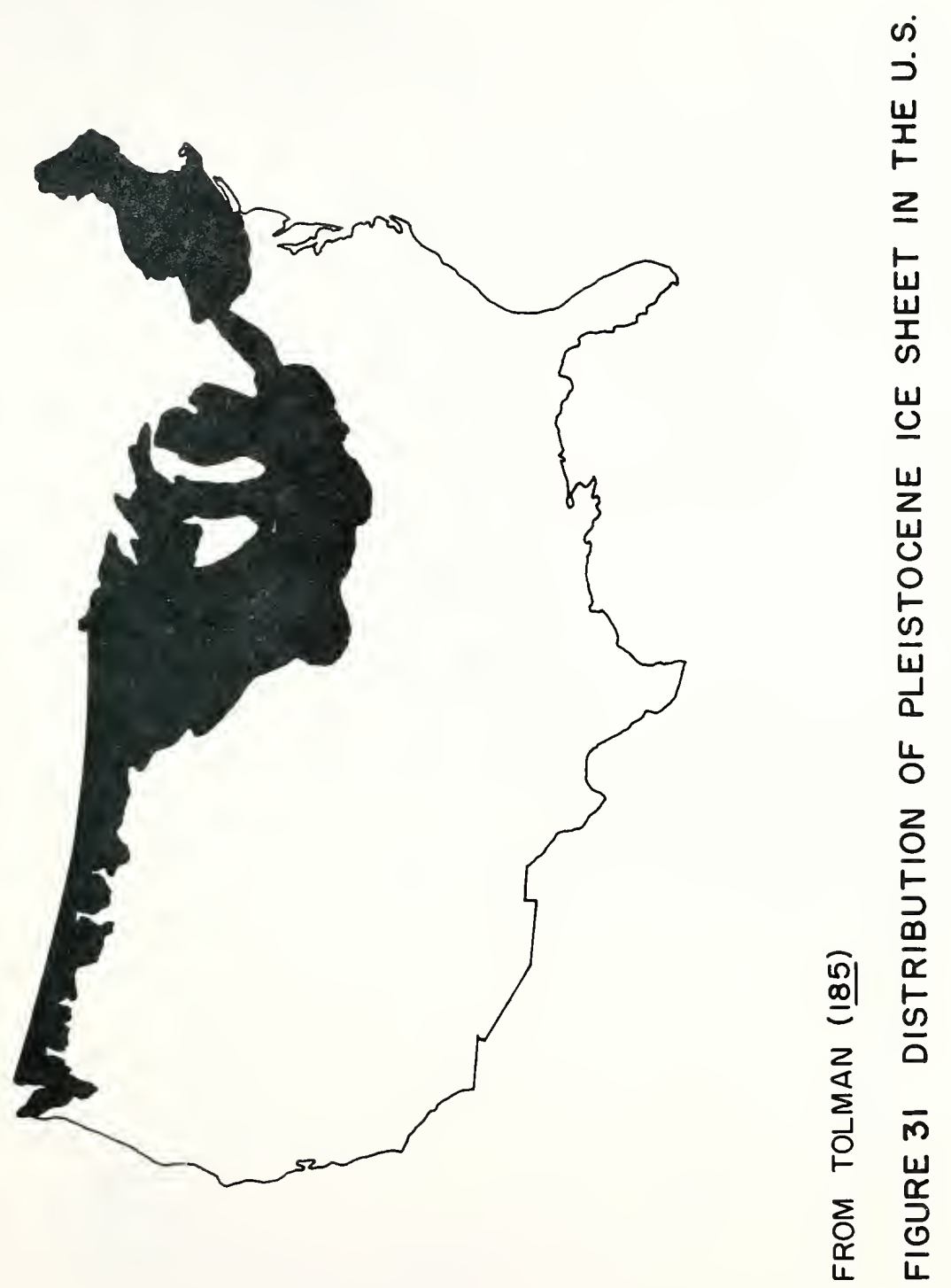
such that it becomes the modal characteristic for several jections of the Central and Eastern Iowland Province.

The final geologic difference between eastern and western grcupings lies in the rather widespread distriblitIon of valley fill sediments found in the west. In particular, the Basin and Range as well as the Facific Troughs are characterized by this material. Smaller, scattered areas occur frequently within the mountainous units of the west. The fresence of valley fill materials (exclusive of Great flains (utwash) is generally not existent within the eastern Frovince groupings.

\section{Climatic Differences}

cne of the nost pronounced aifferences between the east and west groupings is associated with climatic patterms within these two areas. It should be pointed out that topoeraphy exerts a powerful effect upon the overall climatic conditions within a given area. Because of the rather high elevations and relief existent within the western portion relative to the east, much of the west is characterized by large changes in climate within relatively short distances. The cllmatic pattern associated with the lower relief and elevation of the east is displayed by very gradual, uniform changes over large distances. Annual Preclpitation

Figure 32 shows the distribution pattern of annual precipitation within the U.S.. As can be noted for the western grclip, wuch of the area is characterized by 20 inches 


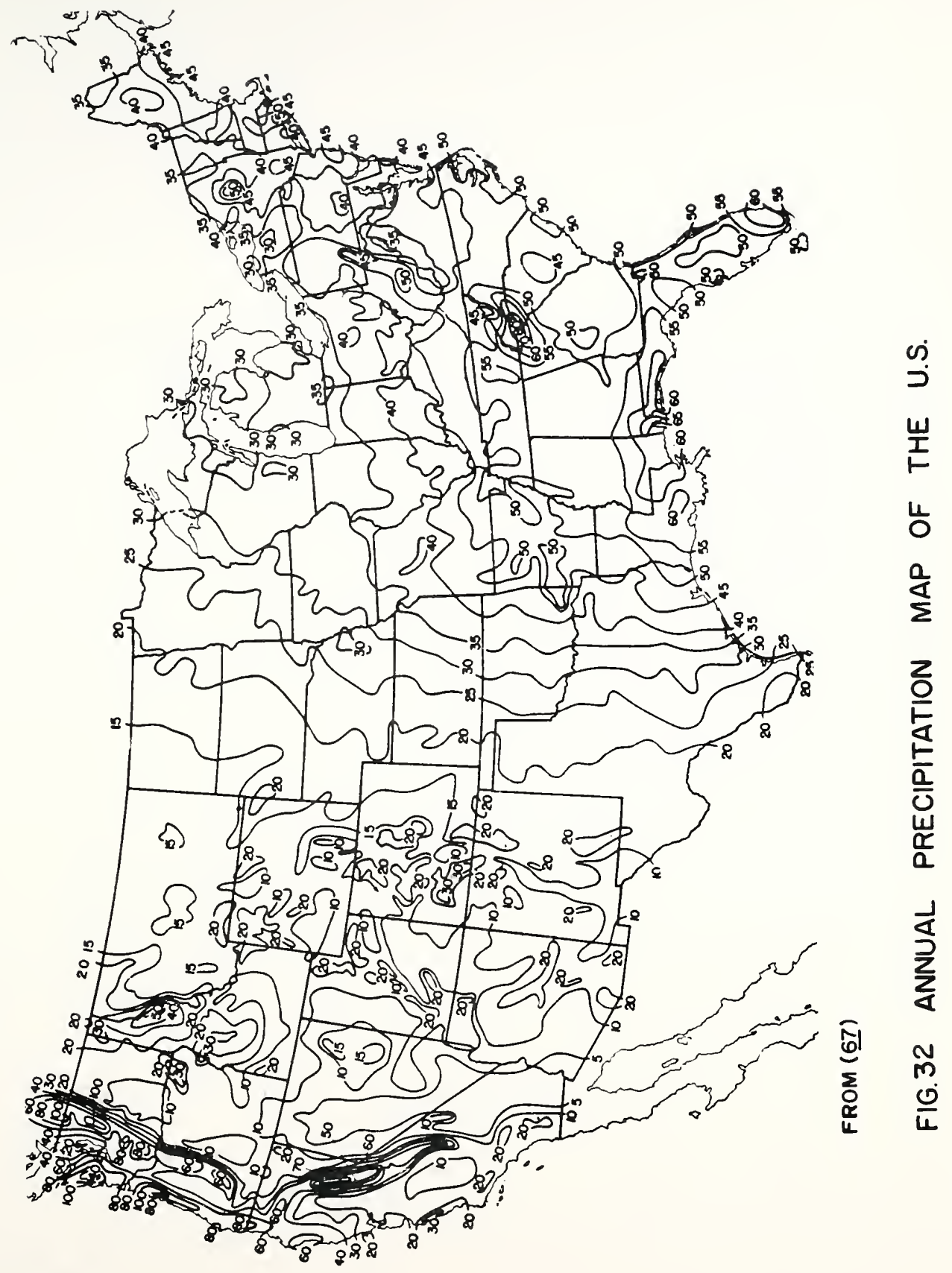


or less of precipitation. This fact is very pronounced for much of the Interrontane plateau System separating the rourtain systems. Exceptions to this occur primarily west of the Sierra-Cascade Frovince and along the Pacific sides of the righer mountainous locations in the area. It is within the latter area where large varlations in precipitation may occur in relatively short distances.

In contrast, most of the eastern grouping has precipitation in excess of 20 inches except along the western edee of the Great Plains Frovince. In general terms, preclpitation tends to gradually increase, from any point in the eastern area, toward the Mississippi and Alabama Gulf coast area. A notable exception to this climatic pattern occurs in the mountainous Blue Ridge area near north-eastem Georgia. Here the topographic effects upon rainfall increase are quite noticeable.

\section{innvial Temperature}

If the earth were a flat featureless plain the temperature would vary gradationally from the equator, decreasing as one would proceed to the poles, For most of the eastern portion of the U. S., this fact is quite markedly displayed in Flgure 33 which shows distribution of annual temperature. The pattem of temperature for the west, although generally increasing to the south shows a much more disruptive pattern.

Sreezing. Index

jince temperature is strongly related to the 


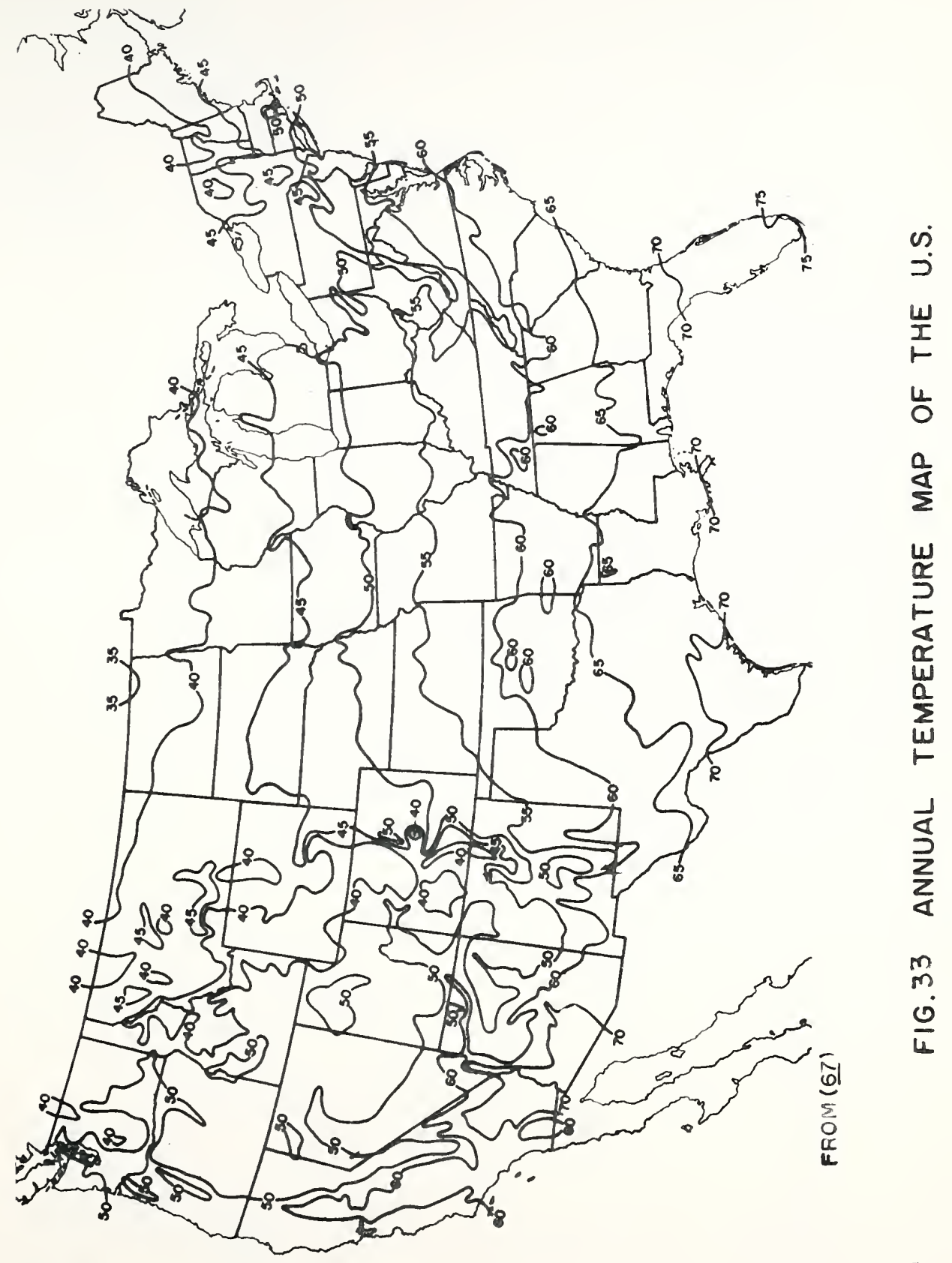


Freezing Index, climatic pattems of this variable are quite similar to temperature patterns. Figure 34111 ustrates the ilstritution of freezing index in the United States. Again, the orcgraphic effects of this variatle within the mountainous systems of the west 1llustrate the rather large change in freezing index which may be expected in short distances. Fotential Evaportanspiration

A climatic variable of importance to the high volume change soll problem in the United States is that of potential evapotranspiration. The distribution of this parameter is shown in Figure 35. As can be quite remarkably seen in this diagram, the diagnostic gradual change in the eastern groupling is contrasted to the very sharp changes occurring in rather short distances in the west.

\section{Population Differences}

From the standpoint of highway engineering and pertinent to this study, a final, but important difference occurring between the eastern and western Province grouplngs is that associated with population densities. Figure 36 shows the distribution of the 1960 census for the unlted states. In the west, the popliation density is, in general, smaller relative to the east. irajor exceptions to this pattern are found, however, in both groupings.

Within the west, extrenely high density concentrations are found existent within much of the Pacific Troughs Frovince, as well as in and around the San Francisco and Ios Angeles areas of California. Iow density areas within 


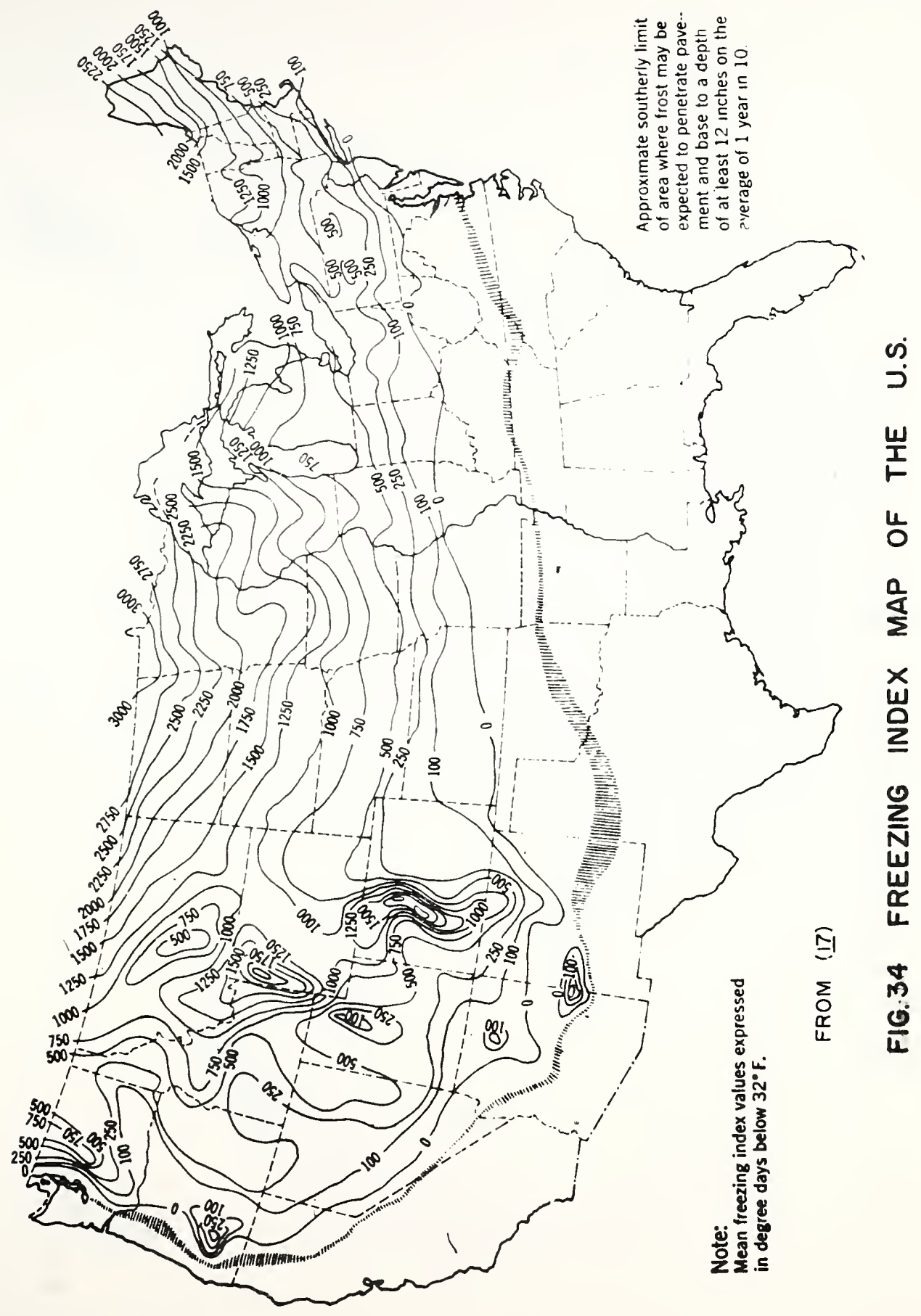




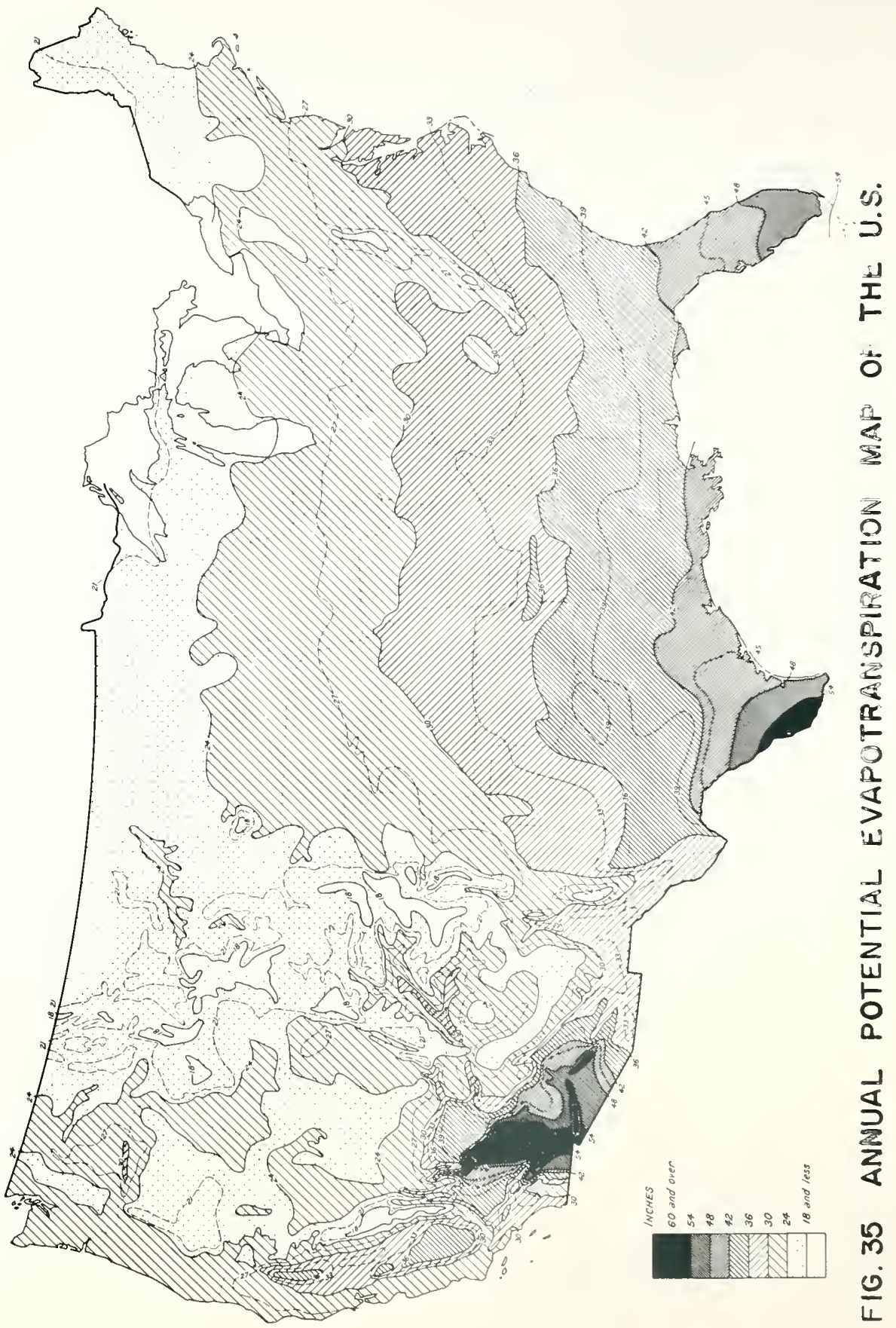




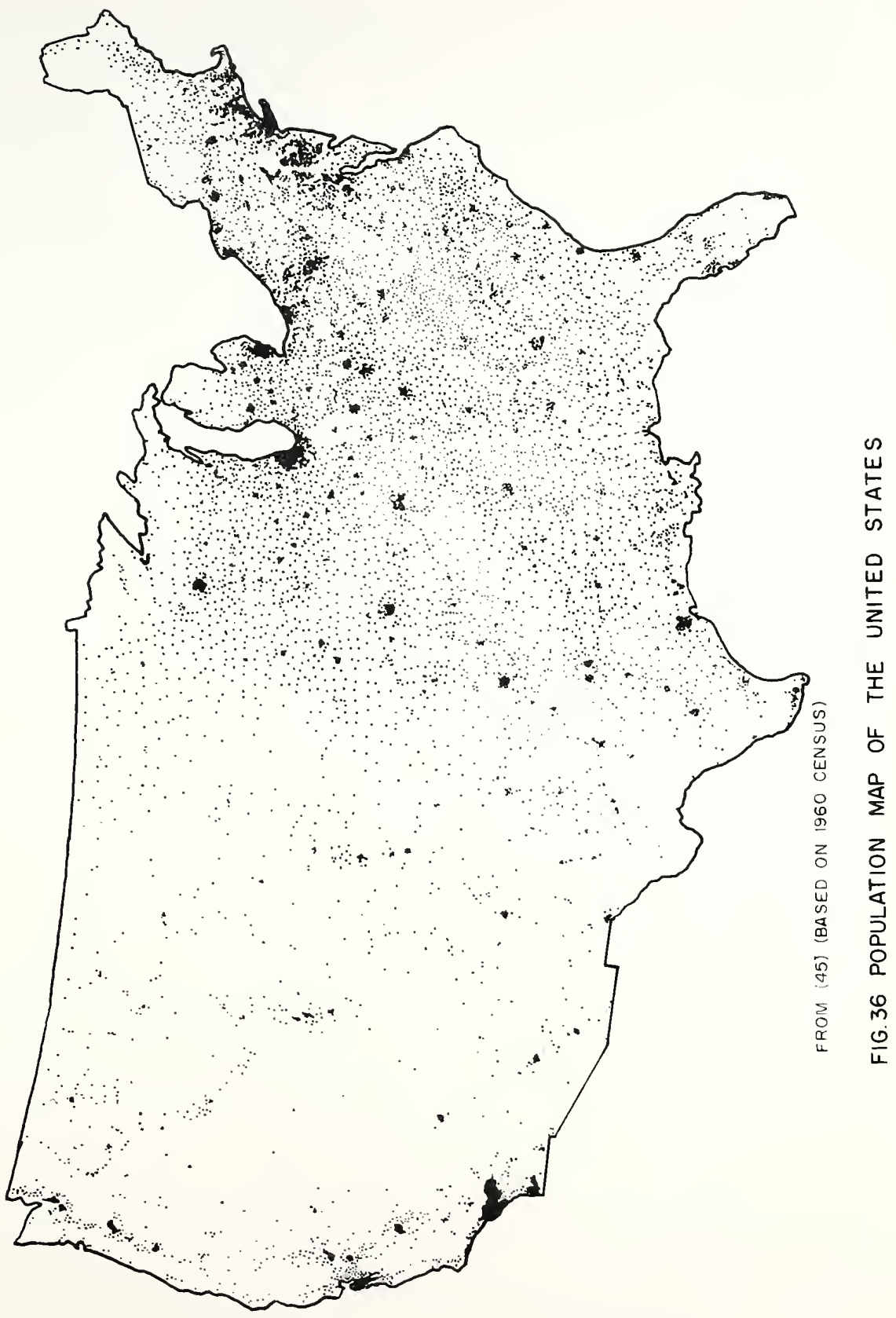


the east lie within much of the westem portions of the Great Plains Province as well as in isolated northem areas of Minnesota, New York and Maine.

The population density is in many cases strongly related to physlographic classifications. The overall $1 \mathrm{~m}-$ portance of this parameter intuitively implies a higher level cf nighway engineering activity. This factor may be interpreted generally as a greater demand for mineral aggregates, greater occurrence of nighway soll problems, etc.

\section{Summary of Major Difference}

In summary, the major significance between the eastem and westem groupings can be characterized by pattem differences. The west is characterized generally by akrupt chinges in topography, geology and climate within relatively short distances. In direct contrast, these jarameters in the east are frequently marked by gradational changes over larger distances or areas. In addition, the gross difference in highway engineering activity related to differences in population concentrations and distributions becomes a very important parameter in the overall effort of utilizing physlographic units to effect generalizations of highway factors of design within the entire United states.

\section{Suinmary of Individual Subject Areas Considered}

Pnyslography and Regional Physlographic Units

Based upon an examination of the regional physiography (geomorphology) of the United States, the following 
pertinent facts are presented.

1. Physiography is the science dealing with the description of landforms. Geomorphology is the sclence dealing with the interpretation or development (genesis) of lanaforms. However, when both sciences study the regional distribution of landforms, the activities of both resemble each other. This is to say that thereare little or no significant differences between a regional geomorphic or physiographic unit.

2. Landforms are described in non-genetic and qualitative terms of altitude, relief and type of landform present. However, the development of landforms is due to the combined interaction of geomorphic processes acting over a period of time and under a particular historlcal climatic environment on a distinct type or set of parent material types existent with 1 ts own unique geologic structure.

3. A regional physiographic unit, at any $l \in v e l$ of examination, attempts to delineate an area possessing a unique or repetitive series of landforms (areas of similar topographic expressions). Variant areas (areas possessing geomorphic control factors which differ from the modal characteristics delineating the regional physiographic unit) may be an inherent part of any level of regional categorization. Generally, the larger the topographic unit examined, the greater the possibility of including more variant types within the defined topographic unit. This is to say, that as larger and larger areas are examined, the 
degree of topographic generalization increases.

4. Because of the subjectiveness involved in defining physiographic units, no strict or definite criteria is known to place consistantly jefined reglonal units to a particular (common) level of reglonal physlographic categorization (e.g..Province, Section etc...). As a consequence, it is possible for different physiographers to jesignate a given unit as a unique province or even as a section of differing provinces. This point is rurther 11lustrated by Figure 37. Within this diagram four differIng categorization systems are noted for the physiographic units confined to the lowlands and valleys found primarily within the state of New York. It can be noted that the fohawk Valley unit is considered, by both this report and the 'Noods-Iovell system, to be a Section of the Central and Eastem Iowland Province; by Fenneman, the combined U.S.G.S.Fenneman System, and also Thornbury (not shown in the Figure) to be a Section of the Appalachian Plateau Province; while Ioteck does not recognize this as a distinct unit category, but rather as a variant portion of the Eastern Iakes and Lacustrine Section of the Central and Eastern Iowland Frovince.

5. Fhyslographic unit borders are quite variable in the degree to which they are definite in delineating adjacent un1ts. In several cases, a glven border seginent, may in 1tself, vary gradationally in its degree of noting contrasting units, e.g., units separated by escarpments frequently 


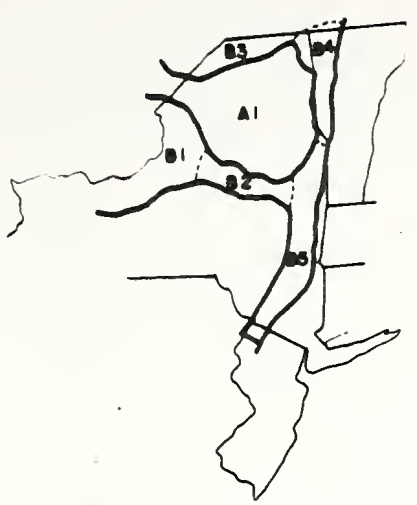

I. NCHAP; WOOOS-LOVELL (20)

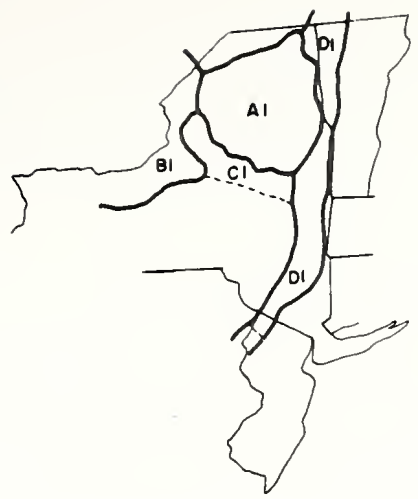

II. FENNEMAN (6)

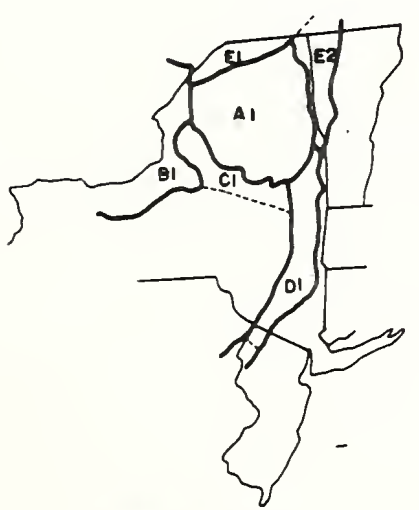

III. FENNEMAN-USOS (II)

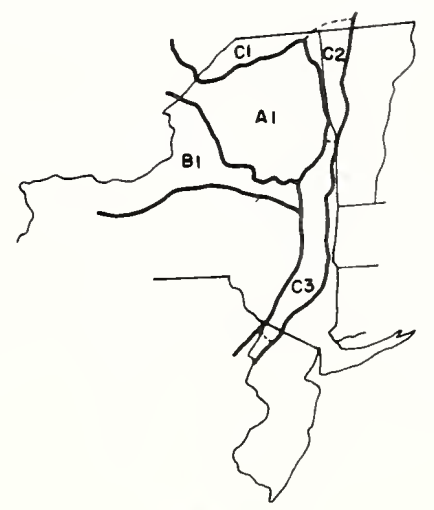

IV. LOQECK (12)

\section{LEOEND}

PROVINCE BOUMDARY

SECTIDN BOUNDARY

NCHAP UNIT CODE

A LAURENTIAN UPLAND PROVINCE I ADIRONDACK SECTION

B. CENTRAL a EASTERN LOMLANO PRONINCE I.EASTERN LAKE LACUSTRINE SECTION

2. MOHAWK SECTION

3. ST. LAWRENCE SECTION

4 CHAMPLAN SECTION

S. HUDSON VALLEY SECTION

NOTE: ALPHA-NUMERIC CODES FOR OTHER CLASSIFICATIONS NOTEO (II TO IV) REFER TO PROVIN CES (SHOWN OY LETTERS) AND SECTIONS (SHOWN BY NUMBERS) COMPRISING THE EASTERN LOWLAND AND VALLEY SECTIONS

FIGURE 37

COMPARISON OF EASTERN LOWLAND AND VALLEY SECTIONS

BETWEEN PHYSIOGRAPHERS 
possess the characteristic of having the altitude difference between the units decrease gradually until topographic signiflicance is lost. An example of such a border is the western torder portion of the Central and Eastern Lowland Frovince which is adjacent to the Great Plains Province from Kansas north to the Canadian-U.S. border. ${ }^{1}$

0. Physlographic areas delineated at the Frovince or jection category, from a U.s. level of examination, may not necessarlly serve as the "skeleton" framework for physiographic areas delineated at a level of greater detall, e.g., state level. Figure 38 1liustrates this for the state of Kansas.

7. In general, reglonal physlographic units possess a unique type or repetitive types of parent material and geologic conditions. However, uniform topographic expressions are not always indicative of uniform parent material or geologic characteristics. This implies that not all regional physiographic units have a unique parent material type. The most general ways in which this occurs in regional physiograpnic units in the United States are as follows:

a. Highly faulted areas: The Basin and Range Frovince is a good example of this. Nany of the mountain ranges are highly variable in geologic age and rock type. Ilkewise, from a mineralogic

1. Th1s border segment corresponds to segment 418 , Central and Lastern Iowland Province boundary description found in Appendix $\mathrm{E}$. 


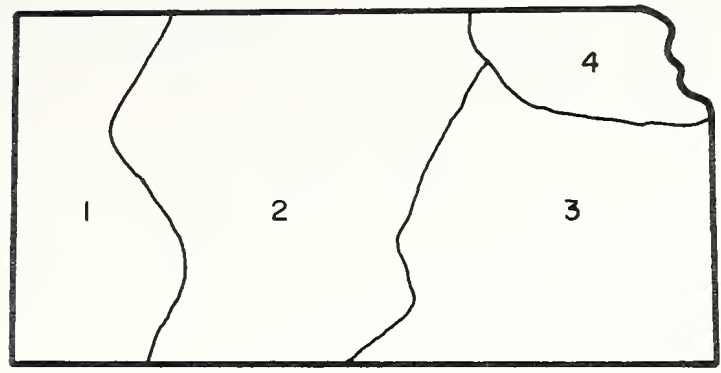

I. HIGH PLAINS SECTION

3. OSAGE PLAINS SECTION

2. PLAINS BORDER SECTION

4. DISSECTED LOESS/TILL PLAINS SECTION

KANSAS PHYSIOGRAPHY AT U.S. LEVEL OF EXAMINATION

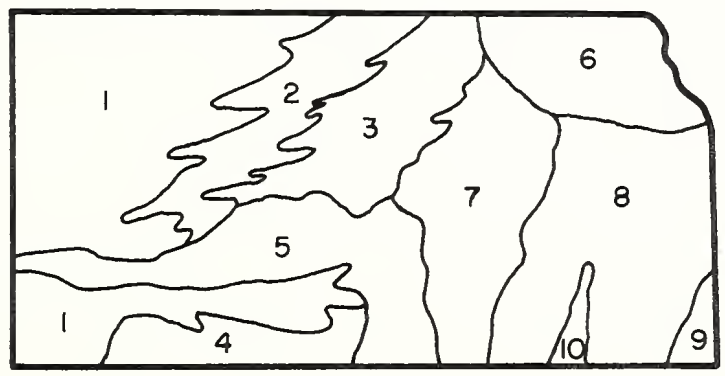

1. HIGH PLAINS

2. BLUE HILLS

3. SMOKEY HILLS
4. RED HILLS

5. ARKANSAS LOWLAND

6. DISSECTED TILL PLAINS

7. FLINT HILLS
8. OSAGE CUESTAS

9. CHEROKEE LOWLAND

10. CHATAGUA HILLS

KANSAS PHYSIOGRAPHY AT STATE LEVEL OF EXAMINATION

FIGURE 38 DIFFERENCE IN REGIONAL PHYSIOGRAPHIC UNIT DELINEATION AT TWO DIFFERENT LEVELS OF EXAMINATION 
composition the alluvium (valley fill) derived from these ranges is highly variable and complex. Another physiographic unit similar in its geologic and parent materlal complexity but unique in its topographic expression is that found in the Montana Section (particularly the southwestern portion) of the Northerm Rocky Mountain Province.

b. Regional facies changes: Differences in 11 thology may occur due to facles changes in bedrock type rut yet still maintain the overall uniford1ty of topographic expression of the physicgraphic unit. An example of this occurs within the Csage Plains Section of the Great Plains Frovince. This section possesses a modsl topceraphic expression of north-south trending cuestas. However in the northerm portion of the Section, the topography is developed upon shale lowlands and limestone scarps. As cne proceeds to the south, the limestone is replaced by sandstone as the rldge makers, maintaining its topographic similarilty to the northern portion.

c. Transported soll areas: In areas where a gradational change in orlein occurs from a non-transported soll area (bedrock or residual soll) to transported solls (primarily of aeolian and glacial origin), the physlographic units may 
may be delineated upon the gross features of the consolldated (bedrock) areas. These units may have transported solls which mantle the bedrock with enough thickness to be signiflcant In highway design and construction considerations but their effect lipon the regional fhysiography is insignificant. An excellent example of this occurrence within a regional scale is the continuous loessial deposits in the midwest. Here the loess occurs in portions of the High Flains and Plains Border Sections of the Great Plains Province and continues into the Central and Eastern Lowland Province, occurring in the Dissected Loessial and T1IJ Plains, Driftless and Central Till Plains Sections of the Province.

8. Distinctive and adjacent unique physicgraphic undts may possess the same general parent material type or types. The major ways in which this can occur are as follows:

a. Differing levels of geomorphic stage: This rather obvious occlirrence for differing regional physlographic unit delineation is generally manifested by similarilty of elevation but differing factors of rellef. An example of this 1s found within the Navajo and Canyon Iand Sections of the Colorado Plateau Province. In 
Eeneral, both Sections possess similar parent material types of flat lying, relatively soft sandstones and shales primarily of post Faleczo1c age. However, because of the perennlal source of water (streams) from the Southerm Rocky Mountain Province to the east, flowing within the Canyon Lands Section, the subsequent dissection within this unit differs significantly from the Navajo section to justify, from a physiographlc viewpoint, separate reglonal units.

t. Fartial regional peneplation (erosion): A good example of this occurs at the contact of the Seaboard Lowland - New England Upland Sections. The Seaboard Iowland is a topographically lower unit develcped by the beveling action of marine erosion upon bedrock similar in type and geologic age to that found in the adjacent New England Upland Section. In some instances, "micro geologic-parent material units", may be continuous through the border segment separating the two units.

Another example where this occurs may be found in the relationship of the Blue Ridge and Pledmont Plateau Sections of the Cld Appalachian Frovince. Here widespread erosion has again beveled parent material in the Pledmont Plateau 
unit generally similar to that which comprises the Elue Ridge Frovince. The topographic distinctions between the two units are notably contrasted by the mountainous area of the Elue Ridge and plateau topography of the pledmont Sections.

\section{Aggregates}

\section{Lesign Factor Rating Summary}

Based upon the examination of the potential aggregate avaliability for the Physiographic Sections comprising the United States, 1t appears that lack of sultatle aggregate scurces is an urgent problem facing a substantial percentage of the highway industry. Table 26 summarizes the estimated potential availability ratings of aggregates by sections, while Figure 39 shows the distribution of these ratings within the continental United States.

As can be noted within the Table, section areas comprising over $26 \%$ of the land mass have a poor potential for aggregate resources while sections totaling almost 6 \% have a very restricted potential aggregate supply. In addition, it should also be mentioned that the "true" or "realistic" (in contrast to "potential") appraisal of aggregate resources may possibly have a greater percentage of areas where aggregate avallability would be a problem. This is due to the fact that in many western areas of the Unlted States, where good potential aggregate sources exist (particularly 

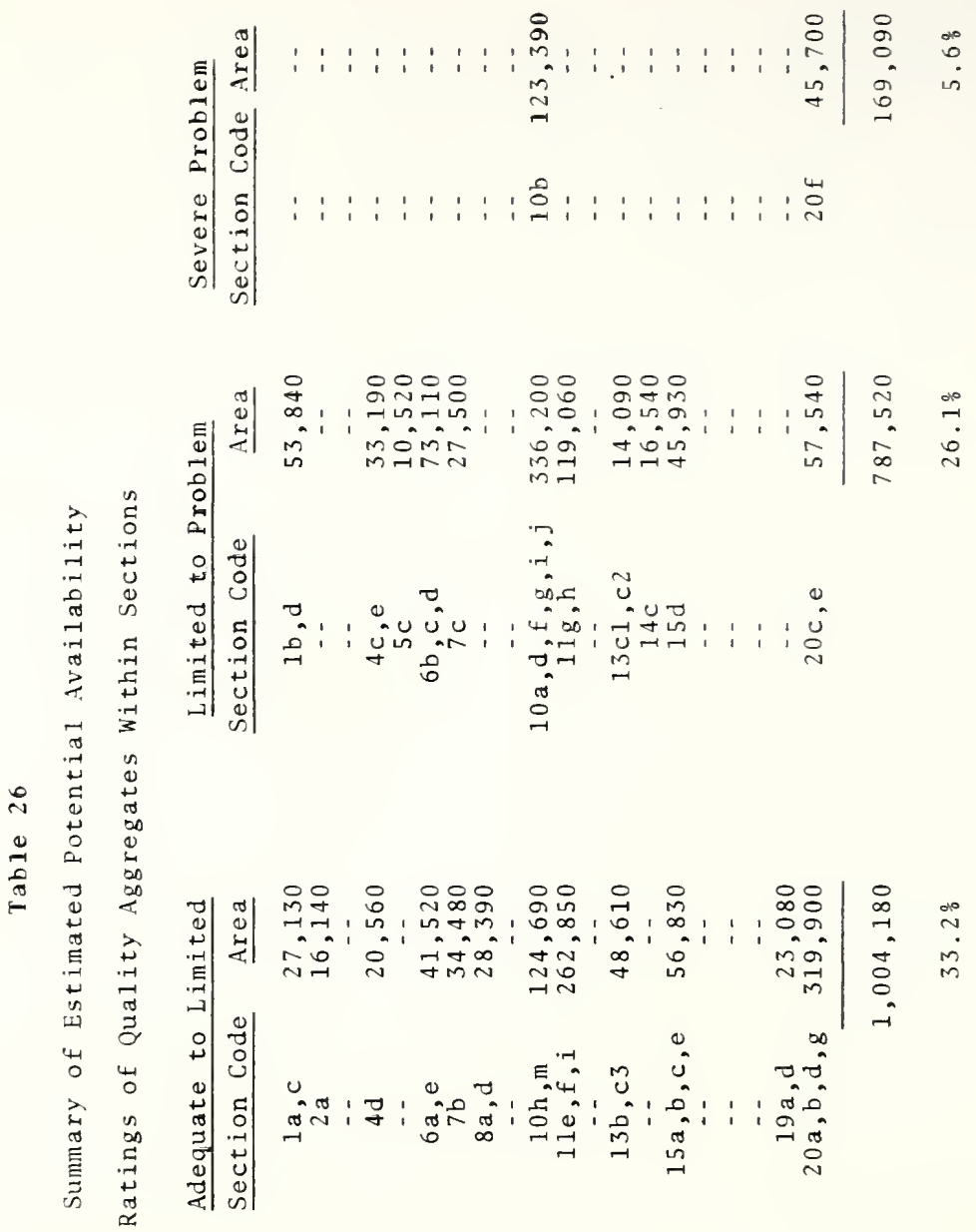

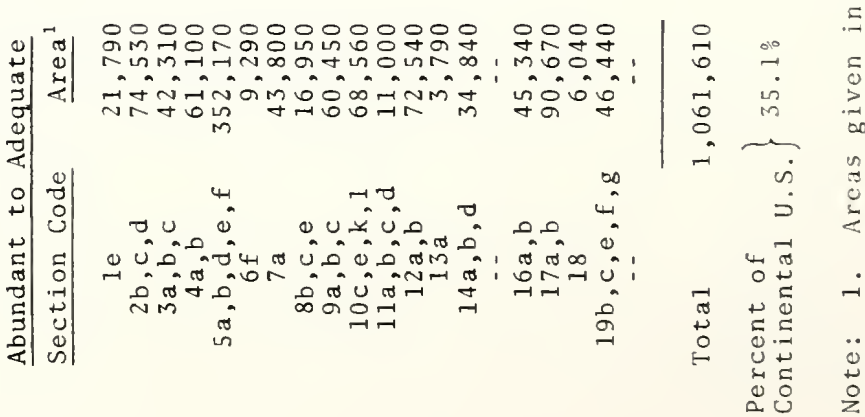




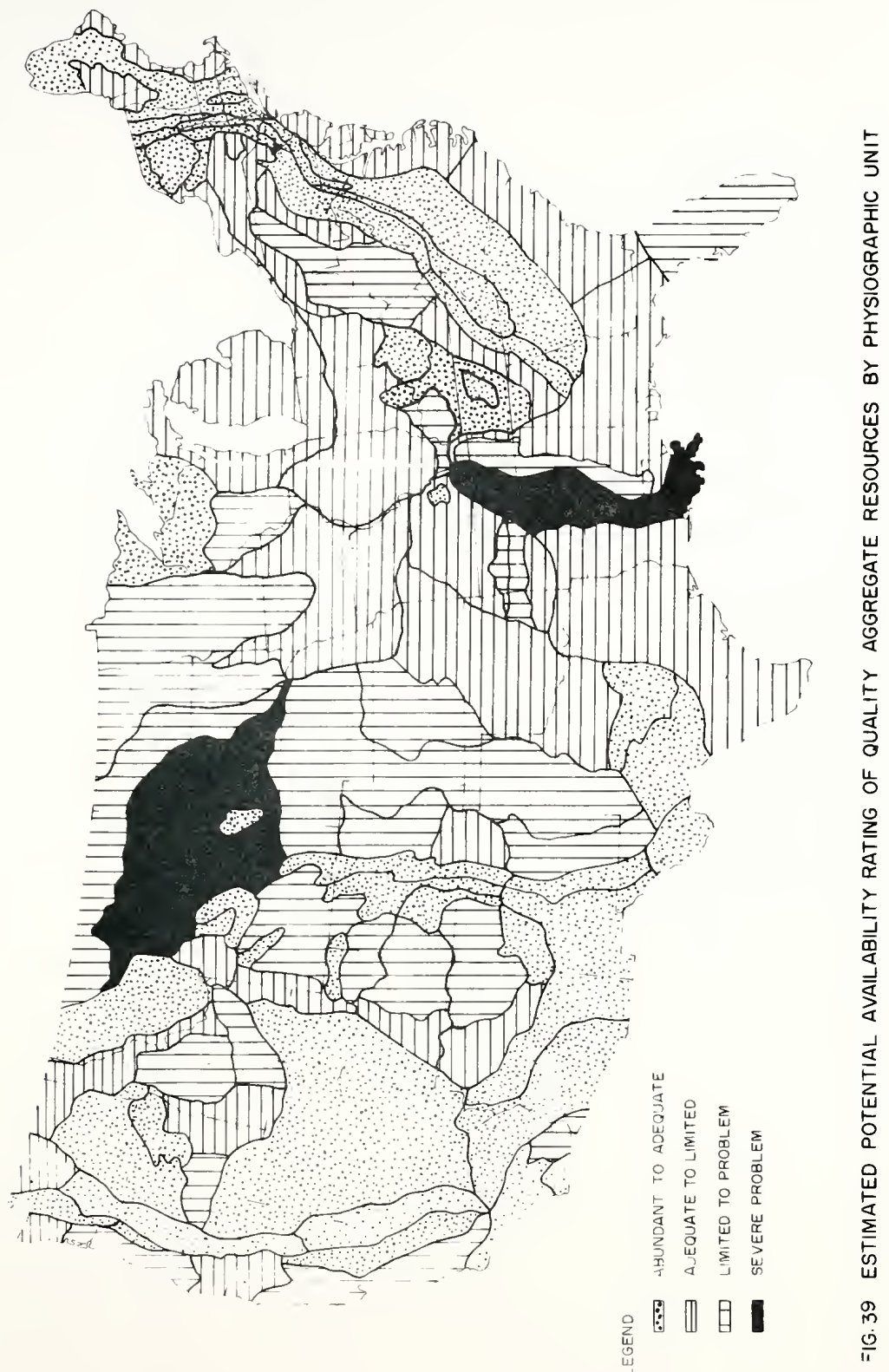


(ushed stcne), the regions are sparsely populated and in many cases inaccessible due to the extremely rugged, mountainous conditions. In this instance, the ruggedness and inaccessibility of these areas would tend to reduce effectively the potential rating to a more realistic lower supply of ageregates. In contrast many of the areas possessing potentialiy adequate supplies in the east may be quite restricted in the exploitation and use of aggregates due to urban development associated with the ingh population ciensities comion to the eastern United jtates. This would I1kewise rave a similar reductive effect.

\section{Generalized Distribution of Aggregates}

General East-West Differences

In discussing the aggregate resources within the united states, utilization of the east-west province grouping provides a convenient first order manner of explaining general distributive characteristics, differences and mafor types of aggregates utilized within the United States. From a general viewpoint, both the east and west possess an equivalent potential for crushed stone sources; however, they differ greatly by major type gvallable. isthin the east, the ereatest source of crushed stone exploited is invariably crushed carbonate with less frequent occurrences ci granitic/metamorphic complex and basaltic types being avaliable. In alrect contrast, the potential types in the 
western provinces are associated more frequently with the latter two categorles of crushed stone whlle the carbonates play a role of decreasing importance to the crushed stone indus try.

In addition, large areas of sand gravel deposits are found within the valley flll areas of the west; characteristic in many portions of this grouping, but generaliy non existent in the east. The importance of glacial assoclated sand gravels is significant in most of the northern glaclated sections found in both the east and west. Isolated regions of coastal plain gravels are also significant within the eastem grouping but are generally absent as a reglonal source within the west. The role of sand gravels obtained and associated with the rivers and streams of the entire United States 1s, of course, a very major and prominent one, appearing to be of equitable importance as sources of highway aggregates irrespective of any east-west border separation. Crushed Stone Distribution

General. Table 27 is a summary of the major types of crushed stone utilized as highway aggregate within sections. The Table is based upon information provided in Table 13. A generalized discussion of each grouping is presented in the following paragraphs.

Carbonate Sources. As previously noted in Table 3, the use of carbonate rocks (IImestone and dolomite) for crushed stone far exceeds that of any other major crushed stone type in 
Table 27

Summary of Major Crushed Stone Types

III ilized As Ilighway Aggregate Within Sections

\begin{tabular}{|c|c|c|c|c|c|}
\hline $\begin{array}{l}\text { Provines } \\
\text { Corle } \\
\end{array}$ & $\begin{array}{l}\text { No Grushed } \\
\text { stone } \\
\end{array}$ & Carbonate & Sands tone & Granitic/Meta & other Igneous \\
\hline 1 & $c^{\star}$ & $d^{*}, e^{*}$ & $a, b, d^{*}$ & $e^{*}$ & $a, b$ \\
\hline 2 & & $b^{*}, c^{*}$ & $\mathrm{a}$ & $a, c^{*}, d^{*}$ & $a, b$ * \\
\hline 3 & $c^{\star}$ & None & $\mathrm{a}$ & None & $\mathrm{a}, \mathrm{b}$ \\
\hline 4 & & None & None & None & $(\underline{a-e})$ \\
\hline 5 & $c^{*}$ & $a^{*}, d^{*}, e^{\star}, f^{*}$ & $d *$ & $a^{*}, b^{*}, d^{*}, e^{*}$ & $a^{*}, b^{\star}, d^{*}, f^{\star}$ \\
\hline 6 & $a, b$ & $\mathrm{f}$ & $\underline{c}, \mathrm{~d}$ & None & $\mathrm{d}, \underline{e}, \mathrm{f}$ \\
\hline 7 & & $a, b$ & a & $a, b$ & $(a-c)$ \\
\hline 8 & e & $\underline{b}, c, d$ & $\mathrm{~d}$ & $\underline{a}, c, d$ & None \\
\hline 9 & & $a, b$ & None & $(a-c)$ & c \\
\hline \multirow[t]{2}{*}{10} & a & $b-e, f^{*}-h^{*}, \underline{i}, j *$ & $b-d, f^{*}, j^{*}, m^{*}$ & $d, e, f^{\star}, m^{*}$ & $c, g, h$ \\
\hline & & $\mathrm{k}^{*}, \underline{1}^{*}, \mathrm{~m}^{*}$ & & & \\
\hline 11 & & $\left(\underline{a}, b, c, d, e, \underline{f}, g^{*}-i^{*}\right)$ & $c, e, g^{*}$ & $b, c, g^{*}, h^{\star}, i^{*}$ & None \\
\hline 12 & & None & None & $\left(a^{*}, b\right)$ & $\left(a^{*}, b\right)$ \\
\hline 13 & & $(a-c 3)$ & $b-c 3$ & $a, c 2$ & $c 2$ \\
\hline 14 & & $(\underline{a-c}, d)$ & $\mathrm{d}$ & None & None \\
\hline 15 & & $b, \underline{c}, d-e$ & $a, b, d, \epsilon$ & None & None \\
\hline 16 & & $(a, b)$ & $(a, b)$ & $\mathrm{b}$ & a \\
\hline 17 & & $(a, b)$ & None & $(a, b)$ & $(a, b)$ \\
\hline 18 & & $(18)$ & None & $(18)$ & $(18)$ \\
\hline 19 & & $a, b^{\star}, f, g$ & $\mathrm{a}$ & $(a, b *, d-g)$ & $a, b^{*}, \underline{c}, e, g$ \\
\hline 20 & $a, b^{*}, e, f, g$ & $\underline{c}, \underline{d}$ & None & None & None \\
\hline
\end{tabular}

Notes: 1. Data summarized from Table 13; Province/Section code keyed to Table 4.

2. General quality of sources variable, but each major type noted to be used as highway aggregate in Section.

3. Sections noted by (*) indicates Sections for which incomplete data are available.

4. Sections enclosed by parenthesis indicate provinces for which all Sections utilize crushed stone type.

5. Sections underlined indicate Sections where the only major crushed stone utilized is that shown. 
the United States. Based upon the results of this project, forty-one (4I) of the forty-eight (48) states ut111ze this source as highway aggregate. ${ }^{1}$ By far the greatest concentration and use of these rocks occur within the vast Paleozolc area in the east shown within Figure 30 . In addition, Figure 40 shows the distribution of the twenty leadIng state carbonate producers for the 1956 to 1958 period. The overall importance of this geologic area can be noted by a general comparison between F1gure 2, 30 and 40. California, which is noted on Figure 40 as one of the leading state producers of carbonate stone utilizes only a small portion (approxinately 10\%) of this for highway aggregate.

In terms of the Physiographic units examined, this vast Paleozolc area forms much of the topography associated with the Ridge and Valley Province, Interior Iow Flateau, Appalachian Flateau and Ozark and Cuachita Provinces. However, within the latter two Provinces, sizeable regional areas occur where carbonate stone sources are lacking. In addition, much of the bedrock underlying the central and Eastern Iowland Province is attributable to the preserce of this geologic area.

Carbonate rocks are not only confined to the raleozolc Era, but occur and are subsequently ut111zed as

1. The following states do not ut1lize carbonate rocks for highway aggregate: Connect1cut, Delaware, Loulsiana, Mississipp1, New Hampshire, North Dakota and Cregon. 


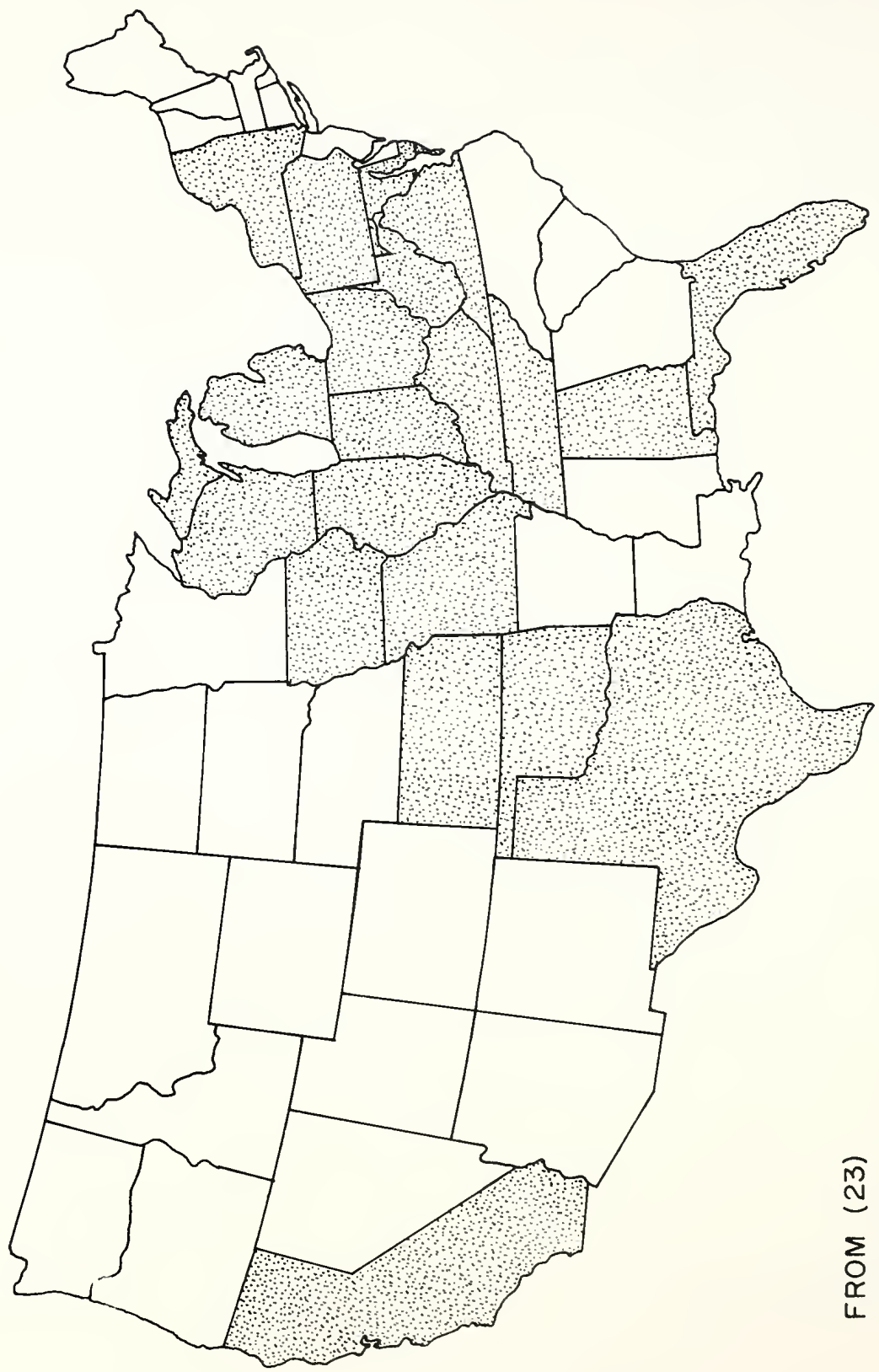

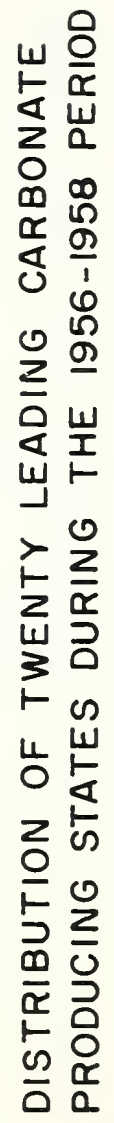

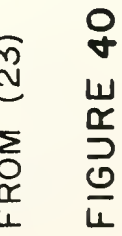


highway aggregate from the Cenozolc and Mesozolc Eras. However, taken as a general rule, the occurrences of quality carbonates in these two Eras are not as w1despread as those assoclated with Paleozolc age.

W1thin the Mesozo1c Era, the largest occurrence of Carbonate rocks is associated with the Cretaceous Period. carbonates of this age are found, to variable degrees within the Atlantic and Gulf Coastal Plain and Great Plalns Provinces. Cther deposits are associated with many areas surrounding nountainous uplifts of the west. The only location of Cenozo1c carbonate deposits, known to the author, that are used as highway aggregate are found within the Atlantic and Gulf Coastal Plain Province (Florida Section primarily). Sandstone Sources. It has been previously noted tnat iue to the wide varlabllity in properties of sandstone, coupled with rather poor geologic inforination for noting the location of these potential crushed stone areas, the mapping of this aggregate source was not conducted at a U. S. level. However, the importance of this material as a crushed stone scurce in isany areas cannot be overlooked even with the regional analysis of aggregate avaliablitty.

Although crushed sandstone is ut111zed as highway aggregate within 31 of the 97 sections examined, its use as a concrete $\mathrm{mix}$ aggregate occurs only within 11 of these sect1ons. Table 28 is a summary of the major highway functional uses of this aggregate by sections. As can be noted, a najor use of this aggregate is related to base/subbase aggregate, 

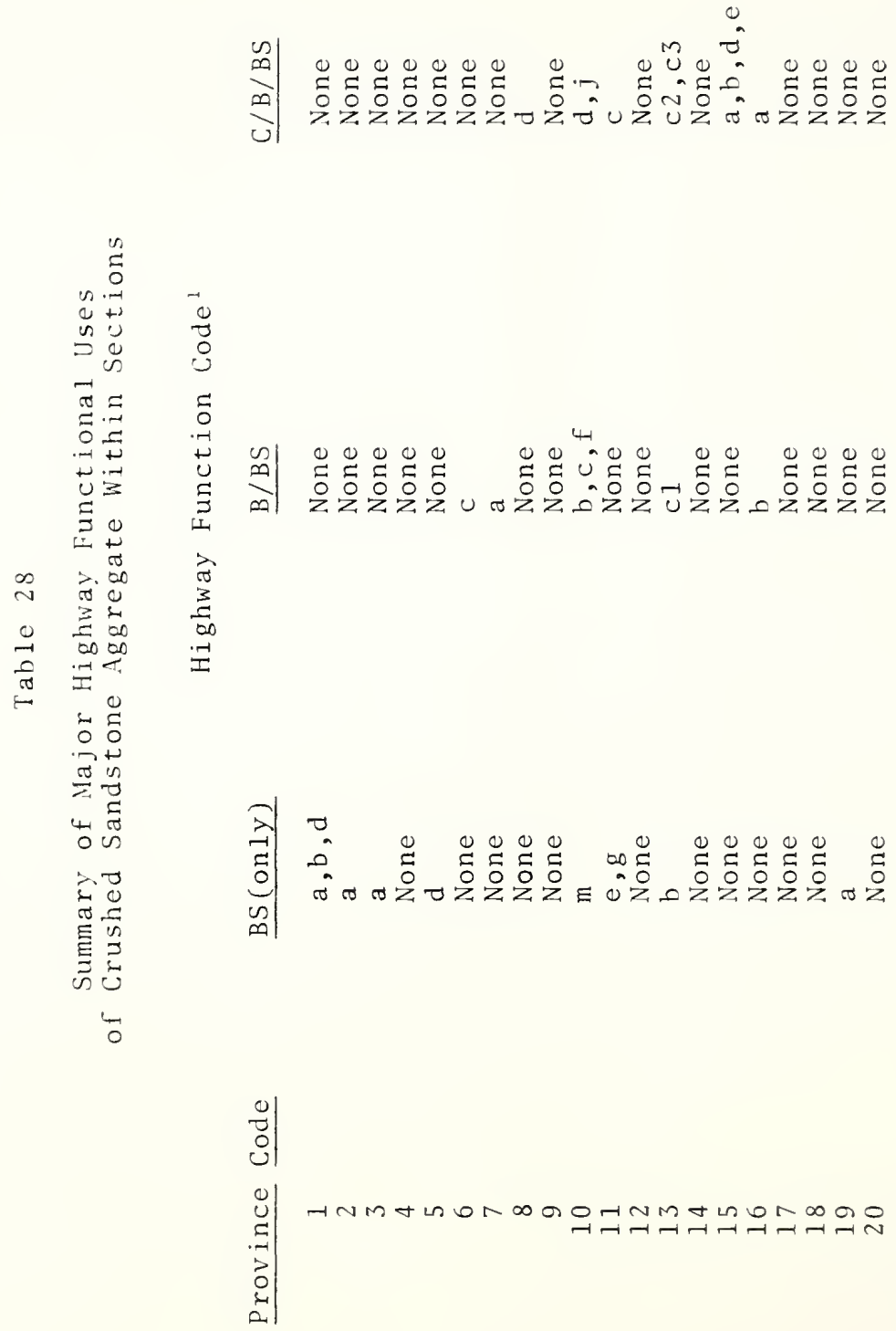

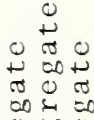
C 500
\& $00 \%$ bo os bo ol 00 क $\times$ 1 $\cup E x$ थ थ E 03 $\therefore 0$ I 的四 0 1 ह 0
$u$ o. - 00 is us us C 00 $\omega+\omega$ तथ 000 $\sigma \circlearrowleft$ $\exists \equiv$ $\infty$ 
reflecting to some degree, the generally lower aggregate quality which may be tolerated in non surficlal pavement layers. In the western U. S. Province groups, these areas are generaliy associated with portions of the pacific Coast Range Province. The Province in which it appears that crushed sandstone scurces are most wldely used for concrete aggregate appears in the Appalachian Plateau. This, in part, nay be necessitated by the relative lack of any other sultable crushed stone source within the area. I A similar analysis may be applied to various other Sections such as the wasatch (8d), Wyoming Basin (10d), Plains Border (10 g), Arkansas Valley (13c2), and Ouach1ta Mountains (13c3). Granitic/Metamorphic Sources. The distribution of this grouplng as a crushed aggregate source is primarily, but not always, restricted to e1ther Pre Cambrian or Jurassic ages. Within the eastem United States, these areas are located in the Cld Appalachian, Laurentlan Upland and the New England Maritine Frovinces.

Within the central portion of the United states, but still confined to the eastern province grouping, the distribution of these rocks is princlpally related to several isolated geologic structural uplifts or domes. Although most of these areas are rather small in areal extent, they do frequently serve as important sources of aggregate.

1. Crushed carbonates are rather restricted in the1r distribution and occurrence within this Province. 
These areas are found primarliy in the Llano Burnet area of Texas (Central Texas Mineral Section), the wich1ta and Arbuckle areas of Oklahoma (variant areas of the Csage Plains Section), the St. Francis Yountain Section, the sioux jplift in the extreme southwest corner of Minnesota and the Black Hills Section.

In the western province grouping, the occurrences of this potential aggregate source are found princlpally within portions of each Rocky Mountain Province, as well as in the Northern Cascade, Slerra Nevida and Iower Califomia sections of the slerra-Cascade Province. In addition, scattered intrusions are found in many other isolated areas within the west.

Cther Igneous jources. The distribution of tinis potential crushed stone source is primarliy concentrated in the western portion of the United States. The major percentage of this category is basaltic in nature and occurs princlpally in the Cascade Mountains and the Columbla Plateau Province. In the east, a very small, but important occurrence is found as traprock within the Triassic sediments comprising the Connecticut Iowland Section and the Trlassic Iowland Province. Smaller Trlassic basins are also found as variant areas within the Pledmont Plateau Section of the old Appalachian Province. Sand Gravel Distribution

Because of the complexity involved in the 
distribution, frequency of occurrence, quality and modes of natural sand gravel deposits existent within the United States, it is quite difficult to formulate a brief yet effective summary relative to the distributive characteristics of this aggregate category. Almost every section contains this source, although quantity as well as mode of occurrence may differ signiflcantly. A general resume may be inferred from the alscussions for each section concerning aggregate avallability previously stated. In adrition, an excellent general summary discussion is found in reterence ( 142 ) in which the author could alford little or no significant contributions to the information present.

\section{Potential Aggregate Ava1lability Ratings}

Potential Ratings Versus Areas Lacking Aggregate

The procedure used in rating potential aggregate availability ratings for each section has been previously discussed. An important source of information which was extensively utilized as a tool for the evaluation rating was the composite map of areas lacking aggregate obtained from the materials questionnalre response and previously shown in Figure 12. In general, there are a few sections in which a poor aggregate avallability rating has been assigned wille 11 ttle or no areas have been designated as lacking aggregate within the section. In contrast, other sections showing a good aggregate availability rating possessed areas lacklng aggregate resources. Many of these discrepancies may be explained by the presence of variant 
materials areas within a section and the attempt to designate the generalized potentlal avallabllity based solely lipon a material type, quality aistribution combination within a section. Some deviations, undoubtedly, are due to the lack of definite information utilized to assess the potential rating.

Table 29 summarizes all of the sections having a potential avallabjlity rating more severe than an adequate to $11 \mathrm{~m}$ ted category and lists the pertinent remarks concerning the status of areas lacking aggregate noted by the questionnalre response. In general, it is felt that the following sections show a distributive pattern of areas vold of aggregate inconsistent (less areas than would be expected) to the assigned rating: $1 \mathrm{~b}, \mathrm{~d} ; 4 \mathrm{e} ; 6 \mathrm{~b}, \mathrm{c} ; 7 \mathrm{c} ; 10 \mathrm{f,l}, \mathrm{g}$ and $13 \mathrm{cl}, \mathrm{c2}$. The basis for these sections having the assigned ratings is presented within the geologic summary of areas lacking aggregates in the ensuing portion of the report.

Table 30 notes only those sections where areas lacking aggregates were noted by the questionnalre results and which have an avallability rating less severe than a limited to problem variety. In general, with the exception of the Grand Canyon section, the remainder of the sections do not exhlo1t any gross inconsistencies between the areas lacking aggregate and the assigned rating. The adequate to $11 \mathrm{mlted}$ potential availability rating given to the Grand Canyon Section is in direct contrast to the entire section being designated by Arizona Highway Department personnel in tre MCARF materials questionnaire as lacking aggregate. 


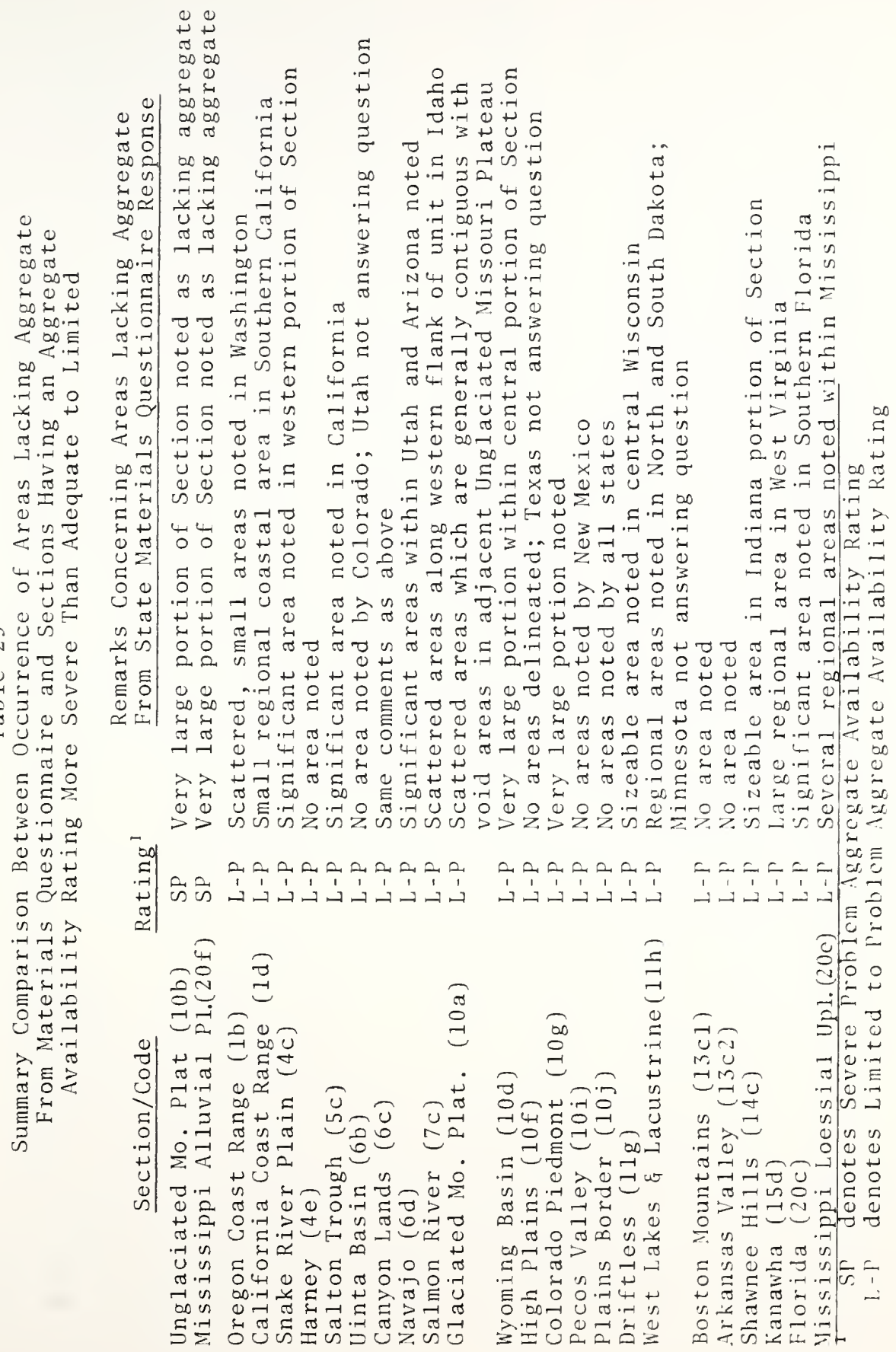




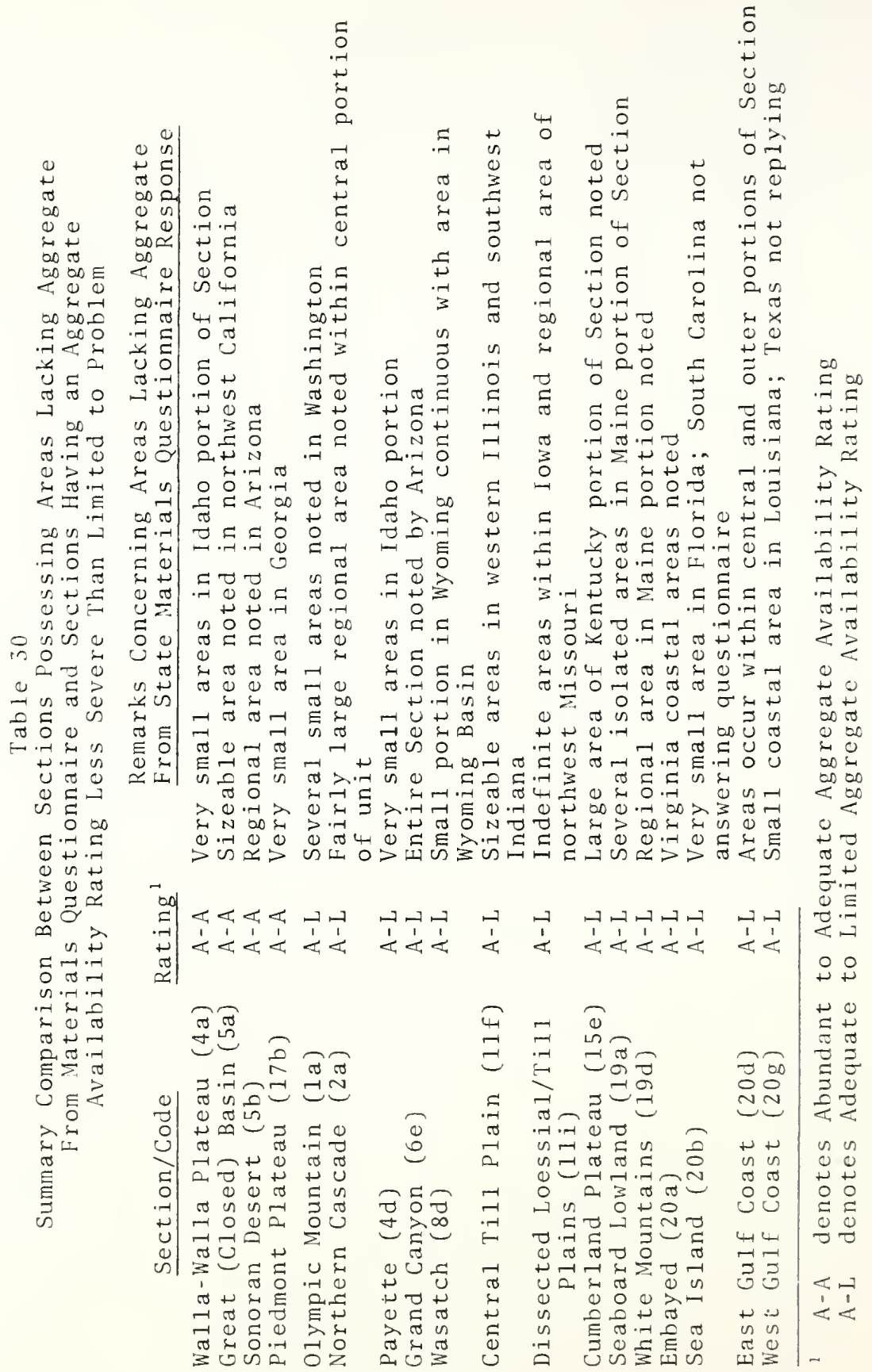


Ithough potential limestone sources do exist in the area, it was notec that no limestone entry was made for the secticn. As a result the true potential quality of this area is unkncwn and it is possible that the areas noted as lackirg aggregate may refiect the difficulty of exploiting this deeply dissected canyon portion rather than based upon quality limitations of the limestone source. Based upon this Iimited information aggregate avallability in the area was designated as adequate to $11 \mathrm{~m}$ ted rather tran as a severe problem category.

Geolcgic Summary of Sections Having Foor Aggregate Avallability Ratings

Although each section possessing a limiteà tc frotlein or severe problem rating had its owr. Feculiar contination of characteristics responsille for its rating; trese linits can be efiectively grouped into three categories dencting Eeneral features responsible, in major part, for the poor pctential aggregate rating. Table 31 is a gereral summary of the sections having a poor avallability rating grouped according to these three categories.

one of the most significant factors contrituting to lack of aggregate within sections can be seen to cccur trom areas possessing widespread distrikution pattern of sandstones and shales. This fact coupled with a relative lack of quality natural sand deposits fenerally yields areas of extremely poor potential. From Table 31, it can also be noted that most of these areas within the Type I groliping 
Table 31

(icneralized Summary of the Predominant fieologic Conditions

lixistent Within Sections Possessing an Aggregate Availahility

Rating More Severe Than Adequate to Limited

Type $\mathrm{I}$ : Sections Possessing Widespread Distribution of Predominantly Sedimentary

Sandstone and Shale Bedrock Which Significantly Contributes to a Poor Aggregate Availability Rating

Section/Code

Dregon Coast Range (1b)

California Coast Range (1d)

Jinta Basin (6b)

Canyon Lands (6c)

Vavajo (6d)

(Jnglaciated Ifissouri Plateau (10b)

Wyoming Basin (10d)

Colarado Piedmont $(10 \mathrm{~g})$

Pecos Valley (10i)

Plains Border $(10 \mathrm{j})$

Driftless $(11 \mathrm{~g})$

Boston Mountain (13c1)

Arkansas Valley (13c2)

Shawnee Hills (14c)

Xanawha (15d)

\section{Remarks}

Tertiary sandstones and shales

Tertiary and Mesozoic sandstones, shales and some slates

Tertiary sandstones and shales

Mesozoic sandstones and shales

Mesozoic, Tertiary and late Paleozoic sandstones and shales

Tertiary and Cretaceous sandstones and shales

Tertiary sandstones and shales

Tertiary and Cretaceous sandstones and shales

Triassic sandstones and shales; Permian sandstones, shales, limestone and gypsum.

Cretaceous and Permian sandstones and shales; Cretaceous 1 imestone

Cambrian sandstone and shales; Ordovician carbonates in southwest may be used as crushed stone

Pennsylvarian sandstones and shales

Pennsylvarian sandstones and shales

Pennsylvanian sandstones and shales; Mississippian limestones quarried

Pennsylvanian sandstones and shales; Permiar limestones and shales

Type II: Sections Possessing Widespread Distribution of Bedrock With Poor Crushed Stone Capability Other Than That Noted in Type I Which Significantly Contributes to a Poor Aggregate Availability Rating

Section/Code

Snake River Plain (4c)

Harney $(4 \mathrm{e})$

Salmon River (7c)

\section{Remarks}

Cenozoic acidic lava plain; regional sand gravel sources generally only available near mountain borders

Cenozoic acidic lava plain with widespread pumice deposits and lacking regionally distributed sand $\mathrm{g}$ rave $1 \mathrm{~s}$

Jurassic granitic rocks are not suitable for use as highway aggregate

Type III: Sections General1y Possessing a Non Existent to Poor Bedrock Crushed Stone Potential Overlain by Transported Deposits Either Deficient in Quantity or Quality of Natural Granular Deposits

\section{Section/Code}

Salton Trough (5c)

Glaciated Missouri Plateau

(10a)

High Plains (10f)

Western Lakes and Lacustrine

Florida $(20 \mathrm{c})$

Mississippi Loessial Upland (20e)

Mississippi Alluvial Plain (20f)

\section{Remarks}

Widespread presence of fine grained alluvial and 1 acustrine deposits characterize much of Section

Glaciated region possessing sand gravel deposits of general poor quality underlain by bedrock similar to that found within Unglaciated Section. (See $10 \mathrm{~b}$ in Type 1 grouping)

Crushed stone potential non existent in Section; major source of oggregates obtained from major rivers and tributaries of Section. Higher density of rivers occur in northern portion of unit; however much of the aggregate lacks coarse fraction and may be reactive with cement.

Western portion of unit possesses Cretaceous 5 andstones and shales similar in characteristics to those found in Type I grouping. Major areas void of aggregate associated with 1 acial lacustrine areas (Lake Agassiz and Dakota).

Sandy unconsolidated coastal deposits veneer almost entire section. Regional crushed carbonate zones present in portions of the unit; but much of entire Section lacks coarse aggregate.

Widespread loessial deposits overlie non existent crushed stone potential areas

Widespread distribution of fine grained alluvium present throughout most of unit 
have geologic ages which correspond to Cenozcic, Mesozolc, late Faleozolc (Permain and Fennsylvanian) and Early Paleczolc (Cambrian) Eras. It is within the Paleozoic periods older than Pennsylvanian in which the majority of the crushed carbonate zones are found within the united states. The existence of poor sandstone and shale bedrock comprising the modal bedrock within a section is of course not always assoclated with an overall poor aggregate availability rating for the section in question. Examples of sections which, in general, are characterized by relatively soft sandstone and shale bedrock yet possess abundant to adequate potential for aggregates can be noted within the Bighorn Easin (10c), Triassic Iowland Province (18) as well as the Connecticut Iowland Section (19c). Within these units, the widespread distribution of quality sand grivels and/or crushed stone (obtained from variant bedrcck types withir the unit) may override the presence of poor quality crushed stone sources attributable to the sandstones and shales.

\section{Solls and Related Factors}

\section{So11 Crigin}

Uniqueness of Crigin to Basic Report Provinces/Sections In general, the physlographic units viewed at a province level shor: a fair degree of uniqueness of surficial soll origin, although this uniqueness varies consideratly within differing provinces. Table 32 summarizes the estimated 


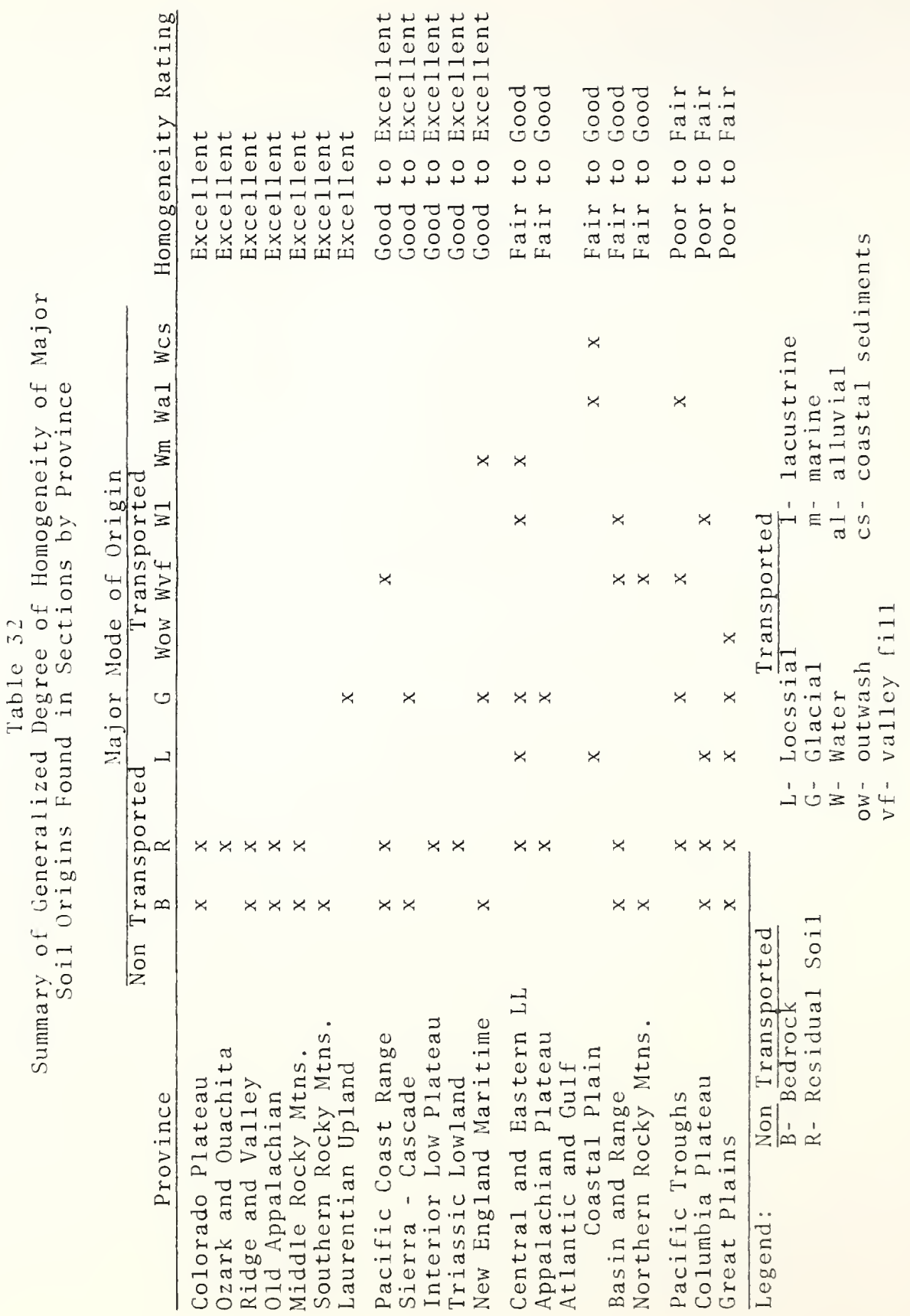


degree of origin homogeneity based upon the major soll origins and their distribution noted within sections of a particular province and previously shown in Table 14. As can be seen from the table, many provinces exhibit an excellent uniqueness by major mode of origin. In addition, several provinces contain minor variant origins to justify thelr homogenelty rating telng slightly less than completely homogeneous. The Faciflc Coast Ranges possess, as a minor variant origin, valley fill depcsits found primarily within the Los Angeles Section. This area is regionaliy extensive but is not the unique origin to the Ios Angeles Section. Within the Sierra-Cascade Frovince cnly a minor fortion of the Nortbern Cascade Section has Leen glaclated. The Triassic Iowland Province similarly possesses a glaciated portion occurring in the northern part of the unit. The Interior Low Plateau, predominantly a Frovince of non transported orlgin, possesses a loessial covering in a regionally signiflcant portion of the Shawnee Hills Section. Hithin the New England Karltime Frovince, sectioning of the Seakoard Lowland and New England Upland Sections generally isclates the marine clays common the the Iowland unit, although the marine orlgin is not entirely unique within the Section.

Although the Central and Eastern Iowland Frovince is primarliy of glacial origin; residual solis, loess deposits, glacial lacustrine as well as marine deposits occur in the province proper. In general, the examination 
cf origin at the section level only slightly improves the uniqueness of orlgins at this reglonal unlt category level. Whin the Appalachian Flateau Province, sectioning of the glaclated Catsklll Mountains and New York Sections provide a perfect unlqueness of orlgins by sections of the Frovince. Tris uniqueness is also exhibited at the section level for the Atlantic and Gulf Coastal Plain Frovince. Although the predominant origin is due to coastal sedimentation, secticning of the province isolates the two major varlant origins in the province. These are the loess deposits (Mississippi Ioessial Upland section) and the alluvial deposits which cnaracterize the Mississippl Alluvial Plains Section. The only minor variant orlgin areas noted after sectioning are found in the glaclated Iong Island and Cape cod areas within tre Embayed Section. The major reason for categorlzing the Easin and Range Province as a "Fa1r to Good" rating is due to the repetitive occurrence of valley flll deposits and the non transported origin areas noted by the mountain ranges of the unit. The major variant crigin unit is uniquelly aelineated by sectioning of the Salton Trough unit. Here the major orlgins are denoted by lacustrine and alluvial deposition. The Northern Rocky Mountain Province is characterized by a northem tier of continental glaclation and an eastern fortion characterized by valley 111 and glacial detris. In general, the effect of sectioning improves the uniqueness of orlgin by physlographic units, particularly 
for the Montana Section, characterized by the basins and valley systems of the section.

The provinces felt to possess the greatest var1ablilty of origin are the Pacific Troughs, Columbia Plateal and Great Plains Province. In general, although the predominating mode of origin of the Pacific Troughs is transported, non transported areas are found within the northern trough. In addition, valley fill areas, alluvial deposits and glaciated regions are existent in the Province. In general, sectioning of the province increases the uniqueness of orlgin by physiographic unit, although non-transported areas are common in both sections of the northern trough. Within the Columbia Plateau Province, non transported origin predominates; however, loessial deposits as well as lacustrine areas are widespread in the Province. Sectioning generally improves the uniqueness of origin by isolating the major loessial deposits to the Walla-Walla Plateau and Snake fiver Plains Sections, as well as the major lacustrine areas to the Payette Section. However, these Sections do not solely possess these origins. The materials of the Great Plajns protably are as variable as the materials within all the provinces of the United States. Non transported areas, water deposited outwash, glacial and loessial deposits exist within the unit. Sectioning of the frovince improves the uniqueness of unit origin romogeneity by delineating the glaciated area (Glaciated Misscuri Plateau Section) and generally restrlcting the outwash to the High 
Ilalns jection. However, loesslal origin areas are not unique to any particular section. The Plains Border sectlon, with its alluvial solls, outwash areas, loessial defosits and non-transported origin areas affords the pcorest indicator of uniqueness in origin displayed by any of the 9 ? basic report sections found in the United States. Relation of Transported Surficlal Crigin Areas to Regional Fhysiographic Units

It 1 s apparent that although several provinces are unique in mode of origin, the examination of physiographic units at a greater level of examination, 1.e., section leve?, improves this uniqueness within a given physiographic unit. However, it should be realized that through simple deductive reasoning between the natural laws inherent to material transport and the principles utilized to delineate physiographic units, a total uniqueness of origin for transported solis can never occur within all physiographic units. The najor reason for the above is aue to the var1able thicknesses assoclated with deposition (and subsequent erosion) characteristic to aeolian, glacial and water transfort. fs a result, where "thin" transported solls partially overlie physiographic units formed upon the gross features characteristic of bedrock, little or no relation to regional physlographic units may exist. Example of this are found extensively with the loessial deposits in the Great flains and portions of the Central and Eastern Iowland Province. In many cases, where a "thin" mantle of transported materlal 
completely covers a physlographic unit jelineated by the underlying bedrock, z "pseudo uniqueness" of origin for that particular regional unit may occur. This is to say, that if the transported material would be stripped from tne area, a new physiographic unit of ldentical outine would be noted. Many examples of this occurrence can te found associated with the glaclal cover of the New England Marit1me Frovince and of the lowlands and valleys in the New York portion of the Central and Eastern Iowland Province as weII as the loess deposits found in the Snake River Plains.

The major reglonal zone where aistinctive regional physlography has developed upon relatively "thick" transported material is found within portions of the Central and Eastern Province. In particular, the Eastern and western Lakes and Lacustrine Sections, Central T1II Plain and Dissected Ioessial and T1Il Plains Sections possess modal topography distinctive to glaciation. If the transported mater$1 a 1$ were not present in these areas, delineation of physiographic units would in no way correspond to the present system and, In fact, wolld be more continuous with tre surrounding non-transported physiographic units.

\section{Poor Subgrade Sucport Areas}

Crganic Deposits

Design Factor Fating Summary. In general, the presence of organic type deposits is an 1mportant highway design factor in only a relatively small portion of the U.S.. Table 33 suminarizes the frequency of occurrence rating of this 


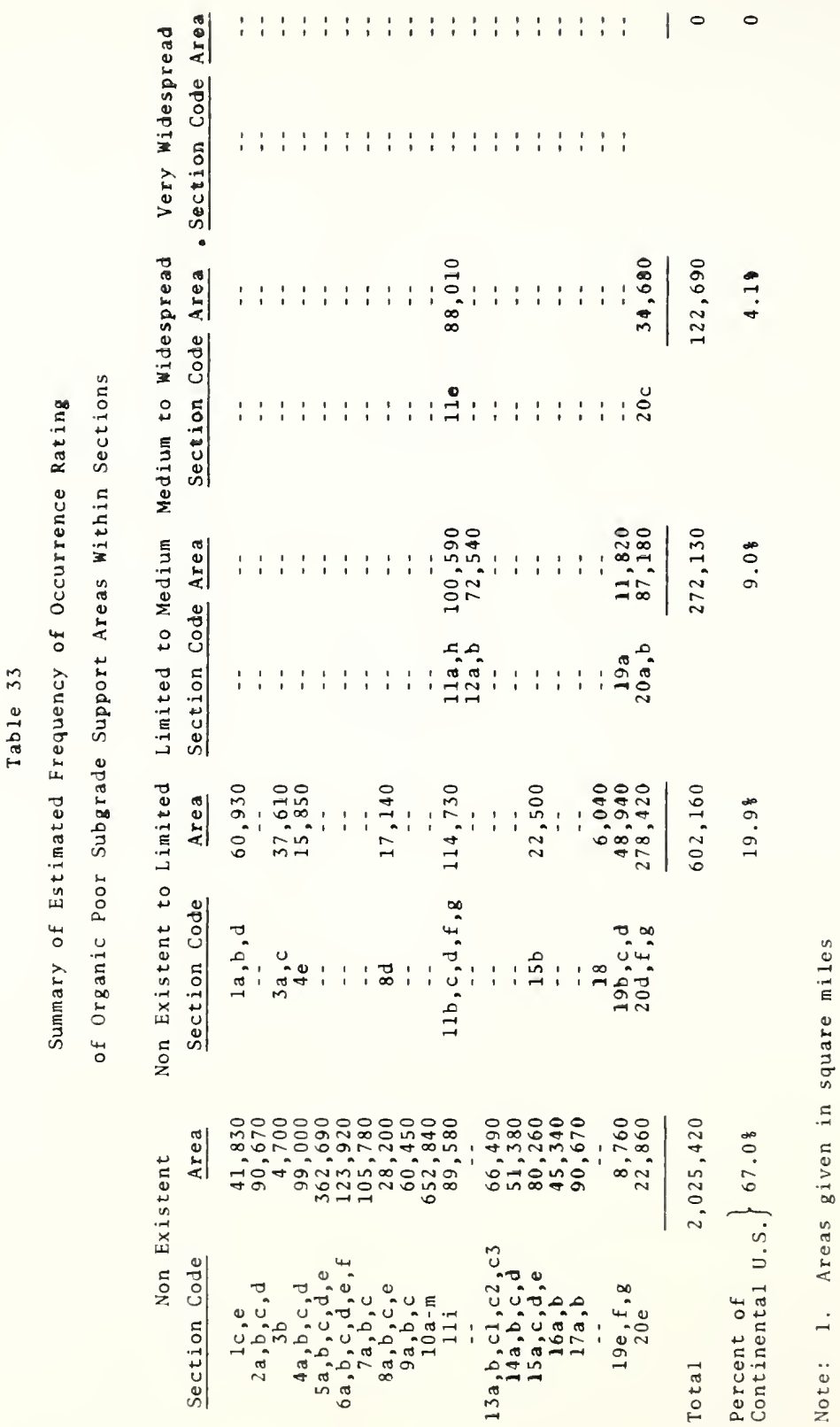


factor of design by sections. Figure 41 lilustrates the distribution of the summary table. In addition, the soli texture maps of the United States, snown in Plgures 16 through 2I, 1Ilustrate the actual regional distribution of these areas. As can be noted from the table, physiographic sections comprising an area of almost $87 \%$ of the united States have, at nost, a non existent to I1mited type frequency rating of this factor.

\section{Distribution.}

General. From a generalized east-west province grouping the greatest frequency of occurrence of organic solls is found in the eastern grouping. The greatest frequency ratings are found within the Eastern Lakes and Iacustrine Plains Section of the Central and Eastern Iowland Frovince as well as the Florida section of the ftlantic and Gulf Coastal Plain Province. It is within these two geomorpic conditions, which characterize these provinces (glaciation and coastal plain development), that the greatest majority of organic type terrain becomes a factor in highway engineering. Table 34 summarizes the Sections by the major geomorphic modes of occurrence. Glaclated Areas. In the westem portion of the United States, the physiographic units possessing organic derosits assoclated with glaclation were noted to exist only in 11 mited parts of the Fuget Sound Section and in the Jackson Hole areas of the Middle Rocky Mountain Frovince. within the eastern group every province possessing glaciated areas 


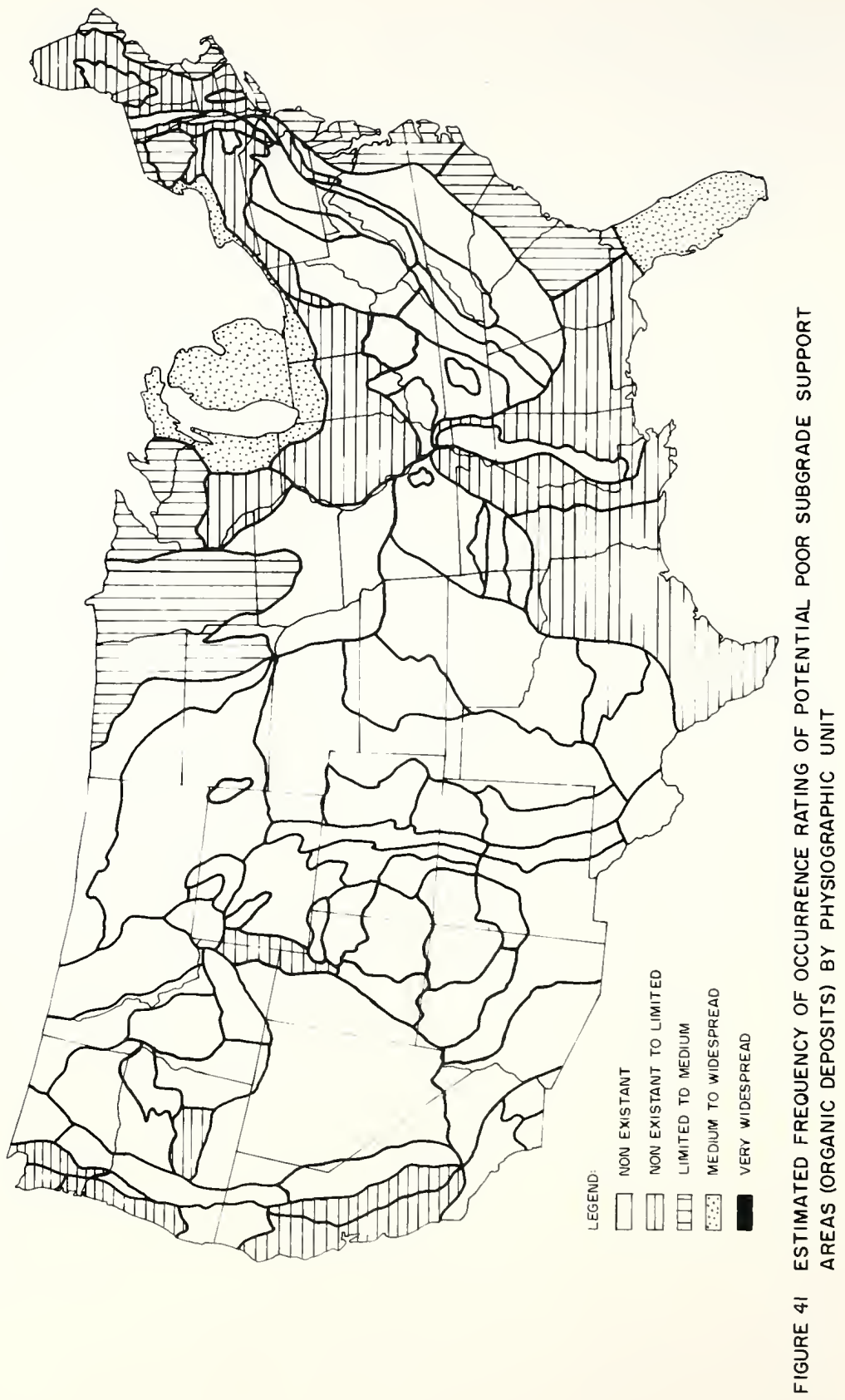


Table 34

Summary of Sections Possessing Organic Type Deposits Grouped by Major Geomorphic Modes

Section/Code

I. Glaciated Areas

Puget Trough (3a)

Wasatch (8d)

Champlain Lowland (11b)

Hudson River Valley (11c)

Mohawk River Valley (11d)

Central Till Plain (11f)

St. Lawrence Lowland (11a)

Western Lakes and Lac. (11h)

Eastern Lakes and Lac. (11e)

Superior Upland (12a)

Adirondack (12b)

New York Glaciated (15b)

Triassic Lowland (18)

New England Upland (19b)

Connecticut Lowland (19c)

White Mountain (19d)

Seaboard Lowland (19a)

II. Coastal and Embayed Areas

Oregon Coast Ranges (1b)

California Coast Ranges

California Valley (3c)

East Gulf Coast (20d)

West Gulf Coast (20g)

Embayed (20a)

Sea Island (20b)

Florida (20c)
Rating Remarks

$N-L$

N-L found with glacial outwash in Jackson Hole area

$N-\mathrm{L}$

$N-L$

$\mathrm{N}-\mathrm{L}$

$\mathrm{N}-\mathrm{L}$

$\mathrm{L}-\mathrm{M}$

$\mathrm{L}-\mathrm{M}$

$M-W$

$\mathrm{L}-\mathrm{M}$

$L-M$

$\mathrm{N}-\mathrm{L}$

$\mathrm{N}-\mathrm{L}$ associated with northern glaciated area

N- L

$N-\mathrm{L}$

$\mathrm{N}-\mathrm{L}$

$L-M$

N-L found within a small coastal plain areas of Oregon

(1d) N-L associated with Section (3c) within San Francisco Bay area

N-L associated with Section (1d) within San Francisco Bay area

$N-L$ occurs primarily in outer coastal plain

$\mathrm{N}-\mathrm{L}$ occurs primarily in outer coastal plain

$\mathrm{L}-\mathrm{M}$

$\mathrm{L}-\mathrm{M}$

$M-W$

possesses largest

swamp area in

United States

III. Deltaic Areas

Mississippi Alluvial Plain (20f)

N-L associated with Mississippi Delta Area 
was noted to have an occurrence of organic type deposits. Altholigh the Trlassic Iowland is generally characterized as non-transported origin (Tertiary sandstones and shales), the nortinem portion of the unit is glaciated. It is within this rather small area where the organic deposits may be found.

With the exception of the mountainous Catskill, sreen, Taconic and Reading Prong Section, every glaciated Enysiografhic section north and east of the New York Glaciated jection was noted to contain organic type terrain. The pattern of frequency of occurrence and distribution of organic terrain found in the glaciated sections to the west of this area is of noteworthy significance. It is within the central portion of the Central and Eastern Iowland Province that the presence and frequency of organic terrain nay be assoclated to the various glacial ice stages of the Iowland area.

Figure 42 shows the distribution of the major ice sheets within this area. It can be seen from comparing either Figure 41 and/or Figures 19 and 21 to Figure 42 that the greatest frequency of organic deposits is associated with the most youthful glaclal substages, Cary and rounger Wisconsin age. As this type of terrain forms the modal topcgraphy of the Eastem and Western Lakes and Iacustrine jections, as well as belng completely present in the superIor Upland Section, the delineation of these physiographic units creates a uniqueness by separating areas of greatly differing frequency of occurrence ratings for organic 


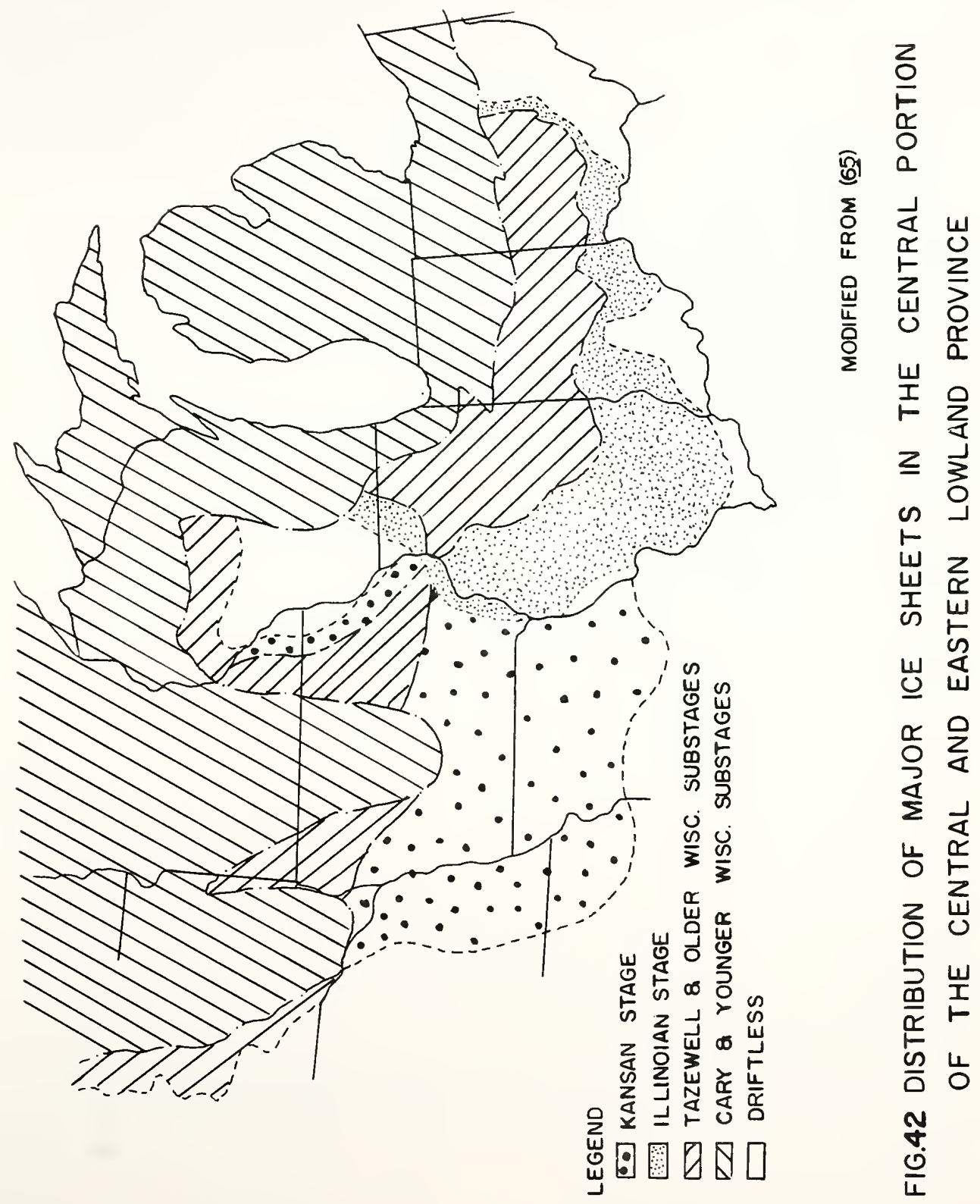


deposits.

Similarily, as older glacial terrains are encountered, the frequency of organic terrain decreases. The oldest glacial drift in the area is Kansan. This glacial terrain, with variable loessial cover, forms the diagnostic topography of the Dissected Ioessial and T1II Pla1n Section (111). As can be seen from Figure 41, organic deposits are non-exlstent within this area.

The major geomorphic reason for this feature is aue to the fact that youthful glacial terrains are of ten associdted with a poorly intergrated drainage system. The presence of this type of drainage system is subsequently conducive to the ficrmation of organic type deposits within young elacial topography.

Coastal and Embayed Areas. Within the western portion of the United States, the sections associated with organic type terrain are found in a small coastal plain region of cregon within the cregon Range Section and Sections in Callfornia assoclated with rather significant organic deposits within the San Francisco Bay area.

Within the eastern United States, the Atlantic and Gilf Coastal Plain Province provides the only physiographic units wivere occurrences of this geomorphic mode are found. From 18 and 20 , as well as F1gure 41, it can ke seen that within the East and west GuIf Coast Sections, only a I1mited quantity of organic deposits is encountered. The Jocation of these areas is also notably confined to the outer 
coastal plain areas of the units.

The Atlantic Plain portion of the Province, particularly the Embayed and Sea Island Sections, generally possessEs a greater frequency of organic deposits tran the Guif sections. The Florida section, in itself, is the most unique organic area in the United States. This Section possesses the largest continous swampland (Everglades) in the country.

Cf final significance, is the fact that the presence of organic type terrain is primarily contalned in the outer portions of the entire Frovince. Recause this province is relatively young and the structure of the sediments is milaly dipping to the outer coastal aress, the younest ieposits are found assoclated with the outer coastai pians. Fence, a general similarity between youthfulress of glacial as well as coastal plain type terrains to the presence and frequency of organic terrains is noted. Deltaic Areas. As can be seen from Figure 18, the Mississippi. Fiver delta area, within the Mississippi Alluvial Plain Section, is a fairly extensive area of organic type terrain. Inorganic Deposits ${ }^{1}$

Design Factor Rating Summary. Table 35 summarizes the est1mated frequency of occurrence- severity rating of clayey soli type areas within the basic report sections of the united

I. Throughout this portion of the report, the wort "clay" is meant to imoly plastic properties of a soll ratier than pure textural connotations. 


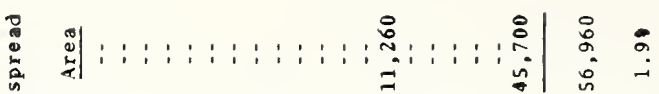

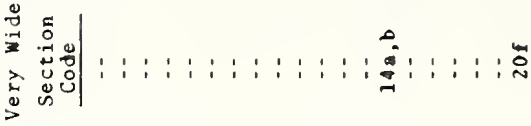

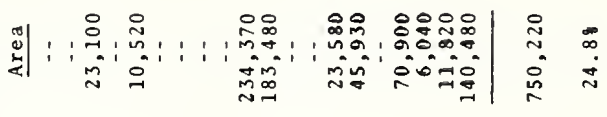

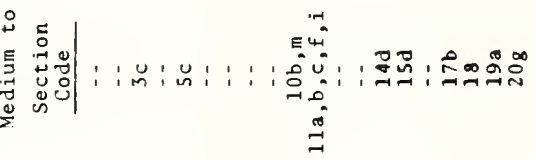

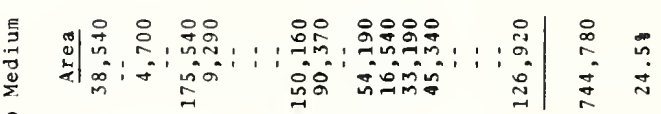

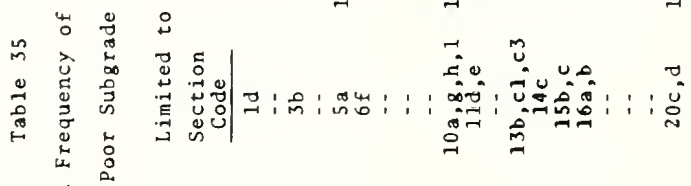

$$
\begin{aligned}
& \text { 足 }
\end{aligned}
$$

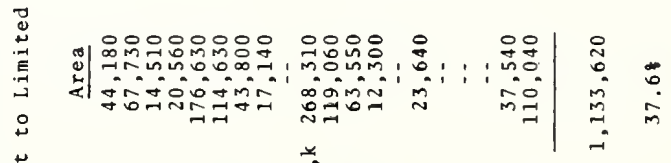

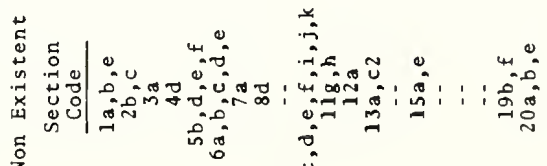

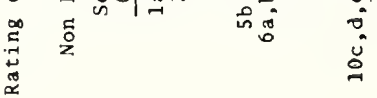

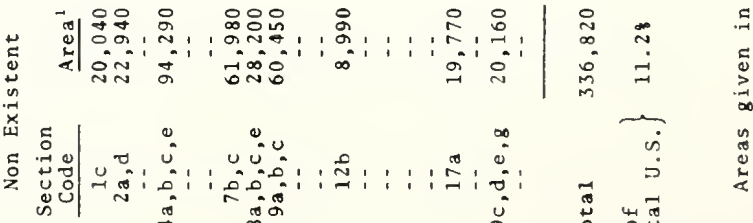

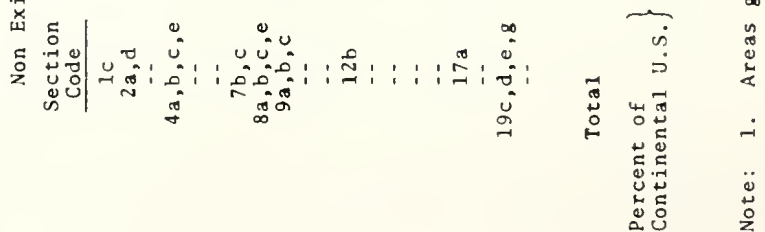


States. Figure 43 illustrates the distribution of these ratings. A most notable generalized point of the summary illustrates the relative lack of clayey type areas existent within the western province groupings in contrast to those found in the east. Approximately $75 \%$ of the western province groupine area possesses sections having a rating of less than or equal to a non existent to 11 mited severity rating; while only slightly greater than $3 \%$ of the area has sections showing a medium to widespread or greater rating. In contrast, the eastern group has almost 40 of of 1 ts area having sections with a medium to widespread or greater rating.

There are several probable reasons for the above pattern, each perhaps interrelated to the cthers. It is felt that the major factors are due to the following:

1. The climatic environment (humid type) prevelent in the east is more conduclve to chemical weatherirg frocesses which generally are associated with clay development in contrast to physical weathering.

2. The overall topographic features (elevation, relief) of the eastern Unted States are likewise nore favorable for chemical weathering in combination with the climatic regime of the area.

3. The grouping of origin-parent material types in the east are conducive to clay deposition and/cr development. Within the glaciated northern portion of the area, 


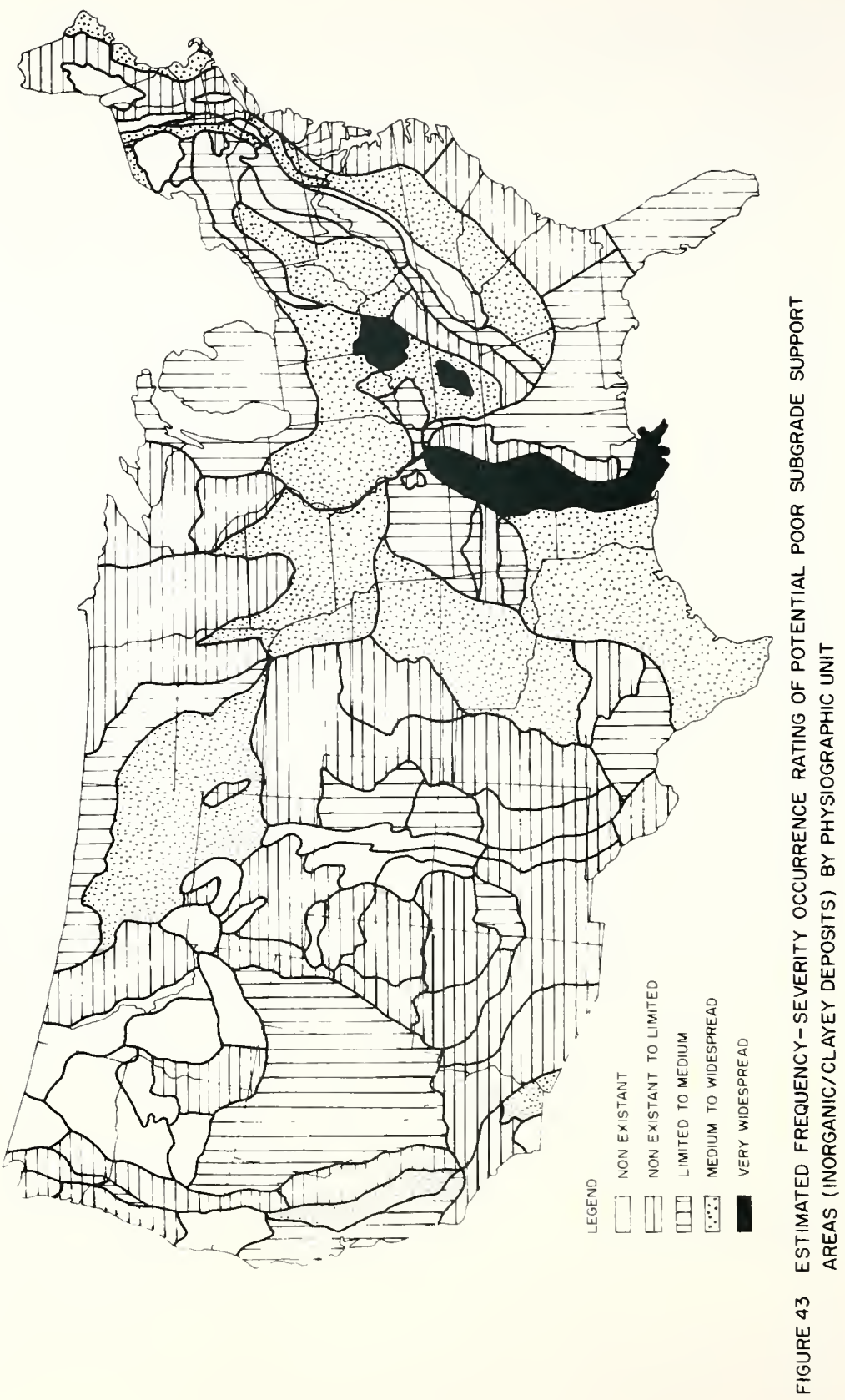


the rost highly plastic solls are generally assoclated with water deposition from glacial lacustrine or marine origin. Iikewise the clays of the coastal plain are primarliy found associated elther w'l th the coastal I1mestones and chalks or widespread fine grained alluvial deposition. Within these two zones lies the consolidated bedrcck region. This area is composed primarliy of sedimentary types, in which clayey type residuum is often developed within the climatic and topographic environments peculiar to this region.

\section{Distribution.}

General. Within the ensuing alscussion on the general distribution of clayey type poor subgrade support aress, the discussion sequence of these areas is conducted by major origin groupings within the east and west province zones. The reader is referred to Table 14 for the general I1stings of major orlgin by province. western Province Group. Within the mountainous provinces of the west, most potentially poor subgrade support areas are assoclated with residual soll development. In general, these areas are not widespread relative to the total area comprising the units nor are they generally considered to be of a heavy clay category. The most frequent occurrence of the clayey solis occlirs within the California Coast Range jection where the major parent materials are sancistenes ant shales. Smaller areas of lean clays also exist within the Cregon Coast Fange Section and Wasatch Section (Widile Focky 
Nountain frovince). Residual lean clays developed from Eranite may also be found within portions on the western llank areas of the Sierra Nevada Section. Clays of a more plastic nature are found near the western flank of the jouthern Cascade Section associated with residual development ircm basaltic type rocks. These latter two clay areas do nct forn a significant portion of the modal soll conditions (or lack thereof) that are existent within the particliar section in question. The only other regionally defined area of clay solis found in the mountainous provinces of the west are associated with the Montana Section of the Northern Focky rountain Province. Within this Section, the clays, I'requently of a "varved" nature, are generally confined to the tasins which characterize this section as a unique topoEraph1c area.

Within the Columbia and Colorado Plateau Frovinces, clayey or poor subgrade soll conditions are enerally not very widespread. The lacustrine areas, characteristic to the Fayette section of the Columbia Plateau, may be associated with the most potentially plastic solls of the Province. lastic clay solis found within the Colorado Plateau Province are Eenerally assoclated solely with the shales and clay shales of the frovince. The occurrence cf these solis is common to each section of the Province but the greatest irequercy of cccurrence is found in the easterr sections. In general, the predominating texture of the residual soils 
fcund in both the Columbia and Colorado Plateau Provinces appears to be a thin sandy type residium.

In general, the most potentially severe subgrade support conditions occurring in the western provinces are asscciated with deposition by water. Plastic solis asscclated with alluvium and valley fill are frequently encountered within the central portions of the California Valiey Section. The willamette Valley Section in addition to possessing clayey solls from residual basalts and sandstores and shales, alsc has much alluvial plain deposits of a fiastic nature. Within the Basin and Range proper, the major areas of potential clay areas are those associated with the old lacustrine deposits and fine textured valley flil occurring within the central portions of the basins. A fairly significant poor subgrade area is found within the Salton Irough section from the widespread lacustrine and alluvial derosits cf the area.

Eastern Province Group. Within the three Frovinces completely veneered (or nearly so) by glaclation (Certral und Eastern Lowland Province, Laurentian Upland Frovince, and New England Marltime Province) the greatest overall frequency of clayey type occurrences is, by far, found within the Central and Eastern lowland Province. The most highly plastic solls noted within the provinces appear to be uniquely assoclated with water deposition.

The only occurrence, within the entire New England Maritime Province, of poor subgrade clay areas is associated 
with the marine deposits found primarily within the Seaboard Icwland jection. Of the two sections comprising the Iaurertian Upland Frovince, the Adrondack Section completely lacks any regional clayey deposits while the Superior lpland jection fossesses only minor areas of clayey solls, associated with lacustrine origin.

The Central and Eastern Iowland Province and the corresponding section level breakdown afford a falrly unique framework for discussion of clayey deposits within the unit. Clay solis within the Province are assoclated with glacial lacustrine, marine and some glacial drift deposits. However, the nost highly plastic deposits are those associated with the Elacial lacustrine and marine areas. The lacustrine areas are generally uniquely confined to the Eastern ard Western Iakes Sections and are pecliliar, like the occurrence of organic deposits, to the Cary and Younger Wisconsin drift areas. The marine defosits are likewise exclusively associated w1th the eastern sections of the Province; occurring within the St. Iawrence Lowland, Champlain Lowland and Hudson kiver Valley Sections.

In contrast, the older glacial arift sections Central Till Plain and Dissected Loessial and T1II Flains jections) lack the highly plastic lacustrine areas, but senerally afford a wider distribution of leaner clays attritutable alrectly to the arift texture.

The most plastic till solls appear to be associated with the older (IIIInoian and Kansan) drift. These drift 
sheets are generally found, respectively, within the central Till Flains and Dissected Loessial and Till Flains Sections of the Frovince. Drift of a leaner variety comprises the remaining portion of the Central Till Flain sectIon (Tazewell and Clder Wisconsin) and is also found in the western and southem portions of the western Iakes and Iacustrine section (Cary and Younger wisconsin).

Ifike the wide variety of clay solis and origins conmon to the Central and Eastern Iowland Frovince, the Atlant1c and Gulf Coastal Flain Frovince alsc exr.1rits tris variability. In general, poor subgrade support regicns irom clayey soils are more pronounced in the Gulf portions rather than within the Atlantic coastal areas. The only jotential regional area of clays found in the Embayed Section occurs within the Cretaceous Faritan Iowland Area. Heavy Flastic clays are found throughout the Florial Section, geveraliy in conjunction with limestones and marls common te the area. within the East Gulf coast Section highly plastic solis are normally associated with the Cretaceous chalks and I1mestone: common to the inner (belted) coastal plain. similar geologir and geomorphic occurrences of clayey solis are also found in the west Gulf coast Section. In adaition, large areas of marine clays form much of the outer coastal plain witrir. the west GuIf Coast Section. The presence of the latter two types of poor subgrade areas, plus the clayey solls asscciated with much of the alluvium in the area constitute a very 
sizeable portion of the total area within this section. The Mississippi Alluvial Plain Section, within the Coastal Province, constitutes one of the largest and homogeneous poor subgrade support areas in the United States. In seneral, most of the alluvium is very fine grained and afiords hlghly liastic scli conditions.

A large portion of the concentration of poor subrade support conditions in the eastern provinces is assodited with the residual development of clayey solis. Cne of the rore extensive zones of clayey type soils is that found within the pledmont jection of the Cld Appalachian Flateau Fovince. Lean to plastic clay solis are derived and witespread from a wide varlety of granites, gneisses, scnlsts and basic lgneous rocks.

$$
\text { Eesidual solis, frequently of a highly flastic }
$$

nature, are associated with I1mestone in many sections of the east. Extensive areas are found throughout much of the Springfjeld-Salem Plateau Section of the Czark and Cuachita Frovince, Interior Iow Plateau Province and Rldge and Valle; Province. However, within many of these areas, the I1mestcne 1s îrequently quite cherty and residuum may frequently contain varicus percentages of these chert, or gravel, particles. Jandstones and shales frequently may also residually weather Into foor subgrade support areas. Cne of the more proncuncei examples of this condition occurs within the Kanawha Secticn of the Flateau Irovince. Within the Frovince lean clays are also assoclated with the glaclal arift of the New York 
Glaciated Section. In general, the plasticlty of this drift texture appears to be greater in the western (chio) portion of the unit.

Highly plastic solis may also te assoclated with the sandstones and shales characteristic to the Triassic Lowland Frovince, Boston Mountain, Arkansas Valiey and portlons of the Cuachita lountain Sections. Within the Great Flains Province, the overall residual character of the sandstone and shale sections appears to be of sandy silt variety; however, solls assoclated directly with the shales and clay shales are generally plastic. The major exception to this occurs within the csage Plains section of the Province. NitiIn this unit much of the residual nature of the sof 1 nay te assoclated with highly plastic soll conditions. Within the glaciated portion of the Province, the overall drift character is of a clayey varlety, increasing in plasticlty chiracteristics to the west. High Volume Change

Design fiactor Rating Summary

Table 36 summarizes the final ad justed irequency of occurrence rating for high volume change solls by sectior. Figure 44 11lustrates the distribution of these ratings withIn the continental United States. Eased upon the analysis, high volume change solis are existent, to some degree, within

* The material in this portion of the report is primarily based on the work by Jensen (333). 


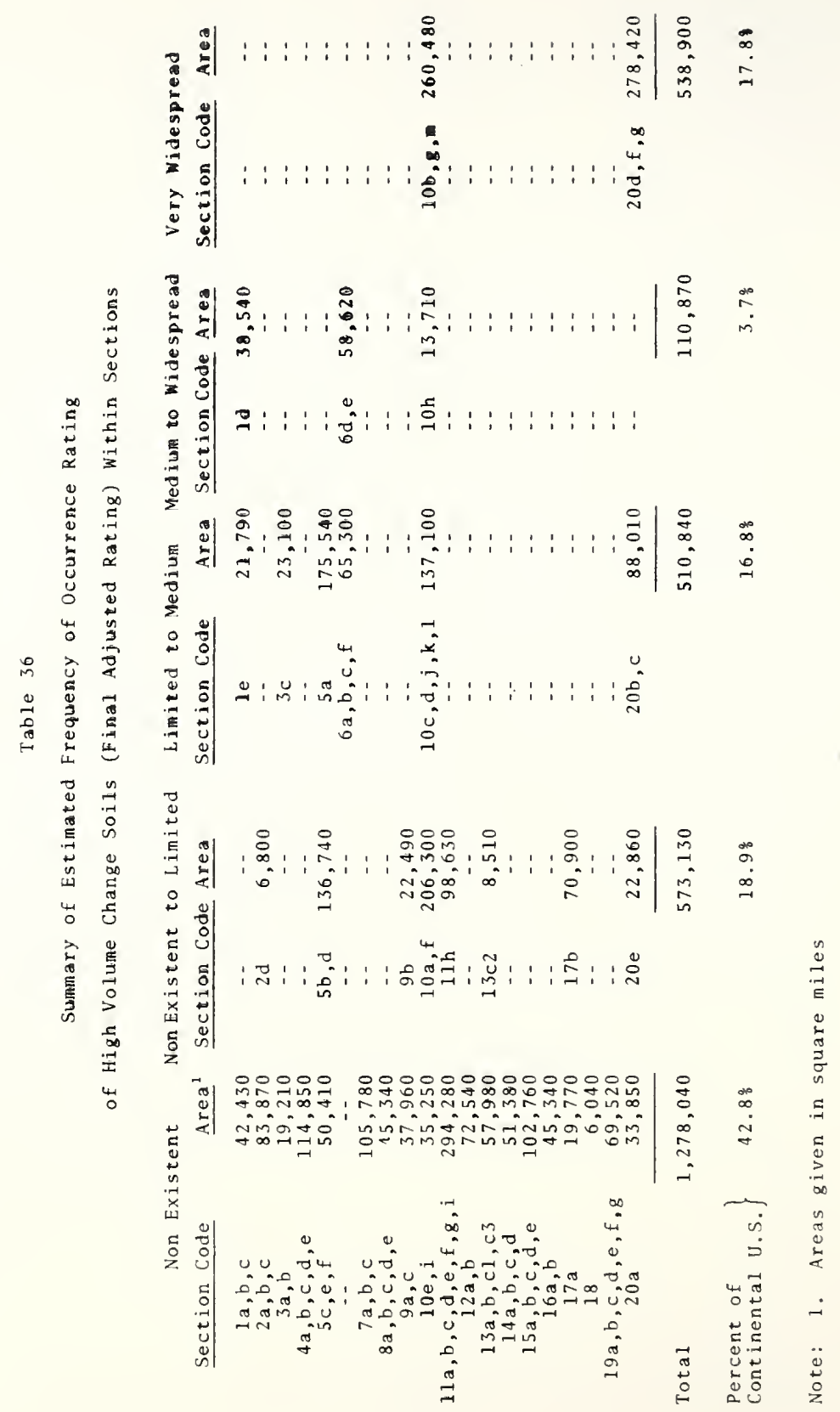




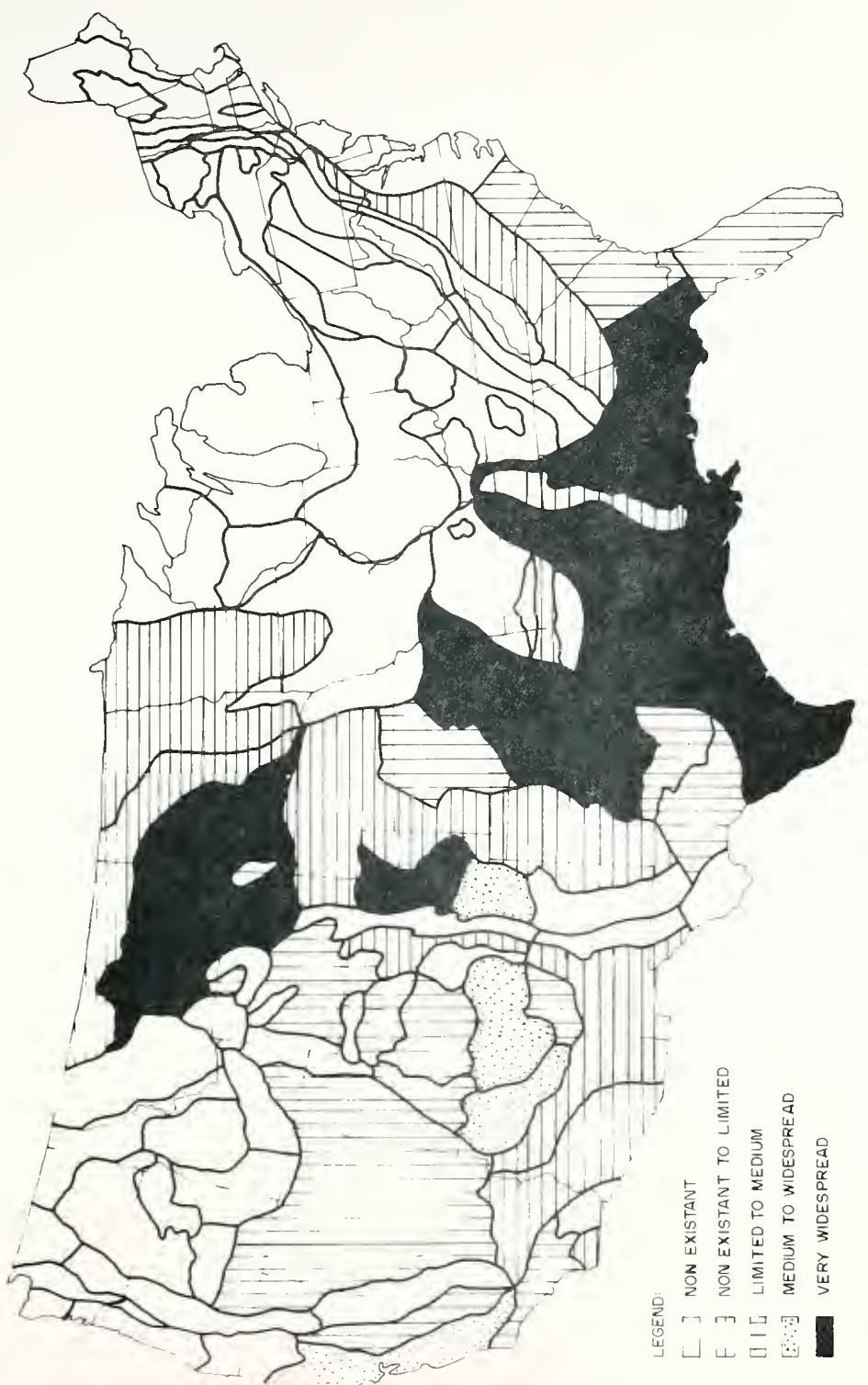

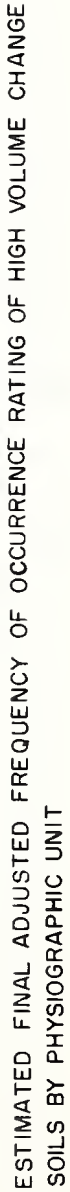

竎 
sections hiving a combined area percentage of over 57 of the united jtates. In addition, sections comprising $22 \pi$ of the inited states have been noted as having a f'requency fi cocurrence ratine nore severe than $11 \mathrm{mited}$ to medium. In essence, the alstribution of tris problem and its subsequent importance upon proper highway design and performance is a problem in a sizeatle portion of the country. Eistriklition General. Within the twenty (20) Physiographic provinces conprising tre United states, high volume change solls have teen noted to exist within half of them. The greatest frequency of occurrence of these high volume change solls occurs witrin the Great Plains and Atlantic and Gulf Coastal Plain Erovinces. These Provinces constitute the western and soutnern areas of the eastern Province grouping. The discussion which follows is grouped according to the generalized eastwest province groupings to afford a maxium insight into the aistribution of tinis problem.

Western Province uroup. Although seven of the nine provinces comprising the western group were noted to possess high volune change solis, the frequency of occurrence in a large portion of these units is, by no means, widespread. Within the Southern Rocky Mountain Province, Jensen $(Z=)$ notes the existence of small scattered areas within the Jan Iuis Valley portion of the Western section. These areas were mapped on a Pedologic basis and correspond to the Iahontan series which is associated predominantly with identical 
geomorphic units found in the closed Basin sectjor but locally occur within the Sonoran Desert and Cpen Easin jecttions.

The high volume change areas ncted within the iacif1c coast Range Frovince are associated prinarily with the clayey solls developed residually fror the sandstones and shales within the area. The most irequent occurrence of these solis is contained within the Callfornia coast Range jection where these rocks are the modal bedrock to the unit. These same solls however, are continuolis along much of the California coast Iine to Mexico. As a consequence, they are noted to exist within the Los Angeles and Iower California Sections proper; however, they are not considered as the nodal bedrock of elther of these preacminantly granitic units. Within the Facific Troughs Province, the Calitomia Valley jection, with its associated clayey valley jeposits, was noted on the basis of both a geologic and pedologlc analysis to exhibit volume change areas. The areas marped within the Colorado Plateau Province are generally associated with the presence of Cretaceous sandstones and shales and clay shales found throughout the Frovince. The Medium to idespread rating within the Grand Canyon Section may not represent the correct potential rating. The area mapped in question is the Valera series, associated with residui ilmestones. Based upon the basic map reference used by Jensen in the pedologic mapping phase, the Valera series occurs prinarliy within the Edwards Flateald unit of lexas as well 
as. In the Grand Canyon Section of Arizona. However, based won work done by the author concerning soli textural distritution within the united States, the residual soli from the Iimestone in the Grand Canyon Section is silty in nature, in contrast to the clayey residuum noted within the Edwaris Zlateau Ifmestone.

Eastern Frovince Group. Within the eastern portion of the united itates, four of eleven provinces were noted to possess areat showing high volume change characteristics. Cf these icur provinces, twc are felt to be of rather insignificant Tagritude in Jefining the scope of the high volume change rrotien. Wltnin the Central and Eastern Iowland Frovince, tre criy ares noted by Jensen occurred in association witr. tre wher ceposited clays within old glaclal lake Agassiz (Ke) River Iowland). This occurs within the Western Iakes and Iacustrine Section of the Province and is the only reason for noting this area as a Non Existent to I1mited irequency. The rocks within the pledmont (Iredell soll series). These units were mapped only up to South Carolina by Jensen. The occurrence of this material is generaliy minor in comparison tc the granites, gnelss and schists of the piedmont flateali jection; however, it is an important clay soll as it is 0 : $^{2}$ tre montmorilionite variety.

The two provinces possessing the greatest occurrence of high volume change solls within the entire united states are the Great Plains and Atlantic and Gulf Coastal Flain. 
Vithin the latter the greatest concentration of these sullis are associated with the Gulf portion (Including filorifiz section) of the Province. The major solls associated with potential high volume change within the Florida Secticn are associated with the plastic clays from the Ccalla and similar Inmestones of the unit. Within both the East and west Gilf Coast jections, clayey soils are associated with cretacecus deposits forming the lowland belts (Selma chalk, Austin chilk and Taylor Narl). In addjtion, lowlands forned by the Eocene (Tertiary) Jackson formation possess similar higl: volitse tendencies within the East Gulf. The West Guif Coast BectSon also has clayey marine deposits along much of $t$ ts coastine wich exhibit this characteristic. The Mississiri Alluvici Plain Section, with its fine textured dluviun, tho possesses a very widespread distribution pattern of these potentiai volume change so1ls. The non existert to limited rating of the Hississippl Loessial Upland is due solezy to the preserce of similar type alluvium prezent in the section snd not the loessial depositis, which form the moda? farent ratertai cl the unit.

The sections noted to possess the incet severest rating of frequency within the Great Flains Frovince in' the Csage Plains, Colorado Fledmont and Unglaciated iriscurl liateal. The parent material with the latter two secticns are characterized strongly by the presence of Iertipry and iretaceous sandstones, shales and cliay shales, nct too issimilar to the righ volume change areas associated with 
much cil the Colcradc Flateau Frovince. The most frequent potential soll showing high volume change characteristics in the Csage Plains is the Permian sindstones and shales of the urit. The reason for the non-existent to Iimited rating assoclated with the High Plains section is similar to that explained for the Mississippi Loessial Upland Section. The potential high volume change areas in the High Plalns sectIcn are associated with geologic formations common to the Plairs Border jection. This unit occurs as an interfingering occurrence across the indefinite border area which separates the two sections. Hence the rating of the section is attributable to a variant material rather than the modal Tertiary outwash of the area. (ieneral Geologic-Crigin/Parent Material Inferences

As can be noted from Table 18, the summary of geologic formations noted to exhibit high volume change conditions within the United States are primarily associated with geologic youthfulness. Cenozoic and Mesozolc Eras are the most frequent occuring whlle Permian (late Paleozolc) also exhibits solls of a high volume change nature. However, the reader should not be misled that older geologic formations do not possess the potential for high volume change. The inportant point to be made is that within the western portion of the United States, most of the older geologic formations are associated with the mountainous topography of the area, generally not conductive to the development of residual clayey solls. Within the eastern united States, it has been 
previousiy stated in the discussion of poor suberade support (clayey) areas that, many reglonal clay soli areas resldually developed from older faleozolc and even fre Camtrian formations exist. However, as noted in the general alscussion of the influence of the climatic variable ufon regional high volume change conditions in the next section, the rumid climatic environment found in the location of these scli areas is generally not conducive to the develcpment of high volume change occurrences on a regional level of txamination. Frcm Table 20 , it can be noted that a wide variety of origin-parent materials are noted to be of potential high volume solls. An obvious and notable origin not present is that of an aeolian (loessial) nature. The mechantes of geolian transport generally restrict the occurrence of cohesive or plastic clays within aeolian jeposits. Ioessial solis are generally uniquely non potentlal high volume change solis even within very favoratle climatic environments to the shrink-swell conditior.

Importance of Climate Upon the Regional Distribution of High Volume Change

The high volume change problem encountered in portlons of the country is a phenomena due to the complex interrelationship between a potentially high volume change soll and a variation in the soll-water equilibrium. It is $1 \mathrm{~m}-$ portant to recall that the analysis of the high volume problem conducted by Jensen from an englneering case study viewpoint, in essence, refjects the complex combination of both 
the soll and water-balance factors. As all clayey type so1ls nave a pctential for swell, and it has been noted that large areas cf clayey solls are found east of the generalized Iimit of specific high volume change locations noted by ilgure 22; the effect of climatic conditions plays a cominate role in the high volume change phenomena.

The ability to collectively determine a single climatic parameter and 1 ts alstribution in the United States, which takes into account all the inherent factors of the soll-water kalance plcture, has not been undertaken for the Lnited states. However, some attempt has been made for the eastern United States ( 325$)$. Jensen has noted that the Lilization of combining major variables which measure the major inconing phase (average annual precipltation) and the misor clitgoing phase (average annual potential evapotransflretion) of the water balance provides a falrly good, but. general, indicator of the average water balance for the year.

Figure 45 shows the areas where average annual precipitation $1 \mathrm{~s}$ less than the average annual potential evapotranspiration. The aajor $1 \mathrm{mpl}$. cation of the areas noted within the diagram is that a falrly good probability exists tnat the soll may be dried out scmetimes iuring the year and hence provide a triggering mechanism for high volume charge ccurrense.

is can te seen from a generalized comparison tetween 


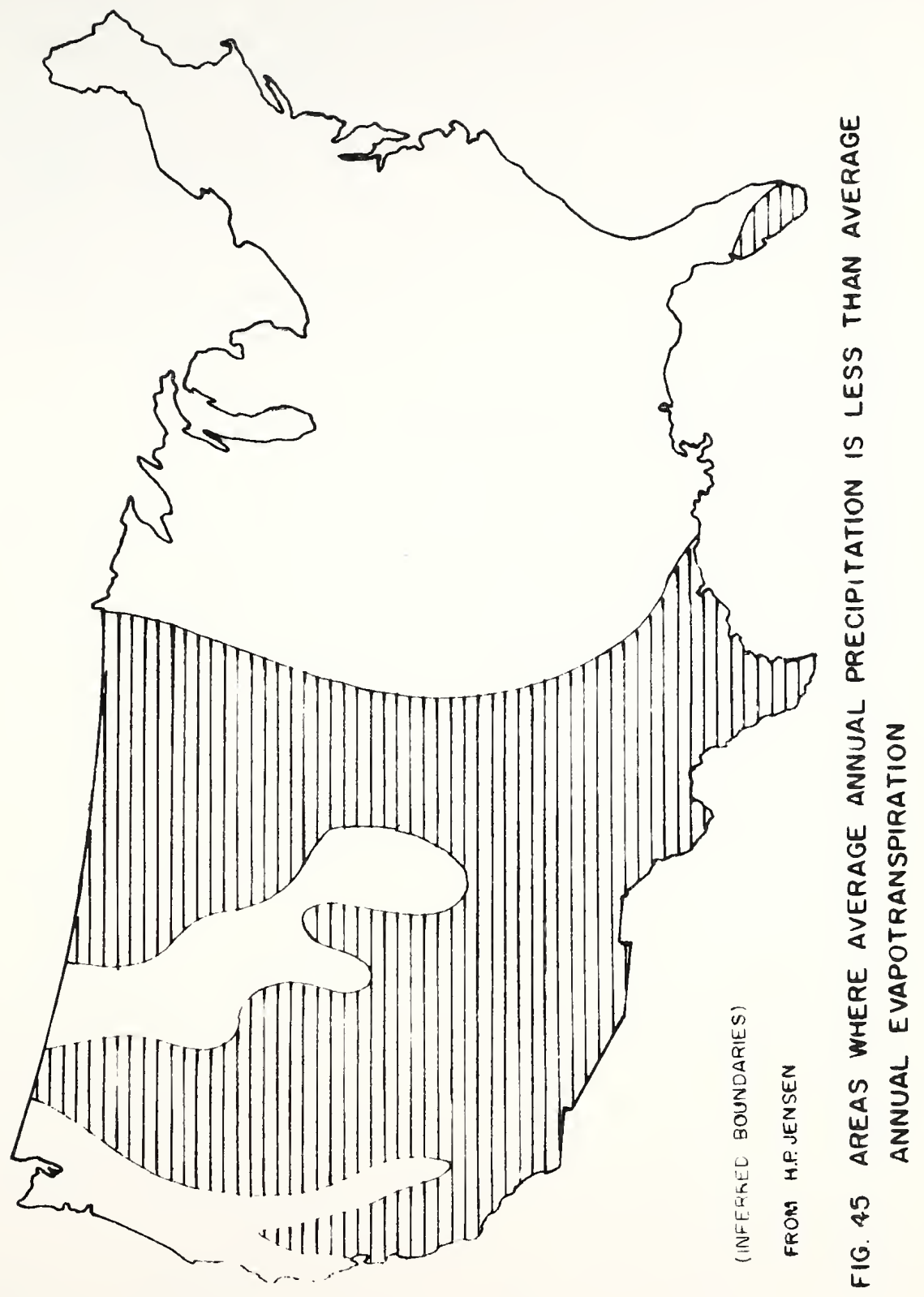


Figure 22 and 45 , a good agreement between most of the case study iocations and the area noted in Figure 45 seem to exist. The major area not noted within Figure 45, where the case study indicates à high volume change occurrence has taken place, is found in the eastem gulf coast regions. Jensen, nowever, has noted thot within much cf this area a marked summer deficlt in the water balance has been reported in the 11 terature $(325)$. Frcst and Frcst Susceptible Solis Distritution

General. The frequency of occurrence rating for each category of frost susceptitle soll within a section ras been noted in Table 24 of the Results portion of this report. Table 37 summarizes the results by type of frost susceptitle soli relative to the frequency rating and section of occurrence. Tatle 38 summarizes the largest frequency rating and sutseguent frost susceptible soli type for each section. Reference to these tables is made within the ensuing aiscussicrs.

In general, the western province grouping is characterized, quite extensively, by either non frost susceptible areas (tedrock) or by $\mathrm{F}^{4}$ solis. The eastern province grourings consist of a somewhat equitable distribution of both F3 and F4 soils. These facts are generally apparent from Takles 37 and 38 .

These generalized statements are consistent with the discussion previously provided for poor subgrade support. 
Table 37

Sumary of Section Frequency of Occurrence

Rating by Frost Susceptible Soil Type

\section{F4 Soils}

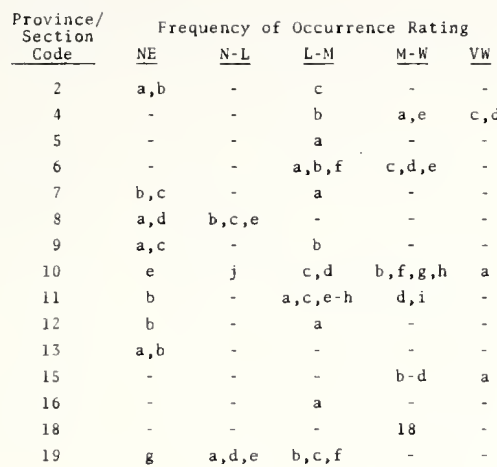

F2 Soils

\begin{tabular}{|c|c|c|c|c|c|}
\hline \multirow{2}{*}{$\begin{array}{c}\text { Province/ } \\
\text { Section } \\
\text { Code } \\
\end{array}$} & \multicolumn{2}{|c|}{ Frequency } & \multicolumn{3}{|c|}{ Occurrence Rating } \\
\hline & $\underline{N E}$ & $\underline{\mathrm{N}-\mathrm{L}}$ & $\underline{L-M}$ & $\underline{M-W}$ & $\underline{\mathrm{VW}}$ \\
\hline 2 & $a-c$ & - & - & - & - \\
\hline 4 & $b, c, e$ & d & $\mathbf{a}$ & - & - \\
\hline 5 & - & a & - & - & - \\
\hline 6 & $a, b, d-f$ & c & - & - & - \\
\hline 7 & $a, c$ & $b$ & - & - & - \\
\hline 8 & $\mathrm{a}-\mathrm{e}$ & - & - & - & - \\
\hline 9 & $a-c$ & - & - & - & - \\
\hline 10 & $b-e, h, j$ & a & $f, g$ & - & - \\
\hline 11 & $a-d, f, i$ & h & $\mathrm{e}, \mathrm{g}$ & - & - \\
\hline 12 & b & a & - & - & - \\
\hline 13 & $a, b$ & - & - & - & - \\
\hline 15 & $a-d$ & - & - & - & - \\
\hline 16 & a & - & - & - & - \\
\hline 18 & 18 & - & - & - & - \\
\hline 19 & $c, e-g$ & $a, b, d$ & - & - & - \\
\hline
\end{tabular}

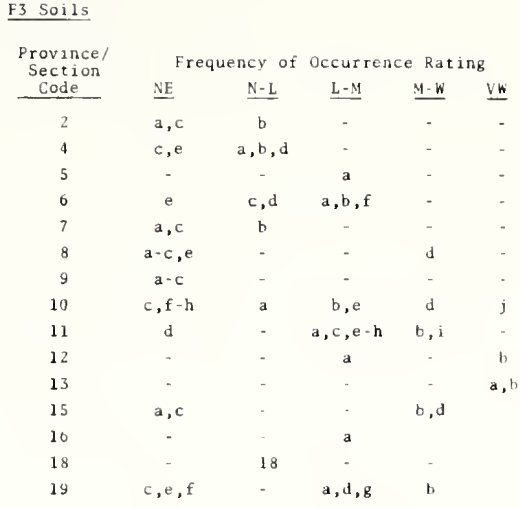

F1 Soi1s

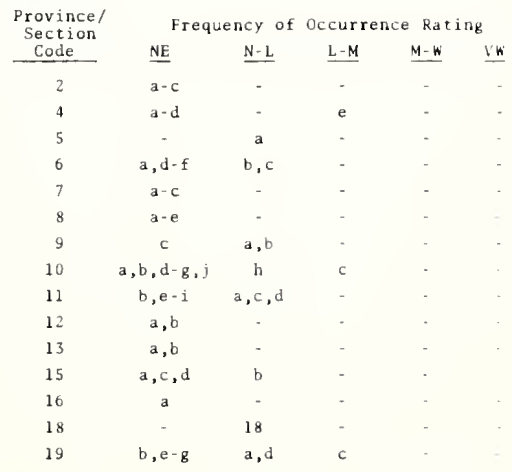

NFS Soils (Includes 8edroch)

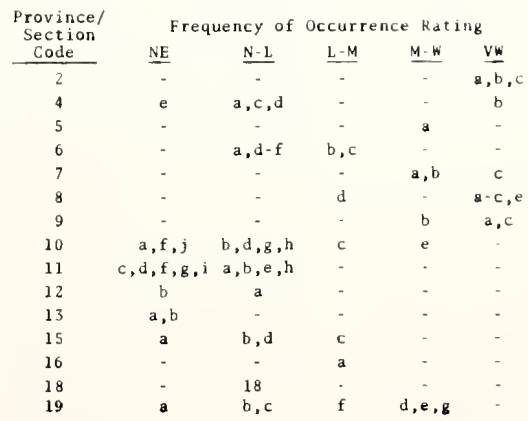


Table 38

Summary of Highest Frequency of Occurrence Rating

of Frost Susceptible Soil Category By Section

\begin{tabular}{r}
$\mathrm{Sec}$ \\
$\mathrm{Co}$ \\
\hline 2 \\
2 \\
2 \\
4 \\
4 \\
4 \\
4 \\
4 \\
5 \\
5 \\
6 \\
6 \\
6 \\
6 \\
6 \\
6 \\
7 \\
7 \\
7 \\
8 \\
8 \\
8 \\
8 \\
8 \\
9 \\
9 \\
9 \\
10 \\
10 \\
10 \\
10 \\
\\
\\
\\
\\
\\
\\
\\
\end{tabular}

\begin{tabular}{|c|c|}
\hline Frequency & Soil Type \\
\hline VW & NFS \\
\hline VW & NFS \\
\hline VW & NFS \\
\hline$M-W$ & $\mathrm{~F} 4$ \\
\hline VW & NFS \\
\hline VW & F4 \\
\hline VW & $\mathrm{F} 4$ \\
\hline$M-W$ & F4 \\
\hline$M-W$ & NFS \\
\hline$L-M$ & F3, F4 \\
\hline$L-M$ & F3, F4, NFS \\
\hline$M-W$ & $\mathrm{~F} 4$ \\
\hline$x-w$ & F4 \\
\hline$M-W$ & F 4 \\
\hline$L-M$ & F3, F4 \\
\hline$M-W$ & NFS \\
\hline$M-W$ & NFS \\
\hline VW & NFS \\
\hline VW & NFS \\
\hline VW & NFS \\
\hline VW & NFS \\
\hline$M-W$ & F 3 \\
\hline VW & NFS \\
\hline VW & NFS \\
\hline$M-W$ & NFS \\
\hline Vw & NFS \\
\hline$V W$ & $\mathrm{~F} 4$ \\
\hline$M-W$ & F 4 \\
\hline$L-M$ & $\mathrm{~F} 1, \mathrm{~F} 4, \mathrm{NFS}$ \\
\hline$M-W$ & F3 \\
\hline
\end{tabular}

\begin{tabular}{|c|c|c|}
\hline $\begin{array}{l}\text { Sect ion } \\
\text { Code }\end{array}$ & Frequency & Soil Type \\
\hline $10 \mathrm{e}$ & $M-W$ & NFS \\
\hline $10 \mathrm{f}$ & $M-W$ & $\mathrm{~F} 4$ \\
\hline $10 \mathrm{~g}$ & $M-W$ & $\mathrm{~F} 4$ \\
\hline $10 \mathrm{~h}$ & $M-W$ & $\mathrm{~F} 4$ \\
\hline $10 \mathrm{j}$ & VW & F3 \\
\hline $11 a$ & $L-M$ & $\mathrm{~F} 3, \mathrm{~F} 4$ \\
\hline $11 \mathrm{~b}$ & $M-W$ & $\mathrm{~F} 3$ \\
\hline I1 c & $L-M$ & $\mathrm{~F} 3, \mathrm{~F} 4$ \\
\hline $11 \mathrm{~d}$ & $M-W$ & F4 \\
\hline $11 \mathrm{e}$ & $L-M$ & $F_{2}, F 3, F 4$ \\
\hline $11 \mathrm{f}$ & $\mathrm{L}-\mathrm{M}$ & $\mathrm{F} 3, \mathrm{~F} 4$ \\
\hline $\mathrm{I} 1 \mathrm{~g}$ & $L-M$ & $\mathrm{~F}_{2}, \mathrm{~F}_{3}, \mathrm{~F} 4$ \\
\hline $11 \mathrm{~h}$ & $\mathrm{~L}-\mathrm{M}$ & F3, F4 \\
\hline $11 \mathrm{i}$ & $M-W$ & F 3, F4 \\
\hline $12 \mathrm{a}$ & $L-M$ & $\mathrm{~F} 3, \mathrm{~F} 4$ \\
\hline $12 \mathrm{~b}$ & VW & $\mathrm{F} 3$ \\
\hline $13 a$ & VW & $\mathrm{F} 3$ \\
\hline $13 b$ & VW & F3 \\
\hline $15 a$ & $\mathrm{VW}$ & F4 \\
\hline $15 b$ & $M-W$ & F3, F4 \\
\hline $15 c$ & $M-W$ & $\mathrm{~F} 4$ \\
\hline $15 d$ & $M-W$ & $\mathrm{~F} 3, \mathrm{~F} 4$ \\
\hline $16 \mathrm{a}$ & $L-M$ & $\mathrm{~F} 3, \mathrm{~F} 4, \mathrm{NFS}$ \\
\hline 18 & $M-W$ & $\mathrm{~F} 4$ \\
\hline $19 a$ & $\mathrm{~L}-\mathrm{M}$ & F3 \\
\hline $19 \mathrm{~b}$ & $M-W$ & F3 \\
\hline $19 c$ & $\mathrm{~L}-\mathrm{M}$ & $\mathrm{F} 1, \mathrm{~F} 4$ \\
\hline $19 \mathrm{~d}$ & $M-W$ & NFS \\
\hline $19 \mathrm{e}$ & $M-W$ & NFS \\
\hline $19 \mathrm{f}$ & $L-M$ & $\mathrm{~F} 4, \mathrm{NFS}$ \\
\hline $19 \mathrm{~g}$ & $M-W$ & NFS \\
\hline
\end{tabular}

Legend: Frequency Rating

Soil Type Rating

L-M: Limited to Medium

NFS: Non Frost Susceptible Soil

M-W: Medium to Widespread

VW: Very Widespread

FI to F4: Corps of Engineers Frost Susceptible Soil Category 
soils (clayey). In this discussion it was noted that the lack of clayey solis was notable in the western province group, while rather adequately distributed tinroughout much cf the eastern province grouping. In addition to this fact, it should alsc be pointed out that several physiograpric units possessing clayey type solls were not considered to be within the defined freezing area leg... Fiedmont Flatedu Section, Tennessee section, Interior Low Flateau irovirce, and Csage Flains Section). Hence, the rather rolative lack of F3 solls in the east contrasted to the presence of clayey solls is due to the subsequent exclusion of many potential F3 soil areas from the freezing zone.

Western Frovince Group. Within the mountainous fortions of the west, the relative lack of substantial soll cover, is responsible for the very widespread pattem of non frost susceptible areas noted for much of the sierra-cascade and Focky rountain provinces. A similar cccurrence is also noted within the Elue rountain Section of the Columbia Plateal. This unit contrasts rather strongly from neighboring sections. ivithin these adjacent units, the widespread aistribution of silty loessial deposits and sandy to silty residual soi:, produce major occurrences of F4 solls. A someninat sinilar cccurrence of frost susceptible solls is also tcun hithin much of the Colorado Flateau Frovince from the residul sandy to silty solis developed from the sandstones ant :rales. The major difference between this Frovince and the Cclumbia lateau irovince, is the greater frequency of cocurrence of 
F3 materials attributatle jirectly to the presence of shales and clay shales. The most notable and rather obvious feature of the distribution and occurrence of frost susceptible solis in the Great (Closed) Easin Section is the very large var1atility by type. This variation in rating reflects the presence of bedrock (ranges) as well as the Eradational texture ct the rasin fill.

Eastern Frovince Group. The predominating frost susceptible soll type over much of the Great Plains Frovince is $F 4$ due to the general widespread distributicn of sandy silt residual solls from the sardstones and shales, Tertiary outwash deposits in much of the High Plains as well as widespread loessial deposits over tuch of the central portion. Much of tro solis in the area, are attributable to the shales and clay shales found in almost all the sections. The largest distribution of i'z regional frost solls in the initect states is fuund within the Nebraska Sand Hill portion of the High ilains Section.

Within the jections characterized primarily by restalia: soll development, much of the $\mathrm{F} 3$ solis found in the Triassic iowland, Czark and Cuachita and ridge and Valley frovinces are a resilt of the plastic residual solls developed from linestones within these areas. Solls associated with an F4 rating in these units apfear to be from sandstones and snales. They are found within portions of the Rldge and Vailey, Triassic Lowland and Appalachian Plateal Frovinces. 
The New York Glaciated Section of the latter Frovince has a F4 rating assoclated with solis in the eastern fortion of the Section while in the western portion, the predominant rating is an F3. This rating is in general agreement with the soli texture descriptions previously provided for this unit.

The glaciated sections found within the freezing zone are generally complex in the distritutive characteristics of frost susceptible soll type. Wlthin the ilew England Maritime Province, the mountilnous sections generally possess a combined non frost susceptibility rating as the major type and $F 4$ types as the minor varlety. F3 solis are generally restricted to the northern parts of the Seaboard Iowlard and the New England Upland Sections. A fairly sienificant fortion of the Connecticut Iowland Section has been categorized as F2 solls. The two glaciated sections of the Iaurentian Upland frovince show a marked contrast in variatility of frost susceptible soli type. Within the Adrondack section the uniform and widespread occurrence of $F 3$ solls is in strong contrast to the non frost susceptible, $\mathrm{F} 2, \mathrm{~F} 3$ and $\mathrm{F}_{4}$ areas common to the Juperior Upland section.

Within the Central and Eastern Iowland Frovince, the most common frost susceptible so1 types are F3 and F4. The distribution of the $F 4$ solis is strongly related to the presence of loessial deposits found in the Driftless, central Tili flains, and Dissected Loessial and T'lll Fláns jections of the province. In adiltion, F4 type arift is fuund ir tre western portion of the western Lakes Section and in nuch 
of tre valleys and lowlands of the Eastern Iowland portion of the Province. The distribution of F3 solis is strongly related to the plastic arift found in the eastem portion of the western Iakes, Dissected Ioessial and T111 Plains and Central Till Flains Sections of the Frovince. Distribution of these soll ratings also are associated with the marine deposits of the st. Lawrence and Champlain Iowland jections. The rost extensive deposits of F2 type so1ls are found in the Centrai Jand Plain area of the Dritess Sections and within the northern drift areas of the Eastern Iakes and Lacustrine Flains jection.

\section{Comeosite Factor of Desion Summary Rating by Section}

Table 39 shows a summary of the ratings for each factor of hesign considered in this report for each physiographic section in the continental United States. The data in Tatle 39 form the basis of discussion in subsequent paraeraphs relative to the recommended design units within the United states. The ratings given in the Table are those previously presented for each factor.

I imitaticns Associated With Using Physiographic in 1 ts as Unique H1 ghway Engineering Factor of Design inits

General

The major purpose of this research has been to evaluate selected highway factors of design on the bas is of regiond physiography. The results concerning the factors of jeslen have teen described in the form of a severity 
Table 39

Composite Factor of Design Summary

Rating by Physiographic Section

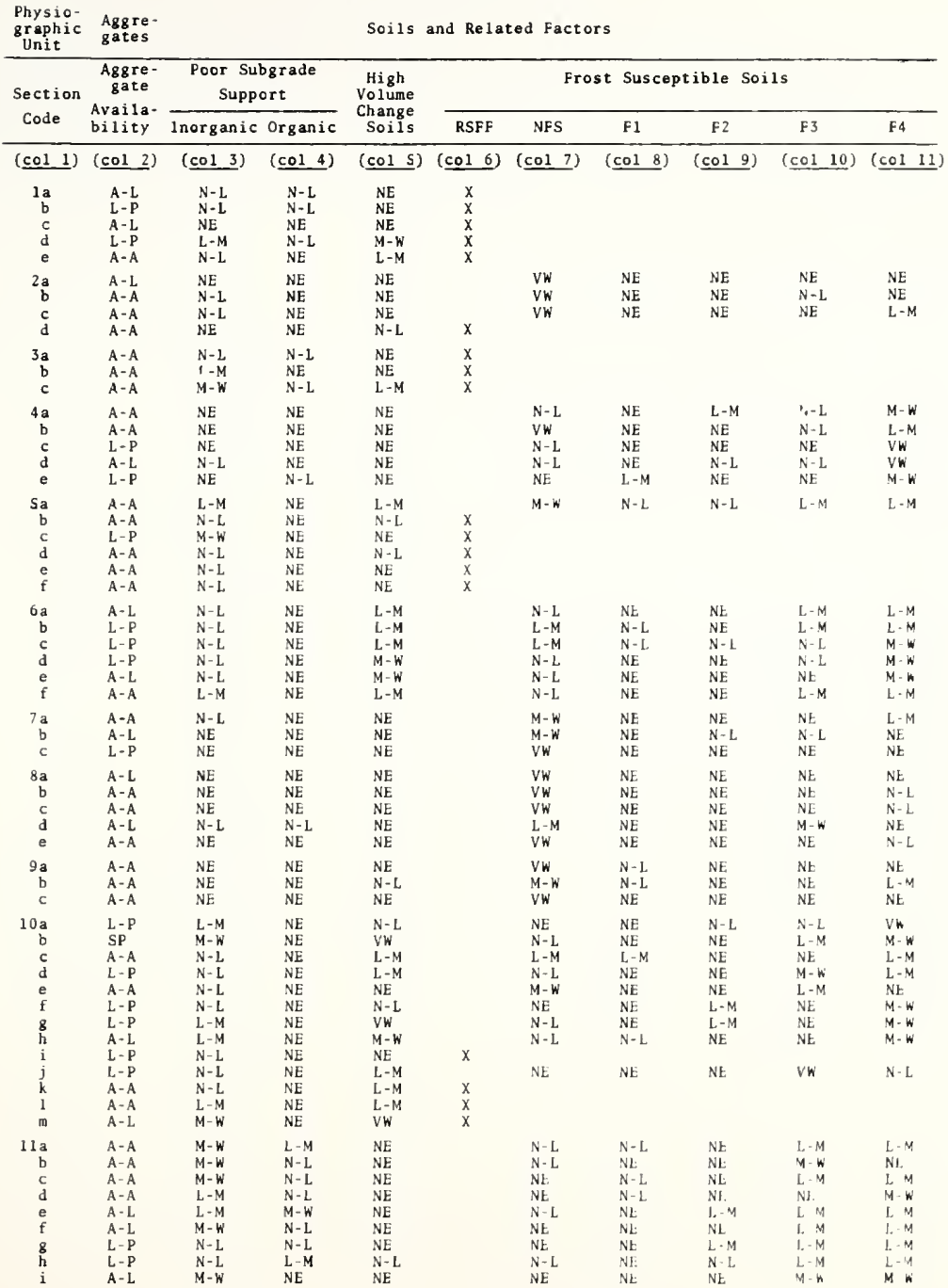


Table 39 (cont'd.)

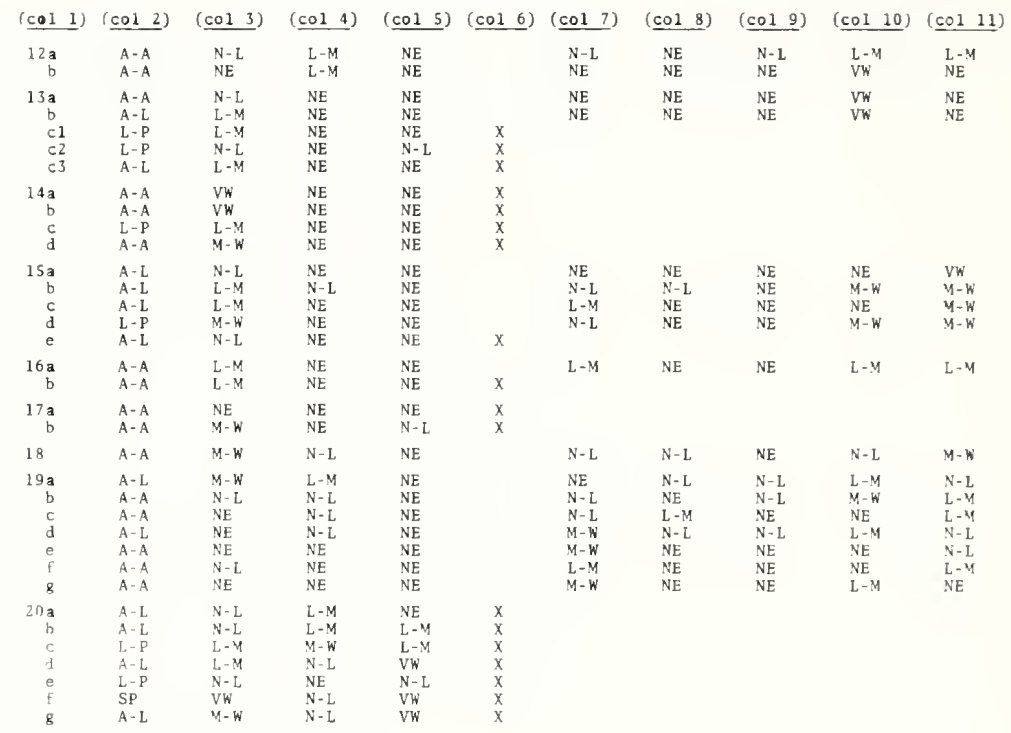

Legend:

\section{Aggregate Factor}

A-A: Abundant to Adequate A-L: Adequate to Limited L-P: Limited to Problem SP: Severe Problem
Soil Factors

NE: Non Existent

N-L: Non Existent to Limited

L-M: Limited to Medium

M-W: Medium to Widespread

VW: Very Widespread
Special Frost Susceptible Soils Column Legend

RSFF: Relatively Safe From Freezing

NFS: Non Frost Susceptible Unit

F-1 to F-4: Corps of Engineer's Frost Susceptible Soil Category 
and/or frequency of occurrence rating for each of the 9 ? initial report physiographic sections.

Najor emphasis has been concentrated on the ratings established, their distritution, occurrence and any eneral physicgraphic and geologic implications developed. However, in so joing., it is acknowledged that within the latelized analysis of assigning a rating to each physiograticic section, two important assumptions have been made. The f'lrst of these is that the physiographic unit is the optimununit for cataloging highway engineering problems, performance and subsequently factors of design. The secona concept, assuires that the inttial physlographic unit classificition system wilize is the optimim classification system for hithway engineering purposes.

At the level of generalization in which this investigation has been effected the ability to make a presise and detalled summary of every pertinent highway char cteristic existing within each physiographic section examined is teyoni the scope of the report. The major reasons for this are aue to the variable input inforination regarding EEcloglc, geomorphic and highway engineering facts for the united states as a whole. In addition, it is readily scknowledged trat many of the sections examined exhit:t c variabijty ir physicEraghic units which can be suriatvided into smaller and core homogeneous units. As a consequence, examples which summarize where physiographic information can be readij tied intc the concepts Aemonstrating the utility of physiograpilc urits 
for highwil engineering purposes are presented in the following firguraikis.

\section{I * ilizen Concerts of Reglonilization}

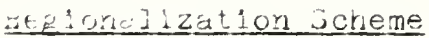

If one were to consider in highly laedizea system fre regensization of a particular factor within a given arriz wit, there would be three cogent consiaerations which should be noted for toe regionalization. The first, and perhaps most silient, involves the uniqueness of the areal usit crosen to effect the regionalization; for, it shoulc ke reaily noted that a generalization or statement cf the averHege corditicn of any factor can be made vithin any type of areal unit. This consideration, therefore, realices to, Elver sto se of dreal unit types, which unit affords the creitest uniqueness or provides the optinum unit for making tru seremaization. The orvious difficulty in roving the existence of such an optjmal urit is apparent. Eecause of the reiative importance of this feature to the cverall profect, trij consideration is jiscussed in some detail in abseritert guragraphs.

The second point to be cunsidered involves only the fiactcr being investigated. The question of effecting a true or condtiung regicnalizaticn is answered by examining each fertinent variabie affecting the factor in question to aeternine whether or rot each is conducive to regionalization witrin a given areal unit as well as if all variarles are to 
te considered in tre analysts. If a variable does not lend itself to regionalization or is not considered in the fnaiysis, then the type of regionalization effected is conditional in nature. If every variable within the analysis car and is evaluated than the type of generalization is considerea a true regionalization.

The final condition to be considered concerms the relative homogenelty of the factor within the areal unit. This is accomplished by examining the distribution of each variable considered in the analysis relative to 1 ts homo efneity within the areal unit. It shoula be notea that complete homogeneity of a factor does not necessarily imply a unique relationship. Simliarly, a non homogeneous factor may not recessarily imply a non unique reiationship.

It should be apparent that within this iffalized. scheme there exist several unique types of regionalization combinations which may be obtained for a particliar factor. The most 1deal combination is a generalization that is unique, true and homogeneous within a given areal unit. In essence this rating wculd be a precise neasure of particular factor wish is uniform or constant throughout an artal unit which. represents the most unique unit for the eneralization tc be obtained. The worst type of generalization that say be effected is the non-unique, conditional and non-homorerecus rating.

Easic Concepts of Regionalization Within Ehysiogrophic units Since physlographic undts have been formed, on en 
iaeal kas 1s, from uniqueness of torographic expression, the valialty of regionalization within physiographic units seemirgly reduces to the relationship of righway factors of design to topographic expression. This may be intultively Aerivej ty the fact that phys ographic units are described in terms of a unique topoeraphic expression by non genetic descriftor; cf altitude, relief and type of landform present.

irwever che of the most important aspects to be hilerstood $\mathrm{k}$ the reader is that the more iundamental questfons asks, "What is tine relationship between the geomorphic control factors and the design and construction factors considered". It is important to reccgnize that, in the main, it is a sique combination of a particular type or repeitive t.pes firent naterial, its arrangenent, the process which act on it to modily, the length of time in wrich the processes nuve acter dad the historical climatic environment which scuiptures the landform or landforms within the physiographic $\operatorname{lin} 1 t$

Each of the factors considered in this report have as a frimary variable, elther uniquely or in combination with ctrer variables, the element of material type. This is to say, that for each of the factors considered, engineering experience can be il rectly related in total, or part, to the rateris? type. As a consequence, the basic concept in applyIng pnys ographic units to engineering experiences is to lormulite an experience with a material condition at a inicro 
level (eg...engineering site or project) and subsequently define the regional extent or macro area of this experience via the application of homogenecus topography, or regional physiographic units.

In the majority of sections considered, the application of this concept is a valid approach to tie analysis. However, it has been previously noted within the summary portion of this report dealing with Physiography and Eegionaz Fhysiographic Units that important exceptions occur within sections and their uniqueness to parent material types. In this summary it has been noted that it is possible for similar material types to be existent with adjacent sections as well as having differing material types within a unique topographic unit.

The 1mplication of the former exception does not provide any gross limitations to the concept of regionalization discussed. In essence; for these units, the maior implication is that the chances of having identical generalizations for the adjacent sections is quite high. The immediate implications of the latter exception are, by far, the most important is posing limitations to the concepts ncted. In essence, within a uniform topographic unit composed of differing parent material and geologic conditions, the rasic concept is not applicable because the generalizations effected on a micro level are not valid for the macro or regional topographic unit. 
Utjlity of Fhysiographic Units to Factors of Design Arsegregates

Crushed Stone

The results of this study, have suggested that the greatest ut111ty of physiographic units concerning aggregates and treir distribution lies in the ablilty to make effective or unique generalizations conceming the potential of crushed stone areas within the united States. However, not ali physiographic sections within the Unitea states afford this uniqueness.

Fhysiographic sections, showing a non uniqueness to delineating crushed stone areas, are generally characterlzed ky topography formed from transported material but naving underlying bedrock at such a depth that the potential of the bedrock as crushed stone sources can still be effectively generalized. For the remaining sections, the uniqueness or utility of formulating generalizations concerning crusked stone sources may generally be considered as gocd. From an overell viewpoint, sections whose modal characteristics are based upon gross tearock features, regardless of the Eresence (e1ther total or partial) or absence of any surfic1al transported deposits afford cases where unique general1zations can be wade. In addition sections having very thick jeposits of transported solis are obviously unique for enerIlizaticrs concerning the distribution of crushed stone aresis in the respect that the potential of such sections is liniquely non-existent. 
An excellent example of physiographic sections that possess non-unique attributes for the generalization of crushed stone sources is found in the central lowland portion of the Central and Eastern Lowland Province. ${ }^{1}$ Within this area lie a large number of the major carbonate producing states in the United States. As the modal characteristics of the sections comprising this area are based upon differences in glaclal terrains, or lack thereor, aksolutely no uniqueness of cartonate stone areas can be effectlvely made within the physiographic units. This is to say that the physiographic sections noted do not afford the optimum unit in these areas for cataloging crushed stone potential.

If one, however, were to follow the underlying redrcck strata from the glaclated Lowland Frovince to the Interior Iow Plateau Province (non transported origin), the utility or uniqueness of using physiographic units teccmes rather apparent. Within this Province, regional cartonate zones are found in the Nashville Basin Section, and portions of the remaining sections. Cther sections, characterized by non transported orlgin, where potential cartonate zones occur are found to characterize the springfield-Salem Flateau Section of the Czark and Cuachita Province, and the Iimestone valleys of the entire Ridge and Valley Frovince. To further 1liustrate the utility of filing crushed stone ageregate information within physlographic unlts; there

1. The central portion of the Province is conpriseci of Sections lle, f, $g, h, 1$. 
Exists within the eastern portion of the United itates several small, varlant, but well defined physlographic unlts in winlon tre potential for crushed carbonate stone is considered to be good. The physiography of these areas are all similar in the respect that old Paleozolc strata are found within the variant valley units. These areas are the Sequatchie-ilils Creek Valleys of the Cumberland Plateau Section, the Frederick, Conestoga (Iancaster) and Chester valieys of the Trlassic Iowland Province and the Ilmestone Valley of Vermont of the Taconic section. I It should alsc be noted that further delineation of units withir the Interior Low Flateau frovince greatly increases the unlqueness of the crusined carbonate zones found in the area. cther types of unique potential crushed stone area examples can te found within many of the sections within the unitei jtates. Jranitic/metamorphic crushed stone areas are uniquely associated with the Black Hills section or st. Francls Mountain section while the crushed basalts of the Columbla Plateau and the traprock of the Triassic Iowland Province and Connecticut Lowland Section are examples of sections where other potential igneous crushed zones are alstributed.

Sections may also be uniquely categorlzed as having poor or non existent capabilities for potential crushed

1. The distribution of the units is shown within tre reconmended physiozraphic-highway engineering units introduced in the next portion of this report. They correspond to unit numbers $192,207,208$, and 214 . 
stone. Sections such as the Kanawha, Cumberland Flateau, California and Cregon Coast Ranges, and many sections of the colorado Flateau and Great Plains Province are examples of this. In general the bedrock characteristics within these units are unfavorable for good performance as highway aggregates. Cther sections, such as the California Valley, High: plains and most of the Sections of the Atlartic and Julf Coastal Plains Frovince, possess a non existent potential due to the widespread presence of relatively thick transported sediments.

Sand Gravel

In alscussing the overall utility of cataloging engineering factors relative to sand gravel sources witrin physiographic units, 1 is convenient to subdivide tris major type source into categories that possess deposits of areal (regional) occurrence and those which are primarly associated with alluvial origin and subsequently possess $a$ nore linsal type of aistribution.

Within the regional sand gravel categories, the utility of using physiographic units to uniquely note pertinent factors concerning these deposits is considered variable, but generally good. Table 40 summarizes the appraisal of sections where the utility of noting fairly urique sand gravel characteristics are somewhat peculiar to the section. The origins of these regional sand gravel occlurrences are generally associated with widely distributed patterns of stratifled drift, valley (includes glaclal sluiceways) and 


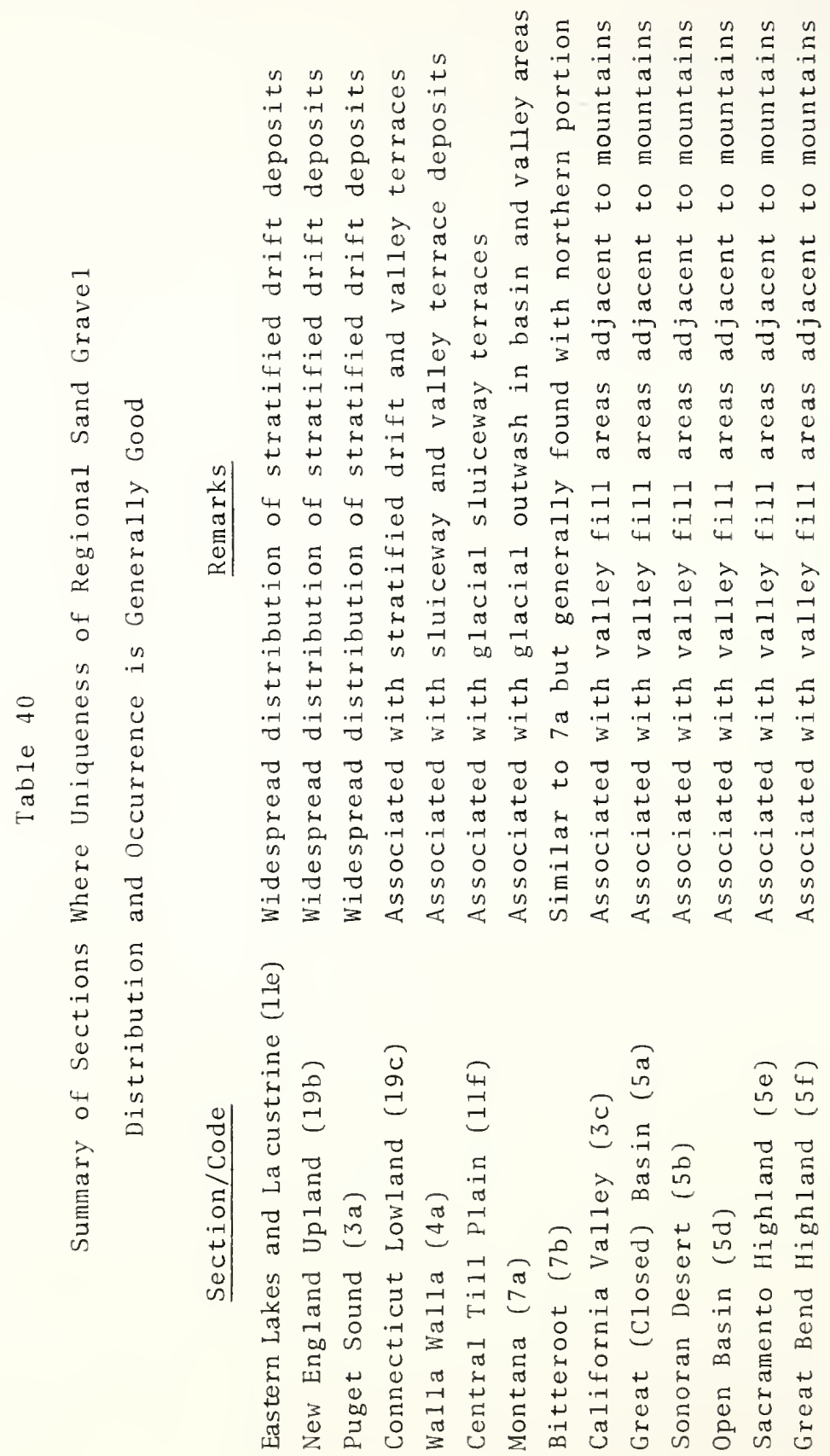


basin deposits generaliy fllled with glacial outwash and potential areas associated with valley fill deposits near mountainous areas.

There also exist smaller regional sand gravel areas within sections, which when further subdivided in subsections; yield a fairly good uniqueness in characteristics similar to those previously noted. These areas are found in the Jackson Hole unit of the Midile Rocky Nountain. Province, the North Park, Middle Park and San Luls Valley areas of the Southern Rocky Mountain Province and the Southern Pine H111s Area of the East Gulf Coast Section. I cnly the letter area directly contributes to the uniqueness of the physiography for the subsection as the gravel cap present in the unit (Citronelle Formation) provides an area of slightly differing relief features with most of the unit relative to its adjacent unit. The other units are delineated primarily because they are intermontane basins veneered by cutwash sands and gravels.

Small regional areas of sand and gravel that generaliy afford little uniqueness within physjographic units are those primarliy associated with remental gravel caps which afford little or no alteration of the regional Fhysiography of the section where they are found. Examples of these

1. The distribution of these units are shown and described within the recommended physiographic - highway engineering units introduced in the next portion of this report. They correspond to unit numbers 75 (Jackson Hole), 59 (North and M1ddle Farks), 65, 67 (San Iuis Valley) and 242 (Southern Pine Hills). 
spcradic deposits are associated with many outwash areas adjucent to mountains, areas within both the Glaclated and Unglaclated rissouri Plateau Sections (Flaxvilie, Cyrress Hills) and Csage Plains Section of the Great Plains Province, as well as preglacial and interglaclal gravels (Buchanan ara Ai tonian gravels) found in the Dissected Lnessial and Till Flains jection.

The poorest uniqueness of utilizing physiographic linits for noting factors relative to sand gravel deposits occurs with alluvial sand-gravel deposits. This factor is unfortunate because the importance of thelr role in the complex totality of aggregate resources is indeed great. within many areas of the United States, these sources are the only potential type of aggregate avallable.

The pocr uniqueness of alluvial deposits to physiographic units is most probakly related to the direct confilct between conditions necessary to delineate adjacent physiographic units and those necessary for fluvial development. In general, the difference in base levels (1e... elevation aifference) necessitated for arainage development and sursequent river and stream development frequently serve as a factor which delineates differing physiographic units. Thus, the streams which radiate from the Front Range flow throligh the Colorado Pledmont, High Plains, Flains Border jections and subsequentiy into the Mississippi River to the Gilf of Vexico. Although generalizations may be made within any of these sections concerning the alluvial sand gravel 
sources, they are not uniquely associated with that particular section.

\section{jo1ls and Related Factors}

All of the soll and related factors of desien investigated within the project have had associated with them; either uniquely or in conjunction with other major varialles (eg...climate), characteristic properties peculiar to the type of surficial soli textural conditions. Thus the lelineation of potentially poor subgrade support areas by physiographic units led to the categorization on the basis of e1ther organic type deposits or clayey areas. The hieh volume change study likewise noted clayey type solls existent within a very generalized climatic envircnment sultable for high vclidne change development. The snalysis conducted on frost susceptible solls was related to the textural chiracteristics of soli units generally asscciated within the frost zone. As a consequence the general overall uniqueress of physiographic sections to denote potentially unique and homogeneous factors of design is depenient loon the textural consideration relative to the factor of design with the modsl characteristics and distribution within the section.

In general, the utility of generalizing soll factcrs of design is good within most units developed solely from non transported origins. Within these areas, the scil type is developed upon the principles of pedolcgy. Hence units with similar parent material types, topopraphic patterns, climatic histories, age and vegetation ldealiy will 
form similar soil types. Witt the exception of the vegetatior variable, each of the other pertinent factors to soll genesis is also common to the geomorphic control iactors which characterize a physiographic unit. The ability to Eliectively generalize within a large regional area is ilrectly related, in sedimentary areas, to the geolcolc structure of the stratí. In areas underlain by horizontal to silghtly dipping strate, the residual soil types within the unit are relat1vely homogenecus or possess a predictable textural range over liarge areas. Physiographic units possessing these characteristics are frequently found in the AppalachIan Flateau, Inters or Iow Flateau, Czark and Cuach1ta, much citre Great Flains and Colorado Plateau Frovinces. Conversely where ceolcglc structure is greatly alpping, the refional (areal) patterns of similar soil type units cover relatively small areas. Examples of this occurrence are generaly associated with massive mountainous uplifts wrich frequently have associated with them highly tilted strata flanking the uplifts. The soll regions found witrin the Elack Hills Section as well as many areas within the Rocky Nountain Frovinces exhibit this patterr.

In sections characterized by rugged mountainous sreas, the factor of toporraphy appears to have a more predominating effect upon soll development than any of the ctner factors which effect soll developmert. Thus, many of the sections found in the mountainous areas of the western United states, as well as much of the Ilve Ridge section 
of the east are, in general, non soll areas. Thus the mountain rances of the Basin and Range can effectively te trested ss non soll areas even though they are comprised of various parent material types.

The uniqueness afforded by transported crigins is nighly varlable. Where transported solls, in part, overlay a physiographic unit based upon geomorphic factors related

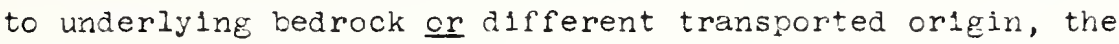
overall utility of the unit to denote soll factors of jesign is consldered to be poor. If transported solls completely overlay a physiographic unit, regardiess of the besis for geomorphic unit identification, the utility nay be considared as good.

Ferhaps the most notable example of this is found with the distribution of regional aeolian (loessial) deposits in the united States and their relationship to prysioEraphic units. In general, the major occurrences of loess are found within the Columbia Plateau Provirce, tre midwest inited states (occurs in parts of the Great Flains and Centrel and Eastern Lowland Provinces) and the Mississippl Loessial Upland Section.

The uniqueness of the Mississippi Loessial Upland Section as a soli unit is considered good recause of the fact that, in the main, the basis for sectioning is due to the presence of a unique topographic unit develoced from the lcess 1tself. ${ }^{1}$ The overall uniqueness of the loesslal areas 1. This statement is more correct for the western portion of the section where the thickest loess deposits occur. In the east the thickness of loess decreases and topography is somewhat influenced by the underlying coastal sedinents. 
of the Columbia Flateau Province are I1kewise considered good. However, the utility of these loessial areas within the Snake ilver Plain and Nalla-Walla Sections was considered good only recause they are pseudo origin units. This is to say that if the loess covering were removed from these areas, the two sections would still be considered as unique physiographic sections because the modal characteristics are tased upon the underlying bedrock rather than the loess. In contrast, the loess deposits in the midwest form a completely non-linique correlation to the regional physiography in the area because the modal characteristics are based upon parent material other than the loess and the loess deposits nowhere completely veneer a section.

The latter example lends itself to a basic point of conflict between the physiographer and the highway enginetr. The important question relative to the above as far as tne highway engineer is concerned, is to ascertain whether or rot the jepth of transported soli is sufficient to justify a regional unit attributable to the transported soll, frcm a highway engineering viewpoint. In areas where this is a factor to be considered, the utility of using transported crigin boundaries (even though gradational in nature) would seemingly aiford a greater utility for soil reiated factors of design than borders established on the basic principles of reglonal physlography. 
Composite Utility of Units

Because of the variety of factors which determine physiographic sections, it is not possible to make $\approx$ blanket conclusion regarding the utility of sections as filing systems for highway factors of design as being elther satisfactory or unsatisfactory. The overall utility of a section to serve as a unique fling system depends, upon the factor keing regionalized relative to the modal characteristics which define the unit.

The best uniqueness of regionalizing rcth aggregates (crushed stone) sources and soll related factors arpears to occur within a section whose modal characteristics are based upon consolidated (tedrock) materlal and having no transported material within the unit, or units whose modal topoeraphy is formed from very thick transported so1ls with the depth to underlying bedrock being slich that no general1zations can be made concerning 1 t.

Within the former case, crushed stone and soll generalizations may be characterized from the same parent material-topographic pattern. In the latter case, the linlqueness of crushed stone may be considered as good because It is a non existent feature within the unit. Soll factor generalizations may be uniquely formed from an interpretation of the transported solis within the unit.

In sections where the modal characteristics are based upon bedrock material but possess a partial covering of thin transported soll within the section, the uniqueness 
of crushed stone sources may be good but the ability to effectively generalize soli factors is considered foor.

Conversely, where transported origins form the rajor characteristics of the section but underlying redrock is at slich a depth so that generalizations may be made; the uriqueress between crushed stone and soll factors is reversed from the latter case. Here the utility of regionalizing sc1l factors may be good while the crushed stone general1zations effected are very poor.

\section{Concept of a Unique Highway Engineering - Physiographic Category}

From a purely physiographic view point, the concept of a categcrization system (1e...Division - Province - Section) is a necessary and integral part of the science. This categorization system places topographic differences at a more detalled level of examination. However, not all sectlons of a province are geomorphicaliy related. For example, there is more uniqueness or similarity in physiography (geomorphology) between the Uinta Section of the ridale kccky Mountain Province, the Colorado Front Range Section of the Southern Rocky Yountain Province and the variant gelt rountain areas of the Northern Bocky Mountain Province than there is with the Uinta and wasatch Sections of the sare irovince.

When utilizing physiographic areas as a means of filing particular characteristics (occurrence, distribution, severity, etc.) of design and construction factors, 
physiographic attrikutes are translated into engineering factors within a given section. As a consequence, the use of a section level to rate engineering experiences joes not and sholid not imply to the highway engineer a similarity of these englneering experiences for all sections comprising a particular province.

For engineering purposes, the most useful meaning of a physiographic province is associated with lising it as an areal unit which is an initial starting or reference join: for the analyzation of smaller "engineering" units (sections). Sections should subsequently be viewed as an sreal unit which is an initial starting point for the analyzation of sxaller units.

Eecause of these factors, the use of a categorical classification system for engineering purposes is not necessary and may, in fact, be potentially misleading. Consequently the use of the term "highway engineering linit" is recommended in lieu of any Province, Section or subsection category levels utilized in regional physiography. This term may be readily defined as the smallest detalled areawith in which hizhway engineering generalizations have been elfecteล่.

Eecomnended Phys 1ographic-Highway Englneering Units of the Continental United states

General

The woods-Lovell physiographic system, fatterned and nodified slightly after a true regional physicgraphic 
classification framework affords some significant englneerinE diflerences which 1 mprove upon a pure physiographic categorization. However, it shoula be noted trat it is a Fart of a continental divisioning system, and as such, the iegree to which the units (sections) are Aelineated may in some cases admit excessive varlability when viewed at the state level. Therefore many of the generalizations effected at the section level may be too broad for maximum utilization for each state highway department.

\section{Peconmenker system}

is th the previously noted factor in nind, a furtiner sitaivision of the United States into a rore homogenecus highway ergineering - physiographic unit classification system has been maje. In so doing, these areas have been delineated with several factors in mind. First, as many individual state physiographic units as possible have been invorporated into the system. Second, because of the overall Importance of origin and parent material considerations within highway engineering, major importance in unit ielineation has been placed upon these factors as well as 1sclating variant parent material areas within the sections of the tylical physiographic system. The final consideration exresses the opinion that a categorization system of higher order units is not necessary and in fact may be nisleadinE. is a consequence the system is simply composed of 242 highway engineering - physiographic units. Figures 46 thru 51 


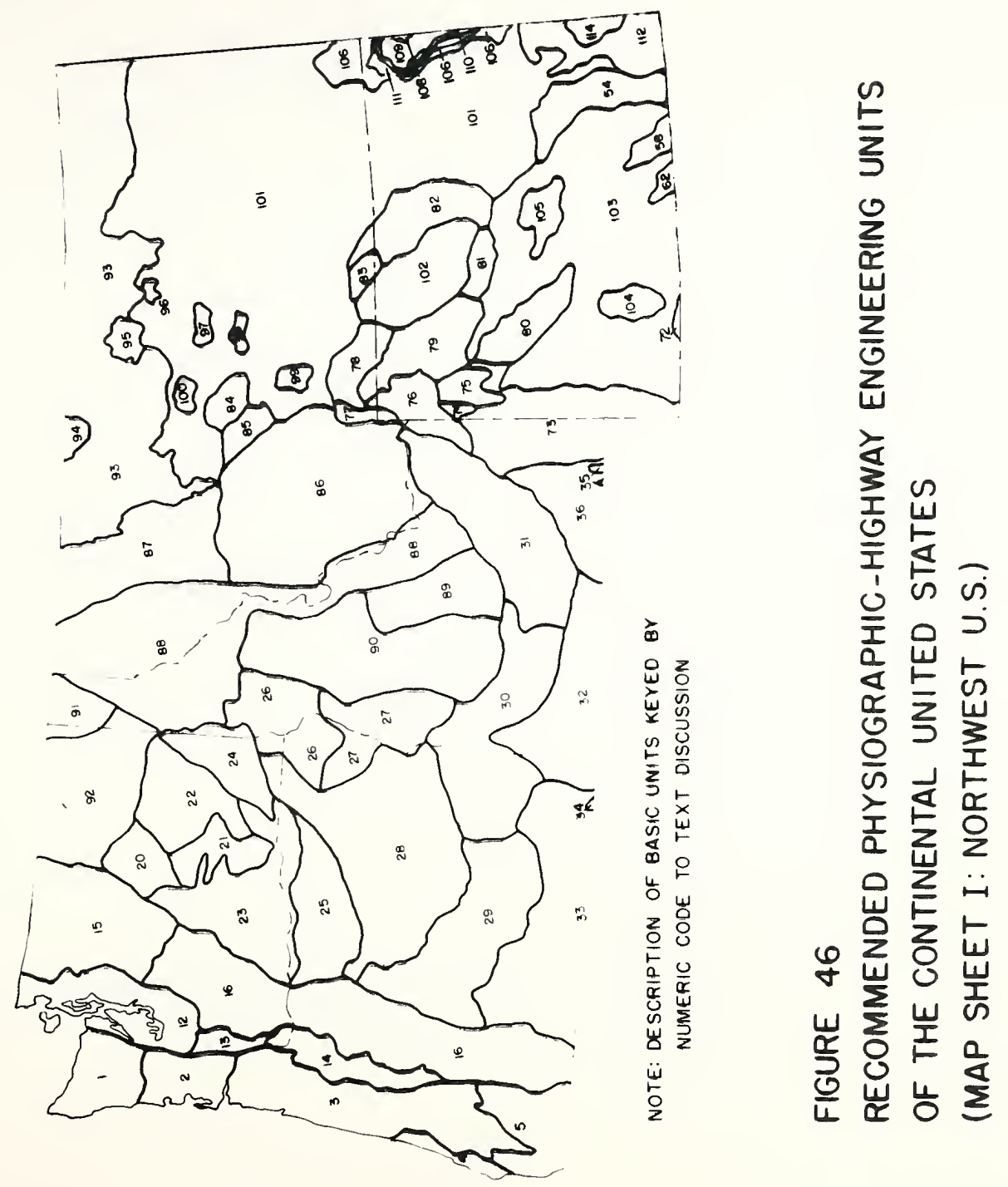




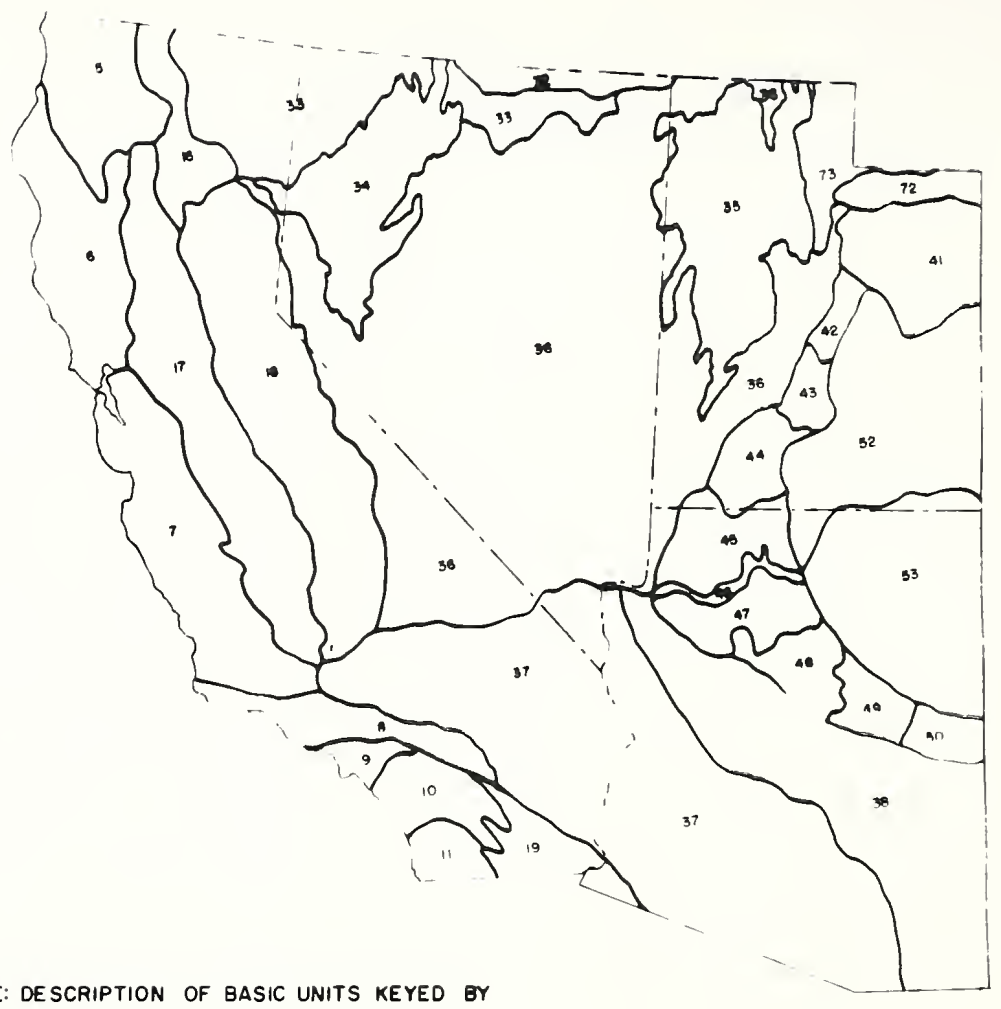

NOTE: DESCRIPTION OF BASIC UNITS KEYED BY NUMERIC CODE TO TEXT DISCUSSION

FIGURE 47

RECOMMENDED PHYSIOGRAPHIC - HIGHWAY ENGINEERING UNITS OF THE CONTINENTAL UNITED STATES (MAP SHEET II SOUTHWEST U.S.) 


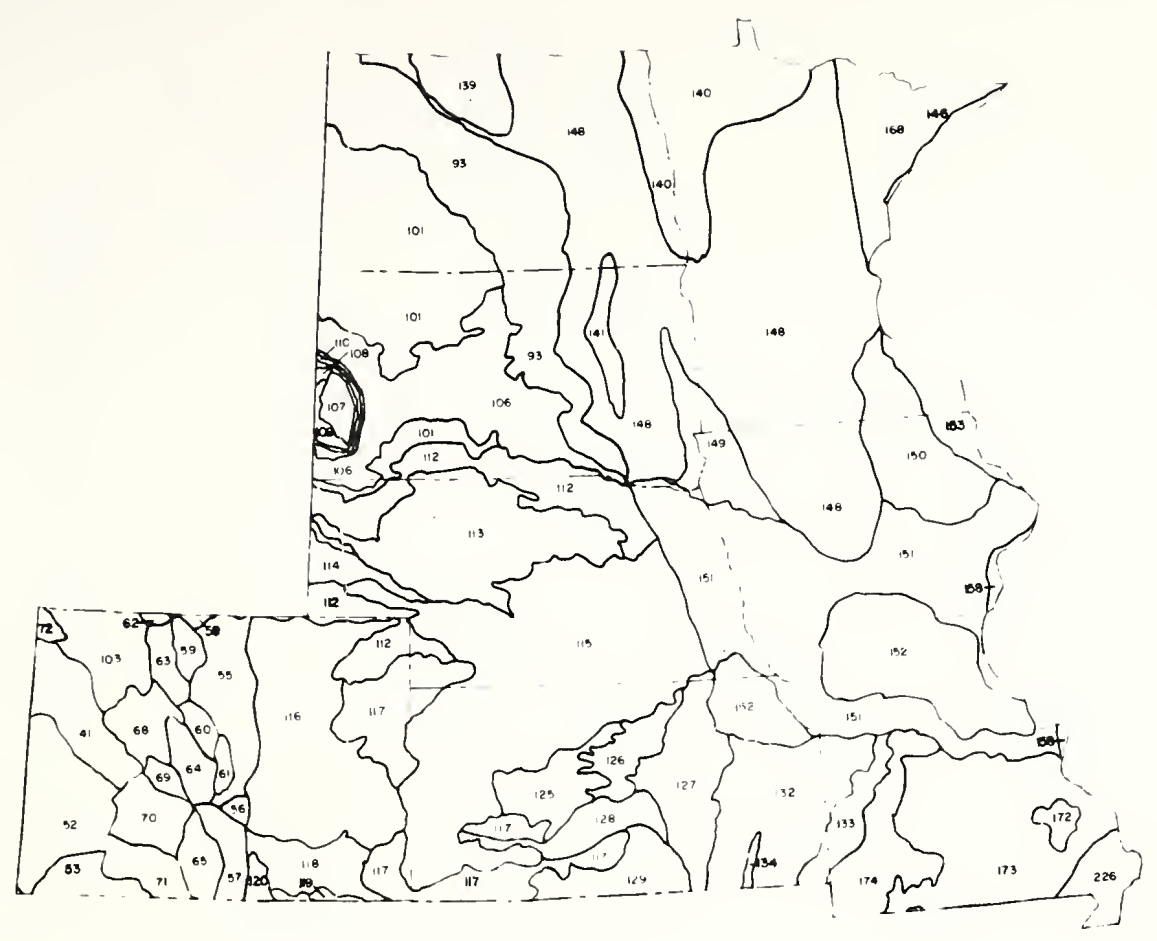

NOTE: DESCRIPTION OF BASIC UNITS KEYEO BY NUMERIC CODE TO TEXT DISCUSSION

FIGURE 48

RECOMMENDED PHYSIOGRAPHIC -HIGHWAY ENGINEERING UNITS OF THE CONTINENTAL UNITED STATES

(MAP SHEET III: NORTH CENTRAL U.S.) 


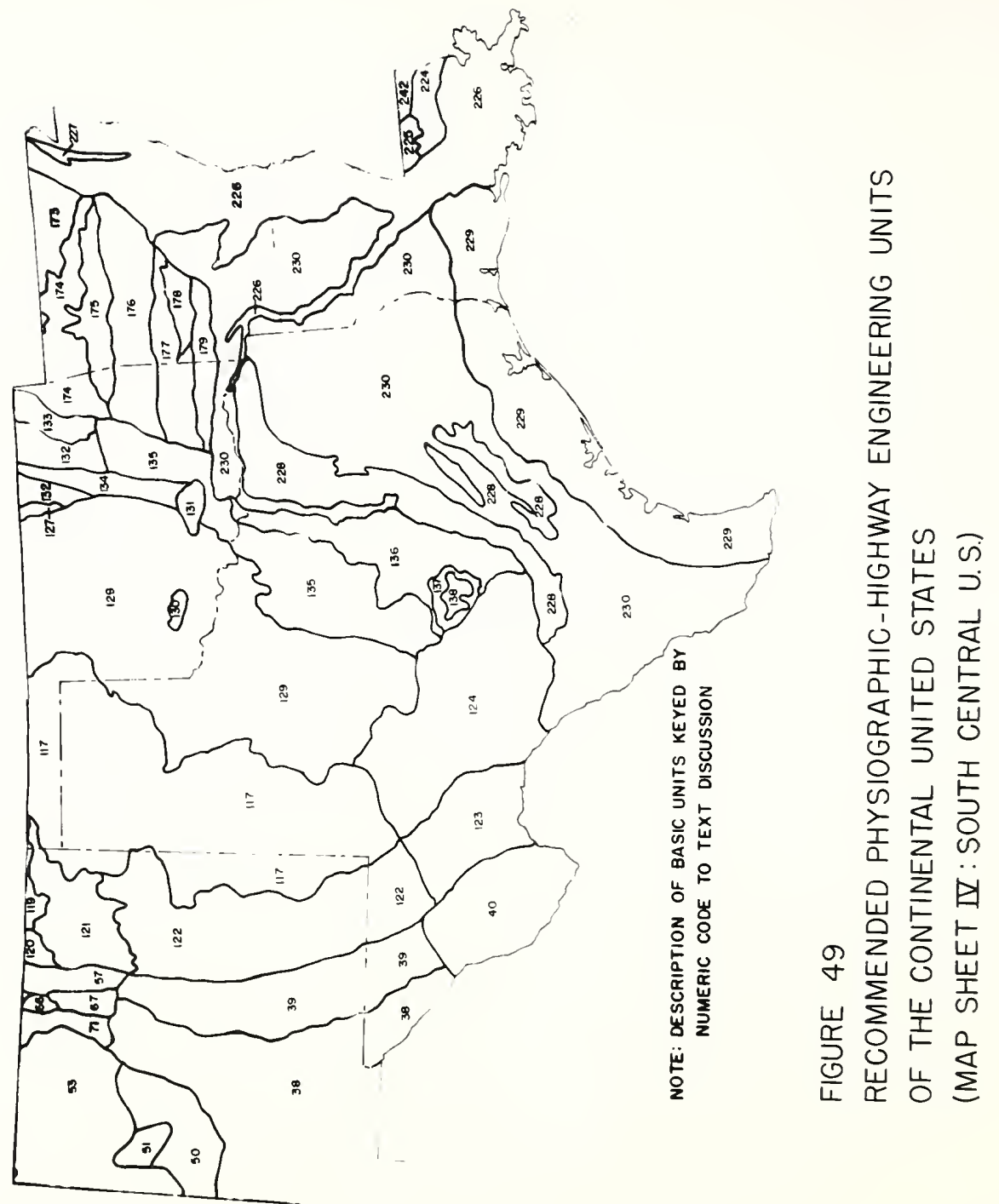



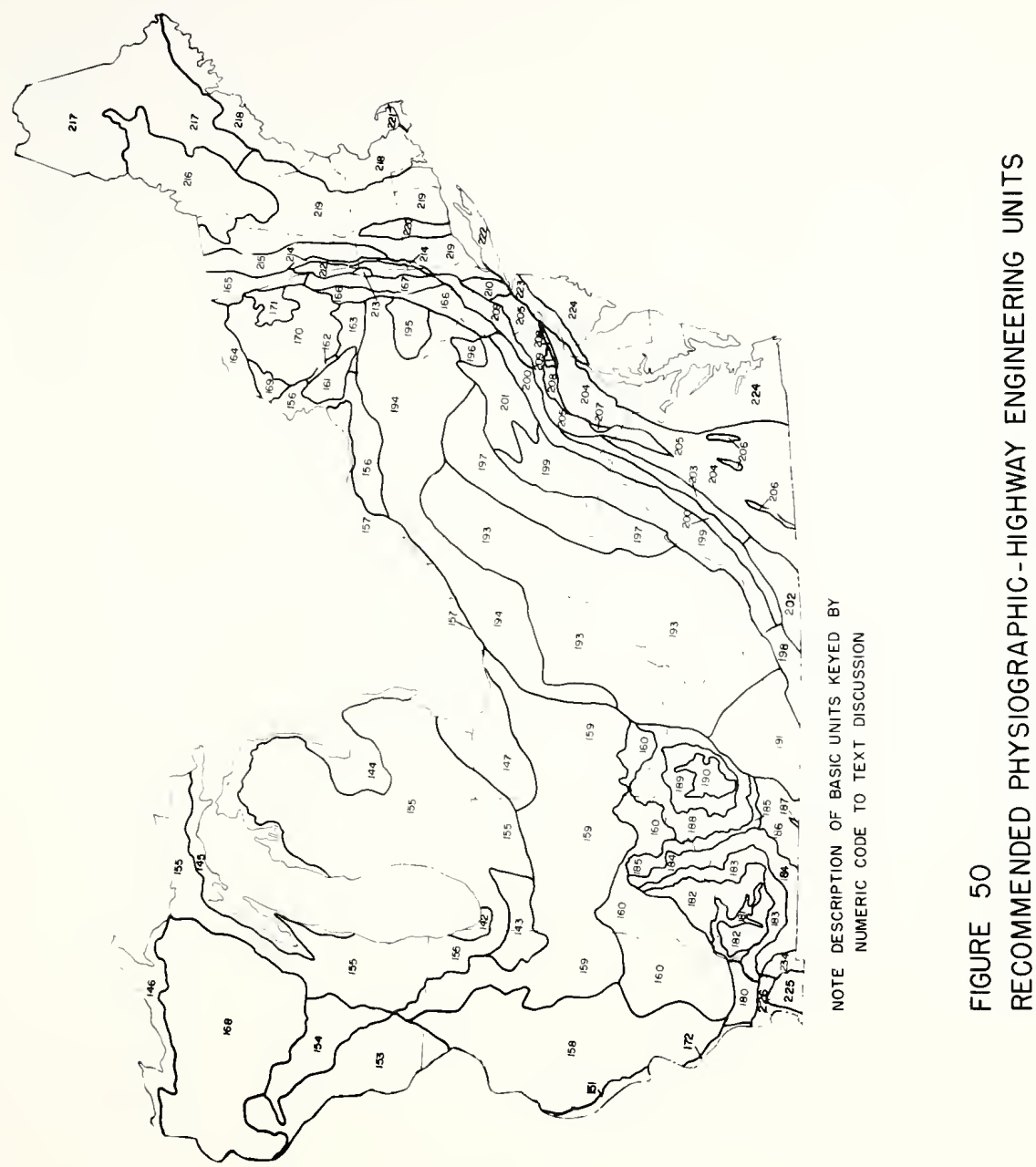

岂

交出

종ㅁำ

논

品文

으ㅁㅣㅗ

충 完

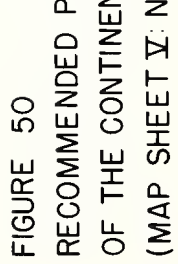




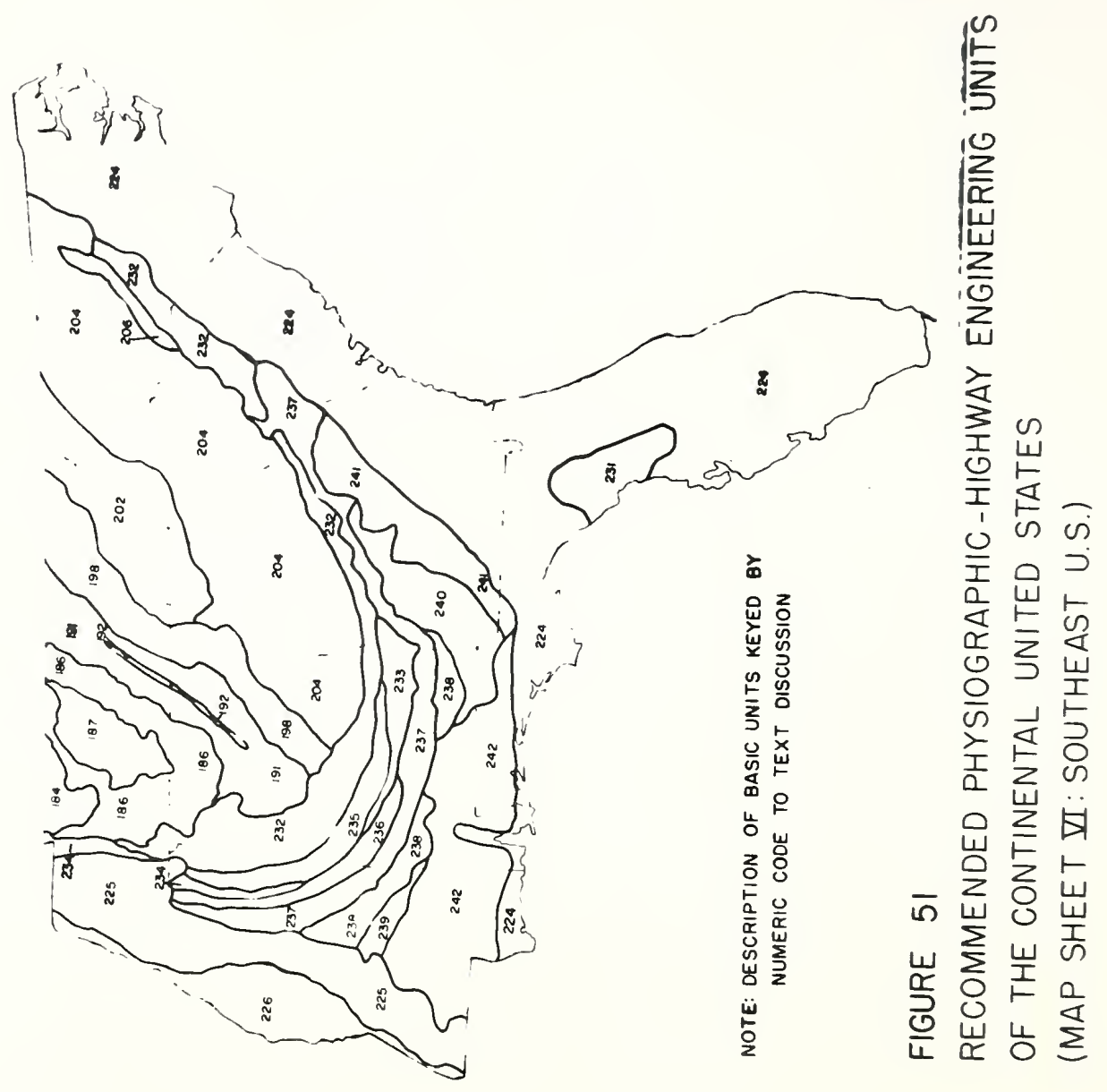


illustrate the ilstribution of the reconmended units.

For the proposed system, only a generalized descriptIon of the factors pertinent to the highway engineer are given. These factors are those of geolcey, gecmopproicey and parent material-origin characterlstics. The numeric core is keyed to the aiagrams which illustrate the cccinrence of these areas.

\section{Generial Description of Recomended Insts}

1. Clympir Mountains - This unit is a rugged, higniy itesected molintainolis area with several pears greater thar 7000 reet. The area is heavily glaciated. The rasor

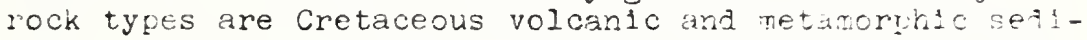
nents. Locally, basalts, volcanle tuffs, kreccias ana interbedaed narine beds of Eccene age as we:l as C.1Eccene narine sediments are found.

2. Willapa Hills - This area occurs as the creeon rortion of the cregon Coast Ranges. The wajor reascil for itstinction is the Tertiary volcanic cover overlyine the Tertiary sandstones and siales of the Cregur Fenges.

3. Cregor coast Range - Parallel trending series of acrtusouth ridges and valleys formed ty mila foling of relatively weak Tertiary sandstcnes and shales.

4. Cregon Coastal Plain - Felatively small sundy coastal area of cregon.

5. Nlamath Wountains - Extremely ruggea, dissectei wisted Flateau composed predcminantly of Paleozcic scrist flanked on the east by deformed faleczolc sedinentartes and volcanles and on the west by metamorpha rocke if Jurassic age.

6. Northern California Coast Range - Matlirejy Aissectez continuous highland area composed prejominantly of Tertiary and Cretaceous sandstones, shales and slates.

7. Southern California Coast Range - Similar to the : vrthern California Coast Range except faulting is more pronounced in the area resulting in a nore ncticeatle ridec ard valley appearance. The predominant rock tyre is Tertiary sandstones and shales; but Jurassic gringtes, sinilar 
to those found in the Sierra Nevada, underlie a central portion of the area.

8. Traverse Ranges - Distinctive east-west trending ranges composed primarily of granitic batholithic cores.

7. Ios Angr jes Basin - Lowland basin area of accumulated rarine and continertal Tertiary sediments. The eastern [.crtion is enerally coarse alluvium from the San

Gatriel and Jan Bernadino Mountains.

IC. Faultea peninsular Range - Highly faulted iurassic granitic area with agerading vallys belng common.

11. Ifulnsular Panges - Nestward tilted fault tlock of Jurassic granite rising to elevations of 10,000 feet. A terraced lowland torders the Paciflc Ccean and gradi$3.12 y$ merges into the broady dissected granitic uplani.

12. Fleget Jounc Easin - This area is the glaciated area cf tré icors-Iovel 1 Puget Trough Section. Topography is predominantly $a$ mixture of morainic hill and cutwash or terrace topography.

13. Easaltic Hills irea - This area is the residual area ir.ich separates the glaciated Puget Jound Zasin to the north frow the redominantly alluviated williamette Jailey unit to south. Topography is generaliy a is corrected series of basiltic hilis.

14. Gilluette Valley - Pairly flat alluvial plain of the hilaratte Fiver and its tributaries overlying Tertiary and iicternary seliments derlved from sedimentary ard velcanlc rocks. Minor hilly areas similar to those of the Easaltic ${ }_{11} 1$ s Area to the north, are located within the area.

15. Northern Cascaje Mountains - Ruged, mountainous area composed of Paleozcic sedimentaries and netamornhics intrided by several granitic batholiths. Alpine glaciatior is heavy in the area but relief is primarliy die to constructional vulcanism rather tran destructional processes.

20. Southern Cascade Mountains - Yountaincus area s\$milar in toposraphy to the Northern Cascade fountains tut ire formed primarily from Tertiary basalts and andesites.

1?. valifornia Valley - An immense, flat valley fillea with icth secent and quaternary sediments in the form of illuvial rans, aprons, mudflows and flood pleins.

I․ Jierra leveda Kountalns - Immense westward tilting fault 
block with elevations ranglne from 7500 feet to 13,200 feet. The major bedrock type is a Jurassic granitic bathol1th. Paleozolc and Yesozolc metamorphic slates, phylittes, graywacke and basalt flows are sutcringte in the area. Alpine glaciation is intense in the area.

19. Salton Trough - Iarge basin area formed in part ty alluvial defosits of the Coloralo fiver lying over valley outwash.

20. Waterville Plateau - Relatively flat lying baialt flows cut by a number of coulee systers and in fart glacistea.

21. Central blains - Major aownwarped area of basilts and related fluviatile lacustrine and deolian sezimentí.

22. Channelea Scablands - Areas cut ky vast meltivater ieposits exposing bare tracts of Columbia River tasalt. The liplands are covered by loess deposits.

2j. Yakima Folas - Area of high, broad anticinal riages and synclinal valleys. Rizges are predominantiy basaltic while the valleys are predominantly granian to semi granular sediments and volcanic ish.

24. Falouse Fills - Naturely dissected hilis forned on per loess.

25. North Central Cregon Plateau - Moderately assaectf basaltic plateau area.

2ć. Iristate uplands - Upwarped lava plateau in which isissection has produced 2000 to 4000 feet carycns.

2?. Nallowa/seven Dev1ls - Complexly folded and fultei area overlaln by basaltic flows of variarle tricress.

28. Elue vountalss - Area characterized by rountin panges and issected plateaus. Bedrcck type within the are is quite varjatie as granitic cores similar to the Rcckies, rise as "Is lands" above the basaltic lavis. Folded Faleozcic and early Mesozolc sodimertiry stiatil are alsc located within the area.

39. Hamey/High Desert - Flat area of recent liva f?cris, ash deposits and cinier cones.

30. Nalheur/Zoise Basin - Moderately Aissectfd reas cf intertedied lava and lacustrine - fliviatile sejimerts.

31. Snake Giver Plain - Structurally derpezijes ired corere? with young (Snake river) lava flows whtor.t. twre gre 
cverlain by loessial deposits.

32. Ciwhee Uplands - Structurally upwarped area of lavas more dissected and of older age than those to the north. Iarge areas are underlain by rhyolites and quartz latites.

33. Northwest Easalt1c Basin Range Area - Somewhat large area comprised in part by plateau topography in the extreme west and basin - range fault controlled topography elsewhere. The major rock type within the area is basaltic lavas, similar to those to the north.

-4. Iake Iahontan - One of two large basin areas in the Easin and Range Frovince characterized by the existence of old jelstocene lakes. Mountain ranges divide this area into irregular straits where the lake deposits occur.

35. Iake Bonnevilie - Largest of the two areas noted in unit 34. Characteristics of this area are essentialiy idertical to those noted for Iake Iahontan.

j6. Great (Closed) Easins - Numerous mountain ranges of complex geologlc age and type, and valleys existing in about equal proportions.

37. jonoran Desert - Area possessing characterist1cs somewhat similar to the Great Basin unit except that the general altitude is much lower and valleys and basins occur proportionally greater than the ranges.

38. Yexican Highland - Area possessing characteristics similar to the Great Basin unit except that geologic structure and rock type are more complex and most of the kasins have external outlets (open basins).

35. Sacramento Highland - Faulted area producing cuesta or lateald type of topography on Fermian l1mestones and sandstones (predominantiy). The area does not exinitit the typical basin-range topography common to other units of the Basin and Range Province; however, basins do occur within the area.

40. Great Eend Highland - iountainous area comprised of Tertiary Igneous (intrusive and extensive) and Cretaceous sedimentary (primarily limestone) mixed with numerous plains and aggradational basins.

41. jinta Easin - Dissected plateaus existing within a structural basin filled with tertiary shales and sandstones, with lesser amounts of 11 mestone.

42. Northern Plateau and Valley Area - Exceptionally high 
north trending plateau separated by scarre tad iuilt controlied valieys. The horizontal rock strats are primarily Tertiary massive sandstones and some urile, witi minor Cretaceous and Jurassic areas presert.

43. Central Iava Area - Similar in characteristics tc the Northern Flateau ana Valley Area except 1 t 15 careez by Tertiary lavas and is not as dissectei.

14. Colcred Cliffs - Similar in characteristics to lint 4 ? except a series of east-west trendine clifis iresert $a$ "stalr step" topography toward the lower Grand Cacjor. sectior (Faulted Flateau unit).

45. Fanited Flateaus - This area, north of the Colcraic Fiver, has parallel type faults that alvije the ares into a series of plateaus developed from young sfodimentary rocks whlch overlook the Grand Canyon kllea to the south.

40. Grand Canyon - This area represents the rijestic crinun area of the Grand Canyon jection.

4?. Jan Francisco Plateau (Western Fortion) - Honceencus Hateali area of slight relief on Permian linestones. Dissection and sapplng have exposed sandetones 2 . shales in some areas.

48. Jan Francisco Mountains - Mountainclis areas of his: relief formed by Tertlary and some quaterrary iave : Lon.

49. San Francisco Flateau (Eastern Fortion) - Sisilan in characteyistics to its western counterfart (...*t thi.

50. Datil Volcanlc Flela - Area characterized by interse volcanic activity in the form of flows, uclcanic necis. and cones. This volcante reglon is l rimsily on the eastern side of the unst. The remalning artit is I.2tesu like derived from horfzontal young seditentary shatstones and shales.

51. Zun1 Uplift - Wountainous uplifted area exresine IreCambrian crystalline rocks in 1 ts core and tirlical gradational dip patterrs of sedimertary rocks of Earconiferous to Cretaceous age which form cliestas ara ho eback topography.

52. Canyon Iands - Deeply incised canyon area cut in sandstones and shales of Cretaceous, Triassic and Cartoniferous age. A few Tertiary intrusive occur as jsilded laccollthic domes in the reglor.

33. Navajo - Somewhat poorly defined arei of sourp i ilatedis 
ievelcped from rock type and ages somewhat similar to the Canjon Iands. The area lacks, however, the extreme issfction characteristic to that unit.

54. Iarimie Eange - vountain range consisting of a centra] IreCambian igneous (rredominantly pranjtic) - netarorihic comrlex core with steeply dipping, flanking Paleczolc - Mesczolc sedimentary strata (predoninantiy scindstone and shale) that of ten form homoclinal ridges.

5. icicrado front Range - Similar to Laramie Range.

5t. Wet fountain Range - S1n1lar to Iaramie Fange.

57. janere de Cristo Fange - Similar to Laramie Rarge.

58. Tf. 1 cire Eow Range - Similar to Laramie Range.

50. Nurtr and Madie rarks - Farly level intermontane basin ares covered by granular Tertiary meterial and Elicial cutiwash. The Farks are separated by a chain cf volcances known ts Rabbit Ears Range. The fidale fark fossesses, in general, nore relief than North Eark.

EC. Sore Fange - Similar to Laramie Range.

61. joutr Fark - Structural internontane basin comprised projominantly of granitic rocks.

.. jlerra Vadre Pange - 31milar to Iaranie Range.

- Fark Hange - Simijar to Iaramie Range.

$\therefore$ - jawatch Range - jimilar to Laramie Range.

-. Northern san Luds Valley - Felatively level tasir area filled with deep deposits of glacial and alluvial outwash.

E. asn Ilis Hils - Northeast - southwest range of Tertiary basaltic nesas, lower in elevation and less dissected than the San Juan Mountains to the west.

67. Southern San Iuis Valley - Topographic area somenhat similar to its northem counterpart. Jeaiments are prinarily Fertiary in age.

58. ivestern jeaimentary Section - This area is characterize: by uplift, without folding, resulting in a subiatire $5: s-$ sectes platean of fairly horizontal faleczolc - iesczcic strata. The northern rortions are lava coverea. In 
many respects, this unit bears more of a similarilty to units found in the Colorado Flateau than the Rccry Mountains.

69. Elk Fange - similar to Iaramie Range.

70. San Juan Flateau - Basaltic lava covered area lachine the mature dissection characteristic to the Jan iliar Nountain unit.

71. San Juan Mountains - Maturely dissected plateald srea of high relief carved from basaltic lavas and tuifs of Tertiary age.

72. Uinta fountains - Similar to Iaramie Range.

73. Wyomide/Wasatch Wountains - Yountaincus areas crarycterized primarily ky complex faleczoic - Vesczcic sedimentary rocks strongly influenced ty trirust faliting.

74. Ieton Range - Similar to Laramie Range.

75. Jackson Hole - Downfaulted intermontrne basin with Cretaceous - Tertiary sediments covered in the north by Elacial till and outwash.

76. Yellowstone Lava Plateau - Flateali surtece composen cf late Tertiary rhyolitic flows.

?? Sallatin Range - Nountainolis area comrosed preicminantly of volcanic breccia.

78. Eeartooth Nountains - Similar to Laranie fience.

79. Absarocka Mountains - Heavily ilssected plateru compop? of late cretaceous and early Tertiary treccias $A a^{\text {? }}$ ? tasalts.

80. Wina River Mountains - 3imilar to Iaramie Furef.

81. CWI Creek Range - Similar to Iararie Fange.

82. Sighorn Vountains - Similar to Iaranie Range.

83. Pryor Mountains - Small but noticestle uplift that is primarily a dissected plateau of strong limfstone.

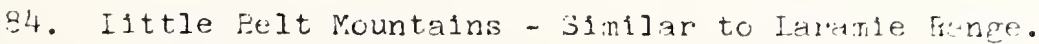

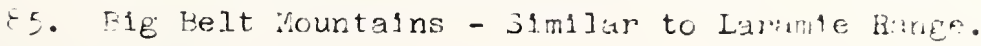

80. Solthwest irontana - Structurally tils ares ilafere from its northern counterpart in that bisin - rane falti; 
dre nore conspicuous leaving a random display of ranges and intervening Tertiary basins. The bedrock type within the ranges varies greatiy by age and type.

2?. Northwest Montana - Ilke the Southwest Montana unit; the major characteristic of the area is the presence of Tertiary basins. The western portion of this area is characterized by Precambrian igneous - metamorphic complex while the eastern portion contains Paleozolc strata. A large portion contains linear type ranges iue to eastward thrust faulting.

88. Eltterroot - Complex and viverse mountainous area jenerally comprised of FreCambrian metamorphic rock complexes. The mountains within the area vary from sprawling to linear.

59. jalnon River Vieta/Volcan1c Area - Th1s area possesses toporraphy not different from the Idaho Patholith linit rut carved primarily from Tertiary volcanics.

0. Jalmon River (Idaho Batholith) Area - Falrly homogeneous area of sprawling mountains developed on Jurassic Eranste.

31. jelkirk Mountains - Rugged mountainous area developed frimarily on Jurassic granite.

92. Ckanogan Highlands - In general, this area is not as rugged as the selkirk unit. It has been covered by variable thicknesses of glacial drift overlying Jurassic granites (primarily).

3. Glaclated rissouri Plateau - Glaciated plateau area with smooth rolling hills and terraced valleys. Underlying vedrock is predominantly Tertiary and Cretaceous sandstones and shales which form the surficial rock of the unglaciated Missouri Flateau unit.

;it. Jweeterass Hills - Mountalnous area formed by Frecanbrian intrusives now being exhumer.

f. Eest faw rountains - Mountains formed ty extinct volcanic group.

30. Ilttle rocky rountains - Similar to Iaramie Range.

;P. Judith rountains - Mountain group of eroded laccoliths.

2. Pfe Jnowy Nountain - Jimilar to Laramie Range.

99. Crazy Kountains - Kountains of volcanic origin.

100. righwood Wountains - Maturely dissected mountains of 


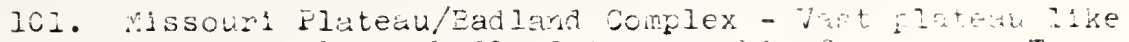
area witr large badana topograrkid festines. The majority of the area is underiain ty Tertiary and Cretaceous clay shales, shales and sandstones. Inirequently, Iignite as well as lfinsstones ar. fun? in the area.

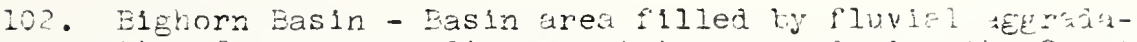
tion from stirrounding ncuntain aresis ding the creat Ilains Tertiary alluviation. Eelrock is prescinastiv sandstones and shales with desert lants, tiari. int alkali flats being cornon.

103. Wyoming Basins - This area is compriged cat itvers? individual rasin areas whose chiractortetic ne identical to the Eighorr easin unit.

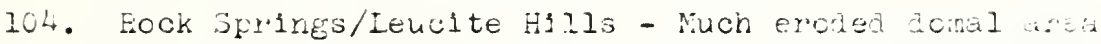
is th steep horbacks and cliestas of Cretsinis arystone. The leucite Hills area is a 7 losals regis corth of the fock Springs area.

105. Sweetwater (Granite) Nountains - jcatterez tractic core is landis surrounded by Tertiary atidats ot tide rasins.

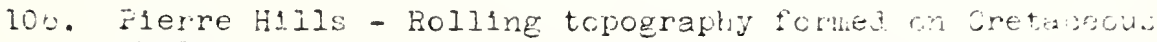
shale.

107. Diack H113 Central Crystaline Area - PreCamlinin Braniti: core of the exposez domal uplift wilch iz tir.

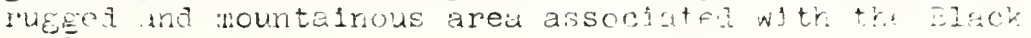
HIİs.

108. Hack Hills Volcanic Nountains - jeries ot scatterei Tertiary jogneous laccolitks found in the rorticer. portion of the jection.

109. Elack Hills Iirestone Flateali - Flateali ares of Permian limestone which encirles (unsyiretriasily) t? olier core of the dome.

110. Elack ilils fied Valley - Iowland ared ferive imcin soft shaley Triassic rocks which encircles the irevicusly lescribel Iimestone Plateal unit.

111. Elack Hills Hogkack Ridges - Narrow cuesta scar or hogbach ridge developed on Cretaceous sanistune. Tris toporrannic area gradually nerges in sil a irection into the Missouri Plateal Ead and Complex dri iteryt ill 11 s units.

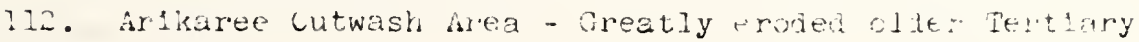


(irikaref) outwish (unconsoliated).

11.. Verrakt janl hills - Junal type topography develored I rou rand teposits.

i". Sarer Hole Iowland - Denuded bajand area deveiofed por ciays (Prule Frn) of Tertiary age.

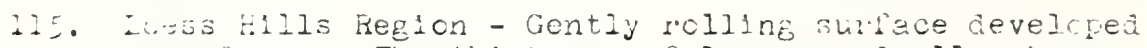
ufce iofse. The thickness of loess rrakuliy changes Cror. 100 feet in Nebraska to a thin veneer in Kansas :iere it eventialiy aisappears.

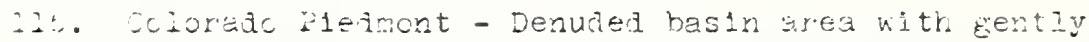
wislatirg topograpry developed upon cretacecus day siriles. Wore highly tilted and Aissected rocis cccir. ding the Rocky Nountain foothilis. Jarastones, Ilmiter I1mestones and chalks, as weil as basalt i'ows are of suboralnate existence in the unit.

117. Ceallala Cutwash Area - In essence, this 1s the crietra: Tortliry outwash mantle wilch veneered nost of the ireat Flains Province. Topography is essentialiy flat weon the younger (relative to the older ixikaree sitinsh) unconsolyated sands, silts and eravels.

ilo. hatuqua ilateau - Strippea plain clit ty canyone and surreunded by voloanic Jandforms. Rock types witin: the flteau are Frimarliy Cretaceous sandstones :na strales.

in. Eitun vesa - Sonewhat indefinite area delineating iava capea resas underlying softer horizontai to olighty dipring sedimentary rocks. Dissection, which crudualy increases westward, has removed portions of the volcinlc cover leavine many gaps between tre nesas.

za. Fark Ilateau - Heavily dissected hiehzand developea ifon late cretaceous to early Tertiary sandstones an strales.

2.1. Lis vejas rlateau - Similar in characteristics to the vrlatagua ilateau.

12. Fecos Valley - Eroded lowiand area developea lifon Pernian unt Triassic shales, sandstone;, evpsur und ac, ne lixestono. The Fecos Valley 1s, in rart, ieepy "II Iej with aliuvium.

12j. jtcokton Flateali - Preaoninantly flat plateau revelopez in Cretaceous I1nestone.

13. Luinaras Ilateau - sinilar to the stockton Flateau, 
which is separated from it by the feccs Canyon.

125. Blue Hills - A flat, plateau-like uplan surface with occussional buttes ana mesas developed frum iretacecus limestone with interkedded shale.

120. jmokey fills - North-south trending rolilag hijl srea consistine of Cretaceous shales capped by resistant sandstones in places.

12?. Flint H1lis - Rolling hill area with escarpments ieveloped upon cherty limestones of Fernian gee.

128. Arkansas Iowland - Flat alluvial plain of the Arracsas River.

129. Permian Golling Flains - Gently rolline tororrachy developed upon Permian shales witr. ninor sandistcne areas. Gypsum occurs along the western rortion of the unit.

ijo. Michlta Mountains - Low mountalnous area develcked upon PreCambrlan 1 gneous rocks and flaring sandstint and limestone of early paleczoic age.

131. Srtuckle lplift - Ilateau like uplift cf sigr.t relief exposing a PreCambrian core of granttle rocks ilaried by early Paleozolo ilmestones and Pennsyluarder chies.

132. Ilmestone Scarped Plains - Parallel trenilng cuesta type topography developed upon Pernsyivanian linestor (scarps) and shales (lowlands).

133. Cherokee Lowland - Cently undulating lowland jeveloped upon Fernsylvanian shale.

134. Sandstune H1lls - Rolling hills developed primariy from fennsylvanlun sandstones.

135. jandstone Scarped Flatns - Th1s area is the torograritc counterfart of the Ilmestone scarfed Flains to the north. In this lait, sandstone of Fennsylvandan age replaces the Ilmestone of the northern unit as the scarp maker.

130. Grand Frairie - Somewhat topographically diverse urea varyine from slightly rolline in the north to higkly alssected in the centril and southern porticns of tro unit. The distinction of this unit is tised primariy upon the Cretaceous limestones and shales which : arn most of the parent material of the area.

137. Ilano Dissected Ilmestone Flateal - This area has, as 
its counterpart, the Black Hill Iimestone Plateali in:t. The topgriphy is primirily a maturely dissected piatinu like drea on Cambrian and ceinvician Ilimestrnes.

I3. IJanr Lrift - Central busin (topographic) area carved irom the old PreCambrian eranites, gneisses and aciilsts. This reat is the counterpart to the Platch Hils Central crystidline Area.

17. Iane Bouris - Lacustrine plain associated with high A tor phases during Fleistocene glaciation. Iacustrine sediments are primarjly very fine textured. Associated with the lacustrine derosits are irregliar grarular tesch deposits marking former levels of the oid lake.

140. Lade Agessiz - Similar in characteristics to Iane junis unit.

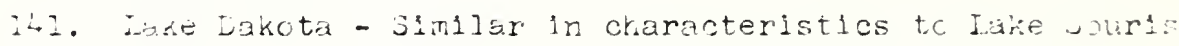
arit.

14. Inte chicagc - similar in characteristics to Iake jouris writ.

3. Tankake jand Easin - Eusin area fllled ry water deposit+ lineis assonated with glacial drainage and poning if several rlacial drainage outlets in northern Ins:-

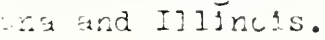

3it. Eare jaginiw - sinilar in characteristlos to isire jouris unit.

745. Iske Green Bay - Similar in characteristias to Eare scurls unft.

14.. Late Duluth - Sinilar in characteristics to Iafe scivis inll 1 .

I47. Lake Numee - Similar in characteristics to Iake jouris init.

I-E. ifatern Iakes orift Area - Frominant to gently roiling icrainic tofography with poorly integrated arairise sister develofed on Cary and younger type of gacisi rift.

443. Discectei Ijess Covered Iowan Jrift Alez - Thas area reresents one of two prongs of highly alssected ir win irift which serve as the northerly extension of the Jissectci Ioessial and Tlll Plain jection. This area; however, unlike the eastern extending prong, is ccverei 
by loessial deposits.

150. Lissected Iowan Drift Area - Similar in chiracterisitics to the Dissected Loess Covered Iowan Drift unit except lacking the loess derosits comnon ti trat init.

I51. Dissected Loess Covered Kansan Drift Area - Inis highli iissected unit is similar in charicteristic topoaraphy to the Dissected Loess Covered Iowan Irift unit except that the glacial till is Kansan in age. The iepth of loess is quite variatle in thickness overlying the drift.

152. Jissected Kansas Drift Area - These Aissected wits: occur where the loess gradually thins and disappears as the surficlal covering over the Kansas irift.

153. Icess Covered Southwest Cuestas - This area, for all practical purposes is the loess covered portion of the iriftless section. Underlying the loess in cuestit fashion (facing the northeast) are Cambrian sunstcres and shales, and Crdovician and Silurian carkcnates as cne proceeds to the southwest. Geologic structire is influenced by the Wisconsin dome.

154. Central Jand Flain - Relatively flat plisin ?roree. cccassional island like buttes of sandstone forme residual weathering of soft Cambrian santstones and shales.

I55. Eastern Iakes Drift Area - This unit 1s quite similar to the Nestern Iakes rrift unit, except that bedrock slightly effects topograchy in the form of $: 11 \mathrm{ght}, \mathrm{z}$ exposed chesta areas.

IEE. Erje-Cntario Rolling Flains - Solline rlain ares developed on glaclal tili. A large rortion of the ane is dorinated by large drumin topograrky.

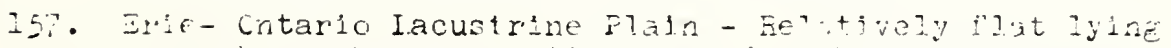

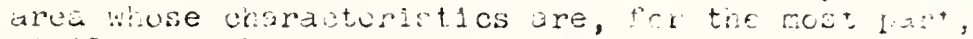

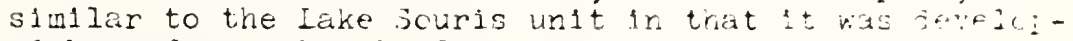
ed by a former level of the present I cntario.

158. Loess Flains of Western Ilincls - Loess ilins of relatively small relief wrilci veneer Illinoten $4: t$ and s.rall areas of Tazewell and older wisconsin inift.

159. Tipton rill Plain - Typical till pluin area Exil t: te flat to gently undulating terrair developed r.. Iezeve: and olcer wisconsin arjft. 
160. Ilinolan Drift Area - Drift plain developed on IIIInclan drift. Relief within the area is slightly more excessive than that found in the Tipton Tili Flain. The depth of the Illinolan drift eradually tbins to the south so that the physlography may in part, reflect the character of the underlying bedrock to a greater degree in these areas.

161. Tug Hill Cuesta - Glaclated cuesta area of moderate relief developed primarliy by Ordovician sandstones and shales.

162. Elack River Valley - Falrly small valley area underlain by Crdoviclan limestones and shales. The valiey is also surfaced by wldespread lacustrine and deltalc deposits depesited during Pleistocene glaciation.

163. Mohawk Iowland - Glaciated plain of high relief due to the slightly dipping sedimentary strata which are continuous with the Appalachian Plateau. The major bedrock underlying the till is Craoviclan shale and limestones with subcrdinate S1lurlan sandstones locally overlying them.

164. St. Iawrence Lowland - Smooth glaclal plain covered for the most part by marine clay deposits. Underlying bedrock is primarily early Paleozolc llmestone and sandstone which do not affect rellef within the drift.

165. Champlain Iowland - Folling glaclated lowland, part1ally covered by marine clays. Bedrock similar in age and type to the St. Iawrence Iowland unit frequently protrudes through the glaclal and marine deposits.

166. Glaciated Ridge and Valley - This area exhiblts topoEraphy as well as a geomorphlc history somewhat similar to the unglaciated portions of the lidge and Valiey Frovince to the south except that is covered by glaclal deposits. The ridges are primarily Devonian sandstones whlle the valieys are primarily CroovieIan shales and 11 mestones.

167. Slate H1IIs Area - Glaclated area exhibiting rounded knoll or "mamilary" topography produced upon glacial drift or slate of Crdoviclan age. The northern portion of the unit is also covered by marine clays sirilar to those found in the St. Iawrence and Champlain Lowland units.

168. Superior Upland - Dissected, glaciated peneplain on Precambrian 1 gneous and tetamorphic rocks of complex structure. Glacial drift is similar in age to those 
found in the East and West Lakes units (Cary and Younger Wisconsin drift) and in many areas controls the physiographic details.

169. Northwest Lowland - Glaclated lowland area of the Adirondack Section which is due to the poor resistance of the underlying metasedimentary rocks of Precambrian age.

170. Central H1ghland Plateau - Uplifted and dissected glacisted peneplain formed on PreCambrian granites and syenite gneisses.

171. High Feaks Region - Glaclated mountalnous portion of the adirondack section formed by very resistant anorthosites of the Adirondack batholith.

172. St. Francis Mountains - Mountain area developed cn the structural crest of the Czark dome. Cambrian sandstones and carbonates, deposited before the upI1ft, are now in various stages of erosion therety exhuming the PreCambrian granitic type core rocks.

173. Salem Plateau - Dissected plateau formed primarily on Crdovician sedimentary rocks. Cherty cartonates predominate in the area.

174. Springfield Plateau - Plateau area formed primarily on Mississipplan sedimentary rocks. Similar to the Salem Plateau, cartonates rccks of cherty character are prevalent in the unit.

175. Boston Nountains - Maturely dissected plateau of Pennoylvanian sandstones and shales left as denudation remants of the Czark Domal Uplift.

176. Arkansas Valley - East/west trending structural trough formed by the syncliborlum of Pennsylvanian sandstones and shales.

177. Fourche Klamichi Eelt - Bugged mountalnous area formed upon Carboniferous sandstones and shales.

178. Novaculite Uplift - Area exhititing ridge and basin topography. Arkansas Novaculite forms the ridges of the unit while the basins are formed on Fennsylvanian shales.

179. Athens Pledmont Area - In essence, the geologic type and age of the bedrock in the unit is similar to the Fourche Klamichi Belt unit. The major distinctiveness of this unit is the plateau like nature of the bedrock and subsequently does not exhlbit the great relief of 
of that unit.

180. Jouthem Illinois Loessial Area - H1ly loess area veneering Mississippian IImestones, shales and sandstones at the extreme southern tip of Illinols.

181. Island Hilis - This area is characterized by widespread valley alluviation in which remants of Pennsylvanian sandstones and shales protrude as hills above the flat alluvial terrain.

18.2. Indiana/Kentucky Coal Fields - Maturely dissected upland formed on Pennsylvanian sandstones, shales and clays.

183. Yammoth Cave Plateau - Heavily dissected plateau exhibiting tcpography somewhat similar to the Kentucky/ Indiana Coal F'ields unit. The bedrock, however, is Frimarily complex Mississipplan formations of shale, sandstone and limestone.

184. Westerr Pennyroyal Iimestone Plain - Plain formed primarily on Mississippian Iimestones. Karst topography is prevalent in much of the unit.

185. Knot Hill - This area generally exhibits conical or hilly type of terrain. Bedrock is primarily rississjpplan - Devonian in age. Massive shale with sandstone or limestone caps comprise the higher hill vortion while shale predominates in the lower hill ares.

186. Kentucky/Tennessee Eastern Pennyroyal - This area is somewhat topographically variable ranging from karst topography on Iimestone to undulating on shales. The bedrock age is Mississippian.

187. Nashville Easin - Fairly homogeneous topographic basin area of rolling plains and low relief developed on Crdovician limestones and some shale.

188. Cuter Rlue Grass - Cently roling topography developed on alternating, thinly bedied shales and Ilmestcnes of upper Crdovician age.

18G. Eden Shale - Throughiy dissected plateau develcped lipon crdovician shales.

100. Inner Elue Grass - Undulating topography formea prinarliy on Iower Crdovician limestones.

101. Cumberland Plateau - Submaturely dissected plateau, 
similar, but lacking the advance degree of dissection of the Kanawha unit. The area is characterized primarily by strone Pennsylvanian sandstones and to a more limited extent, shales.

192. Sequatchie/W1Ils Creek Valley - Valleys formed ty the erosion of upper strata along the axis of the sequatchie anticline exposing craovician limestones.

133. Kanawha - Maturely dissected plateau formed or predoninantly horizontal to slightly dipping sandstones and shales of Pennsylvanian age and soft shales and I1restones of Permian age. Toward the oliter fortions of the section, Mississipplan rocks occur.

194. New York Glaciated Plateau - Maturely dissected plateau of predominantly horizontal to slightly Aifrire shales, sandstones and some 11 mestones of Devonian (primarily) and Yississippian anz Eennsylvanian (minor) age. The area, however, has been significantly nod1fled by late visconsin glaciation.

195. Catskill Mountains - Mountainous upland area of DevonIan sandstones, conglomerates and shales. The area has been glaclated, but physiographic signiflcance is not as great in comparison to the New York Glaciated Plateau unit.

196. Pocono Mountains - Dissected area of flat Iying resistant Vississippian sandstone.

197. Allegheny Mountains - Heav1ly dissected area that has lost the plateau type characteristics common to the remainder of the Province. Mild folling is evident in portions of the Unit. Frimary rifge makers of the unit are sandstones of Pennsylvanian and Mississipfien age with Mississipplan shales and mincr limestone areas being krought to the surface on the slcres of some of the ridges.

198. Tennessee - Series of 11near trending ridges and valieys developed primarily from faulting, folding and subsequent erosion of the sedimentary rocks. In the unit, valleys are predominant over ridges. I.owlands are primarily developed on Cambrian and Crdovician carbonates and shales with subordinate areas of rississippian cherty Ilmestone. Ridges are primarily sandstones of Devonian, S1lurian, Mississifpian and Fennsylvanian age.

199. Parallel Folded Ridge and Valley Area - Series of Iinear parallel ridges and valleys developed primarily from folding and erosion of sedimentary rocks of rir articlinoriun. Most of the valley areas in tr.1s unit are 
lerived from Cambrian and Ordovician shales. Ridges are primarliy Pennsylvanian, Nississippian anä Devon1 an sandstones.

200. Great Valley - Falrly large continuous lowland area developed upon Cambrian and Crdoviclan Ilmestone. This area 1 is generally developed as the synclinorium portion of the combined anticinorium - synclincrium ccmination ccmprising units 199 and 200.

201. ilg-zag Nountains - This unit is somewhat similar in bejrock type and age to the Parallel Folded Bidge and Valley Area. The major alstinction of this unit is derived from the northeast plurging characteristics of the folds in this area resulting in a series of zigzag ridges in lieu of the parallel ridges noted for the former unit.

02. Southerm Elue Rlage - Eelt of mountains that are remnents of a former highland antedating the lower peneflains on either side. Rock type and structure within the area is complex with Cambrian netasediments (quartzites, sandstone, graywacke and slates) iorning a westem strip and the remaining bedrock consisting of Precambrian gneissic and granitic type of kearock. Very small areas of craoviclan limestone are found in the region. These areas are called "coves" cr "windows").

203. Northern Elue B1dge - This unit is the northem countenpart of tile Southern BIue Pidge area. Difierences zetween this area and the latter are: rock type is prinarliy Precanbrian gneissic and granitic; the area $1 \mathrm{~s}$ not a belt of mountains, but rather a single subauej riage; and the elevations are, in general, lower than the southern undt.

204. Fiedmont Flateau - Broady undulating to roling topcEraphy created by peneplation upon complex inetamorphic and plutonic rocks and structure. Precambrian and Cantrian granites, gneisses and schist predominate the bedrock.

205. Trlassic Iowland - Fairly large basin lowland develcfea ty weak Trisssic sandstones and shales. Iowland tcpography is occassicnally modified by lanecus "traf ridges".

20b. Triassic Iowland Inlier - jmall scattered areas having chiracteristics 1dentical to the Triassic Iowland linit.

207. Frewerick Valley - Small lowland area nerging in 
toporraph1c features with the Triass1c I.owland unit, but developed on Crdovician limestone.

208. Chester - Conestoga (Lancaster) Valleys - Similar in characteristics to the Frederick Valley unit.

209. Fiedmont Crystalline Inlier - This rather small area is separated from the Fiedmont plateau unit by the Chester - Conestoga Valleys. Its characteristics sre identical to those of the piedmont plateali unit.

210. Glaciated Triassic Iowland - Th1s area possesses tedrock characteristics similar to the Triassic Iowland unit but hiving its topographic features modifled by wisconsin jlacial arift.

211. Reading Frong - Southwestward extending crystaliine prong of the New England Upland composed preioninantiy of low rountains developed on Précambrian crystalline rocks. The majority of the unit has been Elaciated.

212. Taconic Mountains - Disordered glaclated mountein ares developed primarily on metasedimentary schists, slates and phyllttes.

213. Fennselear Plateau - Glaclated plateau surface with relief generally expressed by broad swells and long slopes. Rock type is primarily Cambrian quartzites.

214. Iimestone Valley of Vermont - This lowland area is not as continuous as noted by the dlagram. The valley is underlain primarily by Cambrian limestones, dolomites and marble.

215. Green Mountains - Structurally complex mountainous area of primarily PreCambrian metamorphic rocks (schists, gneisses and quartzites) that have been intruied by granite and basic igneous rocks. The area is glaciated.

216. White Mountains - Somewhat 1rregular and indefinitely delineated area containing several mountain groups. Continental as well as alpine glaclation covers bedrock of extreme complexity. Rock types are chiefly early Paleozolc and PreCambrian 1 gneous and metamorphic.

217. Northem New England Slate/Shale Area - This area is a maturely dissected peneplained surface which slopes gradually to the southeast. Stoney granular wisconsin drift overlies bedrock, generally, at very thin depths. The underlying bedrock of this area is primarily developed upon sandstones, shales and slates interrupted by scattered granitic intrusions. 
218. Seaboard Iowland - Seaboard sloping margin possessing smoother topography (relative to the Northern and Southern Upland units), underlain by bedrock 1dentical to that found in the adjacent upland units, and characterized, in part, by marine deposits thought to be a result of late Pleistocene submergence.

219. Southern New England Upland - The overall topographic features of this area are similar to the Northern Slate/Shale unit. This area differs, however, from the latter, by being underlain primarily by an uplifted and tilted peneplain of granite and schist. Glacial drift characteristics are also similar to the Northern unit.

220. Connecticut Lowland - Extensively glaclated lowland area underlain by weak Trlassic sandstones and shales containing numerous igneous (trap) ridges.

221. Cape Cod - Glaciated area exhibiting hummocky topography underlain by granular unconsolidated coastal plain deposits.

222. Iong Island - Similar in general characteristics to the Cape cod unit.

223. Raritan Lowland - Iowland area developed on weakly resistant Cretaceous clays (for the most part) of coastal plain origin.

224. Atlantic and East Gulf Terraced Coastal Plain - This rather extensive strip of land mass is primarily the terraced (outer) portion of the Coastal Plain. A series of terraces, primarily of granular (sandy) character are evident throughout the area. Extreme outer portions of the unit frequently possess swampy areas due to relatively high ground water zone. In the northern portion of the unit, embayments reach back almost to the fall line border.

225. Mississjpp1 Loessial Upland - Upland area mantled with loessial deposits gradually thinning and disappearing as one proceeds to the east part of the unit.

220. Mississippi Alluvial Plain - Alluvial and deltalc plain area of the Mississippl and Red Rivers. Alluvial terraces are found inland and coastwise deltalc terraces along its seaward margin. The sediments for the most part are fine textured.

22?. Crowley's Ridge - Upland area existing within the confines of the Mississippl Alluvial Flain developed by Loess deposits generaliy overlying granular cosstal 
sed1ments.

228. Blackland Prarie - Lowland area of gently uniulating character which is developed upon upper Cretaceous limestones and marls of the Coastal Plain.

229. West Gulf Terraced Coastal Plain - This outer coastal plain area consists in general, of marine clays of Quaternary age.

230. West Gulf Coastal Flain - This unit topographically represents a serjes of alternating inland facing cuesta and lowlands developed primarily on Tertiary coastal plain sediments.

231. Florida Ilme Sink Region - This unit, though somewhat indefinite in delineation, represents the area where the Ccalla uplift significantly modifies the terrain in the Florida Section. Karst features are extensively developed in the area and are generally overlain by recently emergent sandy terrace deposits of the coastal plain.

232. Sand and Fall Ine Hills - This area is the innermost zone or strip of belted areas quite pronounced in the East Gulf Coast Section and portion of the Sea Island section of the Woods-Iovell Classiflcation. The unit is primarily a belt of maturely dissected hills produced on the oldest Cretaceous formations of the coastal plain. Texturally, these deposits are primarliy quite granular in nature.

233. Ripley Cuesta - This cuesta or escarpment type area is an upland belt formed on the late Cretaceous sandy Ripley formation.

234. Pontotac Ridge - This unit is essentially the same as the Ripley Cuesta unit being only geographically separated due to thinning out of the Ripley formation in west central Alabama.

235. Black Belt - This unit is a lowland unit developed on the weak Cretaceous Selma chalk.

236. Flatwoods - This unit is a lowland developed on Eocene clays (M1dway). The character of this formation is not as "clayey" as those to the north in the Plack Belt unit and subsequently relief within the area is slightly greater.

237. Red H11ls - This upland, or escarpment area is formed on the Eocene W1Icox formation (sandy). Dissection of this formation is variable, ranging from mature to 
undis sected.

238. Buhrstone Cuesta - Th1s upland area is a cuesta type belt developed upon the very resistant Buhrstone formation of Tertiary age.

239. Jackson Pralrle - Thls lowland belt is developed on clays of the Eocene Jackson formation.

240. Dougherty Plains - This area is a relatively flat plain forming an upland developed on Tertiary limestones. Karst features are evident in the area and in general, the unit is quite similar to the Florida Ilme-Sink unit.

241. Tifton Uplands - This upland area is submaturely dissected and exhibits topography which is generally rolling hill type. The parent materlal of the coastal deposits in this unit are primarily Mocene in age.

242. Southern Pine Hilis - This hiliy area is the outermost of the cuesta (belted) coastal areas. Coastal sed1ments are primarily late Tertlary in age and the caprock of the area is generally the gravelly fliocene Citronelle formations. 


\section{BIBLIOGRAPHY}





\section{BIBIIOGRAPHY}

Because of the rather wide range of subject areas considered in this report, the bibliography is divided into four groupings based upon the major subjects discussed. ithin each grouping, references are arrangea in alphabetical sequence. The numeric listing of the references is, however, maintained continuously between the subject areas. Multiple listings within different major subject groups, for a particular reference, are made for those references whose contents are pertinent to more than one major subject area. The references cited for high volume change solls are those from an unpublished report by $H$. P. Jensen.

\section{Reg1onal Physlography (Geomorphology)}

1. Agrlcultural and Industrial Development Board of Kentucky, "Land Areas of Kentucky and Their Potential for Use," Frankfort, 1953.

2. American Geological Inst1tute, "Glossary of Geology and Related Sclences - With Supplement," 2nd Edition. November 1960.

3. Atwood, W. W., "The Physlographic Provinces of North Amer1ca," Ginn and Company, 1940.

4. Averitt, P., "Coal Reserves of the United States, "Progress Eort Us. Geolog1cal Survey Bulletin 1136, 1960.

5. Baker, R. F., Chieruzz1, R., "Regional Concept of Landslide Occurence," H1ghway Besearch Board. Eulletin 216. 1959. 
6. Beckman, H. C., Hinchez, N. S., "The Iarge Springs of Missour1, "Missouri Geological Survey and Water Resources, Volume 29, 2nd series, 1944.

7. Eelcher, D. J., Gregg, I. E., Woods, K. B., "The Formation, Distribution and Englneering Characteristics of Solls," Jolnt Hlghway Besearch Prolect Bulletin No. 87, Purdue University, 1943.

8. Black, R. F., "The Physical Geography of Wisconsin, "Reprint from Blue Book, Department of Geology, University of is consin.

9. Eranch, J. R., "The Geology of Flora Quadrangle," North Dakota Geolog1cal Survey Bulletin No. 22, 1947 .

10. Eryan, K., "The Formation of Pediments," Beport 16th Intemational Geolog 1 cal Congress. Part II, 1935.

11. "Eulletin No. 17, Maryland Department of Geology, Mines, Water Resources," 1956.

12. "Bulletin No. 37, Minnesota Geologic Survey," University of Minnesota, Mine. Bocks and Waters (by sins, P.K.), 1963.

13. Bureau of Mines, Manufacturing and Agriculture, "Minerals of Arkansas," 1925.

14. Carter, R. I., Giddens, J., "So1ls of Georg1a - Their Formation, Classification and Management," University of Georgla College of Agriculture, Bulletin No. 52 , January 1953.

15. Cherry, R. N., "Chemlcal Qual1ty of Water of Georg1a Streams - A Reconnaissance Study," Georgla State D1vision of Conservation. Geological Survey Bulletin No. 62, 1961.

16. Cornell University, "Solls and Soll Associations of New York," Bulletin No. 230, Revised May 1961.

17. Corps of Engineers, "Engineering and Design, Pavement Design for Frost Conditions" EM-1110-345-306.

18. Fenneman, N. M., "Phys1ography of Eastern United States," McGraw - H111 Book Company, New York, 1938.

19. Fenneman, N. M., "Physlography of Western United States," McGraw-H111 Book Company, New York, 1931.

20. Flint, R. F., "Physical Divisions of South Dakota," Professional Paper No. 262, U. S. Geolog1c Survey. 
21. Fint, R. F., "The Surficial Geology of the New Haven and Woodmont Quadrangles," State Geological and Natural History Survey of Connect1 cut, Quadrangle Report No. 18, 1965.

22. Florida Agricultural Experimental Station," Major Iand Resources of Florida - General Soll Map of Florida," May 1962.

23. Freeman, C. W., Forrester, J. D., Iupher, R. L., "Phys10graphic Divisions of the Columbia Intermontane Province," Assoclation of American Geographers. Annals, 1945.

24. Geological Soclety of Amerlca, "Glaclal Nap of North Amer1ca," New York, 1945 (Scale 1:4,555,000).

25. Geological Survey of West Virginia, "Physiographic Divisions of West Virginia." (Map)

26. Girralnik, D. B. (Editor-in-Chlef) "Webster's New World Dictionary and Student Handbook," The Southwestern Company, 1966.

27. Hammond, E. H., "Classes of Land-Surface Form in the Forty-Eight States, U.S. A., "University of Wisconsin, 1963 (Scale 1;5,000,000).

28. Hardesty, J. S., "Land Resource Areas of Maine," U.S. Department of Agriculture, July 1957.

29. John, B. H., Editor, "Geology of Southern California," Division of Vines. Department of Natural Resources, Bulletin 120, San Francisco, Cal1fornia, September, 1954.

30. Jenkins, D. S., Belcher, D. J., Gregg, I. E., Woods, K. B., "The Crigin, Distribution and Airphoto Identification of United States Solls" Technical Development Fieport No. 52. C1v11 Aeronaut1Cs Administration, 1946.

31. Jenkins, O. P., "Geomorphic Map of California" State of California. Department of Natural Besources Bulletir 188. Plate 2, 1938.

32. Karraker, P. E., "So1ls of Kentucky." Unlvers1ty of Kentucky. C1rcular 6 ? (Rev1sed), June 1955.

33. Kentucky Geological Survey, "Physlographic Divisions of Kentucky." (Map)

34. Latimer, W. J., "Soll Survey of Vermont - Reconnalssance," No. 43 . Series 1930, U. 3. Dept. of Arriculture. 
35. Lelghton, M. N., Ekblaw, G. E., Horberg, I., "Il]1no1s State Geological Survey Beport of Investigations No. 129."

36. Ie1ghton, M. M., WIIIman, H. B., "Loess Formations of the Missiasipp1 Valiey," Journal of Geology, Vol, 58, 1960.

37. Lobeck, A. K., "Geolog1c Map of the United States, The Geograph1cal Press, Columb1a Un1vers1ty, New York, 1941 (Revised 1948).

38. Iobeck, A. K., "Physlcgraph1c Diagram of North America," The Geographical Press, C. S. Hammond and Co.. Maplewood, New Jersey, 1950 (1ncludes Physlographic Province diagram and accompanying text discussion).

39. Mallott, C. A., "Handbook of Indiana Geology - Part II," Indiana Dept. Cons. Publ. No. 21, 192?.

40. Narbut, C. F., "Atlas of American Agriculture, Part III, Solis of the United States," U. S. Department of Agriculture, 1935.

41. McAlpln, G.W., Hofmann, W. P., "Soll Explorations," Section 10, Highway Engineering Handbook, McGraw - H11] Company, New York 1960.

42. Miles, R. D., Scholer, C. F., Shurig, D. G., woods, K. B., Yoder, E. J., "Reglonal Factors Influenc1ng H1ghway Favement Design and Performance", unpublished NCHRP Interim Report 1-3(1), September 1965.

43. Miltary Engineering. Experimental Establishment, "Field Trials of a Terrain Classification System Organization and Methods," MEXE No. 873, England, August, 1965.

44. Miltary Engineering Experimental Establishment, "Report of the Working Group on Land Classification and Data Storage," MEXE No. 940, England, February 1966.

45. Miller, D. W., "Water Atlas of the United States," Water Information Center, Port Washington, New York, 1962.

46. Neal, J. T., Captaln, USAF (Ed1tor), "Geology, Mineralogy, and Hydrology of U.S. Playas," Alr Eorce Cambridge Research Laboratories, Enviromental Research Papers No. 96, Apr11 1965.

47. New York State Museum and Sc1ence Serv1ce, "Geolcgy of New York - A Short Account," Albany, 1966.

48. North Carolina Agricultural Experlment Station, "The Solis of North Carolina - Their Formation, Identification and Use," December, 1955. 
49. Pennsylvan1a Topographic and Geologic Survey, "Physiographic Provinces of Pennsylvania." (rap)

50. Pur1, H. S., Vernor, B. C., "Summary of the Geology of Florida and a Guldebook to the Classic Exposures," Florlda Geologic Survey Speclal Publication No. 5, 1959.

51. Ralsz, E., "Iandforms of the United States" (to accompany Atwood's Fhyslograph1c Provinces of North America), 1957.

52. Reed, R. D., "Geology of Callfornia," Amer1can Assoclation of Petroleum Geologists, Tulsa, Oklahoma, 1951.

53. Ross, Forrester, "Geomorph1c Map of Idaho and Adjacent Areas." Outline of Idaho Geology, Idaho Bureau of Mines and Geology Bullentin No. 15, May 1958.

54. Schoewe, w. H., "The Geography of Kansas, Part 2. - Phys1cal Geography," Kansas Academy of Sclence Transaction, Volume 52 , No. 3 .

55. Schwartz, G. M., Prokopov1ch, N., "Map of Mineral kesources of Minnesota," University of Minnesota, Minnesota Geologlcal Survey, 1956.

56. South Carolina Agricultural Experiment Station, "Solls of South Carolina," Agronomy and Solls Research Series 23, February 1960 .

57. "South Dakota State Geologist Feport of Investigation No. 93," Geology of Selected Highway Strips in S.D. (ky Cox E.J.)

58. Sparks, B., "Geomorphology," Iongmans, Green and Company Itd., London, England, 1960.

59. Stevant, D. P., "Glaclal Geology of Vermont," Vermont Geologlcal Survey Bulletin No. 12, 1961.

60. Storle, R. E., Harradine, F., "Solls of California," Reprint from Soll Sclence, Volume 85 , No. 4, April, 1958.

61. Stose, G. W., Editor, "Preliminary Geologlc Map of Washlngton," State of Washington, Division of Geology, Fullman, Washington, 1936.

62. Swanson, C. L. W., Shear1n, A. E., Bourbeau, G. A., "Characteristics of Some Brown Podzolic Profiles in the Central Lowland of Connectlcut and Massachusetts," heprint from So11 sclence Proceedings, Volume 16, No. 2 , Apr11, 1952.

03. Texas Agricultural Experiment Station, "Land Resources of Texas, " No. L-400. (Map) 
64. Thornbury, W. D., "Principles of Geomorphology," John wley and Sons, New York, 1954.

65. Thornbury, W. D., "Reglonal Geomorphology of the United States," John W1ley and Sons, New York, 1965.

66. Tolman, C. F., "Ground Water", McGraw - H1ll Book Company, New York, 1937.

67. U. S. Department of Agriculture, "Climate and Men," Yeartook of Agriculture, U.S. Printing office, 1940.

68. U. S. Department of Agriculture - Soll Conservation Service, "Descriptions of Soll Besource Areas in Connect1cut," September, 196 ?

69. U. S. Department of Agriculture - Soll Conservation Service (in cooperation with Colorado Agricultural Experiment Station) "Land Resource Areas of Colorado," General Series No. 727. April 1960.

70. U.S. Department of Agriculture - Soll Conservation Service, (In cooperation with the Illinols Agriculture Experiment Station), "Solls of Illinols," Bulletin No. 225, July, 1967.

71. U. S. Department of Agriculture - Soll Conservation Service (In cooperation with University of Arkansas Experimental Station), "Soll Assoclation Map - State of Arkansas," April, 1959.

72. U. S. Department of Agriculture - Soll Conservation Service, "Major Land - Resource Areas - Arizona," September, 1964.

73. U. S. Department of the Interlor, "Physical Divisions of the Unlted States" (prepared by N. M. Fenneman in cooperation with the Physlographic Comittee of the Geological Survey), 1946, (Map).

74. U. S. Geological Survey and American Assoclation of Fetroleum Geologists, "Tecton1c Map of the U. S.," 1962 , (Scale $1 ; 2,500,000)$.

75. U. S. Geological Survey, "Geologic Map of tne United States," 1932 (Scale 1;2,500,000).

76. U. S. Geologlcal Survey, "Rellef Map of the Unlted States," Department of the Interior. (Scale 1;?,000,000).

77. Virginia Polytechnic Institute, "Solls of Virginia," Bulletin 203. Englneerlng Extension Series, Revised Yarch 1968 
78. Washington Division of Mines and Geology, "Mineral and Water Resources of Washington," Bulletin No, 32, 1360.

79. W1dmer, Kemble, "The Geology and Geography of New Jersey," Volume 12. The New Jersey Historical Series, 1964.

80. Wilson, E. D., "A Besume of the Geology of Arizona," Arizona Bureau of Mines Bulletin No. 171, 1962.

81. Winsor, J. H., Balley, H. H., "A Key to Kentucky Solls." University of Kentucky Agricultural Experiment Station, (Map).

82. Woods, K. B., Lovell, C. W. Jr., "D1stribution of Solls in North America," Section 9, Highway Englneering Handbook, McGraw - Hill, New York, 1960.

83. Woods, K. B., Lovell, C. W. Jr., "Physlographlc Reglons of North America Modifled for Englneering Purposes," 1958 (Scale; $1 ; 2,000,000$ ).

84. Wright, H. E., Frey, D. G. et al, "The Quatemary of the Unlted States," Princeton University Press, Princeton, New Jersey, 1965.

\section{Aggregates}

85. Alabama: NCHRP State Highway Materials Questionnalre Response, 1967.

86. Arlzona: NCHRP State Highway Materlals Questionnalre Response, 1967.

87. Arkansas: NCHRP State Highway Materlals Questionnalre Response, 1967.

88. Augenbaugh, N. B., Johnson, B. B., Yoder, E. J., "Degradation of Base Course Aggregates During Compaction", NCHRP Report, School of C1vil Englneering, Purdue University, May 1963.

89. Balmer, G. G., Colley, E. E., "Laboratory Studies of the Skld Resistance of Concrete", Portland Cement Association D-109.

90. Bloom, M. J., "An Analysis of the Highway Frost Problem in the North Central United States", M. S. Thes1s, Furdue University, August, 1965.

91. Bugg, S. L., Firmage, D. A., "Froperties of Plaln and ReInforced Ilmerock Concrete", Proceedings Highway Research Board, 1950. 
92. California: NCHRP State Highway Materials Questionnaire Response, 1967.

93. Calvin, S., "The Buchanan Gravels: An Interglacial Deposit in Buchanan County, Iowa", American Geologist, Volume 12, 1896.

94. Collett, F. R., Warnick, C. C., Hoffman, D. S., "Frevention of Degradation of Basalt Aggregates Used in Highway Base Construction", Highway Besearch Eoard, Bulletin 344, 1962 .

95. Colorado: NCHRP State Highway Materials Questionnaire Response, 196 ?

96. Connecticut: NCHRP State Highway Materials Questionnalre Kesponse, 1967 .

97. Day, H. I., "Progress Report on Studies of Degrading Basalt Aggregate Bases", Highway Besearch Board Bulletin №. 344,1962 .

38. Lelaware: NCHKF State Highway Materials questionnaire Response, $196 ?$.

99. Fenneman, N. M., "Physlography of Eastern Unlted States", McGraw - Hill Book Company, New York, 1938.

100. Fenneman, N. M., "Physiography of Western United States", McGraw - Hill Book Company, New York, 1931.

101. Florida: NCHRP State Highway Materials Questionnaire Pesponse, 1967.

102. French, R. R., Carr, D. C., "Geologic Factors Arfecting the Exploration for lineral Aggregates in the Indianapolis Area" , Proceedings, 18th Annual Highway Geology Symposium, Furdue University, Apri1, 196 ?

103. French, Ir. R., "Crushed Stone Pesources of the Devonlan and Silurian Carbonate Rocks of Indiana", Department of Natural Besources Geological Survey Bulletín No. 32, 1967.

104. French, R. R., "Indlana's Crushed Stone Industry: 1947-1965", Indiana Business Review, Volume XIII, 196 ?

105. Georgia: NCHRP State Highway Materials Questionnaire Response, 1967.

105. Gibson, W. E., "A Study of Map Cracking in Sand-Gravel Pavements," Proceedings, Highway Research Board. 1238. ( Part I). 
107. Glllson, J. L. et al, "The Carbonate Rocks", Chapter 8, Industrial Minerals and Rocks, American Institute of Mining, Netallurgical and Petroleum Engineers, New York, 1960.

108. Goetz, W. H., Wood, L. E., "Bituminous Materlals and Mixtures", Section 18, Highway Engineering Handbook, (Ed1ted by K. B. Woods), McGraw - Hill, New York, 1960.

109. Goodwin, W. A., "Aggregate Characteristles Influencing Skid Resistance," National L1mestone Inst1tute, I1mestone, Fall, 1968.

110. Gray, J. E., Kenninger, F. A., "The Sk1d-Resistant Properties of Carbonate Aggregates", Highway Research Becord No..120, 1965.

111. Gregg, L. E., Havens, J. H., "Application of Geology to H1ghway Englneering in Kentucky", Fourth Annual Symposium on Geology as Applied to Highway Engineering, Morris Harvey College, Charleston, west Virginia, 1953.

112. Hadley, D. W., "Alkal1 React1v1ty of Carbonate Rocks", Portland Cement Assoclation. Research Department Bulletin. No. 132 .

113. Hansen, W. C., "Attack on Portland Cement Concrete by Alkal1 Solls and Waters - A Critical Review", Highway Research Record No, 113, 1965.

114. Havens, J. H., Wllliams, E. G., "A Study of the Properties and Performance of Kentucky (Natural Sandstone) Bock Asphalt", Beport. Kentucky Department of Highways, Highway Research Laboratory, University of Kentucky, Lexington, 1956.

115. Highway Research Board, "Beport of Commltee on Warping of Concrete Pavements", Proceedings, H1ghway Besearch Board, 1945.

116. Hveem, F. N., Sm1th, T. W., "A Durab111ty Test for Aggregates", H1ghway Research Record No. 62, 1903.

117. Idaho: NCHRP State H1ghway Materlals Questionnalre Response, 1967.

118. Ill1no1s: NCHRP State Hlghway Materlals Questionnalre Response, 1967 .

119. Indiana Department of Conservation, "Generalized Geologic Map of Indlana", Survey Report of Progress No. 2, 1956. 
120. Indlana: NCHRP State Highway Materials Questionnalre Response, 1967.

121. Iowa: NCHRP State Highway Materials Questionnalre Response, 1967 .

122. Iowa State Highway Commission, "Iowa - An Engineering Report on Solls, Geology, Terrain and Climate", Ames, Iowa, 1959.

123. Jenkins, D. S., Belcher, D. J., Gregg, I. E., Woods, K. B., "The Crigin, Distribution and Alrphoto Identification of United States Solls," Technical Development Report No. 52, C1v11 Aeronautics Administration, 1946.

124. Jones, T. R., Jr., H1rsch, T. J., "Creep and Shrinkage in IIghtwelght Concrete", Proceedings, Highway Research Board, 1959.

125. Kansas: NCHRP State H1ghway Materlals Questionnalre Response, 1967.

126. Kentucky: NCHRP State Highway Materials Questionnalre Response, 1967.

127. Kentucky Rock Asphalt Inst1tute, "Kentucky Rock Asphalt Speciflcations and Designs", April, 1937.

128. Klinefelter, T. A., "Ilghtwelght Aggregates", Chapter 22, Industrial Minerals and Rocks, Amerlcan Institute of Mining, Metallurglcal and Petroleum Englneers, New York, 1960 .

129. Iandgren, R., Sweet, H. S., "Investigation of Durabll1ty of iyoming Aggregates", Proceedings, Highway Research Board, 1952 .

130. Lelghton, M. M., "The Road Bullding Sands and Gravels of Washington," Bulletin No. 22, Washington Geological Survey, Clympla, Washington, 1919.

131. Ienhart, W. B., "Sand and Gravel", Chapter 41, Industrial Minerals and Rocks, American Institute of Mining, Netallurgical and Petroleum Englneers, New York, 1960.

132. Iew1s, D. W., "Research on Concrete Aggregates", Purdue University Engineering Experiment Station, Englneering Reprint No. 61, 1950.

133. Iou1slana Geological Soc1ety, "Generalized Map of Iou1slana Showing Reglons of Gravel Exposures", Ioulsiana Geological_Bulletin. No, 19. 
134. Loulsiana: NCHRP State Highway Materials Questionnalre Response, $196 ?$.

135. Loss1ng, F. A., "Sulphate Attack on Concrete Pavements in M1s81ssipp1", H1ghway Besearch Fecord No. 113, 1965.

136. Naine: NCHRP State H1ghway Materials Questionnalre Response, $196 ?$.

137. Marbut, C. F., "Atlas of Amer1can Agriculture, Fart III, Solls of the Un1ted States", U. S. Dept. of Agriculture, 1935.

138. Maryland: NCHRP State H1ghway Materials Questionnalre Besponse, 1967.

139. Massachusetts: NCHRP State H1ghway Materlals quest1onnalre Response, 1967.

140. Mayt1n, I. I., G1lkeson, R., "So1ls of Walla-Walla County", Engineering So11s Manual. Bulletin 252, State College of Washington, Pullman, Washington, 1962.

141. Maytin, I. L., Stan, W. A., "Solis of Yak1ma County", Englneering So118 Manual. Bulletin 249, State College of Washington, Pullman, Washington, 1960.

142. Mclaughiln, J.F., Woods, K. B., Mielenz, R. C., Rockwood, N. C., "Distribution, Production, and Englneering Characteristics of Aggregates", Section 16, H1gh way Englneerling Handbook (Edited by K. B. Woods), McGraw - H1II, New York, 1960.

143. Mich1gan: NCHRP State H1ghway Materials Quest1onna1re Response, $196 ?$.

144. M1les, B. D., Scholer, C. F., Shurlg, D. G., Woods, K. B., Yoder, E. J., "Reglonal Factors Influencing Highway Pavement Design and Performance", unpublished NCHRP Interlm Rpt. 1-3(1), September, 1965.

145. Mississ1pp1: NCHRF State Highway Materlals Questionnalre Response, 1967 .

146. M1ssour1: NCHRP State H1ghway Materlals questionna1re Response, $196 ?$.

147. Moavenzadeh, F., Goetz, W. H., "Aggregate Degradation in B1tuminous Mixtures", Highway Research Recora No. 24, 1963.

148. Montana: NCHRP State H1ghway Materials Questionnalre Response, 1967. 
149. Noultrop, K., "Rhode Island Aggregate Survey", D1v1sion of Englneering Research and Development, University of Rhode Island, KIngston, Rhode Island, June 1964.

150. Nebraska: NCHBP State Highway Materials Questionnaire Response, 1967.

151. Neveda: NCHRP State Highway Materials Questionnaire Response, 1967.

152. Neville, A. M., "Properties of Concrete", John W1ley and Sons, 1963.

153. New Hampshire: NCHRP State H1ghway Materials Questionnaire Response, 1967.

154. New Jersey: NCHRP State Highway Materials Questionnaire Pesponse, 1967.

155. New Mexico: NCHRP State Highway Materials Questicnnaire Response, 1967.

15t. New York, NCHRP State H1ehway Materlals questionnaire Response, 1967.

157. New York State Museum and Sclence Service, "Geology of New Iork - A Short Account", Albany, 1966.

158. Newlon, H. H., Sherwcod, W. C., "An Cccurrence of Alkal1Reactive Carbonate Rock in Virginia", Highway Research Eoard Bulletin No. 355.1962.

159. North Carolina: NCHR State Highway Naterials Questionnaire Fesponse, 1967.

100. North Dakota: NCHRF State Highway Naterials questionnaire Besponse, 1967.

161. Chio: NCHRP State Highway Materials Questionnalre Response, 1967.

162. Ciklahoma: NCHRF State Highway Naterials Questionnaire Response, 1967 .

303. Ontario Department of Highways, "Research on Skid Resistance", Bnt. No. 114, Ontar10, Canada, 1966.

164. Orchard, D. F., "Concrete Technology - Volume 2", John Wiley and Sons, 1962.

165. Cregon: NCHhP State H1ghway Naterials Questionnalre Eesponse, 1967. 
166. Osborne, A., "Frost Earrier for H1ghway and Alrfield Regional Studies", Part IJ, Dow Chemlcal Company, 1967.

167. Pennsylvania: NCHRP State Highway Materials Questionna1re Response, 1967.

168. Pergendoff, R. N., "Research Studies in Connection with Design Features of the Florlda Turnplke", Proceedings, Highway Research Board, 1958.

169. P1t and Quarry Fublications, "P1t and Quarry Directory of the Non Metallic Minerals Industries", Chicago, IIIIno1s, 1965.

170. Portland Cement Assoclation, "Aggregates for Concrete," Portland Cement Assoclation, 1962.

171. Rhoades, R., Mielenz, B. C., "Fetrograph1c and Mineralog1c Characteristics of Aggregates", Spec1al lechnical Fublication No. 83. American Soclety for Testing and Mater1als, 1948.

172. B1g1d Pavement Laboratory, Corps of Englneers, "Keport of Aggregate Avallability in Continental United States", Chio kiver Division, Corps of Engineers, Marlemont, Chio, December, 1952.

173. Schuster, B. I., McLaughiln, J. F., "A Study of Chert and Shale Gravel in Concrete", H1ghway Research Eoard Bulletin No. 305, 1961.

174. Schwartz, G. M., Prokopovich, N., "Map of Mineral Resources of Minnesota", University of Minnesota, Minnesota Geological Survey, 1956.

175. Severinghause, N., "Crushed Stone", Chapter 13, Industrial Minerals and Bocks, American Institute of Vining, Metaljurglcal and Petroleum Englneers, New York, 1960.

176. Shupe, J. W., Goetz, W. H., "A Laboratory Invest1gation of Pavement SI1pperiness", Purdue Un1vers1ty EnglneerIng Reprint No. CE 124, June, 1960.

177. Shupe, J. W., "Pavement SI1pperiness", Section 20 , Highway Engineering Handbook, (Edited by K. B. Woods), McGraw - H111, New York, 1960.

178. Stephens, J. E., Goetz, W. H., "Designing Fine Bltuminous Mixtures for High Skid Resistance," Purdue Unlversity Engineering Beprint. CE 181. January, 1961. 
179. Stose, G. W., "Preliminary Geologic Map ot' Washington", State of Washington, Division of Geology, Pullman, Washington, 1936.

180. South Lakota: NCHRP State Highway Materlals Quest1onnalre Response, 1967.

181. Swineford, A., "Cemented Sandstone of the Dakota and Klowa Formations in Kansas", State Geologlcal Survey of Kansas. Bulletin 20. Part 4, Lawrence, Kansas, 1947.

182. Tennessee: NCHRP State Highway Materjals Questionna1re Fesponse, 1967 .

183. Texas: NCHRP State H1ghway Materlals Questionnalre Response, 1967.

184. Thornbury, W. D., "Reglonal Geomorphology of the united States", John Wiley and Sons, New York, 1965.

185. Tolman, C. F., "Ground Water", McGraw - H11I Book Company, New York, 1937.

186. Tremper, B., "Freeze-Thaw Resistance of Concrete as Affected by Alkalies in Cement", Proceedings. American soclety for Testing and Naterials, 1951.

187. United States Department of Commerce Bureau of Publ1c Roads, "Results of Physical Tests of Road Building Aggregate", Washington, D. C., 1953.

188. United States Department of the Interior, "Volume I, Vetals and Minerals (Except Fuels)", 1964 Minerals Yearbook, Washington, D. C., 1965.

189. United States Department of the Interior, "Volume 3 , Area Reports: Domestic", 1964 Minerals Yearbook, Washington, D. C., 1965.

190. United States Geological Survey, "Geolog1c Map of the Un1ted States", 1932.

191. Utah: NCHRP State Highway Materlals Questionnaire Response, 1967.

192. Vermont: NCHRP State Highway Materlals Questionnalre Response, 1967.

193. V1rginia: NCHRP State Highway Materials Questionna1re Response, 1967.

194. Washington: NCHRP State Highway Materials Questionna1re Besponse, 1967. 
195. Washington State Division of Mines and Geology, "Sand and Grave1", Division of Mines and Geology. Bulletin Ne. 37. Part I. Plate 33 (Sand and Gravel Pits of washington); Plate 34 (Map Showing. Principal Areas of Sand and Grave1).

196. West V1rgin1a: NCHRP State H1ghway Materlals Questionnaire Response, 1967.

197. Wiscons1n: NCHRP State Highway Materials Questionnalre Response, 1967 .

198. W1tczak, M.W., "Phys1ograph1c Areas of the Un1ted States", Vol. I of a NCHRF Report in Preparation, 1968.

199. Woods, K. B., Johnstone, J. C., Yoder, E. J., "Some Engineering Problems Associated with the Preglacial Marletta Biver Valley", Fourth Annual Symposium on Geology as Applied to Highway Engineering", Charleston, West Virginia, 1953.

200. Woods, K. B., Lovell, C. W. Jr., "Distribution of Solls in North America", Section 9, Highway Englneering Handbook, (Ed1ted' by K. B. Woods), McGraw - H1l1, New York, 1960.

201. Woods, K. B., "Materials and Engineering Protiems of North America", unpublished course notes, Graduate School of Civil Engineering, Purdue University.

202. Woods, K. B., Sweet, H. S., Shelboume, T. E., "Pavement Elowups Correlated with Source of Coarse Aggregate", Froceedings, Highway Research Board, 1945 .

203. Woolf, D. 0., "Field Experience with Alkal1 - Aggregate Reaction in Concrete: Eastern United States", Highway Research Board. Research Beport 18-C, 1958.

204. Wright, H. E., Frey, D. G., et al, "The Quarternary of the United States", Princetcn University Fress, Frinceton, New Jersey, 1965.

205. Wyoming: NCHBP State Highway Materials Questionnalre Response, 1967.

\section{So11s - Origin and Texture}

206. Agricultural and Industrial Development Board of Kentucky, "Iand Areas of Kentucky and Their Potential For Use", Frankfort, 1953. 
207. Alabama Department of Agriculture and Industries, "So11 Map - State of Alabama", Montgomery, Alabama, 1953.

208. Arneman, H. F., "Solls of the Red River Valley", Reprint, Minnesota Farm and Home Science, 1961.

209. Beaumont, A. B., "So1l Assoc1ations of Massachusetts", Unlted States Department of Agriculture Extension Service, Massachusetts State College, 1939.

210. Beaumont, A. B., "The Solls of Massachusetts", Univers1ty of Massachuetts Special C1rcular No. 64. January, 1950.

211. Belcher, D. J., Gregg, L. E., Woods, K. B., "The Formation, Distribution and Engineering Characteristics of Solls" Jo1nt H1 ghway Research Project Bulletin No, 87, Purdue Un1vers1ty, 1943.

212. Bourbeau, G. A., Swanson, C. L. W., "The Morphology, Mineralogy and Genesis of Two Southem New England So1ls", Connecticut Agricultural Experiment Station Bulletin 584 , June, 1954.

213. Bulck, T. R., "Analysis and Synthesis of Highway Pavement Design", Joint H1ghway Research Project, No, 13, Purdue University, July, 1968.

214. Eunting, B. T., "The Geography of So1I", Aldine Publishing Company, Chicago, Ililnois, 1965.

215. Carter, R. I., Glddens, J., "Solls of Georgla - The1r F'ormation, Classification and Management", College Experiment Station Bulletin No, 2 , Athens, Georgia, January, 1953.

216. Cline, M. G., "Solls and So1I Associations of New York", Corneli Extension Bulletin 230 , May, 1961.

217. Collings, G. H., Montgomery, P. H., "Iand Resource Areas State of South Carolina", South Carolina Experiment Station Circular 112, June 1957.

218. Colorado Agricultural Experiment Station, "Land Resource Areas of Colorado", General Series 227, April, 1960.

219. Corps of Engineers, "Forecasting Trafficability of Solis - Alrphoto Approach", Technical Memorandum No. 3-331. Beport 6. Volume II, June, 1963.

220. Davisdon, D. T. et al. "Geolog1c and Engineering Properties of Pleistocene Materials in Iowa", Bulletin No. 20, Iowa Highway Research Board, December, 1960. 


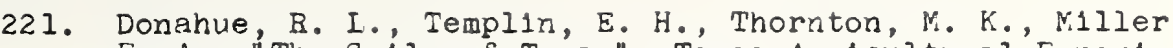
E. A., "The Solis of Texas", Texas Agricultural Exper1ment Station BuIletin 431, 1948.

222. Dregne, H. E., "So1ls of Iaaho", Mimeo-Ieaflet No. IO?, Univers1ty of Idaho Department of Afronomy, June, 1947 .

223. Epperson, G. R., Porter, H. C., "A Key to the Solis of the Southern Pledmont of Virginia", V1rginia Polytechnic Institute of Agronomy C1rcular, No. 3 , June, 1962.

224. Fehrenbacker, J. E., "Ioess D1stribution and Composition in Portions of the Lower Wabash and Ch1o River Basins", PhD Thes1s, Furdue University, June, 1964.

225. Federal Housing Admin1stration, "EngineerinE So1l Class1flcation for Fesidential Developments", FHA No. 223 , 1961 .

226. Federal Housing Administration, "Evaluation of Solls and Use of Soll Surveys for Engineering Furposes in Urban Development", FHA No. 223, Cctober, 1963.

227. Florida Agricultural Experiment Stations, "General Soll Map of Florida", May, 1962.

228. Florida State Geolog1cal Survey, "Generalized jo1I Map of Filorlda", 1925.

229. Foss, J. E., Rust, R. H., "So1l Development in Relation to Ioessial Deposition in Southeastern Minnesota", Reprint. So11 Science Society Proceedings, Vol, 26, No. 3 , June, 1962 .

230. Hampton, D., Yoder E. J., Burr, I. W., "Varlability of Englneering Properties of Erookston and Crosby Solls", Purdue University Civ11 Englneering Reprint 192, July, 1963.

231. H111, D. E., Gonick, W. N., "The Paxton So1ls", Connecticut Experiment Station Bulletin 662, December, 1963.

232. Hole, D. F., Beatty, M. T., "Solls of Wisconsin - A Generalized Map", University of Wisconsin, Madison, Wis consin, 1957 .

233. I111no1s Agriculture Exper1ment Station, "So1 is of Ililnois", Bulletin No. 225, July, 1967.

234. Iowa State Highway Commission, "Iowa - An Engineering Report on Solis, Geology, Terrain and Climate", Ames, Iowa, 1959. 
235. Iowa State University Cooperative Extension Service,

"Principal Soll Association Areas of Iowa", Ames, Iowa, June, 1950.

236. Jenkins, D. S., Belcher, D. J., Gregg, I. E., Woods, K. E., "The Crigin, Distribution and Alrphoto Identif 1cation of United States Solls", Technlcal Development Report No. 52, C1vil Aeronaut1 cs Admin1stration, 1946.

237. Jenny, H., "Factors of So1l Formation", McGraw - H1II Eook Co., New York, 1941.

238. Jo1nt Highway Research Project, Purtue University, "Englneerlng Soll Parent Material Areas of Ind1ana", (Revised Edition of 1943 Nap of Bulletin No. 87), 1950.

239. Karraker, F.E., "So11s of Kentucky", Un1vers1ty of Kentucky Agricuitural Experlment Station, C1rcular 6?. June, 1955.

240. Iat1ner, W. J., "So11 Survey of Vermont - Reconnaissance", U. S. Department of Agriculture No.43. Ser1es 1930.

241. Iee, W. D., Goldston, E. F., "North Carolina Soll Assoclation Map", 1955.

242. I1gon, W. S., Karraker, P. E., "A Key to Kentucky So1ls", Kentucky Agricultural Experimental Station C1rcular 64. November, 1949.

243. I1nell, K. A., "Frost Action and Permafrost", Sect1on 12, H1ghway Eng1neerlng Handbook, (Ed1ted by K. B. Woods), McGraw - Hi11, New York, 1960.

244. I1u, T. K., "A Review of Eng1neering So1l Classification Systems", H1ghway Research Board Record No. 156 , 1967.

245. Ioulsiana Agricultural Extension Service, "So1l D1v1s1ons of Iou1siana", Agricultural Extension Publication 12I?, September, 1961 .

246. Nangum, A. W. et al, "Reconnalssance Survey of Southwestern Washington", U.S.D.A. Beport, May, 1913.

247. Nangum, A. W. et al, "Reconnalssance Survey of the Western Part of the Puget Sound Basin, Washington", U.S.D.A. Report, June, 1912.

248. varbut, C. F., "Atlas of Amer1can Agriculture, Fart III, Solls of the United States", U. S. Department of Agriculture, 1935 
249. McMiller, P. R., "Solls of Minnesota", University of Minnesota Agricultural Extension Service Bulletin No. 278, December, 1954.

250. Miles, R. D., Scholer, C. F., Shurig, D. G., Woods, K. B., Yoder, E. J., "Reglonal Factors Influencing Highway Pavement Design and Performance", unpublished NCHRP Interim Report I-3 (1), September, 1965.

251. Military Engineering Experimental Establishment, "Field Trials of a Terrain Classification System Organization and Methods", MEXE No. 823, England, August, 196:.

252. M1I1tary Englneering Experimental Estatlishment, "Report of the Working Group on Land Classification and Data Storage", MEXE No. 240, England, February, 1966.

253. Mississippi State Department of Agriculture, "So11 Map of M1ssiss1pp1", Jackson, M1ssiss1po1, 1942.

254. Norse, R. K., Thomburm, T. H., "Rellabll1ty of Soll Map Units" University of Illino1s Civil Engineering Studies, So11 Mechanics Series No. 5, 1961.

255. Neal, J. T., Capta1n, USAF (Editor), "Geology, vineralogy, and Hydrology of U. S. Playas", Alr Force Cambridge Research Laboratorles, Environmental Research Papers №. 96, Apr11, 1965.

256. New Jersey Agricultural Experiment Station, "Land Type Areas of New Jersey", (Map).

257. New York State College of Agriculture, "So1l Association Map of New York State", Department of Agronomy, Cornell University, 1961.

258. North Carolina Agricultural Experiment Station, "The Solls of North Carolina - Their Formation, Identification and Use", Technical Eulletin No. 115. December, 1955.

259. North Dakota Agricultural College, "General So1l Areas of North Dakota", 1941.

260. Oh10 Department of Natural Resources, "Cur Chlo Solls", Division of Lands and So11, April, 1958.

261. Pomerening, J. A., "Soll Association Map of Maryland", Department of Agronomy, 1962.

262. Portland Cement Association, "PCA Soll Primer", Chlcago, Illino1s, 1962. 
263. Erince, A. B., Baney, W. A., (Beview Editors), "Some Morphological, Physlcal, and Chemical Froperties of Selected Northeastem United States Solls", University of New Hampshire Agricultural Experiment Station N1scellaneous Publication I, June, 1961.

264. Quakenbush, G. A., "Cur iNew Jersey Land", New Jersey Agricultural Experiment Station Bulletin 23, January, 195:.

265. Fust, F. H., Farnham, R. S., Robertson, A. S., "The Nebish Rockwood Solls of Northern Minnesota", Reprint, Minnesota Farm and Home Sclence, Vol, XVI, October, 1958.

206. Smlth, J. B., Gilbert, B. E., "Rhode Island Soll Types: Texture and Chemlcal Composition, and a Utility Index", Bhode Island State College Agricultural Experiment Station Bulletin 226, Narch, 1945.

207. South Carolina Agricultural Experiment Station, "Solls of South Carolina - Keys for their Identification", Agronomy and So11s Research Series 23, Clems on, South Carolina, 1960.

268. South Dakota Agricultural Experiment Station, "Solls of South Dakota", So11 Survey Series No. 3, Narch, 1959.

269. State of Chio Department of Natural Resources, "Know Ch10's Sol1 Reglons", 1962.

270. Stevens, J. C., Maner, A. W., Shelburne, T. E., "Pavement Performance Correlated With Soll Areas", Virginia Counc1l of Highway Investigation and Research, December, 1949.

271. Storie, R. E., Harradine, F., "Solls of California", Beprint, So11 Sc1ence Vol. 85. №. 4, April, 1958.

272. Storle, R. E., Welr, W. W., "Generalized Soll Map of California", California Agricultural Experiment Stat1on Manual 6. Berkeley, Cal1fornia, April, 1951.

273. Swanson, C. I. W., Bitchie, A. Jr., "Significance of Sand and Gravel in the Classification, Napping and Management of Some Coarse - Textured Solls", Connect1cut Agricultural Experiment Station. Bulletin 580, January, 1954.

274. Tedrow, J. C. F., "Solls of New Jersey", New Jersey Agricultural Experiment Station, 1962. 
275. University of Illinols Agricultural. Experiment Station, "Princlpal Soll Association Areas of Ililno1s", April, 1962 .

276. University of M1ssour1 Agricultural Experiment Station, "Reconnalssance Survey Soll Map of N.1ssour1", 1931.

277. University of wisconsin Agricultural Experiment Station, "Solls of the North Central Region of the United States", BuIletin No. 544, June, 1960.

278. U. S. Department of Agriculture, "Soll Association Map of New England," 1959.

279. U. S. Department of Agr1culture, "So1ls and Men", Yearbook of Agriculture, 1938.

280. Un1ted States Department of Agriculture Sc1l Conservation, "A Look at the Caribou So11s", 1962.

281. Un1ted States Department of Agriculture So11 Conservation Service, "Description of Soll Resource Areas in Connecticut", September, 1959.

282. Unlted States Department of Agriculture Soll Conservation Service, "General So11 Map - Vermont", 1962.

283. United States Department of Agriculture Soll Conservation Service, "Land Resource Areas of Nalne", July, 1957 , (Map).

284. United States Department of Agriculture So11 Conservation Service, "Major Iand Rescurce Areas, Arizona", September, 1964, (Map).

285. Unlted States Department of Agrlculture So1l Conservation Service, "Soll Assoclation Map, States of Arkansas, Apr11, 1959.

286. Undted States Department of the Interior Geological Survey, "Soll Association Areas of Georgla", 1944.(Nap).

287. Virginia Agricultural Experiment station, "Certain Properties of Selected Southeasterm United States Solls and Mineralogical Procedures for Their Study", Southern Regional Bulletin 6., January, 1959.

288. V1relnia Agricultural Experiment Station, "Genesis and Morphology of Virginia Solis", V1rginia Polytechn1c Institute Bulletin 540, Apri1, 1962. 
289. Virginia Polytechnic Intitute and the United States Department of Agrlculture, "A Key to the Solls of the Coastal Plains of V1rginia", V1rginia Polytechn1c Inst1tute Agronomy C1rcular. No. 4, February, 1963.

290. Virginia Polytechnic Institute and the United States Department of Agriculture, "A Key to the Solls of the Appalachian D1vision of Virginia", Virginia Polytechnic Institute Agronomy Circular. No. 2, July, 1960.

291. V1rginia Polytechnic Institute and the United States Department of Agriculture, "Solis of Virginia", Virginia Polytechn1c Institute Bulietin 203, March, 1958.

292. Wahls, H. E., Buchanan, W. T., Futrell, G. E., Lucas, S. P., "Distribution and Englneering Properties of North CaroIina Solls", Englneering Research Department, North CaroIna State, June, 1964.

293. Wahls, H. E., Futrell, G. E., "A Comparison of Soll Classification Systems by Analysis of Variancen, Proceedings. National Conference on Statistical Qualjty Control Methodology in Highway and Alrfield Construction, University of Virginia, 1966.

294. Washington State University, "Solis of the Western Lnited States (exclusive of Hawa11 and Alaska)", September, 1964.

295. Woods, K. B., Lovell, C. W. Jr., "Distrikution of Solls in North America", Section 9, Highway Engineering Handbook, (Edited by K. R. Woods), McGraw - H1II, New York, 1960.

296. Woods, K. B., Niles, B. D., Lovell, C. W. Jr., "Crigin, Formation and Distribution of Solls in North Amerlca", Chapter 1, Foundation Engineering (Edited by G. A. Ieonards), McGraw - H1II Book Co., 1962.

297. Wright, H. E., Frey, D. G. et al., "The Quaternary of the United States", Princeton University Press, Princeton, New Jersey, 1965.

298. Yoder, E. J., "Princlples of Pavement Design", John Wl ley and Sons, 1959.

So1ls - H1gh Volume Change

299. Alabama Geological Survey, "Geolcgy of Alabama", Alabama Geologlcal Survey Special Report No. 14, 1926. 
300. "Anonymus", "Homebullders Protest New Slab Design Criter$1 a^{n}$, Engineering News - Record, January, 1966.

301. Bates, T. F., "The Application of Electron Microscopy in Soll Clay Mineralogy" in"So11 Clay Mineralogy - A Sympos 1um" by Rich, C. I., Kunze, G. W., University of North Carolina, Chapel H1ll, 1964.

302. Benson, J. R., D1scussion of Holtz, W. G., "Expansive Clays - Properties and Problems", Quarterly Colorado School of Mines Vol, 54. No. 4, Cctober, 1959.

303. Bolt, G. H., "Physico - Chemical Analys1s of the Compressibility of Pure Clays", Geotechnique, 6:86, 1956.

304. Bradley, W. F., "X-Ray Diffraction Analysis of Scil Clays and Structure of Clay Minerals" in "Soll Clay Mineralogy - A Symposium" by Rich, C. I., Kunze, G. W., University of North Carolina, Chapel Hili, 1964.

305. Brindley, G. W., "Identification of Clay Minerals by X-Ray Diffraction Analys is" in "Clays and Clay Technolog:" Bulletin 169, Dept. of Natural Resources, State of Cal1fornia, 1955.

306. Brown, J. L., "Laboratory Techniques in the Electron Microscopy of Clay Minerals" in "Soll Clay MineralogyA Symposium", by Rich, C. I., Kunze, G. W., University of North Carolina, Chapel Hill, 1964.

307. Budge, W. D., Sampson, E., Jr., Schuster, R. I., "A Method of Determining Swell Potential of an Expansive Clay", HRB - Record No. 112, 1966.

308. Carson, A. B., "Foundation Construction", McGraw - H11], New York, 1965.

309. Carter, W. T., "The Solls of Texas", Texas Agriculture Experiment Station Bulletin 431, 1931.

310. Chen, F. H., "The Use of Plers to Prevent the Uplifting of Lightly Loaded Structures Founded on Expansive Clays", International Research and Engineering Conference on Expansive Clay So1ls, Texas AsM. College Station, 1965.

311. Collins, I. E., "Some Observations on the Movement of Bulldings on Expansive Solls in Vereeninging and Cdendaalsrus", Symposium on Expans1ve Clays, The South African Inst. of Civ11 Englneers, 1957-58.

312. Department of Highways, State of Colorado and the University of Colorado, "A Review of Iiterature on Swelling Solls", Colorado, 1964. 
313. Croney, D., Lew1s, W. A., Coleman, D., "Calculation of the Molsture Distribution Beneath Structures", C1v1l Englneering and Pudilc Works Rev. Iondon. Vol, 45 , No. 524,1950 .

314. Croney, D., Coleman, D., Black, W. F. M., "Kovement and Distribution of Water in Soll in Relation to Highway Design and Performance", HRB - Spec1al Report 40, 1958.

315. Dawson, R. F., "Movement of Small Houses Erected on an Expansive Clay So11" Proc. 3rd International Conference So11 Mechanles and Foundation Engineering. Vol. I. Sw1tzerland, 1953.

310. Dawson, R. F., Modern Pract1ces Used in the Design of Foundations for Structures on Expansive So11s", Quarterly. Colorado School of Mines. Vol. 54 , No, 4 , Cctober, 1959.

317. Dodd, C. G., "Dye Absorption - A Method of Identifying Clays" in Clays and Clay Technology. Bulletin 169, Department of Natural Besources, State of California, 1955 .

318. Dunnewald, T. J., "Wyoming Solls and So11 Materials", University of Wyoming Agricultural Experiment Station Bulletin 349, Apr11, 1957.

319. Felt, E. J., "Influence of Soll Volume Change and Vegetation on Highway Engineering", 26th H1ghway Conference. Und versity of Colorado Englneering Experiment Station C1rcular 26, 1953.

320. Frye, J. C., Leonard, A. B., "Ple1stocene Geology of Kansas", State Geological Survey of Kansas, Bulletin 22,1962 .

321. Giddens, J., Perkins, H. F., Carter, R. I., "So1Is of Georg1a", jo11 Sclence, Vol. 89, 1957.

322. Giesecke, S. E., "Columns and Walls Iffted by Swelling Clay Under Floor" Englneering News - Record. Vol. 88, 1922 .

323. Griffin, J. G., "Studies on Soll Movement Due to a Change in Moisture Content as It Affects Foundation Construction of Farm Houses", M18siss1pp1 State Univers1ty Agriculture Experiment Station Informat1on Sheet 687, December, 1960. 
324. Griffin, J. G., "So1l Movement and Mo1sture Change as They Affect Footings and Foundations for Dwellings in Heavy Clay Solls", Mississ1pp1 State Unlvers1ty Agriculture Experiment Station Information Sheet 767 , June, 1962 .

325. Grim, R. E., "Clay Mineralogy", McGraw - Hill, New York, 1953.

326. Grim, R. E., "Petrographic Study of Clay Minerals", Clays and Clay Technology, Department of Natural Resources, State of California, Bullettn 162, 1955.

327. Hardy, R. M., "Ident1f1cation and Ferformance of Swelling Soll Types", Canadian Geotechnical Journal, Vo1. II. No. 2, May, 1966.

328. Hepworth, R. C., "Heaving in the Subgrade of Highways Constructed on the Mancos Shale", Transactions AIME, Vol. 231, 1965.

329. Holtz, W. G., Gibbs, H. J., "Englneering Properties of Expansive Clays", Transactions ASCE, Vol. 12I. 1956.

330. Holtz, w. G., "Expansive Clays - Properties and Froblems", Quarterly of the Colorado School of Mines. Vol. 54. No. 4, Cctober, 1959.

331. Jackson, N. I., NacKenzle, R. C., "Chemlcal Analysis in the Quantitative Mineralogical Examination of Clays" in "So11 Clay Mineralogy - A Symposlum", by R1ch, C. I., Kunze, w. C., University of North Carolina, Chapel H111, 1964.

332. Jennings, J. E. B., Knlght, K., "The Frediction of Total Heave from the Double cedometer Test", Sympos lum on Expansive Clays. The South African Institute of C1V1I Engineering, 1957-58.

333. Jensen, H. P., "H1gh Volume Change Solls - Distribution and Englneering Experience, U. S.", unpublished report, Purdue University, May, 1967.

334. Johnstone, J. G., Ramarathnan, S., R1chards, D. B., "The Solls of Eastern Colorado, Their Crigin, Distritution and Englneering Characterist1cs", Quarterly of the Colorado School of Mines, Vol, 52, No. 3, JuIy, 1962.

335. Kassiff, G., W1seman, G., "Control of Molsture and Volume Changes in Clay Subgrades by Subdrainage", HBB - Record No. 111, 1966. 
336. Keller, W. D., "Processes of Crigin and Alteration of Clay Ninerals" in "Soll Clay Mineralogy - A Symposium" by Rich, C. I., Kunze, G. W., University of North Carollna, Chapel H111, 1964.

337. Kelley, W. P., "Interpretation of Chemlcal Analysis of Clays" in "Clays and Clay Technology". Bulletin 169, Department of Natural Resources, State of Cal1fornia, 1955.

338. Kerr, F. F., "Formation and Occurrence of Clay vinerals" In "Clays and Clay Technology". Bulletin 169, Department of National Resources, State of Callfornia, 1955.

339. Kunze, G. W., Cakes, H., Bloodworth, M. E., "Grumusols of the Coast Pralrle of Texas", So11 Sclence Soclety of Amer1ca, Proceedings 22:412, 1951 .

340. Ladd, C. C., "The Identification and Behavior of Expansive Clays", Proceedings 5th International Conference on SolI Mechanics and Foundation Englneering, Par1s, 1961.

341. Ladd, C. C., Lambe, T. W., "Mechanism of Swelling ky Compacted Clay", HRB Bulletin 245, 1960.

342. Ladd, E. F., "North Dakota So1ls", North Dakota Agriculture Experiment Station. Bulletin 24, 1896.

343. Lambe, T. W., Whitman, R. V., "The Role of Effectlve Stress in the Behavior of Expansive Solls", Quarterly of the Colorado School of Nines, Vol. 54, No. 4, 1959.

344. Lambe, T. W., "The Character and Identification of Expansive Solis", FHA - Bulletin 201, Federal Housing Adm., December, 1960 .

345. Ieclerc, R. V., "How to Handle Swelling Solls", Proceedings. 1954 Northwest Conference on Road Building. University of Washington, Seattle, 1954.

346. Iogan, J., "Clay Foundation Problem, Frlant - Kern Canal, California", Bulletin, Geological Soclety of America, Vol, 61, Part 2, №. 12, December, 1950.

347. Iyon, R. J. F., "Infrared Analysis of Soll vinerals" in "So1l Clay Mineralogy - A Symposium" by RIch, C. I., Kunze, G. W., Unlversity of North Carolina, Chapel Hill, 1964. 
348. Mackenz1e, R. C., "The Thermal Investigation of Soll Clays", in "So1I Clay Mineralogy - A Symeos 1um" by R1ch, C. I., Kunze, G. W., Un1versity of North Carolina, Chapel H111, 1964.

349. Narbut, C. F., Bennett, H. H., Iapham, J. E., Lapham, M. H., "Solls of the United States", U. S. Bureau of Solls, Bulletin 26, 1913.

350. McDowell, C., "The Relation of Laboratory Testing to Design for Pavements and Structures on Expansive Solls", Quarterly of the Colorado School of Mines, Vol, 54 , No. 4, 1959.

351. Mclean, E. O., Baker, F. E., "Cationic Activitles as Indexes for Characterizing Five Arkansas Solis Cccurring in the Southern Region", Proceedings. So11 Sclence Society of America. Vol. 18, 1954.

352. Means, R. E., "Soll Investigation for Eullaing Founiation", Engineering Experiment Station, Cklahoma As. College, Publ. 94, stillwater, 1955.

353. Means, R. E., "Eulla1ngs on Expansive Clay", Quarterly of the Colorado School of rines, Vol. 54. No. $4,1959$.

354. Neans, R. E., Parcher, J. V., "Physical Properties of So1ls", Merrill Pooks, Inc., Columbus, Ch10, 1963.

355. Mielenz, R. C., King, M. E., "Fhysical - Chemlcal Properties and Enelneering Performance of Clays" in Clays and Clay Technology. Dept of Natural Rescurces, Bulletin 169, State of Califormia, 1955.

356. Norgan, E. I., "Volume Changes in Solls", The Structural Englneer, October, 1958, pp. 345-351.

357. Nahin, F. G., "Infrared Analysis of Clays and Related Minerals", in "Clays and Clay Technology". Bulletin 169, Department of Natura] Resources, State of California, 1955.

358. "Swelling Measurement and Prediction of Heave for a Iacustrine Clay", Canadian Geotechnical Jcurnal, Vol. II, №. 1 , February, 1966 .

359. "Dark-Clay Solls of Warm Reglons Varlcusly Called Fendzina, Black Cotton So1ls, Regur or Tirs", So1l Sclence Soclety of America, Proceedings, Vol. 15, 1960. 
300. Osthalis, B. B., "Interpretation of Chemical Analysis of Montmorilionites", in Clays and Clay Technology", Bulletin 109, Department of Natural Resources, State of' Cal1fornia, 1955.

361. Peterson, R., Feters, N., "Heave of Splllway Structures on Clay Shales", Canadian Geotechnical Journal, Vol, I, №. I, September, 1903 .

362. Fhllbrick, S. S., "Foundation Problems of Sedimentary Rocks", in "Trask: Applied Sedimentation", John Wiley and Sons, 1950.

303. Redus, J. F., "Experience with Expansive Clays in the Jackson, Mississippi Area", HRB - Eulletin 313, 1962.

364. King, G. W., III, "Shrirk - Swell Potential of Solls", rutilc Boads, Vol. 33 . No. 6, 1965.

365. Scott, R. F., "Frinciples of Soll Mechanics", Addison = Wesley, 1963.

366. Seed, H. B., Mitchel, J. K., Chan, C. K., "Studies of Swell and Swell Pressure Characteristics of Compacted Clays", HRB - Bulletin 313, 1961.

367. Seed, H. B., Woodward, R. J. Jr., Iundgren, R., "Prediction of Swelling Potentlal for Compacted Clays", Transactions, ASCE, Vol, 128, Part I, 1963.

j68. Simpson, W. E., "Foundation Experience with Clay in Texas", C1V1I Englneer1ng, Vol. 4, No. 1, November, 1934.

369. Smlth, C. K., "Soll Froperties of Fort Union Clay Shales", Eroceedings, 3 rd Intemational Conference on Soll Mechanics and Foundation Englneering. Vol. I, Switzerland, 1953 .

370. South Dakota Geologlcal Survey, "Geology of Selected Highway Strips in South Dakota", South Dakota Geologlcal Survey Feport of Investigation No. 23, 1963.

371. Southern Cooperative Series, "Certain Properties of Selected Southeastern United States Solls and Mineraloglcal Procedure for their Study", Southern Coocerative Serles. Bulletin 61, U.S.D.A., 1959.

372. Sowers, G. F., Dalrymple, G. B., Kennedy, C. N., "H1gh Volume Change Clays of the Southeastern Coastal Plaln", Unpublished Report, Law Engineering Testing Co. Atlantic, Georg1a, 1961. 
373. Storle, R. E., Welv, W. W., "Key to the Soll series of California", University of Califomia, College of Agriculture, April, 1941.

374. Thornbury, W. D., "Reglonal Geomorphology of the United States", John Wiley and Sons, 1965.

37 5. Thornthwalte, C. W., Mather, J. R., Carter, D. E., " 3 Water Balance Maps of Eastern North America", Resources for the Future, Inc., November, 1958.

376. Unlversity of Texas, "The Geology of Texas", The University of Texas Bulletin $3232,1932$.

377. Underwood, I. B., "Classification and Identification of Shales", ASCE Water Resources Engineering Conference Preprint 354, Denver, Colorado, May, 1966.

378. United States Department of Agriculture, County So11 Survey Series.

379. United States Department of Agriculture "Solls of the United States", Atlas of American Agriculture, Fart. III.

380. Unlted States Department of Agriculture, "So1ls and Men", Yearbook of Agriculture - 1938.

381. United States Army Corps of Engineers, Missouri fiver Division, "Report of Investigation of Expansive Characteristics of Shale and Weak Rocks", Civil Works Invest1gation No. 465, May, 1954.

382. United States Department of the Interior, Bureau of Reclamation, "Stabilzation of Expansive Clay Solls with Hydrated Ilme and With Fortland Cement, Friant-Kern Canal Lower Cost Canal Iining Frogram - Central Valley Project", Earth Lab. Rep. EM-500, Jure, 1957.

383. United States Department of the Interior - Eureau of Reclamation, "Design of Smal] Dams", U. S. Government Frinting Cffice, Washington. D. C., 1960.

384. United States Geologlcal Survey, "Geologlcal Nap of North America", North American Vap Committee, 1965.

385. Vanderford, C. F., "The Solls of Tennessee", Tennessee Agriculture Experiment Station Bulletin 10, I8\%?.

386. Vanderford, H. B., "Solls of Mississipp1", Mississipp1 State University Agriculture Experiment Station, February, 19062 . 
387. Ventskev1tch, G. 2., "Agrometeorclogy", Translation from Russian USDA and National Sclence Foundation, Washington, D. C., 1963.

388. V1sher, s. S., "Cllmat1c Atlas of the United States", Harvard University Press, Cambridge, 1954.

389. Washington State University, "Solis of the Western United States", Washington State University, 1964.

390. Woods, K. B., Lovell, C. W. Jr., "Distribution of Solis in North America", Section 9, Highway Englneering Handbook, MCGraw - Hill, New York, 1960.

391. Wooltorton, F. I. D., "The Sclent1f1c Bas1s of Road Design", Arnold Press, London, 1954.

392. Yong, B. N., Warkent1n, B. P., "Introduction to So1I Eehav1or", Macmillan Co., New York, 1966.

393. Rangmathan, B. V., Satyanarayana, B., "A Rational Vethod of Fredicting Swelling Potential for Compacted Expansive Clays", Proceedings, 6th International Conference of So11 Mechanics and Foundation Enfineering, Vol, 1, Canada, 1965. 
APPENDIX A

SAMPLE NCHRP MATERIALS QUESTICNNAIKE 

APFENDIX A

\section{Sample NCHRP Materlals questionna1re}

Re: NCHRP Project 1-3(1) Part II

Sublect: Materials Questionnalre

I. Enclosure 1 shows an abbrevlated listing of probable ageregate materials: complled from a literature search, indicatine materials beling produced in your state. Enclosure 2 is a list 1dentifying the abbreviated materlals. Check the materlal listing of Enclosure 1 for completeness. If a materlal type is not shown on the list blit is used as a highway aggregate source, enter the abbreviated form under cthers.

II. Enclosure 3 is a map or your state showing coded areas (location code). Indlcate the occurrence of each materlal type shown in Column 1, Enclosure 1 within these areas by placing the location code/coces in Column 2 . Place only one location type code in each row within a given materlal type.

III. Eelow is a list of general aggregate problems and a severity description. Place the probiem code and associated severity code for that particular problem in Collum 3 for each entry in Column 2. If miltiple entries are necessary, place all entries in the row corresponiting to the referenced location code entry of Column 2. A rormat example of an entry for Column 3 would be (CSu-II).

Problem Code

Concrete Pavement Aggregate $\mathrm{CAB}$

CD

CSU

CAI

$\mathrm{CCb}$

$\mathrm{CDe}$

\section{Froblem}

Abrasion Ioss

Durabll1ty

Chemical Reaction

Sulphate

Alkal1

Carbonate

Deleterlcus Substances*

* Includes presence of organlc silt and clay, ccal

lignite, soft particles, clay lumps or chert particles. 
Problem Code

B1tuminous Pavement Aggregate

BAD

$B D$

BAd

BSk

Severity code

II

Wg
Problem

Abrasion Ioss

Durabllity

Adhesion (Strlpping)

Sk1d (polish1ng)

Severity

IImI ted Local

Wldespread General

IV. Indicate the general functional use or uses of each respective entry of Column 2 by placing the appropriate function code (shown below) in Column 4. Note that more than one function code may be placed in each row.

\section{Function Code}

B

C

BS

NS

\section{Bunct1on}

B1tuninous Pavement** Aggregate Concrete Pavement** Aggregate

Base/Subbase Aggregate Not Sultable for above uses

* Materlal above base course * Materlal above subbase course

V. Indicate on Enclosure 3 approxlmate general boundarles of areas you feel lack sultable aggregate sources for normal highway use. If no such areas ex1st, check below.

None

VI. Does the avallablity (non-avaliability) of sultable aggregate sources within a geographlc area act as a major factor in the selection of a specific pavement type (Concrete or B1tuminous)? 
If yes, state the location code of the area/areas affected.

Location Code

$\frac{13 b}{20 f}$

VII. Does the avallability (non-avallabllity) of a given cementing materlal (Portland cement or Bltuminous material) w1thin a geographic area act as a major factor in the selection of a specific pavement type (Concrete or Bituminous)?

$$
\text { Yes }
$$
No $\quad x$

If yes, state the location code of the area/areas af fected. 
MISSCURI

Enclosure 1

$\begin{array}{cc}\text { Col (1) } & \text { Col (2) } \\ \begin{array}{c}\text { Materlal } \\ \text { Type }\end{array} & \begin{array}{c}\text { Iocation } \\ \text { Code }\end{array} \\ \text { Ls } & 10 \% \\ & 111 \\ & 13 a \\ 136\end{array}$

Ss

$10 \pi$

111

$13 a$

130

Do

$10 \mathrm{~m}$

111

$13 a$

$13 \mathrm{~b}$

ar

111

$10 \mathrm{~m}$

$13 a$

$13 \mathrm{~b}$

$20 \mathrm{f}$

3

$10 \mathrm{~m}$

111

$13 a$

130

$20 \mathrm{f}$

Gn

$13 a$
Re: NCHRP Project 1-3(1) Fart II

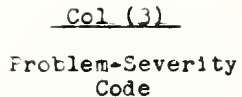

$\operatorname{Col}(4)$

Function Code

$C D-W g ; C D e-W g ; E S K-W g$

CAb-LI;CD-WE; De-Wg;BAb-LI;BSK-Wg

$E ; C ; B S$

$B ; C ; B S$

$\mathrm{B} ; \mathrm{C} ; \mathrm{BS}$

CAb-L1; CDe-Wg;BAb-L1;BSK-Wg

B;C;ES

CAb-Wg;CDe-Wg;BAb-Wg;BD-Wg

$C A b-W g ; C D e-W g ; B A b-W g ; E D-W g$

$C A b-W g ; C D e-W g ; B A b-W g ; B D-W g$

$C A b-W g ; C D e-W g ; B A b-W g ; B D-W g$

NS

NS

NS

NS

CD-Wg;ESK-Wg

$C D-W g ; B S K-W g$

CD-Wg;BSK-Wg

CD-Wg;BSK-Wg

$B ; E S$

$B ; B S$

C;E;ES

$B ; E S$

$\mathrm{CD}-\mathrm{II} ; \mathrm{BAd}-\mathrm{II}$

CD-Wg; $B A d-I I$

$C D-W g$; $P A d-L I$

CD-Wg;BAd-II

CD-Wg;BAb-II

C;B;ES

$\mathrm{B} ; \mathrm{ES}$

$\mathrm{B} ; \mathrm{BS}$

$B ; B S$

$B ; B S$

$C ; B S$

$C ; E S$

$C ; E S$

$C ; B S$

$C ; B S$

B

Ma

$\mathrm{Sg}$ 
Enclosure 2

Material Abbreviations

Material

Andes 1 te

Amph1lbolite

Basalt

Clam/Oyster Shell

Coquina

Dlabase

Diorite

Dolomite

Gabbro

Gneiss

Grand te

Grave 1

Ifmes tone

Marble

Peridotite

Quartzite

Rhyol1te

Sand

Sand/Gravel

Sands tone

Schist

Slag

syenite
Re: NCHBP Project 1-3(1) Part II

\section{Abbreviation}

An

Am

$\mathrm{Ba}$

Cs

Co

Db

Dr .

Do

$\mathrm{Ga}$

Gs

Gn

Gr

Is

Ma

$\mathrm{Pe}$

Qz

$\mathrm{Rh}$

$\mathrm{S}$

$\mathrm{Sg}$

Ss

$\mathrm{Sc}$

SI

Sy 


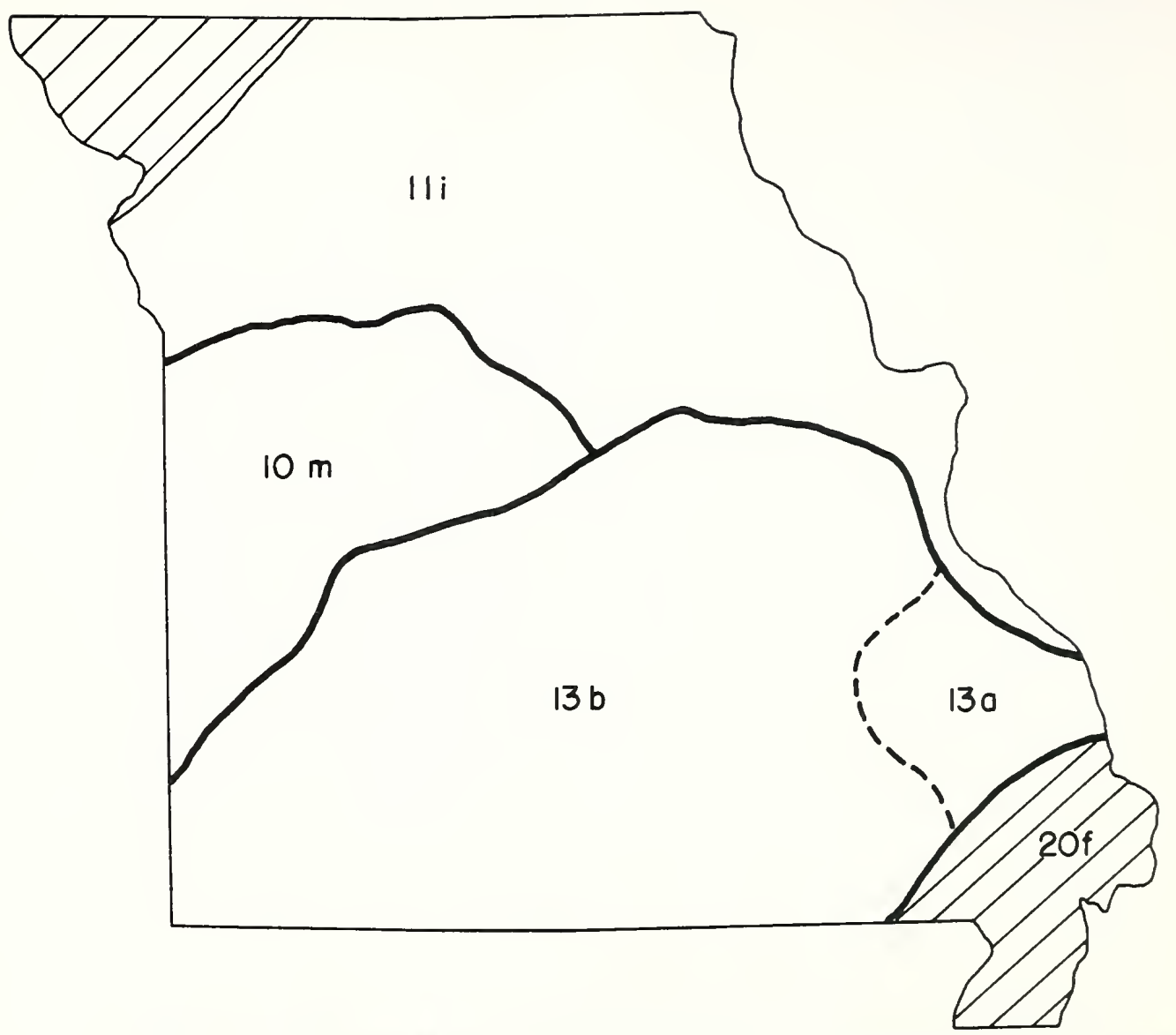

NOTE: I. ALPHA-NUMERIC CODE REPRESENTS PHYSIOGRAPHIC UNIT CODE

2. CROSS HATCHED AREAS INDICATE GENERAL BOUNDARIES THAT LACK SUITABLE AGGREGATE SOURCES FOR NORMAL HIGHWAY USE

FIGURE 52 COMPLETED SAMPLE NCHRP MATERIALS QUESTIONNAIRE DIAGRAM ENCLOSURE FOR MISSOURI 
APPENDIX B

DESCBIPTION OF BASIC UNIT BOUNDARIES 


\section{APPENDIX B \\ DESCRIPTION OF BASIC UNIT BOUNDARIES}

\section{General}

Th1s appendix summarizes avallable information concerning the description of the basic unit boundarles. Figures 53 to 70 are individual Province/Section diagrams for the units discussed in the report. Each unit is 1dentified by the unit code noted in Table 4. Dlagrams containing boundary descriptions have coded border segments shown on each diagram. These segments are keyed to the descriptions, for a particular Frovince/Section, contalned in the ensuing paragraphs. Liberal use has been made of information found in the writings of Thornbury (65), Fenneman (18, 19) and Lobeck $(38)$.

\section{Border Descriptions}

Province I

Flgure 53 shows the border portions used to describe the various Sections of the Province. They are:

1. See Pac1fic Troughs Province.

2. The Pacific Ocean (for highway englneering purposes) is taken as the ent1re weatern border of the Province. 


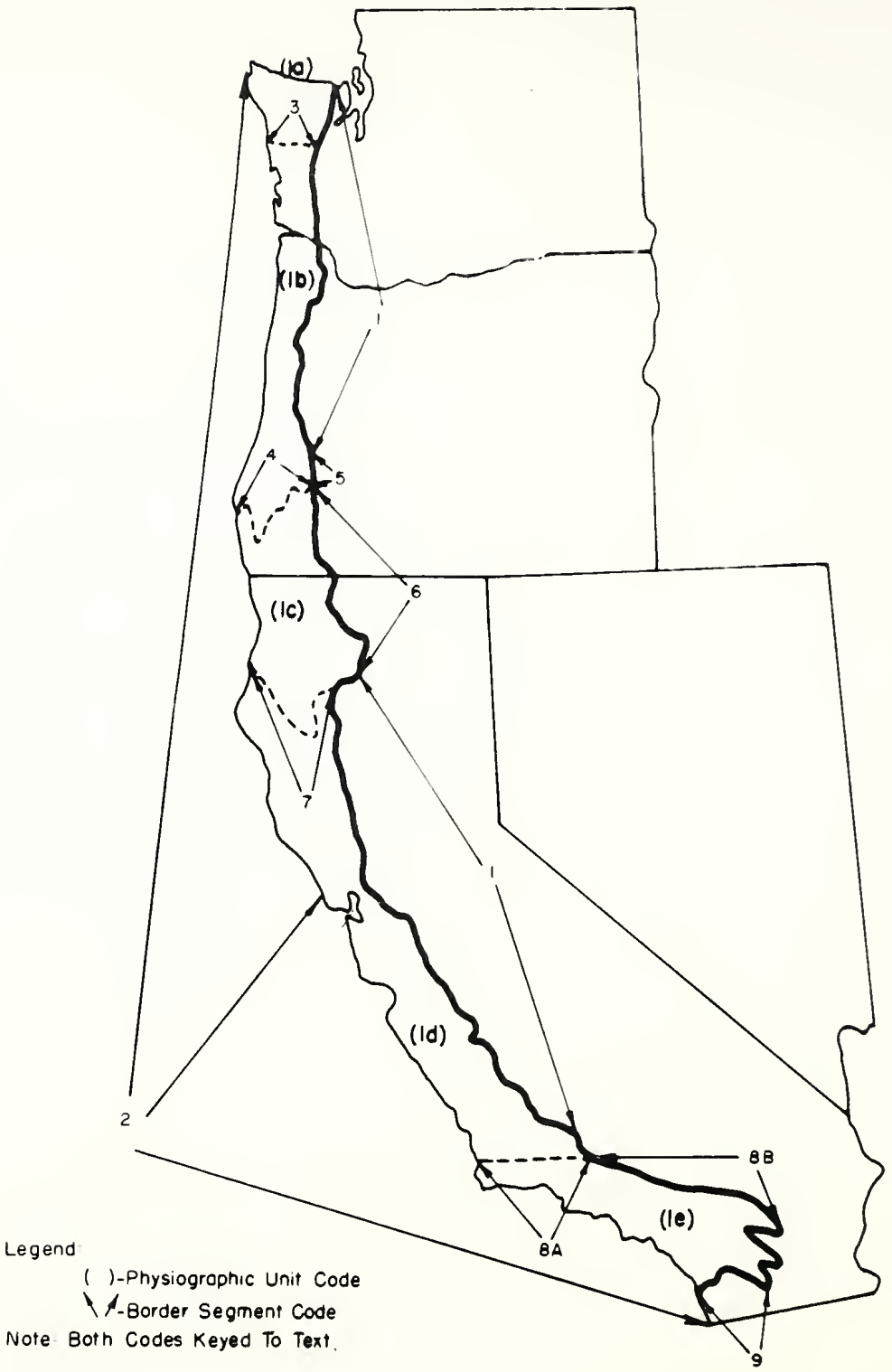

FROM (31) (51) (61)

FIG.53 WESTERN MOUNTAINS OF THE PACIFIC COAST RANGE PROVINCE / SECTION DIAGRAM 
3. The Chehalis River is taken as the border. AIthough this is not precisely accurate it adequately serves to contrast the topographically and geologlcally different physlographic Sections.

4. This border is taken as the southerm $11 \mathrm{mit}$ of Tertiary rocks common to the Oregon Coast Ranges. The Klamath Mountains are older, stronger and, in general, higher.

5. This border portion is common to the Cascade Section and is denoted primarily by differences in 11 thology between the two Sections. The Tertiary sedimentaries contrast with the volcanics common to the Cascades.

6. This border is determined by the western limit of Cenozo1c volcanics of the Cascades which contrast with the older and differing rocks of the Klamath Mountalns.

7. The northerm boundary of the Califormia Coast Range Section is taken as the South Fork Mountains which possess the characterist1c topography of the Coast Ranges but, because its geology has more in common with the Klamath Mountains, it is placed in that Section. All rocks older than Jurassic have been included in the Klamath Sect1on.

8. This border aistingulshes aifferences in the 
trends of the ranges common to the Transverse Range Subsection.

a. This portion is the San Rafeal Mountalns of the California Coast Ranges.

b. The San Gabriel and San Bernadino Mountains comprise the major portion of this border.

9. This arbitrary border is taken as the southern limit of the Santa Ana and San Jacinto Mountains. These mountain ranges are parallel northwest southeast trending block mountains.

Province 2

Figure 54 shows the border segments utllized to distinguish the Sierra - Cascade Province. They are:

1. See Pacific Troughs Province.

2. See Western Mountains of the Pacific Coast Range Province.

3. See Columbia Plateau Province.

4. The east side of this section presents a steep face due to a series of fault scarps that overlook the Salton Trough Section.

5. This border segment is terminated by the Garlock fault.

6. This border segment is terminated by the San Andreas fault.

7. This border notes a definite geologic contrast 


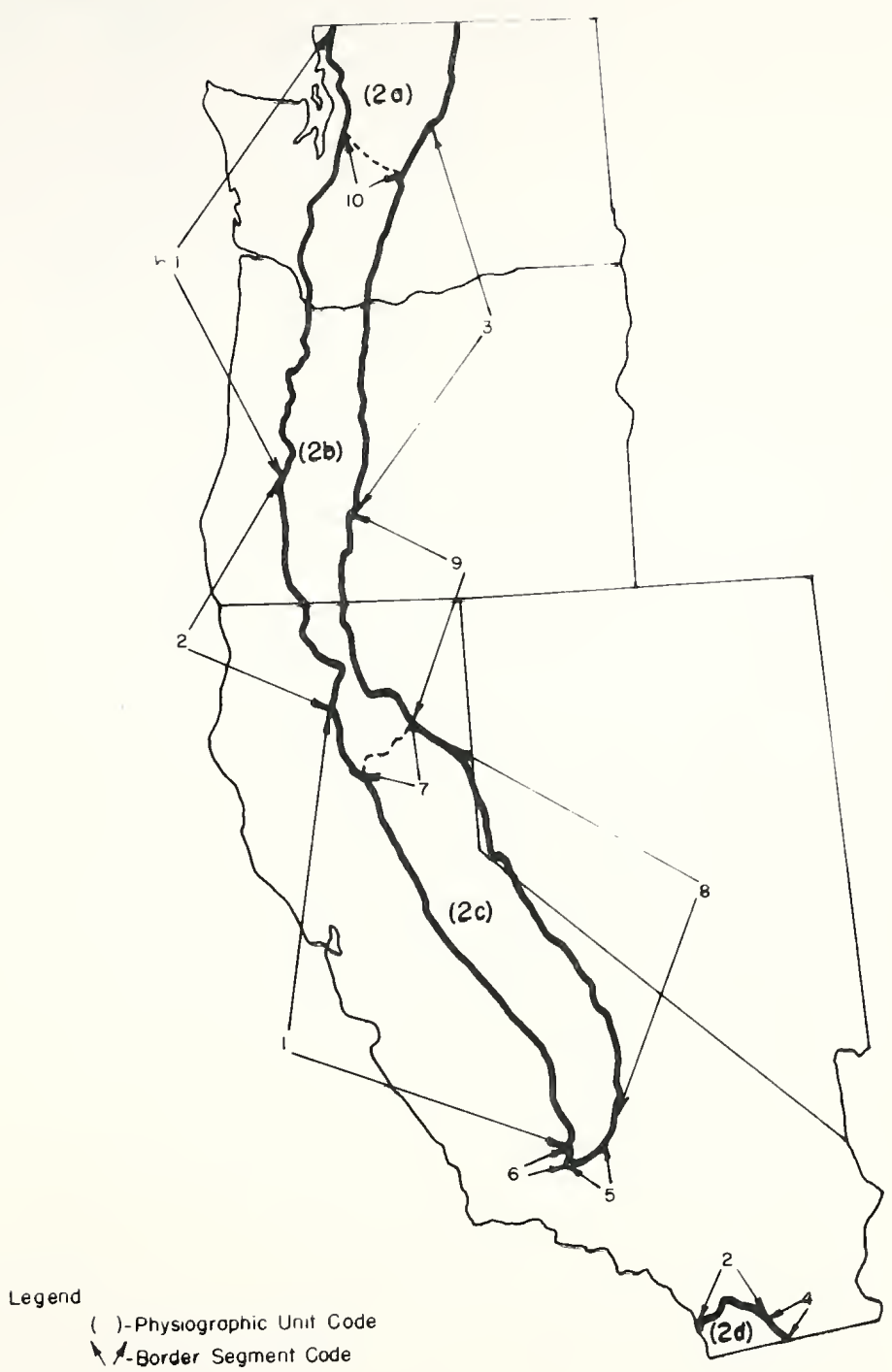

Note Both Codes Keyed To Text 
where the bedrock of the Sierra Neveda disappears under the Cenozolc volcanic cover of the Southem Cascade Range.

8. This border is generally very topographically consplcous as a series of fault scarps of the Slerra Neveda overlook the Basin - Range Area.

9. This border segment can only be generally defined by topographic differences. The bedrock type (Cenczolc volcanics) is contiguous between the Cascade Range portion and the adjacent Basin and Range area (in California known as the Modoc Flateau). This border is quite similar to the southwest border of the Columbia Plateal Province.

10. This border distinguishes the volcanic materials of the Southern Cascade section from the older metamorphosed and intruded granitic areas of the Northern Cascade Section.

\section{Province 3}

Figure 55 shows the border portions used to describe the Facific Troughs Frovince. With few exceptions, the delineation of borders is fairly definite from a topographic viewpolnt due to contrast witr the surrounding mountainous uplands. The border portions are:

1. This border expresses a falrly distinct topagraphic contrast with the clympic Mountains.

2. The topographic contrast is broken by the Chehalis 


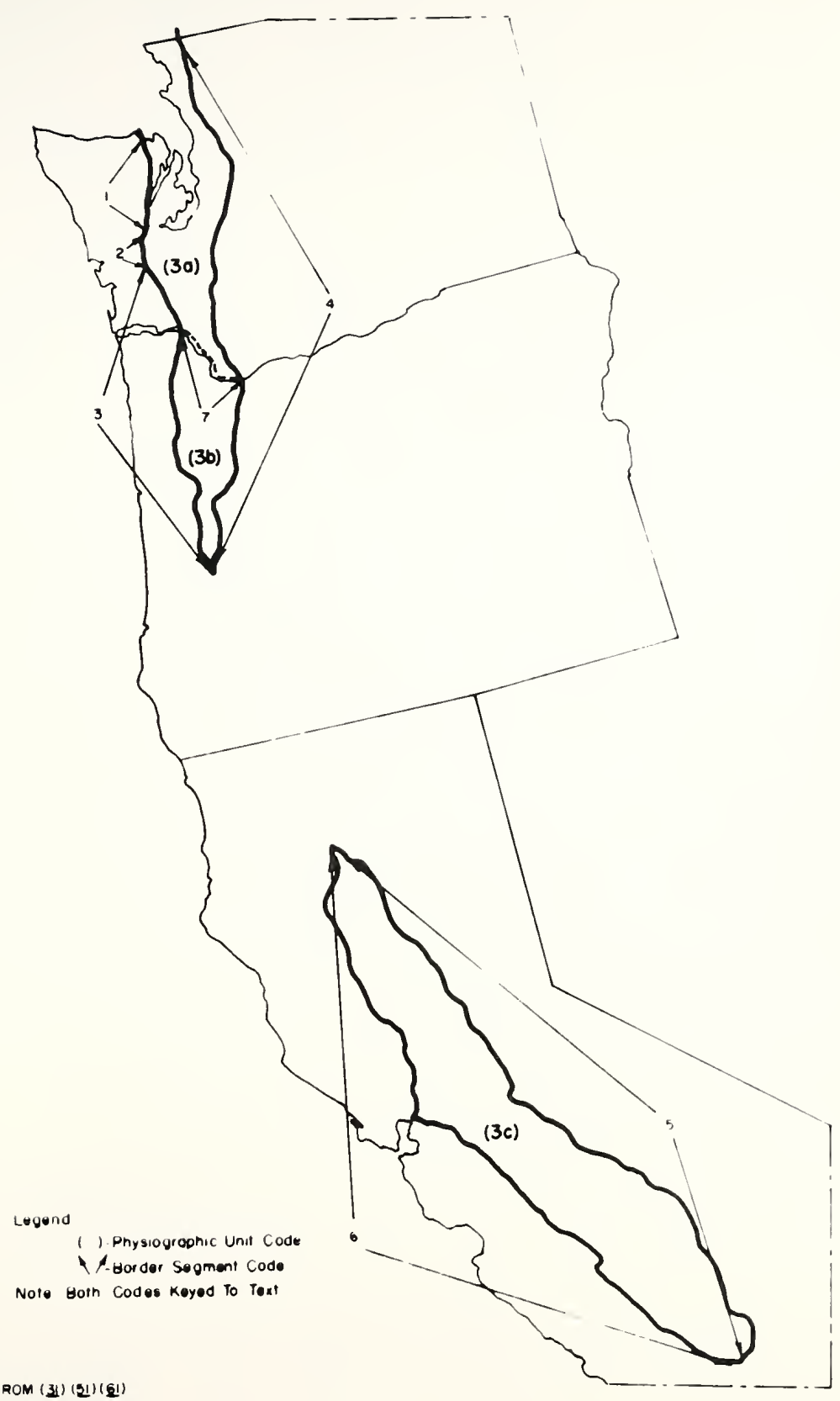

FROM (31) (51)(51)

FIG. 55 PACIFIC TROUGH PROVINCE / SECTION DIAGRAM 
River Valley which traverses the Coast Range to the Pacific Ocean.

3. This torder is similar to $\mathbb{H} 1$, except that the oregon Coast Ranges do not provice as definite a contrast.

4. This border portion presents, for the most part, a falrly definite topographic contrast with the Cascade Range.

5. This border portion is a notable topographic contrast. It occurs with the Sierra Neveda and Cascade Mountains.

6. This border portion is quite similar in many respects with \#1. This segment separates the Californla Coast Ranges from the Valley Section.

7. This korder is the Lower Columbla River Valley, which is located in the Puget Sound Section.

\section{Province 4}

Flgure 56 describes only a few major border features of this Province. For the most part, the borders; as denoted by Fenneman, are falrly 111 defined. Some general facts regarding the two border portions shown are:

1. This border segment is, in general, topographically definite as 1 t contrasts with surrounding mountainous uplands.

2. The southern border of the frovirce is generally very indefinite as it is a transistional zone, 


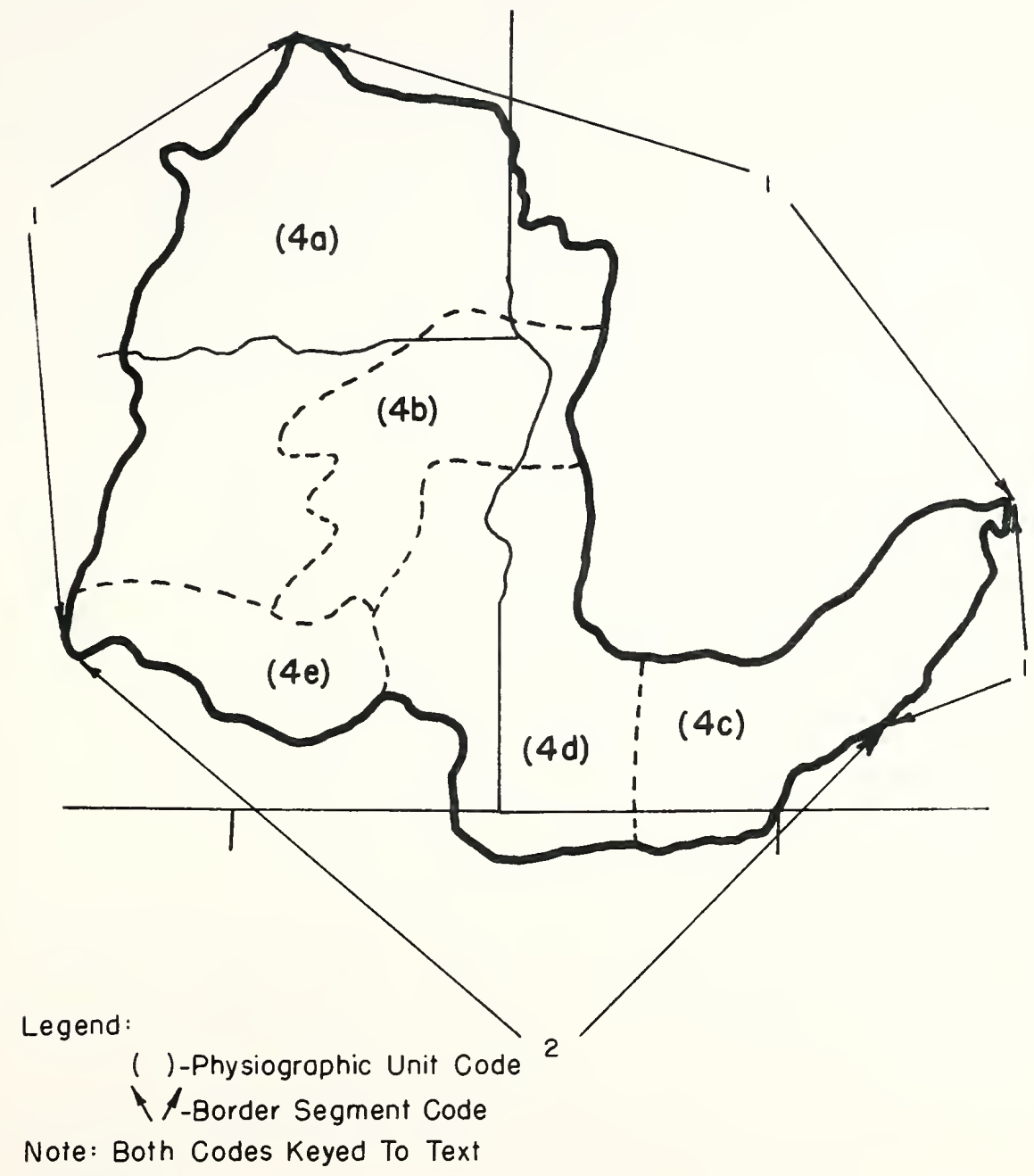

FROM (65) (73)

FIG.56 COLUMBIA PLATEAU PROVINCE / SECTION DIAGRAM 
with much of its length being the dralnage divide between the Snake River and undralned basins of the Basin and Range Province.

\section{Province 5}

Figure 57 11lustrates the general location of the Sections comprising the Basin and Range Province. No descriptions of borders have been noted within the diagram.

\section{Province 6}

Flgure 58 shows the varlous border portions used to describe the Colorado Plateau Province. The border portions are:

1. This border is generally controlled by massive scarps overlooking the topographically lower Basin and Range Province.

a. Calied Mogolion Rim

b. Called Grand Wash Cliffs (Fault)

c. Calles Hurricane Fault

d. Called Sevier Fault

2. This border is a fairly definite topographic contrast caused by the higher Wasatch Range overlooking the area. Th1s range enis in the vicinity of Mt. Nebo.

3. This border is similar to 2 and is overlooked by the Uinta Mountains.

4. This border portion is fairly indefinite topographically and geologically. Topographically 


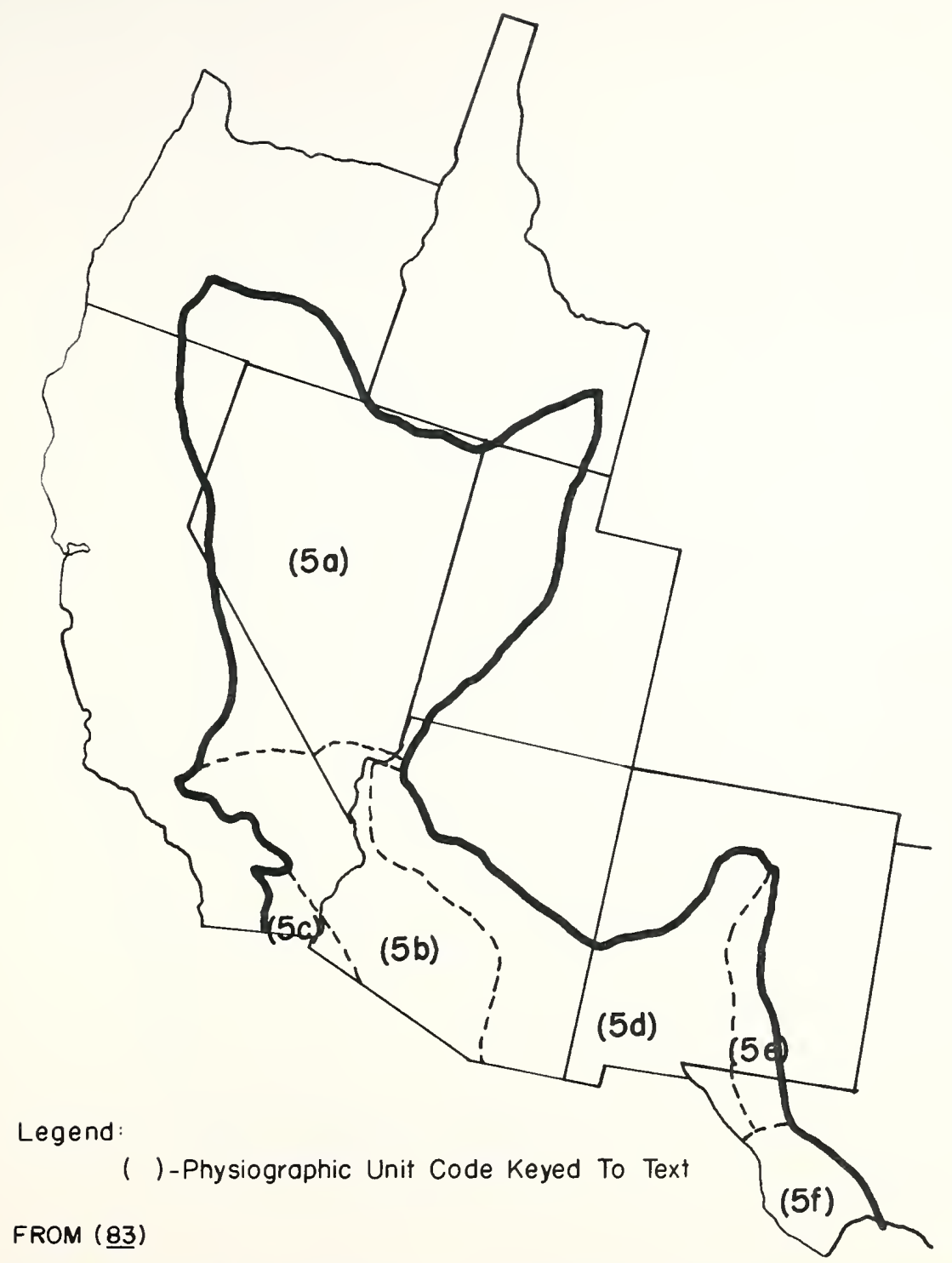

FIG.57 BASIN AND RANGE PROVINCE / SECTION DIAGRAM 


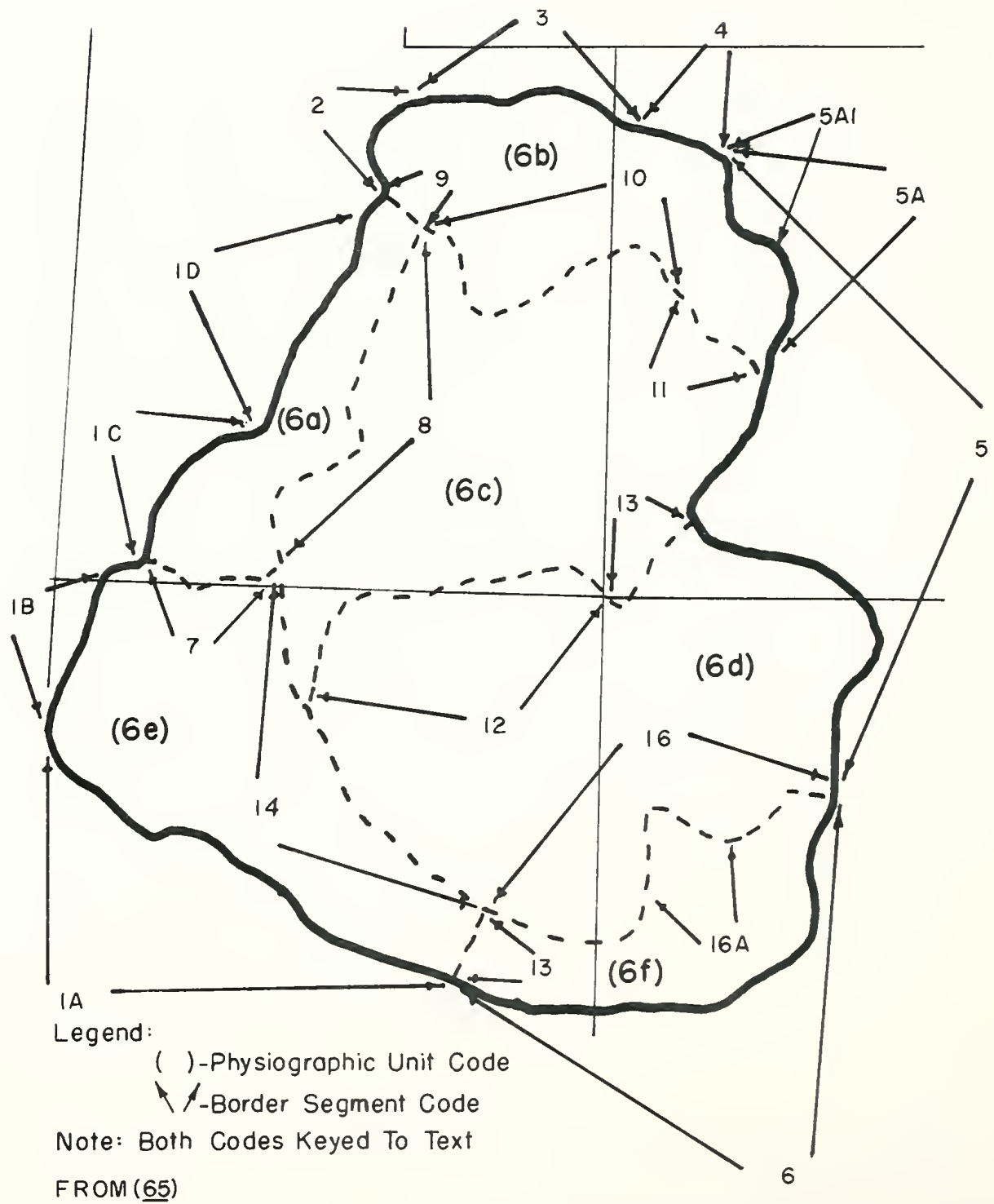

FIG.58 COLORADO PLATEAU PROVINCE / SECTION DIAGRAM 
the area gradually merges intc the Wyoming Basin Section.

5. Th1s border fortion 1s, in general, topograph1cally definite with the Southern Focky Mountain Province.

a. The Steeply dipplng Dakota formation forms hogback rldges as the border between the Unta Easin and the Rockies.

1. This segment is overlooked by the White River Flateau.

6. The boundary with the Rio Grande Depression of the Mexican Highland Section is marked by the westernmost fault of the Rio Grande Depression (very generalized especlally on the southerm. portion of the border).

7. An escarpment (Vermililon Cliffs) formed by the Jurassic Windgate sandstone overlooks the Grand Canyon Section and represents the toundary in this area.

8. This portion is a great escarpment overlooking the Canyon Land Section.

9. This border is arbitrarily Iimited by a 1000 to 2000 foot transverse valley in the vicinity of the old Denver and Blo Grande Rallroad.

10. This border is the south facing escarpment (Book and Roan Cliffs) developed by the dipping strata which comprise the Tavaputs Flateau within the 
Uinta Basin.

11. Th1s border is the southern edge of the Grande Mesa.

12. This border, al though geographically precise, is fairly geomorphically indefinite. The major distinguishing modal characteristics of the adjacent Sections are based upon differences in dissection. The korder is generally taken as the San Juan and Colorado Rivers.

13. No information obtained.

14. This border separates Carboniferous age formations from younger strata in the adjacent sectIons (Triassic in the Navajo Section and Jurassic in the Canyon Iands Section). It essentially follows the Iittle Colorado River.

15. This border is the eastern edge of Carboniferous surficial rocks within the Grand Canyon Section.

16. This border is defined rather arbitrarily by the Puerco River.

a. This border segment is the northern portion of the Zuni Uplift area occurring in the Datil Section.

Frovinces $7-8-9$

Figure 59 illustrates the generalized location of the Bocky Nountain Provinces and Sections within the United States. 


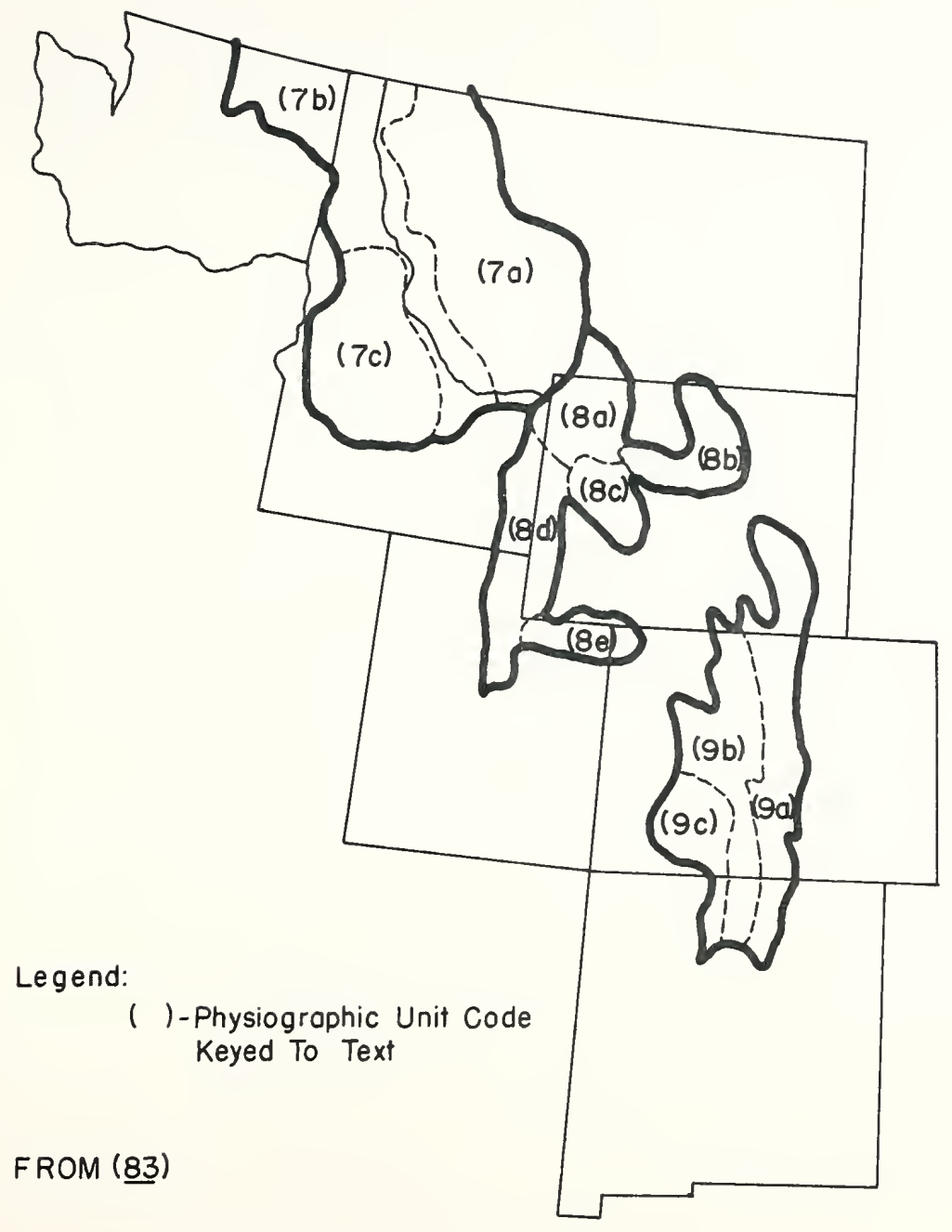

FIG. 59 ROCKY MOUNTAIN SYSTEM DIAGRAM 
Although no speciflc border information 1s presented; many of the outer Province segments are described within the discussions of the adjacent Frovinces.

Province 10

Figure 60 shows the various segments of the borders contained within and adjacent to the Great Plains Province. They are:

I. See Central Lowland Province

2. See Ozark and Cuachita Province

3. See Altantic and Gulf Coastal Plain Frovince

4. The westem portion of the Stockton (Edwaràs) Flateau terminates against the mountains of the Great Bend Highland Section.

5. This border separates the Pecos Valley Section from the Sacramento Highland Section.

a. This portion is taken as the eastern edge of the Guadalupe and Sacramento Mountains. They exhibit a falriy definite topographic contrast.

b. This portion does not afford any gross topographic boundary to distinguish the two Sections and as a consequence is very indefinite.

6. This border delineates the Rocky Mountain System from the Great Plains areas. a. This portion, as noted by Thornbury, 


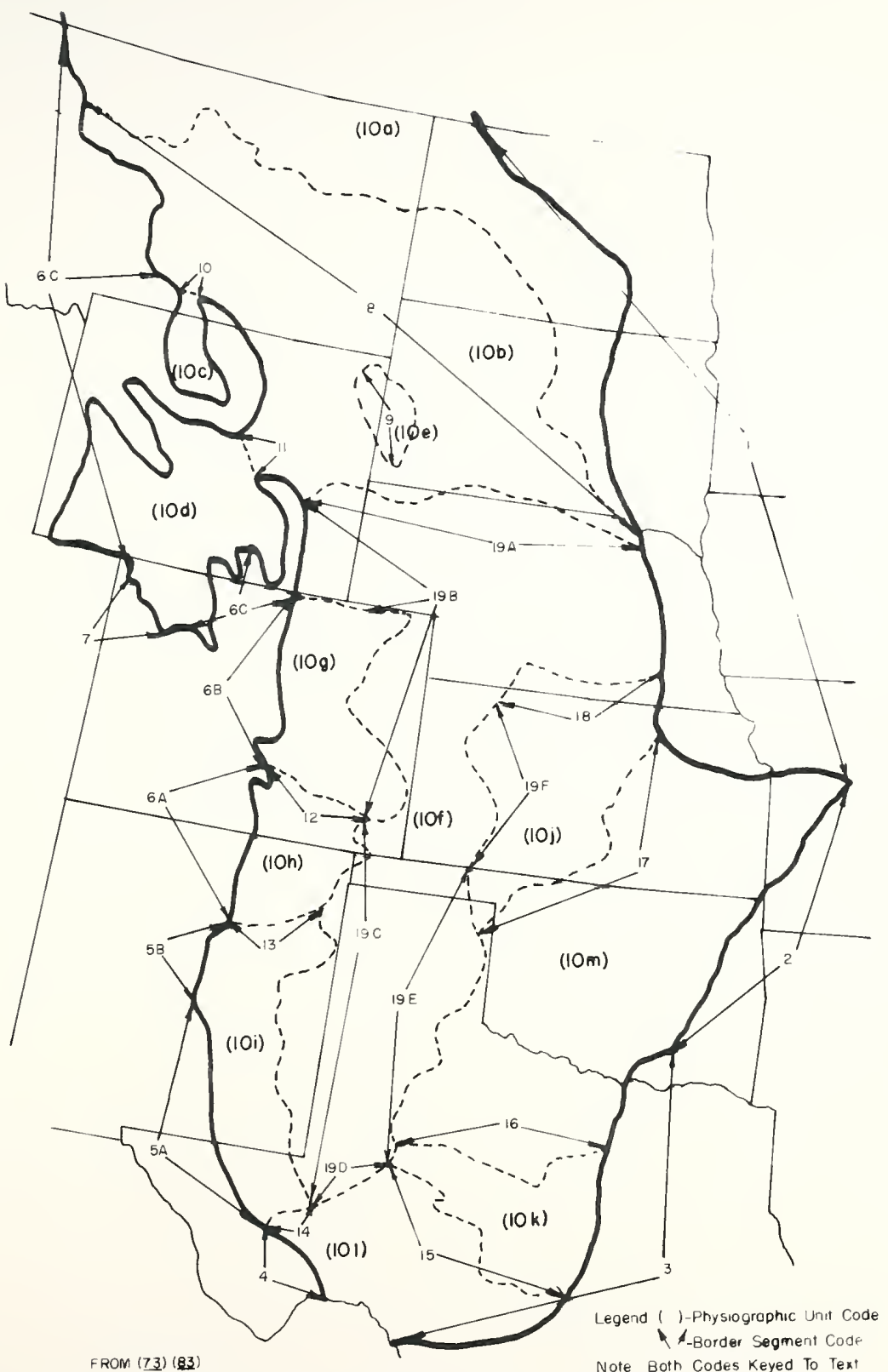

FIG 60

GREAT PLAINS

PROVINCE / SECTION

DIAGRAM 
presents a problem as to whether the border should be based on topography or geology. Similar kedrock types, age, and structure appear both in the Rocky Mountains portion and Great Plains Section. The border is, however, based on topographic differences.

b. The typical and distinctive westem border of the Colorado Pledmont section is the hogback ridges produced by the titled Dakota sandstone formation.

c. This border is generally, although not always, fairly definite in that it provides a strong topographic contrast.

7. See Colorado PIateau Province.

8. This border is taken as the southern limit of glacial deposits.

9. The border of this section is taken as the outer rim of Triassic rocks (Spearfish formation) that comprise the Red Valley portion of the Black Hills. This border is contiguous and surrounded almost in 1 ts entirety by the Dakota formation winlen topographically overlooks the valley as a cuesta scarp on the west and as a hogback ridge on the east.

10. No apparent definite boundary has been established. 11. This border is taken as the 011 Mountain Anticline 
which connects the elbow of the Blghorm Range with the end of the Laramie Range. Th1s anticline causes older Paleozolc rocks to outcrop in the form of monoclinal ridges for most of the borier length.

12. No sharp IIne separates the adjacent sections.

13. Th1s border is the Canadian Escarpment (southern edge of Cretaceous rocks in the Raton Upland Section).

14. This border is a ragged escarpment, more than 1000 feet high, rising to the Stockton (Edwards) Plateau. The escarpment overlooks the Toyah Basin in Texas.

15. Th1s border is an escarpment marking the edge of where the horizontal I1mestone strata of the Edwards Plateau overlook the weaker, eroded, rocks of the Central Texas Section.

16. In the author's viewpolnt, the description of this border from avallable references, appears to be quite vague and difficult to ascertain from topographic, geologic or solls maps. Fenneman describes 1t as an 1nfacing (to Csage Flalns Section) linestone excarpment. However, this east-west border buts across the northeastsouthwest grain of Cretaceous, Permian and Fennsylvanian outcrops found continuous in both sectlons across the border line. 
17. This is a very arbitrary border and much difference of opinion exists as to which of the several cuesta scarps best serve as the boundary of the Section. Fenneman ut1lizes the east side of the Smoky and Red H1ll areas.

18. This border portion, mainly in Nebraska, is very indefinite as the erosion and dissection common to the Plalns Border is veneered with loessial deposits somewhat obscurring the edge of the east facing escarpments of the Plains Border Section.

19. Th1s border is primarliy concerned with various modifications to the Tertiary alluvial mantle diagnostic to the High Plalns section.

a. This portion is the north facing fine Rldge Escarpment capped by Tert1ary (Arlkaree formation) outwash. The escarpment locally attalns helghts of 1000 feet.

b. This boundary is generally taken as the outer (approximate) I1mits of the Tert1ary alluvium (outwash) st1ll existent in this area.

c. This portion is capped by the resistant Ogallala formation that forms the Mescalero (Caprock) Escarpment.

d. The Tertlary alluvium in this portion 
is thin and discontinuous, offering no significant topographic difference. e. This portion is similar in description to $719 \mathrm{c}$. The escarpment is termed the "Ereak of the Plalns" or Caprock. f. This portion is a continuance of the Break of the Plalns Escarpment noted in tige. However, because of climatlc differences as one proceeds northward, the escarpment loses its topographic prominance. Consequently, approximately north of Texas and in Kansas, this torder is not very definite.

Province 11

As noted in Figure 61 there are 19 boundary portions ut1lized to describe the border system of the Central Iowland Province. They are:

1. See Laurentian Upland Province.

2. See Appalachlan Plateau Province.

3. See New England Maritime Province.

4. Th1s border is taken as the west side of Iake Champlain.

5. This border, for purposes of describlng physiography within the United States only, is a Extension of Canadian Shleld rocks that, in essence, connect the Ad1rondacks w1th the Southern Canadian 


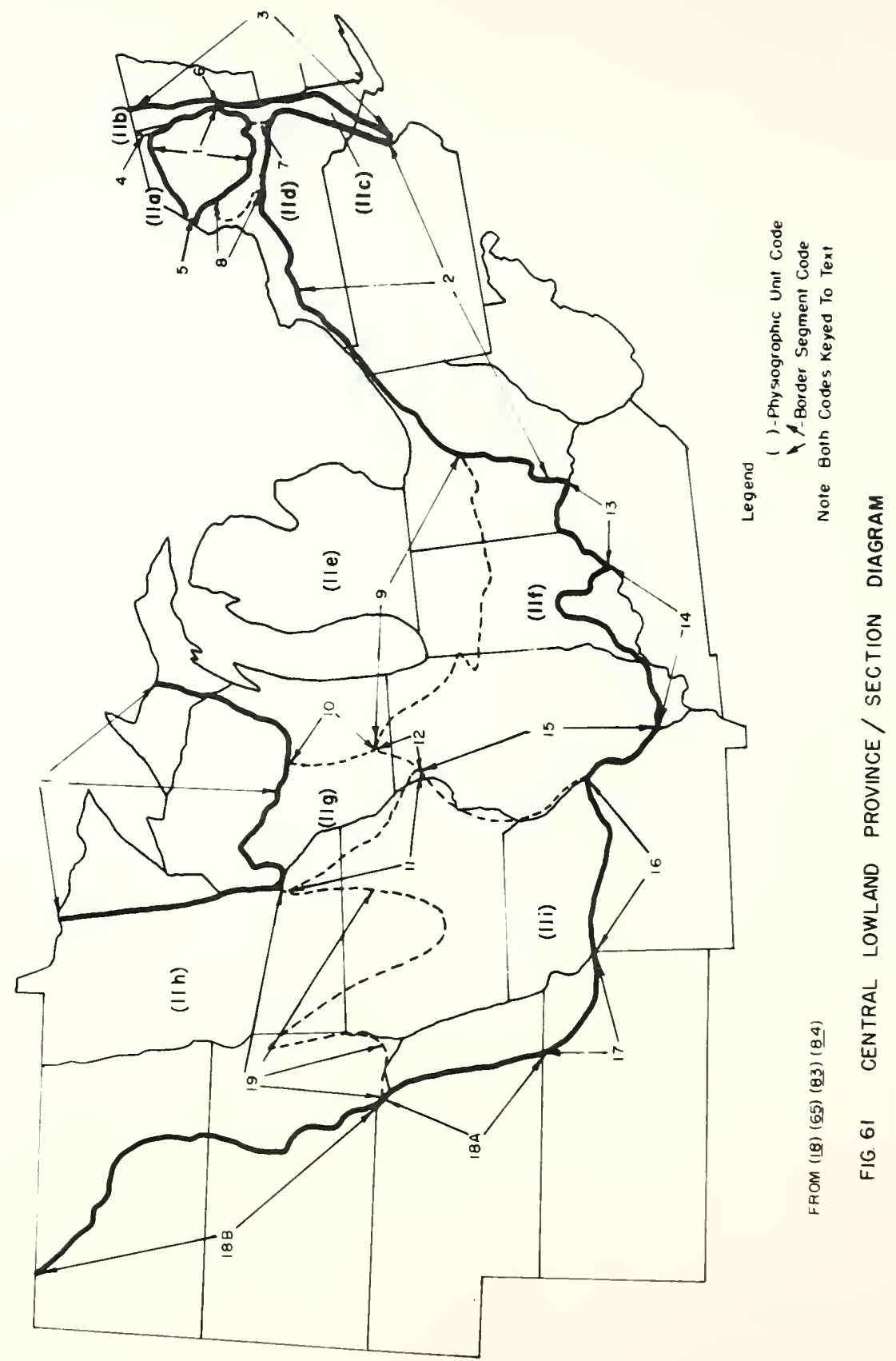


Uplands Section of the Iaurentlan Upland Frovince. The border is actually an area occurring at Thousand Is lands.

6. The border is a relatively low moraine separating the Hudson and Champlain Valleys.

7. This border is a small east facing escarpment passing northward near Schnectady, New York.

8. The border does not follow any one sedimentary outcrop, however, it does follow a falrly definlte west foot of the high cuesta that slopes away from the Adrondacks (1e...Tug H111 Cuesta).

9. Th1s border is taken, as suggested by Thornbury, to essent1ally follow the Cary-Tazewell drift contact.

10. This border is marked by a falrly well defined topographic contrast by the edge of a late Wisconsin terminal moraine. Small areas of outwash are included within the Driftless Section.

11. This border is the western edge of surficlal Kansan drift. This strip of Kansan drift consequently lies within the Driftless Section.

12. This border is taken as the edge of Illinolan arift. However, the topographic contrast is not great between the glaclated and non-glaclated sections as the drift is fairly thin and considerably eroded.

13. Th1s border is taken as the onlo River between 
Lolisville, Kentucky and clncinnati, chio. South of this area, minor known glaclal deposits of Kansan drift have been recorded, but for general analysis this area has been included within the Interior Low Plateau Province. Note that this is a major exception to the border.

14. This boraer is the southem limits of Illinolan arift.

15. This border is the westerm edge of Illinols drift. For practical purposes, the drift approxImates the western boundary of the state of IIIInois (Mississippi River).

16. This border is taken as the Missouri River within the state of Missouri. The exact border actually should be defined by the farthest southern extant of Aeolian deposits within the Dissected Ioessial and T1II Plains section. For most of 1 ts length, the Loessial boundary is slightly to the south of the Missourl Biver.

17. This border is the southerm and westem limits of Kansan drift that appears as surficlal deposits in the northeast portion of the state of Kansas.

18. This border is the east facing Missourl Escarpment.

a. Within Nebraska, this escarpment is, in general, completely lacking. As a result, 
In North Lakota, the escarpment is very prominant and attalns a helght of 300 to 400 feet.

19. Inis korder is placed at the Cary drift bolindary of the Des Molnes - Dakota lce lobes.

Province 12

Figure 62 11lustrates the rorder portions that are used to descrite the boundaries of the Iaurentian Upland Province. They are:

1. This boraer is quite apparent from a topografhic, geologic age, and bedrock type difference. In essence, the Adrondacks can be roted by the outer extent of old Igneous and Metamorphic rocks which contrast w1th Sedimentary rocks present in the adjacent lowlands.

2. This border agrees quite well with dividing the Pre Camtrian rocks of the Superior Upland from the Sedimentary rocks of the Central Iowland Province. In the upper peninsula of Michigan, topographic contrast of the Superior Upland Section (relief and altitude) is quite different from the ad facent area.

3. This border is quite indefinite in that Cambrian rocks common to the Driftless section are placed within the Superior Upland Section because they are covered by thick drift. 


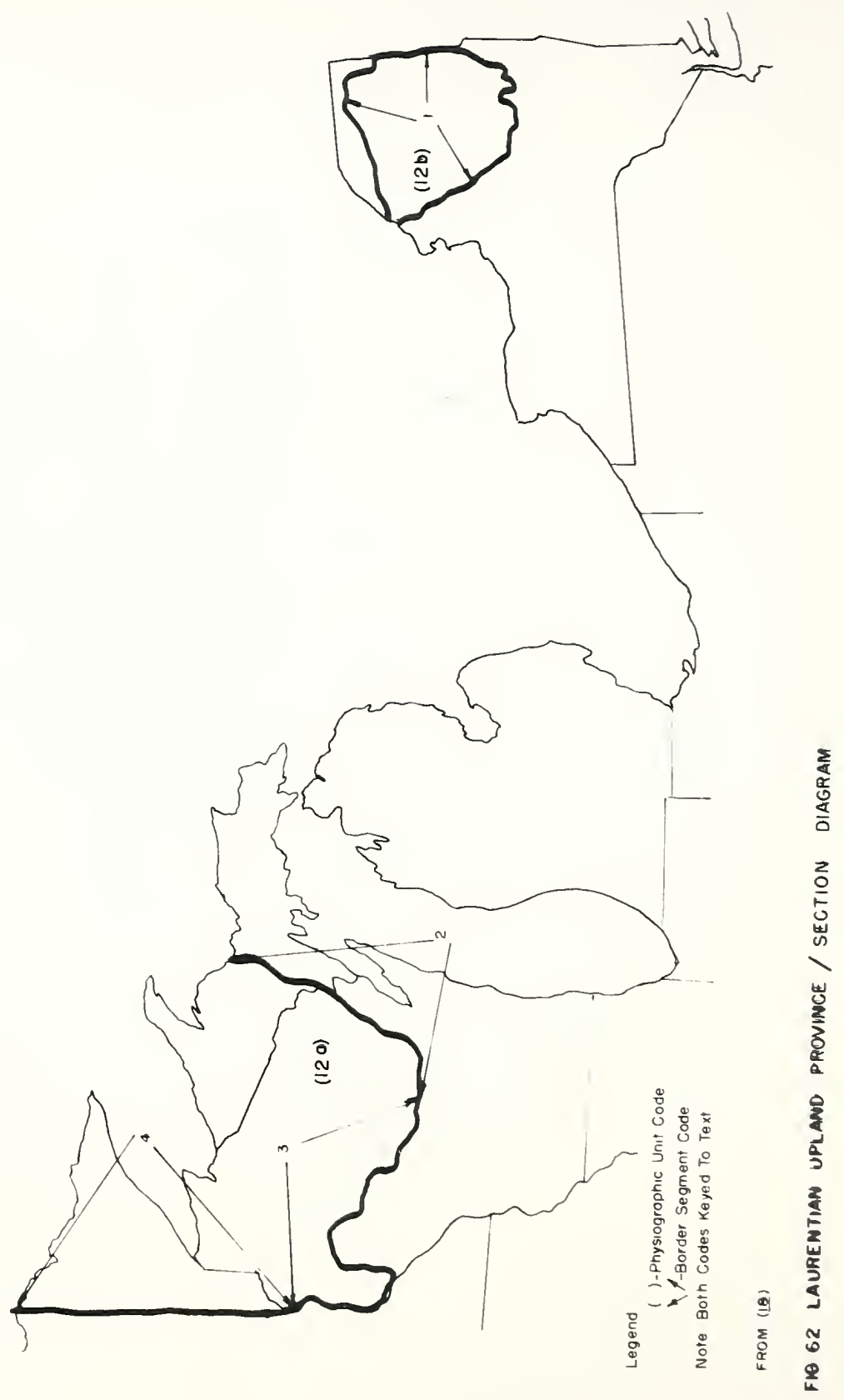


4. This border is very arbitrary. It is taken as a Iine drawn northward frcm a location near $S t$. Paul, Minnesota along the 93rò meriaian.

\section{Frovince 13}

As shown on Pigure 63,10 segments are utilized to describe the borders of the czark and Cuachlta Frovince. They are:

I. See Atlantic and Gulf Coastal Plár Province.

2. See Interior Iow Plateau Frovince.

3. See Central and Eastern Lowland Frovince.

4. This border has very little topographic contrast. The boundary is best located by geclcelc age difference between Mississippian age rocks of the Springfield Plateau and the Pennsylvanian (Cherokee) clay and shale of the csage flains section.

5. This border is recognizable by contrast between the east-west trending ridges of $13 c$ ? and $13 c 3$ with the north-south trending cuestas of the Csage Plains Section. There is no outstanding contrast nor difference in rock type and age between the two adjacent areas. Botr. areas are f,redominantly Fennsylvanian sandstone and shales.

6. This border is highly indefinite due to the partlal exhumation of the Paleozolc Sedimentary rocks that are also found in the Springfield-Salem Plateau Section. It appears that an atterupt is 


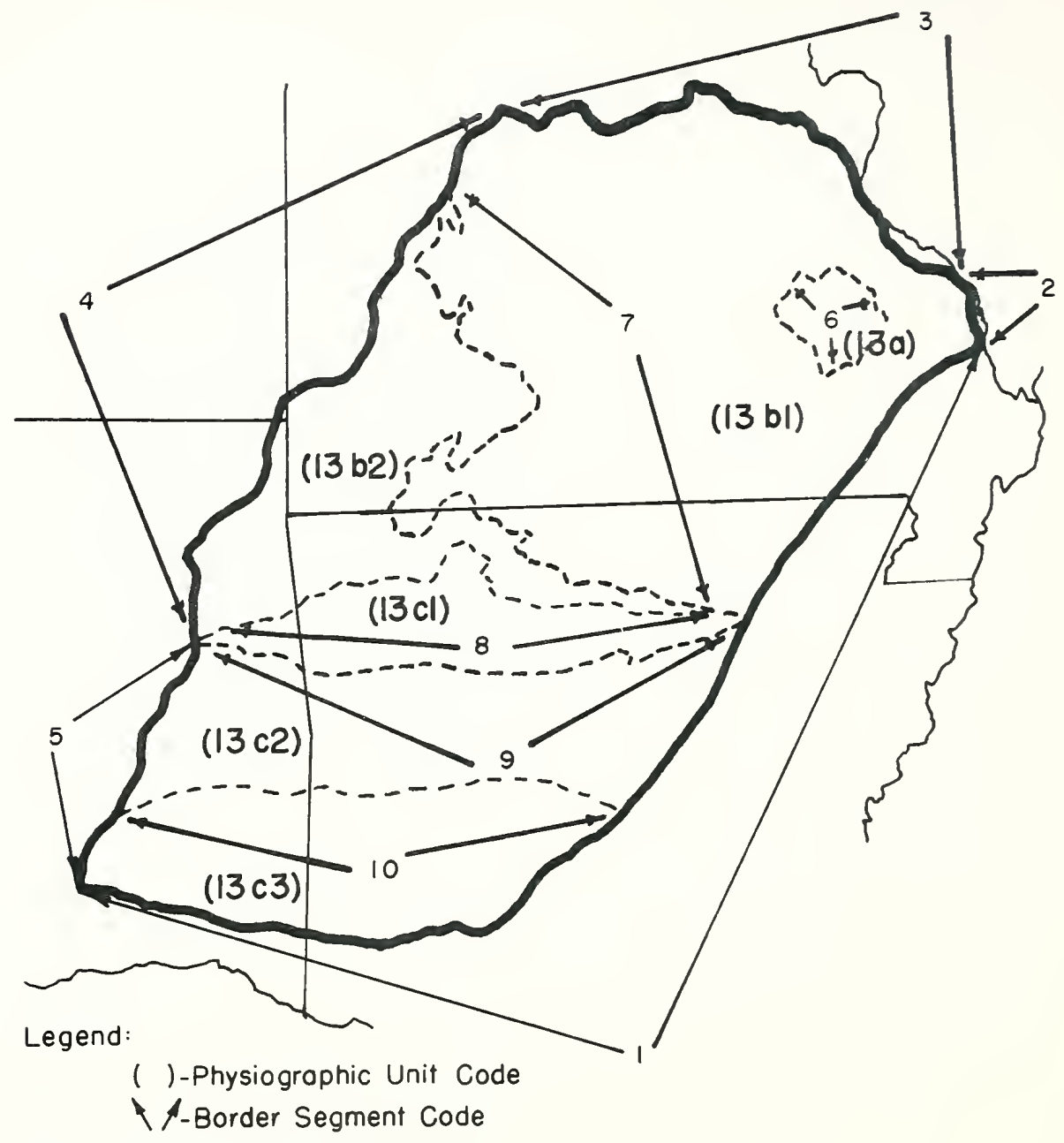

Note: Both Codes Keyed To Text

FROM (75)

FIG.63 OZARK AND OUACHITA PROVINCE / SECTION DIAGRAM 
made to enclose the outer limits of the Frecambrian Igneous rocks that have been exhumed. As a consequence, Paleczcic Sedimentary rocks that appear between the Igneous outcrops may form a contiguous boraer with the Paleozolc rocks ccmmon to the Salem Plateau.

7. Thls border appears to have conslderatle difference in location particularly for that portion in Missouri close to the Nissourl River. The border 1 tself is the Eureka Springs Escarpment, which is the retreating edge of the Mississipplan strata found characteristically in the Springfleld Plateau. The escarpment is quite prominant in southwest Missourl tut decreases gradually as one goes north until its dissappearance as a pronounced topographic expression occurs near the Osage River Valley.

8. The boundary is the Boston Mountain Escarpment. Geologlc age as well as difference in I1thology can also be used to determine this border.

9. Th1s border, as described by Fenneman, occurs where the "mountalnous upland of the Eoston Mountains merges w1th the hills of the Arkansas Valley Section. At places the topographic treak is abrupt, mainly where the boundary is against a local southdifping monocline, but at places the break in topography follows a fault". 
10. The western portion of this border is the Chocktaw Fault that separates north dipping beds of the Arkansas Valley with the south dipplng beds within the Ouachita Mountain area. In Arkansas, the border is descriked as following parts of the Fet1t Jean Creek, Dutch Creek and Poteau Fiver.

\section{Province 14}

Figure 64 shows the border portions utilized to describe the Interior Low Plateaus Province. In general, the borders can be fairly definitely located by elther marked topcgraphic features or by differences in geology except for the northern and westem boundaries. All the remaining borders are noted by escarpments which are directly due to the structure of the bedrock with the area and surrounding Frovinces. The border fortions are as follows:

1. See Appalachian Plateau Province.

2. See Central and Eastem Iowland Province.

3. See Atlantic and Gulf Coastal Plain Frovince.

4. This border is an in facing escarpment (towards the Nashville Basin) known as the H1ghland B1m Escarpment. It essentially separates the criovician (minor Silurian - Devonian) limestone area of the basin from the younger (M1ssissifpian)

Fort Payne Chert of the Highland R1m. The escarpment is several hundred feet high.

5. This border is determined by an escarpment overlooking the Highland Rim Section. In Inllana 1t 


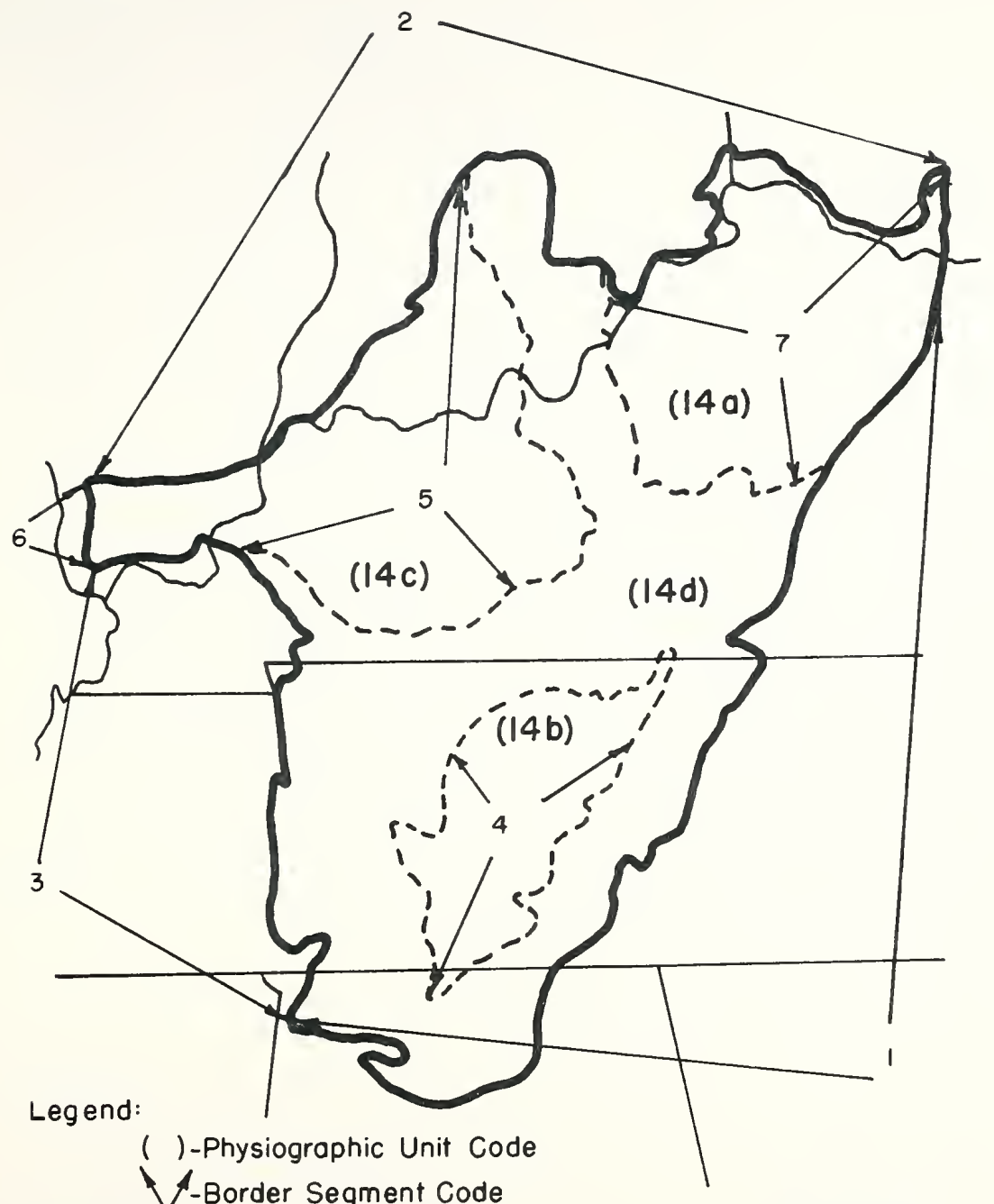

Note: Both Codes Keyed To Text

FROM ( 75$)$

FIG.64 INTERIOR LOW PLATEAUS PROVINCE / SECTION DIAGRAM 
is called the Chester Escarpment while in Kentucky It is called the Dripping Springs Escarpment.

6. Topographic contrast of this border is quite indefinite for, surficially, the area is veneered by unconsolidated aeolian and alluvial materials that gradualiy merge with adjacent sections. In general, the border follows the western limit of Mississipplan rocks within the Shawnee Section and differs from the adjacent Pennsylvanian rocks underlying the extreme southern tip of Illinois.

7. Th1s escarpment is similar in geologic respects to border \#4 in that 1t occurs on Mississippian rocks and overlcoks the Bluegrass Section. In Kentucky the escarpment is called Muldraugh's Hills; while, in Indiana, it is termed the Knobstone Escarpment. In Southern Indlana this escarpment proceeds northward under the glacial drift where it is still topographically conspicuous for some distance.

\section{Province 15}

The border portions utilized to describe the Appalachian Flateau Frovince are shown on Figure 65. In general, the borders that describe the outer margin of the Frovince are very distinct from a topographic viewpoint, while all other interior portions become quite indefinite and in some cases arbitrary. The border portions are: 


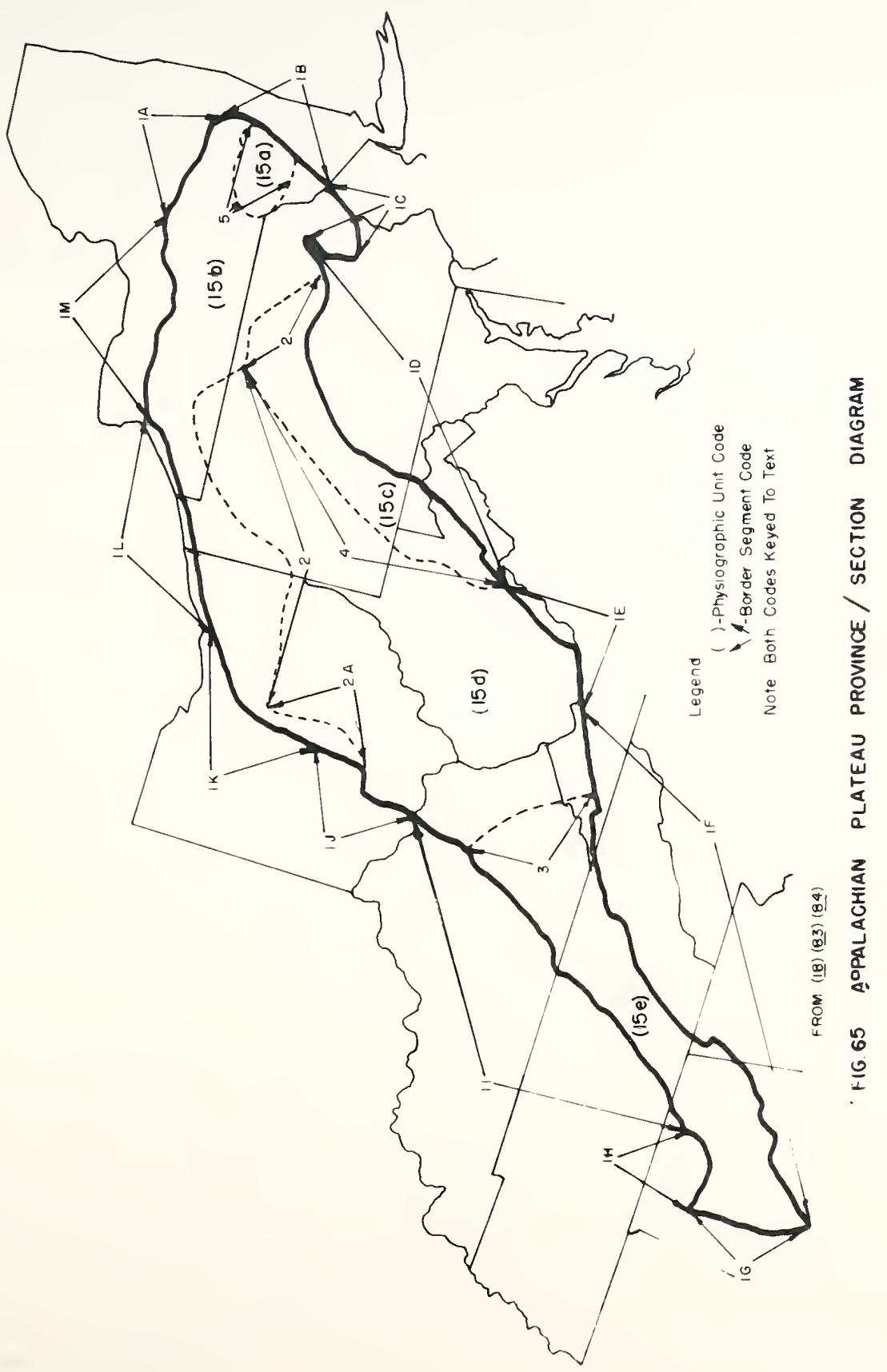


1. The outer margin of the Plateau Province is set off by marked outfacing scarps or dissected mountain fronts. The scarps in the east are generally higher and more clearly deflned than the lower and more jagged scarps on the west.

a. Th1s scarp is called the Helderberg Escarpment.

b. This scarp is called the Catskill Escarpment.

c. This border portion is contiguous with the Pocono Plateau.

d. This scarp is called the Allegheny Front.

e. In central West Virginia, the mountains of the Plateaus have the same altitude as those within the Ridge and Valley Province. However, the dendritic pattern within the Plateau Province contrasts with the Inear ridge-valley pattern of the Rldge and Valley Province.

f. This border portion is called the Cumberland Front.

g. Th1s border offers no marked topograph1c contrast with the Coastal PIain Province. Hills of the Plateau are often capfed by remnants of the coastal plain sediments and merge. (Also see geologic border discussion for Province 20). 
h. Within Alabama the scarp portion is generally lacking. A generallzed border separates the Fennsylvanlan rocks of the Plateau from the Mississipplan rocks in the Interlor Low Plateau.

1. This border portion gives a fairly good topographlc contrast due to the scarp which appears in solithern Tennessee. The scarp approaches some 1000 feet in helght. Geologic differences are similar to torder \#lh.

j. The border is noted by the west facing scarp of Mississipplan rocks within the Appalachlan Plateau.

k. From Columbus, Chio (slightly east) to Cleveland, Ch1o; the west facing escarfment is lost but the contact of the t111 plain topography with the hilly terrain of the Plateau is recognizatie.

1. From Cleveland, Ohlo to an area south of Buffalo, New York; the scarp appears but does not follow any geologlc toundary.

m. From Euffalo, New York to near Ut1ca, New York, the scarp is at the edge of the Portage sandstone and Tully, cnandago, and Helderberg limestones.

2. This border is taken as the southern most $11 \mathrm{~m} 1 \mathrm{t}$ 
of Wisconsin glaciation. (note: older drift extends beyond this $11 \mathrm{mlt}$ but is not topographically prominant).

a. Th1s border portion encloses an area not shown in Fenneman's diagrams. However, recent information indicates the presence of Wisconsin drift in this area.

3. Th1s border is very artitrary as 1 t attemps to separate degrees of dissection between the adjacent Kanawha and Cumberland Plateau Sections.

4. In general the Allegheny Mountain Section stands topographically higher and is dissected greater than the surrounding Kanawha sect1on. In west Virginia the altitude of both sections is about the same and is very difficult to denote.

5. This border may be thought of as arbitrary due to the facies change in resistant stratum that protects and characterlzes the Catskill Plateau section. These stratum generally loose their resistance and character to the west and south and thus gratually merge with the New York Section.

\section{Province 16}

As noted in Figure 66 the border portions that descrite the Ridge and Valley Province are as follows:

1. Th1s border is based upon the southern I1mits of wisconsin glacial drift. 


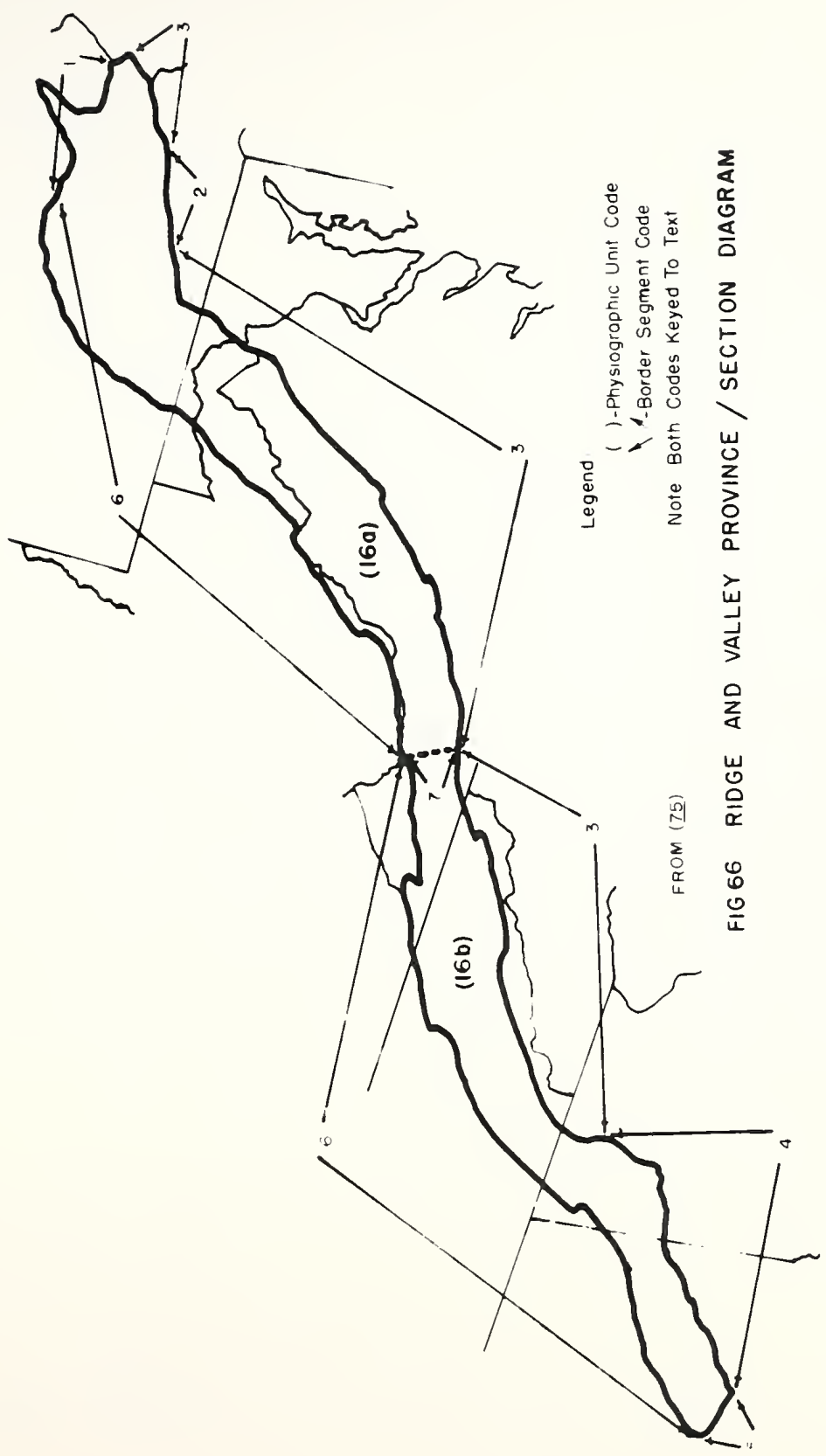


2. See Triassic Lowland Province.

3. This border is generally rather apparent from a topographic viewpoint. The mountainous upland terrain of the Blue Ridge and Reading Prong contrasts with the serles of bordering lowland valleys developed on I1mestone within the Ridge and Valley.

4. This border has as a mutual Province the Fiedmont Section of the cld Appalachians. The topographic difference between the two areas is not as pronounced as the border of \#3. D1fference in rock type exists between the areas.

5. See Atlantic and Gulf Coastal Plain Province.

6. The border is the prominant topographic escarpment of the Appalachian Plateau Province (Alleghany Front). Within central West Virginia, ridges of the Rldge and Valley Frovince are at approximately the same elevation of the plateau areas of the Appalachian Province.

7. This border is arbitrarily taken as the drainage divide between the New and Tennessee Rivers.

\section{Frovince 17}

Figure 67 contains the legend of the border areas jescrited below for the old Appalachian Province. They are:

1. See Ridge and Valley Province.

2. See Trlassic Lowland Province.

3. See Atlantic and Gulf Coastal Plain Province. 


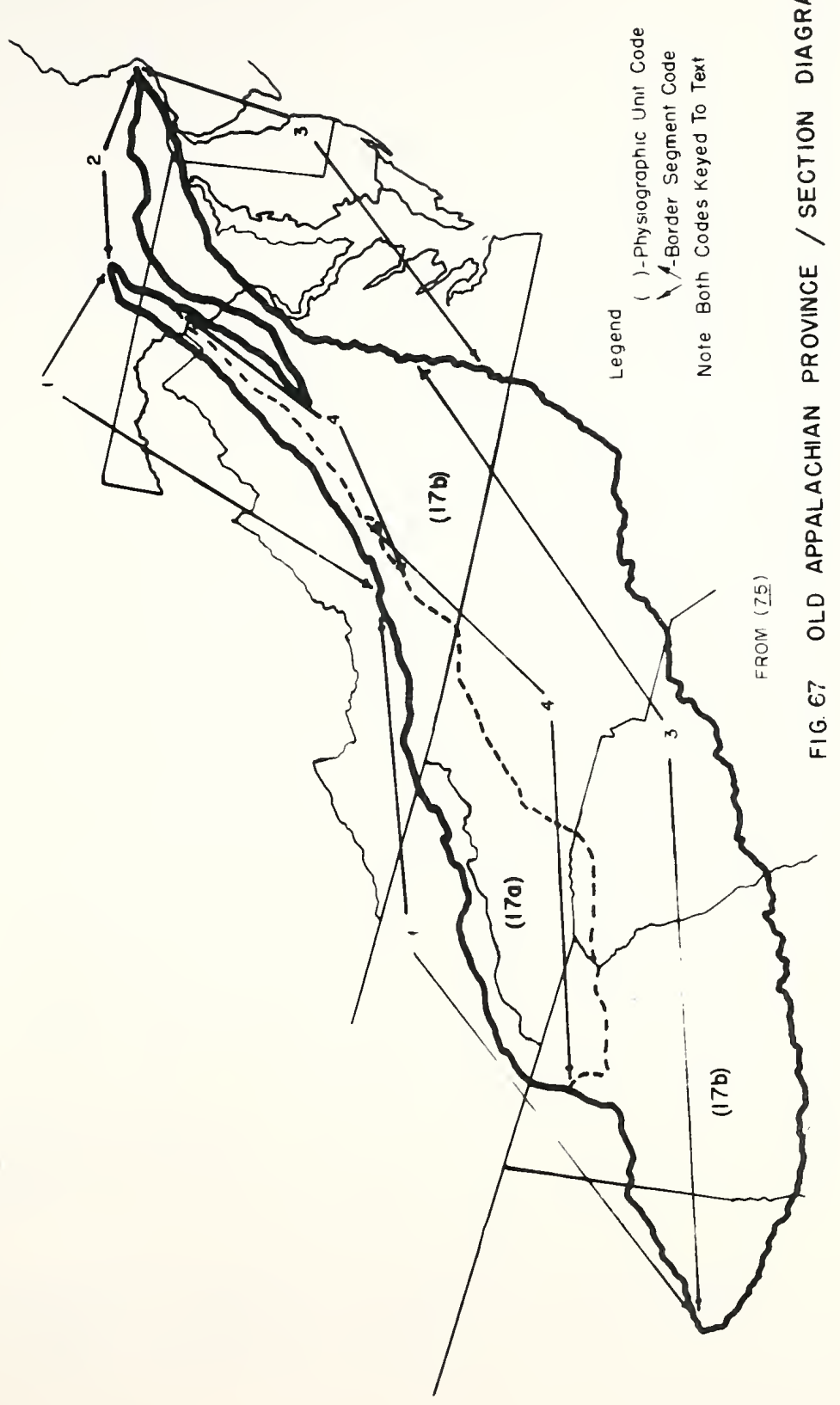


4. This border is generally based upon topographic differences of elevation and relief between the two Sections. The border is termed the Blue Rldge Escarpment and is quite varlable in its clarity toward creating a definite torder. In many cases, particularly in the southern portion of the boundary, the high relief of the Blue Ridge is gradational to the Pledmont. As a consequence, numerous Blue Rldge outliers are found in the Pledmont jection making border placement quite difficult and inderinite.

Province 18

As noted in Flgure 68 , there are 4 boundary portions ut1lized to describe the border system of the Triassic Iowlana. They are:

1. This border is distinguished by geologic age difference between the Triassic rocks and the older (Pre-Cambiran to Early Paleozolc) crystalIine rocks. Topographically, the Triassic areas are lower than the crystalline areas which generally forin the uplands.

2. The border is taken as the crdoviclan I1mestone areas. Topographically they are also lower than the crystalline uplands.

3. This boundary is distinguished by geologic age difference between the Triassic rocks and the 
Legend:

( )-Physiographic Unit Code

A-Border Segment Code Note: Both Codes Keyed To Text

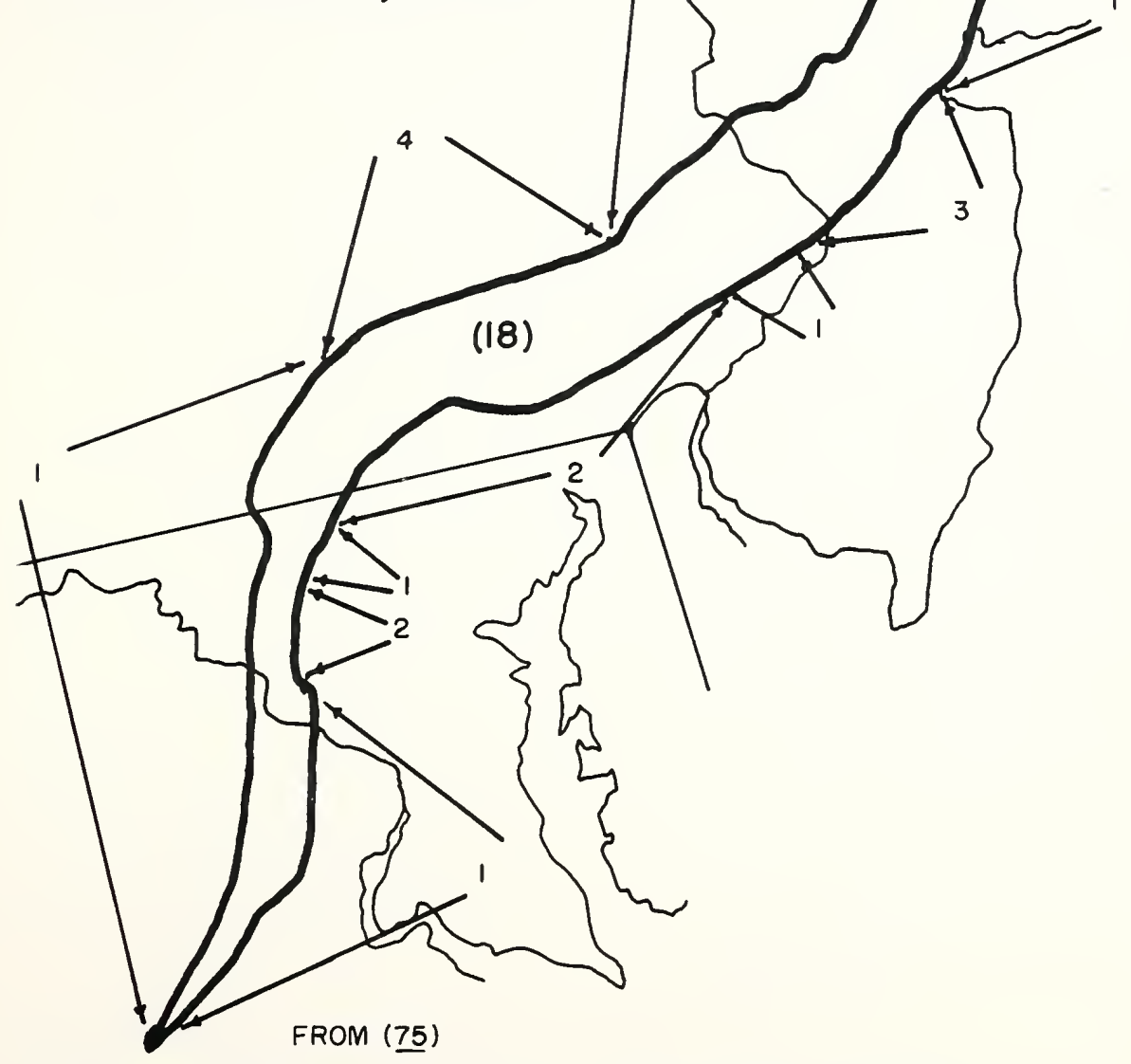

FIG.68 TRIASSIC LOWLAND PROVINCE DIAGRAM 
Cretaceous coastal seilments. Topographic contrast in much of the area is lacking.

4. This border is similar to border \#3 in that the Trlass1c "Lowland" area becomes an upland area when contrasted to the topographically lower Great Valley system of the Rldge and Valley Province. The border can be distingulshed ty the geologic age difference between the Crdovician limestone valley and the Triassic sediments.

\section{Province 19}

As shown in Figure 69, eleven (11) border portions have been utilized to describe the borders of the New England Var1time Frovince. They are:

1. Th1s border can only be generally defined and therefore it is quite indefinite. It attemps to separate areas within which mountainous terrain is sufficlently abuntant to dominate the landscape in a general view. However, plateau surfaces, diagnostic of the New England Upland Section invades the margin of the area and is elsewhere surrounded by monadnocks. The border has been arbitrarily defined as the 1500 foot contour by Fenneman.

2. This border tends to separate the lower, smoother topography of the Seaboard Iowland Section from the higher, less smoother topography of the New England Upland Section. Fenneman defined this 


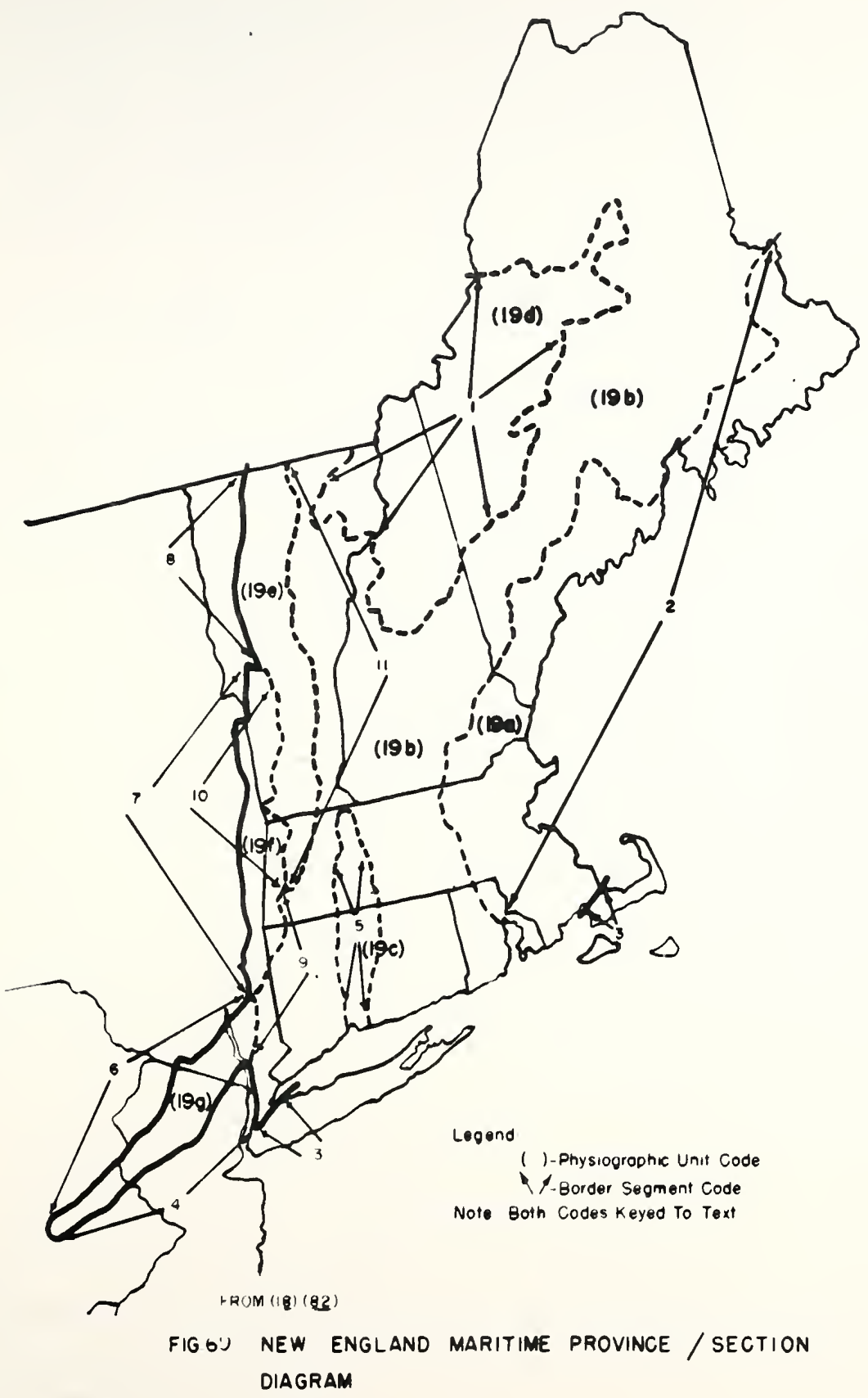


change (1e...border) in topography occurring between the 400 and 500 foot contour intervals. Differences in geologic rock types or ages cannot be ut1lized to obtain the boundary and; consequently, this border is similar in nature to border $t 1$.

3. See Atlant1c and Gulf Coastal Plain Province.

4. See Triassic Lowland Province.

5. This border is fairly definite from both a topographic and geologic standpoint. The lowland area developed on relatively weak Trlassic rocks contrasts with the older schists and granites of the uplands to elther side (east-west).

6. Thls border is falrly definite from both a topographic and geologic standpoint. The crystalline PreCambrian rocks of the Reading Prong topographically overlook the Paleozolc Sedimentary rocks of the Hudson Lowland Section. (note: the northern portion of this border ends approximately 20 miles north of where the Hudson River enters the Highlands (Reading Prong) near Poughkeepsie, New York).

7. This border is based primarliy on differences in rock type attributed to the change of degree in metamorphism. The schists of the Taconics stand above and in a falrly definite Inear trend compared to the slates of the Hudson Iowland. 
8. The southern half of this border portion is quite definite from a topographic viewpoint as it appears as a nearly stralght wall up to 500 feet high. The northern portion becomes quite indistinct and a unique line separating adjacent Sections is difficult to draw.

9. This border portion is quite 111 defined within the I1terature avallable. It appears to be quite difficult to determine particularly in the northern portion as a gradual topographic merger between Sections occurs.

10. This border is separated by a series of valleys developed on carbonate rocks that are physiographlcally treated within the Taconlc Section.

11. Th1s border portion is not well defined due to the gradual change from the plateau-like topography of the New England Upland to the mountainous topography of the Green Mountain Section. The northerm portion of the border is perhaps slightly more noticeable than the southern portion as a terracing effect occurs in the North (due east of the Green Mountains).

\section{Province 20}

As shown in Figure 70 , there are 8 boundary portions to describe the various borders of the Atlantic and Gulf coastal Plain. They are:

1. This boundary occurs from Cape Cod, Massachusetts 


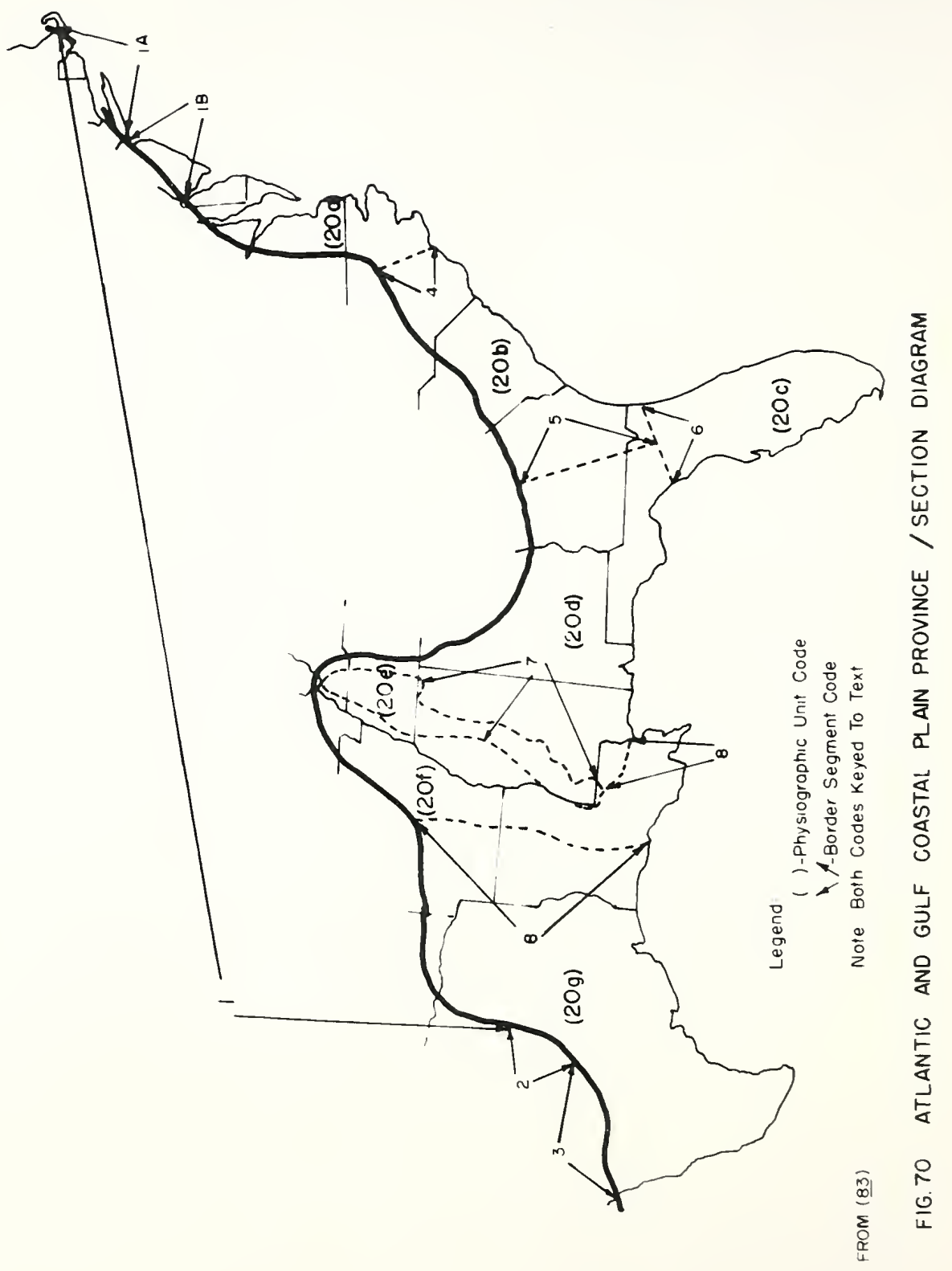


to Waco, Texas. The boundary is easily described as Cretaceous and younger sediments bordering the older consolldated materlals of the uplands. a. Long Island and Cape Cod have both been glaclated. As a result, the border must be based on the northern 11m1t of cretaceous rocks that underlie Ple1stocene glacial sediments.

b. In this area, topography is not signif1cantly different where the coastal sed1ments border soft Triassic age sedimentary rocks.

2. Th1s border is generaliy the contact between lower and Upper Cretaceous rocks. Lower Cretacecus rocks have been assigned to the Central Texas : :Ineral Section of the Great Plains Frovince due to the fact that the dissected topography upon the Lower Cretaceous rocks is more in common with the Section of the Great Plains rather than the Coastal Plains Province.

3. This border occurs approximately from Austin, Texas to the Mexico border. The border is falrly definite, belng recognized by the Balcones Escarpment whlch divides Lower and Upper Cretaceous rocks.

4. The border is very indefinite as it is primarily based upon topograph1c differences of the coast Ine (1e...separates embayed areas of Section $20 a$ from sea 1slands characteristic of Section 20b). 
5. Th1s border is similar to \#4 as 1 t is of the indefinite type. Topographic changes occur a little west of the Georgla - South Carolina border.

6. The border is similar to $\$ 4$ and $\# 5$ in that each Section (20b, 20c and 20d) each have major differIng modal characteristics. However, the location of the border dividing these characteristics is very indefinlte.

7. This boundary is based on the limits of surficlal aeolian deposits. The eastern boundary, in many cases, is of a gradational varlety.

8. This boundary 18 based upon the border that separates the Mississippi alluvial deposits from the coastal sediments. The boundary can te easily located from elther geolog1c, pedologic or soll crigin maps of the area. 
APPENDIX C

STATE AGGEEGATE PRODUCTION DATA 
Iable 41

Summary of Aggregate l'roduction kankings hy state

\begin{tabular}{|c|c|c|c|c|c|c|c|c|}
\hline \multirow[b]{2}{*}{ State } & \multirow[b]{2}{*}{ No. } & \multirow[b]{2}{*}{ population } & \multirow[b]{2}{*}{ Area } & \multicolumn{5}{|c|}{ Kank ing } \\
\hline & & & & $\begin{array}{l}\text { Sand } \\
\text { (tonnage) }\end{array}$ & $\begin{array}{l}\text { Gravel } \\
\text { (ton. per } \\
\text { Pop.-Area) }\end{array}$ & $\begin{array}{l}\text { Crushe } \\
\text { (tonnage) }\end{array}$ & $\begin{array}{l}\text { d Stone } \\
\text { (ton.per } \\
\text { Pop. Ared) }\end{array}$ & $\frac{\text { katio }}{\left(s r_{i} / \mathrm{CS}\right)}$ \\
\hline Al abama & (1) & $3,267,000$ & 52,000 & 41 & 44 & 23 & 25 & $37-39$ \\
\hline Arizona & $\cdot(2)$ & $1,302,000$ & 114,000 & 14 & 25 & 39 & 43 & 8 \\
\hline Arkansas & (3) & $1,786,000$ & 53,000 & 26 & $23-24$ & 24 & 13 & 31 \\
\hline California & (4) & $15,717,000$ & 159,000 & 1 & 40 & 16 & 38 & 17 \\
\hline Colorado & $(5)$ & $1,754,000$ & 104,000 & 12 & $26-27$ & $34-36$ & 37 & 12 \\
\hline Connecticut & (6) & $2,535,000$ & 5,000 & 32 & 5 & 27 & 2 & 28 \\
\hline Delaware & (7) & 446,000 & 2,000 & 48 & 3 & $44-48$ & $44-48$ & $1-5$ \\
\hline Florida & $(8)$ & $4,952,000$ & 59,000 & 38 & 46 & 3 & 10 & $45-46$ \\
\hline Georgia & (9) & $3,943,000$ & 59,000 & 45 & 47 & $18-19$ & 23 & 48 \\
\hline Idaho & $(10)$ & 667,000 & 84,000 & 13 & 15 & $34-36$ & 29 & 16 \\
\hline Illinois & (11) & $10,081,000$ & 56,000 & 6 & 35 & 1 & 15 & 36 \\
\hline Indiana & $(12)$ & $4,662,000$ & 36,000 & 10 & 19 & 14 & 11 & 32 \\
\hline lowa & (13) & $2,757,000$ & 56,000 & $21-22$ & 29 & 5 & 5 & $40-42$ \\
\hline Kansas & (14) & $2,179,000$ & 82,000 & 25 & 33 & $18-19$ & 19 & 34 \\
\hline Kentucky & $(15)$ & $3,038,000$ & 40,000 & 40 & 36 & 12 & 7 & $45-40$ \\
\hline Louisiana & $(16)$ & $3,257,000$ & 49,000 & 23 & 30 & 26 & 26 & $23-24$ \\
\hline Maine & $(17)$ & 969,000 & 33,000 & 24 & 10 & 42 & 41 & 7 \\
\hline Maryland & $(18)$ & $3,101,000$ & 11,000 & 18 & 9 & 25 & 4 & $25 \cdot 20$ \\
\hline Massachusetts & (19) & $5,149,000$ & 8,000 & 11 & 6 & 28 & 8 & 20 \\
\hline Michigan & $(20)$ & $7,823,000$ & 58,000 & 2 & $26-27$ & 21 & $31-32$ & 19 \\
\hline Minnesota & $(21)$ & $3,414,000$ & 84,000 & 5 & $23-24$ & 30 & 34 & 15 \\
\hline Mississippi & $(22)$ & $2,178,000$ & 48,000 & 37 & 32 & $44-48$ & $44-48$ & $1-5$ \\
\hline Missouri & $(23)$ & $4,320,000$ & 70,000 & 27 & 43 & 7 & 16 & $43 \cdot 44$ \\
\hline Montana & $(24)$ & 675,000 & 147,000 & 17 & 17 & 37 & 36 & 11 \\
\hline Nebraska & $(25)$ & $1,411,000$ & 77,000 & 19 & 20 & 33 & $31-32$ & 18 \\
\hline Nevada & $(26)$ & 285,000 & 111,000 & 20 & 8 & 40 & 39 & 9 \\
\hline New Hampshire & $(27)$ & 607,000 & 9,000 & $34-35$ & 2 & $44-48$ & $44-48$ & $1-5$ \\
\hline New Jersey & $(28)$ & $6,667,000$ & 8,000 & 15 & 11 & 20 & 3 & $29-30$ \\
\hline New Mexico & (29) & 951,000 & 122,000 & $34-35$ & 31 & 32 & 30 & $21-22$ \\
\hline New York & $(30)$ & $16,782,000$ & 50,000 & 3 & 39 & 6 & 27 & $29-30$ \\
\hline North Carolina & $(31)$ & $4,556,000$ & 53,000 & 28 & 41 & 10 & 14 & $40-42$ \\
\hline North Dakota & $(32)$ & 632,000 & 71,000 & 30 & 13 & $44-48$ & $44-48$ & $1 \cdot 5$ \\
\hline Ohio & (33) & $9,706,000$ & 41,000 & 4 & 4 & 8 & 1 & 27 \\
\hline Okl ahoma & $(34)$ & $2,328,000$ & 70,000 & 39 & 42 & 17 & 12 & $43-44$ \\
\hline Oregon & $(35)$ & $1,769,000$ & 97,000 & 13 & 28 & 11 & 9 & 35 \\
\hline Pennsylvania & $(36)$ & $11,319,000$ & 45,000 & 16 & 45 & 4 & 22 & $40-42$ \\
\hline Rhode Is land & $(37)$ & 859,000 & 1,000 & 47 & 1 & 43 & 40 & 6 \\
\hline South Carolina & $(38)$ & $2,383,000$ & 31,000 & 44 & 34 & 29 & 20 & 33 \\
\hline South Dakota & $(39)$ & 680,000 & 77,000 & $20-21$ & 12 & $34-36$ & 28 & 14 \\
\hline Tennessee & $(40)$ & $3,567,000$ & 42,000 & 36 & 38 & 9 & 6 & 47 \\
\hline Texas & $(41)$ & $9,596,000$ & 267,000 & 19 & 48 & 2 & 33 & $37-39$ \\
\hline Utah & $(42)$ & 891,000 & 85,000 & 31 & 22 & 41 & 42 & 10 \\
\hline Vermont & $(43)$ & 390,000 & 10,000 & 46 & 7 & $44-48$ & $44-48$ & $1-5$ \\
\hline Virginia & $(44)$ & $4,967,000$ & 41,000 & 29 & 37 & 15 & 17 & $37 \cdot 39$ \\
\hline Washington & $(45)$ & $2,853,000$ & 68,000 & 8 & 16 & 22 & 24 & $21-22$ \\
\hline West Virginia & $(46)$ & $1,860,000$ & 24,000 & 43 & 21 & 31 & 21 & $23-24$ \\
\hline Wisconsin & $(47)$ & $3,952,000$ & 56,000 & 7 & 18 & 13 & 18 & $25-26$ \\
\hline Wyoming & $(48)$ & 330,000 & 98,000 & 42 & 14 & 38 & 35 & 13 \\
\hline
\end{tabular}

Notes: 1. Ranking Number 1 is largest production factor; 48 is lowest production ranking.

2. Information concerning sand gravel obtained from reference (175) for 1964 .

3. Information concerning crushed stone obtained from reference (189) for 1958. 
Table 42

Summary of State Agrregate Production Factors

$8 y$ Increasing Magnitude

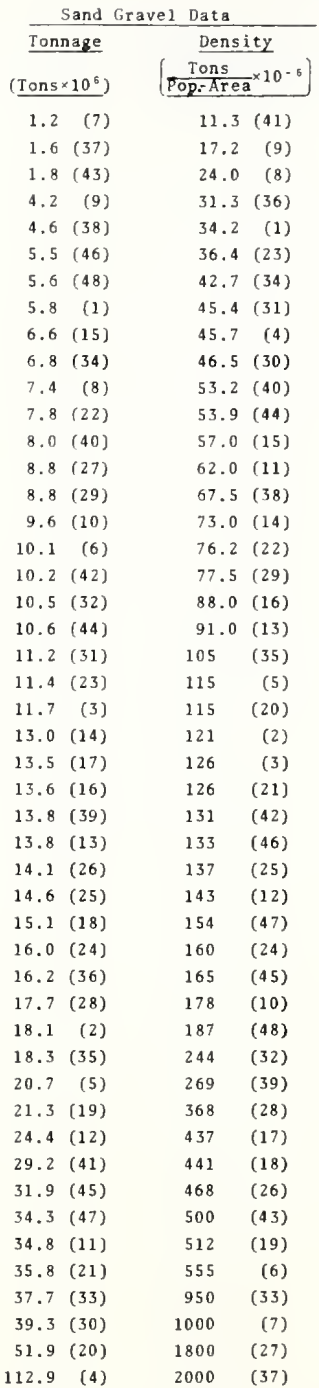

\begin{tabular}{|c|c|c|c|c|c|}
\hline \multicolumn{4}{|c|}{ Crushed Stone Data } & \multicolumn{2}{|c|}{ Ratio } \\
\hline \multirow{2}{*}{\multicolumn{2}{|c|}{$\begin{array}{l}\text { Tonnage } \\
\left(\text { Tons } \times 10^{6}\right)\end{array}$}} & \multicolumn{2}{|c|}{ Density } & \multicolumn{2}{|c|}{$\frac{\text { SG Tornage }}{\text { CS Tonnage }}$} \\
\hline & & $\int \frac{\text { Tons }}{\text { Pop-Area }}$ & $-\times 10^{-6}$ & & \\
\hline 0 & (7) & 0 & (7) & 0.5 & (9) \\
\hline 0 & $(22)$ & 0 & (22) & 0.6 & (40) \\
\hline 0 & $(27)$ & 0 & (27) & 0.7 & (8) \\
\hline 0 & $(32)$ & 0 & (32) & 0.7 & (15) \\
\hline 0 & (43) & 0 & (43) & 0.8 & (23) \\
\hline .002 & $(37)$ & 0.7 & (2) & 0.8 & (34) \\
\hline .04 & (17) & 1.1 & $(42)$ & 0.9 & (13) \\
\hline .08 & $(42)$ & 1.3 & (17) & 0.9 & (31) \\
\hline .09 & (26) & 2.0 & (37) & 0.9 & (36) \\
\hline 0.1 & (2) & 2.8 & (26) & 1.2 & (1) \\
\hline 0.3 & $(48)$ & 3.7 & (4) & 1.2 & (41) \\
\hline 0.6 & (24) & 4.4 & (5) & 1.2 & (44) \\
\hline 0.8 & (5) & 6.0 & (24) & 1.3 & (11) \\
\hline 0.8 & $(10)$ & 7.8 & $(48)$ & 1.5 & (35) \\
\hline 0.8 & $(34)$ & 8.7 & (21) & 1.6 & (14) \\
\hline 1.5 & (25) & 9.3 & (41) & 1.7 & (38) \\
\hline 1.6 & (29) & 13.7 & $(20)$ & 2.4 & (12) \\
\hline 1.7 & (46) & 13.7 & (25) & 2.5 & (3) \\
\hline 2.5 & (21) & 13.8 & (29) & 2.6 & (28) \\
\hline 2.9 & (38) & 14.2 & (10) & 2.6 & (30) \\
\hline 3.3 & (19) & 15.3 & (39) & 2.8 & (6) \\
\hline 3.6 & (6) & 18.3 & (30) & 2.9 & (33) \\
\hline 4.0 & (16) & 25.1 & (16) & 3.4 & (47) \\
\hline 4.4 & $(18)$ & 28.0 & (1) & 3.4 & (18) \\
\hline 4.8 & (3) & 29.5 & (45) & 3.5 & (16) \\
\hline 4.9 & (1) & 34.0 & (9) & 3.5 & (46) \\
\hline 5.7 & (45) & 36.2 & (36) & 5.6 & (29) \\
\hline 6.2 & $(20)$ & 37.8 & (46) & 5.6 & (45) \\
\hline 7.0 & (28) & 39.2 & (38) & 6.4 & (19) \\
\hline 7.9 & (9) & 44.0 & (14) & 8.4 & (20) \\
\hline 7.9 & (14) & 45.2 & (47) & 10.0 & (25) \\
\hline 8.7 & (34) & 45.6 & (44) & 12.3 & (4) \\
\hline 9.2 & (4) & 46.0 & (23) & 12.5 & (10) \\
\hline 9.3 & $(44)$ & 46.5 & (11) & 14.4 & (21) \\
\hline 9.9 & (12) & 48.8 & (31) & 17.5 & (39) \\
\hline 10.0 & $(47)$ & 50.5 & (3) & 24.0 & (48) \\
\hline 10.4 & (15) & 53.3 & (34) & 26.3 & (5) \\
\hline 11.7 & (35) & 59.2 & (12) & 26.7 & (24) \\
\hline 11.8 & (31) & 67.7 & (8) & 125 & (42) \\
\hline 13.2 & $(40)$ & 68.5 & (35) & 167 & (26) \\
\hline 13.3 & (33) & 80.5 & (19) & 180 & (2) \\
\hline 13.9 & (23) & 85.0 & (15) & 350 & (17) \\
\hline 15.3 & (30) & 88.0 & $(40)$ & 1000 & (37) \\
\hline 15.6 & (13) & 101 & (13) & $\infty$ & (7) \\
\hline 18.5 & (36) & 129 & (18) & $\infty$ & (22) \\
\hline 19.8 & (8) & 143 & (28) & $\infty$ & (27) \\
\hline 23.8 & (41) & 200 & (6) & $\infty$ & (32) \\
\hline 26.3 & (11) & 333 & (33) & $\infty$ & (43) \\
\hline
\end{tabular}

Notes: 1. Number in parenthesis refers to state description number in Table 41

2. Information concerning sand gravel obtained from reference (175) for 1964

3. Information concerning crushed stone obtained from reference (189) for 1958 
